


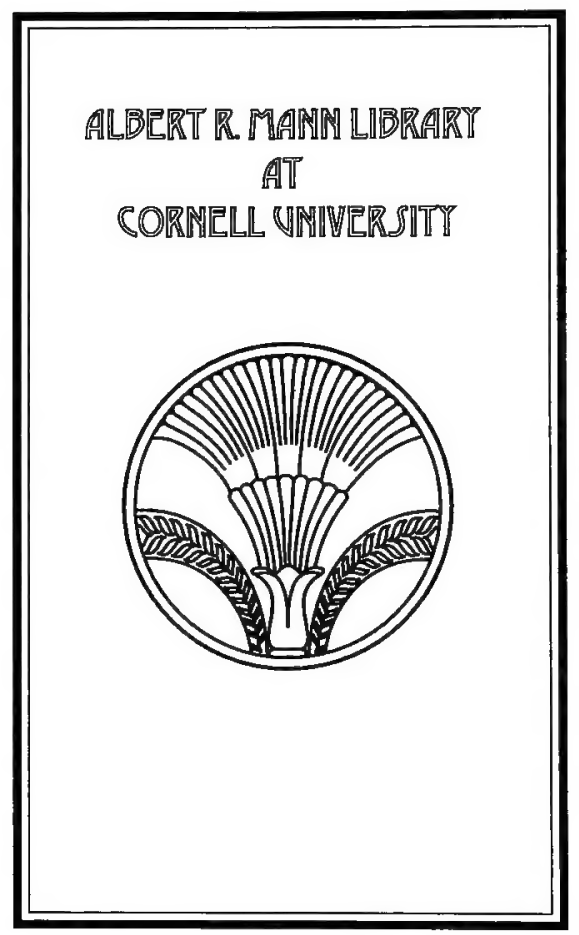


All books are subject to recall after two weeks

\section{DATE DUE}

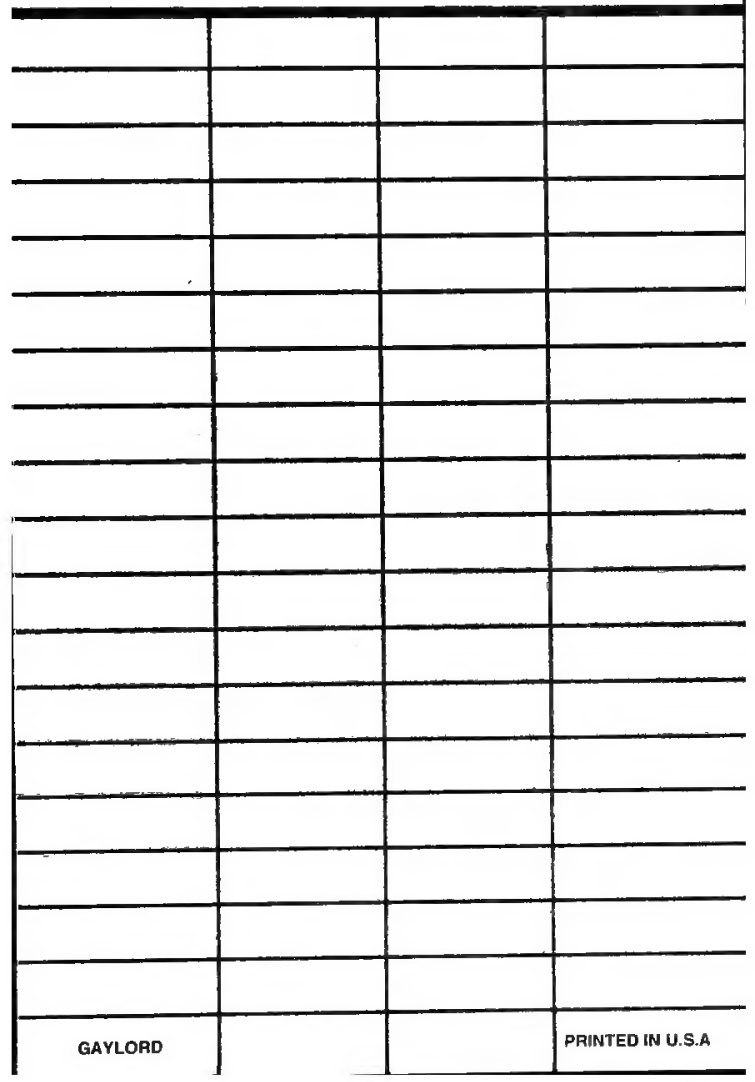


Pellontolyey tratse gos 2 nd est 2 vols. $p$ $47^{50}$ 
STUDIES IN FOSSIL BOTANY 
BY SAME AUTHOR.

In Two Volumes. Crown 8vo. Price 3s. 6d. each.

\section{AN INTRODUCTION TO STRUCTURAL BOTANY.}

PART I.-FLowERING PLANTS (6th Edition). Illus. trated with II8 Figures.

PART 11. - FLowERLESS PLANTS (sth Edition).

Illustrated with 120 Figures.

"Nothing could well be more plain and simple, or more severely accurate or better judged from beginning to end."Journal of Botany.

\section{AGENTS}

America. . The Macmillan Company

64 \& 66 Fifth Avenue, New York

Australasia The Oxford University Press

205 Flinders Lane, Melabourne

Canada - The Macmillan Company of Canada, Ltd.

27 Richmond Street West, Toronto

India . Macmillan \& Company, Ltd.

Macmillan Building, Bombay

309 Bow bazaar Street, Calcutta 


\section{Cornell University Library}

The original of this book is in the Cornell University Library.

There are no known copyright restrictions in the United States on the use of the text. 


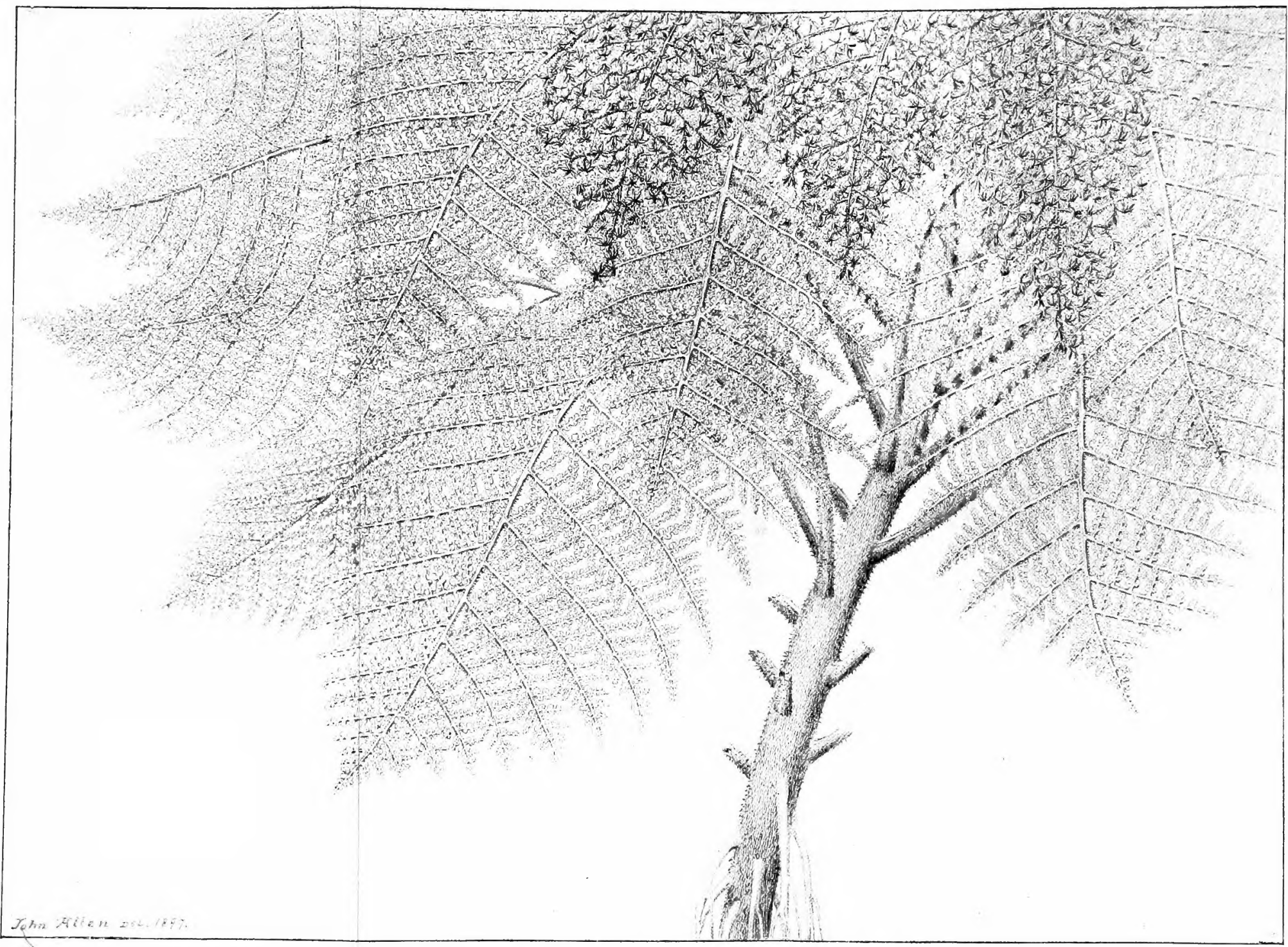

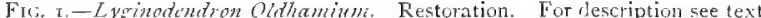




\section{STUDIES}

IN

\section{FOSSIL BOTANY}

BY

\section{DUKINFIELD HENRY SCOTT}

M.A., LL.D., PH.D., F.R.S., F.G.S., F.R.M.S.

PRESIDENT OF THE LINNEAN SOCIETY

LATELY HONORARY KEEPER OF THE JODRELL LABORATORY, ROYAL BOTANIC GARDENS, KEW

AUTHOR OF 'AN INTRODUCTION TO STRUCTURAL BOTANY

"Nous devons donc envisager l'état présent de l'univers, comme l'effet de son état antérieur."-Laplace.

SECOND EDITION

CONTAINING 213 ILLUSTRATIONS

LONDON

ADAM AND CHARLES BLACK

I 909 


$$
\begin{aligned}
& \text { QE } \\
& 905 \\
& 542 \times \\
& 1909
\end{aligned}
$$

First Edition, published Septenber 1900.

Second Edition published May 1909 


\section{PREFACE}

THE exceptionally rapid progress of Fossil Botany during the last eight years has rendered necessary a very thorough revision of this book, and the rewriting of considerable portions. At the same time care has been taken to maintain the original character of the "Studies" as a first introduction to "those results of palæontological inquiry which appear to be of fundamental importance from the botanist's point of view." No attempt has been made to extend the scope of the book, which now, as before, is concerned essentially with the morphological and evolutionary aspects of Palæobotany, but in every chapter new results of research have been incorporated.

Chapters I.-IX. cover the Pteridophyta, i.e. those groups of Vascular Plants which may still be considered as, on the whole, Cryptogamic. Chapters X.XIV. contain the Spermophyta, so far as they are dealt with, concluding with the chapter on "General Results."

The heading "Chapter" now replaces "Lecture," 
for, except perhaps in the Introduction, little trace of the original lecture form survives.

The first three chapters have been slightly rearranged, so as to give a somewhat more logical division of the subject-matter. The substantial changes in these chapters are not great, Mr. Hickling's new observations on Palaeostachya and M. Halle's investigation of Mesozoic Equisetales being the chief novelties.

In Chapter IV. some account is given of a new type of fructification in Sphenophyllum, and Professor Nathorst's discovery of the group Pseudoborniales is shortly noticed.

In Chapter $\mathrm{V}$. the changes are only in details, but Chapter VI. has received important additions; in particular, the curious seed-like fructifications of certain Palæozoic Lycopods, only shortly referred to in the first edition, have demanded fuller consideration.

In Chapter VII. a considerable advance in our knowledge both of Sigillaria and Stigmaria has been placed on record, and a short section on the herbaceous forms (Lycopoditeae) has been added, based on recent researches from French and Swedish sources.

The treatment of the Ferns (Chapters VIII. and IX.) has of necessity been profoundly changed by the discovery (due to Oliver, Kidston, Grand'Eury, White, and others) that so large a proportion of the supposed Palæozoic Ferns were, in reality, seed-bearing plants. 
Chapter IX., in which the now prominent family of the Botryopterideae is described, has been largely extended.

Chapters X.-XIV. have required an even more drastic revision, and are, to a great extent, new.

Chapters X. and XI., which deal with the Fern-like Spermophyta (the new class Pteridospermeae) are now written from a fresh point of view, for it is only since the appearance of the first edition that we have become acquainted with the true nature of this extensive group, as shown by its advanced methods of reproduction.

In Chapter XII., now headed "The Cordaitales," the section on the family Pityeae is altogether new, and that on the Poroxyleae considerably extended. Our ideas of the relationships of the groups concerned have advanced greatly, though, as regards the family Cordaiteae, our knowledge still rests essentially on the work of Renault and Grand'Eury.

The Mesozoic Gymnosperms (Chapter XIII.) now appear in quite a new light, owing to the brilliant elucidation of the flowers of the American fossil Cycadophyta by Dr. Wieland, whose work at last brings the great question of the origin of Angiosperms within the range of scientific discussion.

Lastly, the concluding chapter has necessarily undergone a complete transformation, in order to bring it into harmony with the results of so much new research of fundamental importance. In this chapter a 
fresh classification of the Vascular Plants has been introduced.

The book contains 63 additional figures, besides a few cases in which new illustrations have been substituted for old. The figures now added are: I I, 27, 42, $47,48,76,77,78,80,8 \mathrm{I}, 82,83,84,94,95$, го3, I 6 , I I 4, I I 7, I 20, I 22 , I 23, I 24, I 25, I 26, I 27 , I 28 , I 36, I 37, I 43, I 44, I 45, I 46, I 47, I 48, I 49, I 50,15 I, I 52, I 53,16 I, I 68, I 69, I 70, I 7 I, I 72 , I 73, I 74, I 75, I 77, I 84, I 85 , I 86, I 96, I 97, I 99, 206, 207, 208, 209, 2 IO, 2 I I, 2 I 3.

The new figures signed " R. S." are by my wife, Mrs.

D. H. Scott, F.L.S., who has also made the Index.

\section{H. SCOTT.}

2 I st Aprit I 909. 


\section{PREFACE TO FIRST EDITION}

THESE Studies in Fossil Botany are founded on a special course of lectures, given, under the same title, at University College, London, in the year I 896.

The lecture form has been retained, but the number of lectures, into which the course is divided, has increased from eleven to fourteen. The introductory lecture preserves something of its original character, but all the rest have been completely recast, and most of them wholly rewritten.

At the present day, happily, fossil botany is an eminently progressive branch of science, and thus the mere lapse of time, since the lectures were delivered, has necessitated the introduction of much new matter and of many new points of view. A certain number of unpublished observations are also embodied in the book.

My object has by no means been to write a manual of fossil botany, a superfluous undertaking, in view of the excellent publications of the last few years. To mention only the very latest works, we have Mr. Seward's extensive treatise on Fossil Plants, now in course of publication, Professor Potonie's concise Lehrbuch der Pflanzen-palcentologie, and, within the present ix 
year, M. Zeiller's Éléments de Paléobotanique, all of them, in their several ways, admirable hand-books for the student of palæobotany.

My purpose has been quite a different one, namely, to present to the botanical reader those results of palæontological inquiry which appear to be of fundamental importance from the botanist's point of view. Such far-reaching results have, at present, related almost entirely to two of the vegetable Subkingdoms, the Pteridophytes and the Gymnosperms, and it is to these Subkingdoms that the "Studies" are confined.

Within these limits, the value of the fossil evidence already available is manifest, though as yet hardly realised by botanists. The last few years, however, have seen a considerable advance in this respect, and we may hope that the palæontological record will no longer be ignored by students of the evolution of plants.

The present book, while it assumes no previous knowledge of fossil plants, presupposes a general acquaintance with rccent botany, and with the rudiments, though only the rudiments, of geology. The terminology employed will be familiar to the botanical student; in the few cases where new or less usual terms are introduced, their explanation is given. Only two points seem to require notice here. The term tracheae is used in the wide sense adopted by De Bary, to cover both the vessels of the wood (arising by cell-fusion) and the tracheides (consisting of single cells). ${ }^{1}$ Other authors have used the word in more

1 De Bary, Comparative Anatony of the Phanerogams and Ferns, English edition, 1884 , p. I 55 . 
restricted senses, but a general term for the waterconducting elements is indispensable, and De Bary's usage answers every purpose.

As in my Introduction to Structural Botany, the form megaspore is used throughout, in preference to macrospore, on the ground that the former term is more correct, and less liable to verbal confusion with microspore.

More than a third of the illustrations are new, and of these the majority (over forty in number) were drawn for me by $\mathrm{Mr}$. Gwilliam, as indicated by his initials, G. T. G. In addition, a considerable number of the borrowed figures were redrawn by the same artist, to whose skill the book is much indebted.

Of the figures which are not new, a great many are taken from memoirs by the late Dr. W. C. Williamson, F.R.S., by myself, or by both of us, jointly. The source of all figures borrowed from other authors is of course acknowledged. I have to thank the Royal Society for permission to reproduce a large number of figures from the Philosophical Transactions, and the Linnean Society for a similar permission in the case of that Society's publications.

Mr. W. Carruthers, F.R.S., has kindly allowed me to make use of some illustrations from his well-known memoir on fossil Cycadean stems.

The restoration of Lyginodendron Oldhamium, forming the frontispiece, is the work of Mr. J. Allen, who has carried out a difficult task with much ability.

For various photographic illustrations I am indebted to Dr. E. C. Bousfield, and to my colleague, Mr. L. A. Boodle.

Wherever possible, I have given the number of the 
section or specimen illustrated, in the collection to which it belongs. The abbreviation "Will. Coll." indicates the Williamson Collection (now in the British Museum, Natural History Department), while "S. Coll." refers to my own collection. In other cases the name is given in full.

The progress of scientific fossil botany has been greatly advanced by the skilled and intelligent work, in collecting petrified specimens and preparing sections, of such men as Mr. J. Lomax, Mr. G. Wild, and their colleagues, now deceased, Mr. J. Butterworth, Mr. J. Spencer, and others.

The references to the literature make no pretence to being exhaustive; I hope, however, that the works of chief importance to the botanical reader have been cited, and that justice has in all cases been done to those who have laid the foundations of our knowledge.
D. H. SCOTT.

20 th June I 900. 


\section{CONTENTS}

PReface

PAGE

Preface to First Edition.

CHAPTER I

INTRODUCTION

CHAPTER II

EQUISETALES-VEGETATIVE STRUCTURE

Calamites; Arthrodendron; Calamodendron; Protocalanites

I. The Calamarieae .

2. The Stem of Calamites

3. Branching.

4. Other Types of Stem

5. The Leaves 38

6. The Roots $4 \mathrm{I}$

7. The Medullary Casts 46

CHAPTER III

EQUISETALES-FRUCTIFICATIONS AND CLASSIFICATION

Calamostachys; Palaeostachya; Cingularia; Archaeocalamites; Macrostachya; Classification of Calamarieae; Mesozoic Equisetales

I. The Fructifications

$$
\text { xiii }
$$


2. Calamostachys . 5 I

3. Palaeostachya . . . . . 6 I

4. Cingularia . $\quad 67$

5. Archaeocalamites . . . . . 70

6. Macrostachya . . . 72

7. Classification . . 73

8. Mesozoic Equisetales . 82

CHAPTER IV

SPHENOPHYLLALES

Sphenophylleae; Cheirostrobeae; Pseudoborniales

I. Sphenophylleae

I. Sphenophyllum-Vegetative Organs . $\quad 86$

2: Fructifications of Sphenophyllum-S. Dawsoni Type 99

3. Bowmanites Römeri, Sphenophyllum fertile, and S. majus

II. Cheirostrobeae $\quad$ I 4

4. Cheirostrobus . . . . 114

Pseudoborniales 123

5. Pseudobornia . 123

CHAPTER V

LYCOPODIALES

Lepidodendron and Lepidophloios

Introductory Remarks

I. Habit . 126

2. Stem 133

3. Leaves - I 55

4. Branching I6I 


\section{CHAPTER VI \\ LYCOPODIALES-Continued}

Ulodendron and Halonia; Fructifications of Lepidodendreae; Bothrodendron

1. Ulodendron and Halonia .

PAGE

2. Lepidostrobus I 65

3. Spencerites 173

4. The Seed-like Lycopodiaceous Fructifications 189

5. Bothrodendron 193 199

CHAPTER VII LYCOPODIALES-continued

Sigillaria and Stigmaria; Lycopoditeae

I. Sigillaria 204

I. Habit and External Characters 204

2. Anatomical Structure 2 I 4

3. Fructifications

II. Stigmaria

I. Habit and External Characters

2. Anatomical Structure

3. Morphology

III. Lycopoditeae 262

Conclusion

CHAPTER VIII

THE FERNS

Fronds; Fructifications; Anatomy

Introductory Remarks .

I. Fronds .

2. Fructifications

3. Anatomy-Psaronitus 
CHAPTER IX

THE FERNS-continued

The Botryopterideae-Summary on the Ferns

I. Botryopterideae

PAGE.

305

A. Zygopteris Group

I. Zygopteris

2. Other Genera

B. Botryopteris Group

3. Botryopteris

4. Other Genera

5. Stauropteris

6. Affinities of the Family

II. Summary

\section{CHAPTER X}

PTERIDOSPERMEAE

Lyginodendreae

Introductory Remarks

I. Lyginodendron

I. The Stem

2. The Leaves

3. The Roots

4. Habit

5. The Seed 386

6. The Microsporangia

II. Heterangium

I. The Stem (H. Grievii)

2. The Leaves

3. The Roots 
4. Heterangium tiliaeoides

5. Habit

CHAPTER XI

PTERIDOSPERMEAE-continued

Medulloseae; Aneimiteae; Seed-bearing Pecopterideae; Other Cycadofilices

Medulloseae-

\section{Habit}

Anatomy-Medullosa

Sutcliffia.

Fructification of Medulloseae .

Affinities of Medulloseae

Aneimiteae

Seed-bearing Pecopterideae

Summary on the Pteridosperms

Other Cycadofilices

Megaloxyleae

Calamopityeae

Cycadoxyleae

Protopityeae .

Cladoxyleae
428

$$
\begin{gathered}
\text { CHAPTER XII } \\
\text { THE CORDAITALES } \\
\text { Poroxyleae; Pityeae; Cordaiteae } \\
\text { I. Poroxyleae } \\
\text { II. Pityeae } \\
\text { III. Cordaiteae } \\
\text { Characters . } \\
\end{gathered}
$$

I. External Characters 
xviii STUDIES IN FOSSIL BOTANY

2. The Stem

3. The Root

50

4. The Leaves . . . $\quad$. 532

5. The Flowers . 535

A. The Male Flower . 536

B. The Female Flower . 539

6. The Seeds . . . $\quad 546$

7 Affinities . . 550

CHAPTER XIII

THE MESOZOIC GYMNOSPERMS

I. Cycadophyta 555

I. Bennettiteae . . 559

2. Cycadaceae . . . 594

3. Affinities of Mesozoic Cycadophyta . . 597

II. Coniferae 604

III. Ginkgoaceae $6 \mathrm{rr}$

CHAPTER XIV

GENERAL RESULTS

Introductory Remarks .

6 I 4

$\begin{array}{lll}\text { Sphenopsida . . . } & 6 \mathrm{rg}\end{array}$

Lycopsida . . . $\quad 632$

Pteropsida . . . $\quad 638$

INDEX . 


\section{LIST OF ILLUSTRATIONS}

FIG.

1. Lyginodendron oldhamium. Restoration.

2. Calamites Suckozeii. Medullary cast.

PAGE

Medullary cast $\quad$ I7

4. Calamites, sp. Part of a transverse section of a young stem 21

5. ., sp. Transverse section of a very young twig . . 22

6. .. sp. Part of a radial section through primary wood . 23

7. " sp. Radial section of a decorticated stem. . 25

8. Calamites communis. Tangential section of wood . . . 27

9. " " Tangential section of wood showing a branch 32

ro. Calamodendron intermedium. Part of transverse section of stem 35

I I. Calamites (Protocalamites) pettycurensis. Transverse section . 37

12. Calamites, sp. Transverse fracture through a node showing leafsheath . $\cdot{ }^{\circ} \cdot 3^{8}$

I3. Calamites, sp. Part of a transverse section close to a node 39

I4. ", sp. Transverse section of a bud . . 40

I5. . sp. Part of a transverse section of a large root 43

I6. ." sp. Transverse section of small tetrarch rootlet. 45

17. Calamostachys Binneyana. Radial section of part of cone 50

I8. ". ., Transverse section of cone. 5 I

I9. " " $\quad$ Transverse section of axis of cone 52

2o. ", ", A single peltate sporangiophore 54

21. " ". Part of tangential section of cone 55

22. ", ", A single sporangium. A-D, spores . 56

23. Calamostachys Casheana. Tangential section . 57

24. A. Palaeostachya. Radial section of cone. B. Archaeocalamites
radiatus. Part of cone showing axis bearing sporangiophores 6 I

25. Palaeostachya pedunculata . . 62

26. Palaeostachya vera. Transverse section of cone 65

27. " ," Diagrammatic longitudinal section of cone 66

28. Cingularia typica. Part of branch. . . 68

29. ", ", Enlarged diagram of a verticil of the cone 69

30. Archaeocalamites radiatus. Branch bearing whorled leaves 7 I

3I. " " Single leaf . 7 I

32. Macrostachye infundibuliformis. Cone borne laterally on a branch . . . . . . 73

33. Annularia brevifolia. Twigs bearing whorled leaves. . . 75

34. Asterophyllites densifolius. Branch bearing distichously arranged
twigs.

35. Sphenophyllum, sp. Branched stem bearing leaves and cone $\quad 87$ 
FIG.

36. Sphenophyllum quadrifidum. A. Radial section through a node.

B. Transverse section of same stem. C. Transverse section

through a node. D. Transverse section of a portion of secondary wood

37. Sphenophyllum plurifoliatum. Transverse section of stem through whorl of leaves

38. Sphenophyllum plurifoliatum. Transverse section of older stem .

39. " " Radial section through part of secondary wood

40. Sphenophyllum insigne. Transverse section of rather young stem

4I. Sphenophyllum Dazesoni. A. Diagram of cone in longitudinal section. B. Stele of axis in transverse section. C. Spores in superficial aspect

42. Sphenophyllum Dawsoni. Longitudinal section of cone

43. Sphenophyllum Dawsoni. Transverse section of cone

44. ", , Sporangiophore and its sporangium

45. Bowmanites Römeri. Part of transverse section of cone

46. ", " A. Lamina of sporangiophore. B. Longitudinal section through upper part of sporangiophore .

47. Sphenophyllum fertile. Diagram. A. Node in radial section. B. One lobe of sporophyll

48. Sphenophyllum majus. Forked sporophyll bearing four sporangia

49. Cheirostrobus pettycurensis. Diagram. Transverse and radial section

50. Cheirostrobus pettycurensis. Part of radial section . II7

5I. ". Transverse section of axis of cone II9

52. Lepidodendron elegans. Restoration of tree . . I27

53. Lepidodendron Ophiurus. A. Fragment of stem-surface. B. Leafy branch bearing a cone.$\quad$ I29

54. Lepidodendron Veltheimianum. Portion of surface of stem . I 30

55. Lepidodendron. Leaf-base . . . . 130

56. Lepidodendron Harcourtii. A. Transverse section of stem. B. Stele of same

57. Lepidodendron (Lepidophloios?) Wunschianum. Transverse section from outer part of stele

58. Lepidodendron brevifolium. Transverse section of stem

59. Lepidodendron selaginoides. Transverse section of young branch.

60.

Transverse section of stele. .

Part of radial section

62. Lepidophloios, sp. A. Tangential section from the outside of a stem. B. A single leaf-base

63. Lepidophloios, sp. Radial section of a leaf-base

64. Lepidodendron Hickii. Transverse section of leaf

65 .

Epidermis of leaf, with stomata

66. Lepidodendron selaginoides. Transverse section showing the two steles of a bifurcating stem

67. Ulodendron. Surface of branch

68. Lepidophloios scoticus. A. Bifurcating Halonial branch. B. Leaf-cushions enlarged.

69. Lepidophloios fuliginosus. Transverse section of a young shoot.

70. Lepidostrobus Hibbertianus. Compressed specimen of an almost perfect cone

7r. Lepidostrobus. Diagram of heterosporous cone in radial section

72. Lepidostrobus Veltheiamianus. Transverse section of cone through microspore-region 
FIG.

73. Lepidostrobus Veltheimianus. Transverse section of cone through megaspore-region

74. Lepidostrobus Veltheimianus. Longitudinal section of cone

75. Spores of Lepidodendreae. A. and B. Spencerites insignis.

76. Lepidostrobus foliaceus. Megaspore

77. Lepidostrobus Veltheimianus. Megaspore in section showing prothallus

78. Mazocarpon. Isolated megaspore showing prothallus

79. Spencerites insignis. Somewhat diagrammatic radial section

8o. Lepidocarpon Lomaxi. Sporangium and sporophyll .

$8 \mathrm{I} . \quad$ " " Upper part of integumented "seed"

82. " " Diagrammatic section of "seed" .

83. Miadesmia membranacea. Approximately transverse section of seed-like organ

84. Miadesmia membranacea. Radial section of seed-like organ :

85. Stump and roots (Stigmaria facoides) of a Lycopodiaceous tree

86. Sigillaria tessellata (Favularia type). Surface of stem :

87. Sigillaria mamillaris (Rhytidolepis type). Surface of stem

88. Sigillaria Brardi (Leiodermaria type), Part of surface of stem

89. Sigillaria Menardi (Clathraria type). Section and surface

90. Sigillaria spinulosa. Part of transverse section of stem

91. . ". Part of wood more highly magnified

92. ". " A. Tangential section of outer cortex. B. Leaf. C. Sigillaria latifolia. Transverse section of leaf .

93. Sigillaria (Rhytidolepis type). Segment of stem in transverse section

94. Sigillaria scutellata. Transverse section of a portion of the wood .

95. Sigillariopsis sulcata. Transverse section of leaf.

96. Sigillariostrobus rhombibracteatus. A. Part of cone. B. $S$. ciliatus. Part of axis with sporangia. C. Megaspores

222

97. Stigmaria ficoides. Part of surface.

98. ". ." Transverse section of a small specimen

I03. ". ., Transverse section of rootlet showing vascular system

Io4. Stigmaria ficoides. Transverse section of central part of rootlet.

ro5. ", ", Transverse section of rootlet showing dichotomy

Io6. Stigmaria, sp. Transverse section of an axis with centripetal wood .

107. Pecopteris (Dactylotheca) dentata. Part of a frond . . .

108. Ptychocarpus unitus. Fructification. A. Part of a fertile pinnule. B. Synangia in side view, C. A synangium . . . 109. Group of Palæozoic fructifications of Ferns or Pteridosperms. A. Asterotheca. B. Renaultia. C. Dactylotheca. D. Sturiella. E. Oligocarpia. F. Crossotheca. G. Senftenbergia. H. Hawlea. J. Urnatopteris . . . . .

I ro. Scolecopteris polymorpha. A. Lower surface of a fertile pinnule. B. Transverse section of half a pinnule showing synangium . 


\section{xxii STUDIES IN FOSSIL BOTANY}

FIG.

II Pteridotheca Butterworthii. Fragment of a Fern-frond with sporangia

II2. Pteridotheca Williamsonit. Group of annulate sporangia

II3. Psaronius brasiliensis. Transverse section of stem . . 299

II4. Psaronius Renaulti. Part of transverse section of stem 302

II5. Zygopteris Grayi. Transverse section of stem 308

II6. " ," Transverse section of stele 309

I 17. Zygopteris corrugata. Transverse section of an "Aphlebia" 3 II

II8. Zygopteris bibractensis. Transverse section of a petiole . . 316

II9. Zygopteris, sp. I. Group of four sporangia. 2. Sporangia enlarged. 3. Group of sporangia in transverse section. 320

I zo. Asterochlaena laxa. Part of transverse section of stem 324

I2r. Botryopteris hirsuta (Will.). Transverse section of stem . . 327

I22. ." ". Transverse section of vascular bundle of young petiole

123. Botryopteris forensis. Group of sporangia

329

330

33 I

I24. Botryopteris. Group of sporangia.

125. Sporangium in transverse section
126. Stauropteris oldhamia. Transverse section of vascular bundle of main rachis

I27. Stauropteris oldhamia. Three sporangia inserted terminally on ultimate branches of the rachis

128. Stauropteris oldhamia. Four germinating spores from the interior of a sporangium

129. Lyginodendron oldhamium. Transverse section of stem

I33. Stangeria paradoxa. "Double bundle from petiole

I34. Lyginodendron oldhamium. Transverse section from outer part of stele

35. Lyginodendron oldhamium. Transverse section of a very young stem.

136. Lyginodendron oldhamium. Vegetative gland .

I 37. stem". ,

Transverse section of branching

I38. Lyginodendron oldhamium.

I 39.

I 4 O.

I4I.

I 42. 13

,

Radial section of stem

Transverse section of rachis

Vertical section of a leaflet

Transverse section of root

. " Radial section of stem, showing root

,

Radial section of stem, showin
. Longitudinal section of a small seed

I44. Lyginodendron (Lagenostoma Lomaxi). Restoration of the seed .

145. Lagenostoma Lomaxi. Capitate gland on the cupule

146. Lyginodendron oldhamium. Capitate gland on the petiole

147. Lagenostoma Lonaxi. Apex of seed

$\mathrm{I} 48$. "' ",

Diagram of seed in median longitudinal

I49. Lagenostoma Lomaxi. Diagrammatic transverse sections 390

I50. Lagenostoma Sinclairi. Portion of branched rachis bearing seed $39 \mathbf{I}^{\circ}$

I $5 \mathrm{I}$.

I52. Crossotheca "loningaus. Two seeds

I53. " 
154. Heterangium Grievii. Restoration of a portion of the stem .

stele

"Transverse section from outer part of

I57. Heterangium Grievii. Corresponding longitudinal section

I58. ', tiliaeoides. Radial section.

I59. Sphenopteris elegans. Ribbed stem

I60. ", ", Part of frond

161. Neuropteris heterophylla. Part of vegetative frond

412

416

4 I 7

426

162. Alethopteris lonchitica. Part of frond

r63. Medullosa anglica. External view of stem

r64. " , , Transverse section of stem

165. " $"$ Part of transverse section, showing steles and leaf-traces

166. Medullosa anglica. Two leaf-trace bundles from the outer cortex of the stem

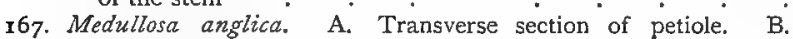
Vertical section of leaflet

168. Sutcliffic insignis. Transverse section of the stem and leaf-bases

I69. Neuropteris heterophylla. Seed

170. Trigonocarpus Parkinsoni. Diagrammatic median section in the plane of the wing

I71. Trigonocarpus Parkinsoni. Diagrammatic transverse section through the body of the seed

I72. Trigonocarpus Parkinsoni. Diagrammatic transverse section through the micropyle

I73. Stephanospermum akenioides. Upper part of pollen-chamber .

I74. " " Multicellular pollen-grains in pollen-chamber .

I75. Pecopteris Pluckeneti. Fragment of a fertile pinna with seeds .

177. Calamopitys fascicularis. Transverse section of central part of stem

I78. Cycadoxylon robustum. Part of transverse section

179. Ptychoxylon Levyi. Transverse section of a decorticated stem

180. Cycadospadix milleryensis. Fructification

I81. A. Poroxylon Edwardsii. Transverse section of stem. B. P. Boyssetii. Transverse section of young stem . . . 503

182. Poroxylon Edwardsii. Transverse section, showing xylem-strands 505

183. Poroxylon Boyssetii. Transverse section of petiole

I84. Poroxylon Sutcliffi. Transverse section of stem

I85. Rhabdocarpus subtunicatus. Transverse section of seed

186. Pitys antiqua. From a transverse section of stem

187. Dorycordaites. Restoration

188. Cordaites lavis. Branch (restored) bearing the large spathulate leaves and inflorescences

189. Cordaites. Part of transverse section of stem.

I9o. Cordaites (Araucarioxylon) Brandlingii. A. Radial section of middle part of stem. B. Inner part of wood

I9I. Amyeion radicans (probably a root of one of the Cordaiteae) . 192. Cordaites. Leaves in transverse section. A. C. angulosostriatus.

B. C. rhombinervis. C. C. lingulatus

193. Cordaianthus Penjoni. A. Longitudinal section of male catkin.

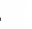


FIG.

194. Cordaianthus Williamsoni. A. Somewhat tangential section of a female catkin. B. Ovule

195. Cordaianthus Grand'Euryi. A. Longitudinal section of female flower. B. Canal of pollen-chamber. C. Grains of pollen

196. Cycas. Longitudinal section of ovule

197. ." Pollen-chamber enlarged .

198. Cycadinocarpus augustodunensis. Upper part of seed . .

I99. Cycadeoiden marylandica. The earliest described American fossil Cycad

200. Bennettites Gibsonianus. A. Stem in transverse section. Stem in tangential section

201. Bennettites Saxbyanus. Transverse section of stem .

202. Bennettites Gibsorianus. Longitudinal section of a fructification 203.

A. Diagram of the fruit in radial section. B. Ramenta, in transverse section. C. Transverse section of a seed. D. Somewhat oblique longitudinal section through the micropyle of a seed .

204. Bennetitites Gibsonianus. Transverse section of fruit

205. " " Longitudinal section of seed

206. Cycadeoidea dacotensis. Median longitudinal section of a bisexual flower . . . . .

207. Cycadeoidea dacotensis. Longitudinal section through the summit of an unexpanded bisexual flower

208. Cycadeoidea ingens. Restoration of bisexual flower

209. ", Plan of the bisexual flower

2Io. Cycadeoidea dacotensis. Transverse section of synangia

2 II. ". " Longitudinal section of a synangium

2I2. Williamsonia gigas. Williamson's original restoration synangium and part of sporophyll. B. Transverse section 


\title{
STUDIES IN FOSSIL BOTANY
}

\author{
CHAPTER I \\ INTRODUCTION
}

IT is a general rule, applying to knowledge of every kind, that we cannot hope to understand any group of phenomena without a study of its antecedents. In political inquiries, no student would attempt to make himself acquainted with the existing constitution of a country, without seeking to gain a knowledge of the historical events by which it has been built up. In like manner, we cannot obtain any adequate idea of the present state of an art, such as sculpture or painting, unless we are prepared to study the history and development of the art in past times. Again, to come nearer to our own subject, scientific geography is impossible without geology, that is to say, without a knowledge of the past changes, to which the surface of the earth owes its present configuration. Vere scire est per causas scire, and causation is only known to us by the succession of events.

The same principle holds good for the spccial case of biology, the science of which botany is a part. 
Botany, on its morphological side, consists in the application of the comparative method to the study of plants, with a view to the determination of their relationships. In these days, most of us, when we speak of relationship among organisms, mean to imply a real affinity, that is to say, a blood-relationship, so that, on this view, the ultimate object of morphological inquiry is to build up the genealogical tree of the organic world. Many attempts at the construction of genealogical trees have been failures, but still this is the object, however remote, which we have ultimately before us when we devote ourselves to morphological studies.

Existing organisms are related to each other more or less as brothers or cousins are related. All the species living at the present day belong, as it were, to the present generation. By the study of living organisms alone, it must necessarily be a matter very much of conjecture to decide which of them, in any given group, stands nearest to the old family stock. As regards some of the main taxonomic divisions, it is true, there can be no doubt. We should all agree, for example, that the Green Algae are, on the whole, much more primitive than the Flowering Plants; but when we come to more difficult questions, such, for example, as the relative antiquity of the various families of Vascular Cryptogams, we find the most different opinions prevailing, and the conclusion at which we may arrive is largely a matter of subjective interpretation.

The only direct evidence which is possible in questions of desccnt among plants is from the ancient plants themselves. Fortunately, the rocks afford us a considerable amount of such direct evidence. I need 
not say that the estimation of this evidence is in itself beset with the greatest difficulties, difficulties which those best appreciate who have themselves worked at fossil remains. The construction of a pedigree of the Vegetable Kingdom is a pious desire, which will certainly not be realised in our time; all we can hope to do is to make some very small contributions to the work. Yet we may at least gather up some fragments from past chapters in the history of plants, and extend our view beyond the narrow limits of the present epoch, for the flora now living is after all nothing but one particular stage in the evolution of the Vegetable Kingdom.

There is a phrase in the introduction to Count Solms-Laubach's admirable Fossil Botany ${ }^{1}$ which I think very appropriate to our purpose. The author says that our object in studying fossil plants is "the completion of the natural system." That is the point of view which we shall take up in this book. I shall endeavour to bring before the reader those discoveries in fossil botany which already contribute something towards the completion of the natural system. If this be our purpose, it is evident that only well-characterised fossils have any interest for us. A specimen which may be an Alga, or perhaps a worm-track, or possibly even a wave-mark, is no doubt a curiosity, but will not help us much towards the end in view. Such specimens we shall leave severely alone!

Fossil botany at one time incurred a certain degree of not wholly undeserved contempt, from the excessive prominence given to doubtful objects, from which

1 Introduction to Fossil Botany, English edition, I892. 
no conclusions of botanical interest could possibly be drawn.

The purpose which we have in view necessitates a botanical arrangement of our subject-matter, but it is essential for us also to bear constantly in mind the geological horizon of the remains with which we are dealing. In botanical history dates are just as important as in human history. In the former, however, absolute dates are unattainable, and only relative ages come into question.

The imperfection of the geological record is a familiar subject, and I need not dwell upon it here. We naturally find that vegetable remains are by no means evenly distributed throughout the series of strata. From some formations they are almost absent, while in others they are relatively abundant. Thus, beginning at the top, the Miocene is rich in such remains, especially in Switzerland; so also is the Oligocene, as shown in the Isle of Wight, and the Eocene, to which the very rich leaf-beds in the Isle of Mull probably belong. All these Tertiary plants bear, as we should expect, a general resemblance to families now living.

Passing to the Secondary system, the Cretaceous formation is of special interest, for the first wellcharacterised Angiosperms make their appearance in these rocks. The remains from the Lower Greensand, however, are of a different type, and often have their structure well preserved; they include some of the most remarkable of fossil forms. The Wealden, which some geologists reckon with the Cretaceous, and some with the Jurassic formation, yields abundant remains, with which we have become better acquainted through the work of 
Prof. Seward of Cambridge. Ferns, Cycadophyta, and Conifers are the most characteristic forms of this period. The Oolitic strata, specially the Purbeck beds at the top of the system, also abound in Cycad-like remains, though most of the Mesozoic plants with the habit of Cycads were very different from any members of the family as now existing. The Wealden and Upper Jurassic of the United States are extraordinarily rich in Cycadophyta, recently investigated, with brilliant results, by Dr. Wieland of Yale. Such remains as we have from the Trias, e.g. the New Red Sandstone, have a still more old-world character (including strange and gigantic Horsetails and Lycopods), and prepare us for the Palæozoic system.

When we descend to the Permian we find ourselves at once among the characteristic Palæozoic familiesespecially the Sigillarias and Calamites, together with extinct Spermophytic types. This brings us to the Carboniferous formation, the flora of which is the richest and most remarkable which the rocks have preserved for us. The Carboniferous formation includes many other strata besides those of the Coal-measures, which belong to its upper part. The Coal-measures themselves reach a thickness of $\mathrm{I} 2,000$ feet, and represent a prodigious period of time. Fortunately, however, we are not limited for our specimens to this part of the formation, extensive as it is, for there are productive beds down to the base of the Lower Carboniferous rocks; when we find well-preserved plants much older than the Coal-measures, we may think ourselves specially fortunate. The plant-remains of the next great formation, the Devonian, though scanty compared 
with those of the Carboniferous, are of the greatest interest, for this is the earliest period from which landplants have come down to us in any abundance. It is very remarkable that in these early days we find not only well-characterised Vascular Cryptogams of various groups, but also highly organised Seed-plants, though not belonging to any family now living. There are probably no biologists left now who oppose in toto the doctrine of evolution, but if there were, they might draw a telling though fallacious argument from the high organisation of the Devonian flora. As regards the Silurian, there is little to say. Most remains from it are very doubtful, though there are one or two remarkable and well-preserved specimens, which have been shown on good evidence to belong to the Algae, while there is some evidence that even at this early period Vascular plants had already appeared.

To us, in these studies, the older formations will be the most interesting, for it is from them that we may expect to fill up gaps among the main groups of the natural system, and it is only with main groups that the limits of the book will allow us to deal. Also, I think that the investigation of the earlier formations (the Palæozoic and the Lower Mesozoic) has really been more fertile in results, up to the present time, than that of the later deposits, though no doubt from them also we may expect brilliant revelations in the future. The centre of gravity of our work will lie in the Carboniferous formation. The wealth of material which has come down to us from this period is marvellous, as every one knows. It is true, however, that the Coal-flora, rich as it is, is a very special one, although it extended with 
a certain degree of uniformity over a large part of the earth's surface. It is essentially a swamp-flora, and we know little or nothing of the vegetation of the uplands. If we obtained all our knowledge of the existing flora from plants growing in such localities as the Great Dismal Swamp near the coast of the Southern United States, or from the mangrove-vegetation of tropical shores, our ideas would evidently be one-sided. On the other hand, when it is argued that on the hills of the Coal-period there may have been flowers and trees and shrubs of the higher Angiospermous families, that, surely, is a wild imagination. The flora of swamps, however peculiar, is made up of plants belonging to the same main groups as those of other habitats, and in so far as main groups alone are in question, we may take the Coal-flora, such as it has come down to us, as fairly representative of its period.

Before beginning our detailed work, we must say something as to the modes of preservation of fossil plants, without some knowledge of which we can form no idea of the relative value of the evidence before us.

There are two different modes of preservation, which we must keep perfectly distinct in our minds. These have been termed incrustation and petrifaction. Incrusted remains include almost all the specimens of fossil plants familiar to the general public. In the case of incrustation, the parts of plants were merely incased in the mineral substance, and any of the larger cavities they may have contained filled with it. Their organic tissue became converted into structureless coal, if it did not previously decay altogether. Hence, incrusted specimens give us impressions or casts, 
which may reproduce with the greatest beauty an external or internal surface, but which tell us nothing of organised structure. The beautiful Fern-like fronds, so frequent in the Coal-measures, are perhaps more familiar to the ordinary observer than any other specimens of fossil plants. In them we have essentially the print of the frond on the shale lying above and below it. The finer the mineral material was when deposited, the more perfect will be the impression. The substance of the frond is reduced to a layer of coal in which there is little or no structure to be traced, though occasionally very resistant parts, such as spores or cuticle, will have left recognisable remains.

Other comparatively familiar fossils are the stems of the Lepidodendra and Sigillariae. In many of these specimens the markings of the surface, as characterised by the bases and scars of the leaves, are preserved exactly as in nature (see Figs. 54 and 86, pp. I 30 and 207). Where this is the case the whole substance of the plant has been replaced by mineral matter. In other instances we have a mould of the external surface, elevations being represented by depressions, and vice versa. The markings, in all these cases, will necessarily depend on the state of preservation of the specimen when incrustation took place. Thus in Lepidodendron we have quite different superficial markings according to the condition of the specimen, whether all its tissues were intact, or the epidermis had been stripped off, or a thin or thick layer of the cortex had also been lost. At least four different "genera" have been founded on these different states of preservation of one and the same plant (see Chapter V. p. I 3 I). 
Among internal casts the most important examples are those which filled the medullary cavity of the Calamites or arboreal Horsetails; these casts, reproducing exactly the internal surface of the woody cylinder, constitute the most familiar remains of this group of plants, and were long confused with the stems themselves.

Seams of coal have been regarded as a case of incrustation on a great scale. ${ }^{1}$ Here it is not single specimens, but whole masses of -vegetable remains which have been incrusted by mineral matter. The remains themselves have been converted into the more or less structureless carbonaceous material which we call coal, but on the upper and lower shales we find impressions of the plants which happen to have been in contact with the adjacent mineral deposits. The coal itself has undergone great chemical changes, the organic substance having been almost entirely converted into various hydrocarbons. In certain cases, however, sufficient structure has been preserved to enable us to form some idea of the kinds of plants to which the coal owed its origin.

We now come to the other great mode of preservation, petrifaction, in which the whole of the organised substance has been completely saturated by mineral matter in solution, which has subsequently been precipitated in a solid form. In this case alone is the structure thoroughly preserved. There have been many petrifying agents; the two most important for us are silicic acid $\left(\mathrm{H}_{4} \mathrm{SiO}_{4}\right)$, and calcium carbonate $\left(\mathrm{CaCO}_{3}\right)$. The most interesting vegetable remains 1 Solms-Laubach, l.c. chap. i. 
showing structure belong to these two classes. So far as the Carboniferous formation is concerned, silicified specimens are -characteristic of the French fossil flora, while calcified remains prevail in the English coal-fields. The former have become classic through the investigations of Brongniart and Renault, the latter through those of Witham, Binney, Williamson, and others. In good specimens of both kinds, the whole microscopic structure is often preserved with marvellous perfection. It has been alleged that the French silicified specimens are the more perfect of the two, but, beautiful as they are in many cases, the calcareous petrifactions are on the whole superior to them in the preservation of structurc. In the calcified specimens the actual organic substance remains, though chemically altered. The entire network of cell-walls, sometimes showing even their most delicate markings, traverses the matrix; in the cavities some remains of the cell-contents are often preserved.

The following analyses, which the authors have kindly permitted me to reproduce, are from a forthcoming paper by Miss M. C. Stopes, D.Sc., and Mr. D. M. S. Watson:- 


\begin{tabular}{|c|c|c|c|}
\hline & $\begin{array}{c}\text { Seam near } \\
\text { Bacup. Upper } \\
\text { Foot Mine. }\end{array}$ & $\begin{array}{c}\text { New Hori- } \\
\text { zon ar } \\
\text { Stalybridge. }\end{array}$ & $\begin{array}{l}\text { Burntisland, } \\
\text { Lower Car- } \\
\text { boniferous. }\end{array}$ \\
\hline Calcium Carbonate, $\mathrm{CaCO}_{3}$ & 51.188 & 87.827 & 80.192 \\
\hline Magnesium Carbonate, $\mathrm{MgCO}_{3}$ & 42.820 & 6.212 & 3.967 \\
\hline Ferrous Carbonate, $\mathrm{FeCO}_{3}$ & 2.342 & 1.026 & 0.825 \\
\hline Ferric (?) Oxide, $\mathrm{Fe}_{2} \mathrm{O}_{3}$. & - & & traces \\
\hline Manganous Carbonate, $\mathrm{MaCO}_{3}$ & $0.52 \mathrm{I}$ & 0.853 & I. 146 \\
\hline Alumina, $\mathrm{Al}_{2} \mathrm{O}_{3}$. . & traces & traces & traces \\
\hline Calcium Phosphate, $\mathrm{Ca}_{3} \mathrm{P}_{2} \mathrm{O}_{8}$. & 0.525 & traces & traces \\
\hline Iron Pyrites, $\mathrm{FeS}_{2}$ & 0.339 & 1.430 & $\cdots$ \\
\hline Silicate of Alumina (Clay) & O. I I 9 & 0.000 & $10.492^{1}$ \\
\hline Carbonaceous Matter & 1.855 & 2.579 & $3.05 \mathrm{I}$ \\
\hline \multirow[t]{2}{*}{ Free Moisture } & 0.264 & O. I 00 & 0.305 \\
\hline & 99.973 & 100.027 & $99.978^{2}$ \\
\hline
\end{tabular}

The carbonaceous material in these analyses is specially interesting, because it represents the actual tissue preserved in the petrifaction. In some silicious specimens, however, the organic substance has entirely perished, and the cell-walls are represented by a system of minute crevices in the matrix. Though all the essential features of the structure may be thus marked out, they may still be very difficult to see. In such cases M. Renault made use of stains, by which the cracks representing the cell-walls were injected. He thus obtained a coloured image of the structure, and so for the first time succeeded in staining a fossil

1 Taken together with all the inorganic residues.

2 The figures are practically percentages, according to weight. The first two columns give the analyses of "coal-balls" from the Lower Coalmeasures of Lancashire. The third column relates to the plant-bearing calcareous deposit near Burntisland, in Scotland, at a much lower horizon. The most important variation is in the amount of Magnesium Carbonate, which in many of the coal-balls is nearly equal to that of the Calcium Carbonate. 
section. Other substances, such as calcium sulphate and phosphate, have played a part in petrifaction, and so too, among organic products, has amber. In a few cases, fine clay has penetrated vegetable substances sufficiently to cause an effectual petrifaction; one important specimen, to which we shall have occasion to refer, is preserved in this way (see Chapter IV. p. I07).

The calcified remains of the English Coal-measures occur largely in the form of calcareous nodules or coalballs, stony masses which are found in certain localities, especially in Yorkshire and Lancashire, in the actual productive coal-seams, and also in the "roof" above them. The former represent, as it were, parts of the raw material of coal which have been saved by petrifaction from carbonisation, and have consequently retained their structure. These nodules are literally crowded with vegetable remains of all kinds. The calcareous material, of which these nodules are formed, may have been derived from the shells of marine Mollusca, which lived and died on the old forest ground when sunk once more beneath the sea, or the lime normally contained in seawater may have sufficed.

We can form a good idea of the sort of material which these nodules contain, if we notice the deposits of vegetable debris left on the banks of a tidal river. There we find miscellaneous fragments of plants heaped together in utter confusion, bits of reeds and rushes, rhizomes of water-lilies and aquatic grasses, twigs and scraps of bark from river-side trees, seeds, nuts, and cones. If we imagine a handful of such a conglomeration, saturated and fixed by some petrifying substance, 
-we shall have a very fair idea of the kind of material a coal-ball consists of.

The question whether coal was formed in situ in the actual forest itself, or from vegetable drift carried by currents to a distance, has been much disputed. The accumulations represented by the nodules in the coal must have been formed within the forest region, for the remains that they contain are penetrated in all directions by the rootlets of the trees which grew there. The roof-nodules, however, contain drifted fragments.

Coal-balls of this kind are limited to certain horizons, and are by no means of general occurrence, even in the Lancashire and Yorkshire district. Naturally, these stony lumps do not improve the value of the coal, and unfortunately for the palæobotanist, the mines which produce them tend to go out of working. At Shore Littleborough, in Lancashire, however, a mine has recently been reopened by the owner, Mr. W. Sutcliffe, F.G.S., for the sake of the petrifactions in which this locality is peculiarly rich.

For the purposes of the botanist, the petrified remains showing structure are the most important, and will form the main basis of our work, though it is always necessary to correlate them, as far as possible, with specimens which exhibit the external characters.

In the classification of recent plants, systematic botanists, so far at least as the Flowering Plants are concerned, are accustomed to rely chiefly on the morphology of the reproductive organs, and usually on their more external, as distinguished from their microscopic features. Such characters, however, are often absent in fossil 
specimens, and it becomes necessary to make use of other means of discrimination. In the case of the Cryptogams, which play so important a part among plants of the earlier periods, few conclusions can be drawn, even where the fructifications are preserved, without the use of microscopic characters. Still more is this the case when vegetative organs alone are preserved. Among the plants of the more ancient formations, necessarily very remote from any now living, little reliance can be placed on the mere external vegetative characters, while experience has shown that anatomical structure affords a much more trustworthy clue, when interpreted with proper care and judgment. Hence the study of the more minute structure, which is beginning to take a more prominent place, even in recent taxonomy, is relatively of far greater importance when we are dealing with fossil specimens. The most favourable cases for investigation are of course those in which the fructification is itself well preserved, and, fortunately, specimens of this nature are tolerably frequent.

In selecting examples of fossil plants for our consideration, I propose to begin with the Vascular Cryptogams. It is among these plants, together with the Fern-like Spermophyta and the Gymnosperms, that palæobotany has so far made its most important contributions towards the completion of the natural system, and to these Sub-kingdoms our studies will be devoted. As we proceed we shall find that the data afforded by the study of fossil plants demand considerable modification of the current system of classification. 


\section{CHAPTER II}

EQUISETALES-VEGETATIVE STRUCTURE

Calamites; Arthrodendron; Calamodendron; Protocalamites

I. The Calamarieae.-We know that among living Pteridophyta we can distinguish three great classes or phyla: the Ferns, the Lycopods, and the Horsetails. The last-mentioned group, though manifestly quite as distinct a stock as the other two, is now represented only by the single genus Equisetum, the species of which exhibit but small variety of structure. We might naturally suppose that in Equisetum, a group at once so isolated and so limited, we have the last surviving remnant of a once more extensive family. Fossil botany affords the most remarkable proofs of the truth of this hypothesis, and indeed shows that in the Carboniferous period the Horsetail stock was among the best-represented divisions of the Vegetable Kingdom. In fact, we may safely say that any adequate knowledge of the Equisetales must be derived to a much greater extent from the study of the extinct forms than from that of the few surviving representatives. In saying this, I am assuming that all the Palæozoic plants known as Calamarieae were of 
Equisetaceous affinities. Though at one time some botanists hesitated to accept this conclusion, we shall find that it is now supported by irresistible evidence. It is a matter of indifference whether, with Zeiller, we name the whole group Equisetineae, after its sole living representatives, or term it, with Endlicher, Calamarieae, after its more important fossil members. The form Equisetales will be adopted in this book, as indicating a group of higher than ordinal rank.

Many of the Calamarieae attained the dimensions of trees. It is not possible to give the complete measurements of any specimen, but the following facts may afford some indication of the size attained. Mr. G. Wild found in the roof of a coal-mine in Lancashire a medullary cast of a Calamite 30 feet long; the diameter of the pith amounted to about 6 inches in the thickest part. This cast must have represented a portion only of the main trunk. In some of M. Grand'Eury's specimens the cast of the pith is over a foot in diameter; if the whole tree were in proportion, it must have been of an immense size. In other specimens of his, a height of 9 feet from the base scarcely takes us above the region where the roots are given off. M. Grand'Eury estimates the height of the stem in many of these Calamarian trees at from 20 to 30 metres. $^{1}$

As already mentioned, the most common mode of preservation of Calamites is in the form of casts of the medullary cavity (see Figs. 2 and 3 ). The marks which they show correspond, not to any features of the external surface, but to the print of the inner

${ }^{1}$ Flore carbonifere du Departoment de la Loire, 1878, p. 29; Bassin houiller du Gard, I89o, p. 210. 
surface of the wood. Hence the superficial resemblance of these specimens to the ribbed stem of an Equisetum is fallacious, except that in both cases the marks on the surface are related to the course of the vascular bundles. In some specimens the tissue of the stem surrounding the medullary cast is preserved, and the true cortical surface shown. The latter is either smooth, or, if ribbed, the ribs do not correspond to those of the

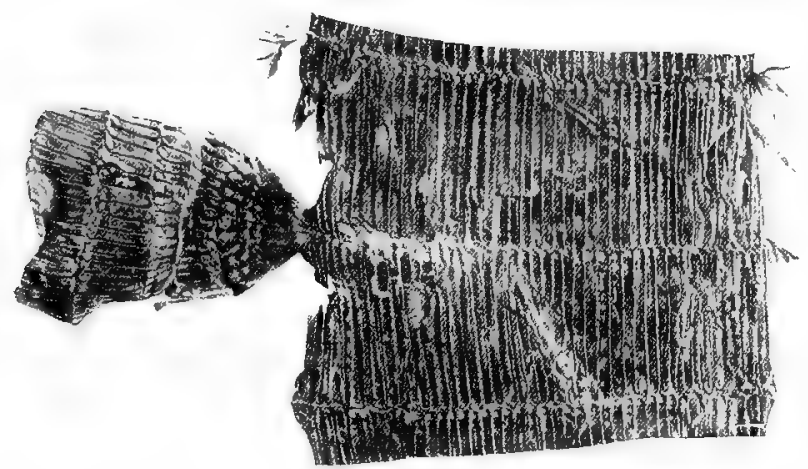

FIG. 2. - Calanites Suckoziii. Medullary cast, showing three nodes, on one of which the cast of a branch is borne. Below each node, and between the furrows, the prints of the infranodal canals are seen. About ${ }^{2}$ of natural size. After Stur.

medullary casts. ${ }^{\text {I }}$ The characters which first suggested Equisetaceous affinities having proved to a certain extent deceptive, the whole question had to be reconsidered, and the systematic position of these fossils has now been determined by arguments of quite a different kind, drawn from the fructifications and from the anatomy of specimens with their structure preserved.

1 The external surface of the zoood, however, in decorticated pertritied specimens, is sometimes ribbed, and may bear a deceptive resemblance to that of a medullary cast. 
The most conspicuous markings on a Calamitcan cast consist of longitudinal ridges and furrows, the former usually broader than the latter. The specimens are

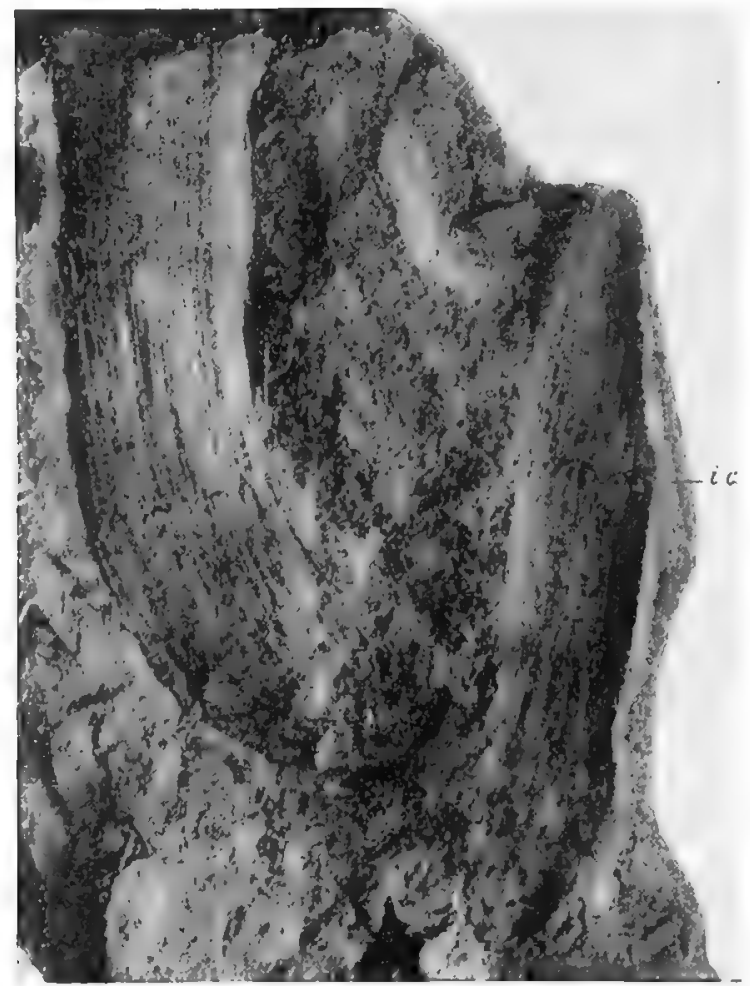

Fig. 3.-Calanites Suckoziz. Medullary cast, learing the cant of a hanch larger than that of the main stem. i.c., the pruts of the infranodal canals below a rulle. 3 of natural size. From a photograph by Mr. R. Kidston, F.R.S.E., taken from a specimen in his collection, found at the Oaks Colliery, liarnsley; Midule Coalmeasures.

distinctly jointed, the joints being marked by zigzag commissural furrows. It has always been recognised that these joints represent the nodes. Often, but not in- 
variably, the ridges and furrows of successive internodes are alternate with one another. Many of the specimens taper towards one end, which, as we shall subsequently show, corresponds to the base of the branch (see Fig. 2). Above the nodes we often find more or less circular scars, of relatively large size, which there is reason to believe mark the position of the lateral branches. In well-preserved casts it is usual to find a small circular or elliptical elevation on the surface of each ridge, just below the node (see Fig. 2, Fig. 3, i.c.). In most of these fossils the tissue of the stem enclosing the cast has become reduced to a comparatively thin coaly rind. In a few cases the anatomical structure of the wood and the cast of the pith are preserved in the same stem, ${ }^{1}$ and such specimens afford the best evidence for the identification of the two classes of remains. We will defer a full explanation of the markings on the cast until we have considered the anatomical structure.

2. The Stem of Calamites.-Petrified specimens of the various parts of plants belonging to the Calamarieae are common in the calcareous nodules of the Lower Coal-measures of Britain and among the silicious remains in the Upper Coal-measures and Permian of France, as well as at other horizons. The anatomical structure of all the organs has thus become known, though the correlation of the fragmentary remains has presented great difficulties.

We will now go on at once to the anatomical description of the first type to be considered in detail,

1 See, for example, Williamson, "Organisation of the Fossil Plants of the Coal-measures," Part i., Phil. Trans. Roy. Soc. 1871, Plate xxui. Fig. 21 . 
namely the genus Calamites. Included in this group there are many so-called species, though they are very difficult of distinction. As to the sense in which the name Calamites is used here, the characteristics of the genus will become evident as we go on, and I will only mention now that Calamites, as the name is employed in the present book, is equivalent to the Arthropitys of many palæobotanists, especially in France.

If we examine, by means of sections, the ordinary form of stem of a typical Calamite in the petrified condition, with well-preserved structure, we find the following characters: the pith is generally hollow, only its outer zone being preserved, and the definite internal limit which we often find to this persistent zone, leads us to believe that the pith was fistular during life, and that the cavity is not merely the result of decay. In Fig. 4 part of a transverse section of a Calamitean stem is shown. The pith, as usual, was hollow, but only the persistent layers of the external part are represented. Around the pith is a ring of collateral vascular bundles; here, as in the great majority of specimens, a considerable mass of secondary tissue has already been formed, so that each of the bundles has assumed a more or less regular wedgelike form. On the inner limit of each, we find, with the rarest exceptions, a definite canal, so that the whole appearance recalls very much that of a section of the stem of one of the living Equiseta. The question whether this appearance indicates a real identity of structure is one which we shall have to consider presently. In most specimens everything outside the 
wood has perished, but in a minority the cortex is preserved (see Fig. 4).

We will defer for the moment the consideration of the wood, which we will take more in detail afterwards, and pass on to the cortex. This consists of two zones, the inner formed of a rather thin-walled tissue, some cells in which contain very dense black carbonaceous

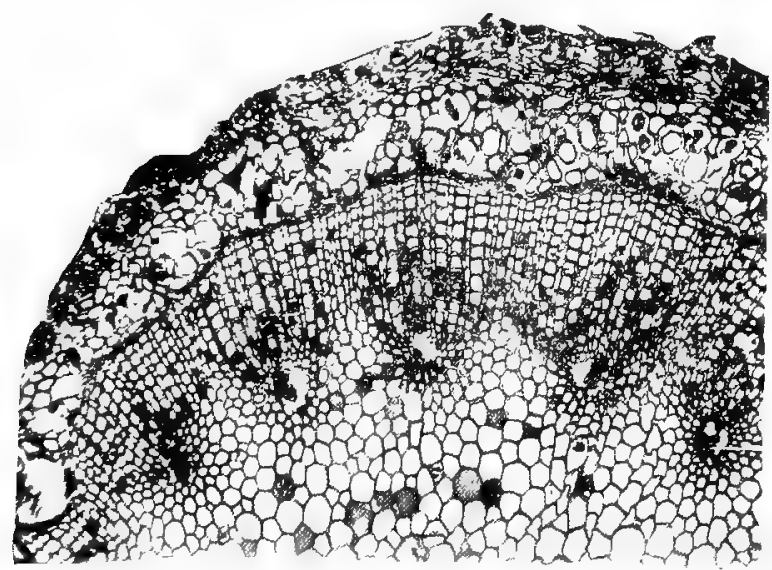

FIG. 4.-Calamites, sp. Part of transverse section of a young stern, showing pith, cortex, and five vascular bunrles, each with a canal at its inner edge. In some of the canals remains of the spiral tracheides can be seen. Beyond the secondary wood, and next the cortex, are traces of the phloëm. $X$ about 40 . From a photograph by Prof. J. B. Farmer. Will. Coll. ${ }_{553}$.

matter, and have been supposed to represent secretory organs, while the outer zone consists of smaller cells, with thicker walls. In some exceptional cases we find in this zone regular fibrous ribs alternating with parenchymatous bands. In fact, we have, in such specimens, very much the same mechanical arrangement as we find in the stems of recent Equisetaceae. In a few instances we have been so fortunate as to find stems 
preserved at the very commencement, or even before the commencement, of secondary growth, as shown in Fig. 5 . This is a comparatively rare stage to find, and when it is found, it is nearly always in a small twig. The larger stems of Calamites are rarely, if ever, met with at so early a stage of development. In a twig in this early condition, before secondary thickening has begun, the pith is often persistent (though fistular in the specimen figured), and round it we find a ring of

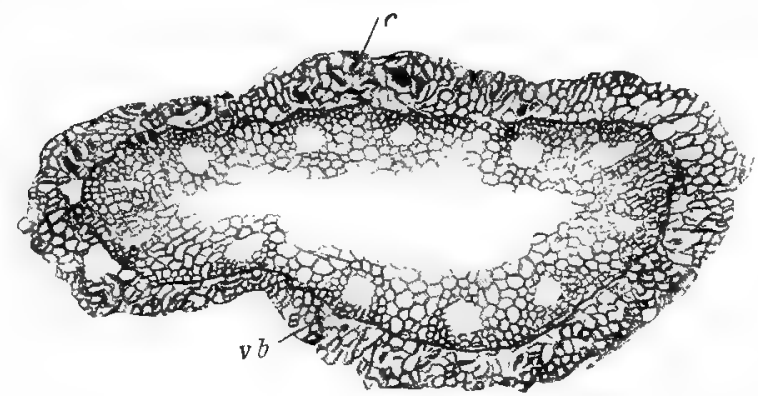

FIG. 5--Calcunites, sp. Transverse section of a very young twig, showing primary structure. $C$, cortex; $a b$, vascular bundles, of which there are twelve, each with its canal. $\times$ nearly 40. Phil. Trans., W. and S. Will. Coll. 156r.

primary vascular bundles, in which the wood is but little developed, and then the cortex. The whole structure is strikingly like that of the stem of an Equisetum. ${ }^{1} \quad$ Now one of the most important questions to be settled, bearing on the comparison with recent Equisetaceae, is this: Are these canals in Calamites really homologous with the carinal canals of an Equisetum, or are they of a different nature, perhaps, as some observers formerly thought, representing the phloèm?

It has been observed that, in many cases, in the

${ }^{1}$ Cp. Scott, Structural Botamy, Part II. Fig. 39, showing the transverse section of a small stem of Equisetum arvense. 
transverse section of a stem, the canals are not perfectly empty, but that they contain minute rings adhering to their edges, as indicated in Fig. 4. This suggests very strongly the position of the annular and spiral tracheides in Equisetum, which are often found within the carinal canal. To determine the true state of the case, however, a very detailed examination was necessary. There are now many sections showing these canals quite clearly, and proving that they contain the firstformed woody elements, or protoxylem, of the vascular bundles.

Fig. 6 represents a radial section passing through the canal of one of the bundles. On the inner side of the canal is pith; on the outer side wood. We notice that the canal is to a great extent

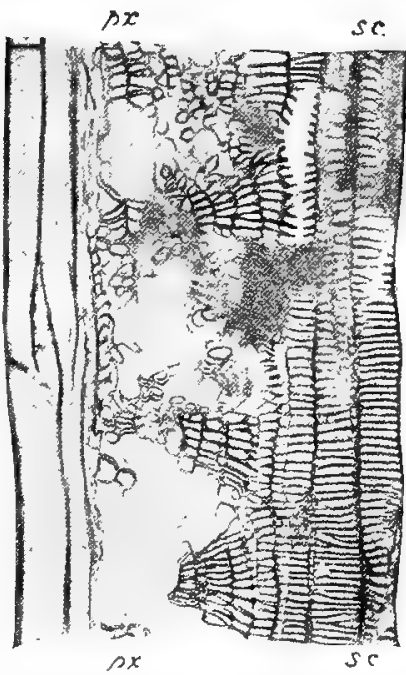

FIt: 6.-Calctmites, sp. Part of radial section through primary wood. $\not x x$, disorganised spiral and annular tracheides in the canal; sc, scalariform tracheides of the more external primary wood. On the left is the pith. $x$ about 160 . Phil. Trans, W. and S. Will. Coll. $20 \mathrm{~A}$. occupied by the disorganised tracheae. It is a point of some importance that the disorganisation is found to be greatest on the inner side of the canal, while, as we approach its outer edge, the tracheae become more continuous. We know that the disorganisation of the tracheae is constantly greatest in that part of the primary wood which is differentiated before the growth in length is completed. Hence we may infer that the 
innermost elements, being the most disorganised, were the earliest formed ; and we thus obtain a proof that the development of the primary wood was strictly centrifugal.

The elements of the primary wood, other than those in the canal, present no special interest. We find the spiral and annular tracheae of the protoxylem replaced by other elements (scalariform or pitted) as we get beyond the canal. I have spoken of these bundles as collateral. In the very best preparations, we can satisfy ourselves that on the inner side of the vascular bundle there are no traces of phloëm; the canal abuts directly on the pith. On the other hand, in very fortunate cases, where the preservation is exceptionally good, we find, on the outer side of the wood, strands of delicate tissue made up of small thin-walled elements; these we can only interpret as phloëm-groups; we find, further, between these groups and the wood, remnants of cells of the cambium itself. Some traces of these tissues will be recognised in Fig. 4, immediately outside the secondary wood. ${ }^{1}$

We thus see that the structure of the young stem of a Calamite is in all essentials similar to that of an Equisetaceous stem. Surrounding the usually fistular pith, interrupted at every node by a persistent diaphragm (see Fig. 7), we have a ring of collateral vascular bundles, with centrifugally developed wood; at the inner border of each is a canal containing the disorganised tracheae of the protoxylem. ${ }^{2}$ Thus, the Calamite, so

1 For special figures of the phloëm and cambium, see Williamson and Scott, "Further Observations on the Organisation of the Fossil Plants of the Coal-measures," Phil. Trans. vol. 185, B, I894, Plate lxxviii. Figs. I2-I4.

2 In a Calamarian stem of Lower Carboniferous age, from the Burntisland 
far as anatomy goes, is simply an Equisetum with secondary thickening. In order to carry the comparison further, we must settle one or two points, especially the course of the vascular bundles. In Equisetum itself their course is exceedingly simple: a single vascular bundle enters the stem from each leaf, and

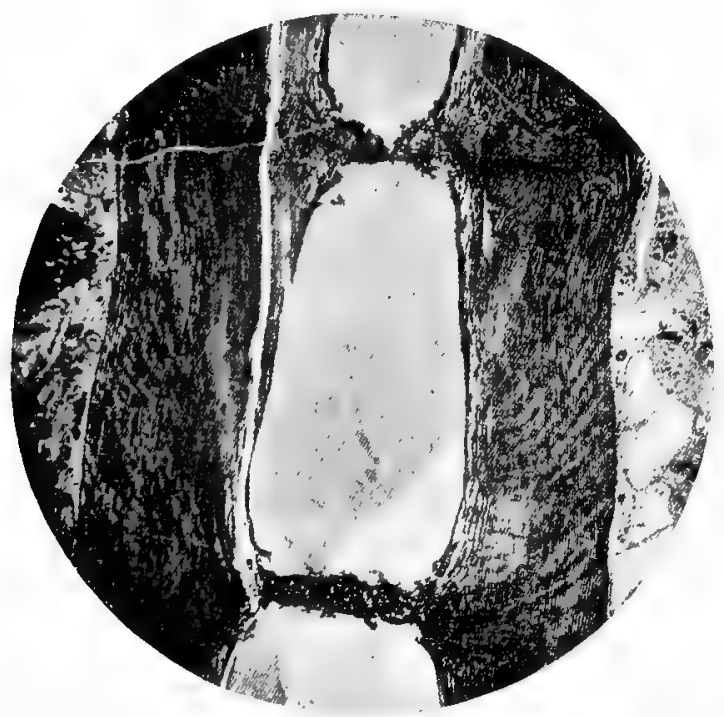

FIG, 7.-Calamites, sp. Radial section of a decorticated stem, with fairly thick wood, showing the fistular pith, crossed by diaphragms at the nodes. $\times 9$. From a photograph. Phil. Trans., W. and S. Will. Coll. 1937.

passes straight down through one internode only. At the node next below, the bundle forks, and its branches attach themselves to the adjacent alternating vascular bundles passing out at that node. This type is often

deposits, named provisionally $C$. pettycurensis, groups of centripetally developed wood are present on the inner sicle of the canals. This is a point of interest, as tending to connect the Calamarieae with the Sphenophyllales, in which the primary wood is centripetal (see pp. 36 and 89). 
found in the Calamites also, but on the whole, the bundle-system of the latter is less regular and more complicated. Sometimes the bundles of successive internodes are not alternate, but run on in the same straight line. Where this is the case, the forks of the bundle, as we trace it down, instead of attaching themselves to the alternate bundles at the node below, converge again on the other side of the outgoing leaftrace, so as to form a loop, through which the trace passes out, and the bundle below the loop continues in the same straight line as before. This straight course of the bundles and absence of alternation between those of successive internodes, is specially characteristic of one very ancient type of the Calamarieae, namely the genus Bornia or Archaeocalamites, which occurs in the Lower $\dot{C}$ arboniferous and the Devonian formation (see p. 70).

Secondly, we may find a greater complexity in the vascular system. In this case the bundle may run down through more than one internode, and pass on to the second node below (Fig. 8). It follows that here the number of vascular bundles in each internode may be double that of the leaves in a whorl. Where a bundle passes between the outgoing traces at the node, it may either be connected with them by lateral strands or remain free. The former case is illustrated by Fig. 8, from a large and perfectly preserved stem. We may therefore express the general characteristics of the Calamarian vascular system by the statement that the whole arrangement is of the type of Equisetum, but more varied, and sometimes more complex. I may further mention that these variations may even occur 
side by side in different parts of one and the same specimen.

The following considerations serve to identify the leaf-traces. We constantly find in all specimens of Calamites, that at every joint a whorl of small and

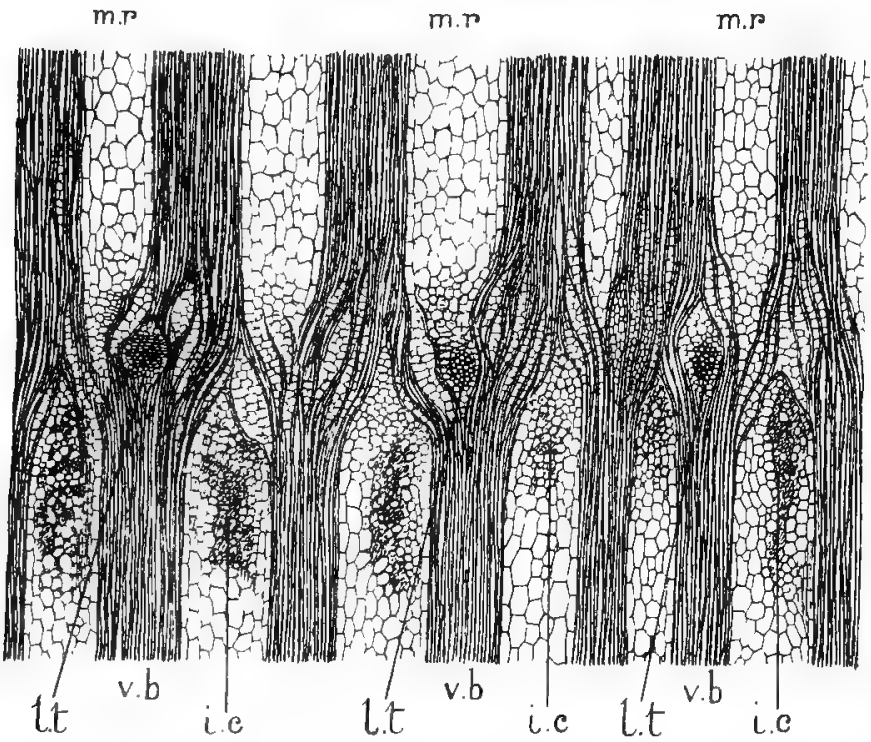

Fig. 8.-Calamites communis. Tangential section of wood, passing through a node, and cut near the pith. $v .6$. , Vascular bundles of the stem. $4 . t$. , leaf-traces cut transversely as they turn outward at the node. Note that they are only half as numerous as the bundles of the stem. m.r. primary medullary rays. i.c., smallcelled tissue of the rays below the node, corresponding to Williamson's "infranoda] canals." $\times$ 12. S. Coll. 897 . (G. T. G.)

uniform bundles passes out, and though it is only in the very rarest cases that we are able to trace out these bundles continuously into the leaf, yct there is no doubt that these outgoing bundles are really the lcaftraces. For one thing, their arrangement precisely corresponds with the arrangement of the leaves, as 
shown in certain specimens which have retained their foliage, and we know that each of these whorled leaves actually received a single bundle from the stem (see Fig. I 2). Secondly, the outgoing bundles form the direct continuation of those which traverse the internode below, precisely as is the case with the leaf-traces of Equisetum. And then again we have the argument of exclusion. If these bundles are not leaf-traces, what are they? They must in that case be either traces of branches or of roots. But as we shall see below, the connection of these organs with the stem is now well known, and is quite independent of the bundles in question. By all these considerations the interpretation of these outgoing bundles as leaf-traces is now fully 'established. If a section be cut tangentially through the wood, it intersects these bundles transversely (see Figs. 8 and 9). They also appear (cut longitudinally) in the transverse sections of the stem, which pass exactly through a node. A radical section in the plane of the outgoing strand shows that the primary bundle passes out as a whole on its way to the leaf, and can be followed through the secondary wood. The whole course of the leaf-traces is thus made clear from every point of view. ${ }^{1}$

The next point to be considered is the structure of the secondary wood. We find that the wood as a whole is divided up into the bundles, and the principal rays between them. The behaviour of these rays in passing through the wood is a matter of some importance, for great emphasis has been laid on it in discriminating

1 For further illustrations of all these points, see the memoir by Williamson and Scott, above cited. 
species. It is obviously desirable to aim at establishing species on anatomical lines, and if possible to correlate them with the various forms of casts. A great many attempts have been made in that direction, but at present with imperfect success. We find, however, the following variations, whatever may be their taxonomic value. In comparatively few cases we can trace the ray in undiminished width throughout the whole thickness of the wood. That seems to be the characteristic of the type which the French authorities call Arthropitys bistriata, a form of Calamites. Then we may have the opposite extreme; the ray may come to an end almost immediately, and thus be shut off by interfascicular wood; or, again, it may gradually die out, becoming encroached upon laterally by the wood, and cut up by strands of intercalated tracheae. This last is the commonest form among English Calamites (Calamites communis, Binney). It is not very easy to determine how this mode of enclosing a ray by the wood was brought about, because the tracheae are very long and the ray-cells which they replace very short, and yet the radial arrangement of the elements is not disturbed. The only explanation appears to be that the growth must have taken place in the cambial cells themselves, rather than in their products.

I have hitherto spoken of tracheae, using the word in its widest sense, so as to leave open the question as to the true nature of the woody elements. First of all, were they tracheides, derived from single cells, or vessels, arising by cell-fusion? We constantly find that they have tapering ends, with no evidence of perforation; but there is this difficulty, that every now and then 
there are distinct traces of transverse walls in these elements. This, however, is very inconstant, and where these apparent transverse walls appear, they seem to be perfect septa, and not merely annular ridges such as we are accustomed to find in vessels, marking the limits of their constituent cells. I am disposed to think that the elements of the wood in Calamites were occasionally septate, unlike true tracheides, but there is no proof that they ever arose by cell-fusion, and we cannot therefore regard them as vessels in De Bary's sense. There is evidence that the pits, which were either scalariform or of the rounder, multiseriate type, were closed.

The disposition of the pits is of some interest. Throughout the whole of the secondary wood they are limited to the radial walls. The general arrangement was thus very much like that in the Coniferae of the present day, and the mechanism of water-conduction must have been similar. The cells of the medullary rays have this peculiarity, that they are generally longer vertically than in any other direction, and thus the rays have not the muriform appearance which is general, though not universal, among recent plants. Some of the rays are very small, and may even consist of a single radial row of cells.

I have already given the principal facts about the primary cortex. In the few cases in which we find the cortex well preserved in an old stem, there is an enormous development of periderm, as shown by a specimen in the Williamson Collection, which has secondary wood two inches thick, and bark of even greater thickness. ${ }^{1}$

I Figured in Williamson, "Organisation of Fossil Plants of the Coal- 
Occasionally, in comparatively young stems, we find tangential divisions beginning in the inner cells of the cortex, and it is highly probable that this was the first commencement of the periderm-formation which attained such a great extent in the older stems. The trunks of the larger Calamites must have had a regular bark, like that of our forest-trees, but thicker than in most of the latter.

3. Branching.-The next question to be considered - is that of the branching of the stem. It is very common to find the bases of branches in connection with the main axis. The section represented in Fig. 9 is a tangential one, passing through the base of a branch, where it joins the primary wood, so that its tissues are shown in continuity with those of the stem which bears it. The insertion of these branches is very regular. They are always placed immediately above the node, and usually between two of the outgoing leaf-trace bundles (Fig. 9). Sometimes a branch may be nearly or quite as large as the main stem, repeating all the characteristics of the latter; in other cases we find lateral branches which are very small in comparison with the main stem ${ }^{1}$ such lateral shoots often occur in considerable numbers in a verticil. It is an interesting point that these little branches were in many cases abortive, as shown by the fact that we often find their bases completely enclosed in the wood. At the same time that this was proved for the English specimens, Renault

measures," Part jx., Phil. Trans. 1878, Part ii. Plate xx. Figs. I4 and $\mathrm{x}_{5}$; also in Seward's Fossil Plants, vol. i. Fig. 78.

1 The medullary casts shown in Figs. 2 and 3 illustrate these two cases. 
came to exactly the same conclusion independently, from the study of the French material. These observations show that very often the small lateral branches

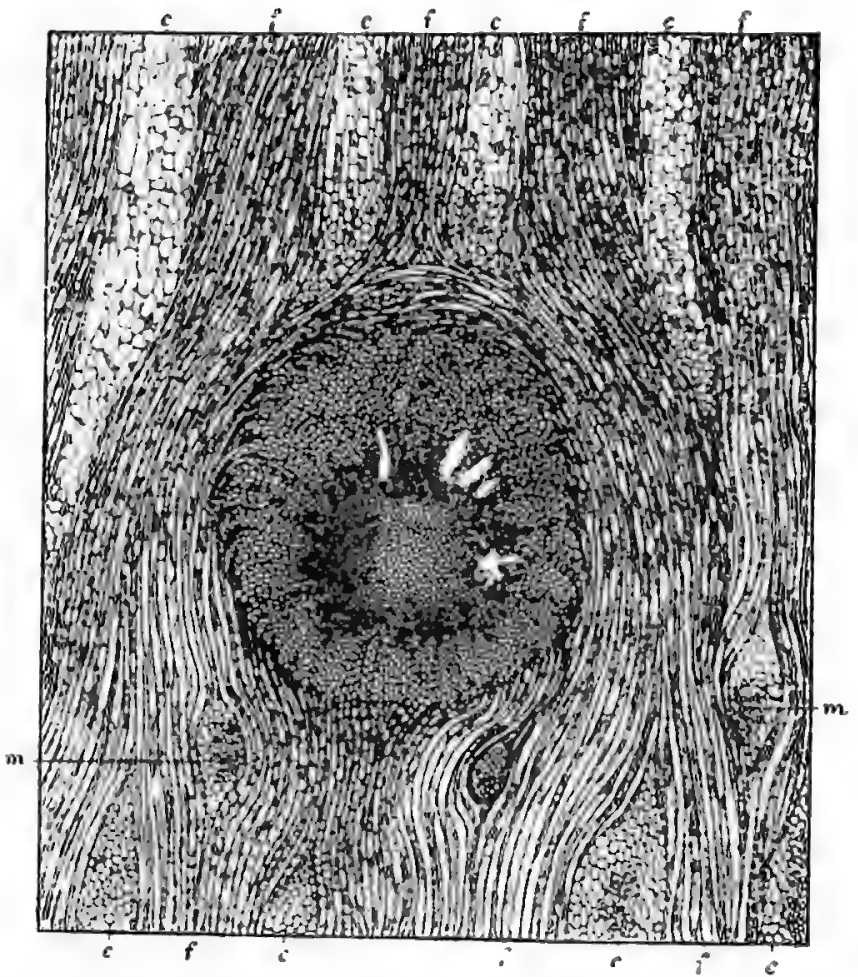

PIG. 9--Calamites commanis. Tangential section of wood, passing through a node, as in Fig. 8, but showing the base of a lranch, inserted between and above two of the leaf-trace bundles. $f$, vascular bundles of stem; $m$, leaf-traces; $c$, medullary rays. $\times$ 20. After Williamson, Phil. Trans. Will. Coll. go.

were cast off early, a fact which admits of two explanations. The branch may either have been abortive altogether, or, which is still more likely, it may have been caducous, forming a limitcd shoot of temporary duration, 
comparable to the spurs which bear the needles in Pinus.

The position of the branches with reference to the nodes and leaf-traces was precisely the same in Calamites as in the recent Equisetum. The pith of the branch tapered towards the point of attachment, so that its actual junction with the pith of the main stem was effected by a slender neck of tissue. This fact is shown quite clearly by sections of specimens passing through the junction of stem and branch, and explains one of the most characteristic forms of Calamitean casts, which in a great many cases are tapered towards one end. Figs. 2 and 3 each show the medullary cast of a branch in connection with that of the stem, and confirm the evidence, derived from sections, that the pith became gradually smaller towards the point of attachment. Some of the older observers thought that the tapered end was the apex, thus turning the specimen wrong way upwards. ${ }^{1} \quad$ The root-bearing base of the main stem was also tapered.

4. Other Types of Stem. - The type which I have been describing so far is, as I have already said, the Arthropitys of the French authors, and this is the least complex of the Calamarian stems. We have seen that the structure of the wood is, after all, very simple. It consists essentially of the tracheae and the medullary rays - including both primary and secondary rays. The differentiation is about on a level with

1 The proof that the pith tapers towards the base of the branch has enabled us to determine with certainty the upper and lower ends of specimens, a point otherwise by no means easy of decision. 
that of the simplest Coniferous woods of the present day, as, for example, that of the Yew.

There are certain other Calamarian types of stemstructure, some of which have long been distinguished. There is one form which became known to us by the observations of Williamson, who founded a new genus for it under the name of Calamopitys, but he afterwards let the generic distinction drop, although the type is quite distinct from the ordinary Calamitean structure already explained. The name Calamopitys is not admissible, as it had previously been employed by Unger in a different sense, ${ }^{1}$ and that of Arthirodendron has now been substituted. The Arthrodendron type of stem is a rare one. The wood, in the specimens known, is of no great thickness, and the primary bundles are widely separated by the principal medullary rays. The chief peculiarity is in the structure of the rays, which are formed, for the most part, of vertically elongated prosenchymatous cells, thus differing widely from the usual parenchymatous structure of these organs; but within these primary rays are little secondary rays of parenchyma, like those of the true wood. Arthrodendron has also some other peculiarities, but the complex rays suffice to mark it off from the ordinary Calamites.

There is another important type, not represented in England - that of Calamodendron,-which is the most complex of all (see Fig. Io). Here each of the principal rays consists of a middle band of parenchyma, more or less like an ordinary medullary ray, and on either side of this, separating it from the wood, is a broad band of fibrous prosenchyma, in which secondary rays occur. 
In fact, the principal rays are here much more complex in structure than the wood itself. The Calamodendron stems are especially characteristic of the Upper Coalmeasures and Permian of Central France.

This brings us to the question of nomenclature, on which I must say a word. Brongniart, in his earlier works, placed all the Calamitean stems then known to

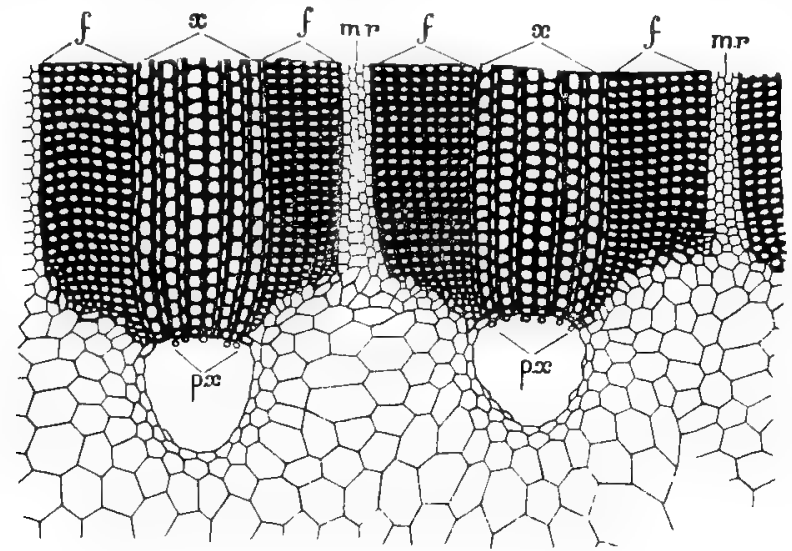

\section{$p$}

FiG. Io.-Calantodendron internedium. Part of transverse section of stem, showing inner portions of two vascular bundles, with secondary wood. $f$, pith : $p x$, protoxylem in canals of the bundles; $x$, fascicular wood, containing secondary rays; $f$, prosenchymatous parts of principal medullary rays; $m$, central parenchymatous portion of each ray. Magnified. After Renault.

him in the one genus Calamites, and believed them to be related to the Equisetaccae; subsequently he investigated specimens with the internal structure preserved, and in all clear cases of the kind he found a well-developed secondary wood. Wherever he found this, he thought he must have to do with a Dicotyledonous flowering plant of Gymnospermous affinities, for in those days Gymnosperms were usually included 
under Dicotyledons. Consequently, Brongniart was led to divide the Calamites into two groups: those which he supposed had no secondary growth, and which he therefore left under the old generic name of Calamites; and those which had such growth. The latter he transferred to Phanerogams, founding the genus Calamodendron for their reception. ${ }^{1} \quad$ Calamodendron was subsequently subdivided by Göppert into Arthropitys, with simple medullary rays, and Calamodendron proper, with the more complex structure which I have just described.

There is at present no evidence remaining that any Calamarian plant was without secondary growth. The Calamites supposed to be without secondary thickening have turned out to be simply medullary casts, from which the surrounding tissues have partly or wholly perished. The specimens with their structure preserved invariably possess secondary tissues, the oniy exceptions being excessively young twigs, and even these often show the commencement of the cambial growth (sce Fig. 5). At present the evidence is that all Calamites, so far as they are known to us, formed secondary wood and bast, and consequently this distinction of Brongniart's falls to the ground. We may therefore go back to the old name Calamites, using it as synonymous with the Arthropitys of the French authors, and retaining the genus Calamodendron in Goppert's restricted sense.

Another type of Calamarian stem is represented by Calamites pettycurensis, already referred to (p. 24). It

1 See Brongniart, Tableau des genres de végetaux fossiles, Paris, I849, pp. 47-50. Brongniart was also influenced by the occurrence of seeds among the branches of Asterophyllites, which he regarded as the foliage of Calamodendron. 
is interesting that this Lower Carboniferous spccies should be the only Calamite so far observed which has centripetal wood. The protoxylem is in the usual position, in or adjacent to the "carinal" canal, but in this case the development of the primary xylem proceeded in both the inward and outward directions, for each bundle possesses a considerable arc of centripetal

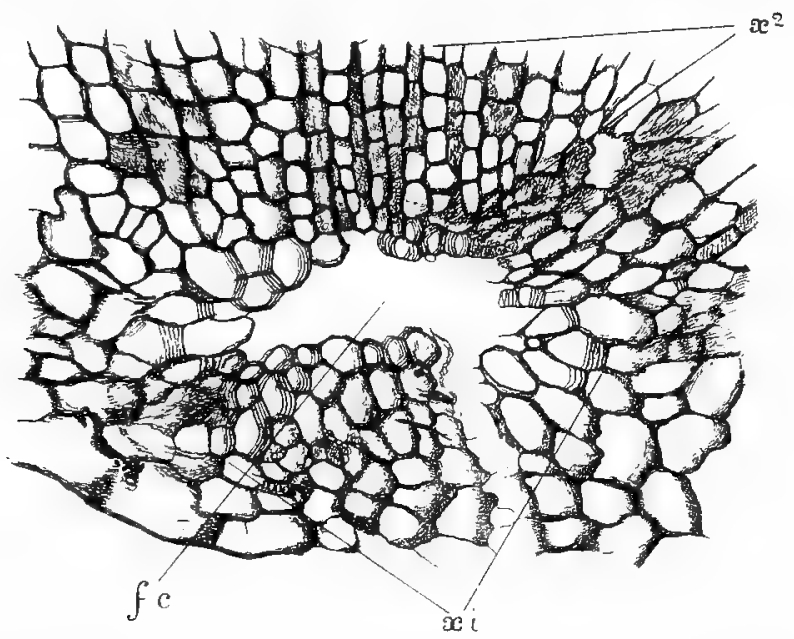

FIG. 11.-Calamites (Protocalamites) pettycurensis. Transverse section of the xylem of a vascular bundle in the stem. $f$, fascicular canal; $x^{2}$, secondary wood; $x i$, centripetal wood, on the inner side of the canal. $\times$ about 140. S. Coll. 1104. (G. T. G.)

wood on the side of the canal towards the pith (Fig. I I, xi). Dr. Lotsy has suggested to me that a new genus or subgenus, Protocalamites, should be founded on this form, and the proposal may be provisionally adopted, but it is possible that when the course of the bundles has been traced the species may prove to belong to Archaeocalamites (p. 70). The significance of the centripetal xylem as a character shared with other 
classes of Pteridophyta will be emphasised in later chapters.

5. The Leaves.-The leaves of the Calamarieae were in all cases arranged in whorls, and were usually of a simple acicular or lanceolate form, though in the genus Archaeocalamites they were forked (Figs. 30, 3I). It is often stated that the lcaves of the Palæozoic Equisetales differed from those of their later successors in being

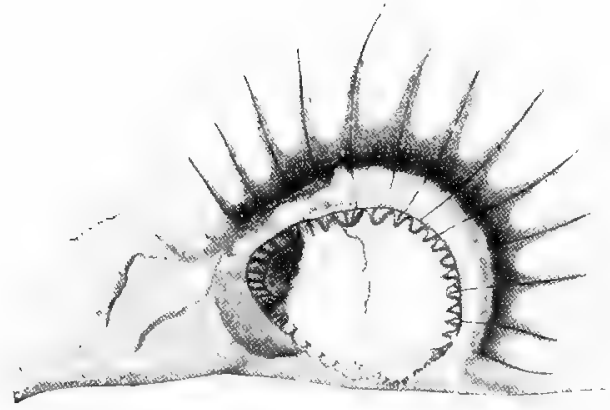

FIG. 12.-Calanites, sp. Transverse fracture through a node, showing leaf-sheath and free tips of leaves, each with its vein. Commissural bundles also shown. $\times$ about 2. From a specimen in the possession of Mr. Parker of Rochdale. (G. T. G.)

free, and not united to form a sheath. It is no doubt true that the free laminae were much more developed in the Calamaricae than in recent Horsetails, but in several cases there is good evidence for the presence of a coherent sheath at the base. This is clearly shown in Fig. I 2, which represents the node of a Calamite, exposed in transverse fracture on the surface of the matrix. The greater part of the whorl of leaves is shown, and they are evidently united into a continuous 
sheath at the base. Each leaf is traversed by a vein, and further to the interior the commissural vascular bundles of the node are visible. It is possible that in many cases the sheath became split up as the stem increased in thickness.

Immediately below a node the cortex of the stem shows in some specimens a number of prominent ribs, corresponding to the bases of the verticillate leaves

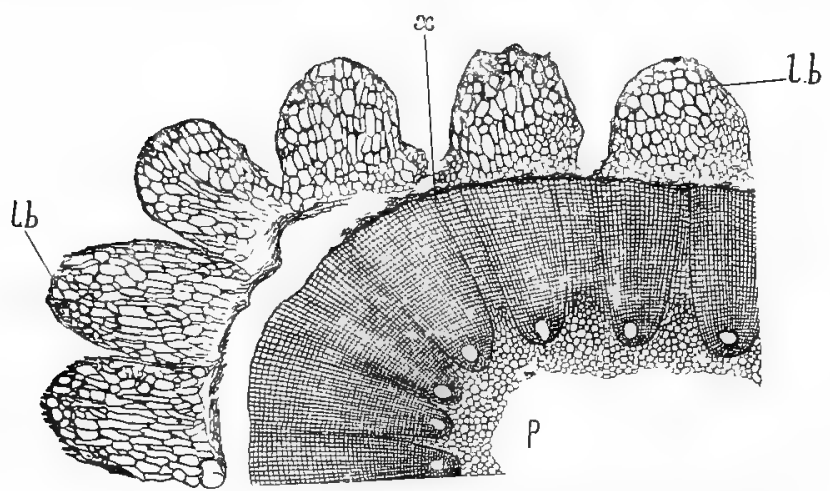

Fig. 13.-Calanites, sp. Part of transverse section close to a node, showing the prominent leaf-bases, 2.b. $x$, secondary wood ; $p$, fistular pith. Magnified. From a section lent by the late Mr. J. Butterworth of Shaw. (G. T. G.)

which sprang from the node. This is well shown, in transverse section, in Fig. I $3 .{ }^{1}$

As regards the anatomical structure of the leaves of the Calamites there is comparatively little to be said. In Calamites itself the simple acicular leaves were each traversed by a single nerve (see Fig. I 2); in some of the other forms, as in Calcanocladus, according to

${ }_{1}$ For the use of the specimens illustrated in Figs. 12 and I3 I am indebted to the late Mr. John Butterworth of Shaw.

2 The foliage of Calamarieae will be further described, as regards its outward aspect, in the following chapter. 
Grand'Eury, they appear to have had several parallel nerves, but nothing is known as to the internal structure of these specimens. The late Mr. Hick of Manchester ${ }^{1}$ published an interesting paper on the structure of the leaves of Calamites, in which he gave a full account of the anatomy of the small leaves which

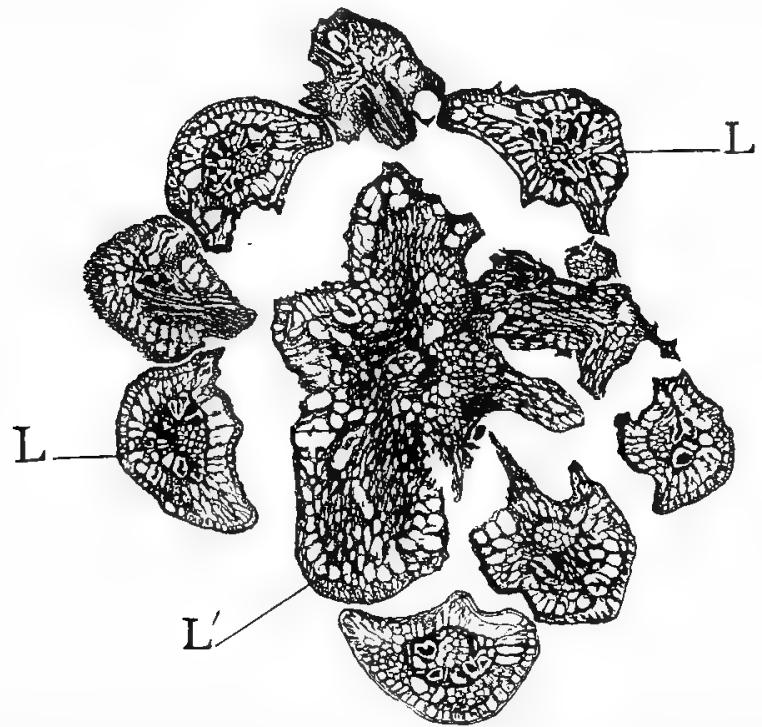

F1G. I4.-Calanites, sp. Transverse section of a bud at the apex of a small twig, showing axis, with parts of two whorls of leaves. $L$, a leaf of outer verticil ; $L$, leaf of inner verticil, in connection with stem. $\times 3^{\circ}$. S. Coll. 17 1. (G. T. G.)

were borne on the most minute twigs. In various cases the axis bearing these appendages clearly shows the structure of Calamites. We know, from the evidence of impressions, that leaves of much larger dimensions were borne on the stems and more considerable

1 Mem. and Proc. Manchester Lit. and Phit. Soc. ser. iv. vol. ix. p. 179, 1895 . 
branches; the larger leaves, however, are practically unknown in the petrified condition. In Fig. I4 a tranverse section of a bud, showing a number of the leaves arranged in whorls around the axis, is represented, They have the same form in transverse section as Pinus leaves. In the middle there is a collateral vascular bundle, usually with the wood alone preserved. The bundle is surrounded by a pericycle of thin-walled parenchyma, and outside this we find a sheath of large cells containing carbonaceous matter, perhaps derived from some product of secretion. Long cells, radiating out from the central cylinder, form a definite palisadetissue, presumably the assimilating layer; at the periphery is an epidermis, in which the stomata are sometimes clearly shown. This is a perfectly simple and straightforward type of leaf, and it is sometimes very well preserved. There is thus no difficulty as regards the structure, in the case of the leaves, of very small size, which were borne on the slender twigs of Calamites. There is a great resemblance between the vegetative leaves and the bracts of Calamarian cones.

6. The Roots. - As regards the roots of Calamarieae, we are now in possession of a considerable stock of information. In Williamson's paper of $187 \mathrm{I}$ - the first of his Royal 'Society series-among the varieties of Calamites the author described some specimens which differed from the ordinary form, for they had a solid pith and no fascicular canals. In a later memoir he distinguished organs of this type under the generic name of Astromyelon. In the meantime Messrs. Cash and Hick had found some beautiful specimens with the 
cortex preserved, which they named Myriophylloides. These also were referred by Williamson to his genus Astromyelon.

The following are the chief characters of Astromyelon: it has often a persistent pith, though, in the larger specimens, it may have become fistular in the middle. In the specimens first described the pith is of relatively large size. It is surrounded by a ring of bundles, and we shall find there is good evidence that the development of their primary wood was centripetal, not centrifugal as in the stem. In almost all the specimens a thick zone of secondary wood is present. Most often the wood is decorticated, but when the cortex is present it has a very lacunar structure, containing a ring of large intercellular spaces. It is only in very good specimens that the phloëm is preserved (see Fig. I 5).

Now some of the smaller specimens, which used to be included in the Myriophylloides of Hick and Cash, have a very different structure from those just described. Some of them have no pith, and the groups of primary wood are very few in number (see Fig. I6). The structure of the cortex, however, is the same in all, and the extreme types are connected by a series of intermediate forms.

Renault, in 1885 , expressed his conviction that the French specimens, which he recognised as agreeing with Williamson's genus, were the roots of Calamites (his Arthropitys) and of Calamodendron, and he made out a strong case for his belief. ${ }^{1}$ His suggestion, however,

1 Renault, "Nouvelles Recherches sur le genre Astromyelon," Mem. Soc. Siz. Nat. de Saône et Loire, 1885. 
was not at once accepted, because he had not obtained the evidence of actual continuity at that time. Later

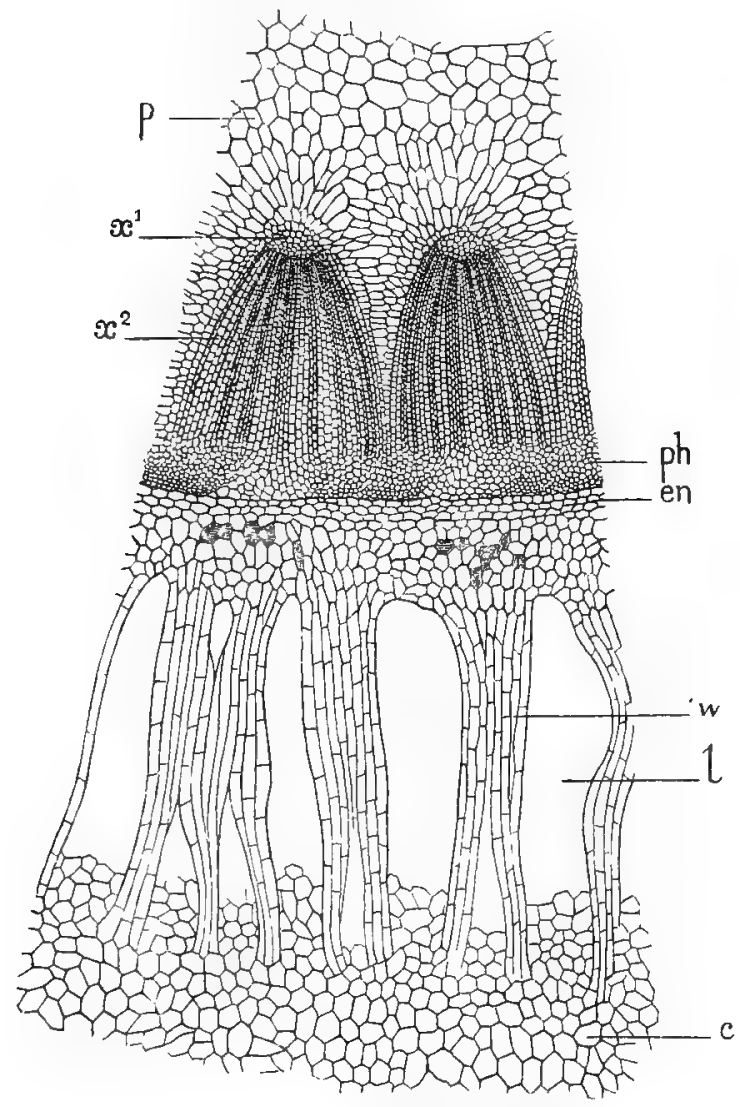

FIG. I5.-Calamites, sp. Part of transverse section of a large root. $p$, pith; $x^{1}$, primary centripetal xylem; $x^{2}$, secondary xylem; $p h$, phloëm; $e n$, endodermis ; $l$, lacunae of cortex; w, cellular walls separating them; $c$, outer cortex. Magnified. After Renault.

on-in I 893-Renault described certain beautiful specimens of Calamites, which afforded the proof required, for in them the Calamitean stem bears 
appendages in which the typical Astromyelon structure is evident. ${ }^{1}$ This evidence proved quite conclusively that Astromyelon was only an appendage of the stem of Calamites. Since then the connection between the two organs has also been clearly demonstrated in various specimens from the English Coal-measures.

The relation between the roots and the stem has recently been fully investigated by $\mathrm{Mr}$. Maslen, ${ }^{2}$ who finds that the roots, like the branches, were commonly inserted on the node, between two of the outgoing leaftraces (cf. Fig. 9); the roots, however, arise on a level with the leaf-traces, and not above them, and pursue a somewhat downwardly directed course in passing through the wood of the main axis.

The question whether these appendages were roots or branches had to be decided from the anatomy. In the first place, as already mentioned, the primary xylem was centripetally developed. On the inner side of each woody wedge we find in transverse section a little triangular group of tracheae, and this triangular group has always the smaller elements towards the exterior (see Fig. I 5, $x^{2}$ ). Radial sections prove that these external elements of the primary wood are spiral tracheae, and thus the position of the protoxylem is shown to be that characteristic of roots.

Another point of crucial importance is the arrangement of the primary xylem and phloëm groups; it is not often that such a point as this can be demonstrated in a fossil. We were able, in one or two favourable

1 Filore fossile du Bassin houiller d'Autun et d' Epinac, Part ii. p. Io6, Plate lii. etc.

${ }^{2}$ A. J. Maslen, "Relation of Root to Stem in Calamites," Annals of Botany, vol, xix. I905, p. 61 . 
cases, to trace the centripetal strands of xylem in a young root, and to find, alternating with them, groups of delicate tissue, which could only be interpreted as primary phloëm. Hence, in this respect also, the structure proves to be that of a typical root.

We further found that the bases of branches of Astromyelon are surrounded by a distinct cortex of their own, as they traverse the outer tissues of the parent organ. Hence they must have been endogenous in origin, thus agreeing with rootlets. Another important point is the entire absence of anything like nodes.

There is thus, on the whole of the evidence, no room for doubt that the old genus "Astromyelon" simply represents the roots and rootlets of Cala-

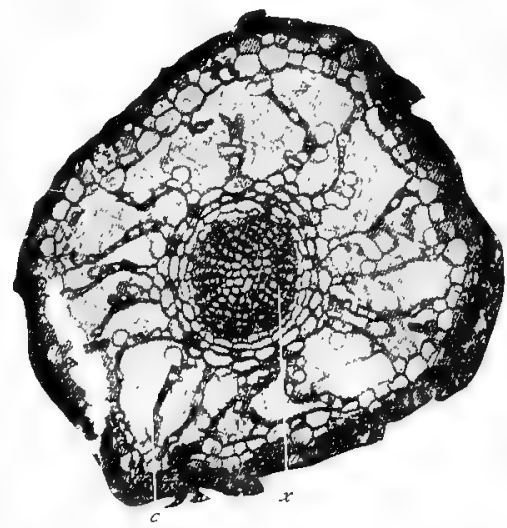

FiG. 16.-Calamites, sp. Transverse section on small tetrarch rootlet, showing wood $(x)$, with slight secondary growth, double endodermis, lacunar cortex $(c)$, and thickened exodermis. 4 25. From a photogiaph. Phil. Trans. W. and S. Will. Coll. I8go, A. mites. ${ }^{1}$ Other allied forms appear to stand in a similar relation to Archaeocalamites and Calamodendron.

The endodermis was evidently double, as in the roots of recent Horsetails; this is well shown in the small tetrarch rootlet represented in Fig. I6. The large intercellular spaces of the cortex were no doubt an adaptation for growth under water, or in wet mud.

1 Williamson and Scott, "Further Olservations, etc.," Part ii. The Roots of Calanites, Phil. Trans. vol. 186, B, 1895 . 
The cortex is bounded externally by a layer of cells with very thick outer walls, comparable to the exodermis of many recent roots (Fig. I6). In the older roots a periderm was formed, the external cells of which, as Dr. M. C. Stopes has shown, thickened their outer walls and replaced the primary protective layer.

We have now obtained a fairly good idea of the whole construction of a Calamarian plant, as regards its vegetative organs. We have a thorough knowledge of the structure of the stem in various types, and though much has still to be learnt about the comparative anatomy of the leaves, we now know almost the whole story of the structure of the roots and branches, and their relation to the stem.

7. The Medullary Casts.-One thing remains to be said before leaving the vegetative organs, in order to complete the anatomical explanation of the markings on the casts. We have already seen, as shown in the first illustrations to this chapter, that every Calamitean cast shows longitudinal ridges and furrows. It is quite evident that the furrows on the cast correspond to the vascular bundles. We have to imagine the soft tissues decayed, leaving only the woody tissues behind, so that each wedge-shaped strand of wood leaves its mark on the mineral matter filling the pith-cavity. Between the furrows thus produced we find the projecting ridges, corresponding to the medullary rays which had decayed. Ultimately the wood itself became reduced to a carbonaceous film, leaving the cast within visible.

On a well-preserved Calamitean cast, a little pro- 
jection is almost constantly found on each ridge, immediately below the node. ${ }^{1}$ Various explanations have been given of these projections, but a remarkable specimen in the Williamson Collection has settled the question. This specimen is a medullary cast of the base of a branch. It owes its interest to the fact that we not only find the little projecting bumps in their usual position, but that many of them are represented by regular spokes, radiating out for a long distance from the cast. Williamson found, in the specimens with internal structure preserved, that there was often a radial canal passing through the parenchyma of each principal medullary ray, near its upper end, which is sometimes dilated. These "infranodal canals," as he called them, extend through the entire thickness of the secondary wood. In other cases, where there is not a definite empty space, or canal, we still find that below the node the rays are dilated, their tissue in this part differing from that of the rest of the ray (see Fig. 8, i.c., and Fig. 9, c). The dilated, infranodal portions of the rays extend far out into the wood, even when the rest of the ray is bridged over by intercalated tracheae.

Williamson's explanation was that these canals, whether natural or, as is more probable, left by decay, had, like the pith itself, become filled with mineral matter, giving rise in ordinary cases to elevations on the cast, which fitted into the hollow canals. In the remarkable specimen referred to, the canals had been filled throughout the whole thickness of the wood, and, when the wood itself perished, the mineral casts of the

1 Clearly shown in Figs. 2 and 3, pp. 17 and I8. In Fig. 3 these prints are marked i.c. on the right. 
canals were left behind intact. ${ }^{1}$ In this exceptionally beautiful case, these radiating spokes correspond in size, shape, and position to the dilated infranodal rays, shown in so many of the specimens with structure. We know, from the evidence of the medullary casts with branches, that the prints in question occurred below the nodes (see Figs. 2 and 3): it follows that the dilated rays, or "infranodal canals," when present, were also below the node, and this fact is often of value in determining the top and bottom of a specimen in doubtful cases (cf. Figs. 8 and 9).

1 This specimen is figured by Williamson in Part ix. of his memoirs "On the Organisation of the Fossil Plants of the Coal-measures," Phil. Trans. 1878 , Part ii. Plate xxi. Fig. 3 I. 


\section{CHAPTER III}

\section{EQUISETALES-FRUCTIFICATIONS AND CLASSIFICATION}

Calamostachys; Palaeostachya; Cingularia; Archaeocalamites; Macrostachya; Classification of Calamarieae; Mesozoic Equisetales.

I. The Fructifications. - We have now to consider the important subject of the fructifications of the Calamarieae. There are four main types of cone referred to this group, and known to us in some detail,. though no doubt there are many more not so thoroughly investigated. First we will take the type of Calamostachys, representatives of which, with structure preserved, are common in the English Coal-measures. This genus is characterised by the fact that the cone does not merely bear whorls of peltate sporangiferous scales, as in Equisetum, but that the successive fertile whorls are separated from one another by intermediate and equidistant verticils of sterile bracts (see Figs. I 7 and 2I). The peltate scales by themselves look like those of an Equisetaceous fructification (see Figs. I 8 and 20). It is better to use the word sporangiophore in this connection, rather than sporophyll, for, as we 
shall see, the fossil forms considerably disturb current morphological ideas. Secondly, there is the Palaeostachya type, distinguished by the fact that the sporangiophores are not inserted midway between the whorls of sterile bracts, but immediately above each verticil of bracts, and, as it were, in its axil (see

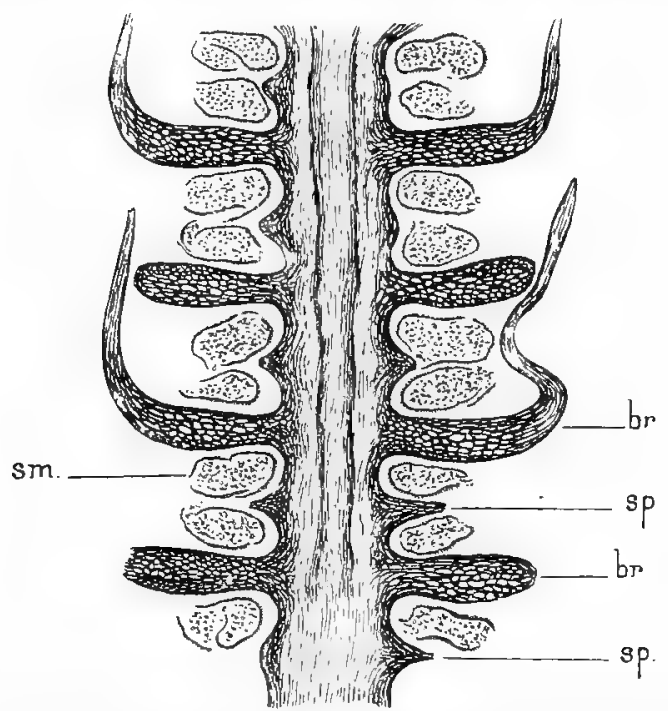

FIG. 17.-Calamostaclyys Binneyana. Radial section of part of cone, showing four whorls of bracts $(b r)$ with the sporangiophores $(s p)$ between them, the peltate part not shown. sm, sporangia. $\times 8$. Will. Coll. rozz. (G. T. G.)

Fig. 24, A, p. 6I). The third type is one about which we do not know so much as we should like, because the remains are not preserved with structure, but only as impressions. This is the Cingularia type, which is just the reverse of that of Palacostacluy, for in Cingularia the sporangiophores are inserted immediately below the bracts, instead of immediately above them (see Figs. 28 and 29, pp. 68 and 69). Fourthly, we 
have a type which is essentially the same as that of Equisetum, e.g. Archaeocalamites, for here the sporangiophores are present alone, without any bracts at all, or only at long intervals (Fig. 24, B). In other cases cones have been found which even more exactly resemble those of recent Equisetaceae.

2. Calamostachys.-I will now shortly describe the

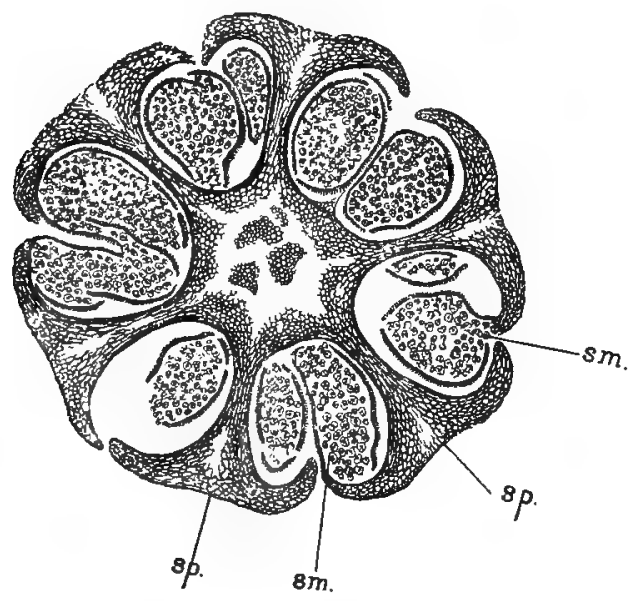

FiG. 18.-Calamostackys Binneyana. Transverse section of cone, passing through a whori of six peltate sporangiophores, $s p$. $s m$. sporangia attached to the peltate laminae of the sporangiophores. $\times$ r6. Will. Coll. rozo. (G. T. G.)

British species of Calamostachys, the genus with alternating and equidistant whorls of bracts and sporangiophores. The affinities of the genus have been very much disputed in the past, but are now cleared up. We will first take the anatomy of the axis of the cone, as shown in the commonest British form, Calamostachys Binneyana. The axis is traversed by a central cylinder (see Fig. I 7), with a distinct and persistent pith (see Fig. 19). Surrounding the pith are the vascular bundles, 
of which there are usually six, sometimes eight; generally they are in pairs, the two at each corner being more or less fused. On the inner side of the wood of each bundle we find a more or less regular canal ( $p x$ in Fig. I 9). If we examine a radial section we see the spiral protoxylem-elements in the canals: we have thus essentially the same structure as in

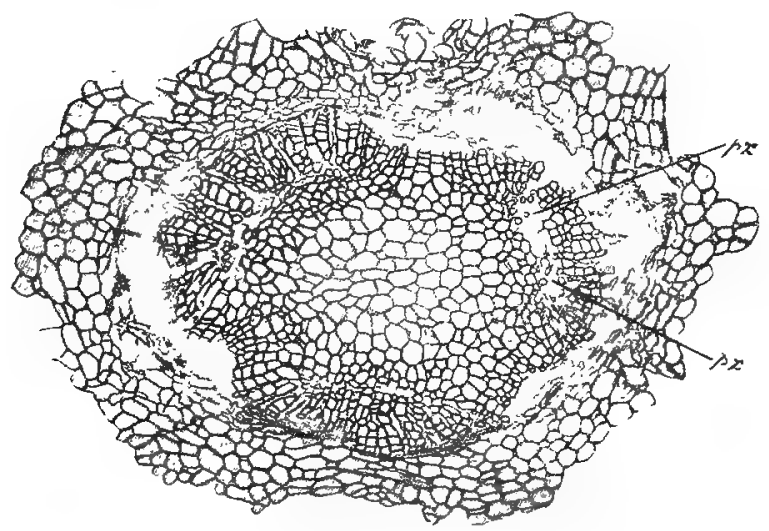

Frg. 19.-Calamostachy's Binneyana. Transverse section of axis of cone, showing stele and part of cortex. Surrounding the pith there are six bundles, in groups of two, with secondary wood. $p x$, protoxylem groups. $x$ about 60. Phil. Trans. W. and S. Will. Coll. זоr6.

Calamites, for the vascular bundles are collateral here also, as shown by specially favourable preparations, in which the phloëm can be recognised outside the wood; in Calamostachys Binneyana, however, there is a solid pith, and the bundles are comparatively few. A very important point is, that in most of these fructifications we find distinct indications of secondary wood in the axis (Fig. I 9).

The bundles in Calamostachys do not alternate at 
the nodes, but go straight down the axis. We see, however, that the anatomy, on the whole, is quite consistent with that of the Calamitean type of stem.

We will now pass on to the structure of the appendages, and will take the sterile bracts first. In our species (C. Binneyana) the bracts are coherent for a considerable distance from their insertion (see Fig. $2 \mathrm{I}$ ). In other species they are free, the whole way through. Through the coherent horizontal disc the vascular strands, springing from the node, pass out, entering the free tips of the bracts, which turn vertically upwards (Fig. I7). The structure of the bracts is much like that of the small vegetative Calamitean leaves, described above, but in the bracts, assimilating tissue appears to have been absent, and fibrous elements, especially in the apical portions, are strongly developed.

The whorls of peltate sporangiophores alternate with those of the sterile bracts, the number of the former in each whorl being often about half that of the latter. Thus in Calamostachys Binneyana there are commonly six sporangiophores and about a dozen bracts in their respective verticils (see Fig. I 8 ), though in other cases there may be eight sporangiophores, while the number of bracts remains at about twelve. The sporangiophores have the same peltate form which is so familiar to us in Equisetum, but in Calamostachys each peltate scale bears four sporangia only, attached in a pendent position to the corners of the lamina (Figs. I 8 and 20), which has a somewhat square form when seen in superficial view. A vascular bundle runs to the base of each sporangium. In tangential sections of the cone a group of four sporangia, diagonally 
placed, surrounds the stalk of each peltate scale (see Fig. 2 I).

The sporangia are elongated sacs, stretching back from the lamina to the axis (Figs. I 8 and 20). The sporangial wall, as preserved, is usually only one cell' thick, and the lateral membranes of its cells are stiffened by projecting ridges (Fig. 22). When cut across, these

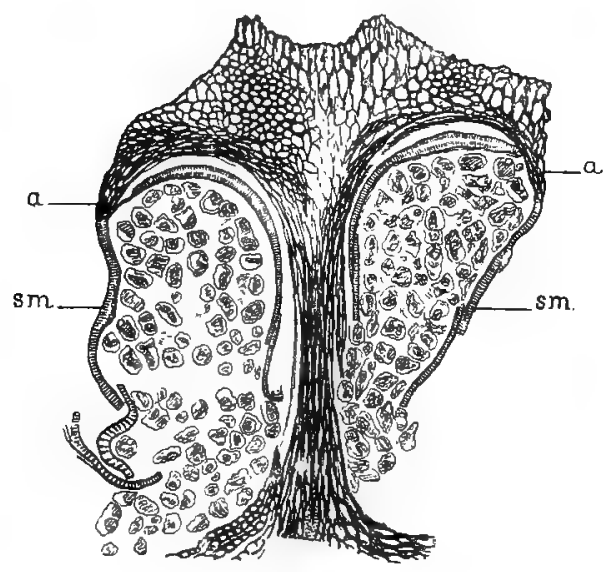

FiG. 20.-Calamostachys Binneyana. A single peltate sporangiophore, in Iongitudinal section. sm, sporangia, attached at $a$ to the edges of the peltate lamina. They are full of spore-tetrads. $\times$ about 40. S. Coll. 174. (G. T. G.)

buttresses are not easily distinguished from the cellwalls.

In Calamostachys Binneyana the spores are very numerous in each sporangium, and, so far as has been ascertained, were all of one kind, the average diameter of the full-grown spores being about .09 $\mathrm{mm}$. Curiously enough, we often find them united in groups of four, the tetrad being still enclosed within the membrane of its mother-cell (see Fig. 22, A, B, C). Hence we see that 
the fourfold division, so general in spore mother-cells, already prevailed among these Palæozoic plants. In many cases the spores of the same tetrad are very unequally developed, some remaining quite small (Fig. 22, B and C); we may regard the latter as abortive spores, their suppression having allowed of the better nutrition of their surviving sister-cells. The mature spores show a triradiate marking on one side, probably

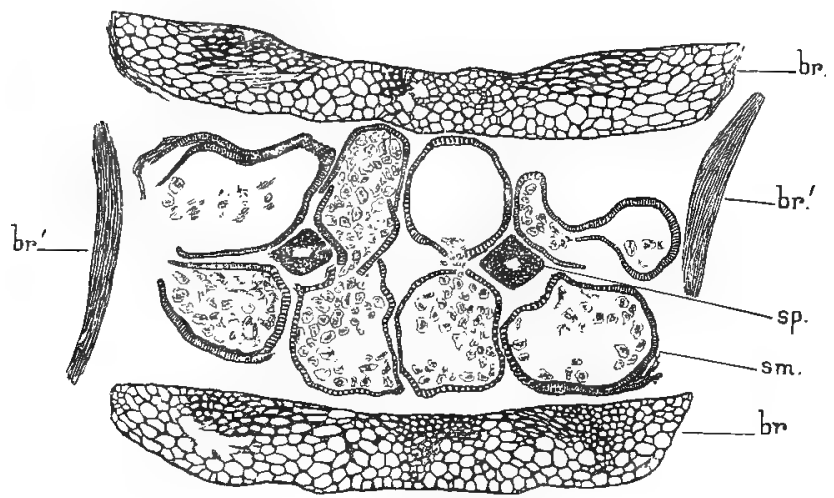

Fig. 2r.-Calamostachys Binneyana. Part of tangential section of cone, showing portions of two whorls of bracts $(b r)$ with sporangiophores $(s p)$ between. Around each of the latter the four sporangia $(s m)$ are grouped. br', free tips of other bracts. $x$ about 25. S. Coll. 175. (G. T. G.)

indicating the lines of junction with the sister-cells (Fig. 22, D).

Numerous specimens of $C$. Binneyana, which is a fairly common fossil, have been examined, and no traces of more than one kind of spore have been found. Except for occasional abortion all the spores are uniform. There is thus a strong presumption that this species was homosporous. In another British species, however, Calamostachys Casheana, heterospory, as Williamson discovered, certainly occurred. In general organisation this cone is 
practically identical with the homosporous species $C$. Binneyana, the differences between them being of a trivial kind. In some of the sporangia, however, numerous small spores are contained-slightly smaller than those

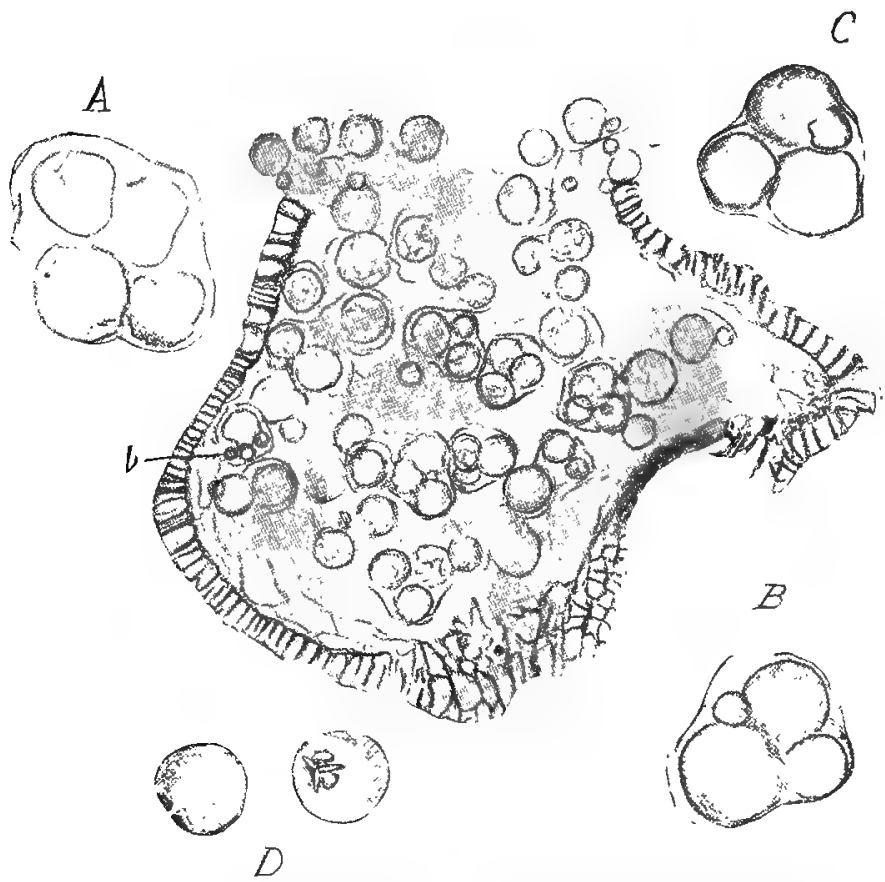

FiG. 22.-Calannostachys Binneyana. A single sporangium, containing spores in tetrads. Many of the spores are abortive (b). The structure of the sporangial wall is well shown. $x$ roo. A. Tetrad with all four spores about equal. B, C. Tetrads, each with one abortive spore. D. Ripe spores showing the triradiate marks. A-D X 200 . Phil. Transs, W. and S. Will. Coll. roI r, etc,

of $C$. Binneyana, while other sporangia on the same cone, and sometimes on the same sporangiophore, contain a much smaller number of large spores, the diameter of which is just three times that of the former (see Fig. 23). Here, therefore, we have a perfectly clear case of a 
heterosporous Calamarian cone, and some of the species from the Continent show the same phenomenon. The difference between microspores and megaspores, though well marked, is, however, less extreme than in the heterosporous Lycopods or Rhizocarps.

We saw, in the case of $C$. Binneyana, that some of the spores were abortive, and this is a point of some importance, because we know that a similar process of

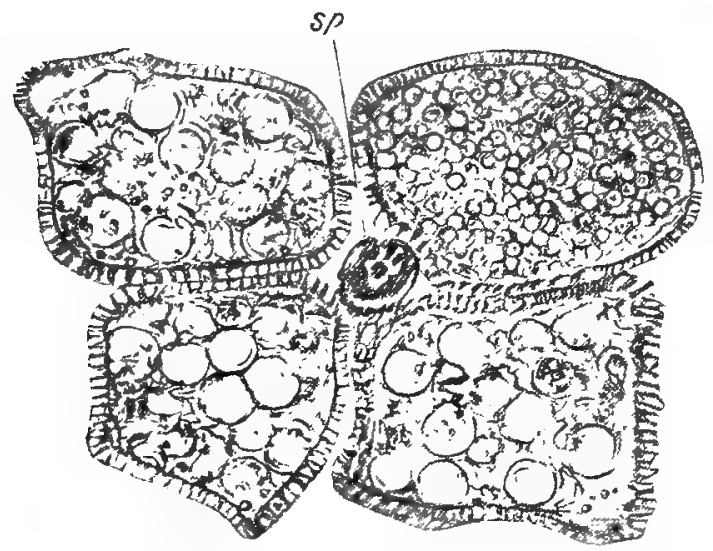

FIG. 23.-Calamostachys Casheana. Tangential section, showing four sporangia grouped around their sporangiophore $(s p)$. Three contain megaspores and one microspores. $\times$ zo. Phil. Trans. W. and S. Will, Coll. 1587.

abortion goes on in heterosporous, as well as in some homosporous Cryptogams, at the present day. It is an interesting fact that in the heterosporous $C$. Casheana we also find this abortion of some of the spores, but it is confined in this species to the megasporangia. It seems then that in this genus we are able to trace how heterospory originated. The facts suggest that in the first instance a certain number of spores became abortive, and so allowed of better nutrition for the remainder; 
this process, going on more freely in some sporangia than in others, may ultimately have rendered possible the excessive development of those spores that survived, at the expense of the others, and may thus have led to the development of specialised megaspores.

In the heterosporous species, Calamostachys Casheana, the axis of the cone formed a zone of secondary wood, precisely as in the homosporous form, C. Binneyana, shown in Fig. I 9. This fact is of considerable significance, in view of the excessive importance which palæobotanists have sometimes attached to secondary growth, as an indication of Phanerogamic affinities.

We have next to consider the relation of Calamostachys to Calamites. Neither of the British species described has as yet been found in connection with the stem or with vegetative organs of any kind. On the other hand, very similar Continental species have been found with such connection. In the Calamostachys Ludzigi of Carruthers, ${ }^{1}$ for example, from the German Coal-measures, the spikes are borne upon a ribbed stem with whorled leaves, agreeing exactly with the smaller Calamitean twigs. In this species the structure of the cone is perfectly well known; it is that characteristic of the British forms of Calamostachys, except that in C. Ludwigi the bracts of the cone are free, instead of being coherent. This fossil thus affords certain evidence that fructifications of the Calamostachys type were borne on Calamitean stems, ${ }^{2}$ a fact fully recognised by $\mathrm{Mr}$. Carruthers, in his memoir of 1867 , just cited.

1 Carruthers, "On the Structure of the Fruit of Calanites," Seemann's Jonernal of Botany, vol. v. 1867. At that time the generic name Volk. mannia was used for Calamarian strobili.

${ }^{2}$ See Weiss, Steinkohles-Calamarien, ii. p. 163; Atlas, Plates 
The evidence from comparative anatomy is also of considerable importance. The anatomy of the axis of the British forms of Calamostachys, which we have described fully above, although it agrees sufficiently well with that of Calamites to allow of the probability of relationship, is not exactly that of a Calamitean stem. It is very interesting to find that in some of the Continental species this difference does not exist. They combine the exactly typical anatomy of the Calamitean stem with the external morphology of a Calamostachys. This is the case, for example, in the fructification originally described by Renault under the name of Bruckmannia Grand"Euryi, which is, to all intents and purposes, a Calamostackys, and is placed by Count Solms-Laubach ${ }^{1}$ in that genus.

In this case the anatomy of the axis is peculiarly well shown; there is a fistular pith, surrounded by a ring of eighteen collateral vascular bundles, and beyond that the cortex. Each bundle has a canal, perfectly defined, at the inner margin of its wood. In fact, the anatomy of the axis is that of a young stem of Calamites, so that the species Calanostachys Grand'Euryi completely removes any anatomical difficulties we might find in referring Calamostachys to Calamitean stems. At the node each bundle gives off two strands

xxii.-xxiv., in Abhandlungen wur geologischen Specialkarte von Prenssen, Band v. I884. In the plates cited the structure of C. Ludreigi is magnificently illustrated.

1 Fossil Botany, English edition, p. 329. M. Renault named this fructification Arthropityostachys Grand" Euryi; Bassin houiller et permien d'Autun et d'Epinac, flore fossile, l'art ii. p. 135, Plate 1xii., I896. See also his Cours de botanique fossile, vol. ii. p. 136, Plates xxi. and xxii., 1882. The structure of this cone is preserved with extraordinary perfection. 
to the bracts, which are here twice as numerous as the main bundles. According to Renault the strands supplying the sporangiophores also spring from the bract-node, pass up through a considerable part of the internode above, and then bend downwards and outwards to enter the sporangiophores. (Cf. Fig. 27 from Palaeostachya).

The morphology of the cone is in all respects that of a Calamostachys. There are the usual alternate whorls of bracts and sporangiophores, and the bracts in each whorl are twice as numerous as the sporangiophores. As in C. Binneyana, the bracts are connate in their lower portion, forming a continuous horizontal disc. The sporangiophores are of peltate form, and each bears four sporangia, exactly as in the species above described. Thirty-six bracts and eighteen sporangiophores were counted in their respective verticils.

I must add that some of the Continental species of Calamostachys (including C. Grand'Euryi) present a complication not found in the English species above described; this peculiarity consists in the presence of radiating vertical wings of tissue connecting each peltate scale with the whorl of bracts just above it. There was thus a membrane connecting the upper edges of the sporangiophores with the lower side of the bracts; in some cases a similar but less complete membranealso extended downwards from each sporangiophore. The sporangia thus lay in groups of four in the compartments formed by these radial plates of tissue. We have here one example among many of the complexity of the Palæozoic Cryptogams, as compared with those of the present day. 
3. Palaeostachya.-We will now go on to the second main type of Calamarian fructification, that described by Weiss under the name of Palaeostachya. ${ }^{1}$

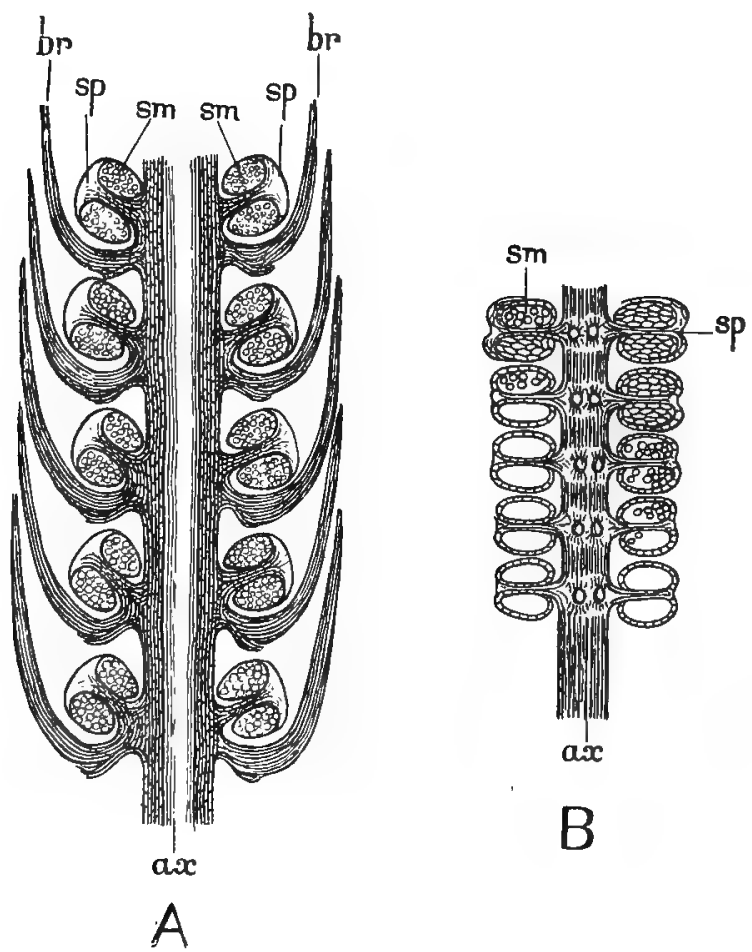

Fig. 24.-A. Palaeostachya. Radial section of cone, showing peitate sporangiophores $(s p p)$ inserted in axils of bracts $(b r)$. $s m$, sporangia; $a x$, axis of cone. Magnified. Diagrammatised after Renault. B. Archaeocalanites radiatzis. Part of cone, showing axis $(a x)$ bearing sporangiophores '(sph) only. szr, sporangia. Magnified. After Renault.

Its peculiarity consists in the fact that the sporangiophores, instead of being inserted midway between the whorls of bracts, are placed in their axils. In

I Steinkohlen-Calamarien, i. p. I03, I876. 
Palaeostachya gracilis, described by Renault, each whorl

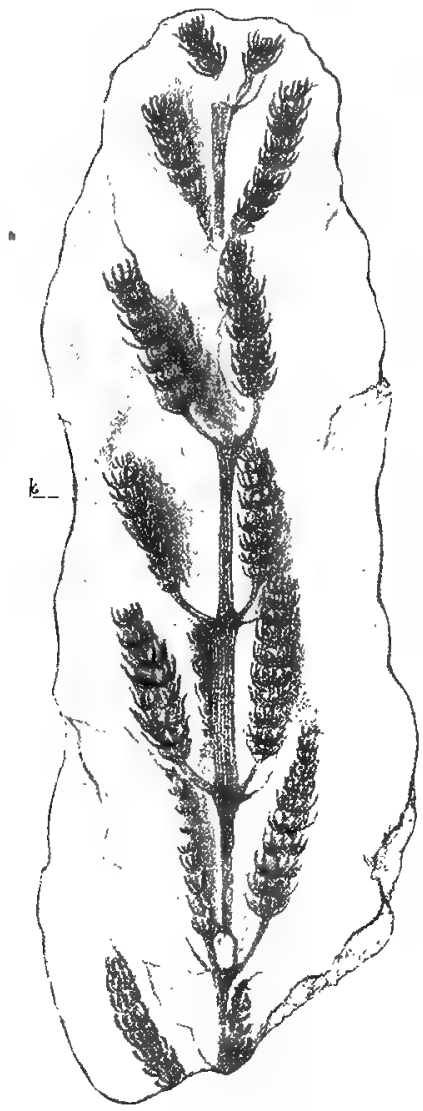

FIG. 25. - Palaeostachya pedunculata. Specimen from the coal-shales, showing a fertile shoot bearing about a dozen cones and a few leaves. $k$, stem. About $\frac{3}{s}$ of nat. size. After Willianson, Phil. Trans. Will. Coll. Io6u.

of bracts has about twenty members; the sporangiophores, about ten in each verticil, are inserted immediately above the bracts, in the angle between the latter and the axis. In the diagrammatic Figure, 24, A, the position of the sporangiophores is well shown. In Fig. 25 another species, Palaeostachya pedunculata, is represented on a small scale, as in the actual specimen. In this case a large number of cones are seen attached to a Calamarian branch.

While the position of the sporangiophores in Palaeostachya is thus strikingly different from that in Calamostachys, their structure is almost identical. Each sporangiophore, as in that genus, is peltate, bearing four sporangia on its lower surface. The spores are of the same type as in the homosporous Calamostachys. The occurrence of

1 This author uses the generic name Volkmannia, and refers these fructifications to the vegetative shoots known as Asterophyllites; see below, p. 70 ; Renault, Cours de bot, foss. vol. ii. p. II 4, Plates xviii. and xix. ; Flore fossile d Autun et d'Epinai, p. 74, Plates xxix. and xxx. 
heterospory is, however, proved in the case of another species perhaps referable to Palaeostachya. ${ }^{1}$

In Palaeostachya gracilis, according to Renault's observations, the number of sporangiophores in the whorl is about half that of the bracts, while the number of vascular bundles in the axis is equal to that of the sporangiophores in a whorl. In its anatomy, the axis closely resembles a young Calamitean stem.

A fructification belonging to the type of Palaeostachya was described by Dr. Williamson for the first time in $1869,{ }^{2}$ and subsequently much more fully in I $887 .^{3}$ This strobilus he called the "true fructification of Calamites," and, for many years, he refused to admit any other fructification as properly belonging to Calamites, the reason being that in this "true fructification" of his, and, as he thought, in no other, the Calamitean anatomy was manifest in all its essential points. In cases where we have both the peduncle and the axis, the former has in all respects Calamitean structure, including a secondary zone of wood, which dies out as the axis itself is approached. This form was called by Dr. Williamson in his last memoirs ${ }^{4}$ Calamites pedunculatus. It was distasteful to him to give any other generic name than Calamites to a fructification which he felt so sure belonged to that genus. It is, however, more convenient to retain special

1 Renault, Flore fossile d"Autun et as Épinac, Part ii. p. 77, Plate xxix. Figs. 6 and 7 .

2 "On a New Form of Calamitean Strobilus," Mem. Lit. and Phil. Soc. of Manchester, 1869 .

3 "Organisation of Fossil Plants of Coal-measures," Part xiv., Phil. Trans. $1888, \mathrm{~B}$.

"See Williamson and Scott, "Further Observations, etc.," Part i., Phil. Trans. vol. I85, B, I894, p. 916. 
generic names for the cones, as it is so rarely possible to refer them to particular forms of stem; while, as we have already seen, some forms of Calamostachys have as good a claim as Palaeostachya to be referred to the genus Calamites. Williamson's specimen has therefore been re-named Palaeostachya vera by $\mathrm{Mr}$. Seward, the specific name serving to recall Williamson's original description of the fructification. ${ }^{1}$

The Calamitean anatomy is shown with great perfection both in the peduncle and in the axis of the strobilus; in the canals accompanying the vascular bundles, the disorganised spiral tracheae are found, just as in the vegetative stem. In this form the number of sporangiophores is from sixteen to twenty in each whorl, the bracts, which were connate at their base, being, according to recent observations by $\mathrm{Mr}$. George Hickling, ${ }^{2}$ about equal in number, as are also the vascular bundles in the axis. Fig. 26 represents a transverse section of the cone. The vascular bundles are here approximated in pairs, the pairs alternating, in the nodal region, with socalled canals, which represent parenchymatous areas in the sclerotic disc which strengthened the node. The peltate part of the sporangiophores is imperfectly preserved in the English specimens, but the sporangia are well shown, and are, as usual, four in number on each sporangiophore. The structure of the sporangial wall is identical with that of Calamostachys. The spores, so far as the existing specimens show, were all

1 The specific designation pedunculata was inadmissible, as it had been previously given to a different species of Palaeostachya, namely that shown in our Fig. 25.

2 The anatomy of Palaeostachya vera, Annals of Botany, vol. xxi. July I907. 
of one kind, and of similar dimensions to those of Calamostachys Binneyana.

The apparently axillary position of the sporangiophores in Palaeostachya evidently suggests caution in

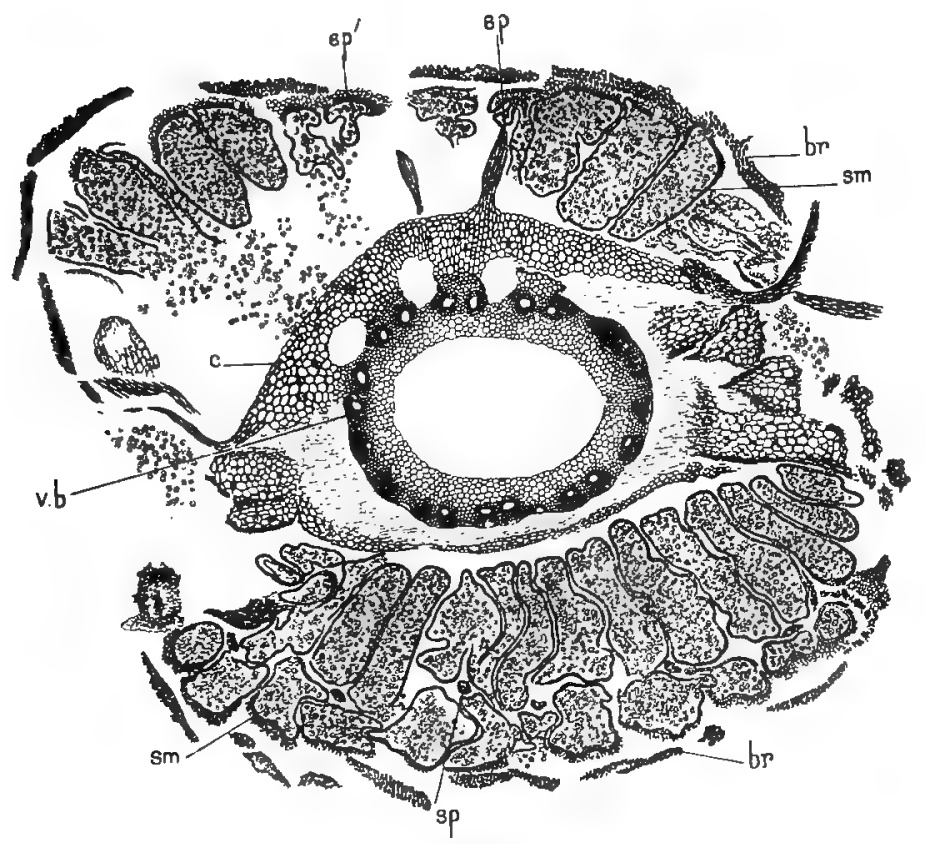

FiG. 26.-Palaeostachya vera. Transverse section of cone. Surrounding the fistular pith is the ring of bundles $(v b)$ grouped in pairs. Outside them is the cortex and disc $(c)$. $s p$, pedicels of the sporangiophores, some shown attached to the axis, others between the sporangia $(s m)$, which are grouped in fours around the sporangiophores; $s p^{\prime}$, remains of peltate lamina of a sporangiophore; $b r$, bracts. $X$ about $7, \mathrm{~S}$. Coll. 474. (G. T. G.)

accepting the current view that these organs in Equisetineae are simply leaves. Mr. Hickling's observations have cleared up, for the first time, the course of the vascular strands which supply the sporangiophores. He finds that they start from the same node as the 
bundles which run to the subtending bracts, and immediately above them. The sporangiophore bundle, however, passes vertically upwards, parallel to the corresponding main bundle of the axis, until it has ascended through almost exactly half the internode.

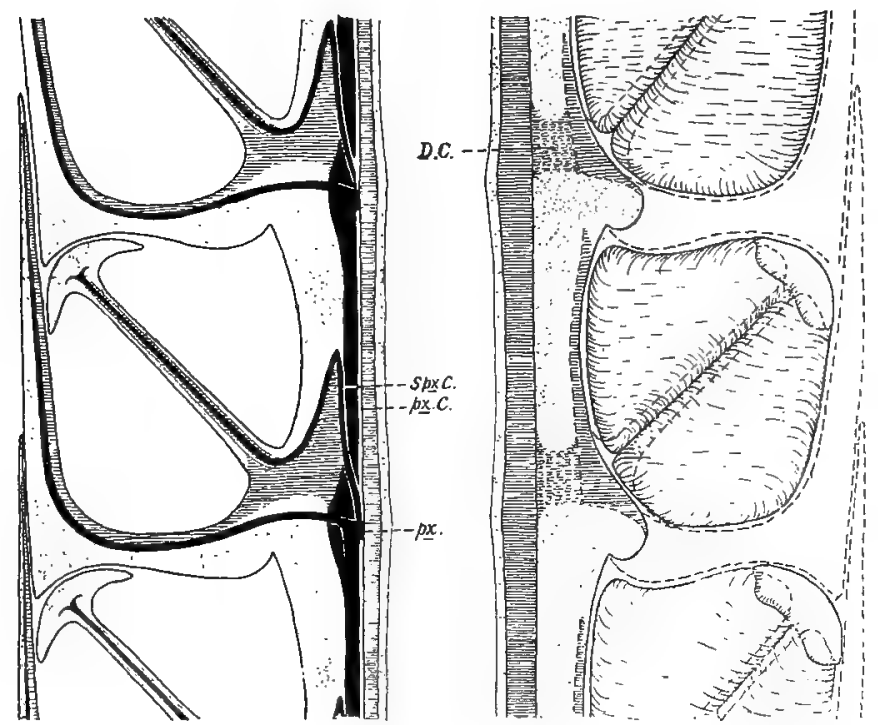

FIG. 27.-Palaeostachya vera. Diagrammatic longitudinal section of cone. Vascular tissue, black; soft parenchyma, dotted; sclerised, lined. Left side passes through bundle; right, between bundles. Sporangia omitted on left side; inserted on right in surface-view. D.C., disc canal; px.C., protoxylem canal of main bundle ; $S p x . C$., protoxylem canal of sporangiophore trace; $p x$. , persistent protoxylem at the node. Note the sharply reflexed course of the bundles supplying the sporangiophores. From Hickling.

It is then sharply reflexed, descends rapidly to the upper limit of the nodal disc, and sweeps horizontally across the upper part of this to the base of the sporangiophore, which it enters ${ }^{1}$ (Fig. 27). Thus in Palaeostachya, as in Calamostachys, the evidence of the ${ }^{1}$ Hickling, l.c. p. 375. 
vascular supply indicates that the sporangiophores may be regarded as the ventral appendages of the bracts subtending them. , On account of the anomalous course of the sporangiophore bundles, Mr. Hickling regards Palaeostachya as derived from the Calamostachys type.

4. Cingularia.-We now come to the third type of the Calamarian fructifications which I shortly described above, namely that of Cingularia. Our knowledge of Cingularia, which is chiefly due to the researches of the German palæobotanist Weiss, ${ }^{1}$ is less satisfactory than in the cases already considered. So far we have been dealing with fructifications with their internal structure preserved. Cingularia is not one of these; it is only known from carbonaceous impressions, and not from petrified specimens, and hence only its external characters are open to investigation. Under these circumstances we cannot feel the same certainty in the interpretation of the facts as in specimens with the whole structure preserved. We may, however, accept Weiss's description as being probably the correct one. The plant itself had the usual Calamarian habit, with a jointed stem and whorled leaves. It appears that the successive whorls were superposed, not alternating as in most Calamarieae. The fructifications were long, very lax cones, with the whorled appendages rather remote from each other (see Fig. 28).

The conclusion at which Weiss arrived is that each whorl was a double one, and that it consisted of a verticil of coherent bracts running out into sharp teeth at the edges, and of another coherent verticil immediately

1 Stcinkohlen-Calamarien, i. p. 99, Plates vi.-ix. 1876. 
below the first, consisting of the sporangiophores (see Fig. 29). Thus the relative position of bracts and sporangiophores is just the reverse of that in Palaeostachya. According to Fischer's observations the bracts and sporangiophores were not free whorls, but were partly united to each other, an important point of

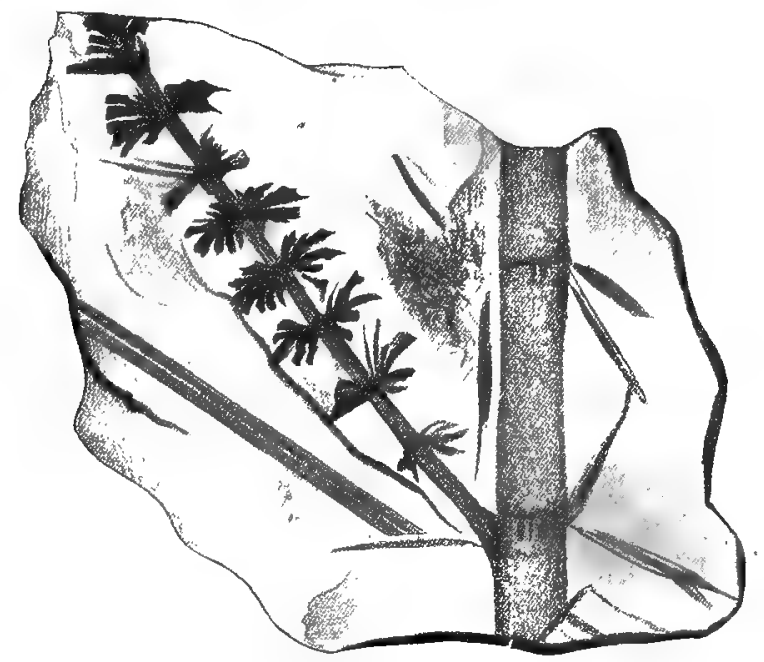

FIg. 28.-Cingularia typica. Part of branch, bearing whorled leaves and a lax cone, with whorled bracts. Nat. size. After W'eiss.

analogy with the Sphenophyllales. (See next chapter, p. 99). ${ }^{1} \quad$ The strap-shaped sporangiophores separate from one another as they approach the exterior, and further to the outside each divides into two lobes, as shown in Fig. 29. Looking at the under surface of a fertile whorl, we notice on each of the flattened sporangiophores four prints, which are known to have

I See Ed. Fischer, "Einige Bemërkungen über die Calamarieen-gattung Cingularia," Mitth. d. Naturf. Gesellsch. in Bern, 1893. 
been the points of attachment of the sporangia, as the latter are occasionally found in situ. Each of the sporangiophores thus bore four sporangia on its lower surface (Fig. 29). The sporangia were of approximately spherical form, and remarkably large, averaging $5 \mathrm{~mm}$. in diameter, which is five times the size of the sporangia of Calamostachys Binneyana. The number of bracts in

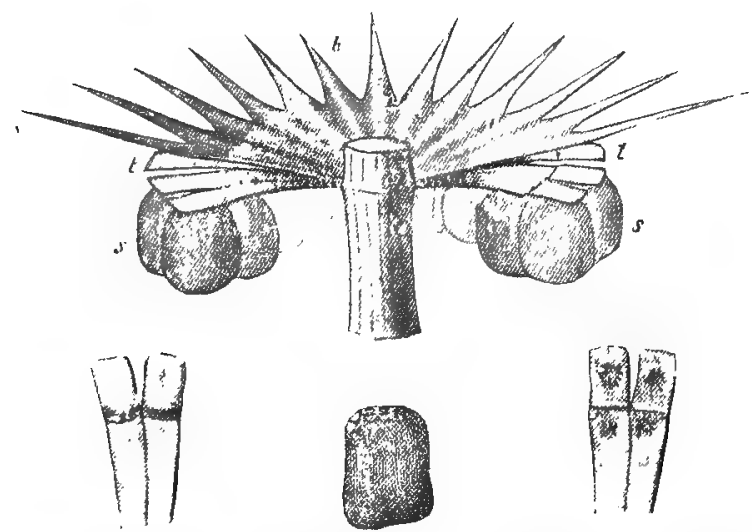

FIG. 29.-Cingularia typica. Enlarged diagram of a verticil of the cone, showing the connate bracts $(b)$ above, and the strap-shaped sporangiophores $(t)$ below, bearing the sporangia $(s)$. The small figures show two sporangiophores, that on the left sean from above, and that on the right from below. In the middle a sporangium. After Weiss.

a whorl seems to have been equal to that of the sporangiophores. The great peculiarity of Cingularia consists in the fact that the sporangiophores lie immediately below the sterile bracts of each whorl, instead of immediately above them, as in the last type. This is different from anything we are accustomed to find among other Pteridophyta. In the absence of better evidence than we at present possess, it is impossible to draw any decisive conclusions as to the 
morphology or affinities of Cingularia. We cannot be absolutely certain of the accuracy of our interpretations, and still less can we be certain whether we have to do with a Calamarian or a Sphenophyllaceous plant. These questions can only be cleared up if specimens with the structure preserved should be discovered.

5. Archaeocalamites. - A fourth type of Calamarian fructification remains to be noticed. This is a simple one to describe, because it has much in common with that of the only surviving genus of Equisetales, the recent Equisetum. The remarkable genus Archaeocalamites, characteristic of the oldest Carboniferous strata and of the Upper Devonian, appears, according to M. Renault's observations, to have borne the fructification of which a fragment is represented in Fig. $24, B$. The cones occur associated with the stems and dichotomous leaves of that genus, though the evidence from actual continuity is wanting. The cone bears whorls of sporangiophores, from eight to ten in each whorl; they have the usual peltate form, with the expanded portion little developed, and each appears to have borne four sporangia. Sterile bracts are not shown, but it is quite probable that they may have occurred in scattered whorls, at long intervals, as was clearly the case in the genus Pothocites, associated with Archaeocalamites in the Lower Carboniferous of Scotland. Pothocites consists of large cylindrical strobili, constricted at intervals, the constrictions no doubt marking the position of the sterile whorls. ${ }^{1}$ The

1 See Kidston, "Affinities of the Genus Pothocites," Trans. Bot. Soc. Edinburgh, $188_{3}$. 
fructifications of Archaeocalamites are not yet known in

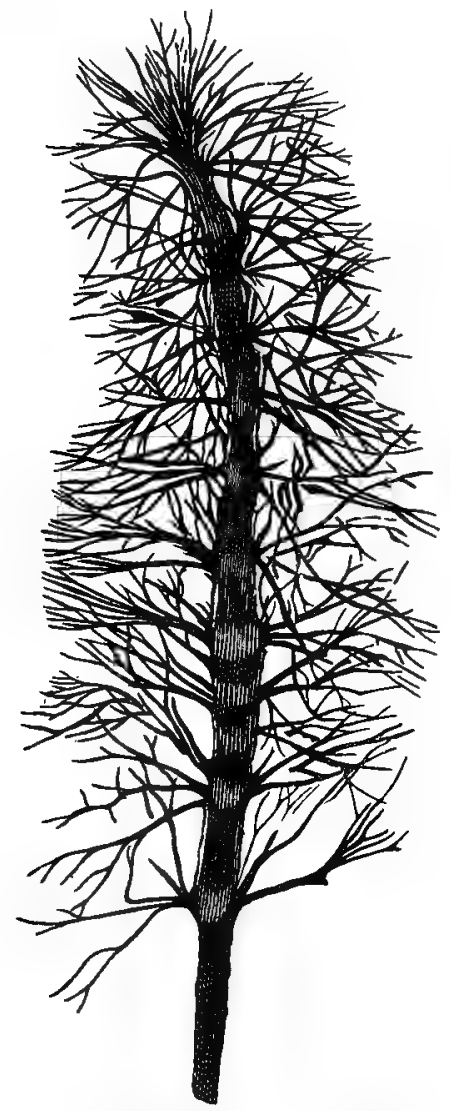

Fig. 30.-Archaeocalnmites radiatus.

Branch bearing whorled leaves, which are dichotomously subdivided. Half nat. size. After Stur. the petrified condition.

Archaeocalamites is a very ancient type of Calamarian tree, characterised by the non-alternation in successive internodes of the furrows on the casts corresponding to the vascular bundles, and also by the

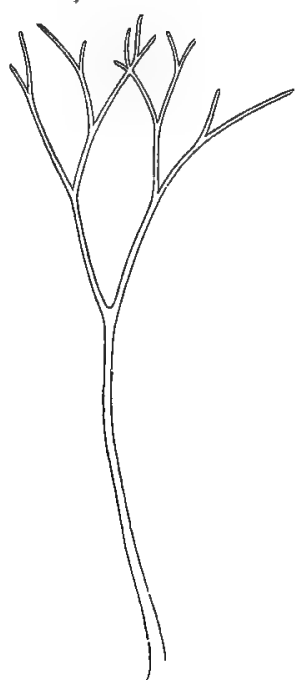

FII. 3I. -Single leaf of the same. Half nat, size. After Stur.

remarkable foliage, for the leaves were forked, instead of being simple. ${ }^{1}$ Fig. 30, from a work by the Austrian

1 The anatomy of the stem of some species of Archaeocalanites has been worked out by M. Renault and Count Solms-Laubach, and is described 
palæontologist, Stur, gives a good idea of the habit of a leafy branch, and in Fig. 3 I a single, repeatedly forked leaf is shown. M. Grand'Eury has discovered fructifications resembling the cones of living Equisetaceae, from the French Coal-measures, and Mr. Kidston has described, under the name of Equisetum Hemingwayi, a large cone, which presents the external characters of a fructification of the recent genus. There is altogether a considerable amount of evidence to show that fructifications of the Equisetum type already existed in the Coal-period, but unfortunately none of the specimens in question have their internal structure preserved. The Permian plant known as Phyllotheca deliquescens, has a fructification presenting some analogies with Pothocites, the long fertile spikes being interrupted at intervals by whorls of sterile leaves. A similar condition occurs as an abnormality in recent species of Equisetum.

6. Macrostachya. - In addition to these wellcharacterised types, we have various fructifications which have been referred to Calamarieae, but as to which our information is contradictory and scanty. Among these it is only necessary to mention the genus called Macrostachya, the cones of which are of great size, attaining 8 inches in length by an inch or more in diameter (see Fig. 32). They were often borne in whorls, on stout stems with typical Calamitean structure,

as exactly that of an ordinary Calamite, of the kind in which the medullary rays become bridged over by interfascicular wood. The roots were of the "Astromyelon" type. See Renault, Flore fossile d"Autun et d" Epinac, Part ii. p. 80, Plates xlii. and xliii.; and Solms-Laubach, Botanische Zeitung, 1897, p. 219. It is possible, however, that the Lower Carboniferous Calamarian stem, with centripetal wood, described on p. 36 , may have belonged to an Archaeocalamites. 
and these cones are among the most striking fossils of the Coal-period. There is great doubt as to the internal structure of the cones. M. Renault examined the carbonised cones of a Macrostachya, found in connection with the stem, which was of the Calamitina type (see below, p. 74), and showed the usual Calamitean structure. The fructification proved to be heterosporous, the microsporangia and megasporangia occurring on the same strobilus, as is the case in Calamostachys Casheana.

7. Classification.-Before leaving the Calamarieae I must say a few words as to their classification. This is a most difficult, and indeed in the present state of our knowledge, insoluble question, because we only have the plants as preserved in the form of fragments. Consequently, we shall not be surprised to find that the classification of Calamarieae has been based on totally different principles, according to the parts of the

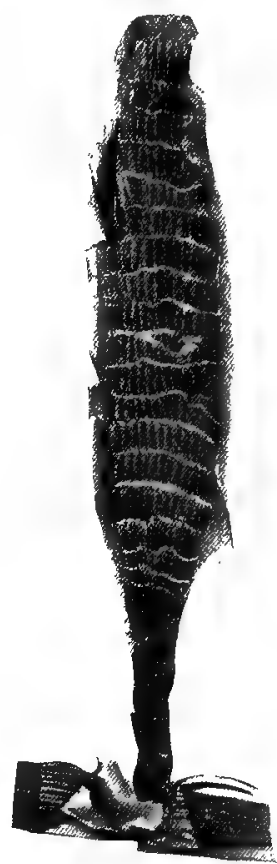

FiG. 32.-Macrostachya infundibuliformis. Cone borne laterally on a branch. Half nat. size. After Weiss. plants selected. For example, Weiss classified Calamarieae by means of the characters presented by their medullary casts, and more especially according to the form and distribution of the scars marking the position of the branches. For the purposes of geologists his is

${ }^{1}$ Notice sur les Calamariées, Part iii., Autun, I 898. 
a useful arrangement. ' Again, we may classify these plants with reference to the structure of their wood. We have ourselves distinguished the simple structure of Arthropitys or Calamites proper from the more complex organisation of Calamodendron, between which the Arthrodendron form is intermediate. Then again it might be possible to arrange them according to their foliage, and as we shall see, considerable use has actually been made of characters drawn from the leaves. For example, the simple leaves of most Calamarieae contrast sharply with the dichotomous leaves of the Archaeocalamites type. A far better plan would be to classify the specimens according to the fructification, the character on which we should chiefly rely in the case of recent plants. But we have not yet any scheme which combines all these characters into a natural classification of the plants themselves, and, from the nature of the material, such a scheme is chimerical, though a slow approach towards it may be made, as new evidence accumulates.

I may give a short summary of an attempt made in this direction by the French palæobotanist Grand'Eury, who has the advantage of knowing more about the Calamarieae and other fossil specimens, as they occur underground, than any other authority. His position as a mining engineer has given him unrivalled oppor-

1 Weiss's subgenera may be shortly characterised as follows:- Stylocalamites: branches few, and irregularly scattered (see Figs, 2 and 3). Calamitina: internodes usually short; branches in whorls, limited to certain nodes, often surmounting internodes shorter than the rest. Eucalamites: branches on every node, in some cases one, in others many, on each. Archaeocalanites : ribs continuous, not alternating as in the three former; branches limited to certain regions of the stem, where they are present on every node. See Steinkohlen-Calamarien, Part ii. I 884 . 
tunities of observing the fossils in situ. Grand'Eury ${ }^{1}$ distinguishes three great groups, represented respectively by Annularia, Calamites proper, and Calamodendron. The first group, Annularia (Fig. 33), is characterised by whorled leaves, usually more or less lanceolate in shape, attached to a stem of Calamitean structure, which is said to have attained only a small diameter, not exceeding 2 or 3 inches in the forms described. The structure of the finer branches is very delicate, and the plants have been supposed to be herbaceous aquatics. There is, however, very little evidence for this, and there is reason to believe that some at least of the $A n$ nulariae, as, for example, $A$. stellata,

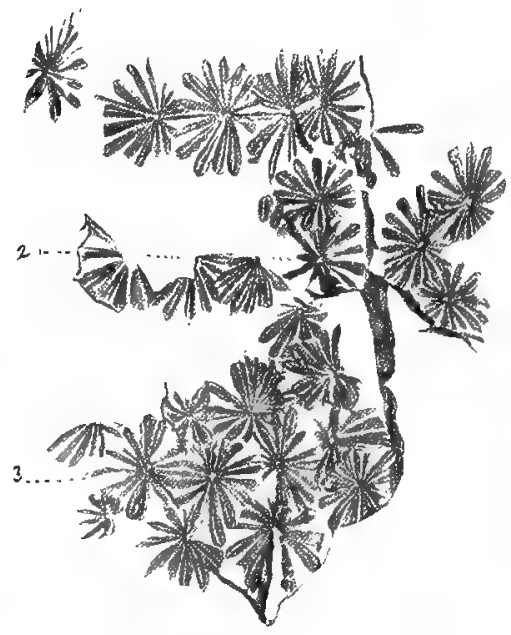
Fic. 33.-Annularia brevifolia. Twigs, bearing whorled leaves. Nat. size. After Stur. were simply the branches of large Calamites. It has lately been shown that in this latter form the leaves were united at the base, to form a regular sheath, as in the recent Equiseta ${ }^{2}$ (cp. Fig. I 2, p. 38). The fructifications of the Annulariae are called by Grand'Eury and Renault Bruckmannia;

1 Bassin houiller du Gard, St. Etienne, I890, p. 200.

"See Potonié, "Aeusserer Bau der Blätter von Annularia stellata," etc., Verhandl. bot. Ver. d. Prov. Brandenburg, Bd. xxxiv. 
they are identical in structure with our Calamostachys, and some of them are known to have been heterosporous.

Secondly, according to Grand'Eury, we have the great division of Arthropitys, or Calamites proper, of which Asterophyllites represents the foliage, or rather the leaf-bearing branches. There appears to be good evidence for the connection between them. The wood, where preserved, is of the simple type of Calamites or Arthropitys, described in detail in the last chapter. The characteristic arrangement of the spikes is in panicles borne on branches with the foliage of Asterophyllites (cf. Fig. 25). The terminal leaf-bearing branches were distichously arranged, with crowded whorls of narrow acicular leaves, which here also were united when young into a sheath (see Fig. 34). Associated with the Calamitean stem, and in connection with the Asterophyllitic foliage, is found Palaeostachya gracilis, which was one of the forms of fructification belonging to this type, a fact which agrees with Williamson's results, but cones of the Calamostachys form also belonged to this group. In fact, the whole position is rather paradoxical, for to the stem known specifically as Calamites cannaeformis (according to the characters of the medullary cast) Grand'Eury attributes fructifications of two different genera! This shows that the so-called species among fossils must not be understood in the same sense as species of living plants. Grand'Eury himself points out that these so-called species are rather of generic value. It is no doubt impossible to recognise strictly specific differences from the medullary casts, and it is quite likely that stems with casts indis- 
tinguishable from one another may even have borne fructifications as different las those of Palaeostachya and

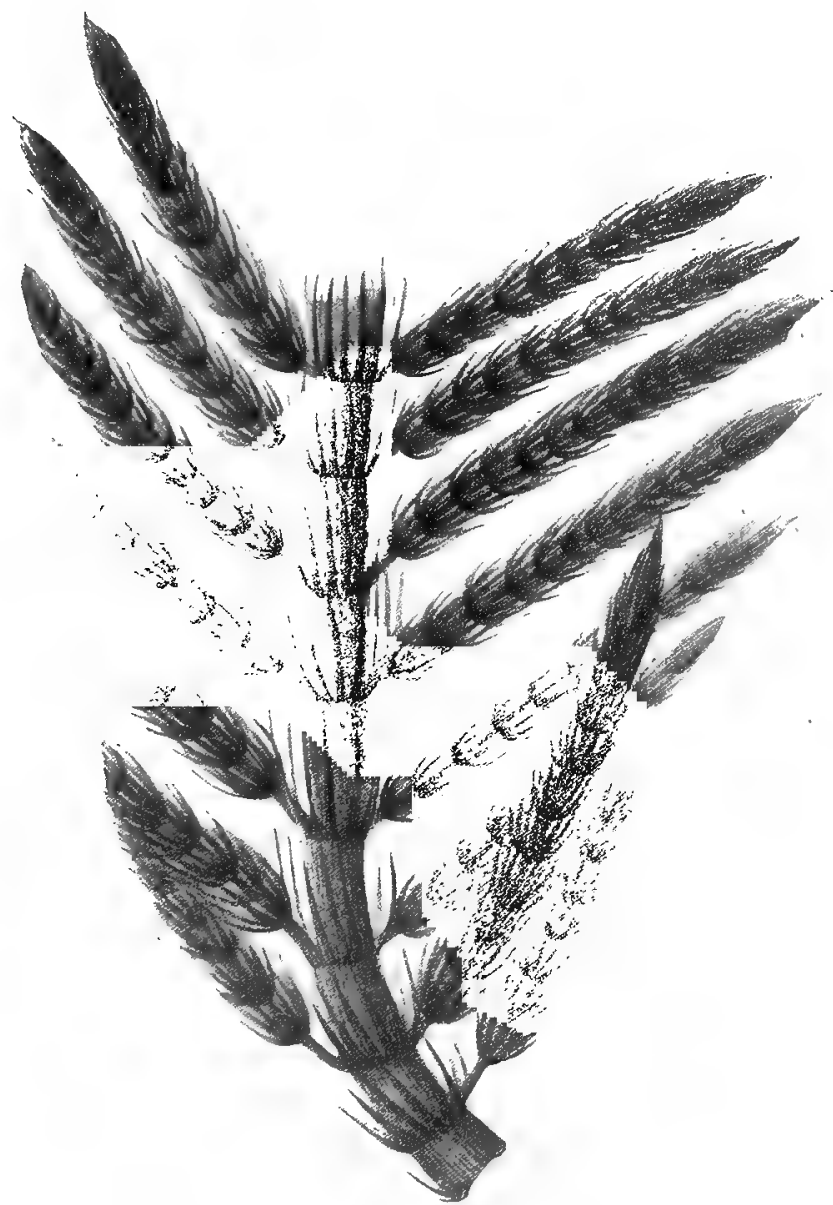

FIG. 34.-A sterophyllites densifolius. Branch bearing distichously arranged rwigs; both branch and twigs with verticillate leaves. Somewhat restored. After Grand'Eury.

Calamostachys. The branches were arranged in whorls limited to certain definite nodes (Calanitina of Weiss's 
nomenclature), and the aërial stems sprang from subterranean rhizomes.

I should mention that Macrostachya fructifications are found in association with the same type of stem. In France this group seems to have been found chiefly in the Middle Coal-measures, and not to extend into their upper beds.

Grand'Eury's third type is Calamodendron, found only in the upper beds of the Coal-measures. This horizon appears to be represented in England by the Somersetshire coal-field, but petrified specimens have not been recorded from it, and at present stems of the Calamodendron type of structure have not been obtained from our coal-fields. Grand'Eury associates with the Calamodendron wood (described above) some small cones, to which he gives the name of Calamostachys (but not, as used by us, in the sense of Schimper), and certain leafy branches quite distinct in character from Asterophyllites; these he calls Calamocladus. Calamocladus is characterised by the whorls of leaves being separated by long internodes, and not crowded together as in Asterophyllites, and also by the fact that the upper branches were not arranged distichously, but radiated out on all sides. The leaves are said to have had several nerves, instead of a single median one, as in the former types. Grand'Eury brings forward good evidence that certain fructifications, usually of small dimensions, really belonged to the branches named Calamocladus. Some of these fructifications are described as having essentially the structure of the cones of recent Equiseta, bearing peltate scales only, without sterile bracts; the preservation, however, does 
not seem to be good enough to settle the point for certain.

It appears that the stems with the structure of Calamodendron had much longer internodes than those of the Arthropitys type, and that the branches were scattered irregularly, and not limited to certain definite nodes as in the Arthropitys group. These and other differences are said to render the casts of Calamodendron recognisable ; they correspond to the Stylocalamites of Weiss's system. In Calamodendron, as in the former group, the upright stems sprang from subterranean or aquatic rhizomes. Grand'Eury believes that the development of the secondary wood, in Calamarian stems of the same type, increases as we ascend from the lower to the higher horizons of the Coal-measures.

In addition to the three groups just enumerated, we have the ancient genus Bornia or Archaeocalamites, with its forked leaves and fructifications of a somewhat Equisetiform character. There is another genus which Grand'Eury has distinguished under the name of Autophyllites; its fructifications are much like those attributed to Bornia, and it had large dichotomous leaves. The plant is of Upper Coal-measure age.

It is important to point out how nearly some of the Calamarieae of the Carboniferous period approached our living Equisetum. In some, as we have seen, the fructification was of a very similar type, and there is no longer any doubt that many members of the family had leaves coherent at the base, so as to form a regular sheath (see Fig. I 2). It is probable, as already mentioned, that the sheath may often have become split, as the stem within grew in thickness, and that 
this may account in certain cases for the apparently distinct leaves.

So far, I have treated the Calamarieae generally as being Cryptogamic plants with manifest Equisetaceous affinities, and I do not think, so far as that goes, that much difference of opinion now remains, though for many years their position was warmly disputed. I mentioned in the last chapter the views of Brongniart. His distinguished disciple, the late M. Renault, took the same side in the controversy, but, as time went on, considerably modified the original Brongniartian view. Brongniart would not have allowed that all the plants now grouped as Calamarieae were nearly allied to one another. He separated them sharply, at least in his later works, into two wholly different families, the one Cryptogamic, the other Phanerogamic. ${ }^{1}$ M. Renault, on the other hand, recognised the family of Calamarieae, as including all fossil plants, whether Cryptogamic or Phanerogamic, which possess a "Calamitoid" stem. ${ }^{2}$ Within this main group, however, he separated the Equisetineae (with Cryptogamic, homosporous or heterosporous cones) from the Calamodendreae; the latter he still inclined to regard as Gymnospermous Seedplants. In his latest works he gave up the distinction based on the presence or absence of secondary wood, and recognised the existence of Cryptogamic Calamarieae with cambium, as in the case of the Calamites which bore Macrostachya as its fructification. Thus, in the end, there came to be substantial agreement between the great French palæobotanist

1 Tableau des gertres de végétaux fossiles, p. 49, I849.

2 Flore fossile d'Autun et d Epinac, Part ii. 1896, p. 60. 
and the English school, of which Williamson was the leader.

If M. Renault's view that a certain part of the Calamarieae bore seeds were tenable, we should have the remarkable case of a transition from Cryptogamic to Phanerogamic plants within the limits of a single family. For this conclusion, though not without analogy, there is, as yet, no satisfactory evidence in this case.

M. Renault was led, by his belief in the existence of Phanerogamic Calamarieae, to regard some of the fructifications of the Calamostachys type as male cones, others as Cryptogamic strobili, a distinction which the identity of structure renders improbable, in the absence of more positive evidence. $\mathrm{He}$ also attributed certain highly developed seeds (e.g. Gnetopsis and Stephanospermum) to the Calamarieae, but this was never more than a conjecture, and on present evidence it appears that the affinities of the seeds in question lay in a totally different direction, i.e. with the Pteridospermeae (see Chapter X.). A specimen, named by M. Renault Arthropityostachys Williamsonis, ${ }^{2}$ was interpreted by him, though with some doubt, as a Calamarian cone bearing at the same time both seeds of the Gnetopsis type and pollen-sacs, but this interpretation has not stood the test of further investigation. ${ }^{3}$

There is, in fact, no evidence, in the present state of our knowledge, that the Calamarieae were anything more than a varied and highly organised family of

1 See below, Chapter VI. p. 193.

2 Flore fossile a'Autun et d'Epinac, Part ii. p. I37, Plate 1xiii.

3 Cf. Zeiller, "Revue des travaux de paléontologie végétale," I893I896, in Revue générale de botanique, 1897, p. $37 \mathrm{I}$. 
Vascular Cryptogams, closely allied to the recent Horsetails. But, although none but Cryptogamic Calamarieae are known to us, the question remains whether they show marked affinities to any of the groups of Seed-bearing Plants, or are likely to have lain on or near any of the lines of Phanerogamic descent.

If there were any such affinity, it would appear to lie in the direction of Coniferae, or possibly, as M. Renault suggested, of Gnetaceae. The anatomy of the stem certainly approaches that of the former family, while the usually simple form and structure of the leaves may be regarded as pointing the same way. Even the fructifications are not without analogy in the two groups. The relative position of the sporangiophore and bract in Palaeostachya has been compared with that of the ovuliferous and carpellary scale in Abietineae. I was at one time disposed to attach some weight to these various considerations, as indicative of affinity. It is more probable, however, that these points of resemblance between Calamarians and Conifers are nothing more than analogies-interesting examples of parallel development, but not marks of relationship. There is an entire absence of transitional forms between Equisetineae and either Coniferae or Gnetaceae, whereas, as we shall see later on, there is strong evidence for the derivation of the Gymnosperms generally (or at least of the Cycads and Conifers) from a different Cryptogamic stock, namely that of the Ferns.

8. Mesozoic Equisetales.-The Calamarieae hitherto considered are strictly Palæozoic plants; the last 
survivors of the Calamites appear to have died out in the Permian at the close of the Primary period. The Equisetineae, however, were well represented during the Secondary epoch, ${ }^{1}$ by forms in some respects intermediate between the Palæozoic Calamites and the recent Horsetails. In the Trias very large Horsetails are found, the stem of one of them, Equisetites arenaceus, even attaining a diameter of $20 \mathrm{~cm}$. ( 8 inches). All parts of this plant-rhizome, aërial stem, leaf-sheaths, and cones-are preserved, and though all the organs are not in connection, there seems no reason to doubt that they really belonged to the same species. In all respects there is a close agreement with our recent Horsetails, but the Triassic plant was on an immensely greater scale; it had, for example, as many as I 20 leaves in a whorl. It is probable that these great stems, like those of the still larger Palæozoic forms, possessed secondary tissues, but at present this is only a conjecture. In the Rhætic and Liassic Equisetites of Sweden M. Halle finds that the internodal bundles are three to four times as numerous as the leaf-teeth of a whorl; the bundles must therefore have traversed at least three internodes. In Neocalamites, a genus separated by M. Halle from Schizoneura (see below), the bundles passed through two internodes, apparently branching in some cases. These facts offer interesting analogies with the Palæozoic Calamites (see above, p. 26). Numerous Mesozoic species are known; on the whole their dimensions diminish as the later horizons are approached. Some of the fossil forms, as,

1 For a fuller account of the Mesozoic Equisetales, see Seward's Fossil Plants, vol. i. 
for example, Equisetites Burchardti from the Wealden, had tubers just like those of some recent species.

The genus Phyllotheca, very similar to Annularia, but with the leaves more united, appears to represent a Palæozoic type which extended into the Mesozoic period as far as the Lower Jurassic. Schizoneura, a characteristic Triassic genus, is remarkable for the splitting of the leaf-sheath into leaf-like segments of variable width. The Secondary Equisetales appear to offer a promising field for research. Professor Nathorst kindly informs me that M. Halle, who is investigating the Stockholm collections of Rhaetic and Liassic Equisetaceae from Scania in Sweden, has succeeded in finding the sporangia on the lower surface of the peltate sporangiferous scales; this is the first time they have been observed in Mesozoic specimens. The sporangiophores, which appear to have been of an almost ligneous texture, have on their lower surface the prints of about twenty-four sporangia-a larger number than in the recent genus. The sporangia and spores closely resemble those of the recent Equisetum; the elaters, however, are not preserved. An interesting point is that the spores show a triradiate marking almost identical with that on the spores of Calamostachys Binneyana (cf. Fig. 22, D). ${ }^{1}$

From the rapid sketch of the fossil Equisetales which has now been given, it is evident how greatly our whole idea of the family is widened by the study of the extinct forms. It is from these alone that we

1 At present M. Halle has only published a preliminary notice, in Swedish, of his interesting discoveries. 
can form any conception of the variety of which this type of organisation is capable, and of the high differentiation to which it once attained. In fact, it is no exaggeration to say that, as regards this important Cryptogamic stock, the study of the fossil forms far outweighs in scientific interest that of the few humble species which have survived to our own day. 


\section{CHAPTER IV}

\section{SPHENOPHYLLALES}

Sphenophylleae; Cheirostrobeae; Pseudoborniales

So far, we have been endeavouring to extend our knowledge of a class already familiar to us, by the study of its extinct representatives. We now go on to fill in a gap in the natural system in a different way, by the description of a group which appears so remote from any recent plants, that it is only quite within the last few years that its probable affinity with an isolated existing family (the Psilotaceae) has been detected. The class in question-that of the Sphenophyllales-was not, so far as our present knowledge shows, an extensive one, but it is of great phylogenetic interest.

\section{Spiienophylleae}

I. Sphenophyllum-Vegetative Organs.-The external aspect of the various species of Sphenophyllum has long been familiar to palæobotanists; the specimens, when preserved in the form of impressions, are often among the prettiest of the Carboniferous remains. The genus, which is nearly co-extensive with the family 
Sphenophylleae, is characteristic of the Carboniferous formation, and occurs throughout its whole extent, appearing also in the Permian immediately above it, but scarcely reaching the Triassic. The slender stems of Sphenophyllum were ribbed; the ribs did not alternate in successive internodes, but ran straight on through the nodes; in like manner, the leaves of successive whorls were not alternate, but superposed, a point of great importance among the distinctive characters of Sphenophyllum. In the typical species, on which the genus was founded, the leaves, usually six in a whorl, were wedge-shaped, with an entire or toothed margin (Fig. 35). It was soon found, however, that the wedge-shaped form of leaf was not universally present. In very many

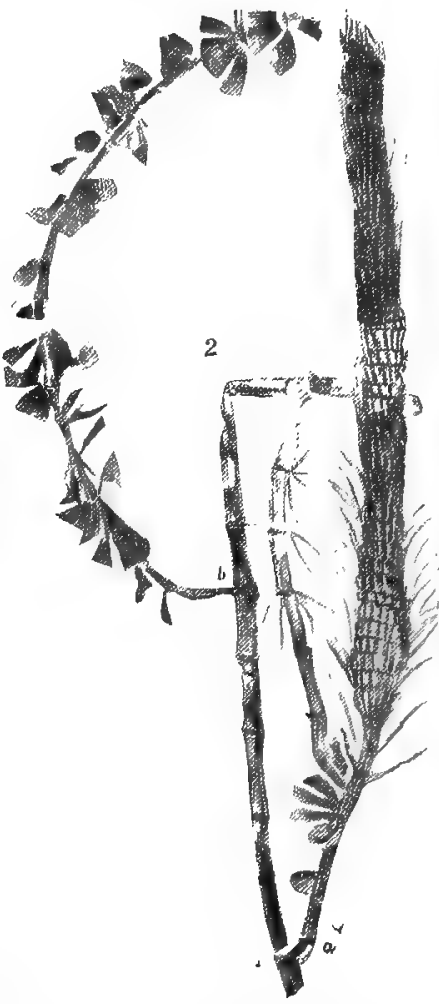

FiG. 35.-Sphenophyllum, sp. Branched stem, bearing linear and cuneate whorled leaves on different parts. The branch $a$ terminates in a long and slender cone. Half nat. size. After Stur.

cases the leaves were dichotomously divided into narrow lobes, and in some we find a whorl of perfectly simple narrow leaves, which may be regarded as corresponding to the segments of a smaller 
number of deeply-cut palmate leaves. In some members of the genus, both forms of leaf, the simple and the compound, are found on the same stem (see Fig. 35); and as, in certain cases, the finely-cut leaves are found below, and the broader wedge-shaped leaves above, a comparison has been suggested with the dimorphic foliage of many aquatic Ranunculi, and other water-plants of the present day. It is a familiar fact that in the Water Crowfoot, for example, the lower submerged leaves are finely divided into capillary segments, while the upper floating leaves are entire or but slightly lobed. Hence it was inferred that Sphenophyllum itself was an aquatic genus. But this comparison will not really hold good, for in S. cuneifolium, for example, the upper cone-bearing branches show the finely-cut foliage, while the leaves of the main stem are often cuneate.

Apart from this difference in the form of the foliage, there is considerable uniformity in the external characters of Sphenophyllum. ${ }^{1}$ The stem was branched, the lateral branches springing from the nodes; their exact relation to the leaves has not yet been cleared up. The fructification consisted of fairly large cones (Fig. 35), which from their external appearance might in some cases very well be taken for those of the Calamarieae. We shall see, however, that their organisation was different.

1 In S. speciosam, sometimes separated under the generic name Tricygia, derived from the Gondwana formation (probably Permo-Carboniferous) of India, the six leaves of each whorl are grouped in three pairs, one pair being constantly smalier than the other two. The leaves are accurately superposed, and the small pair is always on the same side of the stem. A similar differentiation has been observed in some European species of Sphenophyllum. 
We will now go on to describe the internal structure. The anatomy of the stem is exceedingly remarkable, and quite unlike that of the stem in any other group of plants. It was made known, in the first instance, by the investigations of $M$. Renault ${ }^{1}$ on the French specimens. This observer was so fortunate as to find the internal organisation preserved, in specimens which at the same time showed the external characters of definite species, and this is one reason why Sphenophyllum has become one of the best-known fossil genera. One anatomical feature is constant in all the forms examined. We always find, in the middle of the stem, a solid strand of primary wood without pith, and this strand is either triarch or hexarch in structure, and was always centripetally developed, as shown by the position of the spiral elements at the prominent angles (see Figs. 36-38, 40, and 4I, B).

First of all, we will confine ourselves to the primary structure, as shown, for example, in the species from the Lower Coal-measures of Lancashire and Yorkshire, named Sphenophyllum plurifoliatum ${ }^{2}$ (Figs. 37 and 38). The primary wood, as seen in transverse section, is triangular ; it consists entirely of tracheae, without pith or conjunctive parenchyma. At the angles, narrow spiral or reticulate elements are found, marking, no doubt, the starting-points of the development. The more internal part of the wood consists of large, pitted tracheae. In this case the structure is clearly triarch, like that of so

I See his Cours de botanique fossile, vols. ii. and iv., and the earlier papers there cited.

${ }^{2}$ See Williamson and Scott, "Further Observations on the Fossil Plants of the Coal-measures," Part $i$., and the earlier memoirs of William. son, there clted. 
many roots; such a structure is very rare in stems, though we find an example in the smaller branches of Psilotum. In some French species of Sphenophyllum,

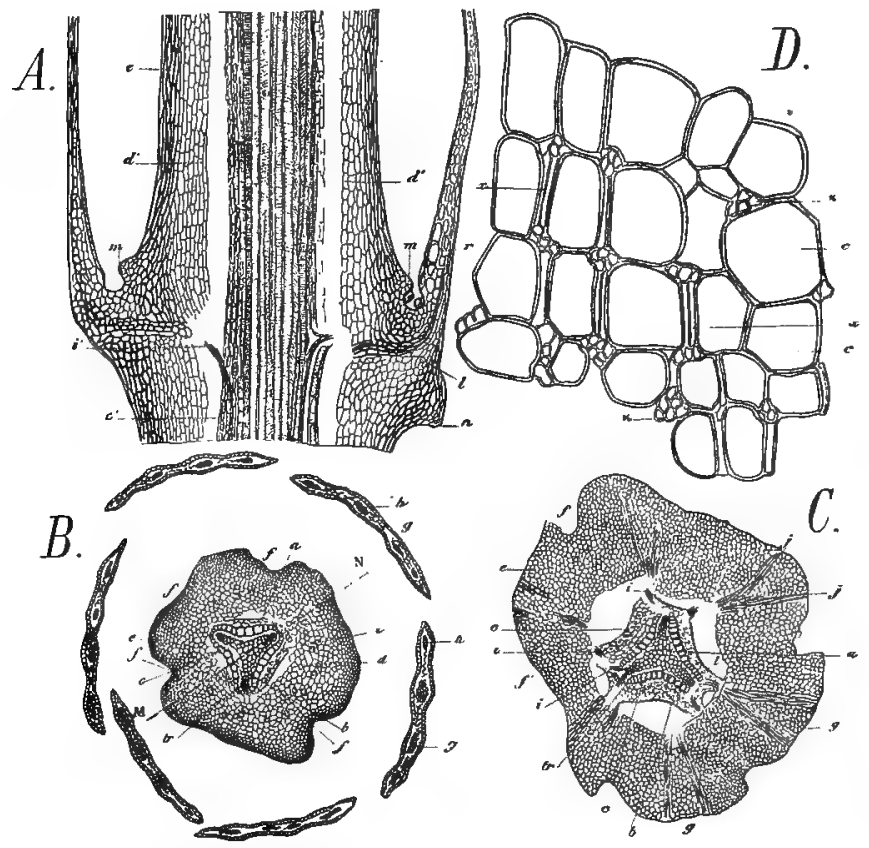

FiG. 36.-Sphenophyllnm quadrifidun. A. Radial section through a node, showing leaves, cut in the plane MN of Fig. B. In the middle is the stele, showing primary and secondary wood. $c^{\prime}$, phloëm; $d^{\prime \prime}$, inner, $e^{\prime}$, outer cortex ; $i^{\prime}$, leaf trace; $l$, base of leaf; $m$, axillary bud (?); $n$, cortical emergence below node. B. Transverse section of same stem, a little above node, showing six leaves surrounding stem. $a, b$, primary wood; tr, protoxylem; $c$, secondary wood; $c$, phloëm; $d$, $e$, cortex; $f^{\prime}$, furrows ; $g, h$, leaves, each with four vascular bundles. C. Transverse section through a node, showing the forking leaf-trace bundles, $j, j$. Other lettering as before. A, B, C $\times 9$. $D$. Transverse section of a portion of secondary wood. $c$, tracheides; $x$, parenchyma between them. The radial direction is vertical in this figure. $\times$ about 60 . All after Renault.

described by M. Renault, the protoxylem-groups are double, ${ }^{1}$ so that here the wood may be described as

1 The scale of Fig. $36, \mathrm{~B}$ and $\mathrm{C}$, is too small to show this point. Cf, however, Fig. 4I, B. 
hexarch, though the triangular sectional form is retained. In the young specimens but little remains of phloëm have been found; the inner layers of the cortex are of delicate tissue, but towards the outside is a fibrous zone (Fig. 37). The external outline of the cortex, as seen in transverse section, is characteristic, for there

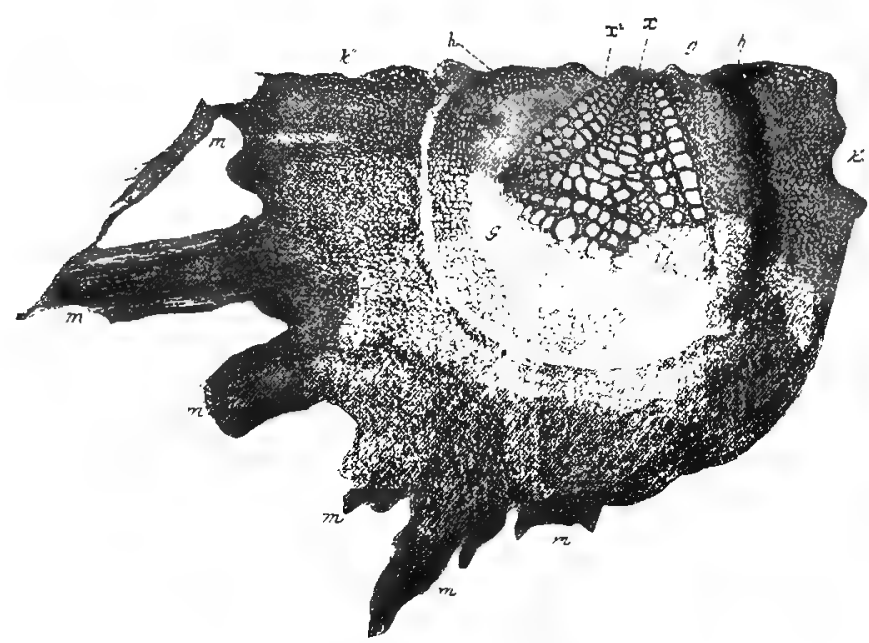

FIG. 37.-Sphenophyllum plurifoliatum. Transverse section through whorl of leaves, in. $x$, primary wood ; $x^{2}$, secondary wood $; g$, phloëm $(?) ; z$, periderm; $k$, outer cortex. $\times$ about 20 . After Williamson, Phil. Trans. Will. Coll. 874.

are three well-marked furrows, lying opposite the three flat sides of the triangular stele (see Fig. 36, B).

It is only in the most minute specimens that the primary structure just described is found unaltered. At a very early stage the formation of secondary wood and bast, by means of a normal cambium, began (Fig. 37). The secondary wood possesses some very

1 See Fig. 36, B and C, where only one layer of secondary wood is shown. Cf. Fig. 4I, B. 
remarkable characteristics. It consists of radial series of tracheae, of large size, with numerous bordered pits, chiefly on the radial cell-walls (Fig. 39). Between these tracheae, which, as seen in transverse section, appear square with truncated angles, we find little groups of

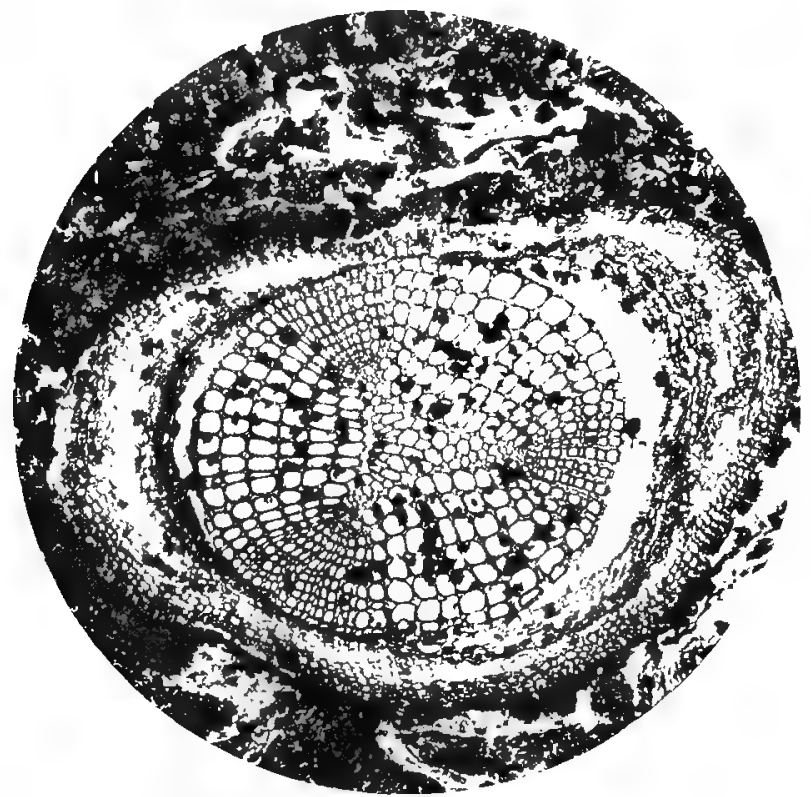

FIG. 38.-Sphenophyllum plurifoliatum. Transverse section of older stem, showing triangular primary wood, broad zone of secondary wood, remains of phloèm, and thick periderm; primary cortex cast off. $\times 18$. From a photograph. Phil. Trans., W, and S. Will. Coll. 899 .

thin-walled cells, fitting into the spaces at the corners (see Fig. 36, D). These represent vertical strands of parenchyma, which are not isolated, but are connected with one another, in the radial direction, by horizontal cells or strands of cells, which are usually quite short, not forming continuous medullary rays (Figs. $36, \mathrm{D}$, and 
39. This peculiar structure of the wood is found both in the English (Figs. 38 and 39) and in the French forms (Fig. $36, \mathrm{D}$ ), but is not common to the whole genus, as we shall see presently. The elements of the wood are arranged with the greatest regularity (Fig. 38). There is a marked difference in size between the secondary elements found opposite the sides of the primary wood, and those corresponding to its angles; the former are much the larger (see Fig. 38). In the small-celled wood opposite the angles there is an approach to the formation of continuous rays.

In the best-preserved specimens we find, immediately beyond the wood, the delicate tabular cells of the cambium itself, sometimes most distinctly shown, and beyond this we come to a zone of thin-walled radiallyarranged tissue, which can only be interpreted as the phloëm (see Fig. 38 ). ${ }^{1}$ Beyond this again, in older stems, lies a wide band of firmer tissue, also radially arranged, which we must regard as internal periderm (Fig. 38). If we examine a comparatively young stem of Sphenophyllum, we find, in many cases, a very distinct beginning of periderm-

1 For more complete illustrations of the various tissues, see Williamson and Scott, l.c. 
formation in the inner cortex (Fig. $37, h$ ). In older stems, the primary cortex had been cast off altogether. Sometimes traces of its disorganised tissues remain, but ultimately the primary cortex was replaced by a regular scale-bark, formed by successive layers of periderm (Fig. 38). This formation cut deeper and deeper into the cortex, until it reached the phloëm itself, just as in an oak-tree, for example, at the present day. So it appears that the secondary tissue lying outside the wood consists in its inner part of the phloëm, and in its outer part of the periderm, which was formed by a phellogen, arising first in the cortex and afterwards in the phloëm itself.

The species Sphenophyllum plurifoliatum is based on petrified specimens; it is not improbable that it may prove to be identical with the contemporary $S$. myrioplyyllum, Crépin, known in the form of impressions. The species agree in the large number of linear leaves or leaf-segments in a verticil, and in the large diameter (about $\mathrm{I} \mathrm{cm}$.) attained by the main stems. ${ }^{1}$

I must now say something as to another form of Sphenophyllum, known by the name of Sphenophyllum insigne. This species was described by Dr. Williamson as long ago as 1874 . It is a very interesting form, because it comes from some of the oldest Carboniferous strata, namely from the Burntisland beds, belonging to the Calciferous Sandstone series, at a horizon far below the Coal-measures. In this species, the stem attains a diameter of almost a centimetre- a rather large size for a Sphenophyllum. In its general anatomy, the stem,

1 See Zeiller, Bassin houiller de Valenciennes, Flore fossile, p. 422, Pl. lxii. Figs, 2-4. 
which has been found at all stages of growth, is like that of the former species, but there are some not unimportant differences of detail. At each of the three

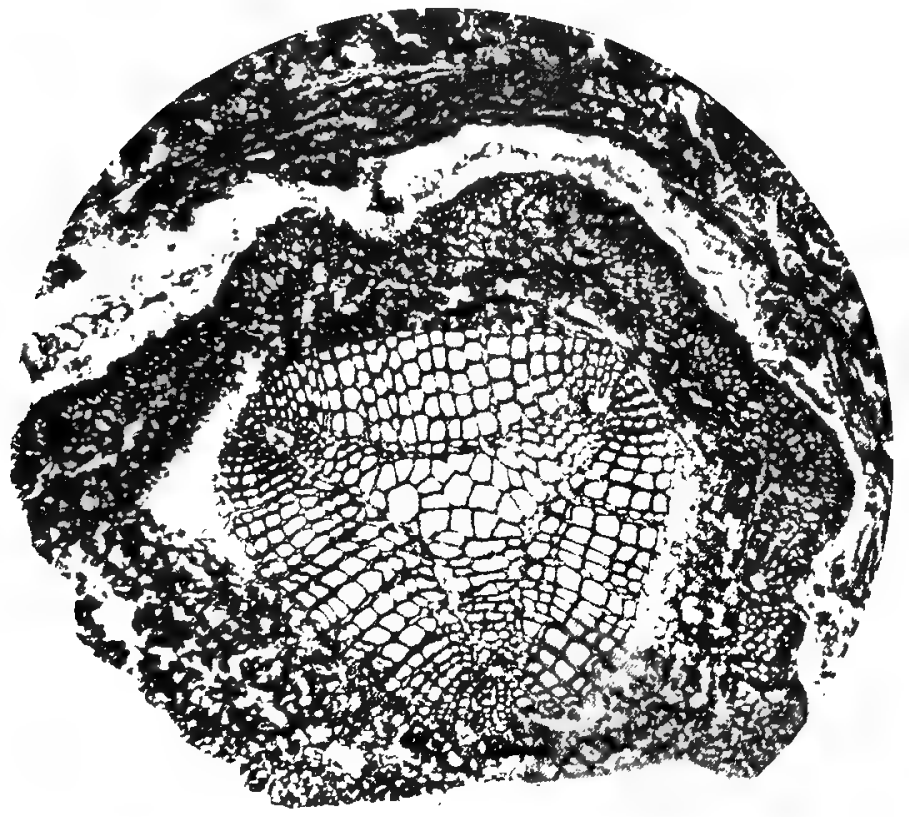

FiG. 40.-Sphenoplyllum insigne. Transverse section of rather young stem, showing triangular primary wood, with a canal at each angle, marking the protoxylem, then secondary wood, remains of phloëm, and the primary cortex, showing two of the furrows. $\times$ about 3 . From a photograph. Phil. Trans., W. and S. Wilt. Coll. grg.

angles of the primary wood is a canal, formed, no doubt, in consequence of the disorganisation of the primitive tracheae (Fig. 40). The tracheae generally have a scalariform sculpturing, instead of the numerous rows of bordered pits characteristic of other species. A still 
more important difference is the constant presence, in $S$. insigne, of continuous medullary rays, which replace the complicated system of vertical and radial parenchymatous strands in the species above described. In these latter points the Burntisland species differs, not only from S. plurifoliatum, but from all other species of Sphenophyllum of which the structure is known. For these reasons, and because the older specimens, which have lost their primary cortex, present a very root-like appearance, several palæobotanists disputed the identification of the fossil as a Sphenophyllum, imagining that it might be a root of a Cycad or of some unknown plant. The discovery of younger plants, still retaining their cortex (Fig. 40) and nodes, and even portions of the leaves, has completely removed these doubts, and justified Williamson's original opinion. ${ }^{\text {I }}$ The same species has now been found in the Lower Carboniferous of Silesia, of an age comparable to that of the Scotch specimens. In some specimens of Sphenophyllum insigne, the phloëm is remarkably well preserved, and large elements, much resembling the sieve-tubes of some recent Cryptogams, are present.

It is a fact of interest that this, the oldest known Sphenophyllum with structure, presents a less peculiar organisation than the forms from later deposits. This fact would seem to indicate that the remarkable arrangement of the wood-parenchyma in the latter species is a later modification, and not a primitive character of the group. Although the near affinities

1 Williamson and Scott, l.c., p. 926. Williamson's original description is in Part v. of his "Organisation of the Fossil Plants of the Coalmeasures," Phil. Trans. 1874. 
of S. insigne with Sphenophyllum are now clearly established, it is possible that its anatomical characteristics may ultimately justify its generic separation.

Now that we have dealt sufficiently with the morphology and anatomy of the stem, the organisation of the leaves and roots remains to be considered, before going on to the organs of fructification. I have already mentioned that the leaves of Sphenophyllum are whorled, and that they vary very much in form, some being broad and wedge-shaped (the type of leaf from which the genus derives its name), while others are deeply divided, or even assume a very simple linear form. It appears to be the rule, that the number of leaves in a whorl was always some multiple of three, a fact which is no doubt correlated with the triarch or hexarch structure of the vascular cylinder. Six was perhaps the most usual number (see Fig. 36, B); but where the leaves were linear this number was considerably increased. In the Coal-measure species, Sphenophyllum plurifoliatum, the leaves in each verticil seem to have been eighteen, at least, on the larger stems (Fig. 37). The nodes from which the leaves spring are somewhat enlarged, and the vascular strands pass out almost horizontally (Fig. 36, A). As regards the course of the leaf-trace bundles, our information is chiefly due to M. Renault, who succeeded in working out this question in some of the French forms. In these species, as we have seen above, there are two distinct groups of spiral elements at each angle of the stele-six such groups in all. At the node, one bundle starts from each of these groups, dividing, as it passes through the cortex, into two, three, or four branches, which supplied the 
various veins of the leaf (Fig. 36, C). Further division of the bundles took place within the leaf itself, as it widened out, or divided into segments. Where the leaves were linear, the course of the bundles was the same, but in this case each leaf received a single strand only, as in the British species, S. plurifoliatum. Numerous vascular bundles, apparently equal in number to the leaves in a whorl, have been found in this species in the outer cortex of the node. They no doubt arose, here also, from the subdivision of a smaller number of strands, given off from the angles of the stele. The branching of the leaf-traces within the cortex is very characteristic of Sphenophyllum.

- The anatomical structure of the leaf was fully worked out by Renault. The vascular bundles are small and simple, apparently of the concentric type. The tissue of the leaf was strengthened by bands of sclerenchyma, lying next the epidermis of the upper and lower surfaces. The parenchyma is uniform throughout. There is thus nothing remarkable in the anatomy of the leaf, unless it be the strong mechanical construction, a point of some interest, for it seems to show that these leaves could not have been floating, as some botanists have assumed, though with but little reason. The narrow, unifascicular leaves or segments of $S$. plurifoliatum had a rather simpler structure.

The roots have also been investigated by Renault. The specimens which he examined were of diarch structure, with secondary wood, resembling that of the stem. Somewhat similar structures are occasionally found in association with the Burntisland Sphenophyllum (S. insigne), and with the Coal-measure species, S. pluri- 
foliatum, and were probably the roots of those species. As regards the insertion of the roots, we do not know any details, but they appear to have been borne on the nodes.

\section{Fructifications of Sphenophyllum-S. Daresoni} Type--We now come to the question of the fructification of Sphenophyllum, our knowledge of which has grown rapidly during the last few years. Our first accurate information, with regard to the fructification of the genus, depended on the observations of Williamson, who described in the greatest detail a fructification which has since been proved to be that of a species of Sphenophyllum, named provisionally S. Dawsoni. We are now, however, acquainted with four distinct types of fructification in Sphenophyllum, on which a subdivision of the genus will no doubt ultimately be based.

We will begin with the description of the type of cone investigated by Williamson, with which, as $M$. Zeiller has shown, the fructifications of the well-known species Sphenophyllum cuneifolium agree in all essential respects. ${ }^{1} \quad$ The British specimens, which come from the calcareous nodules of the Lower Coal-measures, show the internal organisation in great perfection, ${ }^{2}$ while

${ }^{1}$ Zeiller, "Etude sur la constitution de l'appareil fructificateur des Sphénophyllum," Mém. de la Soc. géol. de France, "Paléontologie," Mém. I I, I893.

* Williamson first described his specimens under the name of Volk. mannia Dazusoni, using a generic name of very indefinite signification, and subsequently called them Bownanites Dawsoni. The name Bowmanites (a. genus founded in I87 I by Binney) is still retained for fructifications of Sphenophylleae, but, as we have some evidence in this case as to the vegetative structure, it is simpler to call Williamson's specimens Sphenophyllum Dazesoni-a name which may turn out to be synonymous in part with $S$. cuneifoliun. See Williamson, "On the Organisation of an 
those of the French observer, which are preserved in the form of impressions, give an excellent idea of the external characters, and afford the proof that these cones were really borne on Sphenophyllum stems. It appears that under the type-name Sphenophyllum Dawsoni two forms are included, the larger of which is probably identical, as $\mathbb{M}$. Zeiller believed, with $S$. cuneifolium, while the smaller may represent the fructification of $S$. plurifoliatum (=S. myriophyllum?). The following description applies, except when otherwise stated, to the larger species, which may be distinguished provisionally as the $a$ form.

In external aspect, the cones, which reach a length of several inches, with a diameter of half an inch or more, are not unlike some of the Calamarian fructifications (see Fig. 35). The free surface of the cone is formed by the upturned tips of the whorled bracts. The arrangement of the organs, as shown in Sphenophyllum Dawsoni, and illustrated by the diagram, Fig. 4I, A, is as follows: the cone has an axis $2-3 \mathrm{~mm}$. in diameter, bearing at intervals numerous whorls of bracts; the bracts of each verticil are coherent for a considerable distance from the axis, forming a kind of cup; at the edge of the cup, the individual bracts become free from one another and turn vertically upwards, extending for a distance equal to several internodes, so that the tips of several successive verticils overlap each other (cf. Figs. $4 \mathrm{I}, \mathrm{A}$, and 42). The number of bracts in each whorl varies, ranging from fourteen to about twenty in the

undescribed Verticillate Strobilus, etc.," Manchester Lit. and Phi. Soc. I871 ; "Organisation of Fossil Plants of the Coal-measures," Parts v. (1874) and xviii. (1891); Villiamson and Scott, l.c. 
cases where it was possible to count them. It has not yet been decided for certain whether the bracts of successive whorls were alternate or superposed; though the
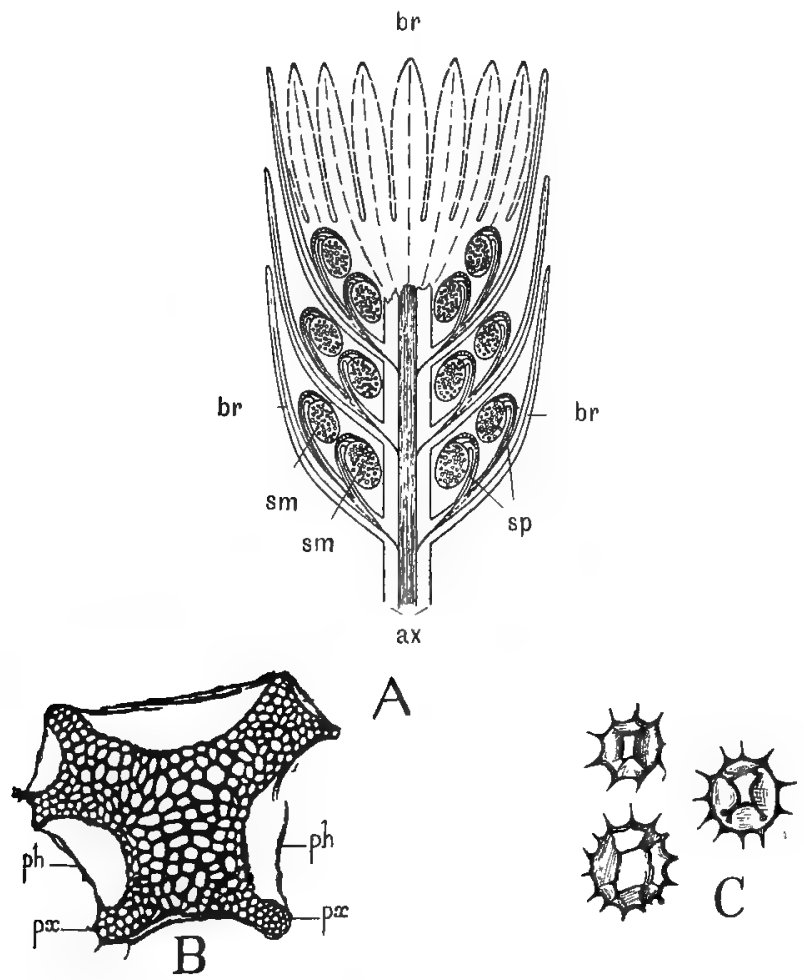

FIG. 4I.-Sphenopliyllam Dazusoni. A. Diagram of cone in longitudinal section, showing three whorls. $a x$, axis; $b r$, bracts; $s p$, sporangiophores; smt, sporangia ; $b r^{\prime}$, whorl of bracts seen from the inside in surface view. (G. T. G.) B. Stele of axis, in transverse section. Wood only preserved. $p x$, protoxylem-groups, of which there are six in all; ph, remains of phloëm. $\times$ about 20. Will. Coll. ıо49. C. Spores, in superficial aspect. $\quad \times$ about 100. $\mathrm{B}$ and $\mathrm{C}$ after Williamson, Phil. Trans.

analogy of the vegetative leaves would lead one to expect superposition, the direct evidence is in favour of an alternate arrangement. The sporangia were 
borne singly on long pedicels or sporangiophores, which sprang from the upper surface of each verticil

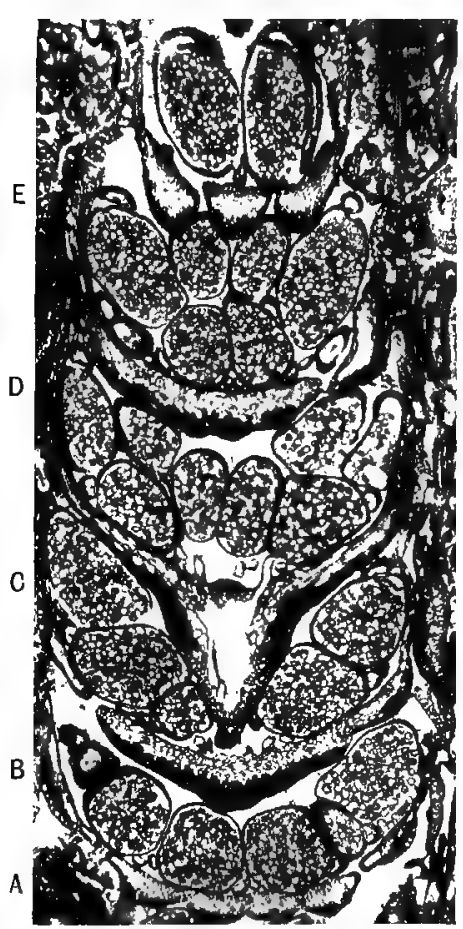

FIG. 42,-Sphenophyllam Darusoni, $\beta$. Somewhat oblique longitudinal section of cone, mostly tangential, but passing through axis below $C$, where the bracts are connected with the axis. Five verticils (A-E) are shown. At $B$ and $D$ the bracts are connate; at $A$ and $\mathrm{E}$ they have separated; at $\mathrm{B}$ and $\mathrm{C}$ the attachment of sporangiophores to bracts is shown; at $\mathrm{E}$, especially to the right, the relation of sporangiophore to sporangium is very clear. $\times 9$. From a photograph by Mr. Lomax. University College Collection, $\mathrm{EE}$, i, c. of bracts in its united part, near the axis (Fig. 4I, A, $s p$, Fig. $42, \mathrm{~B}$ and $\mathrm{C}$ ). The pedicels are generally twice as numerous as the bracts; they are ranged in a single whorl, but are of unequal lengths, so that the sporangia of the same whorl overlap each other (Fig. 42). This gives the impression that more than one verticil of sporangiophores may spring from a single whorl of bracts, but this is not the case, though the point at which the sporangiophore becomes free from the bract is variable.

The pedicel is a slender stalk, becoming rather thicker near the top, where it bends over towards the axis of the cone, and bears a single pendulous sporangium. The position of the sporangium on its pedicel is much like that of an anatropous ovule in relation to its funiculus (cf. Figs. 4I, A, 42, E, 43, and 44). 
We have now gained some idea of the general . morphology of the cone, the chief points in which are the gamophyllous verticils of sterile bracts, and the sporangiophores, twice as numerous as the bracts, springing from their upper surface, and bearing each a single pendulous sporangium at the end. The complex structure of the whole strobilus is well shown in the transverse section, Fig. 43, from one of Williamson's drawings, and in the longitudinal section, Fig. 42 .

We will now go on to describe the structure more in detail. In some specimens of $S$. Dazesoni the axis is well preserved; it is traversed by a triquetrous strand of solid wood, without pith (Fig. 4I, B), like that of the vegetative stem in other species of the genus. It was this anatomical similarity which first led Williamson to regard his specimens as akin to Sphenophyllum, long before Zeiller's observations proved their identity. In S. Dawsoni, form $a$, the corners of the wood are truncated, or even widely forked, and there were two strands of primitive tracheae to each (Fig. 4I, B, px), so that the whole stele was hexarch, ${ }^{1}$ as in some French species. Associated with the cones of S. Dawsoni a single fragment of a vegetative stem has been found, showing a primary structure just like that of the axis of the strobilus, but with the addition of a broad zone of secondary wood and bast. There can be little doubt that this specimen represents the vegetative stem of Sphenophyllum Dawsoni, form $a$, and if so, that species was evidently distinct from any other Sphenophyllum of which the structure is known, though probably identical

${ }^{1}$ Owing to irregularities in the forking, the stele sometimes appears pentarch. 
with $S$. cuncifolium. In the smaller form $(\beta)$ there is a slender, triarch xylem.

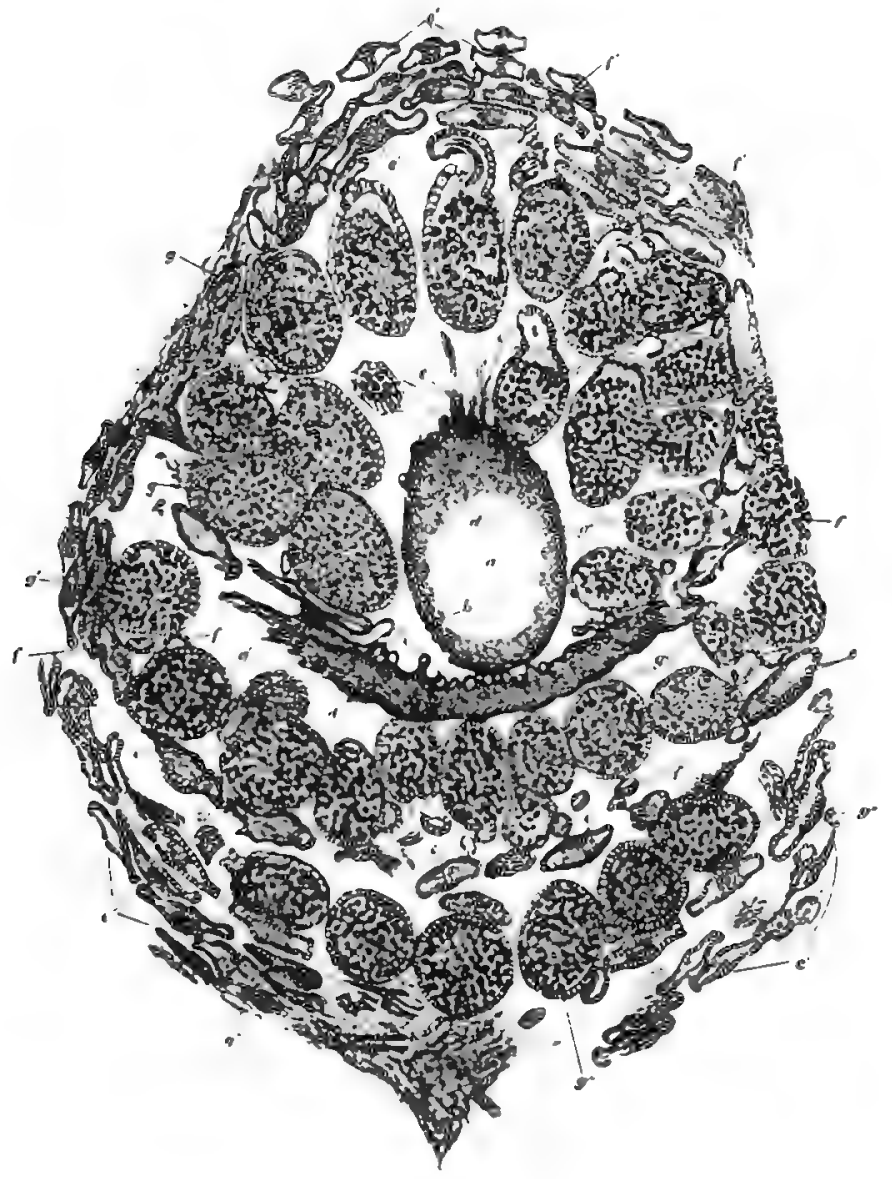

Fig, 43.-Sphetophyllum Dausoni, a. Obliquely transverse section of cone, showing parts of three whorls of bracts. $\boldsymbol{\alpha}^{\prime \prime}$, hollow axis (stele missing); $b, d$, cortex of axis ; $\ell, \ell^{\prime}$, bract 5 cut al different levels; $f$, sporangiophores, the innermost just springing from a whorl of bracts, which are here coherent; $f$, sporangiophores in connection with their sporangia ; $g, g^{\prime}, g^{\prime \prime}$, sporangia of the three whorls. $\times 7$. After Williamson, Phil. Trans. Will. Coll. ro:19 B. 
In the axis of the cone we find that the cortex, so far as it is preserved, resembles that of a young vegetative stem. The course of the vascular strands supplying the bracts and sporangiophores has been, to some extent, traced; the bundles given off from the central cylinder underwent much subdivision in passing through the cortex, until they were equal in number to the bracts in a verticil. The most interesting point is, that each of these strands, immediately on entering the verticil, divides into three branches, one of which lies below the other two. The lower branch passes through the coherent whorl and out into the free tip of the bract to which it belongs; the two upper branches of the strand pass out into the pedicels of the two sporangiophores corresponding to the bract in question (see Fig. 4I, A, sp). Thus we see that by anatomy, as well as position, the sporangiophores are shown to be appendages of the bract from which they arise.

The bracts themselves are of simple structure (Figs. 42, 43); the epidermis contains stomata, similar to those of some Ferns. The slender vascular bundle extends right through the bract.

The sporangiophores either separated from the whorl of bracts as soon as the latter became free from the axis, or remained adherent for some distance to their upper surface; the vascular strand in each sporangiophore traversed the whole length of the pedicel, increasing in thickness towards the top, and eventually ending suddenly at the base of the sporangium (see Fig. 43, $f^{\prime}$; Fig. 44). In the upper part of the pedicel, and especially where it bends over 
towards the axis, the epidermal cells are much enlarged, and these large cells of the pedicel are continuous with those that form the wall of the sporangium itself
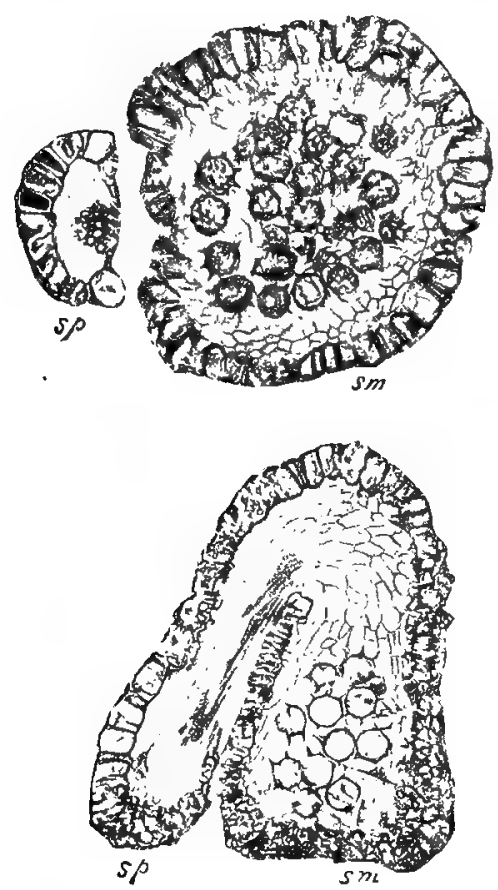

FIG. 44,-Sphenophyllum Dawesoni. Sporangiophore and its sporangium, shown in transverse section above, and in longitudinal section (some what oblique) below. $s \not p$, sporangiophore; $s m$, sporangium, containing spores. $\times 45$. Phil. Trans,, W. and S. Will. Coll. 1898, H. and E.

(Figs. 43 and 44). Towards the free end of the sporangium, the cells of the wall become much smaller, and it was probably at this end that dehiscence took place, the large cells perhaps performing the functions of an annulus. These cells were strengthened by buttresses projecting from their lateral cellwalls, much as in the sporangium of Calamostachys. The sporangium is seated, with a broad base, on the recurved end of the pedicel; the sporangial wall in this region is lined by a delicate tissue (Fig. 44).

The spores were numerous in each sporangium, and so far as at present observed, were all of one kind, though rather variable in size. Their average diameter is about $.09 \mathrm{~mm}$. The spore-membrane shows a characteristic sculpturing, consisting essentially of prominent spines, connected 
together by a network of elevated ridges or wings (see Fig. 4 I, C).

The above description, based on the Sphenophyllum Dawsoni of Williamson, is now known to hold good, in all essential points, for Sphenophyllum cuneifolium, with which, indeed, M. Zeiller, to whom we are indebted for a most minute comparison of the two cones, thinks-it identical; this conclusion is probably correct as regards the larger form of $S$. Dazesoni. Several species, in addition to $S$. cuneifolium, were examined by M. Zeiller, and in these also he was able to show that the sporangia were borne on pedicels, arising from the upper surface of the bracts.

So many specimens of $S$. Dawsoni, all showing spores of the same kind, have now been investigated that there is little doubt that these cones were homosporous. A specimen described many years ago by M. Renault, and supposed to show heterospory, is now admitted to have been wrongly interpreted; the structure which was formerly regarded as a megaspore is in reality nothing but a fragment of tissue, probably forming part of the wall of a sporangium.

The occurrence of spores of somewhat different dimensions in adjacent sporangia (averaging .083 $\mathrm{mm}$. in one sporangium, and .106 $\mathrm{mm}$. in another), those of the larger size being accompanied by minute, presumably abortive spores, has recently been interpreted as a possible indication of incipient heterospory. ${ }^{1}$

3. Bowmanites Römeri, Sphenophyllum fertile, and S. majus.-About twelve years ago the investigations of

1 Thoday, New Phytologist, vol. v., April 1906. 
Count Solms-Laubach made us acquainted with a fructification, of the Sphenophyllum type, which differs in important respects from those already described. The author named his specimen Boremanites Römeri, ${ }^{1}$ using the generic name Bormanites to include all fructifications referable to the family Sphenophylleae. ${ }^{2}$ This nomenclature is the most suitable in this case, for, in the absence of any vegetative organs, we cannot be certain that the specimen belonged to a member of the genus Sphenophyllum, though most probably this was the case. Bormmanites Römeri is at present only known from a single fragment, happily very well preserved, from the Coal-measures of Cracow. The axis is not present, but the arrangement and structure of the bracts and sporangia have been made clear by the researches of the discoverer. The bracts are in whorls, and those of each whorl are united towards the base, though not for so long a distance as in Sphenophyllum Dazesoni; the bracts are directed steeply upwards, and several successive verticils overlap each other. In this case it seems to be proved that the members of successive whorls were superposed, like the foliage-leaves of Sphenophyllum. The structure of the bracts is similar to that in S. Daresoni; each is traversed by a single vascular bundle. (See Fig. 45, for an outline transverse section of half the strobilus.)

The point of chief interest is the position of the sporangia, two of which were borne on each sporangiophore. The pedicel expanded at the top into a scale

1 "Bowmanites Römeri, eine neue Sphenophylleen-Fructification," jahrbuch der h. k. geolog. Reichsanstalt, Vienna, 1895.

2 The appropriate but, as the author allows, sesquipedalian name, Sphenophyllostachys has been introduced by Prof. Seward in the same sense. 
of considerable size (Fig. 46, A), from which the two sporangia hung down side by side, towards the axis of the cone. It appears that the pedicels in this species were short, and that they were arranged in three concentric verticils, on each whorl of bracts-another apparent difference from Sphenophyllum Daresoni. The pedicel, which much resembles a sterile bract in structure,

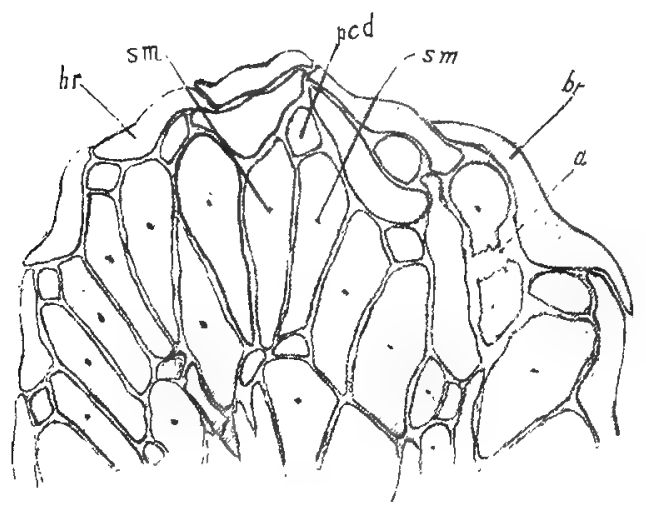

Fig. 45.-Bowmanites Röneri. Part of transverse section of cone. br, bracts; pcd, pedicel of sporangiophore; $s m$, the two sporangia belonging to it. At $a$ the lamina of a sporangiophore is shown. $\times$ ro. After Solms-Laubach.

is traversed by a vascular bundle, which, where it enters the scale at the top, divides into two branches to supply the two sporangia (Fig. 46, A). The anatomical structure of the sporangiophore, allowing for the greater size and complication associated with the presence of two sporangia instead of one, closely resembles that of Sphenophyllum Dawsoni (Fig. 46). The sporangium has a wall several cells in thickness; in S. Dawsoni this is

1 In the transverse section (Fig. 45) the pairs of sporangia $(\mathrm{sm}$ ) are shown, with the pedicel $(p c d)$ between the two sporangia, and on their outer side. 
only the case at the base, but the difference may be merely a matter of preservation. The spores in each sporangium are numerous, and closely resemble those of Sphenophyllum Darusoni, the resemblance extending

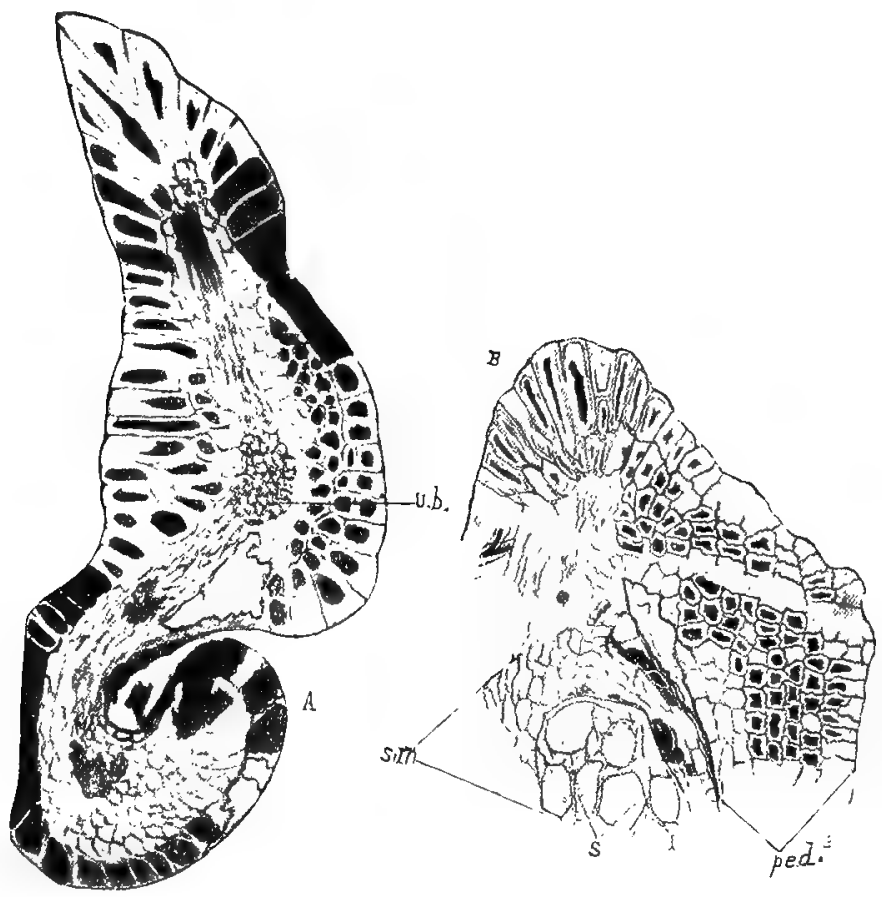

FIG. 46.-Bowmanites Römeri. A. Lamina of sporangiophore, cut nearly parallel to its upper surface, and above the insertion of the sporangia. v.b*, vascular bundle. B. Longitudinal section throngh upper part of sporangiophore, showing insertion of sporangium. ped., pedicel; $s m$, part of sporangium; $s$, spores. $X$ about 60. After Solms-Laubach.

to the most minute details of structure of the sporemembrane.

There can be no doubt that this discovery of Count Solms-Laubach's threw a great light on the morphology 
of Sphenophyllum. In particular, the structure of the complex sporangiophores, each bearing two sporangia, showed that these organs cannot be regarded as mere sporangial stalks, but that they are rather comparable to the peltate scales of the Equisetales. At the same time, their structure and position go far to confirm Zeiller's opinion that the sporangiophores of Sphenophylleae may be interpreted as ventral lobes of the leaf, the bract itself representing the dorsal lobe. On all these points much further light has been thrown by the still more recent discovery of other new types of fructification, now to be described.

A recently discovered fructification (Sphenophyllum fertile, Scott ${ }^{1}$ ) from the Lower Coal-measures of Shore Littleborough, in Lancashire, resembles Boremanites Römeri in having peltate, bisporangiate sporangiophores, but is peculiar in the fact that both the dorsal and ventral lobes of the sporophyll are fertile; the sterile bracts, which in other Sphenophyllaceous strobili represent the dorsal lobes, are here replaced by additional sporangiophores. The sporophyll is also more complex than in other species, its lobes, both dorsal and ventral, dividing in a palmate manner into several branches, each of which constitutes a sporangiophore (Fig. 47). The anatomy of the axis of the cone is in all respects that of a typical Sphenophyllum, so that in this case there can be no doubt as to the attribution of the fructification.

It is only in a few cases, of which the three types already described are the chief, that the preservation of

1 Scott, "On a New Type of Sphenophyllaceous Cone (S. fertile) from the Lower Coal-measures," Phil. Trans. Roy. Soc. B, vol. I98, 1905. 
structure enables us to clearly understand the organisation of Sphenophyllaceous strobili. Specimens preserved only as carbonaceous impressions may, however, afford
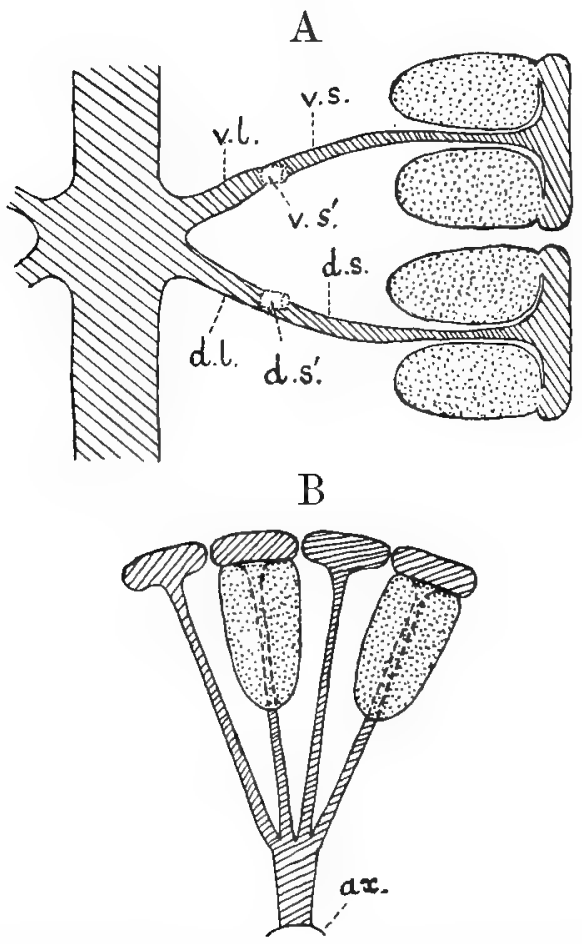

Frc. 47.-Sphenophyllum fertile. Diagram A. Node in radial section, showing one sporophyll. $v . l$., ventral lobe ; $v_{s} s_{*}$, a ventral sporangiophore bearing two sporangia; $z^{\prime} . s^{\prime}$., stump of another sporangiophore; $d . l ., d^{\prime} . s ., d^{\prime} s^{\prime}$., corresponding dorsal parts. B. one lobe of sporophyll, as seen in a transverse section of the cone; $a x$, axis. On two of the sporangiophores a sporangium is shown. From Scott, Phil. Trans.

suggestive indications, and suffice to show that, within the limits of what we call the genus Sphenophyllum, there must have been great variety in the fructification. In S. majus, for example, the impressions of the lax fertile 
spikes show the sporangia grouped in fours, the groups resting on the upper surface of a repeatedly forked bract, below the points of bifurcation (Fig. 48). This form is interesting from its analogy with the fructification of the recent Tmesipteris, while in S. trichomatosum, ${ }^{1}$ on the other hand, the arrangement seems to have been a very simple one, the sporangia appearing to be sessile and solitary on each bract in the axils of the bracts. It is quite possible, however, that a short pedicel was present.

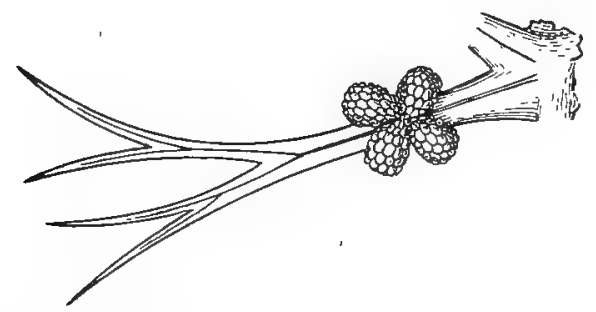

FIG. 48.-Sphenophyllum majus. Forked sporophyll bearing four sporangia. After Kidston.

The four most important types of fructification are those of S. Dawsoni, Bowmanites Römeri, S. fertile, and S. majus.

It follows sufficiently, from what has already been said, that Sphenophyllum represents a perfectly distinct group of plants, of which all the parts-stem, leaves, roots, and fructification-are known in one species or another. There is no longer any room for the idea, once sanctioned by good palæobotanical authorities, that

${ }^{1}$ I am indebted to my friend, Mr. R. Kidston, F. R.S.E., for information as to these species. On Sphenophyllann trichomatosum, see Mr. Kidston's paper in Proc. Royal Phys. Soc. of Edinburgh, vol, ii. I89I, and on S. majzus and other species, his Carboniferous Lycopods and Sphenophylls, Trans. Nat. Hist. Soc. Glasgow, vol. vi. Part i. 1899-1900. 
Sphenophyllum might represent the foliage of some of the Calamites. This mistake arose from the fact that the finely-divided or linear form of foliage, often occurring in species of Sphenophyllum, sometimes bears a great external resemblance to the foliage of the branches known as Asterophyllites, which really belonged to Calamitean stems. This resemblance may easily lead to confusion, in cases where we have to deal with imperfect specimens without structure, but of course it proves nothing as to any connection between the two groups of plants. External characters of the foliage are as unsafe a guide among fossil as among recent plants. If the genus Galium had existed in Carboniferous times, we should no doubt have often been puzzled to distinguish its remains from those of Sphenophyllum or of Calamites. It is the specimens with their structure preserved which give the only safe clue to the interpretation of the rest. The discussion of the affinities of Sphenophyllum will best be postponed until the next family has been considered.

\section{Cheirostrobeae}

4. Cheirostrobus. - This very distinct type of strobilus was originally described from a single specimen of the actual cone, and another fragment containing the peduncle. The specimens, of which two more have since come to light, were derived from the famous deposit at Pettycur, on the Firth of Forth, belonging to the Calciferous Sandstone series, at the base of the Carboniferous formation. The fossil is therefore of great antiquity, and is, in fact, among the oldest 
fructifications of which the structure is known. It occurs side by side with the stems of Sphenophyllum insigne, from which, however, it differs so much in structure as to preclude all idea of any connection between them.

The structure is admirably preserved, so that the whole organisation of the strobilus could be worked out, though unfortunately nothing is known for certain as to the vegetative organs on which it was borne. The cone was a large one-from $3.5 \mathrm{~cm}$. to $4 \mathrm{~cm}$. in diameter, and certainly exceeding $\mathrm{IO} \mathrm{cm}$. in length. Its whole organisation is exhibited in the diagrammatic sections in Fig. 49. The axis, about $7 \mathrm{~mm}$. thick, bore numerous, crowded verticils of modified leaves or sporophylls, of which there were about twelve in each whorl, the number diminishing towards the apex; the members of successive whorls were accurately superposed in vertical series, as in Sphenophyllum. The sporophylls were compound, and indeed remarkably elaborate in form and structure, so much so as to differ widely from any other organs to which the name is applied. The important point is, that in Cheirostrobus, each sporophyll was subdivided in two planes; immediately above its base it branched into an inferior and a superior lobe, while at the same time both lobes subdivided, in a palmate manner, into segments. The total number of segments was usually six, of which three belonged to the lower lobe, and three to the upper, the latter lying directly above the former (see diagram, Fig. 49). The sporophyll attained a length of $1.4 \mathrm{~cm}$. or more, almost the whole of which was occupied by the free segments, for the common basal 


\section{portion was quite short. The general direction of the} whole organ was horizontal (see diagram, Fig. 49).

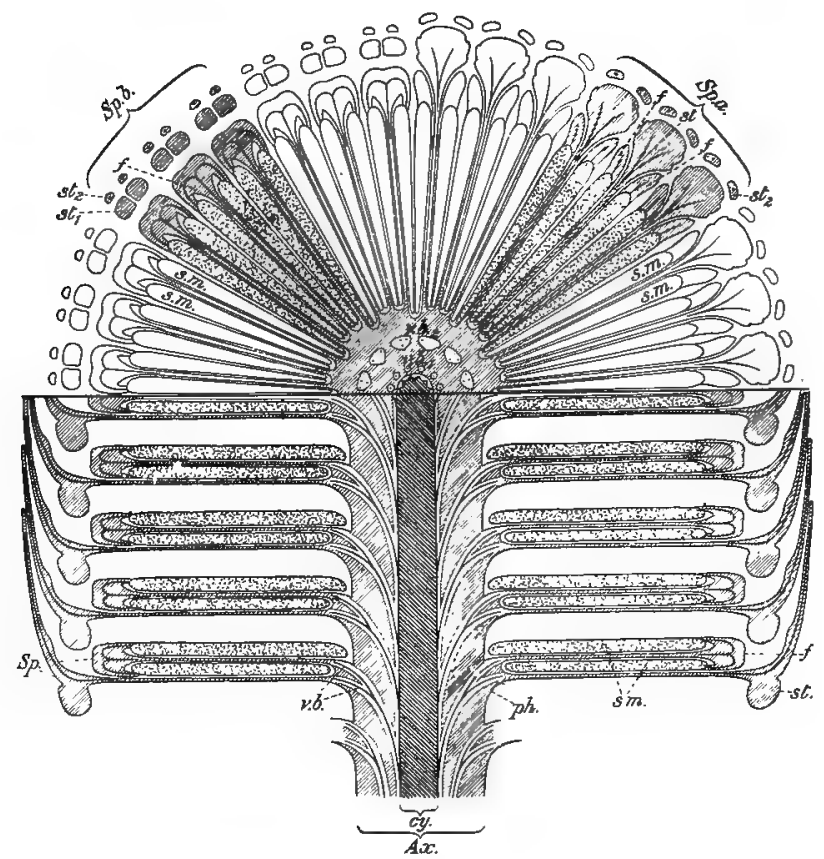

Fig. 49.-Cheirostrobus pettycurensis. Diagram. The upper part in transverse, the lower in radial section; the position of the organs corresponds in the two sections.

1. Transverse section. Six complete sporophylls, each with three segments, are shown. $S p . a$. , section passing through sterile segments; $S p, b$, do. through fertile segments or sporangiophores; st, lamina of sterile segment ; $s t_{1}$, downward outgrowths of sterile laminae, cut transversely ; $s t_{2}$, their apices, transverse ; $f$, peltate sporangiophores ; $s, h_{\text {, }}$ sporangia. Note that in $S p . a$. each peltate lamina, $f$, is seen in two distinct lobes, with the sterile lamina between. $v_{. b .1}, 7 . b_{.2}$, vascular bundles of two whorls.

2. Radial section. The sporophylls are separated from one another for clearness' sake; in nature they are in close contact. $A x$, axis of cone; $c y$, its stele; ph, base of sporophyll. Other lettering as in transverse section. The diagram is true to nature as regards proportions of parts, as well as their relative position. $\times$ about 2. Phil. Trans., S.

The segments of each sporophyll were of two kinds, the one set fertile, bearing the sporangia, the other 
sterile; the three superior segments were the fertile sporangiophores, while the three inferior members were sterile bracts. ${ }^{1} \quad$ The two kinds of segments resemble each other in their stalks, which are long and slender in both, but differ in the form of the laminae in which they terminate at their distal extremities.

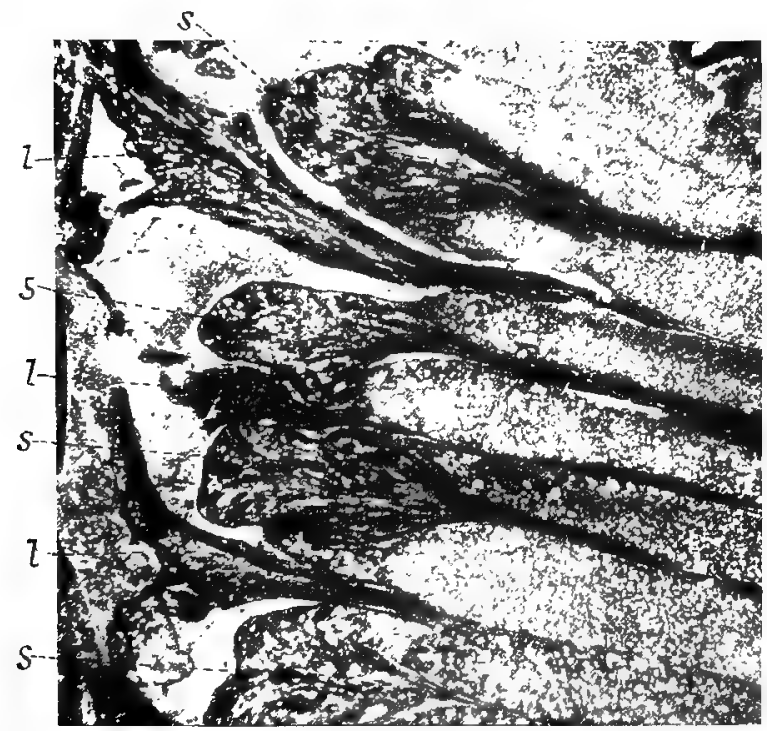

FIG. 50.-Cheirostrobus pettycurensis. Part of radial section, showing the peltate sporangiophores, $s$, with the foliaceous sterile segments, $l$, between them. The lowest sterile segnent shows the form of the lamina well. The sporangia are seen to the right. $\times$ about 1o. Phil. Trans., S. Kidston Coll. 87.

The fertile segments or sporangiophores had each a thick peltate lamina, much like that of an Equisetum or Calamostachys, bearing four sporangia on its inner side (see Fig. 49, $f$, and Fig. 50, s). The sporangia

1 This latter point was not determined without difficulty, as the same segment can rarely be traced from end to end, but is now settled beyond doubt. 
were of great length, extending inwards as far as the axis, parallel to the stalks of the segments, between which they were closely packed (Fig. 49). The sterile segments or bracts were slightly longer than the sporangiophores, so that their laminae overlapped those of the latter. The packing was so close that the fertile laminae were grooved above and below to allow the sterile pedicels to pass through (Fig. 49, Sp.a,f). The sterile lamina was itself a complex structure, for it divided into two apical prongs, directed almost vertically upwards, while it was prolonged below into two shorter and stouter outgrowthis (Fig. 50, l, and Fig. 49, st). The whole external surface of the cone was thus effectually protected by this complex system of overlapping laminae. We see then that the complete sporophyll consisted of three lower sterile segments and three sporangiophores above them, each of which bore four sporangia, so that the sporophyll as a whole produced no less than twelve sporangia. As there were eleven or twelve such sporophylls in a verticil, and the verticils were very numerous, the total production of sporangia by a cone of Cheirostrobus must have been on a great scale. In each sporangium a vast number of spores were produced, which were all of one kind, so far as the single known specimen shows.

It remains for us to describe the anatomical structure of the strobilus. Its axis was traversed by a central cylinder; the wood, which is alone preserved, had a stellate transverse section, with about twelve prominent angles, corresponding in number and position to the vertical series of sporophylls (Fig. 5 I, x). At these angles the spiral clements are placed, so the development 
of the wood was evidently centripetal, ${ }^{1}$ as in Sphenophyllum or in the Lycopodiaceae. The rest of the tracheae bear multiseriate bordered pits, as is commonly the case in Sphenophyllum. There was no

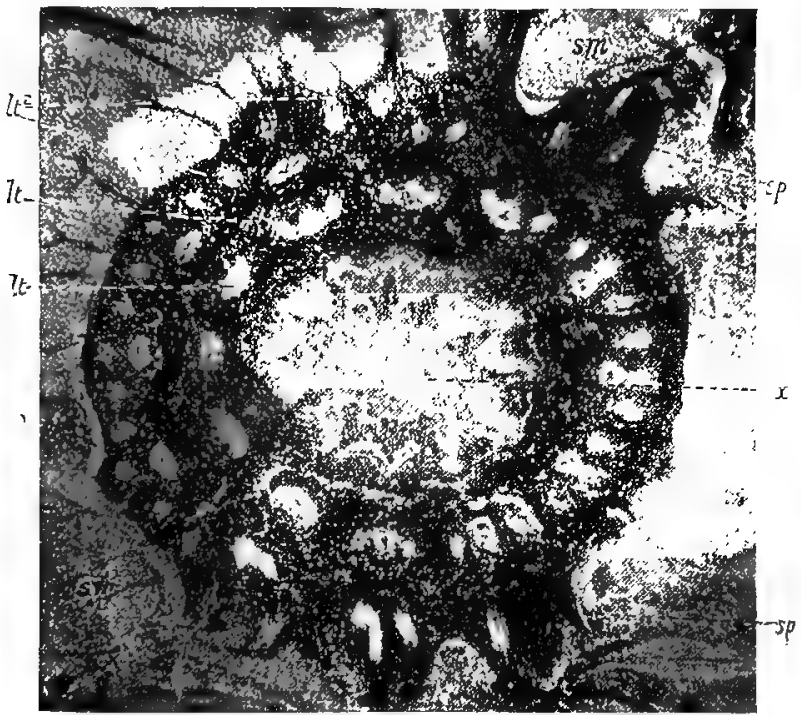

FIG. 5r.-Cheirostrobus pettycurensis. Transverse section of axis of cone. $x$, xylem with twelve prominent angles; $l t$, leaf-traces, one undivided, the other divided into three; $t^{2}$, leaf-trace, already divided into four bundles, and the inner one subdividing ; $s p$, bases of sporophylis; sm, sporangia. $\times$ about 8. P/izi. Trans., S. Kidston Coll. 84 A.

pith, the wood extending to the centre of the stele, though intermixed with conjunctive parenchyma.

The cortex presents no points worth special notice, except that it contained long sacs, perhaps of a secretory nature. The course of the leaf-trace bundles, however, is highly characteristic. They start from the angles

1 There is some evidence that a minute amount of primary xylem was developed centrifugally. 
of the stele, as simple vascular strands, each of which ultimately supplies one sporophyll. When about onethird of the way through the cortex the trace divides into three bundles, a median and two smaller lateral strands (see the triple bundle $l t$ in Fig. 5 I). A little further out the median bundle branches again, but this time in a plane at right angles to the first division, so that one of its branches lies above and inside the other (see Fig. 5 I, on right ${ }^{1}$ also diagram, Fig. 49, v.b.). The upper median bundle next divides into three, just as the main strand had previously done, so that now there are six bundles altogether, constituting each leaftrace, three above and three below; all six enter the base of the sporophyll, and pass out into its segments, the three upper strands supplying the three sporangiophores, while the lower three enter the sterile leaflets (Fig. 49).

The bundle of the sporangiophore, on reaching its peltate lamina, divides into four branches, which run out to the bases of the four sporangia (Fig. 49, $f$ ). In the sterile lamina the vascular strand divides into two, which enter the two apical points.

The vascular system was thus a highly complex one, corresponding to the great elaboration of the external organisation. Each of the four sporangia of a fertile segment is connected with the peltate lamina by a neck of tissue (Fig. $50, s$ ), into which the vascular bundle enters, ending at the base of the sporangium itself. The wall of the latter, which in its actual state of preservation is only one cell thick, consists of long

1 The reference-line to $x$ crosses the median bundles of the trace referred to. 
cells, with their lateral membranes stiffened by buttresses, precisely as in a Calamostachys. A similar structure occurs, as we have seen, in Sphenophyllum Dawsoni. The spores have an average diameter of $.065 \mathrm{~mm}$.; their outer membrane is ridged, the ridges apparently corresponding to the lines of junction of the four sistercells. The specimens known are too few to afford decisive evidence as to whether the plant was homosporous or heterosporous; it is worth noting, however, that the sporangia at the base of the cone show no difference from those borne near the apex, as regards the dimensions of their spores. The peduncle much resembles the axis of the cone itself, but in the peduncle well-marked secondary tissues are present, which in places are well preserved, so as to show the phloëm, and even remains of the cambium, as well as the secondary wood, in which medullary rays can be recognised, separating the rows of tracheae. In one specimen of the cone slight secondary growth had also taken place in the axis.

The cone of Cheirostrobus pettycurensis is perhaps the most complex Cryptogamic fructification at present known to us, and it is a striking fact that it should occur at so ancient an horizon as the base of the Carboniferous formation. But, highly modified as it is, Cheirostrobus bears the impress of great antiquity in the fact that it is a synthetic type, combining the characters of very different groups of plants. In its peltate sporangiophores, and in the insertion and details of structure of its sporangia, Cheirostrobus agrees exactly with the Calamarieae. In the anatomy of the stele, on the other hand, it resembles a Lycopod, of the type of 
Lepidodendron, as we shall see in the next chapter. While thus combining certain characters of the Horsetails and the Club-mosses, Cheirostrobus shows the most marked affinities with the Sphenophylleae in the following characters: the arrangement of the appendages in superposed verticils, the palmatifid segmentation of the leaves (sporophylls), the repeated branching of the leaf-traces within the cortex, and the relation of the sporangiophores to the sterile segments or bracts. In Cheirostrobus it is evident that the sporangiophores are ventral or superior segments of the same leaf of which the sterile bracts are the dorsal or inferior segments. The same relation holds good for Sphenophyllum Dawsoni, and still more clearly for Bowmanites Römeri, where the homology between sporangiophores and bracts is patent. In fact, this latter species occupies, in this respect, exactly an intermediate position between Sphenophyllum Dawsoni and Cheirostrobus. Sphenophyllum fertile, in which both dorsal and ventral segments are fertile, resembles Cheirostrobus in their palmatifid branching. The course of the vascular bundles supplying the sporangiophores and bracts is essentially the same in Sphenophyllum and Cheirostrobus, though necessarily more complex in the latter.

The general conclusion, to which the various characters point, is that Cheirostrobus has more in common with Sphenophyllum than with any other group of plants at present known, and that, though the former genus must constitute the type of a distinct family, it is most naturally placed in the same main division of Cryptogams, which we may call the Sphenophyllales. 
At the same time, Cheirostrobus ${ }^{1}$ combines in certain respects the characters of Equisetales and Lycopods. Thus the present genus throws great light on the position of Sphenophyllum, which had previously been quite undetermined. We can now scarcely doubt that the Sphenophyllales generally were the highly modified representatives of an ancient stock, with which both Lycopods and Horsetails have affinities.

\section{PSEUdoborntales}

5. Pseudobornia.-Professor Nathorst has recently described a remarkable type of plant from the Upper Devonian of Bear Island in the Arctic Ocean, which may belong to the same stock with the Sphenophyllales. Pseudobornia ursina ${ }^{2}$ is only known at present in the form of impressions, but the external characters are shown in great perfection. The main stems, believed to have been creeping, attain a diameter of about Io $\mathrm{cm}$. in their present flattened condition. The stem was articulated and branched; the smaller branches still bear the whorled leaves, of which there appear to have been four in a verticil. The leaves are compound, dividing by repeated dichotomy into several leaflets, each of which is deeply pinnatifid, with numerous fine segments. The isolated leaves were formerly supposed to belong to some unknown group of Ferns. The fructification is in the form of long, lax spikes, bearing

1 A fuller account of the organisation of Cheirostrobus is given in my "Structure and Affinities of Fossil Plants from the Paleozoic Rocks," Part i. On Cheirostrobus, Phil Trans. vol. I89, B, I897.

2 A. G. Nathorst, "Zur Oberdevonischen Flora der Bären-Insel," Svenska Vetenskaps-Akademiens Handlingar, Bd. 36, No. 3, Stockholm, Igor. 
whorled sporophylls which resemble reduced vegetative leaves. In the sporangia, borne on the lower part of each sporophyll, indications of probable megaspores have been traced.

Professor Nathorst makes this striking plant the type of a distinct class, the Pseudoborniales, showing affinity with the Sphenophyllales, as well as with Archaeocalamites among the Equisetales. The complexity of the leaves suggests a comparison with the compound sporophylls of Cheirostrobus, of which the vegetative organs are still unknown, though the fructification of Pseudobornia does not favour any near affinity. In Pseudobornia we appear to have a new and impressive representative of that ancient synthetic race of plants of which the Sphenophyllales have, until now, formed the only known examples. 


\section{CHAPTER V}

\section{LYCOPODIALES}

\section{Lepidodendron and Lepidophloios}

WE now come to another of the great divisions of Vascular Cryptogams, that of the Lycopods, or Clubmosses. Here, just as in the case of the Equisetales with which we began, our object, as students of fossil botany, is to extend and deepen our knowledge of a group already more or less familiar to us from our experience of recent plants. We shall find that, as regards the Lycopodiales also, our idea of the Class will become a much more adequate one, when we have made ourselves acquainted with its ancient representatives.

The recent Lycopods are all, in one direction or another, highly specialised forms, with the possible exception of Phylloglossum, and even with respect to Phylloglossum we are left in some doubt whether its simple organisation may not be due to reduction, rather than to the persistence of primitive characters.

In Lycopodium itself, while the external characters are simple enough, we find a singularly complex anatomy of the stem, very different from that of any 
other plants, and evidently much modified along peculiar lines of its own.

Selaginella, in a few species (e.g. S. spinosa), has a simple and probably primitive anatomical structure, but in a great majority of the forms this has become much elaborated; in a large part of the genus the dimorphic foliage is another mark of specialisation.

The genus Isoëtes is clearly a reduced form, and differs in so many points from the rest of the Lycopods, that some doubt has even been cast on its affinity with them, and it is largely by a comparison with fossil types that its position has been re-established.

The Psiloteae, as we shall see in the concluding chapter, appear, in the light of our present knowledge, to be remote from the true Lycopods, and rather to show affinity with the Sphenophyllales.

Broadly speaking, then, we may say that the representatives of the Class now living consist of a number of specialised forms, from which it is not easy to form an idea of the primitive characters of the common stock. The Palæozoic Lycopods throw a new and welcome light on the problem. They were not, it is true, simple forms; like so many other Cryptogams of early periods, they attained in some respects a much higher grade of organisation than their living representatives. Yet, in the ground plan of their structure, the fossil forms probably give us a better idea of the essential characters of the group than any of their recent allies.

I. Habit.-We will begin with the great genus Lepidodendron, of which more than a hundred so-called species 
have been described, according to their external characters. The genus has a wide geological range, first appear-

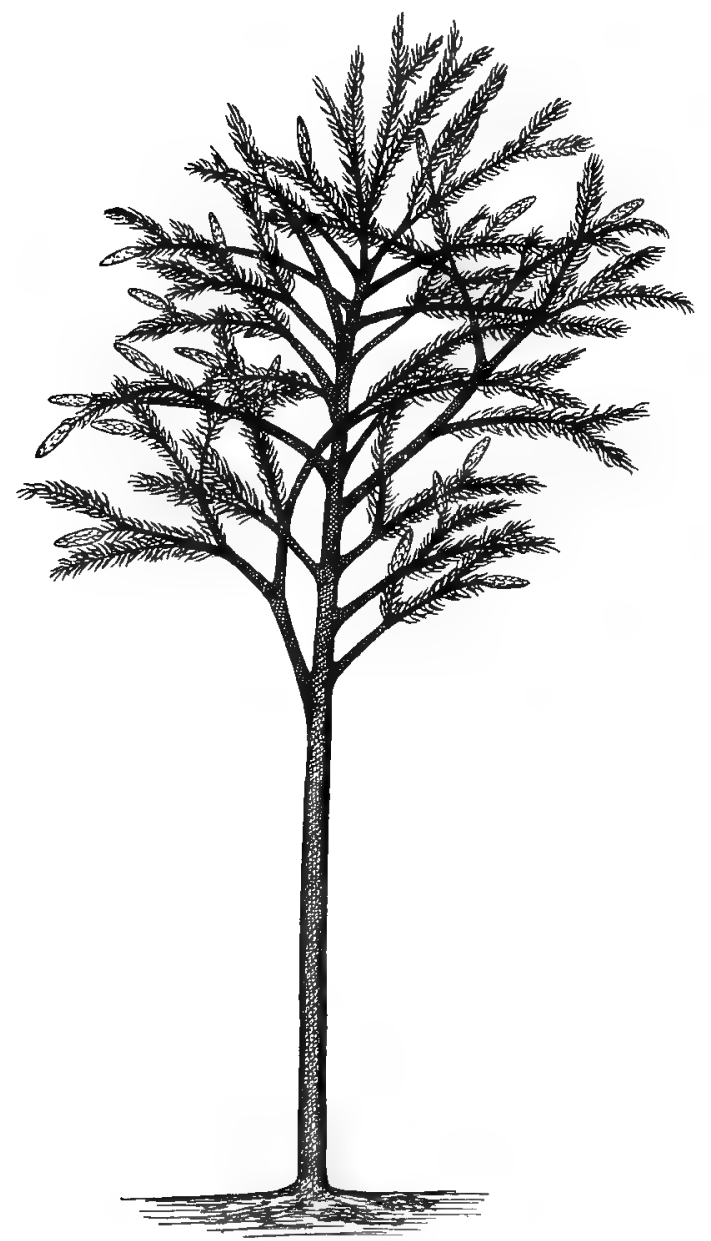

FIG. 52.-Lepidodendron elegans. Restoration of tree, bearing cones. After Grand'Eury, modified.

ing in the Devonian, attaining its maximum in the 
Carboniferous period, and dying out, according to our present knowledge, in the Permian. These plants had much the same habit as the Lycopodia of the present day, but enormously exceeded them in dimensions, growing into large trees, of which trunks a hundred feet long have been found. The main stem was vertical, rising to a great height before the crown of branches was reached (see restoration, Fig' 52). The ramification was constantly dichotomous; the two limbs of the dichotomy were sometimes equal, as in the forking of the main branches, but were often very unequal; in the latter case the relatively main shoots formed a sympodium, the smaller members of the successive dichotomies simulating lateral branches (Fig. 52). The whole system of ramification was thus an exceedingly complex one, built up of branches of many degrees, and differing much from each other, not only in size, but in structure-a fact which is of great importance in dealing with the comparative anatomy of trunks and twigs.

The young stems and branches were densely clothed with numerous simple leaves of acicular or linear form (Fig. 53), and sometimes of great length, amounting in certain cases to as much as 6 or 7 inches. The phyllotaxis was either a close spiral with some very complex divergence, such as $\frac{89}{23}$, or consisted of a system of whorls, the members of successive whorls having themselves a complicated spiral arrangement.

When the leaves were shed, their bases remained attached to the surface of the stem, forming the leafcushions (Fig. 53, A), which were persistent even on the larger trunks. It is chiefly on the superficial 
characters, presented by this armature of leaf-cushions, (Fig. 54) that the distinction of species has been

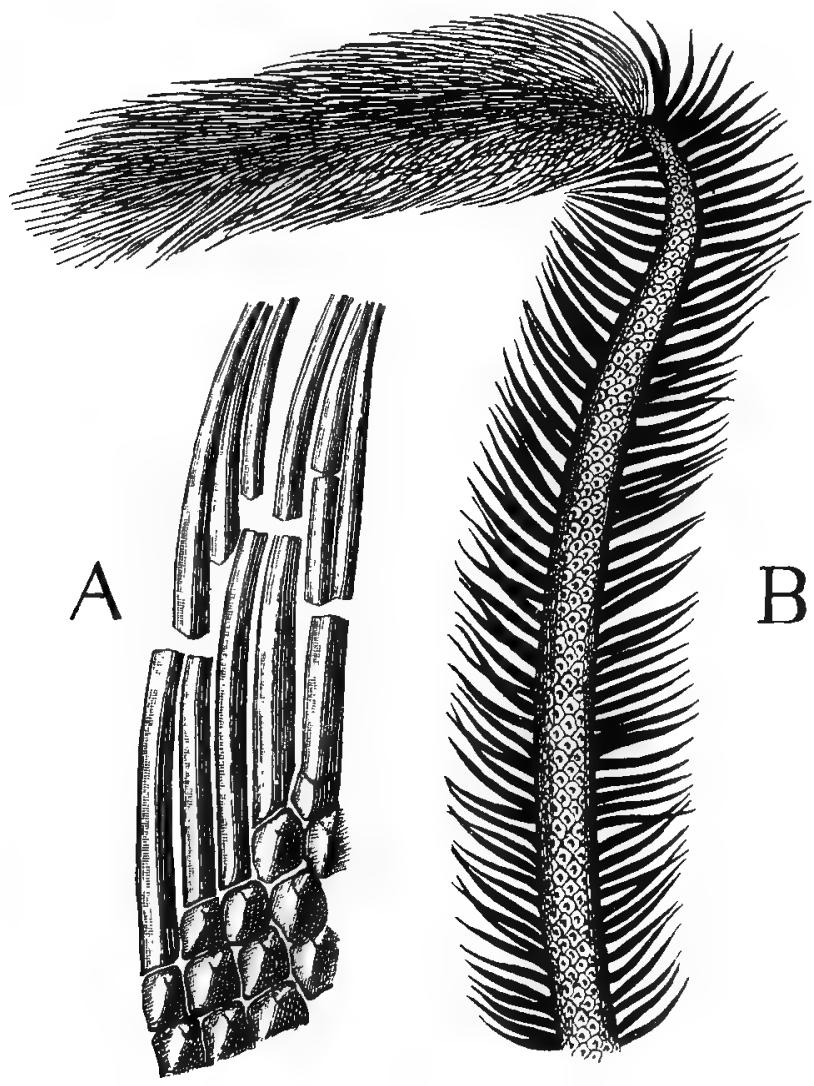

FIG. 53.-Lepidodendron Ophiurus. A. Fragment of stem-surface, showing leaf-bases and leaves. R. Leafy branch, bearing a cone at its extremity. Nat. size. After Zeiller.

founded. It will be well to describe in some detail the essential features of the persistent leaf-base.

The leaf-cushions are either packed together quite 
closely and separated only by narrow grooves (Fig. 54 ), or more scattered, with wider flat bands of the

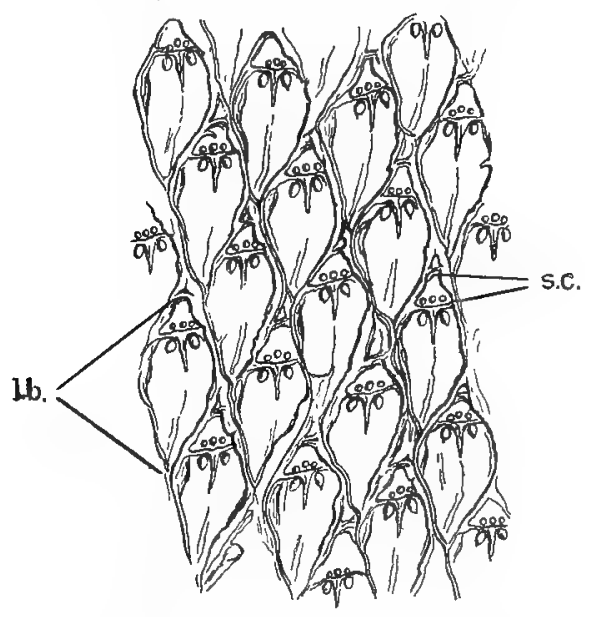

FIG. 54.-Lesidodendron Veltheimianum. Portion of surface of stem, showing the leaf-bases (l.b.), with the leaf-scar $(s . c$.$) at the upper end of each. 4$ nat. size.

stem-surface exposed between them. The whole cushion is rhombic in outline, and somewhat prominent,

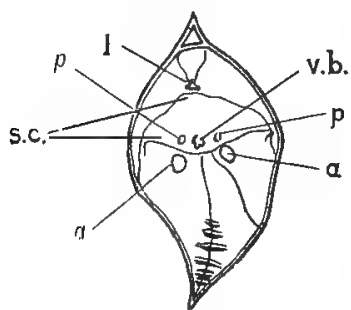

Fig. 55. - Lepidodendron. Leaf-base. $s c$, leaf-scar; $v . b$., print of bundle; $\not p$, double parichnos; $a$, superficial prints on either side of cushion; $l$, ligule. Figs, 54 and 55 after Stur. having a flatly pyramidal form. The apex of the pyramid is truncated, forming a flat surface, which represents the scar left by the fall of the leaf (see Fig. 55, s.c). Thus the actual scar only occupies a small part of the whole rhombic area, most of which is formed by the persistent leaf-cushion. The whole is not symmetrical, for the leaf-scar always lies near the upper end of the cushion. On the flat surface of the scar itself, three 
marks or prints are seen, all of which lie in a horizontal line, towards the lower edge of the scar. The anatomy of specimens with their structure preserved has shown that, of these three marks, the median one alone represents the vascular bundle, which originally passed out into the leaf. The two lateral scars, as we shall see presently, represent parenchymatous strands; together they bear the name of the parichnos.

Besides the marks on the actual scar, there are others on the surface of the leaf-cushion. The most conspicuous of these are two large round prints or depressions below the scar, lying one on each side of the prominent angle of the pyramidal cushion (see Fig. 55, a). These, as is shown by anatomical investigation, were connected internally with the parichnos.

Immediately above the scar, and in the median line of the cushion, is a small triangular print (Fig. 55,l), which has been proved to mark the position of the ligule; in Lepidodendron this organ was constantly present on the upper side of the leaf-base, as in the genera Selaginella and Isoëtes at the present day. Other marks are sometimes found on the leaf-cushions, but those already described are the most constant and important.

The above description is based on the most perfect specimens preserved as casts, i.e. with the surface showing its natural form. Where, as is often the case, the specimen represents a "mould" of the exterior, the depressions and elevations are, of course, reversed.

We have a curious illustration of the difficulties of nomenclature in fossil botany, in the fact that distinct genera have been founded on specimens which are now known to represent merely imperfect states of preserva- 
tion of various Lepidodendra. Thus, when the epidermis had been lost before fossilisation, some of the characteristic markings disappear, or change their form, and we get the so-called genus Bergeria. If the destruction had gone a little deeper, removing the outer layers of cortex, the leaf-trace is the only print that remains, and that now lies in the middle of each rhombic area, giving rise to the form called Aspidiaria. Lastly, where the whole bark of an old stem had been stripped off, a totally different appearance is produced, resembling an irregularly fluted column. The inclined, overlapping ridges here correspond to the course of the leaf-trace bundles through the middle cortex, and on this state of preservation the genus Knorria has, in part at least, been founded. ${ }^{1}$

Leaving these false genera, which are only of botanical interest in so far as they illustrate the difficulties of the subject, we pass on to a group of fossils which are really distinct from, though closely allied to, Lepidodendron. This is the genus Lepidophloios, typically characterised by the form of the scale-like, imbricating leaf-cushions, which are in most cases transversely elongated, the horizontal diameter exceeding the vertical ${ }^{2}$ (Fig. 62, p. I 56). The leaf-scar, which bears the usual three prints, is also, as a rule, elongated in the horizontal direction, and of rhomboidal or oval form. Another peculiarity is, that in Lepidophloios the leaf-cushions are very prominent, with the pyramidal form much more marked than in Lepidodendron (see Fig. 68, B, p. I69). It appears that the leaf-scar was placed towards the

1 Illustrations of these forms of preservation will be found in SolmsLaubach's Fossil Botany, English edition, Figs. I9 and 20.

"See Kidston, "On the British Species of the Genus Lepidophloios," Trans. Roy. Soc. Edinburgh, vol. xxxvii. 1893. 
upper side of the cushion in the younger specimens, but that the leaf-bases bent downwards in the older stems, bringing the scar to a lower level (cf. Fig. 63, p. I 59). Lepidophloios is of interest, though differing so slightly from Lepidodendron, because some of the specimens with structure certainly belonged to it, as did also some of the forms to be described further on, in which the probable position of the fructifications on the branches has been determined. So far as is known, however, there is no constant difference in internal structure between Lepidophloios and Lepidodendron, and in dealing with the anatomy, the latter name will usually be employed, treating Lepidophloios, for our present purpose, as a subgenus.

2. Stem.-We have now a very considerable mass of material for the study of the internal structure of Lepidodendreae, and of this material the greater part has been derived from the British Carboniferous rocks. Our knowledge of the anatomy of the group is chiefly due to the researches of Williamson, who worked out and described the anatomy of no less than nine distinct forms of the group, though some of these are better known than others. The Continental strata have so far yielded comparatively few specimens of Lepidodendron, with structure preserved, so our description will be chiefly based on the British fossils.

The great anatomical feature, which is common to all known stems of Lepidodendron, is the presence of a single stele, with centripetally developed primary wood. The occurrence of a pith is inconstant, not only among different species, but even in different 
parts of one and the same individual; sometimes (as in the larger stems of most species) the interior of the vascular cylinder is occupied by a medulla, around which the wood forms a continuous ring (Figs. 56 and 58); sometimes the wood constitutes a solid mass extending to the middle of the stele (Figs. 59 and 60). In all cases, the wood of the stem, whether solid or hollow, forms a perfectly continuous cylinder or ring, and is not broken up, as in the higher plants, into distinct vascular bundles. The xylemcylinder is surrounded by a ring of phloëm (Figs. 57 and 60). From the outer border of the stele, numerous leaf-trace bundles arise, passing out obliquely through the cortex to the leaves, each of which receives a single bundle (Figs. 56 and 59). The cortex is of great thickness relatively to the vascular cylinder. Its structure varies much according to the species, and to the dimensions and age of the branch.

The majority of the British species, in which the anatomy is preserved, are known to have formed a zone of secondary wood and bast, often of considerable thickness, around the primary cylinder. In addition to this growth of the stele, a still more extensive development of secondary tissues went on in the outer cortex, leading to the formation of a thick periderm (Figs. 58 and 59), which seems to have been produced in all the species, even in cases where no secondary vascular tissues have so far been found. The following is a list of the British forms, hitherto described, of which the structure is known:- 


\section{Secondary WOOD Not ObSERVEd}

1. Lepidodendron Harcourtii, Witham; Coal-measures.

2. L. parvulum, Williamson; Coal-measures.

3. L. macrophyllum, Williamson; Coal-measures.

4. L. Hickii, Watson; Coal-measures.

5. L. aculeatum, Sternb.; Coal-measures.

\section{With SECONDARY WOOD}

6. Lepidodendron brearifolium, Williamson; Calciferous Sandstone series, at base of Carboniferous formation.

7. L. (Lepidophloios?) Wunschiamum, Williamson; also from Lower Carboniferous strata.

8. L. selaginoides, Carruthers; Coal-measures.

9. L. (Lepidophloios) fuliginosum, Williamson; Coal-measures.

Io. L. intermedium, Williamson; Coal-measures.

I 1. L. obovatum, Sternb. ; Coal-measures.

L. mundum, Will., formerly included in this list, has now been shown by Mr. Lomax to be the stem of a Bothrodendron (see p. 200).

Now, of all these forms, there are only two which are known to have attained any considerable size without showing secondary growth of the vascular tissues; these species are L. Harcourtii, the first Lepidodendron discovered with its structure well preserved, and L. Hickii, recently recognised as a distinct species by Mr. D. M. S. Watson. The original specimen of L. Harcourtii was found in 1832 , in the Hesley Heath Colliery, Northumberland, and was first described by Witham of Lartington, ${ }^{1}$ who named it Harcourtii after its discoverer. Our first minute knowledge of the structure of this fossil was due to the great French palæobotanist, Adolphe Brongniart, who gave an

1 Internal Structure of Fossil Vegetables, Edinburgh, I833. 
admirable account of the anatomy. ${ }^{1}$ Subsequent investigations, especially those of Williamson and Bertrand, aided by the discovery of a few additional specimens, have rendered Lepidodendron Harcourtii one of the best known among fossil stems. Mr. Watson regards this species as a Lepidophloios. The largest specimen hitherto found has a diameter of over $8 \mathrm{~cm}$. (not counting the leaf-bases), while its stele, or rather the wood, which is alone perfect, is rather more than a centimetre in diameter. The wood forms a broad continuous ring, enclosing a parenchymatous pith (see Fig. 56). The outer edge of the wood is crenulated, having a large number of prominent angles, with furrows between them. It is at the prominent angles that the narrow spiral tracheides are placed; all the interior of the wood is made up of uniform, scalariform elements. Hence it is evident that the whole ring of xylem was centripetally formed, the development having started at the external angles. It appears from M. Bertrand's researches that these angles formed a prominent network on the surface of the woody cylinder; from the lower corners of the meshes the leaf-trace bundles, or rather their xylem-strands, passed out. The attachment of the strands was at the sides of the tracheal prominences, and not at their extreme points. The phloëm, of which the preservation is very imperfect, appears to have formed a narrow continuous band round the wood (see Fig. 56, B).

The leaf-traces passed very gradually outwards through the cortex to the leaves, one bundle entering each leaf. Hence a large number of the outgoing

1 Histoire des végétaux fossile, vol. ii. 1837 . 
strands are met with in every transverse section of the stem, forming a very characteristic feature (see Fig.
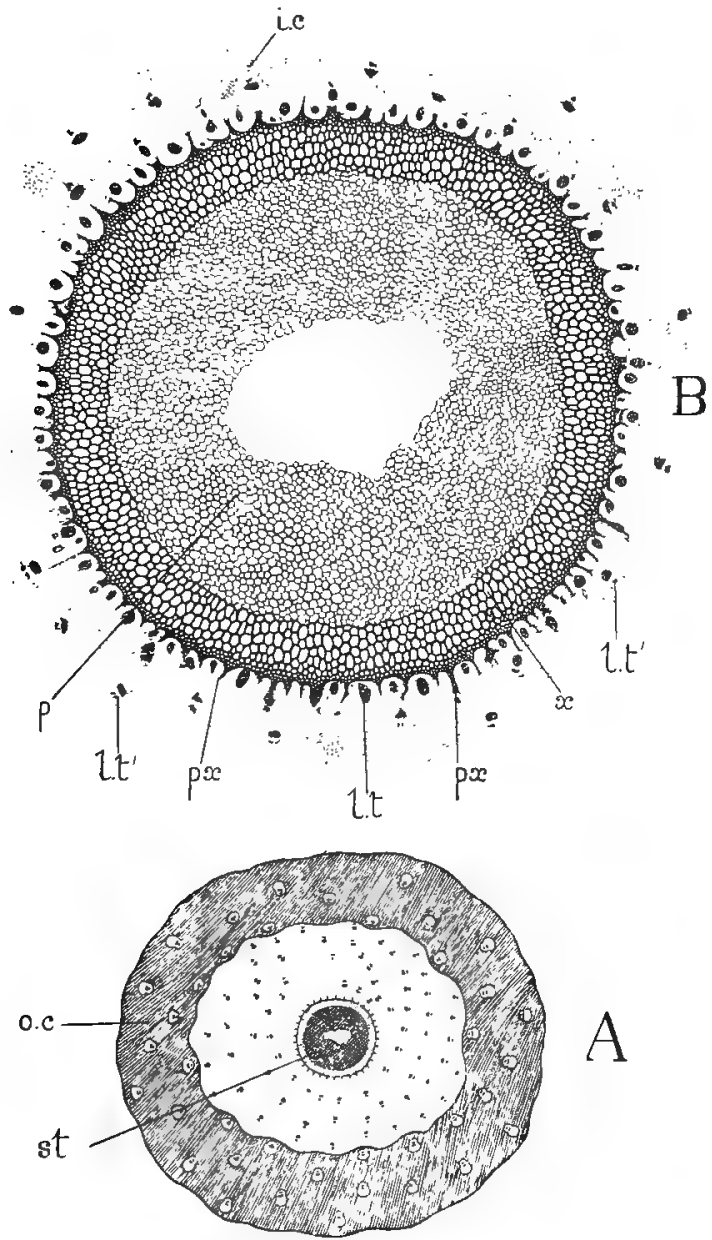

FIG. 56.-Lepidodendron Harcourtii. A. Transverse section of stem. st, stele; o.c., outer cortex ; both here and in the inner cortex the leaf-traces are shown. About nat. size. B. Stele of same, $\not p$, pith, hollow in middle ; $\sigma$, xylem-ring ; $\beta x$, protoxylem. points; the leaf-traces join the stele between them. l.t., the leaf-trace bundles, of which the outer, l.t.', show xylem and phloëm; i.c., inner cortex. $\times 7$. Will. Coll. 1594. (G. T. G.). 
56, A). They have a complex spiral arrangement, related to that of the leaves to which they ran. ${ }^{1}$

The structure of the individual leaf-trace bundles in L. Harcourtii has been described as characteristic of the species; its peculiarity consists in the presence of a conspicuous strand of dark-coloured, apparently fibrous cells, on the outside of the bundle (see Fig. $56, \mathrm{~B}$, l.t.' ). Other Lepidodendreae, however, show the same structure, as Prof. Seward found in the case of Lepidophloios fuliginosus, and Mr. Watson in his new species, Lepidodendron Hickii. That the elements in question were really of the nature of hard bast is very improbable. Prof. Bertrand regards them as organs of secretion, comparable to laticiferous cells, and Prof. Seward's observations led him to a similar conclusion, ${ }^{2}$ which may be provisionally accepted.

The vascular bundles appear, judging from the bestpreserved specimens, to have been of the collateral type, the phloëm lying between the xylem and the strand of secretory elements, and perhaps including the latter. The spiral tracheae are placed near the middle of the xylem, a position which they often occupy in the foliar bundles of Lycopods. Outside the phloëm of each bundle, where it traverses the outer cortex, is a large strand of delicate parenchyma, seldom perfectly preserwed, which was continuous with the parichnos of the leaf-base.

1 For a detailed account of the anatomy of L. Harcourtii, see Bertrand" Remarques sur le Lepidodendron Harcourtii de Witham, Lille, 1891. For L. Hickii see Watson, "On a Confusion of two Species under Lepidodendron Harcourtii," Ne'm. and Proc. Manchester Lit. and Phil. Soc. vol. li. Part iii. 1907.

2 A. C. Seward, "Notes on the Binney Collection of Coal-measure Plants," i. Lepidophloios, Proc. Cambridge Phil. Soc. vol. x. I899. 
The inner zone of cortex consisted of soft parenchyma, usually badly preserved, while the more external region, where the whole tissue was thick-walled, is perfect (Fig. $56, A)$. The cortex was covered on the exterior by the crowded bases of the leaves, but the latter have often been lost. In the outer cortex, a little below the leafbases, periderm was formed at a rather early stage, by the tangential division of the cortical cells. The development of the periderm took place on both sides of the initial layer, and was therefore partly centripetal and partly centrifugal in direction. The leaf-bases were thus separated by a zone of secondary cortex from the inner tissues of the stem, but remained attached to the outer surface of the bark, even on old trunks.

Very definite groups or strands of cells, no doubt of the nature of internal glands, occur in the outer cortex, just within the periderm. These secretory organs are also present in various other Lepidodendreae, as in Lepidophloios fuliginosus and in Lepidodendron Wunschianum, where they are ranged in concentric bands in the periderm.

Except for the periderm, Lepidodendron Harcourtii, as known to us at present, shows no sign of secondary formations. It is, however, perfectly possible that cambial activity may have started at the periphery of the stele, in specimens still larger than any we possess. That this may have been so, is rendered highly probable by the analogy of another species, L. Wunschianum, from the Lower Carboniferous strata in the Isle of Arran. In this case secondary wood was formed in great quantity, but it is never found except in stems 
of still greater dimensions than the largest known specimens of L. Harcourtii.

Williamson sometimes said that it was an unfortunate chance for fossil botany that the first Lepidodendroid stem, of which the structure was investigated, happened to be that of L. Harcourtii. The absence of secondary wood in this species, which we now know to have been quite exceptional, led Brongniart to believe that the Lepidodendra generally were without exogenous growth. On this ground, he removed Sigillaria, in which the secondary tissues were discovered early, both from the Lycopodiaceae and from the Cryptogams, and classed the genus among Gymnospermous Phanerogams. Even when Lepidodendra with secondary wood began to be discovered, there was for a long time a strong tendency, on the part of the French school of palæobotanists, to regard all such specimens as really Sigillariae, and so to keep up the supposed distinction. We now know, chiefly as the result of Williamson's researches, that most of the Carboniferous Lepidodendra agreed essentially with Sigillaria in their anatomy, and that the two genera were closely allied members of the Lycopodiales. The controversy, however, proved valuable as a stimulus to research.

Lepidodendron Wunschianum, a species which is abundant in the volcanic beds of Arran, belonging to the oldest part of the Carboniferous formation, essentially resembles $L$. Harcourtii in its primary structure, and needs no detailed description here., ${ }^{2}$ Secondary wood has only been found in stems with a primary

1 Possibly referable to the genus Lepidophloios.

2 Seward and Hill are inclined to identify these two types, but I do not find sufficient evidence to justify us in uniting them. 
xylem-cylinder $2 \mathrm{~cm}$. or more in diameter. Cambial growth here went on vigorously, producing a zone of wood nearly $3 \mathrm{~cm}$. thick in the larger trees, some of which were a couple of feet in diameter. In one particular specimen the state of preservation was very remarkable. To quote Williamson's words :- "At Laggan Bay [Arran] the bases of thirteen large stems stood erect and closely aggregated. Further investigation showed that twelve of these were merely cylinders of outer cortex, all their more internal tissues having disappeared and been replaced by volcanic ash, with which the trees had been destroyed and buried. The decay of the softer portions of the bark had loosened all the harder vascular structures compassing their several steles, and allowed them to float out when the area became submerged. But the exceptional stem had met with different treatment. In the first instance, it also had lost all its vegetable contents, which had evidently floated out upon the neighbouring waters. Directed by some fortunate current, a quantity of the floating débris had been washed back into and filled the vacant cavity of the thirteenth stem. Further examination of this débris showed that it consisted of fragments of bark and of Stigmarian rootlets, including a fragment of a vascular axis of a Stigmaria; ${ }^{1}$ but what was still more important, we found in it the entire and fully developed steles of no less than five of the remaining trees, which had been tumbled into this single one." ${ }^{2}$

1 We shall see further on that these Stigmariae were the rhizomes or roots of the Lepidodendra themselves, and of the allied Sigillariae.

2 Williamson, "Growth and Development of the Carboniferous Arborescent Lepidodendra," Men. and Proc. Manchester Lit. and Phil. Soc. ser. iv, vol. ix. p. 45,1895 . 
The base of this curious stem, showing all the steles thus accidentally enclosed in it, is now preserved in the Museum of the Owens College, at Manchester.

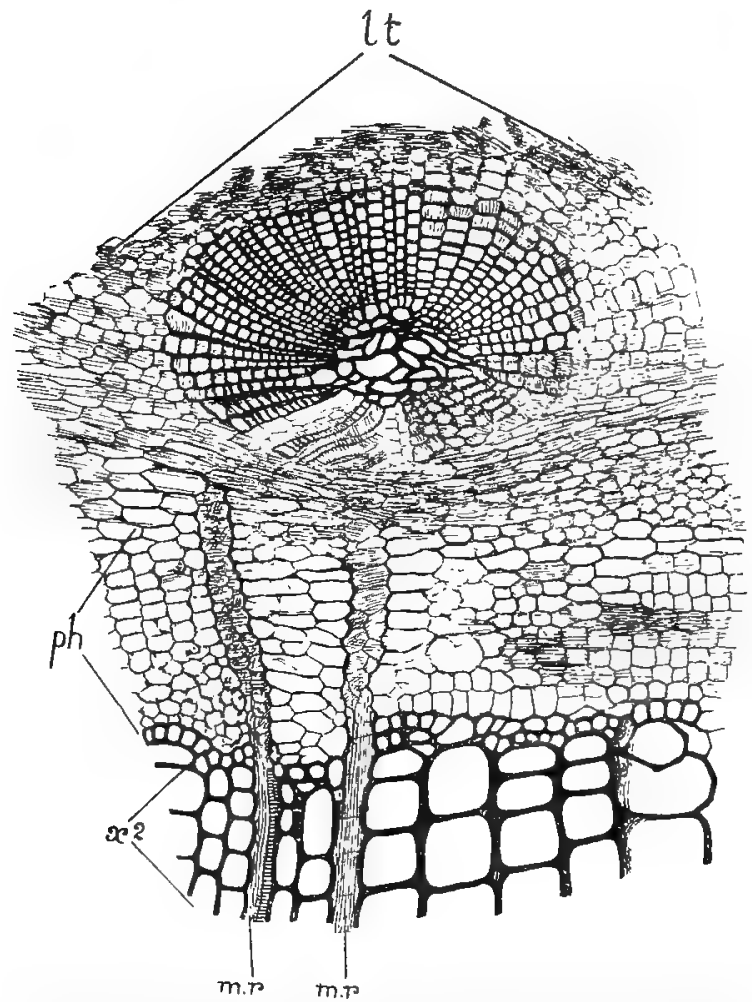

F1G. 57.-Lepidodendron (Lepidophloios?) Wunschianum. Transverse section from outer part.of stele, showing leaf-trace. $x^{2}$, secondary wood: $m . r$, medullary rays, one of which contains tracheides; $p / 2$, phloëm (meristematic zone of Seward); $l t$, leaf-trace, with a small mesarch strand of primary xylem, and a broad zone of secondary wood (with short tracheides) and phloëm. $\times$ about 55. From a section presented by Mr. Kidston. S. Coll. 1183 . (G. T. G.)

A magnificent specimen from Dalmeny (see Fig. 57), referable to the L. Wunschianum type, has the interesting peculiarity that the leaf-traces, after leaving 
the stele, are accompanied by a broad arc or zone of secondary wood and phloëm, the only case of the kind hitherto found in a Lepidodendroid, as distinguished from a Sigillarian, stem. The specimen is fully described in the Transactions of the Royal Society of Edinburgh, by Prof. A. C. Seward and Mr. A. W. Hill. ${ }^{1}$

Another form, which in its primary condition somewhat resembles Lepidodendron Harcourtii, is the Burntisland species named by Williamson $L$. brevifolium. This, like L. IVunschianum, comes from the Calciferous Sandstones, at the base of the Carboniferous formation. Twig's and branches of all sizes have been found in abundance, and the first beginnings of secondary growth have thus been traced. The species differs strikingly from $L$. Wunschianum, in the dimensions of the branches with secondary tissues. In $L$. brevifolium, even comparatively small twigs have a zone of radially seriated wood of cambial origin, surrounding a primary cylinder, sometimes only about $3 \mathrm{~mm}$. in diameter. In the larger branches, the secondary zone of wood attained a thickness enormously greater than that of the primary ring. An example of this stem, at a fairly advanced stage, is shown, in transverse section, in Fig. 58.

For the more detailed study of the structure and development of the stem in a Lepidodendron with secondary growth, we will choose, however, another example, namely L. selaginoides, which, from the abundance of specimens and their extraordinarily good preservation, has proved exceptionally favourable for investigation.

In this form, which is abundant in the Lower Coalmeasures, the specimens showing structure have been

$$
\text { 1 l.c. vol, xxxix. Part iv. } 1900 .
$$




\section{identified, at least with great probability, with those}

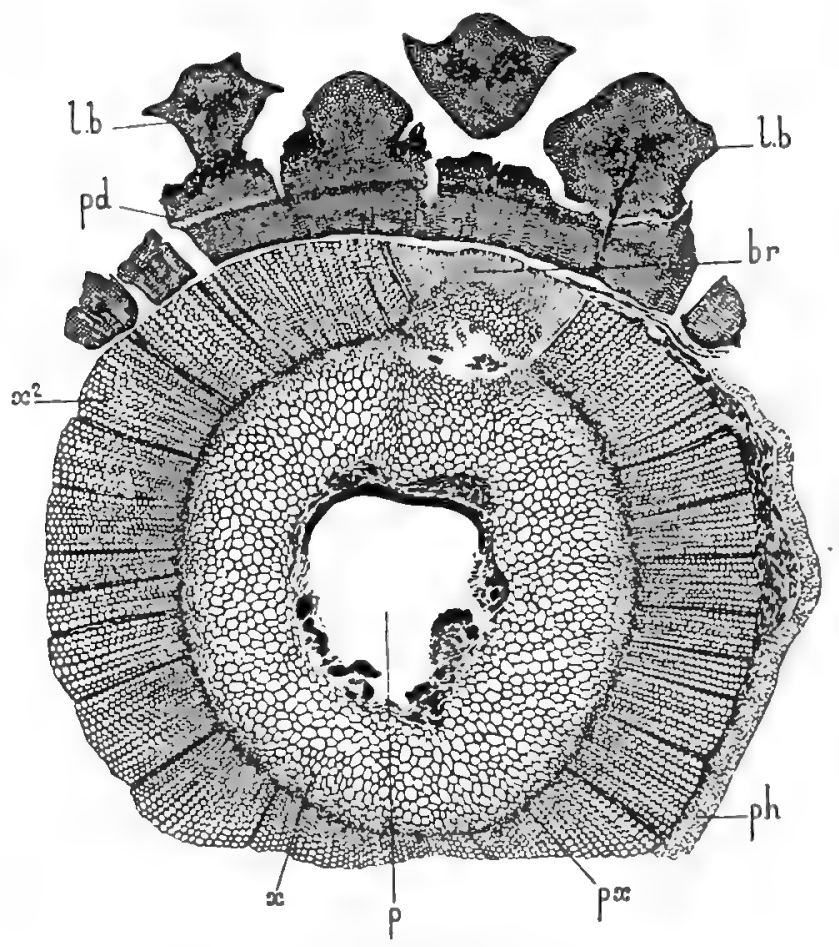

FIG. 58.-Lepidodendran brevifolium. Transverse section of stem. ps, pith, almost wholly destroyed ; $x$, broad zone of primary wood; $p x$, protoxylem at periphery of primary wood; $x^{2}$, secondary wood; $p h$, phloëm; $b r$, small stele becoming detached to supply a branch; $p d$, periderm ; $2 . b$, lenf-bases, showing bundle and parichnos. All the more internal cortex, which once intervened between stele and periderm, has perished. $\times 4 \frac{1}{2}$. S. Colt. 54. (G. T. G.)

preserved as impressions or casts, in which the external characters are visible. ${ }^{1}$

1 See Carruthers, "Structure of the Stems of the Arborescent Lyco. podiaceae of the Coal-measures," Monthly Miiroscopical Journal, vol. ii. 1869. As, however, the identification is not absolutely certain, some authors prefer to use Binney's name, $L$. vasculare, rather than $L$. selaginoides. 
Lepidodendron selaginoides is at once distinguished anatomically from the other species by the peculiar structure of the central cylinder. No definite pith is present; the tracheae of the primary wood extend to

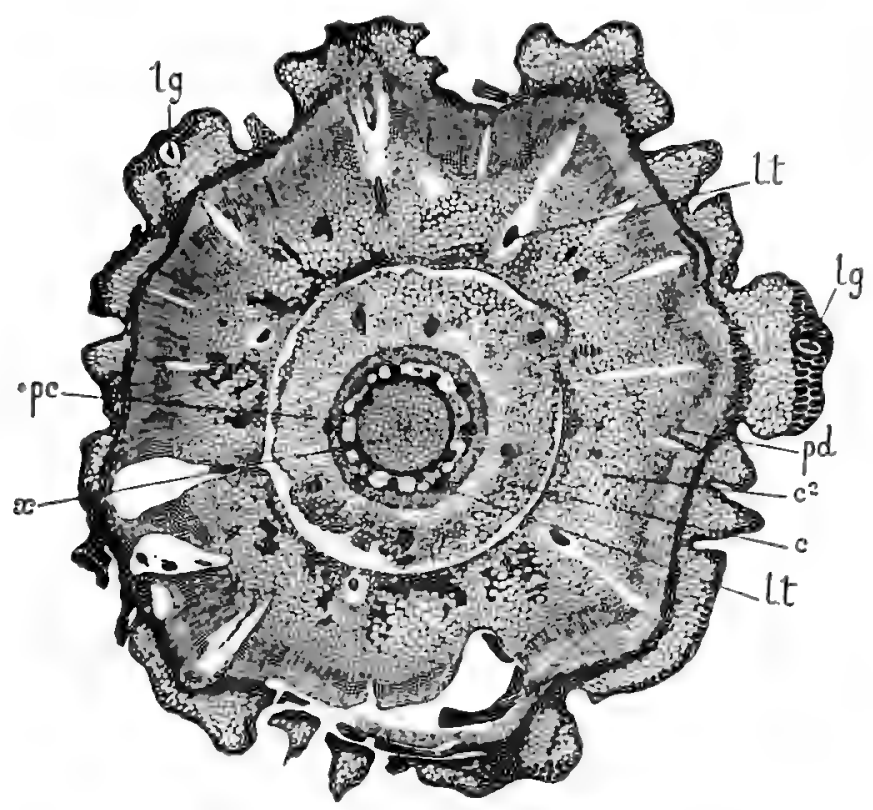

Fig. 59-Lopidodendron selaginoides. Transverse section of young branch, before secondary wood has formed. $x$, primary xylem-cylinder; $p c$, zone of phloëm and pericycle; $c$, inner cortex, differentiated into three layers; $c^{2}$, outer cortex; $p d$, periderm; beyond this are the leaf-bases; $/ g$, ligule; $l . t$, leaf-traces, at various points on their outward course. $\times$ about 7 . S. Coll. 1376 . (G. T. G.)

the centre of the stele (Figs. 59 and 60). The outer part of the primary xylem has the structure usual in the genus; at the extreme periphery there are a number of slightly prominent points, at and near which the spiral elements are placed. Here then, as in other 
forms, the development of the xylem must have been centripetal. Immediately within the protoxylem the elements become much larger, forming a broad continuous zone, which consists exclusively of long scalariform tracheides, without any admixture of parenchyma (Figs.

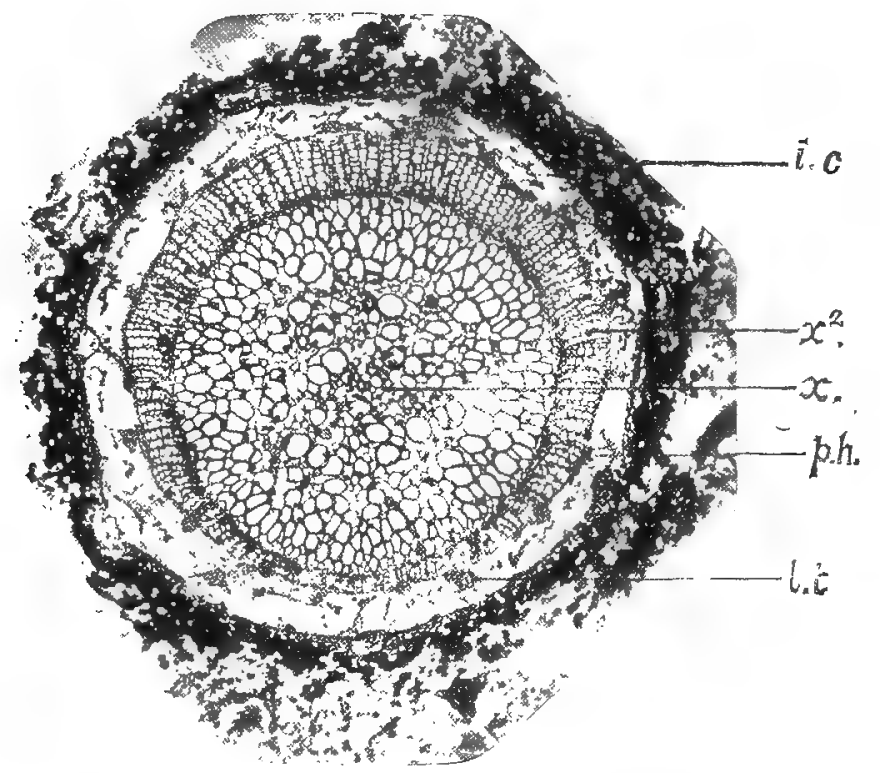

FIG. 6o.-Lepidodendron selaginoides. Transverse section of stele after commencement of secondary thickening. $i$, primary xylem-cylinder, with reticulate tracheides in central part, and small protoxylem-elements at periphery; $x^{2}$, secondary wood, unequally developed; $p h$, phloëm-zone; i.c, part of inner cortex; $l . l$, leaf-traces. $\mathrm{x}$ 17. From a photograph by Dr. Bousfield. S. Coll. I7.

60 and $6 \mathrm{I}$ ). As we advance further inwards, however, parenchyma begins to make its appearance, and at the same time the tracheides change their character, becoming much shorter, with horizontal transverse walls (Fig. 60, $x$ ). Thus the whole central part of the stele is occupied by mixed tracheides and parenchyma. 
The former are often no longer than the cells which accompany them. The transverse walls of the short tracheides are reticulately thickened, and form a conspicuous feature in the transverse sections, by which the species can be easily recognised.

The phloëm, which is fairly preserved in some of the best specimens, forms a zone of thin-walled tissue, including strands of elongated elements, surrounding the wood, and itself surrounded by a somewhat broader band of larger-celled parenchyma, which may be regarded as the pericycle. The leaf-trace bundles, where they cross this zone, are each enclosed in a special sheath, sometimes forming a kind of bridge or trabecula across the more delicate tissues of the phloëm and pericycle (Fig. 60).

The endodermis is simply a layer of tangentially elongated cells. Then we come to the broad zone of inner cortex, which consists of delicate short-celled parenchyma, only preserved in the best specimens, as in that shown in Fig. 59. The more internal layers, however, are of firmer structure, and often persist when the rest has perished. In the middle part of this zone the cells show some trace of radial arrangement. Through this region the leaf-trace bundles pass, still taking a steep upward course (Fig. 59). Beyond the inner cortex is another broad belt, the outer cortex, the tissue of which is formed of elongated cells with, for the most part, rather thick cell-walls; this zone, owing to its solid construction, is always well preserved. The leaf-traces, which in this region gradually assume a more horizontal course, often pass through gaps, due to the disappearance of delicate tissue (Fig. 59). 
The outer cortex ends at the exterior of the stem in the zone of the leaf-bases, which collectively cover almost the whole surface. The tissue immediately within the leaf-bases remained thin-walled, for it was here that the phellogen arose.

The leaf-trace bundles start, so far as their xylem is concerned, directly from the angles of the primary wood, and not between them, as in L. Harcourtii. The leaf-traces are normally collateral, with xylem directed inwards and phloëm, consisting of elongated narrow elements, outwards. The spiral elements, where their position can be determined with certainty, lie on the inner edge of the xylem, which was thus, as a rule, endarch, another point of difference from $L$. Harcourtii, where the structure in the corresponding region was regularly mesarch. ${ }^{1}$ The soft bast is bounded on the exterior by some elements with thicker cell-walls, which may be most probably interpreted as secretory sacs. The whole bundle is surrounded by a well-marked sheath.

Where the leaf-trace enters the denser outer cortex, a large strand of delicate parenchyma-much larger than the bundle itself-accompanies the latter on its lower side, ${ }^{2}$ and passes out with it into the leaf-base; here the parenchymatous strand forks into two, the two branches diverging to the right and left of the bundle. It is these strands of tissue which give rise

1 These are convenient terms for shortly characterising the development of the wood of a vascular bundle. If the protoxylem lies on the inner side the strand is endarch; if in the middle of the xylem, mesarch; if on its outer side, exarch.

2 Indicated by the gaps accompanying the leaf-trace bundles in Fig. 56, A, from L. Harcourtii. 
to the two lateral prints on the leaf-scar, called the parichnos (cf. Fig. 62). This structure is common to the Lepidodendreàe in general.

We have so far considered the anatomy of the stem in its primary condition; in most of the specimens the structure is modified by the appearance of secondary tissues, namely, of periderm in the outer cortex, and of new wood and bast around the stele. , In L. selaginoides even the smallest twigs found (which, however, are not usually less than $I \mathrm{~cm}$. in diameter) may show both these new formations, while in some of the other species, as we have seen, the secondary wood and bast appear to have been limited to the main stem and its principal branches.

The periderm began to appear early; in some of the younger specimens its first origin can be traced. It was developed from a zone of cells of the outer cortex, lying immediately within the leaf-bases, between which it was only separated by a few cells from the outer surface of the stem. This zone of tissue became meristematic; its elements divided tangentially, and acted as a phellogen, producing a very large quantity of secondary cortical tissue (see Fig. 59, pd, and compare Fig. 58). There has been some difference of opinion as to the position of the phellogen in the older specimens, but there is now little doubt that it lay in the outer part of the secondary zone, so that the larger portion of the new tissue was produced on its inner side, and a smaller portion towards the exterior. Thus the greater part of the secondary cortical zone, as it was produced on the inside of the generative layer, is to be regarded as phelloderm. Whether the smaller outer portion 
was really of the nature of cork is doubtful-the more so, as the bases of the leaves outside it certainly persisted for a very long time.

The periderm (as we may call the whole of the secondary cortical tissue) consisted of elongated, rather thick-walled cells, and must have contributed very materially to the mechanical strength of the stem. It may have had other functions as well, and was certainly much more than a mere bark. ${ }^{1}$ The late M. Hovelacque, to whom we owe the most detailed study of the anatomy of this species, ${ }^{2}$ was mistaken in supposing that the periderm was formed entirely from within; on its inner margin the tissue is, as a rule, thick-walled, and quite unlike a meristem, while a delicate zone of cells is constantly to be found in its outer part (see Fig. 59). It appears probable, however, that additions may sometimes have been made to the periderm from the interior also, new layers of primary cortical cells taking up the divisions.

In old specimens, the periderm attained a thickness of as much as 2 inches. The course of the leaf-trace bundles through it is marked by radial strands of tissue more delicate than the rest. The periderm also shows concentric markings, due to the alternation of zones of wider and narrower elements. What has been said of the periderm of Lepidodendron selaginoides may be taken as holding good for the genus as a whole (cf. Figs. 58 and 59).

1 In L. Wunschianum it contained strands of cells probably with a secretory function.

2 Hovelacque, "Recherches sur le Lepidodendron selaginoides," „HIm. Soc. Linneenne de Normandie, I892, This fine memoir is magnificently illustrated. 
The secondary vascular tissues began to develop rather later than the periderm. Very often the new growth began on one side of the central cylinder, so that for a time the secondary wood formed a crescent, and not a complete ring (cf. Fig. 60); in other cases it was fairly equal all round from the first. The cambial

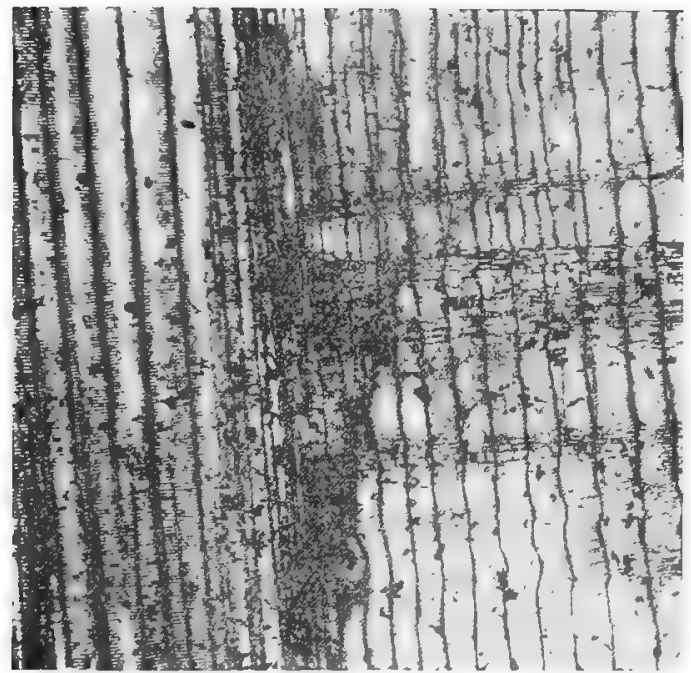

FIG. 61.-Lepidodendron selaginoides. Part of radial section, showing primary wood on left, and secondary wood, with medullary rays, on right; the narrow elements between the two are the protoxylem. $x$ about 25. From a photograph by Dr.

Bousfield. S. Coll. 24 .

divisions started in the conjunctive tissue between the primary wood and phloëm; the very first beginning of the new formation can be traced in some of the specimens (see Fig. 60, on lower side of figure). The secondary wood usually abuts directly on the small external tracheides of the primary ring (see longitudinal section, Fig. 6I); sometimes a layer of 
parenchyma intervenes. The secondary wood consists of regular radial series of tracheides, with medullary rays between them; the tracheal rows are more numerous than the rays. The secondary tracheides, like the primary, are scalariform (Fig. 6I), with the pits on their tangential as well as their radial walls. The rays vary much in height and width; sometimes a ray consists of a single row of cells; sometimes it is one cell thick, but many cells high; while in other cases the middle part of the ray is several cells in thickness. We must remember that these rays are only called "medullary" from analogy with those of other plants; in Lepidodendron they do not really reach the pith, even where one is present, because the ring of primary wood is quite continuous, so as to shut off the rays completely at their inner ends. The muriform character of the rays, as seen in radial section, is shown in Fig. 6 .

The leaf-traces, or rather their woody portions, extend through the secondary wood, traversing enlarged medullary rays. Quite apart from the leaf-traces, however, the rays generally contain numerous reticulated or spirally thickened elements, which probably served to keep up water-communication in the radial direction throughout the wood; they would thus be analogous to the tracheides occurring in the medullary rays of many of the Coniferae.

The phloëm underwent comparatively little increase, at least during the earlier stages of cambial activity. In the older stems, where the secondary wood reaches a thickness of half an inch, the phloëm is seldom preserved. 'The actual amount of new vascular tissue 
was small compared with the much greater development of periderm.

Although the details of the cambial growth have not yet been satisfactorily cleared up, there is no doubt that it was normal, in the sense that the cambium produced wood internally, and phloëm, though probably to no great extent, on its external side.

The cells of the cambium in Lepidodendreae, where preserved, are not usually found to correspond exactly to the radial series of xylem-elements on their inner side (cf. Fig. 57). It appears probable that the same initial layer was not active throughout the duration of secondary growth, but that new zones of cells may have taken up the cambial divisions periodically. In this respect there would be a certain similarity to the secondary increase in Isoètes, among living plants.

The phloëm of the Lepidodendreae also presents considerable difficulties. Typical phloëm, consisting of delicate elongated elements, has not always been recognised, even in the best-preserved specimens, such as that illustrated in Fig. 57. In other cases, however, as in the leaf-traces of $L$. selaginoides and in the vascular bundles of the cones, the phloëm appears to have been quite of the normal type, ${ }^{1}$ so we are not justified in supposing that there was any fundamental difference in this respect between the Lepidodendreae and their recent allies. ${ }^{2}$

1 See Maslen, "Structure of Lepidostrobus," Trans. Linn. Soc. vol. v. I899, Plates xxxvi.-xxxviii. Figs. I 1, 13, 14, and 33 .

2 On the controversy as to phloëm in Lepidodendreae, see F. E. Weiss, "On the Phloëm of Lepidophloios and Lepidodendron," Mem. and Proc. Manchester Lit. and Phil. Soc. vol. xlv. Part iii. I901; and Seward, "The So-called Phloëm of Lepidodendron," New Phytologist, vol. i. I902. 
Before leaving the subject of the anatomy of the Lepidodendroid stem, it is of some interest to note that in Lepidophloios fuliginosus (Williamson), a species which resembles Lepidodendron Harcourtii so closely that for many years they were not distinguished, a certain amount of secondary xylem was formed. It was, however, much less regular than in the other species which show it, such as Lepidodendron selaginoides or L. brevifolium. In L. fuliginosus the cambium was an anomalous one, arising irregularly in various parts of the phloëm-zone and pericycle. It produced a good deal of secondary parenchyma, among which there are usually scattered groups of wood; the secondary tracheides have a very sinuous and irregular course. In some cases tracheides appear to be altogether absent from the secondary zone. We may regard this species (which, from the form of its leaf-bases, must certainly be referred to Lepidophloios, as first pointed out by Cash and Lomax in $\mathrm{I} 890$ ) as exhibiting either a primitive and rudimentary or a reduced form of secondary growth. In a rather doubtful species, Lepidodendron intermedium, there is a similar mode of secondary thickening; this form derives its specific name from combining to some extent the characters of Lepidophloios fuliginosus and Lepidodendron selaginoides.

Two new cases have recently been described in which the external features of a petrified specimen are preserved, so as to allow of its reference to a definite species, based on the superficial characters, while at the same time the internal structure can be investigated. In a stem clearly referable to Lepidodendron obovatum, Sternb., various details of the anatomy, and especially 
the presence of a parenchymatous secondary zone, show a close agreement with Lepidophloios fuliginosus. ${ }^{1}$ Curiously enough, the other specimen in question, referred by Mr. Seward to Lepidodendron aculeatum, Sternb., likewise "exhibits an exceedingly close agreement with that type of structure which it has been customary to describe as Lepidophloios fuliginosus." ${ }^{2}$ It is thus evident that no anatomical distinction can be drawn between the two so-called genera Lepidodendron and Lepidophloios.

3. Leaves.-We next come to the structure of the leaves of the Lepidodendreae. It is, of course, necessary to distinguish between the leaf-bases or cushions, which remained in connection with the stem, and the leaves themselves, which were thrown off. The great majority of the specimens with structure preserved bear the leafbases only; in the literature it has sometimes happened that the latter have been confused with the actual leaves.

The external form of the leaf-base has already been described. We have also seen that on the scar, left by the fall of the leaf itself, there are three prints (cf. Fig. 55, p. I 30). The middle one is caused by the vascular bundle, which remained simple throughout the leaf. The two lateral prints, called the parichnos, are, as stated above, of quite a different nature; a strand of largecelled parenchyma accompanies the leaf-trace through the outer cortex on its lower side, and divides, in the base of the leaf, into two strands, which take up their position to the right and left of the vascular bundle. When the

1 Scott, "Structure of Lepidodendron obovatum," Ann. of Bot. vol. xx. 1906, p. 317

2 Seward, "Anatomy of Lepidodendron aculeatum," ibid. p. 378. 
leaf fell off, the broken ends of these two parenchymatous strands appeared on the scar, with the print marking the bundle between them (see Fig. 62, showing the leaf-bases of a Lepidophloios in tangential section).

The two external prints on the surface of the leaf-

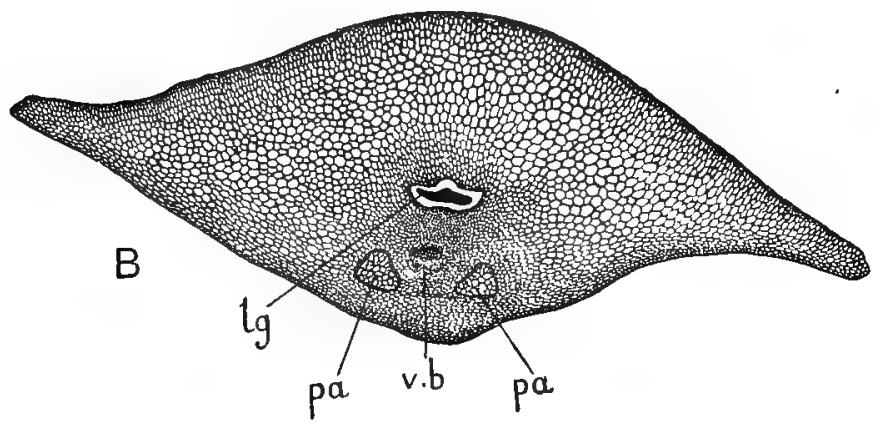

A

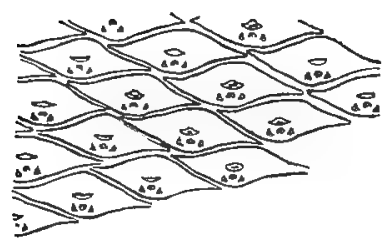

Fig. 62,-Lepidophloios, sp. A. Tangential section from the outside of a stem, passing through the leaf-bases, and showing their characteristic form. Slightly enlarged. B. A single leaf-base, to show details. $v . b$, collateral vascular bundle; $p a$, the two parichnos-strands; $g g$, ligule in its pit. $x$ ro. Will. Coll. I974 A. (G. T. G.)

cushion below the scar(see Fig. $55 a, a$ ) were in connection with the parichnos, as was first shown by Potonie in a Lepidophloios. Professor Weiss has recently investigated the structure, and finds that in Lepidophloios the parichnos-strands run very close to the surface and communicate with a delicate sub-epidermal tissue containing well-developed intercellular spaces. In a Lepidodendron, 
probably L. Hickii, Watson, this lacunar tissue lies at the base of the depressions which constitute the external prints. There appear to have been numerous stomata in the overlying epidermis.

The parichnos-strands die out in the leaf itself, losing themselves in the mesophyll. Thus the parichnostissue kept up communication between the delicate parenchyma of the inner cortex and the assimilating mesophyll of the leaves, as well as with the patches of aërenchyma in the persistent leaf-bases. The function may probably have been to facilitate respiration. ${ }^{1} \mathrm{Mr}$. T. G. Hill has lately shown that strands comparable to the parichnos occur in the leaves of Isoettes Hystrix and various species of Lycopodium; in these cases the function of the strands is secretory, as may sometimes have been the case in fossil Lycopods. ${ }^{2}$

The little triangular print on the upper part of the cushion, immediately above the leaf-scar, is of special interest, for we now know that this represents the ligule, an organ which is characteristic of Selaginella and Isoëtes, though absent from the other recent genera of Lycopods. Stur was the first to identify the ligule in Lepidodendron, but until it was demonstrated in specimens with structure preserved, there was no proof of the correctness of his interpretation. The presence of a ligule was proved almost simultaneously by Count Solms-Laubach ${ }^{3}$ in specimens from the Lower Carboniferous of Silesia, probably referable to the L. brevifolium

1 F. E. Weiss, "The Parichnos in the Lepidodendraceae," Mem. and Proc. Manchester Lit. and Phil. Soc, vol. li. Igo7.

${ }^{2}$ T. G. Hill, "On the Presence of a Parichnos in Recent Plants," Ann. of Bot. vol. Xx. I 1906 .

3 Bot. Zeitung, 1892, p. I10, Plate ii. Fígs. 2 and 4. 
of Williamson, and by the late $\mathrm{M}$. Hovelacque ${ }^{1}$ in $L$. selaginoides. It has since been demonstrated in several other species, and was probably common to the whole family.

In all the species in which the ligule has been found, it presents much the same features. Its position is always on the upper surface of the cushion, immediately above the leaf-scar.

The ligule is seated at the base of a deep flaskshaped cavity, and is very rarely found projecting beyond it (see Figs. 62, B, and $63, l g$ ). The ligule was, of course, a delicate organ, and is often imperfectly preserved; often the ligular cavity is shown, when the ligule itself has perished altogether. In some cases, however, the cellular structure of the ligule is perfectly shown, and is found to agree, on the whole, with that in recent Ligulatae. The deep ligular cavity is very characteristic of Lepidodendreae, but is not without parallel among recent plants, for Professor Harvey Gibson has shown that in Selaginella oregana and rupestris "the free margin of the ligule scarcely appears above the edge of the very deep pit in the leaf in which it is seated." ?

The base of the ligular cavity lies just above the vascular bundle, and is in many cases, if not in all, surrounded by a sheath of short tracheides, forming a connection with the wood of the leaf-trace bundle, just as in Isoëtes and in some Selaginellae among recent plants. The cavity slopes from its base, upwards and

1 "Recherches sur le Iepidodendron selaginoides," Mlem. de la Soc. Linnéenne de Normandie, Caen, I892.

2 "Anatomy of the Genus Selaginella," Part ii. The Ligule, -tmals of Botany, vol. x. p. 83, Plate viii. Fig. I9, 1896. 
outwards, opening just above the scar, where the leaf itself was inserted (see Fig. 63). The print on the casts corresponds to the mouth of the ligular cavity.

The presence of a ligule in Lepidodendreae is an interesting discovery, indicating affinity with Selaginella or Isoëtes, rather than with Lycopodium, among recent members of the order. There are a few other facts which point in the same direction, but it is not likely

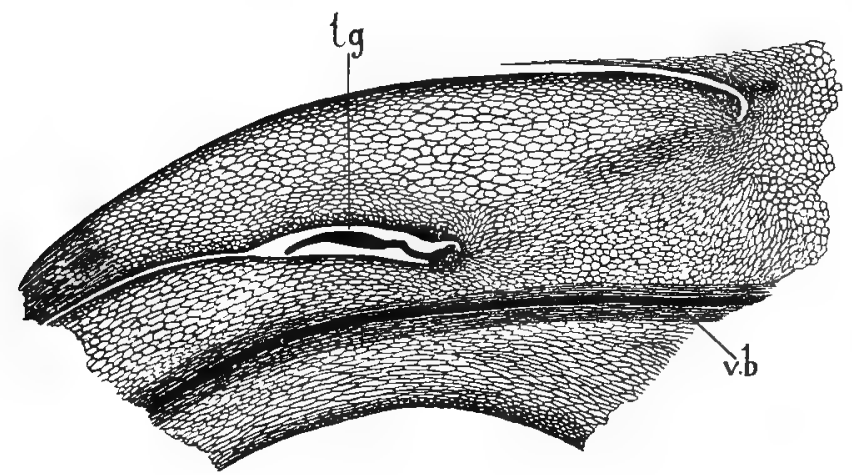

Fig. 63.-Lepidophloios, sp. Radial section of a leaf-base from the same specimen as

Fig. 62. $v_{.} b_{\text {, }}$, vascular bundle of leaf; $l_{s}$, ligule, seated in a deep pit, communicating by a canal with the upper surface. $\times$ ro. Will. Coll. $\tau$. 60. (G. T. G.)

that the relation to any recent genus was at all a close one.

The structure of the free part of the leaf was thoroughly worked out by M. Renault ${ }^{1}$ in a species ( $L$. esnostense) from the Lower Carboniferous rocks (Culm) of France; certain leaves, associated with, and probably belonging to the British form L. Hickii, Watson, agree in several respects with the French specimens, while leaves of other British Lepidodendreae are also similar. In

1 Flore fossite d'Autzen et d'Epinac, Part ii. p. 178, Plate xxxiv. Figs. 4-8. 
$L$. esnostense the leaves were acicular, and not very different in form from those of some species of Pinus. Along the under surface, on either side of the midrib, are two furrows, which are very deep near the base

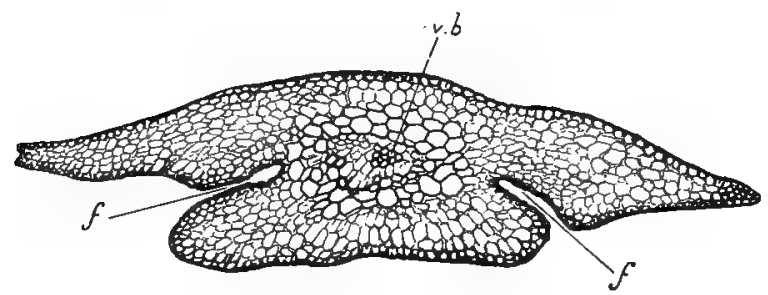

FiG. 64.-Lepidodendron Hickii Transverse section of leaf $v . b$, vascular bundle; some of the large elements round it constitute the transfusion-tissue; $f$, furrows in which the stomata are placed. $\times 60$. S. Cobll. 5T. (G. T. G.)

of the lamina, but become less marked towards the apex. It is on the epidermis lining these furrows that the stomata are found. They are very numerous, and of the usual bicellular structure. The rest of the leaf is covered by a small-celled epidermis with a

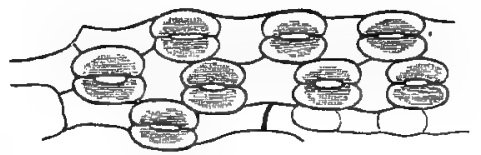

FIG. 65.-Lesidodendron Hickii. Epidermis of leaf, with stomata. $\times$ about zo'. S. Coll. SI. (G. T. G.)

thick - walled hypoderma below it. The mesophyll consists of a spongy tissue, like that of many recent leaves. This was no doubt the green, assimilating part of the leaf when alive. The middle of the leaf is traversed by a central strand of tissue, enclosing the vascular bundle. The bundle itself is small, but it is surrounded by a wide zone of spiral or reticulated 
tracheae, much larger and more numerous than those of the xylem itself. This peculiar formation appears to have been analogous to the transfusion-tissue in the leaves of Coniferae. In the leaf of Lepidodendron, as in that of the Coniferae, there is some ordinary parenchyma surrounding the bundle, in addition to the tracheae.

In the leaves referred to L. Hickii, the structure is much like that just described, except that their form was not acicular, but linear, or narrowly lanceolate, the leaf having a lamina of some width (see Fig. 64). The stomata are extremely well shown (see Fig. 65), and appear to have occupied the same position as in the French species.

In the structure of the leaves, as in so many other points, we see that the Palæozoic Lycopods were more highly organised than their representatives in our own period.

4. Branching.-We now come to the question of the branching of the stem. So far as the external and anatomical characters enable us to judge, the branching was dichotomous throughout, and it is usual to assume that this was the case, though, in the absence of any knowledge of the growing point, it is impossible to say whether the strict definition of dichotomy applied here.

We must distinguish, with Williamson, between equal and unequal dichotomy. The former prevailed in the forking of the main stem and its principal branches, where the two limbs into which the parent axis divided were similar (Fig. 66). Immediately below the dichotomy the stele separates into two 
parts, which for some distance have the form of horseshoes, with the pith of each stele open towards the other. Where there was secondary growth, the cambium in this

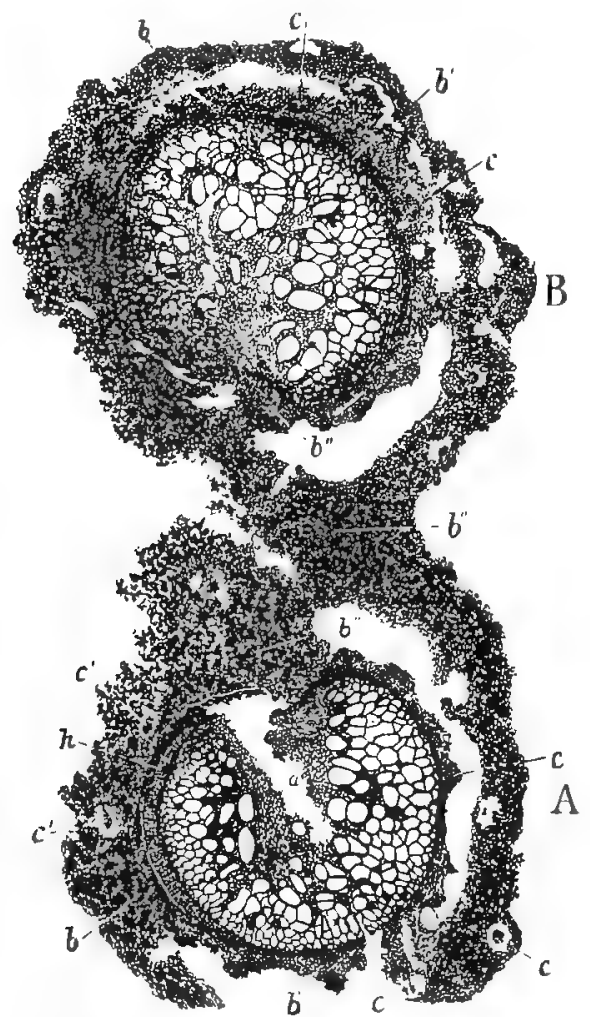

FIG. 6б. Lepidodudron selaginozdes. Transverse section showing the two steles ( $A$ and $B$ ) of a bifurcating stem. $a$, pith ; $b$, inner cortex ; $c$, leaf-traces; $h$, secondary wood. The pith in this species only exists near a bifurcation, where the steles are still incomplete on the inner side. $x$ about 9 . After Williamson, Phil. Trans. Will. Coll. 340.

region sometimes extended into the medulla, forming an inverted band of secondary tissues within the primary wood. This occurred even in L. selaginoides, where the 
pith was replaced by scattered parenchyma. Although limited to the place of bifurcation, this condition is of some interest, because analogous anomalies occur among the higher plants at the present day. The cambium, in fact, shows similar eccentricities in its behaviour wherever it occurs, quite irrespective of taxonomic relationship. As we trace the two branches higher up, we find that the stele in each gradually regains its normal circular form. (Fig. 66, from a forking branch of $L$. selaginoides, shows the steles in an intermediate state.)

Unequal dichotomy simply means that one branch of the fork is much smaller than, and sometimes differently organised from, the other. This no doubt often occurred in the vegetative region, in cases where a main axis bore a comparatively small twig, as an apparently lateral branch. Unequal dichotomy was, however, of common occurrence in connection with the fructification, when one branch of a dichotomy was fertile, while the other remained vegetative. Such cases, however, will be considered in the next chapter.

Anatomically, unequal dichotomy is characterised by the behaviour of the stele. It is frequently the case that the smaller of the two branches has no medulla. Then, instead of the two equal horse-shoes described above, we find only a small part of the main stele diverging to the minor branch. Sometimes a segment of the wood was cut out, as it were, from the stele, leaving a small opening, which soon closed up. The segment destined for the branch was thus solid from the first (e.g. Lepidophloios fuliginosus, Fig. $69, b^{\prime}$ ). In other cases the strand of wood passing out to the smaller 
member was so insignificant that the continuity of the main ring was never interrupted, a group of its more external tracheae sufficing to supply the wood for the branch (see Fig. 58, br, from L. brevifolium).

To complete the description of the vegetative organs of the Lepidodendreae, we ought now to describe the root. As, however, we cannot as yet distinguish with certainty between the underground organs of Lepidodendron and those of Sigillaria, it will be necessary to postpone their consideration until the latter genus has also been described. ${ }^{1}$

1 The anatomy of Lepidodendroid stems was dealt with by Williamson in Parts ii., iii., ix., x., xi., xii., xvi., and xix. of his series of memoirs in the Philosophical Transaitions, 1872-93. Some of his final conclusions are summed up in his last work, "Growth and Development of the Carboniferous Arborescent Lepidodendra," Mem, and Proc. Manchester Lit. and Phit. Soc. ser. iv. vol. ix. 1895. 


\section{CHAPTER VI}

\section{LYCOPODIALES-continued}

\section{Ulodendron and Halonia; Fructifications of}

Lepidodendreae; Bothrodendron

I. Ulodendron and Halonia.-In the last chapter we described the morphology of the stem and leaf of the Lepidodendreae; we have now to consider their organs of reproduction. Before going on to the cones, something must be said as to two forms of Lepidodendroid stem (commonly regarded as bearing the fructifications) which differ so conspicuously from the ordinary type that they were long described as belonging to distinct genera, to which the names Ulodendron and Halonia were given. The genus Ulodendron is still kept up for certain species by M. Zeiller.

The Ulodendroid form of stem is often of large size, attaining in some cases a diameter of about a foot, and is sometimes dichotomously branched. The general surface bears the ordinary markings of the Lepidodendreae; where the leaf-bases are perfect they present, however, in some cases, according to Mr. Kidston, the characters of a Sigillaria, and so do not come under our immediate subject, but in other specimens the superficial characters are clearly those of a Lepidodendron (see 
Fig. 67). The characteristic feature of the Ulodendron

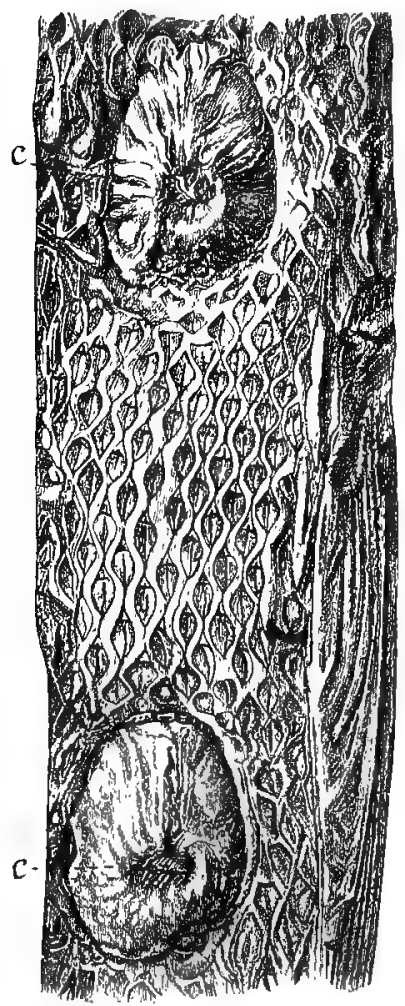

Fic. 67. - Ulodendron. Surface of branch, showing two large scars, with the central print $c$, and numerous Lepidodendroid leaf-bases. On the right the leaves are seen. Reduced. After Schimper. The large scars are really depressions, but, owing to the shading, appear in the figure as elevations. They can be seen as depressions if the figure is reversed.

stem consists in the presence of roundish scars, often of very large size, usually arranged alternately in two vertical rows, one row on each side of the stem. On the larger Ulodendra these scars have a diameter of from 4 to 6 inches. Within the scar, usually somewhat below the centre, is a print or stump, representing either the stalk or the woody cylinder of some lateral appendage. The scar as a whole is depressed, having the form of a shallow cup, with the print or umbilicus at the bottom (see Fig. 67). The surface of the cup is usually marked with radiating ridges on the part above the umbilicus, while the lower part bears spirally arranged prominent points.

The nature of these curious objects was long in dispute, and is still by no means cleared up, though specimens have been described with "cones" still attached to the scars, ${ }^{1}$ thus ${ }^{1}$ D'Arcy Thompson, "Notes on Ulodendron and Halonia," Trans. 
appearing to confirm by direct evidence an idea which had long previously been suggested. The Ulodendra, then, were supposed to represent the fertile branches of various species of Lepidodendron (e.g. L. Veltheimianum), Bothrodendron, and perhaps Sigillaria also, which thus bore their fructifications on thick stems, and not on terminal twigs. The peduncle, represented by the print within the scar, was assumed to be quite short, so that the base of the almost sessile strobilus was in contact with the leafy surface of the main axis; the large cup-shaped scar appeared to have owed its origin to the mutual pressure between the two organs. The great size of the scars in some cases was still, however, unaccounted for, their shape being inconsistent with dilatation by secondary growth.

Mr. D. M. S. Watson ${ }^{1}$ has quite recently pointed out the great difficulties involved in the current interpretation of the Ulodendroid scar, and the inadequacy of the evidence in its support. He maintains that the scars are those of caducous branches, which were attached to the whole area of the scar, the umbilicus corresponding to the central cylinder and the dots and radial marks on the scar representing the leaf-traces of the branch. For certain cases, at all events, his interpretation appears to correspond best with the observed facts, though various difficulties remain.

The other form of stem to be considered-that Edinburgh Geol. Soc, vol, iii. I880. Cf. Solms-Laubach, Fossil Botany, English edition, p. 208. Kidston, "On the Relationship of Ulodendron to Lepidodendron, etc.," Ann. and Mag. Nat. Hist. vol. xvi. I 885 ; Zeiller, "Sur les Ulodendron et Bothrodendron," Bull. Soc. Gél. de France, sér. iii. t. xiv. 1885 .

1 "On the Ulodendroid Scar," Mem. and Proc. Manchester Lit. and Phil. Soc. vol. lii. Part i. 1908. 
known as Halonia-has certain points in common with the Ulodendroid branches, but presents a different appearance. The Halonial branch, which, though on the whole smaller than Ulodendron, is often several inches in diameter, is characterised by bearing a number of prominent knobs or tubercles, most often spirally arranged (see Fig. 68, A). The general surface is usually badly preserved, the specimens having evidently been partially decorticated before fossilisation. Where, however, the external characters are well exhibited, so as to show the leaf-bases clearly, they prove that the specimens belonged to Lepidophloios, though it is quite possible that the Halonial condition may have also occurred in the true Lepidodendra. Halonial branches have been found in connection with the ordinary vegetative stems of Lepidodendreae, though whether of Lepidodendron or of Lepidophloios could not in all cases be determined - a point, however, which is of secondary importance. The fact that the Haloniae occurred as ultimate branches of the dichotomous stem, ${ }^{1}$ quite disposes of the idea, once maintained by some French writers, that they were of the nature of roots or rhizomes.

As regards the anatomy, the main Halonial axis may either have in all respects the structure of an ordinary vegetative stem, or may differ from it in the absence of a medulla. The latter was the case in a Halonial branch of the Arran species, Lepidodendron Wunschianum, investigated by Williamson. ${ }^{2}$ The

1 See Williamson, "Organisation, etc." Part xii., Plates iii., iv., I883.

I "Organisation, etc.," Part xii. I883. This species was perhaps a Lepidophloios. 
branch is not quite an inch thick, and contains a stele about $3.5 \mathrm{~mm}$. in diameter. The wood is perfectly solid, consisting entirely of tracheae, without

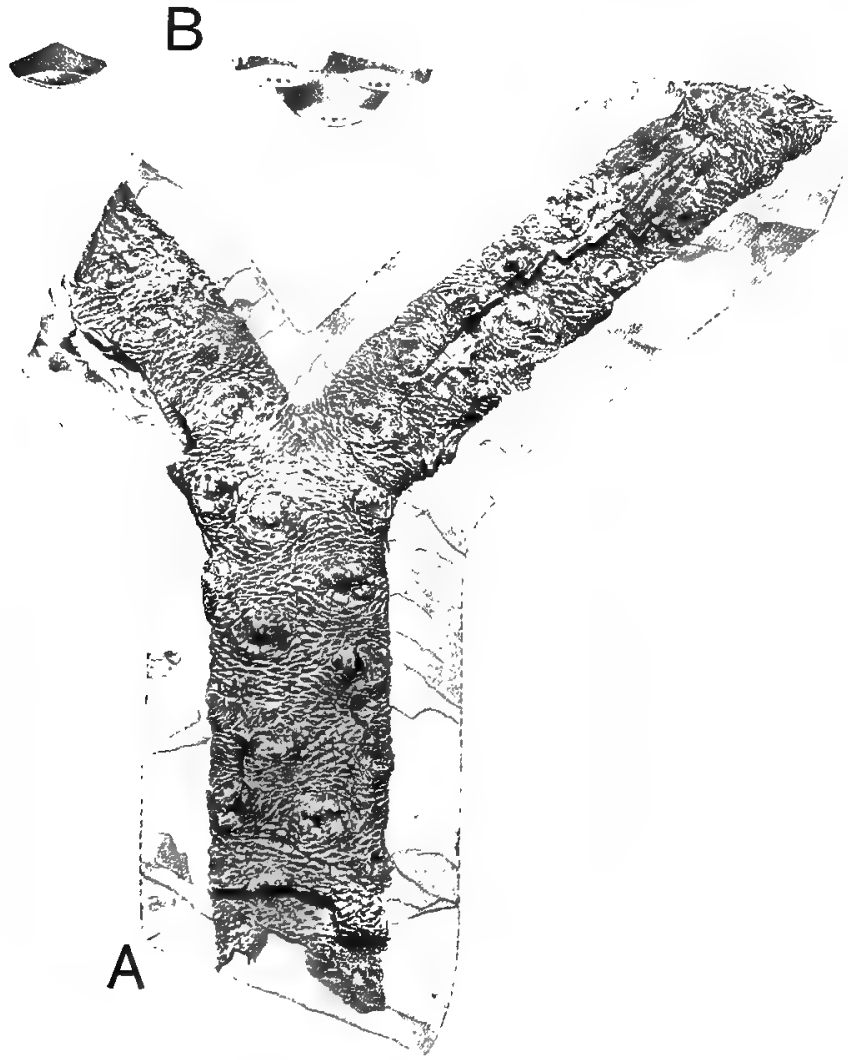

Fic. 68.-Lepidophloios scoticrs, Kidston. A. Bifurcating Halonial branch, showing numerous tubercles, and the characteristic leaf-bases. About $\$$ nat. size. B. Leaf. cushions enlarged, showing the scar with the usual three prints. From the Calciferous Sandstone series. After Kidston.

any indication of a medulla. This is not, however, a peculiarity of the Halonial form of branch, for in this species, $L$. Wunschianum, the ordinary vegetative 
branches of the same size also have a solid woody axis, and it is only in the larger stems that a pith is present. As regards the leaf-traces and cortical structures, the Halonia shows no peculiarities; a thick layer of periderm forms its outer boundary. From the central cylinder small cylindrical steles are given off, which pass obliquely outwards to supply the tubercles (see Fig. 69, b', from Lepidophloios fuliginosus). The tubercular steles are surrounded by their own leaftraces, which no doubt supplied the leaves, borne on the lateral appendages of which the tubercles are the persistent bases.

In Lepidodendron Hickii similar tubercles have been observed on some of the smaller branches. In this case the branch itself has the ordinary structure of the species, with a medullate stele, while the small strands running out to the tubercles are without any pith. A similar condition has been found in Lepidodendron obovatum and in Lepidophloios fuliginosus (Fig. 69). All these cases afford striking examples of the so-called unequal dichotomy described in the last chapter (p. I63).

What then was the nature of these Halonial branches, which evidently did not constitute a separate genus, but occurred as terminal ramifications on certain Lepidodendroid stems? Their position and structure alike prove that they were neither roots nor root-bearing rhizomes. Evidently they bore some kind of lateral appendages of the nature of branches, but different from the ordinary vegetative twigs.

The distinction between Halonia and Ulodendron is 
not always an obvious one. As a rule the appendages of Ulodendron were distichously arranged, while those of Halonia were multiseriate, and quincuncially disposed. Williamson, howcver, described a specimen with

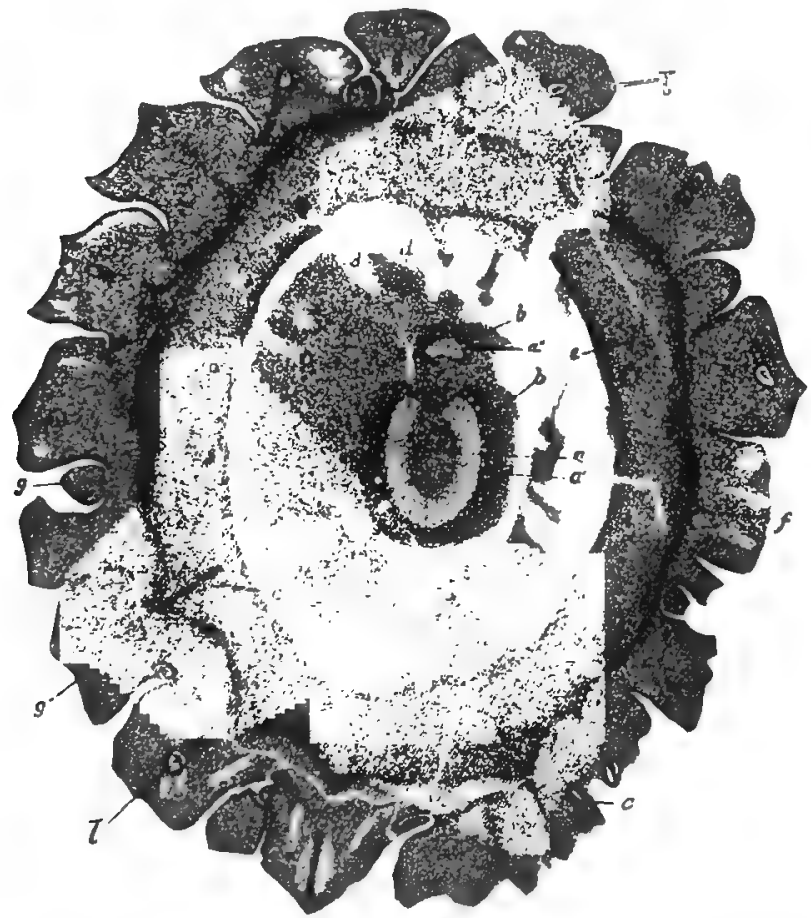

FIG. 69.-Lepidoplloios fuliginosus. Transverse section of a young shoot (probably in the Halonial condition); $a$, pith, $a^{\prime}$, xylem, of main stele ; $a^{\prime \prime}$, xylem of branch; $b, b^{\prime}$, phluëm of main and branch steles; $c$, leaf-traces ; $d$, inner cortex ; $c$, middle cortex; $f$, periderm; $g$, leaf-bases; $l$, ligule. $\times$ about 2. After Williamson, Phil. Trans. Will. Coll. 379 .

multiseriate, quincuncially arranged scars apparently of the Ulodendron character, and also a Halonia with the tubercles in two series, so this distinction loses its value. ${ }^{1}$

1 Willianson, xix. 1'late vi. Figs. 22 and $25, \mathrm{~A}$. 
A magnificent specimen of the latter kind was discovered some years back by Mr. J. Lomax, and described by Prof. F. E. Weiss. The stem, which has a mean diameter of about $8 \mathrm{~cm}$, , bears, on opposite sides, two series of large tubercles, with all the characteristics of Halonia. The main stem, the structure of which is perfectly preserved, agrees very closely with that of Lepidophloios fuliginosus. ${ }^{1} \quad$ Fig. 69 is from the latter species, and shows a younger branch, also with the Halonial mode of branching and apparently biseriate. These specimens, together with others, in which the leafbases are preserved, have been regarded as showing that the Halonial shoots of Lepidophloios in some cases bore their tubercles in two rows, though this conclusion is disputed by Mr. Kidston, ${ }^{2}$ who considers the attribution of these specimens to Lepidophloios as unproved.

The tubercles of Halonia appear in most specimens more prominent than they were in nature, owing to the axis which bears them having lost its outer cortex. In specimens with the natural surface preserved, the tubercles appear rather as scars, but are quite distinct from those of Ulodendron, owing to the absence in Halonia of the cup-shaped area characteristic of the former. The conclusion to which the facts appear to point is that the so-called Halonia consisted of fertile branches of Lepidophloios (and possibly other Lepidodendreae) bearing deciduous stalked cones.

A specimen figured by Grand'Eury ${ }^{3}$ appears to

1 F. E. Weiss, "A Biseriate Halonial Branch of Lepidophloios fuliginosus," Trans. Linn. Soc. Bot. ser. ii. vol. vi. 1903.

"Kidston, "On the Internal Structure of Sigillaria elegans," Trans. Roy. Soc. Edinzburgh, vol. xli. Part iii. 1905.

${ }^{3}$ Grand'Eury, Bassin houiller du Gard, Plate vi. Fig. I7, 1890. 
strongly support this conclusion. He represents a portion of a thick stem of Lepidophloios laricinus, bearing four slender branches, on which are scales differing entirely from the vegetative leaves. These branches he regards, with great probability, as the peduncles of cones. The specimen seems to be of the same nature as the Halonial branches which are known to occur in this species. It is fair, however, to mention that Grand'Eury, in the same work, still inclined to regard Halonia as a rbizome.

From the whole of the facts, we may take it as very probable, though more direct evidence is much needed, that Halonia consists of the cone-bearing branches of certain Lepidodendroid plants (especially Lepidophloios), the tubercles representing the places where the cones themselves were inserted. In these forms, then, the cones would have been borne on relatively thick branches, but this was not always the case in Lepidodendreae, for there is no doubt that in many species the cones occurred at the ends of slender twigs, the ultimate ramifications of a much-branched stem (see Fig. 53, B, p. 1 29). Considering the serious doubts that now exist as to the nature of Ulodendron, it must be admitted that the question of Halonia also demands re-investigation.

2. Lepidostrobus. - We now come to the consideration of the actual fructifications. In a few instances, the strobili have been found in connection with the branches of Lepidodendron, as, for example, was the case in L. Ophiurus (see Fig. 53, B). As a rule the specimens are isolated, but their nature has been determined 
by comparison with the cones still in position. In cases where the structure is preserved, additional and

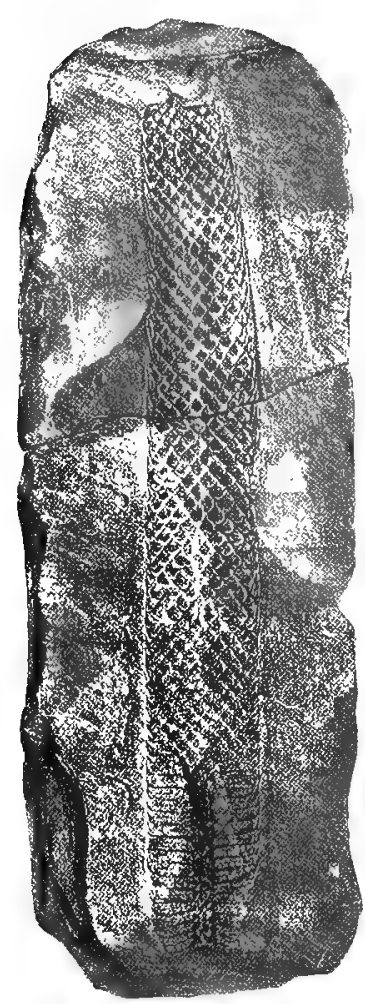

F1G. 7o. - Lepidostrobus Hibbertianus, Binney. Compressed specimen of an almost perfect cone, with the matrix. The exterior surface is shown, except at the base, where the axis, with some of the megasporangia, is exposed. $\frac{2}{3}$ nat. size. After Binney. convincing evidence is afforded by the anatomy of the axis of the cone, which is quite similar to that of a young vegetative twig of Lepidodendron.

As it is very rarely possible to refer the fructifications to the particular species of stem to which they belonged, it is convenient to retain a distinct generic name for them. Most Lepidodendroid cones are described under the name of Lepidostrobus, but, as we shall see below, all the fructifications of the group cannot be included under a single genus. For the present we will confine ourselves to the characters of the true Lepidostrobi.

The cones of different species vary greatly in their dimensions, the length ranging approximately from about an inch to about a foot. The form is usually cylindrical (Fig. 70), but in some of the shorter cones is more ovoid. The strobilus was either sessile or stalked; the former was no doubt the case if the fruiting stem was ever of the Ulodendroid form, while the 
stalked cones were borne either on Halonial branches or on the twigs of the young growth.

The general characters of the cones of Lepidostrobus are those of Lycopodiaceous fructifications. In habit the agreement is closest with Lycopodium, while in some important details there is a nearer approach to Selaginella, but of course the Lepidodendreae have no near affinity with any of the modern genera. The axis of the strobilus bore a very large number of crowded sporophylls (or bracts, as they are often called), usually arranged spirally, but occasionally verticillate. Each sporophyll bore a single sporangium on its upper surface. The sporangia were of large size, enormously exceeding the dimensions of those in existing Lycopods. Thus, in the magnificent specimen known as Lepidostrobus Brownii, Schimper, the radial length of the sporangia approaches $2 \mathrm{~cm}$., with a maximum breadth of about $5 \mathrm{~mm}$. The great radial elongation of the sporangia is characteristic of the genus, and is correlated with the peculiar form of the sporophylls, which consist of a long, slender stalk or pedicel, usually more or less horizontal, terminating in a large lamina, which turns vertically upwards, several sporophylls overlapping each other. There is also usually a shorter downward prolongation of the lamina, so that the form of the whole is somewhat peltate (see diagram, Fig. 7 I). The sporangium is attached all along its lower side to the upper surface of the horizontal pedicel, but is free from the lamina. In its form, and mode of attachment to the sporophyll, the sporangium resembles that of Isoëtes.

The cones are often preserved as casts or impres- 
sions; where the external surface is perfect, it is completely invested by the overlapping laminae of the sporophylls, which are closely packed together (Fig. 70). When the preservation is less complete, the free tips of the laminae have perished, leaving only their more solid basal portions, which often assume a hexagonal form from mutual pressure. The fractures of the casts

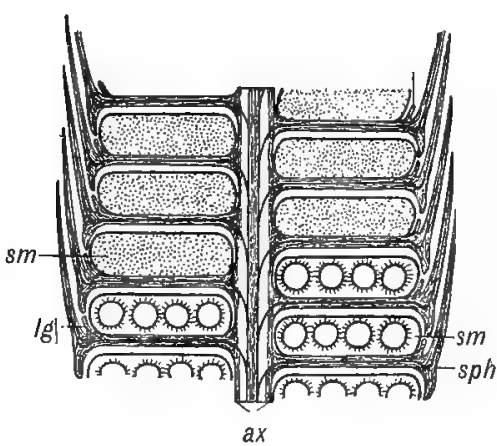

Fifi.7r.-Lepidostrobus. Diagram of heterosporous cone in radial section. $a x$, axis; sphe, sporophylls; sm, sporangia, seated singly on the upper surface of each sporophyll; $l g$, ligules; the microsporangia, in upper part of cone, contain numerous microspores, while the megasporangia below are shown containing four megaspores each. (G. T. G.) often show something of the internal organisation, the tissues being preserved to some extent, though in a carbonised condition (Fig. 70). It is only, however, in the petrified specimens that the structure is completely revealed.

Our more detailed description will be based on a form named by Williamson Lepidostrobus oldhamius, ${ }^{1}$ of which several examples in a calcified state have been yielded by the calcareous nodules of the English Coalmeasures.

The largest specimens of this strobilus reach a diameter of about $4 \mathrm{~cm}$. ; the axis is slender, about 4 or $5 \mathrm{~mm}$. in thickness. The anatomical structure is of the usual Lepidodendroid type. The centre of

1 For a full illustrated account of the organisation of these cones, see Maslen, "Structure of Lepidostrobus," Trans. Linm. Soc. vol. v. I899. 
the axis is occupied by a small stele, in which a ring of primary wood surrounds the pith. In the wood the larger elements, which have a scalariform thickening, are towards the interior; the outer margin is produced into a number of somewhat prominent points, and here the narrow spiral elements of the protoxylem are found; thus the development of the wood was evidently centripetal, as in the vegetative stem. In exceptionally well-preserved specimens, the phloëm-zone, surrounding the wood, is preserved; this zone is largely parenchymatous, the elongated elements, presumably forming the true phloëm, occupying only a small space. From some of the best-preserved specimens, it appears that the tissue next the wood was entirely parenchymatous, while the true phloëm lay more to the exterior. In Lepidostrobus Brownii, the structure of which is better preserved than that of L. oldhamius, a distinct endodermis, separating the stele from the inner cortex, can be traced.

The inner and outer zones of the cortex are usually well preserved in L. oldhamius, while the intermediate region has perished-a common condition in the stems of fossil Lycopods. The inner cortex consists of a narrow zone of parenchymatous tissue; beyond this is the gap representing the position of the wide middle cortex; the outer cortical zone is usually perfect, and consists of thick-celled tissue, largely made up of fibrous elements. This zone is continuous on the exterior with the bases of the sporophylls.

The leaf-trace strands, one of which runs out to each sporophyll, have a very steep course, so that a large number, corresponding to several circuits of the 
foliar spiral, are seen in transverse section. The structure of these bundles, which is sometimes admirably preserved, is normally collateral. The smallest spiral tracheae lie at about the middle of the xylem-strand, as in Lepidodendron Harcourtii. The xylem is surrounded by a layer of delicate parenchyma, which on the outer side separates it from the phloëm. After passing through the inner cortex, the whole bundle is further surrounded by a parenchymatous sheath, continuous with the inner cortical tissue. In this condition it passes through the middle zone of the cortex, where the leaf-trace bundles, with their sheaths, are usually the only tissues preserved.

In Lepidostrobus Brownii, where the middle cortex is partly preserved, the leaf-trace bundles are connected with the surrounding tissues by trabeculae, analogous to those radiating from the steles in Selaginella. The leaf-traces of Lepidostrobus closely resemble those of living Lycopods in structure. ${ }^{1}$

On reaching the outer cortex, where the bundles gradually assume a more horizontal course, the same structure is preserved. Here the sheath, immediately surrounding the vascular strand, has less thick walls than the enveloping cortical tissue. In this region a gap in the tissue constantly appears below each bundle, and accompanies it outwards into the sporophyll. There can be no doubt that this gap was in nature occupied by a delicate parenchyma (sometimes preserved in other species), continuous with that of the middle cortex, and that this tissue, accompanying the leaf-trace,

1 See Bower, "On the Structure of the Axis of Lepidostrobus Brownii," Annals of Botany, vol. vii. I 893 . 
corresponds to the parichnos-strand in the vegetative axis (see pp. 148 and I 55 ).

The sporophylls in L. oldhamius are more than a centimetre in length, and stand out at almost a right angle with the axis. Each consists of a long, slender pedicel, terminating in a foliaceous lamina. Near the axis the pedicel is narrow, with a triangular section, while further to the exterior it becomes broader and flatter. It consists chiefly of thick-walled tissue like that of the outer cortex, and is traversed by the vascular bundle, which retains essentially the same structure as in the cortex. The lamina broadens out rapidly at the end of the pedicel, where at the same time it attains a considerable thickness. It turns upwards almost at a right angle with the pedicel, and becomes both narrower and thinner towards its termination. The general form of the lamina is thus lanceolate; as mentioned above, it has a shorter downward prolongation, rendering the whole somewhat peltate (see diagram, Fig. 71). The structure is simple, the mesophyll consisting of rather small-celled parenchyma, in the outer layers of which the cell-walls are much thickened. The single vascular bundle which traverses the lamina is surrounded by a very well developed transfusion-tissue of short spiral or reticulated tracheides, most abundant where the leaf is thickest. In this respect the sporophyll resembles the foliage-leaf, and in both cases this accessory system of tracheides no doubt served to facilitate the supply of water to the mesophyll.

An interesting feature of the sporophyll is the ligule, the presence of which was demonstrated by 
Mr. Maslen in L. oldhamius. The ligule is seated on the upper surface of the sporophyll, near its distal end, and just where the lamina begins to bend upwards. It is a small pointed body, about half a millimetre in height, with a triangular transverse section, and consists of very small-celled parenchyma. In itself it thus resembles the ligule of the vegetative leaves, but differs in the entire absence of any ligular chamber. In allied forms of strobilus, however, a deep ligular chamber is present. As the discoverer points out, "the position of the ligule in Lepidostrobus, with the sporangium between it and the axis, is identical with that in Selaginella; but whereas in the latter genus it is quite close to the axis of the cone, in the former the great elongation of the sporangium, which had taken place in the radial direction, had of course carried the ligule with it, and so the latter comes to be situated near the periphery of the cone, and at a considerable distance from the axis. The whole of the horizontal (sporangium-bearing) portion of the sporophyll thus appears to be homologous with the short leaf-base or cushion on the vegetative stem" 1 (see diagram, Fig. 7 I, $g$ ).

The large, elongated sporangium is seated on the upper surface of the pedicel, to which it is attached throughout almost its whole length, from a point close to the axis, up to the beginning of the lamina (see diagram, Fig. 7 I). The connection between sporangium and sporophyll thus extends for a long distance in the radial direction, amounting to about a centimetre in large specimens of $L$. oldhamius, but at the same time

1 Maslen, Annals of Botany, vol. xii. I898, p. 259. 
the attachment is extremely narrow tangentially, so that a radial section of the cone seldom follows the plane of insertion for more than a small part of its length. Hence the connection between the two organs has sometimes been represented as much less extensive than is actually the case. The pedicel is grooved along its upper surface, and into this groove the narrow band of tissue fits, by which the sporangium and sporophyll are connected. The large baggy sporangium projects on either side considerably beyond the limits of the pedicel.

The wall of the sporangium, as preserved, consists of a single layer of prismatic palisade-like cells, very characteristic of Lepidostrobus sporangia, though in some species the wall has a more complicated structure. Along the lower side of the sporangium, where it is attached to the sporophyll, a pad of delicate tissue rises into its cavity, and spreads laterally for some distance along the interior of the wall. In other forms this internal tissue is more developed, and may even be prolonged into trabeculae, comparable to some extent with those of Isoëtes. It has been suggested by Bower, ${ }^{1}$ that these extensions of the sterile tissue into the cavity of the sporangium may have served to facilitate the nutrition of the developing spores, and may also have contributed to the mechanical support of the sporangial wall. Both points may well have been of importance in spore-sacs of such large size, with so slender an attachment to the subtending leaf.

In Lepidostrobus oldhamius and some other forms,

1 "Studies in the Morphology of Spore-producing Members," Part i., Phil. Trans. B, I894- 
only the small spores are known with certainty. They are present in countless multitudes in each sporangium, and are usually found still grouped in fours, with a tetrahedral arrangement. The spores are very minute, about $.02 \mathrm{~mm}$. in diameter. From the analogy of other cones of Lepidodendreae there is a strong presumption that $L$. oldhamius was heterosporous, like Selaginella, the microspores alone having been identified at present. Several forms are known to have been heterosporous, and it is most probable that all Lepidostrobi will prove to be so when we have a more complete knowledge of the strobili. ${ }^{l}$ Fragments of a heterosporous cone, with large megaspores nearly a millimetre in diameter, have been found in the same beds which have yielded the specimens of $L$. oldhamius.

We will, however, choose as our example of heterospory in Lepidostrobus a cone from a lower horizon, named Lepidostrobus Veltheimianus, a small species which is very abundant in the plant-bearing beds of the Calciferous Sandstones, near Burntisland, in Scotland. These cones are indistinguishable from those of Lepidodendron Veltheimianum, one of the few Lepidodendra which have been found with the fructification still attached to the branches. As this species is extremely abundant in the Calciferous Sandstone series, of which the Burntisland beds form part, it is extremely probable that the cones with structure preserved belong to it. Hence I have ventured to use the specific name Veltheimianus for the cones also. For information

1 In certain cases, the apparently homosporous strobili were doubtless the male fructifications corresponding to the "seed-bearing " cones of Lepidocarpon, describerl below, p. 193. 
on this subject I am indebted to Mr. R. Kidston, F.R.S. ${ }^{1}$

This strobilus is only about I $\mathrm{cm}$. in diameter, and was probably not more than $4 \mathrm{~cm}$. in length. In general morphology and structure it is essentially similar to $L$. oldhamius, but all the parts are on a smaller scale, and the slender stele of the axis has but little pith (see Fig. 72). The sporophylls have the

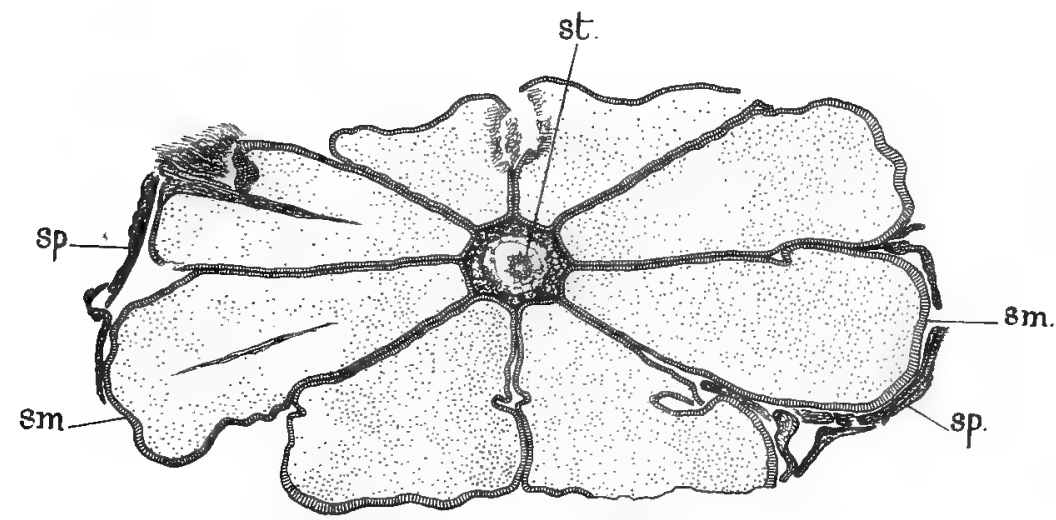

FIG. 72.-Lepidostrobus Veltheimianus. Transverse section of cone, through microsporeregion. st., stele of axis; sp., laminae of sporophylls (only partially shown); sm., microsporangia; in the two to the left trabeculae are shown. $x$ about $7 . \mathrm{S}$. Coll. 400. (G. T. G.)

same general form as in the previous species (Fig. 74), but the pedicels on which the sporangia are seated are relatively flatter and wider. In some, at least, of the specimens, their arrangement is in alternating verticils. The heterospory is beautifully shown in several specimens; from the longitudinal sections it is

1 This Lepidostrobzes was described and figured by Williamson in his "Organisation of the Fossil Plants of the Coal-measures," Part iii. I872, and Part xix. 1893, Phil. Trans. 
evident that all the upper part of the cone was occupied by microsporangia, and the lower by megasporangia, as in most species of Selaginella at the present day (Fig. 74). Fig. 72 represents a transverse section from the upper, and Fig. 73 one from the lower part of the cone; the former shows microsporangia, the latter megasporangia only.

The structure of the sporangium is similar to that of

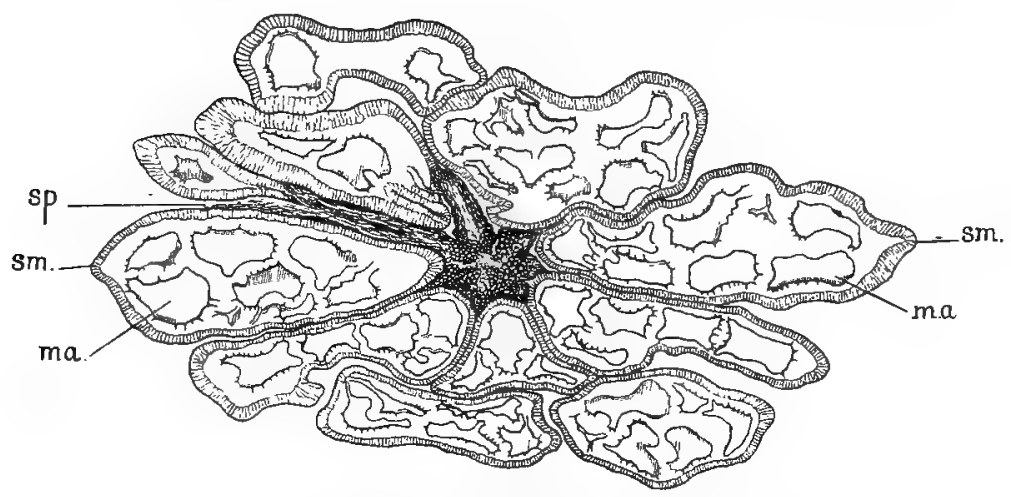

FIG. 73, -Lepidostrobus Veltzeinianus. Transverse section of cone, through megasporeregion. $s p .$, sporophylls (only partially shown); sn., megasporangia; ma., the spinose megaspores. $\times$ about 7 . S. Coll. 4I3. (G. T. G.)

the last species; the wall consists of narrow prismatic cells, sometimes divided by a transverse septum. From the base of the sporangium a radial plate of tissue runs up into the cavity, and often forks into two above. This structure may be compared with the trabeculae of Isoëtes. It is best shown in the microsporangia, but evident traces of it are present in the megasporangia also. The microspores occur in immense numbers in their sporangia, and are generally found united tetrahedrally in fours. They are of small size, not exceeding 
about $.02 \mathrm{~mm}$. in diameter. The megaspores are relatively of enormous dimensions, so that they are easily visible to the naked eye. Their mean diameter

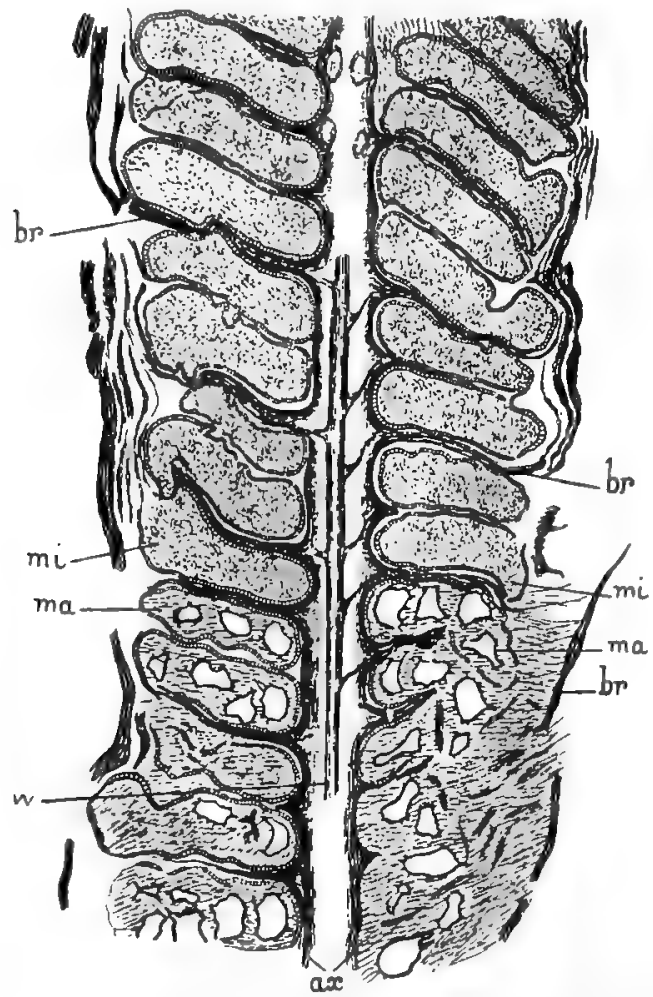

FIG. 74. Lepidostrobus Veltheintianus. Longitudinal section of cone, showing microsporangia above and megasporangia below. $a x$, axis of cone, showing stele $(w)$ and leaf-traces, passing out to sporophylls, br; $m i$, microsporangia ; ma, megasporangia, containing a few spinose megaspores. $x$ about 4 . S. Coll, 1008. (G. T. G.)

is at least $.8 \mathrm{~mm}$., quite forty times that of the microspores (see Fig. 75, C). The number of megaspores in each sporangium was small, certainly not more than sixteen, and perhaps as few as eight (cf. Figs. 73 and 
74). The thick membrane of the megaspores was
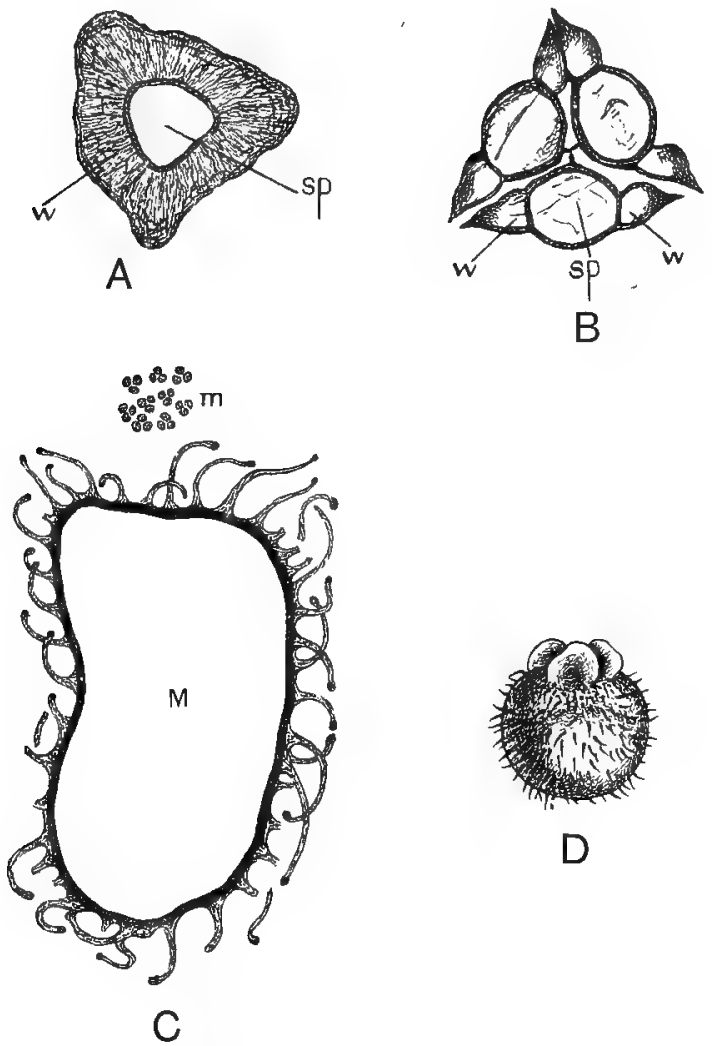

FIG. 75--Spores of Lepidodendreae. A. Spencerites iusignis. Spore, showing wing in surface-view. sp, cavity of spore; $w$, wing. B. Tetrad, in section, showing three out of the four spores, tetraheclrally arranged. $s p$, cavity of spore; $w$, wing. A and $\mathrm{B} \times$ about go. C. Lepidostrobus l'eltheimiantss. M, a single megaspore, showing the blunt spines; $m$, tetrads of microspores, on the same scale. $X$ about 70 . After Williamson, phil. Trans. D. A single megaspore, probably of L. Vettheiniantes, showing spines and lobes of membrane, surface-view. $\times{ }_{15}$. After Kidston and Bennie.

prolonged on the outside into a number of stout curved spines (see Figs. 73, 74, and 75, C). Detached mega- 
spores of Lepidostrobus and allied fructifications are very abundant in the Carboniferous formation, and show a great variety in size and surface-sculpture. Some of these megaspores (which were investigated by Messrs. Kidston and Bennie) appear to be identical with those of Lepidostrobus Veltheimianus; in addition to the spines, these detached specimens show a curious threelobed appendage to the membrane of the spore (see Fig. 75, D), which very commonly appears in the sections also. It is probable that this structure, which was of very general occurrence in the megaspores of Lepidodendreae, formed a passage for the admission of the microspores or of the spermatozoids produced by them. Microspores are often found entangled among the bristles of the megaspores.

The megaspores of Lepidostrobus foliaceus, a Coal-measure species, of which until recently

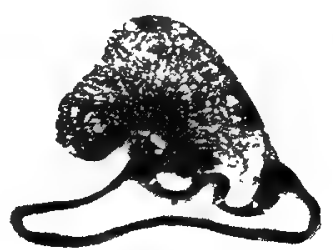

FrG. 76.-Lepidostrobus foliaceus. Megaspore (somewhat collapsed) bearing large episporic appendage. $\times 28$. From $R$. Scott, New Phytologist. S. Coll. 1217 . only the microsporangia were known, appear to have numbered not more than four in each sporangium, and possess a curious episporic appendage, comparable to the so-called "swimming apparatus" of Azolla" (see Fig. 76).

In favourable cases the prothallus is preserved within the megaspore. This is sometimes the case in L. Veltheimianus, as is well shown in Fig. 77; the prothallus is here almost complete, and fills the megaspore. Fig. 78, from a photograph, represents 1 R. Scott, New Phytologist, June 1906. 
the megaspore and prothallus from a fructification, provisionally named Mazocarpon, distinguished by the

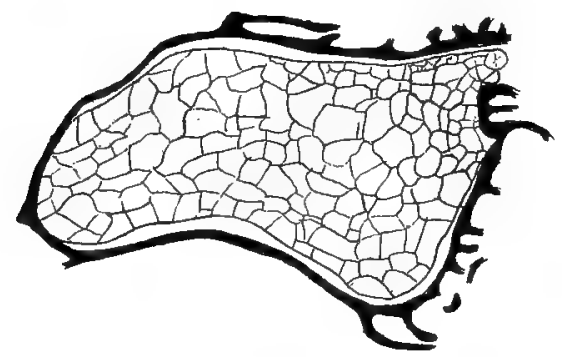

FiG. 77.-Lepidostrobus Veltheimianus. Megaspore in section, filled with prothallus, which protrudes somewhat through the opening of the megaspore-wall. $\times 50 . \mathrm{S}$. Coll. 912. R. S.

fact that the megaspores in the sporangium are embedded in a massive parenchymatous tissue. In other specimens traces of the archegonia are recognisable. M.

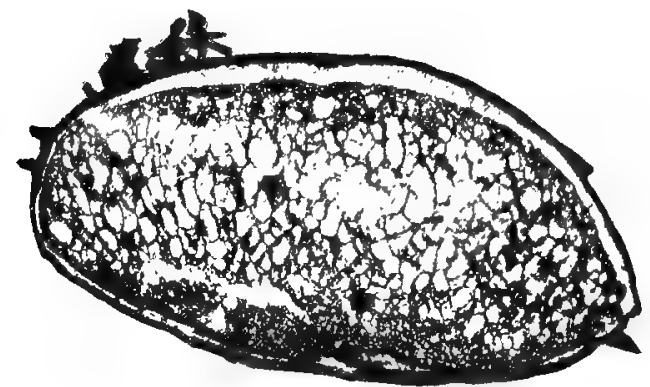

FrG. 78, - Mazocarpon, Benson in MS. Isolated megaspore filled with prothallus. $\times$ abont 35. From a photograph by Mr. W. Tams. S. Coll. 1756 .

Renault found megaspores of a Lepidostrobus in which the prothalloid tissue contains flask-shaped cavities, strongly suggestive of archegonia.

There is thus every reason to believe that the mode 
of reproduction in many of the Lepidodendreae agreed closely with that of the heterosporous Lycopods of the present time, but certain other fructifications of the same group attained, as will be explained below $(\S 4)$, a much higher organisation.

3. Spencerites. - The chief generic character of Lepidostrobus, distinguishing it from most other Lycopodiaceous strobili, is to be found in the great radial elongation of the sporangium, and its attachment by a long and narrow insertion to the upper surface of the sporophyll-pedicel throughout its length. There is another form of Lycopodiaceous cone from the Coalmeasures, which differs in this, as well as in other important points, from Lepidostrobus, and which has therefore been separated, under the name of Spencerites. ${ }^{1}$ This type will now be shortly described, and the description will be based, in the first instance, on Spencerites insignis (Will.), the smaller of the two known species.

The strobilus, which is from 8 to $10 \mathrm{~mm}$. or more in diameter, is pedunculate, the peduncle bearing scattered bracts. The sporophylls are in some cases arranged in regular alternating verticils, of about ten members each, though a spiral arrangement has also been met with. As Miss Berridge has shown, the sporophyll consists of a narrow pedicel, about 2.5 to $3 \mathrm{~mm}$. long, carrying an upturned lamina with a broad fleshy base. The lamina

1 See Scott, "On the Structure and Affinities of Fossil Plants from the Palæozoic Rocks, ii. On Spencerites," a New Genus of Lycopodiaceous Cones, Phil. Trans. Roy. Soc. vol. 189, B, 1897. The earlier papers by Williamson are there cited. See also Miss E. M. Berridge, F.L.S., "On two New Specimens of Spencerites insignis," Annals of Bot. vol. xix. I905. 
is produced into a thick dorsal lobe below, and a larger ventral lobe above (see Fig. 79). The sporangia are not elongated, but ovoid or spherical, and not in any way attached to the pedicel, but inserted, by means of

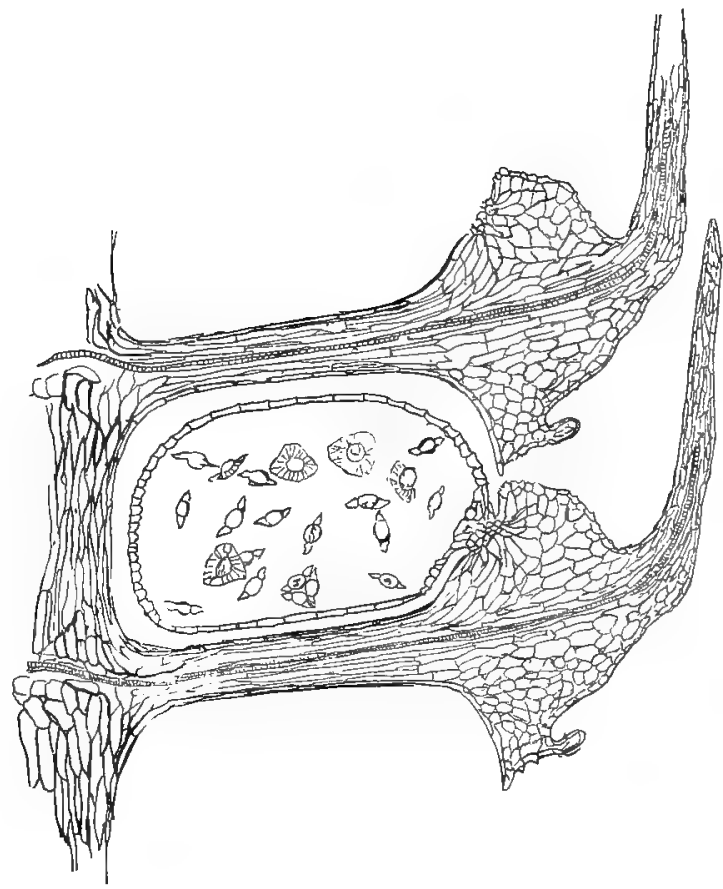

FIG. 79.-Spencerites insignis. Somewhat diagrammatic radial section showing two of the sporophylls in connection with the axis. On the lower sporophyll the sporangium is seen, attached at its distal end to the ventral outgrowth; a few of the winged spores are shown. After Miss Berridge.

a short stalk at the distal end, on the upper surface of the ventral lobe (Fig. 79). No ligule has been observed. The structure of the sporangial wall is also quite different from that of Lepidostrobus, for it consists of prosenchymatous cells, elongated in the plane of the 
wall, and not at right angles to it as in the former genus.

The winged spores are a remarkable feature of the cone (Fig. 75, A and B). They measure about . I $4 \mathrm{~mm}$. in maximum diameter (not reckoning the wing), and are thus intermediate in size between the microspores and megaspores of a Lepidostrobus. They are often found still grouped in tetrads, with a tetrahedral arrangement (Fig. 75, B). Around the equator of cach spore runs a broad, hollow, annular wing, formed by the dilation of the cuticle (Fig. 75, A and B). It is probable that this wing served the same purpose as the well-known air-sacs of the pollen-grain in Pinus and some other Coniferae, namely to facilitate dispersal by the wind. The form of the air-chamber is, however, quite different, for in Spencerites it constitutes a continuous rim all round the spore (Fig. 75, A), while in the Conifer it forms two distinct sacs, one on each side of the pollen-grain. These spores are thus quite unlike anything known in Lepidostrobus, and at once distinguish Spencerites insignis from allied fructifications.

Indications of a tissue, or of distinct cells, are frequently found in the cavities of the large spores, but there is reason to suspect that these appearances were caused by the presence of some parasitic organism. No signs of microspores have been detected, and so the homosporous or heterosporous character of the strobilus remains uncertain.

The anatomy of the axis is of a simple Lycopodiaceous type, with an axial strand of centripetally developed wood; in some specimens there is a small pith, which is quite absent in others. The leaf-trace 
bundles passed out more horizontally than in Lepidostrobus, having a somewhat arched course in approaching the pedicel. The inner cortex and, in some cases, the phloëm are preserved: the middle cortex has often disappeared, but when present sometimes shows a remarkable structure, consisting of interwoven trabecular filaments, connected with the inner and outer tissues, and with the sheaths of the outgoing vascular bundles. The outer cortex consists of fibrous sclerenchyma, either continuous or forming a network, with a more delicate tissue occupying the meshes through which the leaf-traces passed out to the sporophylls.

The other species, S. majusculus, which is larger, has relatively still shorter sporophylls; as regards the form and insertion of the sporangia, the two species of Spencerites agree, but the spores themselves are smaller in S. majusculus, and of different shape, having the form of quadrants of a sphere, with narrow wings along the angles. Vegetative stems are known, which in structure much resemble the axis of the Spencerites cones. They are of the Lepidodendroid type, and have something in common with the stems of Bothrodendron (see p. 200).

The insertion of the sporangium by its distal end on a ventral lobe of the sporophyll suggests a comparison with Sphenophyllales, but the absence of any vascular supply to this lobe in the case of Spencerites is a serious point of difference.

Lepidostrobus and Spencerites are typical Lycopodiaceous strobili, as to the affinities of which no doubt can arise. The well-marked heterospory of some species (possibly of all) shows that these fructifications had 
reached at least as high a differentiation as the most highly organised Lycopods of the present day. They differ most strikingly from recent strobiliferous forms in the mode of insertion of the sporangia, which in existing Lycopodiaceous cones are either axillary (Selaginella), or are seated on the sporophyll, close to the axis ${ }^{1}$. (Lycopodium and Phylloglossum). In Lepidostrobus, as in the recent, non-strobiliferous Isoëtes, the enormous development of the sporangia is due chiefly to radial elongation, and this brings with it a corresponding extension of the base of the sporangium, which is attached to the long pedicel of the sporophyll from end to end. The displacement of the ligule, as described above, affords a good measure of the radial extension of the whole organ. The presence in some cases of trabeculae was no doubt an adaptation to the great bulk of the sporangium.

\section{The Seed-like Lycopodiaceous Fructifications.-} We can well understand that an enormous output of spores must have been necessary in the Lepidostrobi, in so far as they were heterosporous. For fertilisation and the development of an embryo to take place, it was essential for microspores and megaspores to germinate together, and where these cones were borne on trees, and often at a great height above the ground, the chances must have been enormously against such an association. The successful accomplishment of the reproductive act could only be ensured by the production of a prodigious number of spores, and especially of microspores. It

1 Psilotum and Tmesipteris are left out of consideration, as it is quite doubtful whether the synangium of these genera is comparable to a single sporangium of the typical Lycopods. See Chapter XIV. 
is quite probable, however, that the bristles and other appendages of the megaspores may have served to

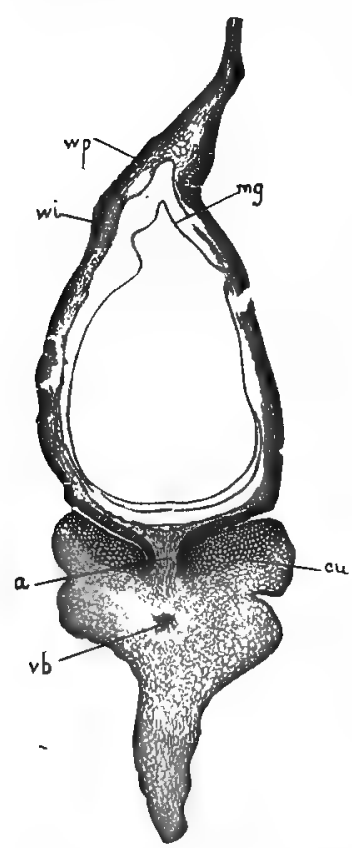

FIG. 80.-Lepidocarpon Lomaxi. Sporangium and sporophyll before integument was formed, in tangential section of cone. cu, lateral cushions of sporophyll ; $a$, base of sporangium; $v b$, vascular bundle; wp, palisade layer of sporangium; $w i$, inner layer of wall; mg, membrane of megaspore or embryo sac. This section does not pass through the abortive spores. $X$ about I2. (G. T. G.) Scott, Phil. Trans. S. Coll. 607 . the sporangium, the wall of which was identical in structure with that of a Lepidostrobus, the tissue of the bract grew up to form a regular integument, closing secure their presence when dispersal took place.

Recent discoveries have shown that the difficulty was met, in some of the Palæozoic Lycopods, in another way, namely, by the formation of a kind of ovule or seed, which may probably have been fertilised, or at least pollinated, while still on the plant. In Lepidocarpon Lomaxi, a cone so closely allied to Lepidostrobus that male specimens were formerly regarded by myself and others as a mere variety of $L$. oldhamius, each megasporangium contains a single mature megaspore or embryo-sac, filling almost the whole cavity (Fig. 8o), but accompanied by three abortive spores, so that the original number in each sporangium was no doubt four, of which one gained the upper hand over the rest. Around

catch the microspores, and thus .

.


in at the top, but leaving a narrow crevice or micropyle (Figs. 81 and 82). This opening, however, differed from the micropyle of ordinary seeds in not being tubular, but forming a long narrow slit, extending in the radial direction almost the whole length of the sporangium,

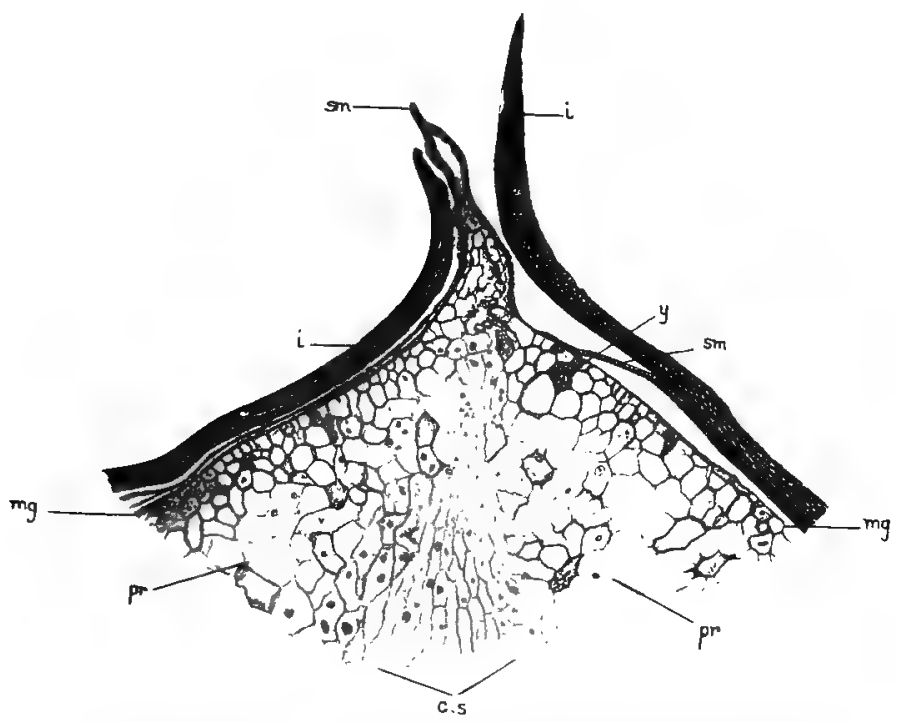

FIG. 81.-Lepidocarpon Lomaxi. Upper part of integumented "seed," containing prothallus, $i$, integument; sm, wall of sporangium; $m g$, membrane of megaspore ; $p r$, tissue of prothallus; $y$, possible central cell of an archegonium; c.s, central strand of prothallus. $\times$ zo. (G. T. G.) Scott, Phil. Trans. S. Coll. Io73.

which was radially elongated, as in an ordinary Lepidostrobus. A ligule was present, at the distal end, just as in that genus.

When cut at right angles to this slit-like micropyle, the appearance of the sporangium with its integument is altogether that of a seed (see Fig. 82), and detached specimens were long known to science under the 
name Cardiocarpon anomalum of Williamson ${ }^{1}$ (not of Carruthers). The seeds, which attained a great size, became detached, together with the remains of the sporophyll, and in this condition were never suspected of belonging to a Lycopod until their origin had been traced. The prothallus within the megaspore is not un-

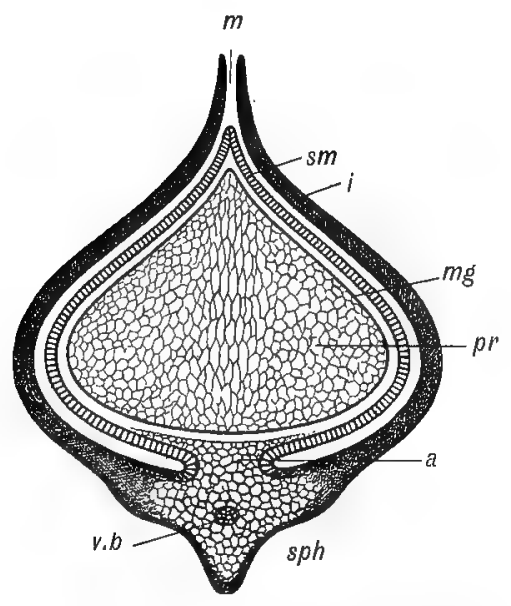

FIG. 82.-Lepilocarpon Lomaxi. Diagrammatic section of "seed," tangential to cone. sph, sporophyll ; $\imath^{\prime} . b$. , vascular bundle; $i$, integument; $m$, micropyle; $s m$, wall of sporangium; $u$, base of sporangium ; $m g$, membrane of megaspore; $p r$, prothallus, (G. T. G.) commonly preserved (see Figs. 8I, 82), and is found in the younger stage, before the integument has grown up, as well as in the mature "seeds." The tissue of the prothallus may show a considerable amount of differentiation (see Fig. 8I); only doubtful traces of archegonia have so far been observed.

In a microsporebearing strobilus, probably belonging to Lepidocarpon Lomaxi, the microsporangia were also provided with integuments, less developed than those of the megasporangiate cone.

Lepidocarpon Lomaxi, and other undescribed species, belong to the Lower Coal-measures; the closely similar

i "Organisation, etc." part viii., Phil. Trans. 1877, p. 254, Figs. II7-II9; part x. 1880, p. 518, Fig. 64. The identification of these "seeds" with the Cardiocarpus of Brongniart is certainly incorrect. 
L. Wildianum is frequent in the more ancient Burntisland deposits of Lower Carboniferous age.

The cone of $L$. Lomaxi was first discovered by the late Mr. G. Wild and Mr. J. Lomax, working independently. ${ }^{1}$

Lepidocarpon no longer stands alone among Palæozoic Lycopods in possessing organs analogous with true seeds. Another instance is afforded by Miadesmia membranacea, the vegetative organs of which were discovered by Bertrand in 1894 in the calcareous nodules of the English Lower Coal-measures. The stem is very slender, and the plant appears to have been of herbaceous habit. The stele is of simple structure, with centripetal wood and no pith; the cortex contains trabeculae comparable to those of Selaginella. The leaves appear to have been borne in four rows; the ligule is remarkably well developed, and the lamina is fringed by a membrane one cell thick, breaking up into uniseriate hairs at the margin. Within the last few years a megasporangiate fructification has been discovered, which is shown, by the structure of the ligule, the fringed margin of the sporophyll, and other characters, to have belonged to Miadesmia. ${ }^{2}$ The fructifications are borne in a rather lax strobilus. Each sporophyll bears a megasporangium, attached to its upper surface at the proximal end, containing a single megaspore, filling its cavity (Fig. 84). As in Lepidocarpon,

1 See their note "On a New Cardiocarpon-bearing Strobilus," in the Annals of Botany for March 1900 ; for the full description see Scott, "On the Seed-like Fructification of Lepidocarpon," Phil. Trans. Roy. Soc. vol. I94, B, I90I.

${ }^{2}$ Miss M. Benson, "On a New Seed-like Lycopodiaceous Fructification," Neze Phytologist, vol. i. I902. For the full paper see Phil. Trans. Roy. Sac. B, 1908. 
the megasporangium is enclosed in an integument, which in Miadesmia, however, completely roofs in the sporangium above, leaving only a narrow opening or micropyle at the distal end (Figs. 83 and 84 ). The integument is provided with long tentacles, which, as they project beyond the micropyle, may probably have assisted pollination. The sporangial wall is less developed than in Lepidocarpon, the integument having, as it appears,

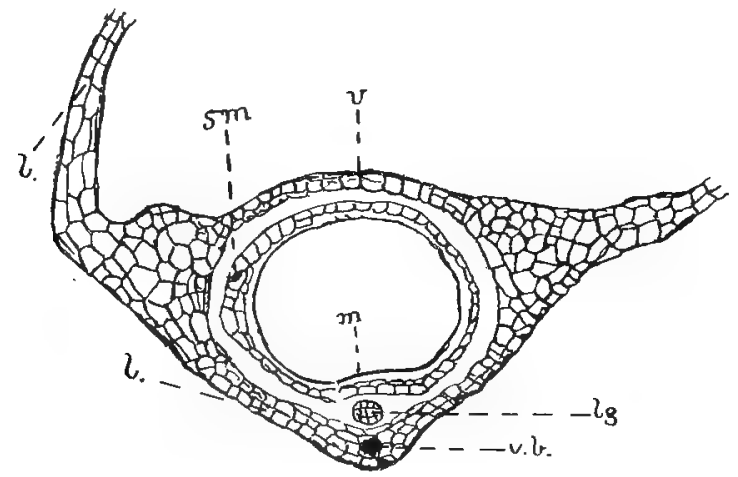

FIG. 83.-Miadesmic membranacca. Approximately transverse section of seed-like organ. $l, l$, lamina of sporophyll; $v . b$., vascular bundle; $v$, velum or integument; $\mathrm{g}$, ligule; $s m$, sporangium-wall; $m$, membrane of megaspore. $\times$ about $z^{\circ} . \mathrm{R} . \mathrm{S}$. S. Coll. 2237.

more completely taken over the function of a protective organ, and no abortive sister-cells of the single megaspore (in which the prothallus is sometimes present) have been observed. Thus the seed-like character is even more striking in Miadesmia than in Lepidocarpon. There seems to be no near affinity between the two genera, which differ widely, especially in the insertion of the sporangium and the position of the micropyle, and in each of which, presumably, the seed-habit was independently evolved. 
In both genera the most important difference from true seeds, such as those of the Pteridosperms, consists in the fact that the sporophyll as a whole formed part of the seed-like organ, and was shed together with it. In other respects-the single megaspore, the integument, and the indehiscent character-the analogies with seeds are complete. In the case of Miadesmia the wide lamina of the sporophyll gave the organ the character of a winged seed.

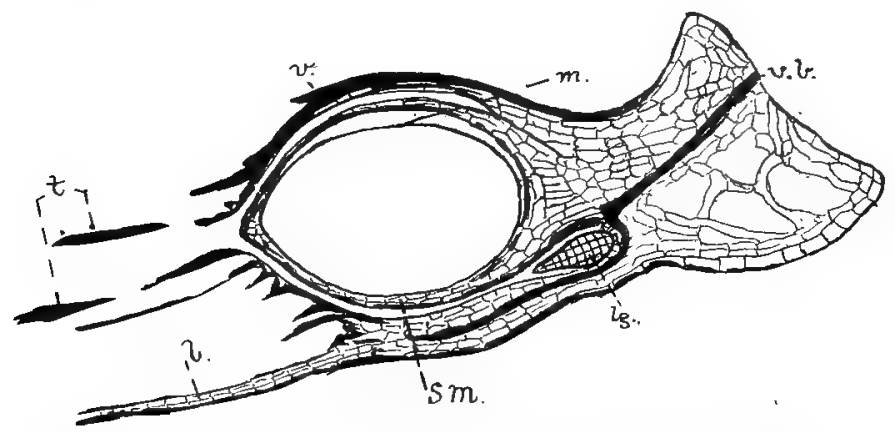

FIG. 84.-Miadesmia membranacca. Radial section of seed-like organ. $t$, tentacles; other lettering as in Fig. 83. $\times$ about 3o, R. S. S. Coll. 2240.

5. Bothrodendron. - The genus Bothrodendron, of Lindley and Hutton, represents another group of Palæozoic Lycopods, very near Lepidodendron, though differing from it in the surface-characters of the stem. The genus is now well known, and presents several points of interest. On the larger stems, the surface of the cortex is smooth, the leaf-scars are very small, and flush with the surface, for leaf-cushions were not developed. This causes a striking difference in appearance from Lepidodendron, though the leaf-scars are in themselves quite similar to those of that genus, showing 
the usual three prints on the actual scar, with the ligular pit above. On the younger twigs the foliage is sometimes preserved; the leaves are small, and resemble those of a recent Lycopodium. 'The smooth character of the stem-surface has suggested a comparison with a group of the Sigillariae, which we shall consider in the next chapter; some authors have even united these two genera.

The stem of Bothrodendron punctatum is commonly found in the Ulodendroid condition, bearing the large, cup-shaped scars described in the last chapter. It has, therefore, been inferred that its cones were in these cases borne on the old wood, but in other species they have been found in connection with small twigs, and it has become very doubtful whether the large Ulodendron scars really had any relation to the cones. The strobili borne on the slender branches in $B$. minutifolium are identified by $\mathrm{Mr}$. Kidston with a Lepidostrobus described by M. Zeiller under the name of L. Olryi, a small cylindrical cone with verticillate sporophylls. On the whole, there is no reason, to doubt the very close affinity of Bothrodendron with Lepidodendron.

The group is of great antiquity, chiefly occurring in the lower beds of the Carboniferous formation, while one species has been described from the Upper Devonian of Ireland.

Bothrodendron is thus among the oldest known genera of Lycopods, and it is therefore of much importance that its internal structure should be recognised. This has recently been discovered by Mr. J. Lomax, who finds that a stem showing the characteristic 
external "features of a Bothrodendron has the anatomical structure of the Lepidodendron mundum of Williamson. ${ }^{1}$ The structure of Bothrodendron mundum, as the species may now be provisionally named, is of a simple Lepidodendroid type. In the largeir stems there'is a massive pith, surrounded by a comparatively thin zone of centripetal wood with well-marked protoxylem groups; in the more minute twigs, however, the xylem is solid. A characteristic feature is the radial arrangement of the primary tissue of the outer cortex, quite apart from the subsequent formation of periderm. No secondary wood has been observed in the stem, but in a Stigmaria described by Professor Weiss, probably belonging to the same plant, extensive secondary growth took place (see p. 257).

Still more recently Mr. D. M. S. Watson ${ }^{2}$ has identified the cone of Bothrodendron mundum in structural material. The cone is a small one, less than a centimetre in diameter, and is hermaphrodite, with the microsporangia above and the megasporangia below. The sporophylls are short in the radial direction, and the sporangium is attached by a narrow neck of tissue to the middle of the horizontal portion; there is a large ligule in the usual position. Each megasporangium was found to contain only four megaspores, which are characterised by their long branched spines. The cone is evidently quite distinct from a Lepidostrobus, though apparently nearer to that genus than to Spencerites.

Bothrodendron is further of interest from the extra-

1 "Organisation of Fossil Plants of Coal-measures," Part xvi., Phil. Trans. Roy. Soc. B, I889.

2 "The Cone of Bothrodendron mundum," Men. and Proc. Manchester Lit. and Phil. Soc. vol. lii. Part i. 1908. 
ordinary mode of preservation in which one of the species, B. punctatum, occurs. At Tovarkovo, in the province of Toula, in Central Russia, beds of a peculiar kind of coal, called leaf-coal or paper-coal, have long been known. The seams are about 8 inches thick, and lie near the surface of the ground, only covered by sand. The so-called coal has all the appearance of a bed of excessively thin dead leaves, intermixed only with structureless organic matter of the nature of humic acid. The leafy films, on investigation, have proved to consist entirely of layers of cuticle, belonging to the stems of ancient plants, from which all other tissues had rotted away, ages before. The cuticles are perfectly fresh and pliable, and not in any way fossilised, although geologists are agreed that the bed (which covers an area of many square miles) belongs to the Carboniferous Limestone horizon, in the lower part of the Carboniferous formation. The cuticle is in some cases complete, corresponding to the whole circumference of the stem which it once enclosed; it is perforated by numerous small round holes, regularly disposed, and corresponding in arrangement with the leaf-traces of a Bothrodendron. The cuticularisation had evidently extended to a portion of the vertical cell-walls abutting on the outer skin, for the network of cells is marked out with perfect clearness on the inner surface of the cuticle. Irregular borings, which occur here and there in the membrane, were attributed by M. Renault to the activity of Palæozoic Bacteria.

The cuticles, when freed from the formless organic matter adhering to them, are of a light brown colour; 
they swell up in water, can be stained with aniline dyes, and on chemical analysis prove to have much the same composition as the cuticle of recent plants. That a vegetable tissue should thus have come down to us, fresh and unaltered, from a period more ancient than that of the Coal-measures, is certainly one of the most remarkable among the curiosities of palæontology. ${ }^{1}$

I See Renault, Les cuticules de Tovarkovo, Autun, 1895. 


\section{CHAPTER VII}

\section{LYCOPODIALES—continued}

\section{Sigillaria and Stigmaria; Lycopoditeae}

\section{Sigillaria}

WE now come to the great genus Sigillaria, one of the most extensive and important groups of Palæzoic plants, and one of those of which the affinities have been most keenly discussed. In geological range the Sigillariae are somewhat more restricted than the Lepidodendra; they have not been detected with certainty below the rocks at the base of the Carboniferous formation, and scarcely extend above the Permian; they attain their maximum in the Middle and Upper Coal-measures.

I. Habit and External Characters.-The Sigillariae must have been among the largest trees of the Palæozoic forests. A trunk of Sigillaria reniformis, found near Saarbrücken, in Germany, in situ, was 6 feet in diameter at the base, where its roots were attached. This trunk was only I 8 feet high, diminishing towards the top to a diameter of about a foot. Other gigantic specimens have a very different form. M. Zeiller ${ }^{1}$ describes a

1 Bassin honiller de Valenciennes, flore fossile, p. 512. 
trunk found at L'Escarpelle, near Valenciennes, in France, which was traced for a distance of 22 metres (over 70 feet). At the lower end it had a diameter of $60 \mathrm{~cm}$. (about 2 feet), which at the upper extremity had only diminished to $50 \mathrm{~cm}$. (I foot 8 inches). The stem was thus a slender, nearly cylindrical shaft. Both this and other, even longer, trunks, reaching a length of 30 metres (nearly i oo feet) were unbranched. In some cases the large stems are found still clothed with leaves in their upper part. Thus M. Grand'Eury ${ }^{1}$ describes a stem of Sigillaria lepidodendrifolia, which, for a distance of 3 metres (nearly Io feet) from the top downwards, was covered by rigid and erect linear leaves, more than a metre in length. The foliage of Sigillaria is in some cases scarcely to be distinguished from that of Lepidodendron, and as we shall see below, the agreement extends to histological structure. The stems of Sigillaria are often found connected at the base with their subterranean organs, which we will provisionally call roots, though their morphological nature is doubtful, and will have to be discussed later on. These roots (known under the name of Stigmaria) are extremely common in the "underclay" of the Coal-measures, immediately below the seams of coal, and no doubt belong to the same plants, the stem and leaves of which have contributed to form the coal itself, the underclay representing the soil in which the trees grew. It is usually, however, impossible to say whether the root-like organs belonged to a Sigillaria or a Lepidodendron. Fig. 85 shows an enormous specimen of the stumps and roots of one of

1 Flore carbonifere du Departenent de la Loire, P. 156. 
these trees found in a sandstone quarry, of Coal-measure age, at Clayton, near Bradford, in Yorkshire. The actual stump of the tree is here 4 feet 4 inches in diameter, while the whole specimen, including the forked roots, is almost thirty feet across. This gigantic fossil is now set up in the Museum of the Owens College at Manchester, and affords a striking example of the scale of Palæozoic vegetation. Fragments of other

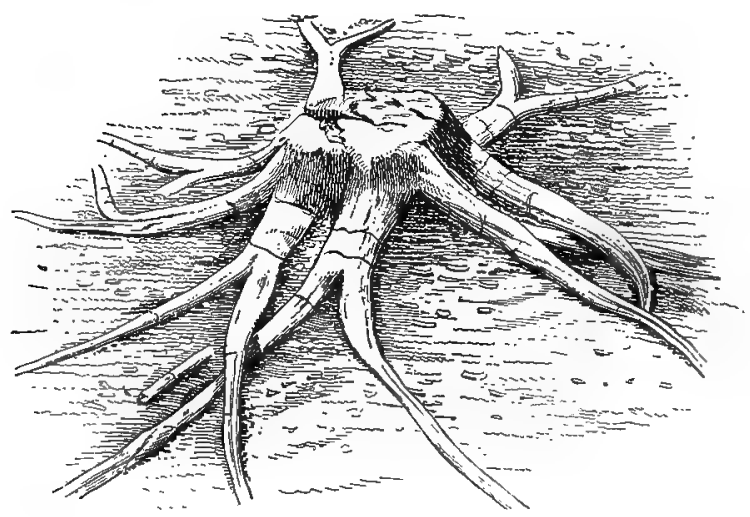

FIG. 85,-Stump and roots (=Stigmaria ficoides) of a Lycopodiaceous tree from the Coal-measures. For description, see text. After Williamson.

specimens, which must have been about twice the size of this one, were found at the same time.

Before going further into the question of the habit of the Sigillarian trees, it will be necessary to give some account of the characteristic superficial markings, by which the genus is commonly recognised, and according to the variations in which, the so-called "species" are distinguished.

Sigillaria, like Lepidodendron, is characterised by the form and arrangement of the leaf-scars, left on the 
surface of the stem after the leaves themselves had fallen. The wonderful perfection with which these markings are often preserved, even on large trunks, is certainly a surprising fact, and seems to show, either

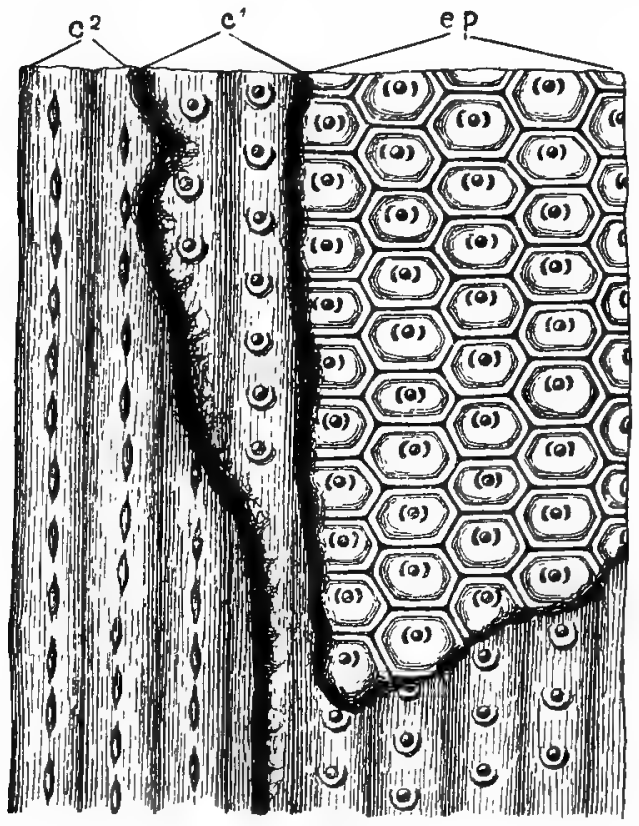

FIG. 86. -Sigillaria tessellata, Surface ofistem. ep, external surface, showing leaf. scars, with the prints of the vascular bundle and parichnos; $c^{1}$, sub-epidermal surface ; $c^{2}$, deeper cortical surface, showing "Syringodendron" characters. Nat. size. After Schimper.

that the growth of the trees was extremely rapid, or that the Carboniferous forests were singularly free from epiphytic or parasitic vegetation.

The leaf-scars of Sigillaria are, as a rule, arranged in conspicuous vertical series, the scars of adjacent series alternating with one another (see Figs. 86-89). The 
marked longitudinal seriation of the soars affords, in typical cases, the most obvious distinction from the sculpturing of Lepidodendron. The scars are not always seated on distinct leaf-cushions, or if such cushions are present, they are not much larger than the scars themselves (Fig. 86). The individual leaf-scar has, as a rule, an approximately hexagonal outline, with the angles more or less rounded (see Figs. 86-89). The form

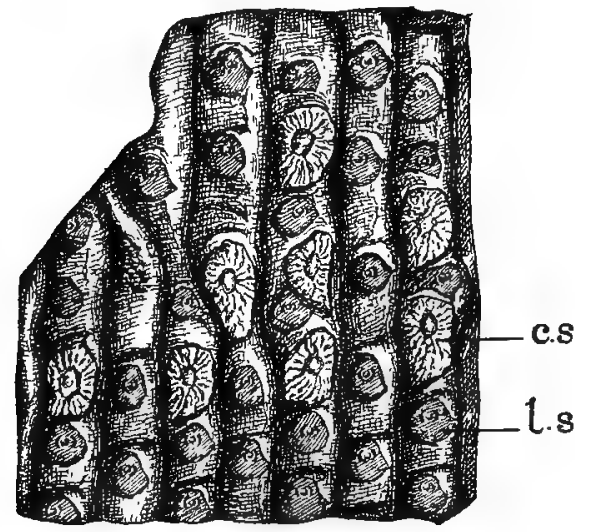

FIG. 87.-Sigillaria mamillaris (Rhytidolepis type). Surface of stem, showing vertical ribs with leaf-scars"( l.s. $\left._{\text {. }}\right)$ and scars of the cones $($ c.s. $)$. Nat. size. After Zeiller.

of the scar varies much, not only in different species, but on different parts of the same stem; as the stem increased in diameter with age, the scars not only became more widely separated, but were also themselves stretched out in the horizontal direction.

The prints on the scar are essentially similar to those of Lepidodendron, and are here also three in number, forming a transverse row, usually a little above the centre of the scar (see Fig. 88). The middle print, 
which is dot-like, or transversely elongated, is the smallest, but the most important, for anatomical investigation has shown that this alone represents the vascular bundle of the leaf. The two lateral prints are vertically elongated, and are either straight or crescentshaped, with the concavity directed inwards. These lateral marks are of the same nature as the parichnos of Lepidodendron. Immediately above the scar, and sometimes seated in a depression of its upper edge, is another print, which evidently represents the ligular pit (Fig. $88,(g)$. We thus see that, except for trifling details, there is no difference in morpho$\operatorname{logy}$ between the leafscars of Sigillaria and those of Lepidodendron.

When we come to

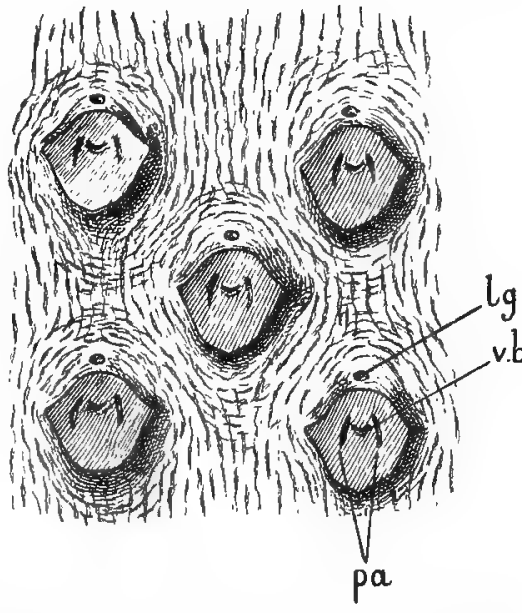

Frc. 88.-Sigillaria Brardi (Leiodermaria type). Part of surface of stem, showing five leaf-scars. $l g$, ligule; $v . b .$, print of vascular bundle; $p a$, paricbnos. $X$ It

the arrangement of the scars, we meet with considerable variations within the genus; these variations have been used for the distinction of subgenera, which some authors have even erected into distinct genera. We shall see, however, that in the light of our present knowledge very little, if any, taxonomic value can be attached to these differences, though they are worth noting for descriptive purposes. 
In the first instance, the genus Sigillaria has been divided into two main series, those with ribbed stemsthe Eu-Sigillariae, and those without ribs-the SubSigillariae. The ribs, characterising the former series, are broad longitudinal ridges, each of which bears a single vertical series of leaf-scars. The ridges are separated by comparatively narrow furrows (Figs. 86 and 87 ).

The Eu-Sigillariae were formerly divided into two subgenera, Rhytidolepis and Favularia-names which, though no longer of taxonomic significance, may be retained to designate types of surface. In Rhytidolepis the ribs, which are often much broader than the leaf-scars borne upon them, are separated by straight vertical furrows. The scars of the same vertical series are in some cases almost contiguous; more often they are separated by considerable spaces (see Fig. 87). The ribs have been looked upon as representing series of fused leaf-bases, a view, however, which is negatived by the observations of Arber and Thomas, who find that the true leaf-bases form bracket-like projections from the ribs, the latter being really part of the cortex. Rhytidolepis is the most characteristic form of Sigillaria, and the most remote in outward appearance from Lepidodendron. The great ribbed stems of this type are a striking and familiar feature of the Coal-flora, and are among the best-known fossil remains.

The other ribbed type of surface--termed Favularia by Sternberg - has the ridges separated by zigzag furrows, while a marked transverse furrow intervenes between the adjacent leaf-scars of the same series (see Fig. 86). Here, in fact, each scar is seated on a well- 
marked hexagonal leaf-cushion, though the arrangement in vertical series is still manifest. The extreme forms of Rhytidolepis and Favularia are distinct enough, but both may occur on different parts of one and the same stem, connected by intermediate forms, so no systematic value can be attached to the distinction. Generally speaking, the Eu-Sigillariae are geologically more ancient than the Sub-Sigillariae, and some of the oldest stems known show the Favularia type of surface.

The Sub-Sigillariae, which are characteristic of the Upper Coal-measures and Permian, agree in the absence of distinct ribs, and have likewise been grouped under two subgenera, to which the same remarks apply as in the case of the previous group. In the Clathraria of Brongniart, the surface of the stem is formed by somewhat prominent, contiguous leaf-cushions, separated by oblique furrows, each cushion bearing the scar of a leaf (see Fig. 89, which, however, is too much like a Favularia). Here the oblique parastichies stand out more conspicuously than the vertical orthostichies, and there is a certain approach to the Lepidophloios form of surface, from which, however, the typical Clathraria differs in the greater size of the scar relative to the cushion, and in the form of both.

In the other division of Sub-Sigillariae, the Leiodermaria of Goldenberg, there are no prominent leafcushions; the scars are remote from each other, and separated by a smooth cortical surface (sce Fig. 88). This form shows some approximation to Bothrodendron, which has even been united with this group of Sigillariae by some recent authors. The Clathrarian and Leiodermarian sculpturings may both occur on the 
same stem-in fact, the characteristic markings of the type-species of Clathraria and Leiodermaria respectively, S. Brardi and S. spinulosa, have repeatedly been found associated in this way. The two forms of surface frequently occur in alternating zones on the stem, and the same is the case with the Rhytidolepis and Favularia markings among the Eu-Sigillariae. It has been suggested that the crowded leaf-scars characteristic of Favularia and Clathraria may have coincided with periods of slow growth, while the more scattered arrangement in the Rhytidolepis and Leiodermaria forms may have been due to seasons of rapid elongation. All these four types, however, have been regarded, even by some modern authors, as distinct genera. As a matter of fact, only the division between Eu-Sigillaria and SubSigillaria holds good taxonomically, and even here the distinction is not always a sharp one, for some forms of Favularian and Clathrarian ${ }^{1}$ surface approach each other very nearly, ${ }^{2}$ and may even occur on the same stem.

A hundred or more so-called species of Sigillaria have been described, according to the superficial markings, but they are admittedly of doubtful value at the best. The genus, however, was evidently a rich and varied one, though the characters available are altogether insufficient for the clear limitation of the different forms.

Just as in Lepidodendron, so also in Sigillaria, the appearance of the stem was often much changed by the partial destruction of the external tissues, and the various

I Clathrarian Sigillariae are also spoken of as Cancellatae.

2 On the subject of the surface-characters of Sigillariae, see Zeiller, "Revue des travaux de Paléontologie," Rev. genz. de botanique, 1897, p. 404; Elements de Palébotanique, Paris, I900, p. I90. 
types of more or less decorticated surface noticed under Lepidodendron recur here. One very characteristic form may be noticed, to which the name Syringodendron has been given. In this, the epidermis and the leaf-scars have perished; the ribs-if the specimen belonged to the Eu-Sigillariae-remain, and are marked by the same prints which occur in the typical leaf-scars. In these cases, the middle print-that marking the leaf-trace bundle-is usually inconspicuous, while the two lateral lines of the parichnos are extremely marked. Corresponding forms of preservation, without the ribbing, occur in the Sub-Sigillariae. The Syringodendron character may also be found, even on the epidermal surface, at the base of the old stems, where excessive growth in thickness has obliterated the leaf-scars. Fig. 86, from Sigillaria tessellata, one of the Favularian forms, shows the surface exposed at three different levels. At $e p$ the natural epidermal surface is shown, with the characteristic hexagonal leaf-scars, each of which shows the three prints (representing the vascular bundle and the double parichnos) as described above. On the part marked $c^{\mathrm{l}}$, the superficial layers, with the leaf-scars, have peeled off, exposing the outer cortex, on which the longitudinal ribs come out more clearly than before. The leaf-trace bundles are still evident; the two parichnosscars have united below each vascular bundle, forming a crescent. At $c^{2}$ the process of destruction has gone deeper; a considerable thickness of cortex has broken away, and a deeper layer is laid bare. The ribs are still evident; the fused parichnos-scars show conspicuously as lenticular outlines, but the vascular bundle within each loop is not visible. This lowest level may 
be taken as representing the Syringodendron surface, though on a small scale. In typical Syringodendron the parichnos-prints may be enormously enlarged, reaching a length of more than a centimetre.

In some cases the leaf-scars on the Sigillarian surface are accompaned by other scars, usually regarded as marking the insertion of the fructifications (see Fig. 87, c.s.). We will, however, postpone the consideration of these, until we come to deal with the cones themselves.

As regards the habit of the Sigillariae, our knowledge is still very imperfect. In some of the forms, forking branches have been observed, though they are not as a rule common; in stems with the Rhytidolepis type of sculpturing no branching has yet been observed. In the unbranched forms the habit appears to have been something like that of the Australian Grass-tree, Xanthorrhoea, the tall, upright shaft terminating in a sheaf of long, grass-like leaves. In other cases, as in the Favularian species S. elegans, and in S. Brardi, of the Clathraria group, the stem divided, by successive dichotomy, into a few large branches.

2. Anatomical Structure-Recognisable specimens of Sigillaria with structure preserved are comparatively rare; of late years, however, several new examples have come to light. It is possible that the rarity of specimens with structure, while the structureless casts are so common, may be in part due to the smaller branches not having always been recognised as belonging to Sigillaria. The fact, however, would also find an explanation, if branching occurred very sparingly, for, 
of course, the small branches, rather than the great trunks, are likely, as a rule, to have been preserved in the petrified condition.

The first specimen of a Sigillaria showing anatomical structure was described by Brongniart, ${ }^{1}$ as long ago as the year 1839, and has played a most important part in the history of fossil botany. The fragment was about $4 \mathrm{~cm}$. in diameter, and about $2 \mathrm{~cm}$. long, and showed a portion of the external surface with its leafscars, as well as the internal anatomy (see Fig. 89). The superficial characters have rendered it possible to identify the specimen as belonging to the form Sigillaria Menardi, one of the Clathraria group. ${ }^{2}$ The parts in which the structure is preserved consist essentially of the wood and a portion of the outer cortex; the pith and the inner region of the cortex have perished (see Fig. 89). Fortunately, however, the parts which remain are the most important, as Brongniart pointed out. His whole description, though nearly seventy years old, might still serve as a model for such investigations. The ring of wood is complete, and has a diameter of about $16 \mathrm{~mm}$. The pith was of large size; for the woody zone is only about a millimetre in thickness. It consists of a large number (between forty and fifty) of vascular bundles, each of which is made up of an inner or primary and an outer or secondary portion. The primary strands are distinct from each other, though close together, and are crescent-shaped, as seen in transverse section, with

1 "Observations sur la structure intérieure du Sigillaria elegans," Archives du musézum d’hist. nat. vol. i. 1839 .

${ }^{2}$ Brongniart himself referred the specimen to the Favularian species, $S$. elegans, but this determination was subsequently corrected by Zeiller and Renault. 
the convex side towards the pith. The small, spiral tracheides are placed on the outer, slightly concave, side of each bundle. The rest of the primary xylemelements, which are irregularly arranged, and increase

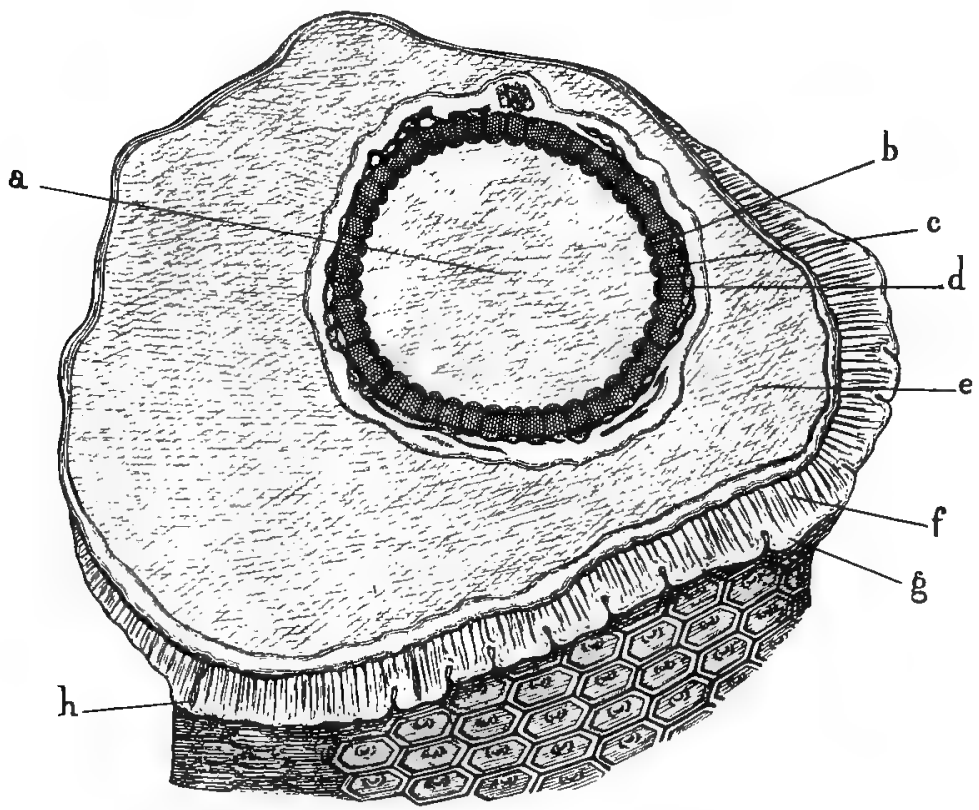

FIG. 89.-Sigillaria Menardi(Clathraria type). Brongniart's original specimen, show. ing transverse section and part of surface with leaf-scars. $a$, pith (perished); $b$, primary wood, forming many distinct bundles; $c$, secondary wood; $d$, phloëm-zone ; $e$, middle cortex (perished) $f$, periderm; $g$, leaf-base; $h$, foliar bundle. $\times$ about 2. After Brongniart.

in size towards the interior, are reticulated or finely scalariform tracheides.

The secondary zone, which is almost continuous, though showing some signs of division into distinct bundles corresponding to the primary strands, consists of radially arranged scalariform tracheides, and narrow 
medullary rays of very variable height. The interfascicular rays seem to have been only slightly broader than those opposite the primary bundles. The secondary tracheides, as in the Lepidodendreae, are pitted on their tangential as well as on their radial surfaces; the smallest elements lie towards the interior, adjacent to the protoxylem of the primary strands.

The leaf-trace bundles, so far as their xylem is concerned, were given off from the outer, concave part of the primary strands, and passed obliquely through the secondary wood; the preservation only allows of their being traced for a short distance beyond the woody zone. M. Renault finds that these leaf-trace bundles are "diploxylic," each consisting of an inner centripetal primary strand, and an outer centrifugal secondary portion continuous with the secondary wood of the stele. This character was long regarded as peculiar to Sigillaria, as distinguished from Lepidodendron, but the distinction no longer holds good, for it is not constant in Sigillaria, while, as already mentioned in Chapter V., Prof. Seward and Mr. Hill found typical "diploxylic" leaf-traces in a fine specimen of Lepidodendron Wunschianum, a plant which may belong more properly to Lepidophloios, but is, at any rate, not a Sigillaria. This structure is shown in Fig. 57, p.

\section{42.}

The outer cortex, which is alone preserved, consists of two zones; the more internal is composed of uniform, radially arranged tissue, and no doubt represents a secondary formation, of the nature of periderm, such as we so constantly find in Lepidodendron. The outer zone, bearing the leaf-cushions, is simply the primary 
external cortex, within which the periderm had formed (Fig. $89, f$ and $g$ ).

If we compare the structure of Sigillaria Menardi with that of the Lepidodendreae with secondary thickening, such as L. Wunschianum or L. brevifolium, we find one difference of importance. The primary wood in the Lepidodendreae forms a continuous zone, usually of considerable thickness, while that of Sigillaria Menardi is less in amount, and is broken up into a ring of distinct and definite bundles. The latter difference is striking enough, but, as we shall see, it does not serve to distinguish Sigillaria generically.

The inference which Brongniart himself drew from the study of the structure of his Sigillaria was this: "The arrangement of the woody tissue in bundles composed of radial serics is a character foreign to all the Cryptogams; it is, on the contrary, characteristic of the Dicotyledons"; ${ }^{1}$ and hence he was led to conclude, "that the Sigillariae and Stigmariae constituted a special family, entirely extinct, probably belonging to the great division of Gymnospermous Dicotyledons." ${ }^{2}$ This conclusion, which was natural enough at that time (I839), still has an historical interest, owing to the dominant influence which the views of this great investigator long exercised, especially in his own country. The force of Brongniart's argument is now, of course, entirely invalidated by the discovery of a great number of Cryptogams with secondary growth, and by our knowledge of the Cryptogamic fructification of Sigillaria itself.

In I 875 MM. Renault and Grand'Eury described 1 "Sigillaria elegans," p. $440 . \quad 2$ l.c. p. 447. 
some specimens of another Sigillaria showing internal structure ${ }^{1}$ the superficial characters of the stem enabled them to identify it as belonging to the Leiodermarian form S. spinulosa; the latter, however, as mentioned above, is now known to have been identical with the Clathrarian S. Brardi, so there is no important distinction, so far as external characters are concerned, between Renault's and Brongniart's species. Some authors, indeed, have even united S. Menardi with $S$. Brardi, in which case the two French observers would have been dealing merely with varieties of the same species. The anatomy, however, appears to negative this view; the two species are probably distinct, though nearly allied.

In the case of $S$. spinulosa several specimens were available for investigation, from branches of various sizes. The primary wood is of about the same thickness as in the former species, but shows curious variations in its arrangement. At some points it is broken up into distinct bundles, quite similar to those of S. Menardi (see Fig. 9I), but elsewhere, even in the same transverse section, it forms a continuous band for a considerable distance (see Fig. 90). ${ }^{2}$ We thus see that the separation of the primary xylem-zone into definite strands is not necessarily a character of any taxonomic importance. The primary wood was centripetal, and agrees in minute structure with that of S. Menardi. The secondary zone (which in some of

1 "Étude du Sigillaria spinulosa," Mim. prés. par divers sazants à IAcadémie des Sciences, tome xxii. 1875.

${ }^{2}$ For the photographs reproduced in these two figures I have to thank my friend Mr. Kidston, who took them from sections of one of the original specimens. 
the specimens attains a thickness of about $2 \mathrm{~cm}$.) is here perfectly continuous, but otherwise agrees closely

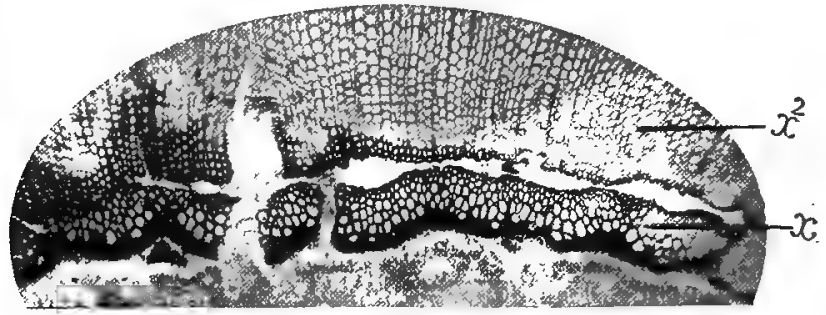

FiG. ga.-Sigillaria spinulosa. Part of transverse section of stem, showing primary $(x)$ and secondary $\left(x^{2}\right)$ wood. The former consists partly of separate and partly of confluent bundles. $x$ about 9 .

with that of the former species. The leaf-traces arose, in this case also, at the outside of the primary wood,

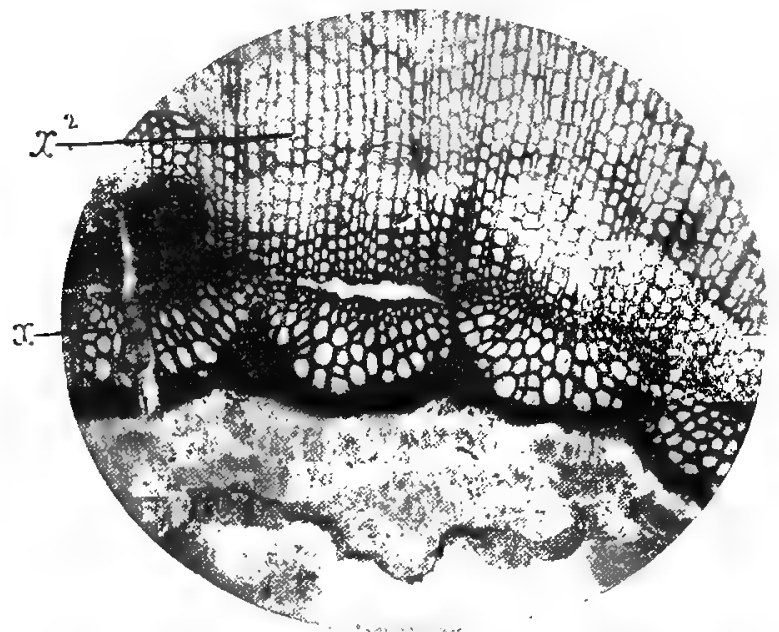

FIG. 9r.-Sigillaria spinulosa. Part of wood, more highly magnified, showing separate primary strands $(x)$ and secondary wood $\left(x^{2}\right) . \quad \times$ about $18 . \quad$ Figs. 90 and $9 x$ from photographs by Mr. R. Kidston, F.R.S.

passed through the secondary zone, and then took a nearly vertical course through the inner cortex, which 
is partially preserved in these specimens. In the outer cortex the bundles assumed a more horizontal direction. In some of the sections they show a diploxylic structure. In this species M. Renault first made the interesting observation that two large lacunae accompanied the bundle on its outward course, one on each side, forming, at the point where they entered the leaf, the two lateral prints on the foliar scar, which are now termed the parichnos. In this and in other species of Sigillaria M. Renault subsequently showed that the lacunae, which are surrounded by a definite sheath of radially elongated cells, were filled by a delicate cellular tissue traversed by secretory canals (see Fig. 92, A). The same observer also proved, by anatomical investigation, that the well-known prints on the partially decorticated Syringodendron stems are of the same nature, though here much enlarged. The identity of Syringodendron with Sigillaria thus received fresh demonstration. ${ }^{\text {I }}$

In Sigillaria, as in Lepidodendron, the parichnosstrands start from the inner cortical zone. That their function was in part secretory is highly probable, but the persistence and enlargement of the parichnos on the surface of old stems suggests a respiratory function, like that of lenticels.

The outer cortical layers of $S$. spinulosa have a peculiar structure. There is a broad zone of secondary periderm, but its tissue is not uniform; it is made up of radial anastomosing bands of narrow elongated cells, while the meshes between these bands are occupied by

1 See also K. H. Coward, "On the Structure of Syringodendron, the Bark of Sigillaria," Mem. and Proc. Manchester Lit. and Phil. Soc. vol. li. Part ii. I907. 
short thin-walled cells of greater diameter. As the fibrous bands, which no doubt had a mechanical
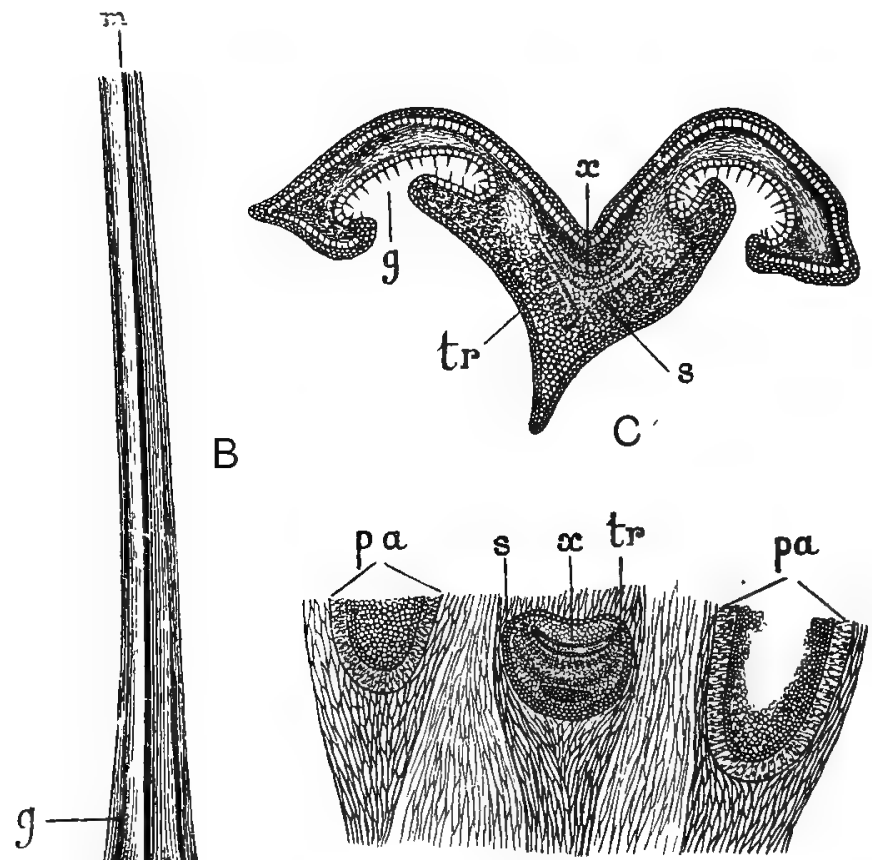

A

FIG. 92,-A and B, Sigillaria spinulosa. A. Tangential section of outer cortex, showing leaf-trace, with the parichnos $(p a)$ on either side. In the leaf-trace; $x$, primary xylem; below this the secondary xylem $(t r)$ and phloëm, then a sclerenchymatous strand; $s$, sheath of bundle. Magnified. B. Leaf, showing the lower surface, and the scar (sc) at base; on the scar the prints of the bundle and parichnos are seen. $m$, midrib of leaf; $g$, one of the stomatiferous furrows. Nat. size. C. S. latifolin. Transverse section of leaf. $x$, xylem; $s$, sclerenchyma; $e$, transfusion-tissue; $g$, stomatiferous furrows, lined with hairs. Magnified. All after Renault.

function, fuse with each other in every direction, they form a network, whether seen in tranverse or tangential 
section. The existence of this highly differentiated secondary cortex, so distinct from the uniform periderm of S. Menardi, certainly seems to justify the specific separation of these two forms, even if there were no other diagnostic characters. The fibrous periderm attained an immense development; fragments 7 or 8 $\mathrm{cm}$. thick are found, and these appear to be only exfoliated laminae of a much thicker bark.

Beyond the secondary cortical zone lies the primary outer cortex, bearing the leaf-bases, where they are preserved. The interest of this species lies chiefly in two points-the transition which it shows between continuous and discrete primary xylem, and the complex character of the secondary cortical zone.

Both in S. spinulosa and S. Menardi the structure of the leaf-bases has been made out, thanks once more to M. Renault's researches. Towards the exterior of the cushion there is a rather thick-walled hypoderma; the softer tissue within contains the two parichnosstrands already described, and between them lies the vascular bundle (cf. Fig. 92, A). The primary wood forms a narrow transverse band, surrounded by a delicate tissue. ${ }^{1}$ The secondary wood is separated by this tissue from the primary xylem; it forms an arc of radially arranged elements towards the lower side of the bundle. Below this again is a layer of phloëm. Some light is thrown on this peculiar arrangement of the parts of the bundle by the structure of the leaf

1 M. Renault regarded this as primary phloëm, which may be correct, as in the leaf the transfusion-tissue (apparently continuous with the secondary xylem) lies outside the primary phloëm. See Flore fossile d'Autun et d'Epinac, Part ii. p. 212. 
itself, which was also thoroughly investigated by $M$. Renault. ${ }^{1}$

The leaves with their structure preserved are in association, but not in actual connection with the stems. In cases, however, such as that illustrated in Fig. 92, B, where the base of the leaf itself shows a characteristic scar, corresponding with those on the stem-surface, there can be no doubt as to the attribution. The general form and structure of the Sigillarian leaf (the species chiefly studied was S. Brardi, with its variety, S. spinulosa) is much like that of a Lepidodendron. Here also there are two deep longitudinal furrows on the lower surface, one on either side of the midrib, and it is only on the surface of these furrows that the stomata are found (see Fig. 92, C, g). The single vascular bundle appears to have been concentric in structure, the xylem having its spiral elements placed laterally. Below the bundle itself is a double layer of sclerenchyma, beyond which is a band of delicate parenchyma with scattered tracheides. This accessory xylem may be regarded as corresponding functionally to the transfusion-tissue of Coniferous leaves. We have already described the same tissue in the leaves of Lepidodendron, where, however, the extrafascicular tracheides are more abundant, and form a complete zone round the bundle. The transfusiontissue of the Sigillarian leaves was at first regarded by M. Renault as secondary xylem, but he afterwards withdrew that view, considering that the true secondary wood is limited to the leaf-trace, where it passes through the cortex of the stem. It seems,

${ }^{1}$ Flore fossile d'Autun et d'Epinac, Part ii. p. 213, Plate xli. 
however, to be clear that the secondary xylem and the transfusion-tracheides are continuous, one with another; the relations of the tissues require further investigation.

The mesophyll is lacunar in the neighbourhood of the stomatiferouns furrows; elsewhere it is described as consisting of transversely elongated elements, which may have enabled the leaf to roll up its lamina, and othus diminish transpiration. There is a band of sclerenchyma below the epidermis, except in the stomatiferous furrows. The stomata are of the ordinary kind; they are accompanied on the epidermis of the furrows by multicellular hairs, (Fig. 92, C, g). The whole arrangement of the tissues of the leaf is suggestive of a plant occasionally exposed to drought, but we must remember that the plants of salt marshes assume in many respects a xerophytic habit.

It will be seen that the leaves of the species of Sigillaria in question agree nearly, though not exactly, in structure with those of Lepidodendron, as described above in Chapter $V$. The differences between them are such as are often found even among species of the same genus; the resemblances, taken in conjunction with the other characters, are undoubtedly indicative of near affinity.

It appears probable that the leaves of Sigillaria were separated from the stem by the formation of a definite abscissile tissue.

So far we have dealt exclusively with the structure of the Sub-Sigillarian group. Our knowledge of the anatomy of the Eu-Sigillariae has until recently been extremely meagre, but is now much augmented. A fragment of stem with Favularian surface was described 
by Williamson ${ }^{1}$ in $187 \mathrm{I}$, but except as proving the presence of a secondary zone of wood, and of a periderm, the investigation yielded little result. The same author described at the same time, under the name of Diploxylon, a vascular cylinder which he afterwards referred to Sigillaria reniformis, one of the Rhytidolepis group (l.c. Figs. 33 and 34). In this stem there is a perfectly continuous zone of primary wood, with a crenulated outer margin, beyond which is a much broader layer of secondary xylem. The first really good English example of a stem of the Rhytidolepis type, with structure preserved, was a specimen which came several years ago into the hands of Professor Boyd Dawkins, and has not yet been fully described. ${ }^{2}$ The specimen is a fragment only, forming a segment of the stem, but it includes the whole thickness of the tissues from the pith to the outer surface (Fig. 93). The latter is ribbed in the characteristic manner of Rhytidolepis, and there appears to be no doubt of its belonging to a Sigillaria of that type. From the inner margin of the wood to the exterior surface of the ribs the radius of the specimen is about $18 \mathrm{~mm}$. The zone of primary xylem, which is less than a millimetre in thickness, is quite continuous as far as it can be traced. Its outer edge, where the smallest elements are placed, is crenulated, just as in Williamson's specimen, referred to above. The secondary zone of wood, which has the usual structure, is about $4 \mathrm{~mm}$. thick, and has an undulating outer surface, corresponding to the crenula-

1 "Organisation of Fossil Plants of Coal-measures," Part ii. I872.

2 For photographs of this specimen, one of which is reproduced in Fig. 93, I am indebted to Mr. A. Gepp of the British Museum, Natural History Department. 
tions of the primary zone. This latter character may serve to distinguish a Sigillaria from a Lepidodendron, but too much stress must not be laid on it. The inner cortex is imperfectly preserved; the outer bark consists chiefly of a thick zone of radially seriated periderm (Fig. 93, $p d$ ), beyond which a narrow band of primary cortex $(c)$ abuts on the surface of the ribs. The leaftraces are ranged in vertical rows corresponding to the

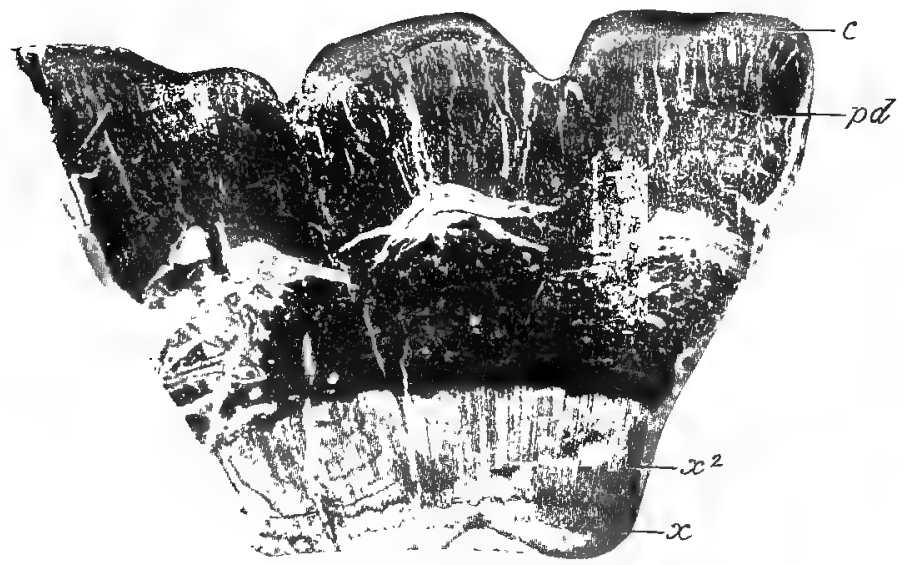

FIG. 93.-Sigillaria (Rhytidolepis type). Segment of stem, in trausverse section, including three ribs. $x$, crenulated primary wood; $x^{2}$, secondary wood; $\not d$, , periderm; $c$, outer cortex. $x_{3}$. From a photograph by Mr. A. Gepp.

ribs of the cortex. The xylem-strands of the leaf-traces start from the depressions of the crenulated primary wood, just as in Sigillaria Menardi or spinulosa, and in Williamson's specimen mentioned above. It is thus evident that each concave segment of the continuous primary wood, in the Rhytidolepis type of stem, corresponds to one of the distinct bundles, as shown in the Sub-Sigillarian forms previously described.

A more perfect specimen of the stem of a ribbed 
Sigillaria (probably S. elongata), from the Hardinghen coal-field, in the Pas de Calais, has been described by Professor C. E. Bertrand (Annals of Botany, December 1899). His more complete observations agree essentially with the short account just given of an English specimen. Professor Bertrand points out that the ribbed Sigillaria is in certain respects intermediate in structure between the Sub-Sigillariae and the Lepidodendra with secondary growth.

More recently Mr. Kidston has given a full account of the structure of a petrified specimen of Sigillaria elegans from the Lower Coal-measures of Yorkshire. ${ }^{1}$ This is a Favularian species; the characteristic leaf-scars are shown quite plainly on the surface of the specimen. The structure of the stele is essentially the same as in the form already described, and here also the leaf-traces invariably start from the base of the furrows of the crenulated primary wood. The medullary rays are one cell thick, and of varying height ; their cells, as in Lepidodendron, sometimes show scalariform markings The leaf-trace has a distinctly mesarch structure, and is without any secondary xylem. The structure of the bodies known as "cone scars" shows them to be the bases of small lateral branches, which may well have borne the fructifications (see p. 2r 4).

Quite lately the structure of certain species of the Rhytidolepis group has been investigated by Kidston and by Arber and Thomas $^{2}$ in material from the

1 Kidston, "On the Internal Structure of Sigillaria elegans," Trans. Roy. Soc. of Edinburgh, vol. xli. Part iii. I905.

2 Kidston, "Prelim. Note on Internal Structure of Sigillaria mamillaris and S. scutellata," Proc. Roy. Soc. Edinburgh, vol. xxvii. Part iii. I907; Arber and Thomas, "On the Structure of Sigillaria scutellata, etc. " Proc. Roy. Soc. London, I907 (abstract). 
Coal-measure nodules. In S. mamillaris (see Fig. 87) the structure is almost identical with that of the Favularian S.elegans; in S. scutellata the crenulations of the primary wood are comparatively slight (Fig. 94). On the whole the wood structure in both is the same as

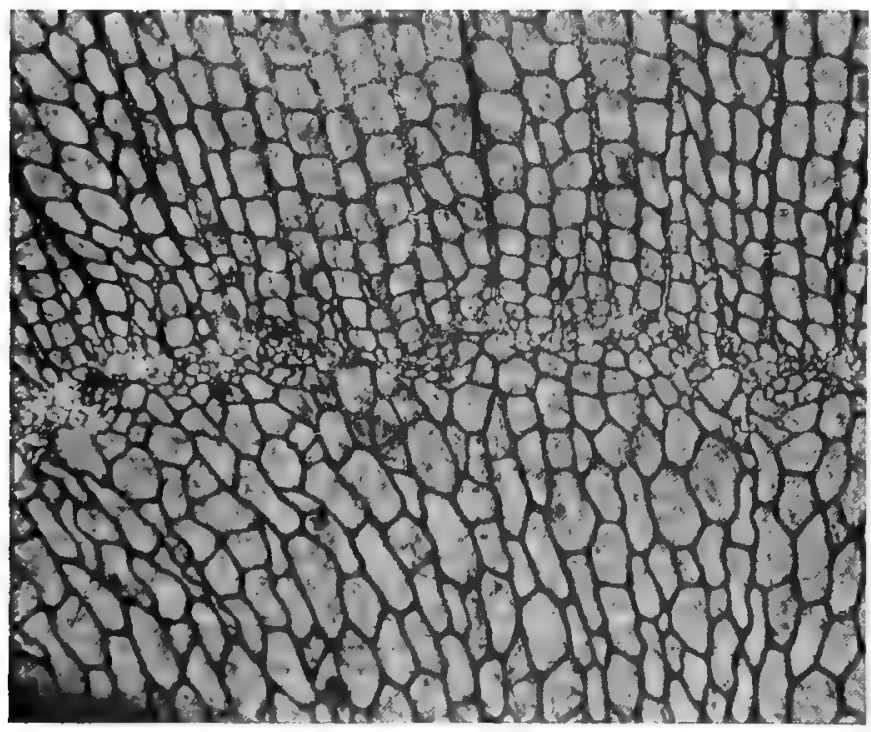

FIG. 94.-Sigillaria scutellata.-Transverse section of a portion of the wood, showing primary xylemibelow and secondary xylem above. The protoxylem-groups lie at the outer border of the primary xylem. $X$ about so. From a photograph lent by Mr. E. A. Newell Arber, F.G.S. S. Coll. 2300.

that above described. Arber and Thomas find that in $S$. scutellata the periderm was formed on the inner side of a meristematic zone which was active periodically. The ribs consist largely of the phelloderm, but were probably already present in the primary condition of the stem. The authors were able to demonstrate the presence of a ligule and ligular pit on the leaf-base. 
The most remarkable point, however, which they observed is, that in traversing the phelloderm the leaftrace divides into two; in the leaf-base the two xylemstrands are wide apart.

In I 879 Renault described, under the name of Sigillariopsis Decaisnei, a small stem, with leaves attached, from the Permian of Autun; the stem resembles that of Sigillaria Menardi in structure, but the wood contains pitted as well as scalariform

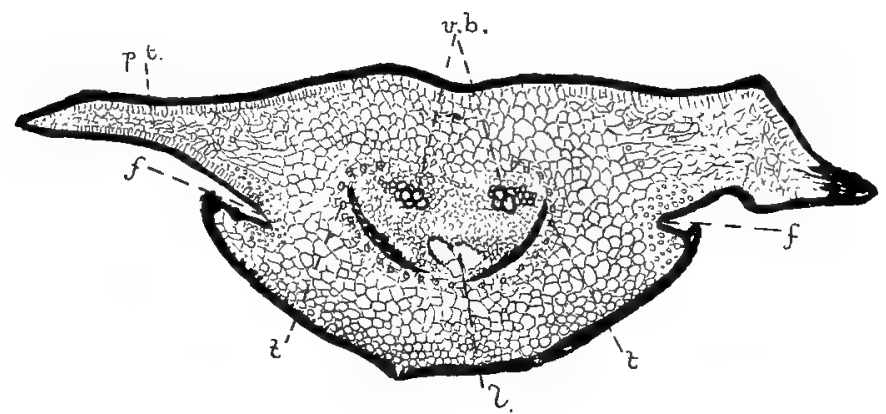

FIG. 95.-Sigillaviopsis sulcata. Transverse section of leaf, v.b., the xylem-groups of the double vascular bundle; $l$, lacuna, representing secretory tissue; $t, t$, transfusiontissue, forming a horse-shoe, surrounding the double bundle, but open ahove; p.t., palisade tissue on the upper side and flanks of the leaf ; $f, f$, stomatiferous furrows. $\times$ 22. S. Coll. 2272. R. S.

tracheides; the leaf is traversed by two parallel vascular bundles, which only fuse towards the tip. These characters are altogether exceptional among Lycopods, but in other respects the structure is quite of the Lycopodiaceous type. Leaves occur in the nodules of the British Coal-measures which agree with those of Renault's plant in possessing two distinct vascular bundles, though presenting some specific

I Structure comparąe de quelques Tiges de la Flore Carbonifiere, Paris, I879, p. 270 . 
differences. In all other respects their structure is that of a Sigillarian leaf (see the details in Fig. 95). The name Sigillariopsis sulcata ${ }^{1}$ has been given to the English species, for the leaf has two stomatiferous furrows, as in Sigillaria or Lepidodendron. Sigillariopsis, which may correspond to a part of Sigillaria, is interesting from its analogies, in certain points, with the structure of some of the Coniferae, with which, however, an affinity is improbable. There is good evidence that the British Sigillariopsis was borne on the stem known as Sigillaria scutellata (or some closely allied species), in which, as Arber and Thomas have shown, the double leaf-traces are quite similar in structure to the double bundle of the leaf. It thus appears that the Sigillariopsis type of leaf probably occurred both on Eusigillarian and Subsigillarian stems. The double bundle is an important character, and may prove to be of generic value.

3. Fructifications.-Our examination of Sigillaria has shown us, up to the present point, a very close agreement with Lepidodendron, as regards the external morphology and the anatomy of stem and leaf. It is, however, on the character of the fructification that the determination of the systematic position of the genus must ultimately depend. This knowledge we owe primarily to M. Zeiller, who in I 884 first demonstrated the nature of the cones of Sigillaria." Before that date several specimens had been described as Sigillarian

1 Scott, "On the Occurrence of Sigillariopsis in the Lower Coal-measures of Britain," Ann. of Bot. vol. xviii. I 904 .

2 "Cônes de fructification des Sigrillaires," Antı. des sci. nat. (Bot.), ser. vi. vol, xix. I 884 . 
fructifications, and some, as it has turned out, rightly so, but evidence of identification was not forthcoming. This was supplied by M. Zeiller, for the peduncle of one of the cones described by him is partly clothed by acicular leaves or bracts, and where these have become detached, the leaf-scars are found to lie in vertical rows on the ribbed surface, and to correspond very closely to the markings on the stem of definite species of Sigillaria, of the Rhytidolepis type. This correlation having once been effected, it became possible to identify various other specimens as cogeneric, and the genus Sigillariostrobus, as the fructification of Sigillaria is called, now includes several species. The cones are often of large size, reaching a diameter of about $6 \mathrm{~cm}$. (S. nobilis) and a great length. None of the French specimens were complete, but Mr. Kidston has since described a complete cone, from the Yorkshire coal-fields, 9 inches long. All the known Sigillarian cones agree in having long peduncles clothed with acicular bracts. The fertile part bears large, crowded sporophylls, arranged spirally, or in alternating whorls. The form of the individual sporophylls varies in the different species; thus in S. Tieghemi (which shows Rhytidolepis markings on the peduncle) it is broadly lanceolate and contracted at the base to a narrow claw, so that only a small round scar is left on the axis when the sporophyll has become detached. The short claw is approximately horizontal in direction, while the lamina is bent more or less sharply upwards. In other species, the lamina is prolonged into a fine point, and may be toothed or ciliate at the margins (see Fig. 96, A, from one of the English species discovered by $\mathrm{Mr}$. 
Kidston ${ }^{1}$ ). M. Zeiller was not able to observe the sporangia in any of his cones (with the exception of a doubtful form to be mentioned immediately). In several specimens, however, he found groups of large spores, obviously megaspores, lying on the upper surface of the sporophylls, as if they had been set free by the breaking down of the sporangial wall. Though the specimens were not petrified, and their internal structure was thus not preserved, it was found possible to isolate and carefully examine the carbonised megaspores. They are spherical, and of large size, ranging from I to $2.25 \mathrm{~mm}$. in diameter in the various species. The cell-wall generally shows three radiating lines, corresponding, no doubt, to the limits of the sister-cells in the same tetrad. The membrane may either be smooth or echinulate, according to the species.

M. Zeiller has also described a small cone, under the name of Sigillariostrobus Crepini, ${ }^{2}$ in which the sporangia, but not the spores, can be recognised. In this form, the sporangia appear to be attached at their distal ends to the spoon-shaped laminae of the sporophylls. In dimensions and general organisation this cone agrees very nearly with Spencerites insignis, described in the last chapter. The relation of $S$. Crepini to Sigillaria is, however, not quite beyond doubt.

The observations of M. Zeiller established the Cryptogamic nature of Sigillaria, for the fructifications were clearly those of a heterosporous member of the

I Kidston, "On the Fossil Flora of the Yorkshire Coal-field," second paper, Trans. Roy. Soc. Edinburgh, vol. xxxix. Part i. I897.

2 Zeiller, Bassin houiller de Valenciennes, Flore fossile, p. 605, Plate lxxvii. Fig. 3. 
Lycopodiaceae. Mr. Kidston, in his memoir above cited, has made further important additions to our knowledge of these strobili, for in certain new forms of Sigillariostrobus, which he has described, from the

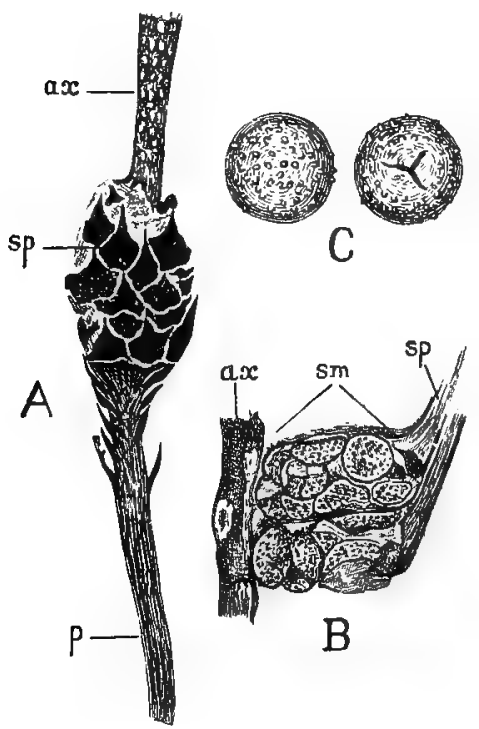

FIG. 96.-A. Sigillatiostrobus rhombibracteatus, Kidston. Part of cone, showing the pedicel $(p)$ with sterile bracts. $s p$, sporophylls; $a x$, axis exposed, showing scars of sporophylls. $\frac{3}{3}$ nat. size, B and C. S. ciliatus, Kidston. B. Part of axis $(a x)$ with sporophylls $(s p)$ and megasporangia $(s m)$ seen in radial fracture. $\times 3$. C. Echinulate megaspores. $\times$ about 7 . All after Kidston.

Coal-measures of Yorkshire, he has been able to demonstrate the form and position of the sporangia, and to obtain at least indications of the presence of microspores in some of them. The sporangia were observed in longitudinal section on the fractured surface of a specimen which had been split down the middle; for it must be remembered that in no case has an undoubted cone of Sigillaria been found with the tissues actually petrified. The sporangia prove to have been oval bodies with their long axis directed radially, and were seated each on

the horizontal pedicel of the sporophyll, to which the sporangium was to all appearance attached along the whole of its lower surface (Fig. 96, B). The sporangial membrane also appears, so far as the state of preservation allows us to judge, to have been continuous with 
the upturned laminar portion of the sporophyll, or possibly it may have been covered in by an indusium, as in Isoëtes. The sporangia contain large megaspores, with an echinulate membrane (see Fig. 96, C). It would appear, therefore, that the sporangia of Sigillaria, in their form and mode of insertion, resembled those of Lepidostrobus, while differing from those of Spencerites or of Sigillariostrobus Crepini, which should perhaps be removed from its present genus.

A fine granulation, strongly suggesting the presence of small crowded microspores, was observed by the same investigator in the sporangia of another specimen, which at the same time showed distinct megaspores in other parts. If this indication is to be relied on, it follows that Sigillariostrobus, like so many forms of Lepidostrobus, bore both kinds of spore on the same cone.

The discovery of the fructification of Sigillaria affords an explanation of certain scars which have long been known to occur occasionally on the stems, either between the vertical rows of leaf-scars, or scattered among them in the same series. These scars occur on all forms of Sigillarian stem. Fig. 87 (p. 208) represents them (c.s.) on the surface of S. mamillaris, which is of the Rhytidolepis type. Each scar has a central print, no doubt corresponding to a vascular strand, the structure of which has been demonstrated by Mr. Kidston in the case of $S$. elegans (see p. 228). In one case, small leafy shoots, the dimensions of which agreed well with those of the peduncles of the cones, are said to have been found seated on the scars. It is therefore reasonable to assume that we have in these marks the prints 
left by the deciduous cones after their fall. It would follow that the fructification must have been borne on the large stems (for it is on such that the scars occur), and not on small terminal branches. This conclusion is quite in agreement with the unbranched or littlebranched character of the Sigillarian stems. The occurrence of Ulodendroid scars on stems referred to Clathrarian Sigillariae (e.g. S. discophora) may be mentioned here, though their relation to the cones is open to doubt (see p. 167).

The controversy as to the systematic position of Sigillaria has gradually died out since the discovery of the manifestly Cryptogamic fructifications of the genus. The view, long maintained by Brongniart and his school, that Sigillaria, or at least the smoothbarked species, belonged to the Gymnosperms, no longer has any basis. The recent discovery of the seed-like fructifications of certain Palæozoic Lycopods might at one time have been used in support of this position, but there is at present no evidence that any of the Sigillariae possessed organs of this kind.

We may take it as now definitely established that Sigillaria was a genus of highly developed Lycopodiaceous Cryptogams, having the closest affinities with Lepidodendron. The difficulty, in fact, is rather to find constant distinctions between the two genera, than to prove their relationship. ${ }^{1}$

It is not probable that Sigillaria had even a remote affinity with the Cycads, the family with which Brongniart and his followers endeavoured to connect it.

\footnotetext{
1 The family Lepidodendreae is thus most naturally regarded as including the genus Sigillaria.
} 
As we shall see later on, there is strong evidence for tracing the origin of the Cycadales from quite a different Cryptogamic phylum, namely that of the Ferns.

The question of a possible affinity between the Palæozoic Lycopods generally and certain of the Coniferae, an hypothesis advocated by some modern writers, will be considered in the concluding chapter.

\section{STIGMARIA}

I. Habit and External Characters.-The subject of the roots or other subterranean organs, both of Lepidodendron and Sigillaria, has been postponed so far, because it presents considerable difficulty, and we are not even now in a position to distinguish the roots of the one genus from those of the other. ${ }^{1}$ Yet Stigmaria ficoides, which includes most of the specimens in question, is the very commonest of all fossils in the English Coal-measures, and other strata of similar horizon, and its outward appearance is familiar to every one who has paid the least attention to fossil remains. The Stigmariae, which are ordinarily preserved as structureless casts, are long, more or less cylindrical or slowly tapering bodies, varying in diameter from an inch or so up to more than two feet. The surface is marked all over with quincuncially arranged circular scars. Each scar is depressed, with a raised margin; within the scar is a second, much smaller circle, in the centre of which a raised point can be detected in good specimens (Fig. 97). The scars mark the insertion of

1 The morphological character of these organs is considered below, p. 259. The word "root" is used here in a physiological sense. 
the appendages, which are often found in situ, radiating out in all directions, and forming approximately a right angle with the main axis (see Fig. 97). The appendages have been found to reach a length of I 2 or I 5 inches; they have a nearly cylindrical, but gradually tapering form, and are slightly constricted at the base. Their dimensions are small compared with those of the

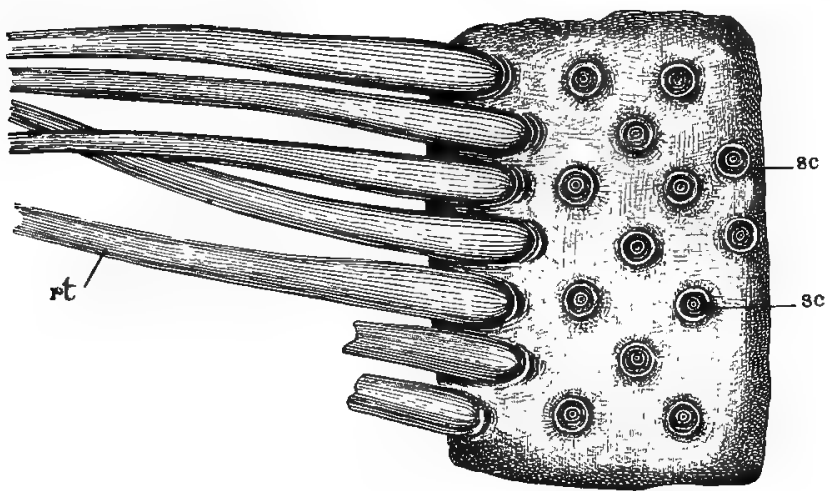

FIG. 97.-Stigmaria fucoides. Part of surface, showing the rootlet-scars (sc) to some of which the rootlets $(r t)$ are still attached. Reduced. After Schimper.

main axis, scarcely reaching a diameter of half an inch, while they are often quite slender.

The main Stigmariae themselves attained an immense length; one was traced by the late Prof. W. C. Williamson for a distance of 37 feet 4 inches from its base; in this length it twice forked, but the only branch which could be followed to its full extent measured about 28 feet, from the second dichotomy to its end. At the base of the whole, the diameter was no less than 32 inches, which diminished to a mere point at the extremity of the 
long branch. This specimen appears to be the largest Stigmaria which has been found in actual connection with the tree-stump to which it belonged; detached specimens have been described of much greater length.

Up to the year I 839 there seems to have been no good evidence as to the nature of Stigmaria, though the probability of its being the root of Sigillaria was recognised by some investigators, as, for example, by Brongniart. In I 839, during the construction of the Manchester and Bolton Railway, the stumps of several large fossil trees were discovered at Dixon Fold, with four great dichotomous roots radiating from the base of each trunk. The distinctive characters of these trees and their roots, however, could not be determined. A few years later a number of similar trees were found by Binney at St. Helen's and at Dukinfield, in Lancashire. Their trunks showed the characteristic Sigillarian markings, while the branches of the forked roots bore the Stigmarian scars. ${ }^{1}$ Thus the proof was first given that Stigmaria is identical with the subterranean parts of the Sigillarian trees, a conclusion which has been confirmed by various later observations. Subsequently, other specimens of Stigmaria were found in connection with tree-trunks, which showed the markings, not of Sigillaria, but of Lepidodendron. Specimens of this kind were first observed in the Coal-measures of Nova Scotia, by Richard Brown, soon after Binney's discoveries in England, but there was some doubt as to whether Brown's trees were

1 See Williamson, "Monograph of Stigmaria ficoides," Palæontographical Society, I886. 
rightly identified as Lepidodendron. Other cases, however, observed in Germany and in England, seem to leave no doubt that the Stigmariae formed the subterranean organs of Lepidodendron as well as of Sigillaria. It is not even possible to distinguish specifically between those of the two genera; the name Stigmaria ficoides does duty for both, and though other species have been distinguished, we are rarely able to correlate their diagnostic characters with those of the stems. One or two special cases, on which rather more light has been thrown, will be mentioned after the common "species" has been dealt with. In the meantime, we may take Stigmaria ficoides as representing the "roots" of various Lepidodendra, as well as of various Sigillariae of the ribbed division.

The mode of connection between the Stigmaria and its Sigillarian or Lepidodendroid stem has been shortly noticed above (p. 206, Fig. 85). This has now been observed in a great number of specimens, and the main features appear to be constant. There is never a tap-root forming the direct downward continuation of the vertical stem; the Stigmarian roots are always given off laterally from the base of the stem, and there are always four of them to start with, the four occupying at their attachment the whole circumference of the trunk, which ends abruptly between them; its under surface is marked by a cruciate furrow, corresponding to the lines of junction of the Stigmarian roots. Each of these main roots forked at least twice, and if the first dichotomy took place very near the base, their number may appear to be greater than four. Whether the stem be large or small, 
the arrangement is just the same; thus in the Clayton specimen shown in Fig. 85, the stump of the stem is more than 4 feet in diameter, while in another figured by Williamson in his Monograph it only measures 6 inches. The angle at which the Stigmarian roots pass off from the stem is variable. Sometimes they take a nearly horizontal direction from the first; in other cases they first strike sharply down at an angle of $50^{\circ}$ or $60^{\circ}$, and only begin to take a more horizontal course at some distance from the main trunk.

The Stigmarian roots, as mentioned above, are especially abundant in the clay underlying the coalseams, to which the name "Stigmarian clay" has been given by English geologists; they are, however, by no means limited to this position. The conditions must often have been more favourable for the preservation of these underground organs than for that of the aërial stem; hence it is not surprising that in some Carboniferous beds on the Continent, Stigmariae are found without any corresponding remains of Sigillaria or Lepidodendron. It is still uncertain whether Stigmaria when living ever occurred except in connection with aërial stems. The Stigmaria, with its appendages, manifestly performed the functions of a root, taking up food from the soil. A rich soil seems to have suited it, for the Stigmarian rootlets burrowed in every direction through the mass of decaying vegetation which formed the organic material of the calcareous nodules. They occur in countless numbers, crowded together and penetrating every kind of vegetable fragment-stem, leaf, root, or cone, so that the first lesson a beginner has to learn, in studying the 
microscopic structure of coal-plants, is to avoid confusing these intruders with integral parts of the organs which they invade. We may form some idea of the conditions under which the Stigmariae grew, from the analogy of weeds growing on a leaf-mould heap, and sending their roots in all directions through the decaying vegetable mass beneath them; only, in the case of the Stigmaria, the weeds are represented by gigantic trees. Special care is necessary in the frequent cases where the rootlets led a kind of cannibal existence, burrowing into roots and rootlets of their own kind. Such cases have deceived even practised observers; thus Göppert described an intruding rootlet, found in the pith of a Stigmarian axis, as part of the structure of the latter, and this elementary blunder misled several of his successors, until Williamson set the matter right.

2. Anatomical Structure-We have now to consider the internal structure of Stigmaria and its appendages; our description will be based in the first place on the common type $S$. ficoides, which is by far the best known.

The main axis of Stigmaria consisted of a welldeveloped vascular cylinder, surrounded by cortex and periderm (see Fig. 98). The centre of the stele was occupied by a fair-sized pith, the tissue of which is rarely found preserved, except in the outer part, next the wood. Possibly the pith may have been fistular during life. The wood forms a broad zone, divided up into bundles by the principal medullary rays (Fig. 98, $x$ ). These bundles constantly anastomose laterally with each other, forming a network, in 
which the principal rays occupy the meshes. Throughout almost the whole thickness of the woody zone, a regular radial arrangement of the elements prevails; there is no sharp distinction between primary and

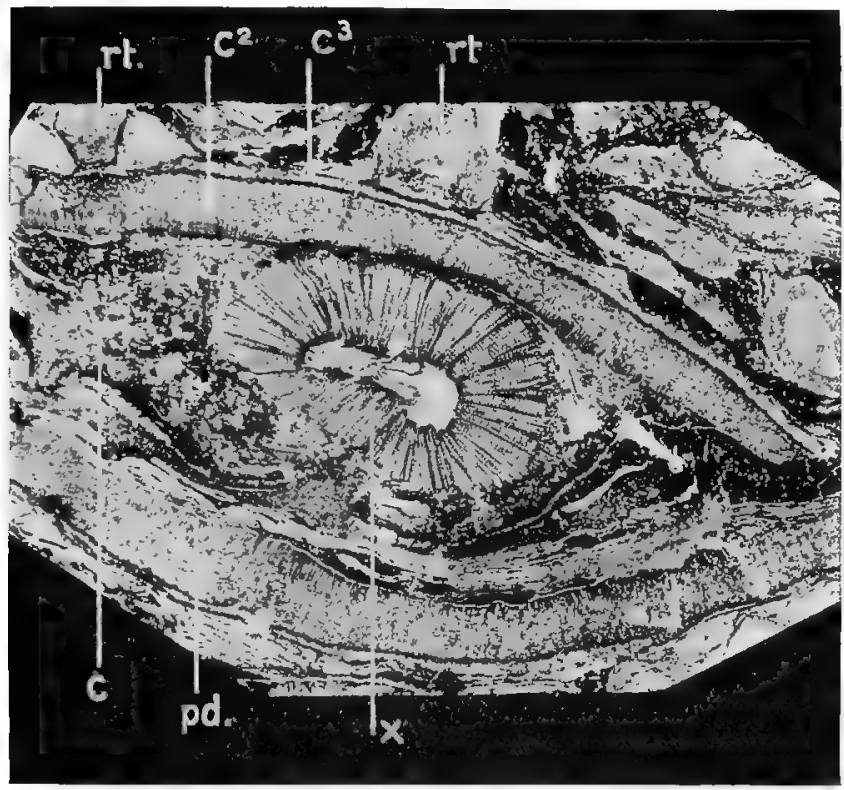

F1G. 98.-Stigmaria ficoides. Transverse section of a small specimen. $x$, zone of wond, radially seriated throughout ; $c$, middle cortex, only partially preserved; $\not p d$, periderm; $c^{2}$, outer primary cortex; $c^{3}$, hypodermal zone of cortex; $r t$, bases of rootlets; free rootlets are also shown, $\times 3 \frac{1}{2}$. From a photograph by Mr. L. A. Boodle. Spencer Coll. 147 (now S. Coll. 1465 ).

secondary xylem, but at the inner end of each wedge the elements are smaller and less regular than elsewhere. Good radial sections show that the spiral tracheides are placed at the extreme inner edge of the wood, next the pith, so that centripetal wood in this form of Stigmaria was entirely absent. This is a rather surprising 
anatomical peculiarity, considering that the centripetal primary wood is one of the chief structural characters of Lycopods, both recent and fossil. The case of Stigmaria ficoides is not, however, without analogy within the Order. Thus, in the creeping stem of Selaginella spinosa, the first-formed tracheae are central, so that the whole of the wood is centrifugally developed. The same is the case in the hypocotyl and rhizophores of S. Kraussiana and other species. ${ }^{1}$ In both plants the upper parts of the axis have the normal structure, with centripetal xylem, just as in the case of the Sigillarian or Lepidodendroid stems to which Stigmaria ficoides belonged. As we shall see presently, the absence of centripetal wood does not hold for all forms of Stigmaria.

The bulk of the xylem in S. ficoides consists of radially arranged scalariform tracheae, the pits occurring on the tangential as well as on the radial walls of the elements (Fig. 99). In addition to the principal rays, numerous narrow secondary rays traverse the wood; they may consist of a single radial row of cells, or may be several cells in height; usually they are one cell thick, sometimes more (Fig. 99, m.r). It is an interesting fact that the rays consist partly of spirally or reticulately thickened elements, presumably tracheides, a peculiarity which, as we have seen, is very general in the secondary wood of Lepidodendroid stems. There is here an obvious analogy with the complex organisation of the medullary rays in the Abietineae, though the two structures no doubt arose quite independently.

1 See the papers by Bruchmann and Harvey Gibson, cited on p. 260. 
The regular radial seriation of the secondary xylemelements is sometimes interrupted by the intercalation of a tangential band of much smaller tracheae, beyond

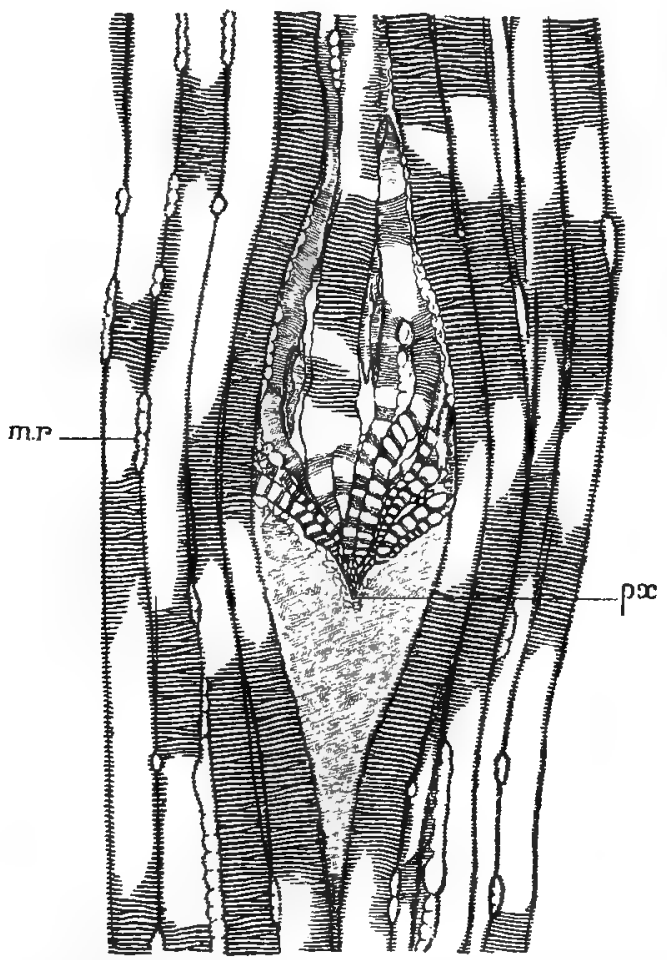

Fig. 99.-Stigmtaria ficoides. Part of tangential section through wood, showing an outgoing rootlet-bundle. All the tracheides are scalariform. m.r, medullary rays; $\not p x$, protoxylem of rootlet-bundle. The top of the figure is directed towards the base of the Stigmaria. $\times 40$. Spencer Coll. I50 (now S. Coll. 1469). (G. T. G.)

which the regular formation of large elements recommences. These interruptions no doubt point to a break in the activity of the cambium, but the smallcelled layers are not always continuous, and cannot be regarded as marking annual rings. To use Williamson's 
words: "The meristemic activity of the cambial layer may have manifested itself irregularly rather than periodically." I At the exterior of the wood, some remains of the cambium can sometimes be traced, passing over externally into a zone of delicate tissue, more or less radially arranged, and consisting, as shown by longitudinal sections, of elongated elements. This was no doubt the phloëm. On its outer margin is an imperfectly preserved lacunar zone, such as often occurs in a corresponding position in the stems of Lepidodendron. The middle cortex (Fig. 98, c) is never perfectly preserved, but where parts of it remain, it appears to have the same curious trabecular structure, as if made up of interwoven filaments, which we so often find in the same region in Lepidodendron. In some specimens the preservation of the outer cortex is very perfect (see Figs. 98 and Ioo). The primary structure of this region can only be observed in fairly young examples (Fig. 98, $c^{2}$ ). Most of its thickness is made up of a very uniform large-celled parenchyma. On the external surface is a hypodermal zone of smaller cells, marked off from the rest of the cortex by a narrow band of dark tissue, probably sclerotic (Figs. $98, c^{3}$, and IOO).

Periderm-formation set in early, and the older specimens were provided with an immensely thick bark, fragments of which are among the "common objects" of the coal-balls. The devclopment of periderm (Figs. 98 and roo, $p d$ ) began in a deepseated layer of the outer cortex, and appears to have gone on for some time, chiefly in the centripetal

1 "Monograph of Stigmaria ficoides," p. I7. 
direction, for it is on the inner edge of the secondary cortical zone that remains of the delicate phellogen can be traced. The tissue thus formed cannot have been of the nature of cork, for the outer tissue shows no sign of withering, and some of its cells had sometimes undergone tangential division, as if starting a

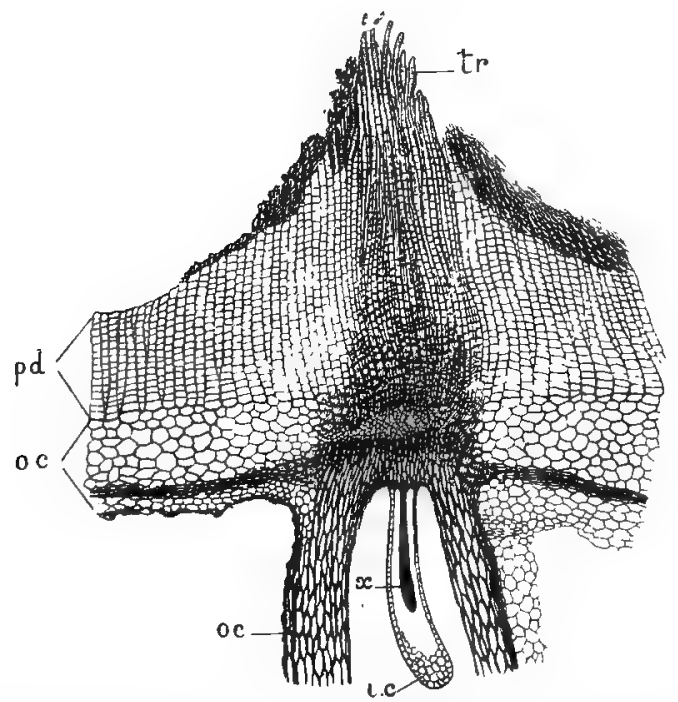

FIG. 100.-Stigllaria ficoiltes. Part of transverse section, to show base of a rootlet. $f a$, periderm of main axis; o.c, outer cortex (including hypoderma) of main axis and of rootlet; i.c, inner cortex, $x$, xylem of rootlet; tr, tracheides passing out to rootlet.

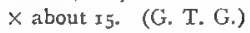

new, more external phellogen. In many of the Carboniferous plants the formation of secondary cortex played a much more important part than is usually the case in recent vegetation, and though we use the words "periderm" and "bark," it is certain that many of the structures thus indicated were very different in nature and function from the recent tissues which 
answer to them morphologically. A characteristic feature of the Stigmarian bark is the great tangential dilatation of the more external peridermal cells.

The above must suffice for a general account of the anatomy of the Stigmarian axis; it remains to describe its appendages, and their relation to the parent organ.

As already mentioned, the appendages, which we will call simply rootlets, following Williamson's terminology, are arranged in quincuncial order on all parts of the Stigmarian surface (see Fig. 97). The vascular strand of each rootlet, so far as its xylem is concerned, starts from the inner, primary margin of the wood of the main axis, and bends sharply outwards, taking a nearly horizontal course through the secondary xylem. Every principal ray is traversed by one of these rootlet-bundles, which appear in tangential sections of the axis as tongue-shaped bodies, with the point projecting freely into the lenticular cavity, left by the decay of the ray, while the base is continuous with the adjacent wood (see Fig. 99). The orientation is such that the free point (protoxylem) of the rootlet-strand is directed towards the apex, while its connection with the wood is towards the base of the main axis. ${ }^{1}$ Thus the water absorbed by the rootlet would have been directly conducted through the wood of the main organ, to the aërial stem.

The xylem of the rootlet was increased to some extent with the growth of that of the main axis, for the strand becomes larger as we follow it outwards through

1 Thus in Fig. 99 the growing point of the Stigmaria would have lain in the dowmward, and its base in the upward direction, as the figure is drawn. 
the secondary wood. In the ill-preserved middle cortex the rootlet-bundles are often met with, and here their course seems to have approached more nearly to the vertical. The parenchyma immediately surrounding the bundle is often preserved when the general cortical tissue has perished. In this region the sectional form of the xylem of the rootlet is triangular, with protoxylem at the apex. At the opposite side the phloëm can sometimes be recognised.

On entering the outer cortex the bundle again takes a more horizontal course. It is here surrounded by a well-marked zone of tissue, in which layers corresponding to the inner and outer cortex of the free rootlet can already be distinguished. In passing through the periderm the parenchymatous tissues of the base of the rootlet kept pace, by tangential divisions, with the growth of the surrounding secondary zone (Fig. IOO).

Fig. I 00 shows, in longitudinal section, the structure of the rootlet at its base, where it is just escaping from the cortex of the principal axis, which is shown in transverse section. At its attachment, the rootlet is a solid structure with its tissues complete, but as soon as it, becomes free the inner and outer cortex are separated by a wide lacuna, in which only slight remains of the probably trabecular tissue, which once occupied it, can be traced. The outer cortex is continuous with that of the main organ, the hypoderma extending over from one to the other without change (Fig. 100, 0.c). The inner cortex, enclosing the vascular strand, is seated directly on the solid tissue of the transitional region. The continuity of the outer tissues from the main axis to the rootlet appears to prove that 
the origin of the latter could not have been endogenous. Probably the rootlets were formed excessively near the apex of the parent organ.

We have now to describe the characteristic structure of the free rootlet, but may first point out how the anatomy of its base exactly accounts for the configuration of the scars on the ordinary Stigmarian surface

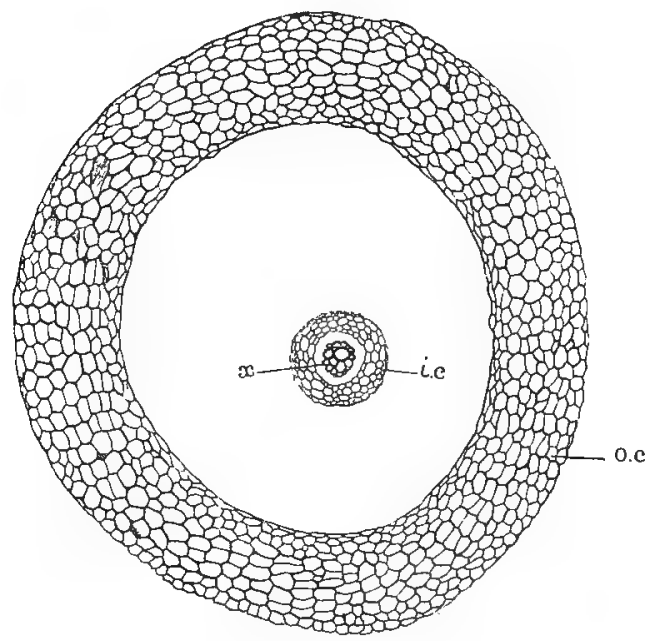

Fig. 1or. Stigmaria ficoides. Transverse section of rootlet, in usual state of preservation. o.c, outer cortex; i.c, inner cortex; $\ldots$, xylem. $x$ I6. S. Coll. Ir 3. (G. T. G.)

(compare Fig. 97 with Fig. IOI). The outer cortex answers to the raised external rim of the scar; the lacunar middle zone to its depressed surface; the inner cortex to the internal circle of the scar; and the vascular strand itself to the minute central point seen in the latter, when especially well preserved.

The rootlets of Stigmaria ficoides are absolutely the commonest specimens among the petrified material of 
the calcareous nodules. Their structure is on the whole very uniform, though their dimensions vary greatly, the diameter ranging from a centimetre to a millimetre or less. The external cortex, which is generally well preserved, is several cells in thickness, and is often divided into an outer and inner zone by a band of thick-walled tissue. Sometimes the inner zone as a whole has thicker walls than the outer (Fig. I05), but often there is an entire absence of differentiation (Fig. IOI). These distinctions may possibly turn out to be of specific value, but at present we have no clue to their significance. As we have already seen, all the layers of the cortex in the rootlet are continuous with the corresponding tissues of the main Stigmaria, and present similar characters. The outermost layer of the rootlet is sometimes papillose, but no true root-hairs have been observed.

Indications of tangential division are sometimes found in the cells of the external cortex, which may thus have undergone some slight secondary increase in thickness. Within this external zone we almost always find a wide empty space, from which all tissue has perished. It is rare, except at the base of the rootlet, to find any remains of the middle cortex, which must once have bridged the gap. Occasionally, however, especially in young rootlets, some thin-walled tissue is still preserved in this region, or a single, stout trabecula may connect the inner with the outer cortex (Fig. I03).

The internal cortex forms a ring, of very small size compared with the outer layer, and immediately encloses the vascular strand (Figs. I O I-I 05). As, after the decay of the intermediate tissue, there was nothing to 
keep the internal cortex in place, we seldom find it in its natural central position; usually it is more or less excentric. It consists of a few layers of delicate parenchyma; an endodermis has not yet been distinguished.

We now come to the vascular strand, which occupied

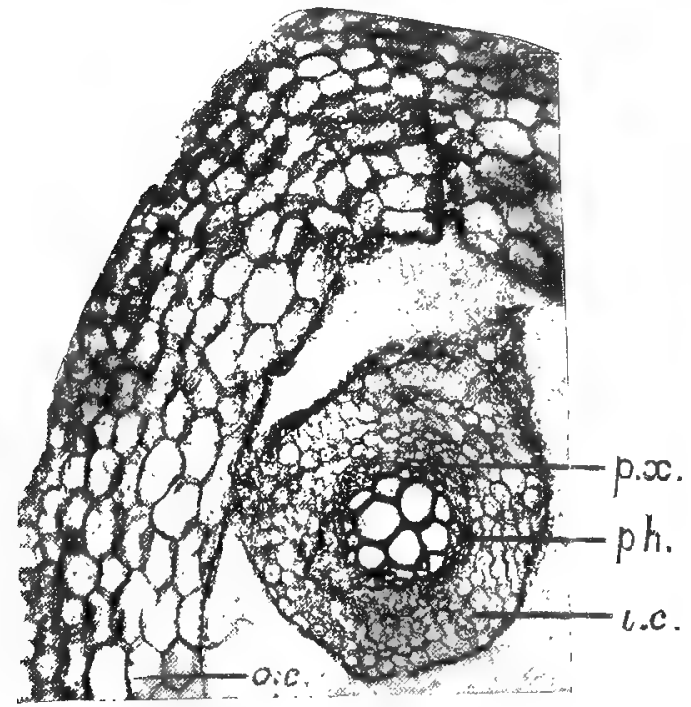

FIG. 102. -Stigmaria ficoides. Part of transverse seclion of rootlet, to show monarch structure. $p x$, protoxylem, at one corner of the thick-walled strand of wood; $p h$, phloëm, which thins out opposite the protoxylem; i.c, inner cortex; $0 . c$, part of outer cortex. $x$ about 5o. From a photograph by Dr. Bousfield. S. Coll. II4.

the central position in the whole structure. As a rule the wood only remains; occasionally, as in the specimen shown in Fig. IO2, the delicate tissue which no doubt constituted the phloëm, and perhaps the pericycle also, is preserved. We will consider the xylem first. It consists of a small strand of tracheides with a somewhat triangular transverse section (Figs. IO I-IO5). One 
angle is more prominent than the others, and is in contact with the surrounding parenchyma (Figs. IO2I04, $p x)$. At this angle the smallest elements are situated, and longitudinal sections show that they alone are spirally thickened; the remaining elements of the xylem are scalariform. It is therefore clear that the rootlet had only a single group of protoxylem, and thus, if we are to adopt the terminology usual in the case of roots, must be termed monarch. This conclusion is confirmed by the comparison of rootlets at , various stages of growth, which always show the first differentiated tracheae at one angle only, never at three. So far as the English specimens are concerned, there can be no doubt that in S. ficoides all the appendages agree in having a monarch vascular strand.

A remarkable feature in the structure of the Stigmarian rootlet has recently been investigated by Professor F. E. Weiss. ${ }^{1}$ Renault in I 882 had described rootlets with a very delicate vascular strand given off from the stele, and had regarded this as indicating a mode of branching distinct from the usual dichotomy. Professor Weiss confirms this observation (on which some doubt had been cast), but finds that the vascular strands in question have no connection with branches. They consist of spiral tracheides, and start from the protoxylem, pass out, obliquely or horizontally, through the middle cortex, enclosed in a sheath or traversing a trabecula, and terminate in connection with an extensive patch of tracheidal tissue in the outer cortex (Fig. Io3).

1 "On Xenophyton radiculosum and on a Stigmarian Rootlet," Mem. and Proc. Manchester Lit. and Phil. Soc. vol. xlvi. I902; "The Vascular Branches of Stigmarian Rootlets," Ann. of Bot. vol. xvi. I902; "The Vascular Supply of Stigmarian Rootlets," ibid. vol. xviii, 1904. 
On Professor Weiss's view "the vascular strand and the transfusion cells in which it terminates form a special means of conducting water from the peripheral to the central tissues of the rootlet, a means which is rendered necessary by the development of the middle cortex into an air-conducting tissue or space."

When the phloëm is preserved, it appears to be

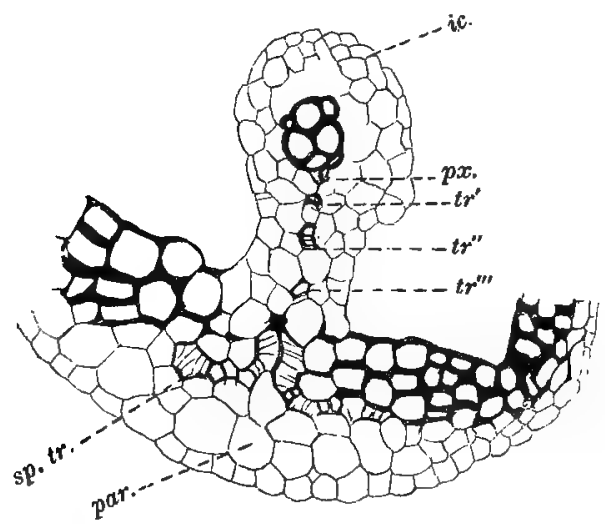

Fig. 103,-Stignaria ficoides. Transverse section of rootlet, showing vascular bundle and part of cortex; i.c, inner cortex, connected by a parenchymatous bridge with the outer cortex; $p x^{\prime}$, protoxylem; $t r^{\prime}, t r^{\prime \prime}, t \gamma^{\prime \prime}$, three portions of vascular strands running to outer cortex; sp. tr., spiral tracheides of outer cortex; par., patch of largecelled parenchyma. $\times 6$. After F. E. Weiss. Hick Collection (Manchester), 75.

thickest at the side remote from the protoxylem-angle, extending also along the flanks of the xylem, but not round the point (see Fig. IO2, $p h$ ). It must be remembered, however, that in the state of preservation of these specimens the phloëm cannot be distinguished with certainty from pericycle or from cambium.

The elements of the wood do not, in the ordinary cases, show any radial arrangement, and are no doubt to be regarded as primary. In exceptional cases, 
however, we find an addition of radially arranged secondary wood (see Fig. I O4, $x^{2}$ ), and where this is the case the secondary formation is always limited to the side remote from the protoxylem, thus affording yet another indication of monarch structure. The formation of secondary wood, though rare in the free rootlets, is

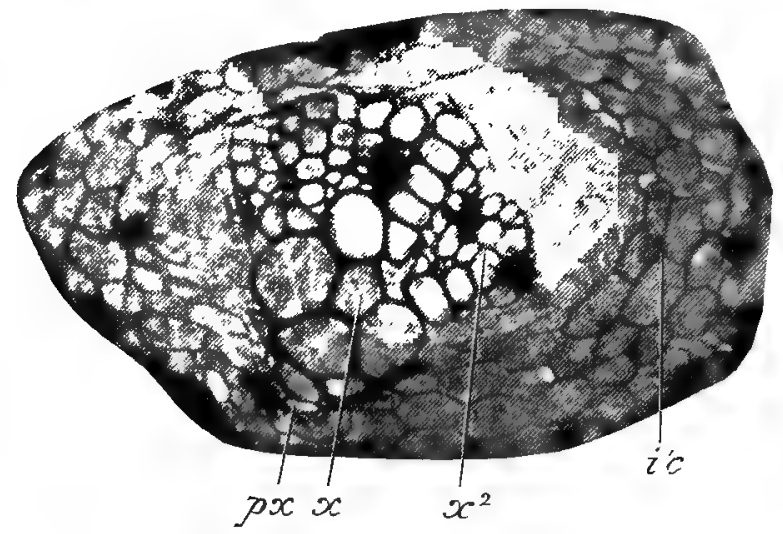

FIG. 104.-Stigmaria ficoides. Transverse section o central part of rootlet, to show secondary thickening of wood. $x$, primary xylem; $\not x x$, protoxylem; $x^{2}$, secondary xylem, limited to one side of bundle; i.c, inner cortex. $X$ nearly Ico. From a photograph by Mr. I. A. Boodle. Will. Coll. 65 I.

commonly found in the rootlet-trace, where it passes through the cortex of the main axis.

The branching of the rootlets was by dichotomy. A transverse section of a rootlet at the point of bifurcation is shown in Fig. I05. The plane of division passes through the protoxylem, and coincides with the plane of symmetry of the bundle. The dichotomous branching is an obvious point of agreement with the roots of modern Lycopods.

Something may now be said of other forms of 
Stigmaria, differing in certain respects from the specimens grouped under Stigmaria ficoides.

Xenophyton radiculosum, a fossil described by $\mathrm{Mr}$. T. Hick in $189 \mathrm{I},{ }^{1}$ has been shown by Professor F. E. Weiss, in agreement with a suggestion of Williamson's, to be a Stigmaria. The pith and the whole of the cortex are preserved, giving the specimen a very different character from that of the ordinary S. ficoides. The wood,

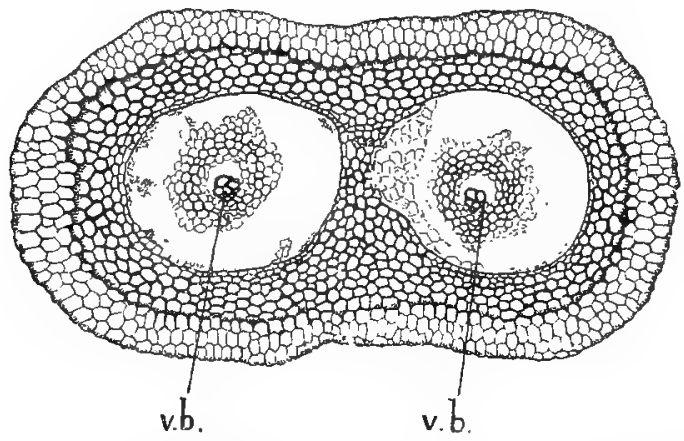

FIG. I05.-Stigmariaficoides. Transverse section of rootlet, showing dichotomy. The outer cortex, differentiated into two zones, is still continutous, while the inner cortex of the two lranches has completely divided. v.b., the two monarch vascular bundles. $\times$ 25. S. Coll. 172. (G. T. G.)

which is little developed, appears to be wholly centrifugal, as in that species. The rootlet-bundles take a steeply acropetal course, like leaf-traces, and secondary parenchyma is formed about them in passing through the middle cortex, which has a similar structure to that of Lepidophloios fuliginosus, the plant to which Professor Weiss believes this Stigmaria to have belonged. Within the periderm there are strands of secretory cells, as in so many Lepidodendroid stems. It was in a

1 Hick, "On a New Fossil Plant from the Lower Coal-measures," Journal Linnean Society, vol, xxix. 1892. 
rootlet, attributed to the same plant, remarkable for the perfect preservation of the middle cortex, that Professor Weiss first observed the radial vascular strands, thus confirming Renault's previous statement.

As mentioned above, the absence of centripetal primary wood from the main axis is not constant in Stigmaria. M. Renault ${ }^{1}$ found this tissue in various cases, and notably in a Stigmaria which he attributed to Sigillaria Brardi. Here the centripetal wood is very distinct, though of no great thickness. It forms more or less separate bundles, so that the structure is not unlike that of the corresponding part of the aërial stem.

Another species with centripetal wood, the Stigmaria fexuosa of Renault, is regarded by Solms-Laubach ${ }^{2}$ as having very probably belonged to the fossil called Stigmariopsis, a form which differs in the shape of the scars from the ordinary Stigmaria, and which is characterised by its well-marked medullary casts, resembling those of a Calamite, though of course without the nodal constrictions. Solms-Laubach, from the geological distribution of Stigmariopsis, suggests that it may have constituted the underground organs of the Sub-Sigillariae, while the typical Stigmariae belonged to Eu-Sigillariae as well as to Lepidodendron. This, however, is not yet established, and, in fact, there are few questions in fossil botany more difficult than that of the relation of Stigmaria to its stems.

Professor F. E. Weiss has quite recently described a very interesting Stigmaria, from the nodules of the Lower Coal-measures, which possesses a perfectly

1 Flore fossile a'Autun et d’ Epinac, Part ii. p. 226, Plates xxxviii.-xl. 2 Ueber Stigmariopsis, Jena, I 894. 
distinct centripetal primary xylem, surrounded by a wide zone of secondary wood. This fossil was originally described by Williamson as an advanced condition of the stem of Lepidodendron (now Bothrodendron) mundum. It is probable that it really belongs to that plant,

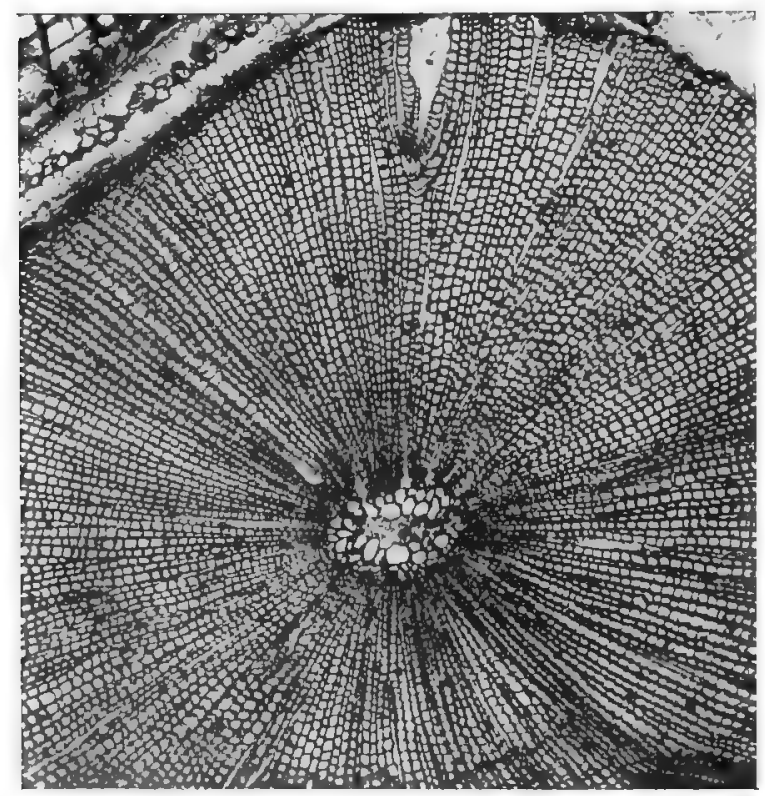

FIG. ro6.-Stigmaria, sp. Transverse section of an axis, showing pith and large-celled centripetal primary xylem, with broad zone of secondary wood. At the top of the figure the bundle of a rootlet is seen. $\times$ 24. From a photograph lent by Professor F. E. Weiss.

representing its root or rhizophore. The primary wood gives the axis its stem-like character, but it is shown to be of the nature of a Stigmaria by the structure of the cortex and by the bases of rootlets attached to it. The rootlet-bundles are remarkable for having, usually, a mesarch xylem, with secondary growth on all sides, 
instead of on the outer side only, as in S. ficoides. In passing through the cortex these bundles are connected with groups of reticulate tracheides, which probably served for water-storage. ${ }^{1}$ If this Stigmaria is rightly attributed to Bothrodendron mundum, of which $\mathrm{Mr}$. Watson has now described the cone, that plant will become the most completely known of the Palæozoic Lycopods.

3. Morphology.-It only remains to consider very briefly the morphological nature of Stigmaria and its appendages. If we call Stigmaria a "root," it is chiefly on physiological grounds that the term is used. The main axis of Stigmaria ficoides has in no respect the structure of a root; in fact, this species, in the absence of centripetal wood, departs from typical rootstructure more widely even than the aërial stems themselvęs. Other forms of Stigmaria, though they may possess centripetal wood, are no more root-like in structure than the Sigillarian stem. The arrangement of the appendages (which, in the rare cases where the growing end is preserved, are found to have converged to form a kind of bud at the apex of the main Stigmarian axis) is unlike that of rootlets, nor does their origin seem to have been endogenous.

On the other hand, the appendages agree so exactly in structure and in the dichotomous mode of branching with the monarch roots of the allied recent genera Isoëtes and Selaginella, ${ }^{2}$ that it seems impossible to

1 Weiss, "A Stigmaria with Centripetal Wood," Ann. Bot. vol. xxii. I908.

2 In the Stigmarian appendages the position of the phloëm, which appears to have formed an arc on the side of the strand remote from the protoxylem, agrees exactly with that in the roots of these recent plants. 
doubt their homology. Some authors have regarded the appendages as modified leaves, a view which was primarily suggested by their arrangement on the axis. Recent discoveries have tended somewhat to increase the analogies with leaves; the so-called transfusiontissue of the Stigmarian rootlet (see above, p. 253) has been compared with that of the leaf, though the two tissues differ as much in arrangement as they no doubt did in function. Quite recently Professor Weiss has found, in connection with the rootlet-trace of the Stigmarian Xenophyton, a strand of cells analogous to the parichnos of the leaves, but situated on the opposite side of the bundle (next the xylem instead of next the phloëm). ${ }^{1}$ Such resemblances as these do not count for much in establishing an homology, as Professor Weiss points out. On the other hand, the course of the rootlet-traces in Xenophyton, as already mentioned, is remarkably like that of the leaf-traces in the stems of Lepidodendreae.

The arguments in favour of the root-nature of the appendages are their dichotomous branching, monarch structure, general resemblance to the root of allied recent Lycopods, and the occurrence of secondary thickening. In favour of their homology with leaves we have their quincuncial arrangement (see Fig. 97), bud-like convergence at the apex, the transfusion-tissue

Cf. Bruchmann, Selaginella spinulosa, Plate i. Fig. 13, 1897; Farmer, "On Isoëtes," Ann. Bot. vol. v. Plate v. Fig. 4, 189I ; Scott and Hill, "Structure of Isoëtes Hystrix," Amn. Bot. vol. xiv. Plate xxiv. Fig. 30, Igoo. For information on the structure of rhizophore and root in many species of Selaginella, see Harvey Gibson, "Contributions towards a Knowledge of the Anatomy of the Genus Selaginella, Part iv. The Root," Ann. Bot. vol. xvi. r9oz.

I Weiss, "The Parichnos in the Lepidodendraceae," Mem, and Proc. Manchester Lit. and Phil. Soc, vol. li. Igo7. 
and parichnos, and the course of the rootlet-traces. There is no analogy among the Lycopodiales for such a modification of a leaf, but the water-leaves of Salvinia might be cited as remotely comparable. The presence of leaf-like characters in the Stigmarian appendages may be in part the survival of a more primitive morphology, but on the whole it seems evident that they are the same organs as the roots of recent Lycopods. Their apparently exogenous origin offers no hindrance to this interpretation, for we know that among recent Lycopods, as in Selaginella and Phylloglossum, roots may arise exogenously. ${ }^{1}$

What view, then, are we to take of the organs which bore the appendages? They are, as we have seen, often very different from typical roots. Neither, however, do they show the characters of rhizomes; they bear no leaves, and we have no convincing proof that they gave rise to aerrial stems, though it is possible that they may have done so. Those Stigmariae, however, the relations of which are the most clear, are beyond doubt appendages of the aërial stems, and not their parent organs. How those stems arose in the first instance, whether directly from the embryo, or from some creeping form of axis, of which, as a rule, no traces remain, ${ }^{2}$ is at present an unsolved problem.

It appears, then, that the main Stigmariae cannot be classed morphologically either as roots or rhizomes.

1 Van Tiegham et Douliot, "Origines des membres Endogènes," Ann. des sci. nat. (Bot.), ser. vii. vol. viii. p. 552, I888; Bower, "On the Development and Morphology of Phylloglossum Drummondi," Phil. Trans. ii. 1885 .

2 M. Grand'Eury maintains the latter view. See his Bassin houiller du Gard, p. 236; also "Sur Ies Sols de Végétation fossiles des Sigillaires et des Lepidodendrées," Comptes Rendus, t. cxxxviii. I904. 
The leafless rhizomes of Psilotum and Tmesipteris offer but a poor analogy, for they bear no roots or other appendages, except hairs. The best analogy we can find for the Stigmarian organs is in the rhizophores of Selaginella. These, like the former, are leafless branches, having no other function than to bear the roots; they may also be regarded as being themselves modified roots. In some cases, as we have seen above (p. 244), their structure shows some slight approximation to that of Stigmaria ficoides. The position of the rhizophores on the stem is, it is true, very different in the two genera, but this is not an insuperable difficulty, for we are not assuming a strict homology, but rather suggesting a parallel modification.

It may be suggested that the terminology most in harmony with the facts would be to call the main axis of Stigmaria a rhizophore, and its appendages roots. Considering, however, that even in existing Lycopods, as notably in Lycopodium itself, the differentiation between root and stem is often far less sharp than in other vascular plants, ${ }^{1}$ we need feel no great scruple in applying the terms roots and rootlets to the Stigmarian organs, as was constantly done by Williamson, their chief investigator. Some further suggestions will be considered in Chapter XIV.

\section{LyCOPODITEAE}

Under this name are included certain fossil Lycopods, occurring from the Devonian onwards, which

${ }^{1}$ On this subject see C. E. Jones, "Morphology and Anatomy of the Stem of the Genus Lycopodizum," Trans. Linnz. Soc. ser. ii. vol. vii. I905; G. Wigglesworth, "Young Sporophytes of Lycopodium complanatum and L. clavatum," Ann. of Bot. vol. xxi. I907. 
appear from their habit to have been herbaceous plants. One such herbaceous Lycopod-Miadesmiahas already been described in connection with its seedlike fructification (p. I 97). As a rule, the Lycopoditeae are only known as impressions, but in favourable cases the essential morphological features can be recognised in these carbonised specimens. The plants, which until recently were all included in the genus Lycopodites, branched dichotomously, and have quite the habit of recent Lycopods; in some the leaves are uniform, as in most species of Lycopodium, while in others they are ranged in four rows, two of large and two of small leaves, just as in many species of Selaginella. This character is not, of course, sufficient in itself to establish affinity; within the last few years, however, the reproductive organs have been investigated in certain species and a clear relationship to Selaginella shown to exist. The genus Selaginellites has been founded by Zeiller for species known to have been heterosporous. S. Suissei, Zeiller, ${ }^{1}$ from the Upper Coal-measures of Blanzy in France, has a dichotomous stem, with four rows of dimorphic leaves of the type of the tetrastichous Selaginellas. The strobili are of considerable size, $8-10 \mathrm{~mm}$. in diameter by $15 \mathrm{~cm}$. in length, with the sporophylls in numerous vertical series. The sporangia of the upper part of the cone contain numerous microspores, $40-60 \mu$ in diameter, while those of the lower part are megasporangia, each of which contains from sixteen to twenty-four megaspores, about ten

1 Zeiller, "Bassin houiller et permien de Blanzy et du Creusot," Fasc. ii,, Flore fossile, 1906, p. I40. M. Zeiller's observations were first published in 1900. 
times the diameter of the microspores $(500-650 \mu)$. Both kinds of spore have an equatorial ring or collar. The chief differences from Selaginella are in the numerous series of sporophylls, as compared with the tetrastichous vegetative leaves, and the relatively large number of megaspores in the sporangium, while in Selaginella they do not exceed four. M. Halle, in his recent paper on fossil herbaceous Lycopods, ${ }^{1}$ describes a Coalmeasure species ( $S$. elongatus (Goldenberg)), likewise with dimorphic foliage, in which the sporangia appear to arise in the axils of ordinary leaves, no strobilus being differentiated. Microspores were not observed, but some of the sporangia were found to contain from twenty to thirty spores, about $450 \mu$ in diameter, so there can be no doubt that the species was heterosporous; the absence of a specialised strobilus is interesting, as no such case is known among recent Selaginellas. Another species of similar age, investigated by $M$. Halle, S. primaevus (Goldenberg), is remarkable for its close agreement with the recent genus. In this case definite terminal strobili are differentiated; the sporophylls as well as the leaves of the smaller branches are uniform and spirally arranged (as in Selaginella spinosa), though it is possible that dimorphism may have occurred in the main stems. The most interesting point is that each megasporangium contained four tetrahedrally arranged megaspores (400-500 $\mu$ in diameter), just as in the living Selaginellas. Thus the Selaginella type, if not the actual genus, is shown to date from Palæozoic times. The species S. Suissei and

1 Halle, "Einige krautartige Lycopodiaceen Paläozoischen und Mesozoischen Alters," Arkiv för Botanik, Stockholm, 1907. 
S. elongatus may represent a less advanced condition, but it must be remembered that Miadesmia, a contemporary or older genus, went far beyond any other known herbaceous Lycopods in the specialisation of its megasporangia. Nothing certain is known, as yet, of any homosporous type of Lycopoditeae. If, however, the Rhaetic plant Naiadita is rightly referred to Lycopodiaceae, we may have an example from the Mesozoic, for the spores, which are found grouped in tetrads in the sporangia, have a diameter of $80 \mu$, and only one kind has been observed. ${ }^{\text {I }}$

\section{CONCLUSION}

We have now completed our survey of the Palæozoic Lycopods, a group remarkable for the high development which they attained, both in vegetative and reproductive characters. The anatomical complexity of the Lepidodendreae was clearly correlated with the arboreal habit, which was then so prevalent. Apart from this, the structure, so far as the primary tissues are concerned, was on the whole of a simple type-simpler than that of the majority of recent Lycopods. The remarkable morphology of the subterranean organs (Stigmaria) may possibly indicate a somewhat primitive stage in the differentiation of root and shoot, though it may also be interpreted as a special modification, due to the peculiar conditions of growth. The morphology of the vegetative organs, even in the highly organised Lepidodendreae, is not in itself

1 See Miss J. B. J. Sollas, "Naiadita lanceolata," Quart. Joum. Geol. Soc. vol. Ivii. I901, p. 307. 
inconsistent with the view that the Lycopods are among the most primitive of Vascular Plants.

On the other hand, the reproductive organs were generally of a very advanced type. With the still doubtful exception of Spencerites, it appears that all Palæozoic Lycopods of which the reproduction is known were heterosporous, and this applies, so far as our information extends, to the herbaceous as well as the arboreal forms. Lepidocarpon among the latter, and Miadesmia among the former attained, in the evolution of an organ closely analogous to a true seed, a higher level than any existing members of the Class, and rivalled the Spermophytes themselves.

Recent discoveries appear to show conclusively that Selaginella, at all events, had no direct connection with the Lepidodendreae, but sprang from a distinct and equally ancient herbaceous stock. If any modern member of the Class can claim affinity with the Tree Lycopods of the Palæozoic, it would appear to be the greatly reduced genus Isoëtes. ${ }^{1} \quad$ No light has yet been thrown on the ancestry of Lycopodium, which certainly had no near relation to any of the Palæozoic forms in which the nature of the spores has been determined.

In spite of the high organisation of the Palæozoic Lycopods, it is very doubtful whether they have any true affinity with the Seed-plants which some of them simulate, but this is a question which may best be postponed to the concluding chapter.

1 See Chapter XIV. 


\section{CHAPTER VIII}

THE FERNS

\section{Fronds; Fructifications; Anatomy}

WE have now reached the fourth of the classes, or phyla, under which the Vascular Cryptogams-recent and fossil-naturally group themselves. This fourth phylum is that of the Filicales, or Ferns in the widest sense; among all the Pteridophyta it is this stock which holds the strongest position at the present day. The Lycopods are unimportant now, compared with what they once were; the Equisetales survive only in one single genus; the Sphenophyllales disappeared altogether about the close of the Palæozoic period. ${ }^{1}$ But the Ferns form one of the most prominent groups among living vegetation, numbering, on the most moderate computation, not less than 60 genera and 3000 species.

Until quite recently all palæobotanists held that the Ferns were even more important in Palæozoic times than they are at present, in fact that they were the dominant class of plants at that period. According to

1 Unless we regard the Psilotaceae as their last surviving remnant; see the concluding chapter of the book. 
the estimates of the systematists the Ferns constituted almost exactly half of the total number of species known from the Carboniferous rocks. Now, however, the position has completely changed, so much so that Professor Zeiller, speaking of the Lower Carboniferous Flora, says that the Ferns, "though they were probably not entirely absent, occupied an altogether subordinate rank." 1 The ground for this radical change of view is to be found in the recognition of a new class of seed-bearing plants, the Pteridosperms, to which, as it now appears, the majority of the supposed Palæozoic Ferns really belonged. This class coincides in part with the Cycadofilices dealt with in the first edition of this book, but has proved to be much more extensive, and also more remote from the Ferns, than was realised at that time.

The reduction in the number of the true Ferns becomes more marked, the earlier the period to which we go back. "The Westphalian" Flora," according to Professor Zeiller, "is already less rich in true Ferns than the Stephanian, and one might almost raise the question whether in the epochs of the Culm ${ }^{4}$ and Devonian, Ferns really existed." The Pteridosperms, in fact, appear to be actually older than the majority of the known Ferns, though certain groups of the latter, such as the Botryopterideae, to be subsequently described, are doubtless of great antiquity.

From the characters of the frond alone (the part

1 Zeiller, "Une nouvelle Classe de Gymnospermes : Les Ptéridospermes," Rev. Générale des Sciences, I6me année, I905.

2 Middle and Lower Coal-measures.

U Upper Coal-measures.

4 Lower Carboniferous. 
most commonly preserved) it is now impossible to say whether a given Palæozoic plant belonged to the true Ferns or to the Fern-like Seed-plants.

It is probable that the impressions of "Fern-fronds," often preserved in such exquisite beauty in the strata of the Coal-measures, are better known to the nonbotanical observer than any other specimens of fossil plants. The character of such leaves has specially lent itself to this mode of preservation, and as regards form and venation, nothing more perfect could be desired than many of the impressions from the Carboniferous and other strata.

Almost all the well-known genera of conspicuous Fern-like fronds have now, however, fallen under suspicion. In several of them the presence of seeds has been actually demonstrated, in many others all the probabilities point the same way, but there is good reason to believe that some of these artificial form-genera include true Ferns as well as Seed-plants of similar habit. It will therefore be necessary, before going further, to say something of the fronds hitherto attributed to Ferns.

I. Fronds.-Brongniart was the first to construct a regular system of classification of the Fern-like plants, based entirely on the form and venation of the leaf, and since his time this system has been further elaborated, so that any fossil "Fern-frond" can now be referred to a provisional genus and species, according to its conformation and the course of its veins. The same system can be, and has been, applied to recent Ferns, and has, of course, proved to be purely artificial. 
It would be quite useless for us to go into the distinctive characters of these provisional genera, which, while they are of the greatest use to those working practically at fossil floras, tell us nothing by themselves as to affinities. It will be sufficient to explain two or three of the principal generic names, which will frequently recur in our subsequent descriptions.

One of the largest of the artificial genera is that named by Brongniart Pecopteris, which includes many of the most striking Carboniferous "Fern-fronds," and is of special interest, because a good deal is known as to the fructification and anatomical structure of various plants which possessed this type of leaf. It is certain that some of its members were seed-bearing plants, but there is still a strong probability that others were true Ferns. The characters are thus given by M. Zeiller, whose diagnosis I have somewhat abridged:- " Fronds generally tripinnate, often quadripinnatifid or quadripinnate, more rarely bipinnate only. Rachis of diverse orders naked between the pinnae, or bearing pinnules between the latter. Pinnules attached to the rachis by their whole breadth, usually very broad, contiguous, sometimes more or less confluent, with parallel or slightly convergent margins, usually entire, more rarely lobed or dentate; apex usually obtuse, sometimes acute. Median nerve distinct, extending almost to the apex of the pinnule; secondary nerves pinnately arranged, always springing from the median nerve, with which they make a wide angle, and not directly from the rachis; sometimes simple, sometimes dichotomous." 1

${ }^{1}$ Bassin houiller et permien d"Autun et d" Épinac, Flore fossile, Part i. I890, P. 4I. 
The more essential characters are indicated by italics.

Among recent Ferns this form of frond is best represented among some of the Tree-ferns (Cyatheaceae). Fig. 107, illustrating the species $P$. (Dactylotheca $)^{1}$ dentata, will give a sufficient idea of the habit of a Pecopteris frond, though the true affinities of the plant are

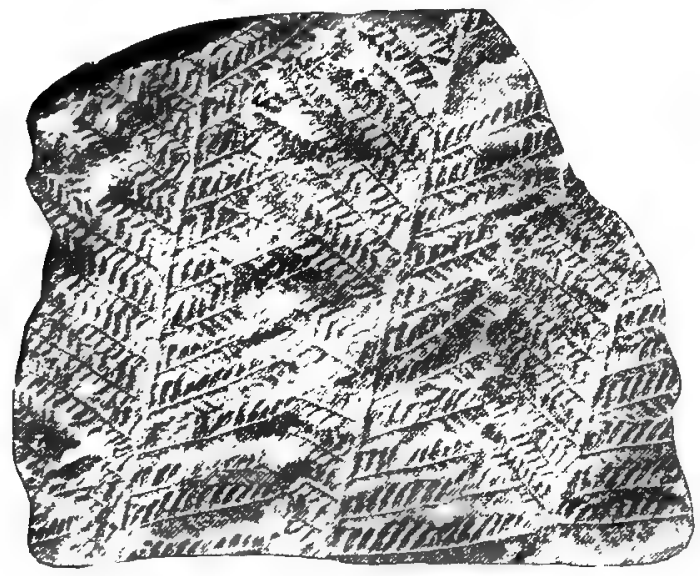

Fic. 107.-Pecopteris (Dactylotheca) dentata. Part of a frond, with the matrix. Reduced. From a photograph by Mr. W. Hemingway.

doubtful. There is good evidence that some of these fronds were really borne by Tree-ferns of the Carboniferous epoch, belonging, however, to a family quite distinct from that which includes our recent arborescent Ferns. A considerable variety of fructifications has been found in connection with fronds of the Pecopteris type; in many cases the reproductive characters point

1 The second generic name, Dactylotheca, is based on the fructification, which happens to be known in this species. It may be Pteridospermous (see Fig. IO9, C). 
to an affinity with Marattiaceae, but in others they are of quite a different nature.

The important form-genus Alethopteris, ${ }^{1}$ which comes near Pecopteris in foliar characters, is postponed to a future chapter, because there is reason to believe that all, or almost all, the species belonged to seed-bearing plants. The same remark applies to Neuropteris. We will therefore pass on to another of the great frondgenera, Sphenopteris, the characters of which are as follows:- "Fronds generally tripinnate or quadripinnate, more rarely bipinnate; pinnules usually small, contracted at the base, with a more or less narrow pedicel, habitually divided into acute or rounded lobes, which are themselves contracted into a wedge towards their base. Nervules simple or branched, forming acute angles both with the median nerve and with their own branches." 2

Generally speaking, the habit of the species of Sphenopteris, a most heterogeneous group, may be compared with that of members of the recent genus Asplenium (see Fig. I60, Chapter X.). The Sphenopteris type of frond is of great interest, not only on account of the elegance of its varied forms, but also from the fact that a great variety of fructifications, both Filicinean and Pteridospermous, have been referred to it.

The genus Diplotmema, Stur, as limited by Zeiller, ${ }^{3}$ differs from Sphenopteris, only in the fact that the primary pinnae are forked, dividing into two similar branches, each of which is repeatedly subdivided, after the manner of Sphenopteris.

1 See Chapter XI. Fig. 162.

2 Zeiller, l.c. p. $30 . \quad 3$ l.c. p. 37. 
In some species of Sphenopteris the main rachis is itself forked. These species, as well as Diplotmema, no doubt represent the foliage of Pteridosperms, but some other Sphenopterid fronds are known to have borne fructifications referable in all probability to Ferns (e.g. Oligocarpia, Corynepteris).

It will, of course, be understood that there are many other form-genera to which Fern-like fronds are referred by systematists; the enumeration of these would serve no purpose here. Full accounts of the artificial system of classification will be found in any of the manuals of fossil botany. Some other types of frond will be referred to in describing the Pteridosperms, for in the majority, as mentioned above, the evidence, either direct or indirect, indicates that the leaves in question belonged to seed-bearing, plants. The well-known example of the recent Stangeria, which, when first discovered, was referred to the Fern-genus Lomaria, already showed plainly enough that Fern-like foliage is not necessarily any proof of close affinity with Filicineae. $^{1}$

Before leaving the subject of the fossil Fern-like fronds, we may briefly mention the curious stipellar outgrowths, or adventitious pinnae, as they have been called, which occur on the rachis of many of these leaves, and.are usually known as Aphlebiae. These bodies, when detached from the frond, have been described as independent genera of Ferns, or even as

1 It is now generally acimitted that there is a real relationship between the Cycadaceae (to which Stangeria belongs) and the Ferns, so that the occasional resemblance in the leaf-characters is not wholly without significance. The question is discussed at length in the following chapters. 
Fucoid Algae, and when found in situ have sometimes been interpreted as epiphytic Hymenophyllaceae. There is, however, no longer any doubt that they formed part of the fronds on which they occur. The Aphlebiae are present in considerable numbers, along the rachis and its branches, in various forms of Sphenopteris, Pecopteris, Neuropteris, etc. They are common to fronds which were probably those of true Ferns, and to leaves which belonged to Pteridosperms. In some cases the Aphlebiae are entire, orbicular or spathulate, in others they are finely divided in a dichotomous or pinnate manner. They usually differ entirely in form from the normal pinnae of the frond to which they belong, but in some cases transitional conditions have been observed. The position of these organs shows that they are not directly comparable with the stipules of the Marattiaceae; the best analogy which has been suggested for them is with the feathery outgrowths which occur on the base of the rachis in the recent Cyatheaceous Fern Hemitelia capensis. In this case, as in that of the fossil forms, they were at one time described as independent parasitic Filmy Ferns. ${ }^{1}$ M. Zeiller has pointed out that somewhat similar anomalous pinnae are also produced on the rachis of various species of Gleichenia, at the point where the frond resumes its growth after a period of rest.

2. Fructifications.-We will now endeavour to gain an idea of the nearer affinities of some of the fossils which there are still grounds for referring to the class

1 See Schenk, "Palæophytologie" (in Zittel's Handbuch der Palaonto. logie, vol. ii. 1890), p. I4I. 
Filicales. The evidence from the fructification, when available, was formerly considered decisive, but we shall find that this is no longer necessarily the case (see p. 289); anatomical characters, if carefully interpreted, may carry equal weight.

A few of the chief forms of fructification attributed to Palæozoic Ferns will now be considered, in relation, where this is possible, to the form and structure of the fronds on which they were borne. Certain special groups, in which our knowledge of the plant as a whole is more complete than usual, will be dealt with later on (Chapter IX.).

In the majority of cases, fossil fructifications referable to Ferns have been found on specimens preserved as impressions. In favourable instances such specimens may show something of the structure, as well as the form of the reproductive bodies, for spores and the walls of sporangia usually have more or less cuticularised membranes, so that they withstand decay, and may often be found in a recognisable form in the carbonaceous layer coating the surface of the impression. In other cases, again, petrified fructifications have been found, and here, of course, the evidence as to structure is far more satisfactory, though the petrified specimens are usually fragmentary, and hence difficult to correlate with those in which the external characters are shown.

It has been customary, for some time past, to divide living Ferns into two rnain series-the Eusporangiatae and the Leptosporangiatae-according to the development of the sporangium, which arises from a group of cells in the former, and from a single cell in the 
latter series. The distinction, though not so absolute as was at first supposed, coincides well enough with natural divisions, for the only two Eusporangiate families - the Marattiaceae and the Ophioglosseae-are very distinct from any of the Leptosporangiate groups. ${ }^{1}$ In the living flora the latter enormously outnumber the former, as regards both genera and species. In dealing with fossil specimens it is, of course, impossible to study the development of the sporangium, and our judgment as to affinities must necessarily be based on the mature characters. The sporangia of the Marattiaceae and Ophioglosseae are, on the whole, of relatively large size, attached to the frond by a broad base, with a wall more than one cell thick, and without a definite annulus, though its place may be taken by a small group of thickened cells. In the former of the two families, we have also to consider the grouping of the sporangia, which are often united together in each sorus to form a synangium. Among the Palæozoic plants with a Fern-like fructification we find a surprisingly large proportion which present these characters, or some of them, and it was hence inferred, apparently with good reason, that in those early days the Eusporangiate section of Ferns, now so restricted, was predominant. It is especially the Marattiaceae to which this conclusion applied; the Ophioglosseae have not been determined, from the earlier strata, with any degree of certainty.

We will first consider a few representative fructifications of the Marattiaceous type, postponing the question whether they actually belonged to Ferns of that family

${ }^{1}$ See, however, Professor Bower's arrangement, given below, p. 352. 
or not, and will begin with one in which very definite confluent synangia were present.

This fructification, to which the generic name of Ptychocarpus, Weiss, has been given, was borne on leaves of the Pecopteris form; the species described is $P$. unitus, Brongn., from the French Coal-measures.

The fructification of Ptychocarpus unitus was borne on the ordinary frond. The sporangia are grouped six to eight together, in circular sori; the sporangia of each sorus or synangium are united laterally among themselves, and are at the same time adherent to the central receptacle, which rises up in the middle of the group (see Fig. I08, C). The synangia are ranged in one or two series, along each side of the median nerve of the fertile segment (Fig. I08, A). They are prominent and shortly-stalked bodies (Fig. I08, B), which often became detached entire from the surface of the pinnule. As shown by the transverse section, each sporangium has a wall, or rather perhaps a tapetum, of its own, but the whole sorus is embedded in a delicate tissue, which is quite continuous round the periphery (Fig. I08, C). The receptacle is traversed by a vascular strand. The spores in each sporangium are numerous and very small, measuring. only from $I 8$ to $20 \mu$ in diameter. There is no trace of an annulus. M. Renault, to whom our detailed knowledge of this fructification is due, conjectured, with much probability, that each sporangium discharged its spores through an apical pore. In general characters, the Ptychocarpus fructification approaches most nearly to that of the recent genus Kaulfussia, in which the synangia are also circular, but there are many 
differences in detail. In Kaulfussia the interior of the synangium is hollowed out into a cup, into which the sporangia open, dehiscence taking place on the inner
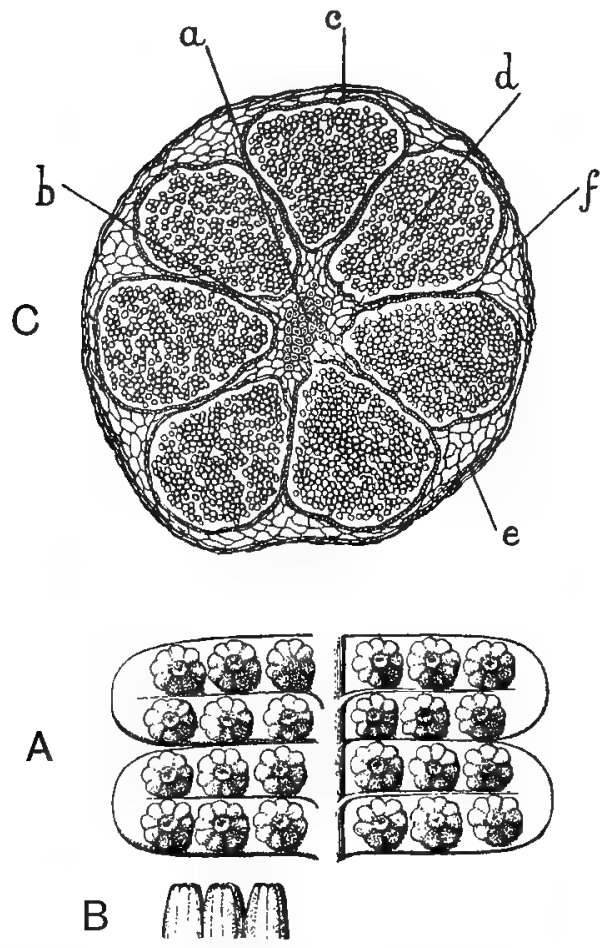

Fig. I08.-Ptychocarpus unitus. Fructification. A. Part of a fertile pinnule (lower surface), showing numerous synangia. B. Synangia in side-view. A and $B \times$ about 6 . After Grand'Eury. C. A synangium, in section parallel to the surface of the leaf, showing seven confluent sporangia. $a$, bundle of receptacle; $b$, its parenchyma; $c$ tapetum; $d$, spores; $e, f$, common envelope of synangium, $\times$ about 60 . After Renault.

face of each sporangium. In the fossil genus there is no central depression, and, as the entire synangium was embedded in a continuous enveloping tissue, dehiscence could only have taken place at the apex. 
The fructification of Ptychocarpus unitus is, however, a good example of a typical Marattiaceous synangium, and affords strong evidence as to the affinities of the plant. ${ }^{I}$

Mr. Watson has recently described, under the name Cyathotrachus altus, a synangium of Lower Coalmeasure age, differing from Ptychocarpus in its taller shape, in having a cup-like central depression, and in the presence of tracheides at the base of the sporangia ; in the two latter characters it approaches Kaulfussia. The specimens were isolated, but were associated with a pinnule, probably of a Pecopteris. There is a presumption in favour of Marattiaceous affinities, but the same doubts apply here as in other cases of the kind. ${ }^{2}$

The important genus Asterotheca resembles Ptychocarpus $^{3}$ in the fact that in each sorus the sporangia are grouped in a ring around the receptacle, but the receptacle is short, the sporangia are usually from three to six only in number, and are less closely united to one another. The sori are ranged on the under surface of the pinnule in two rows, one row on each side of the median nerve (see Fig. 109, A). The individual sporangia are ovoid in shape, and there is reason to believe that when ripe they separated from each other, bending outwards from the central receptacle, and dehiscing by a longitudinal opening on the inner

${ }^{1}$ See Renault, Bassin houiller et permien a'Autun et d'Êpinac, Part ii. p. 9.

" D. M. S. Watson, "On a 'Fern' Synangium from the Lower Coalmeasures of Shore, Lancashire," Joumal R. Microscop. Soc. 1906, Part i.

3 These genera are founded solely on the fructification, and are thus likely to represent more natural groups than those based on the form and venation of the frond. See Stur, "Zur Morphologie und Systematik der Culm- und Carbonfarne," K. Akad. a. Wiss. Vienna, 1883. 


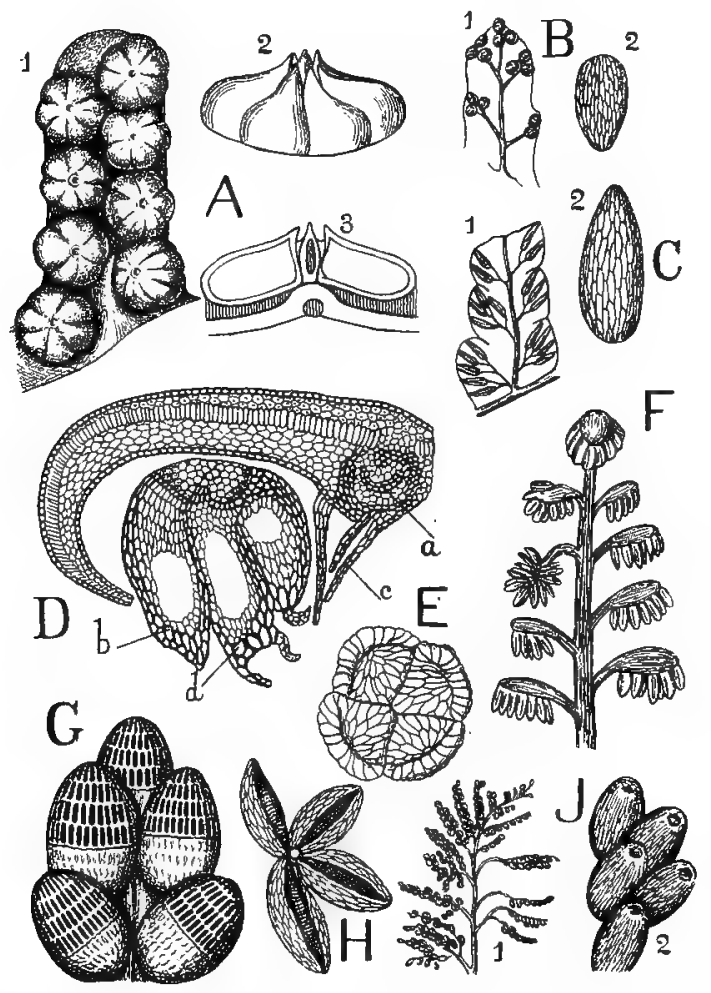

FIG. Iog.-Group of Palzozoic fructifications of Ferns or Pteridosperms. A. Asterotheca (probably Marattiaceous). I. Fertile pinnule showing eight synangia. Enlarged. 2. Synangium in side-view ; 3 . in section (diagrammatic). After Stur. B. Renattltia, Zeiller (affinities doubtful). I. Pinnule, showing sporangia on veins. Nat. size. 2. Single sporangium. Enlarged. After Zeiller. C. Dactylotheca (affinities doubtful). r. Pinnule, showing sporangia on veins. Nat. size. 2. Single sporangium. Enlarged. After Zeiller. D. Sturiella, Weiss (cf. Corynepteris). Transverse section of pinnule, showing a synangium. $a$, vascular bundle of pinnule; $c$, hairs; $b, d$, annulus of confluent sporangia. $\times 8$. After Renault. E. Otigocarpia (cf. Gleicheniaceae). Sorus in surface-view. Magnified. After Stur. F. Crossotheca ( $\delta$ of Lyginodendreae). Fertile pinna, bearing several pinnules with sporangia. Enlarged. After Zeiller. G. Senftenbergia (cf. Schizaeaceae). Tip of fertile pinnule, showing five annulate sporangia. Magnified. After Renault. H. Hrawlea (probably Marattiaceous). Synangium, after dehiscence of the sporangia. Magnified. After Stur. J. Urmatopteris (affinities doubtful). I Part of fertile pinna. Nat. size. 2. Sporangia, enlarged, showing apical pores, After Kidston. 
side of each sac. Certainly some of the preparations show quite clearly that the sporangia are separate down to the base of the synangium. Forms with the sporangia distinctly separate are, however, regarded by Stur as constituting a different genus, to which he has given the name Hartea (see Fig. I09, H). It thus appears that in Asterotheca and allied fructifications, the cohesion of the sporangia was much less perfect than in the living Marattiaceous genera Kaulfussia, Danaea, and Marattia.

A number of species with fronds of the Pecopteris type are known to have borne the fructifications of Asterotheca. They are chiefly characteristic of the Upper Coal-measures and Permian.

The genus Grand'Eurya of Stur is interesting from its resemblance to the recent Angiopteris. The fructifications in question were first described by Renault from silicified specimens, and referred by him to two species of Pecopteris, $P$. oreopteridia and $P$. densifolia. ${ }^{1}$ The sporangia are inserted along either side of the lateral veins of the fertile pinnules, and appear to be quite free from each other. There is, however, some indication of a grouping of the sporangia in fours. Thus in Grand'Eurya Renaulti of Stur (attributed to $P$. oreopteridia by Renault) there are usually eight sporangia belonging to each lateral vein, and forming apparently two quadrate groups of four each. On account of the latter arrangement, Zeiller attributes these species to the genus Asterotheca; in Grand'Eurya there seems to be no formation of synangia, butZeiller considers that this condition, as in Hawlea, is only due to age.

1 Renault, Cours de Bot. Fossile, t. iii. I883, p. IIO, Plate I9. 
Another genus, Scolecopteris, also belonging to Pecopteris according to its foliar characters, has the same arrangement as in Asterotheca, but the synangia are stalked, and the sporangia long and sharply pointed at the apex. Fructifications of Scolecopteris have been found in a silicified condition, and their structure has thus been more thoroughly investigated than is usually possible. In one species, S. polymorpha, the large tripinnate fronds bear two long rows of sori on the lower surface of each pinnule. The sporangia in each sorus are four in number; they are free for the greater part of their length, which reaches about $4 \mathrm{~mm}$; at their base they are attached to the surface of the pinnule, and on their inner side to a short receptacle, not more than one-third as long as the sporangia (see Fig. I IO). The receptacle is described by M. Renault as having a cruciform transverse section, each arm of the cross corresponding to one of the four sporangia constituting the synangium (see Fig. I IO, A, sp). Each of the long, pointed sporangia has a wall with thickened cells on its free outer surface, but on the inner side the wall is thin. It is probable that this unequal thickness of the wall caused the dehiscence of the sporangium on the inner side, and thus worked in the same way as the annulus of ordinary Ferns. The margins of the pinnule were incurved, so as to partly cover in the sori. Another species of Scolecopteris, S. elegans, was investigated many years ago by Strasburger. ${ }^{2}$ The sporangia are here smaller, and there are often five in each sorus. Towards the base they are confluent with one another,

1 Renault, l.c. p. II6, P1. 20, Figs. I-Io (Pecopteris polymorpha). 2 Jenaer Zeitschrift fïr Naturwissenschaft, vol, viii. 1874. 
and with the central receptacle; higher up they become free, and dehiscence appears to have taken place on the inner side, where the sporangial wall was thinnest. Strasburger's remarks on the affinities of

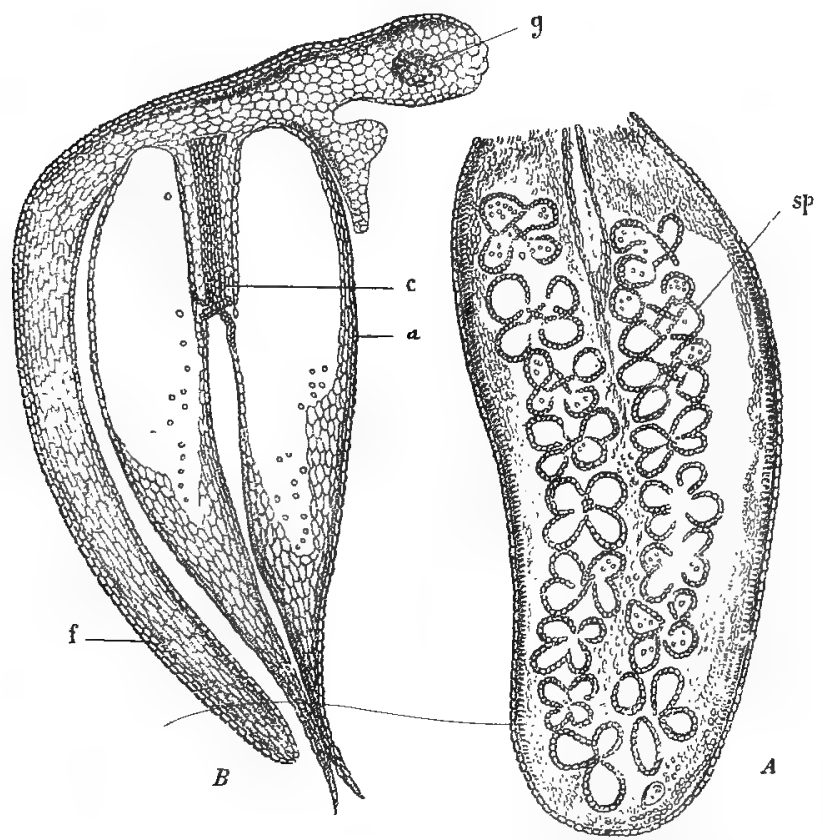

FIG. rro.-Scolecopteris polymorpha. A. Lower surface of a fertile pinnule, showing numerous quadrisporangiate synangia $(s p)$. Note the cruciform receptacle at the centre of some of the synangia. $\times$ about 8 . B. Transverse section of half a pinnule, passing through a synangium. $g$, vascular bundle of pisnule; $f$, infolded margin of pinnule; $a$, wall of sporangium; $c$, receptacle, fused to the sporangia. $\times$ about 18 . After Renault.

this fossil may be quoted, for they apply to the genus as a whole, and express the view still generally held. "Zenker's Scolecopteris elegans, according to the formation of its sorus, certainly belongs to the Marattiaceae, and, in fact, comes nearest the genus Marattia in the 
form of the sporangia of which the sori are composed, while it approaches the genus Kaulfussia in the circular grouping of the sporangia, and finally resembles the genus Angiopteris in the fact that the sporangia become free in their upper part. In the mode of dehiscence of the individual sporangia, Scolecopteris agrees with all three genera mentioned, but the similarity to Maratia is again the most striking, to which it also bears the greatest resemblance in the structure of the sori."

So far as the pedicellate sori are concerned, the agreement is especially close with the subgenus Eupodium of Marattia.

In the genus Dactylotheca of Zeiller, another of the Pecopteris group (see Fig. I 09, C), the sporangia are somewhat similar in form to those of Scolecopteris. They are, however, completely independent of one another; each sporangium is placed singly over a lateral vein. The line of dehiscence can be recognised, but there is no trace of an annulus; it is mainly on this ground that Dactylotheca and various other genera with separate sporangia have been placed in the Marattiaceae. For example, in the genus Renaultia of Zeiller ${ }^{1}$ (see Fig. I O9, B), the ovoid sporangia are independent, isolated, or grouped in small numbers at the extremity of the nerves. In this case there is an indication of a rudimentary annulus, like that of the recent Angiopteris, at the apex of the sporangium. Renaultia, Zeill., was the fructification of certain species with fronds of the Sphenopteris type.

1 Hapalopteris of Stur, whose genus Renaultia is quite different, having typical synangia. The nomenclature of these fructifications is lamentably involved. 
It must be confessed that in such cases the reference to Marattiaceae has always rested on very slender evidence. Where no synangium is formed, and the sporangia are not even grouped in definite sori, we really have very little to go by, in default of anatomical evidence, for the mere absence or rudimentary development of the ring is of course no proof of Marattiaceous affinities. The position of genera such as Dactylotheca and Renaultia is entirely doubtful, and it is quite possible that their fructifications may really be of the nature of microsporangia, the plants being in that case Pteridosperms and not Ferns.

Among the Palæozoic plants with definite synangia, the circular or radiate type of synangium, now limited to the genus Kaulfussia, seems to have prevailed. In the genus Danaeites, however, which includes some Pecopteroid forms from the Coal-measures, the synangia were linear in shape, and appear to have closely resembled those of the recent genus Danaea. In this case the sporangia were arranged in a double row along each secondary nerve of the fertile pinnule; they were sunk in the tissue of the lamina, and fused laterally with one another, the constituent sporangia each dehiscing by an apical pore. The agreement with the recent genus was thus remarkably exact.

The forms hitherto described bore their sporangia on the ordinary vegetative fronds, as is the case with a majority of the Ferns at the present day. A considerable number, however, of the Palæozoic Fern-like plants were dimorphic, the sporangia appearing on fertile leaves, or parts of the leaf, quite different in form from the sterile foliage. 
Many of these dimorphic fronds no doubt belonged to Pteridosperms and not to Ferns. Thus a species of Crossotheca (Fig. I09, F) has been shown by Mr. Kidston to be the male fructification of Lyginodendron (Chapter $\mathrm{X}$.) ; Calymmatotheca is now known to represent a condition of the seed-bearing apparatus of the same genus; Urnatopteris (Fig. IO9, J) is probably, like Crossotheca, a microsporangiate fructification. Some examples of dimorphic fronds in plants which appear really to come under the head of Ferns will be given in the next chapter in describing the Botryopterideae.

Before leaving the supposed Marattiaceous fructifications, we may shortly refer to a genus which combines Marattiaceous characters with those of other families. This is the Sturiella of Weiss (Renaultia of Stur). The structure of the leaf and sorus was worked out by Renault ${ }^{1}$ from silicified specimens. The frond was of the Pecopteris type, though its form is not completely known, as the specimens were fragmentary. The sori are ranged in two series on the pinnule, along either side of its median nerve. Each sorus constitutes a synangium, for the five sporangia of which it consists are fused at the base, and attached by a short common pedicel to the lower surface of the pinnule (see Fig. I 09, D). Hence their arrangement is altogether that of a Marattiaceous Fern. The structure, however, of the individual sporangia is peculiar, for the free end of each is capped by an apical annulus of large thick-walled

1 Cours de botanique fossile, vol, iii. p. 122, I883. M. Renanlt named the species Pecopteris intermedia. Stur appropriately founded the genus Renaultia for its reception, but this generic name was adopted slightly earliẹ by Zeiller for another fructification, above mentioned. 
cells, which also extends for some distance along the outer side of the sac (Fig. I O9, D, $b, d$ ). The annulus is accompanied by multicellular hairs.

The leaf was a thick fleshy one, with a layer of palisade-cells, but the most characteristic anatomical peculiarity is the horse-shoe bundle of the midrib (Fig. rog, D, a). Authorities differ as to the systematic position to be assigned to this curious Fern. Stur, relying on the characters of the sorus, places it among Marattiaceae, near Asterotheca and Scolecopteris, while Zeiller rejects this attribution, on account of the well-marked annulus. The latter feature suggests a comparison with Schizaeaceae or Osmundaceae, but Zeiller leaves the position of the genus an open question. On the whole, the balance of characters seems to weigh on the side of Marattiaceae, for there is no reason why the annulus, still represented at the present time in Angiopteris, should not have been more highly developed in some Palæozoic members of the family. A relation, through Corynepteris, to the Botryopterideae is also possible (see next chapter, pp. 323,344 ).

This brings us to yet another genus, Senftenbergia, of still more dubious affinities. Several species have been included under this genus, the foliage of which was of the Pecopteroid type. The sporangia are inserted singly over the lateral nerves of the pinnules, near their outer end, so as to form a marginal series. There is thus no formation of synangia, or even of definite sori (see Fig. I09, G). In the typical species there is a definite apical annulus, several cells in width. Pecopteris exigua, referred to Senftenbergia by Stur, has no annulus, and appears to be a Crossotheca (see Chapter X.). The 
sporangia of Senftenbergia find their nearest parallel in the Schizaeaceae, to which family Corda, the discoverer of the genus, referred it. The pluriseriate structure of the annulus has been brought forward as an argument against this view, but in Lygodium, among recent Schizaeaceae, the annulus, as Zeiller has pointed out, is often more than one cell in breadth.

Upon the data available, it remains impossible to determine the position of the genus. The analogy with Angiopteris, on which Stur, who maintained the Marattiaceous affinities of Senftenbergia, laid stress, appears remote. There is, however, some evidence that in the fossil genus the sporangial wall was several cells in thickness, a character which points in the direction of Marattiaceae.

Sporangial characters, like any other characters, are, in fact, insufficient by themselves to determine the position of a genus in a doubtful case.

The evidence for the Marattiaceous affinities of such genera as Ptychocarpus, Asterotheca, Scolecopteris, and Danaeites, in which the fructification is in the form of synangia borne on the ordinary foliage, is still generally accepted, and is much strengthened by the presence, at -similar horizons, of stems (Psaronius) with a Marattiaceous anatomy (see below). Any doubt there may be arises from two considerations : (I) Practically all the fructifications in question were borne on Pecopteris fronds, and one species referred to Pecopteris ( $P$. Pluckeneti) is now known to have been a seed-bearing plant (see Chapter XI.); (2) a species of Crossotheca, formerly regarded as a Marattiaceous genus, has been shown by Mr. Kidston to be the male fructification of the Pteri- 
dosperm Lyginodendron, and the Crossotheca type occurs in species of Pecopteris (e.g. P. exigua) as well as in Sphenopteris. Even typical "Marattiaceous" synangia, such as those of Scolecopteris, are remarkably like other fructifications (Telangium Scotti, Benson) which there is reason to regard as microsporangia. Hence the question has arisen, whether all the supposed synangia of Marattiaceae may not represent the microsporangia of Pteridosperms, a suggestion which has been supported by the remarkably close agreement between the stamens of the Mesozoic Bennettiteae and the fertile fronds of Marattiaceae (see Chapter XIII.). On the whole, however, the balance of evidence, if we also take the anatomical data into account (see below, p. 294), is still decidedly in favour of the view that a considerable group of Marattiaceous Ferns existed in Carboniferous times, side by side with Pteridosperms of similar habit. The former are mainly, though not exclusively, characteristic of the Permian and Upper Coal-measures, and are not known to extend to the Lower Carboniferous.

As regards the other Eusporangiate family there is little to say. A couple of genera, Rhacopteris and Noeggerathia, formerly referred by Stur to the Ophioglosseae, were more probably the microsporophylls of Pteridosperms. A fructification resembling that of an Ophioglossum has been described by Renault, from the Permo-Carboniferous of Autun, under the name of Ophioglossites. We shall find in the Botryopterideae - to be described in the next chapter-a family, which, in certain characters, bears a resemblance to Ophioglosseae, though very different in other respects. There is some slight evidence for the existence in 
Palæozoic times of Ferns allied to Gleicheniaceae. As Professor Bower has pointed out, "the type of sorus" in Gleichenia "is that of the Marattiaceae." 1 Hence, on soral characters alone, it. would not be possible to distinguish between a fossil fructification of this family and one of the Marattiaceae with free sporangia arranged circularly. The genus Oligocarpia of Göppert, with Sphenopteroid foliage, bore such sori, which in surface view certainly look wonderfully like those of a Gleichenia (see Fig. I09, E). Each sporangium shows a transverse, or somewhat oblique annulus, just as in that genus; though some authors have denied that the apparent annulus is really distinct from the rest of the sporangial wall, the inspection of the specimens, especially those of $O$. robustior, Stur, leaves no doubt that the former interpretation is correct. Zeiller, who supports the Gleicheniaceous affinities of this genus, further cites certain isolated sporangia, which have been found in the Quartz of Autun, as having unmistakably the characters of that family.

Sporangia with a transverse annulus, much like that of the Hymenophyllaceae, have been observed on the fronds of some Sphenopteroid Ferns from the Coalmeasures (Hymenophyllites quadridactylites), but the evidence as to their position on the leaf is not sufficient to place the affinities of these fossils beyond doubt. The Devonian genus Archaeopteris or Palaeopteris, the type-species of which, the famous $A$. hibernica, is characteristic of the Old Red Sandstone of Ireland, was once referred by some authors to the Hymenophyllaceae, by

1 "Studies in Morphology of Spore-producing Members," Part iv., Phil. Trans. Roy. Soc. vol. 192, B, p. $38,1899$. 
others to the Marattiaceae, but is now regarded by Mr. Kidston as most probably a member of the Pteridospermeae.

The evidence for the existence of Palæozoic Osmundaceae is now under investigation $;^{1}$ it is not at all uncommon to find isolated sporangia in the petrified material, which might well be of that nature. The presence of a lateral group of enlarged cells, resembling the annulus or areola of Osmundaceae, is a frequent feature. Professor Bower some years ago drew attention to the Osmundaceous character of certain Carboniferous sporangia; ${ }^{2}$ some of the sporangia of this type no doubt belonged to the Botryopterideae described in the next chapter.

In the calcareous specimens showing structure, from the British Carboniferous strata, sporangia like those of Ferns are frequent enough, but unfortunately they are usually isolated, so that it is impossible to tell what was their arrangement, or to determine the nature of the leaf on which they were borne. The specimens, however, prove the frequency, in Palæozoic times, of free sporangia not grouped into synangia. They also prove that the presence of an annulus of some kind was almost as common then as now, though the form of the annulus was, no doubt, different from that usual among recent Ferns. The generic name Pteridotheca may conveniently be used provisionally for such

1 See the work of Kidston and Gwynne-Vaughan referred to below (pp. 345, 351).

2 "Is the Eusporangiate or the Leptosporangiate the more Primitive Type in the Ferns?" Annals of Botany, vol. v. 189I. The Sarcopteris Bertrandi of Renault also has Osmundaceous characters (see Cours de bot. foss., vol, iii. p. I29 Plate xxi. Figs. I2-15). 
unassigned petrified sporangia, of Palæozoic age, as possess an annulus or other characters indicating Filicinean affinity. In Figs. I I I and I I 2, examples of Fern-sporangia from the English Coal-measures are represented. In the former figure two sporangia are shown, seated side by side on a fragment of leaf, in which a vascular bundle with scalariform tracheides

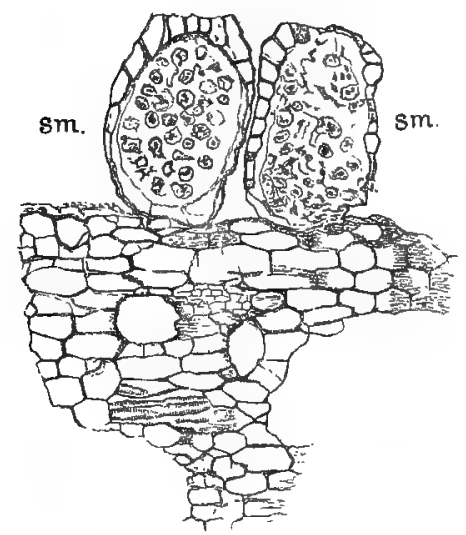

FIG. III.-Pteridotheca Butterworthii. Frag. ment of a Fern-frond from the Coalmeasures, in vertical section, showing two sporangia ( $(\mathrm{mm})$, each with an apical annulus, and containing spores. In the tissue of the leaf, part of a vascular bundle is shown. $\times$ 34. Will. Coll. I87 L. (G. T. G.)

is present. It will be noticed that the sporangia are free from each other, and that each shows a cap-like annulus, or group of enlarged cells, in the upper part. The fructification is certainly not a synangic one, but might conceivably belong to some Marattiaceous Fern comparable to Angiopteris, or might equally well be compared either with Schizaeaceae or Osmundaceae. An affinity with the Botryopterideae is, however, quite as probable (see next chapter). This fructification may be distinguished as Pteridotheca Butterworthii, after its discoverer.

In Fig. I I 2, on the other hand, we have a section passing through a large sorus, or rather a group of sori. The plane of the section was no doubt approximately parallel to that of the fertile frond, which was highly compound and apparently of the Sphenopteris type, the 
lamina being well developed, like that of a vegetative frond rather than a specialised sporophyll. The pinnules are much incurved, and the sporangia are seated on their margins. In the section figured, several

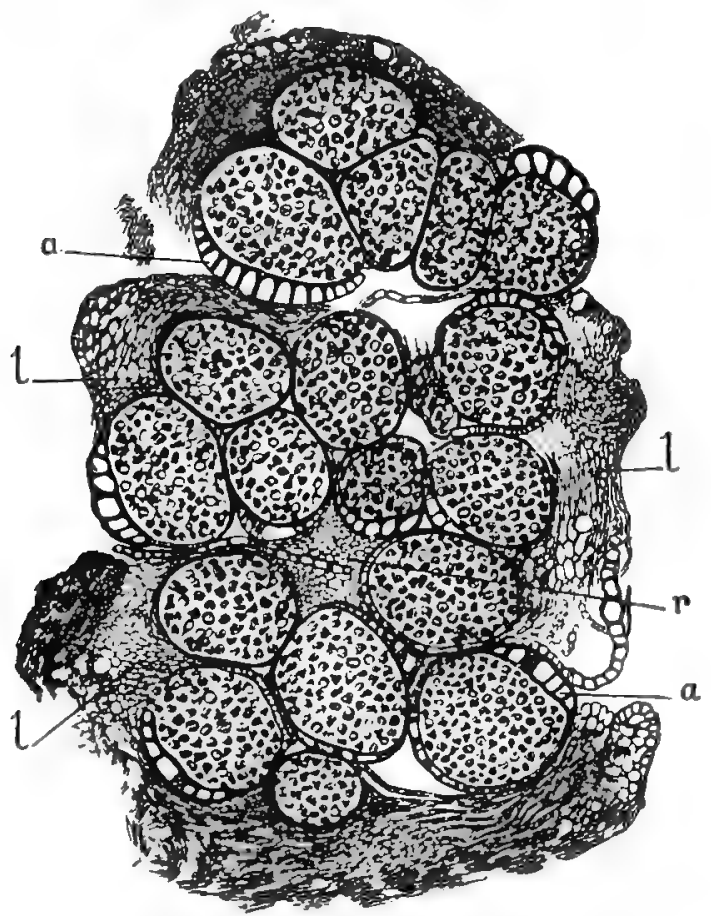

FIG. 1r2.-Pteridotheca Williansonii. Group of annulate sporangia, seen in section, parallel to surface of frond. The sporangia contain numerous spores; at $a$, the annulus is specially clear. $l, l, r$, parts of tissue of the fertile pinnules $\times 36 . \mathrm{S}$. Coll. 215 (Coal-measures). (G. T. G.)

pinnules, cut in various planes, are shown. The sporangia are scssile, with a multicellular base, and are of nearly spherical form, except where their sides are flattened by mutual pressure. The most striking feature of the sporangia, which contain numerous small 
spores, is the extreme distinctness of the annulus, which, when cut lengthways (a), quite suggests that of a Polypodiaceous Fern, and contrasts sharply with the small cells of which the remainder of the wall is composed. The annulus was evidently longitudinal or somewhat oblique, rather than transverse; it agrees in detailed structure with the annulus of recent Ferns, especially in the thinness of the external cell-walls, and the gradual thickening of the radial walls from without inwards; transverse sections of the annulus show, however, that it was regularly two cells in width, thus differing from that of any recent Ferns. Specimens of this fructification, which I have named Pteridotheca Williamsonii, are of frequent occurrence in the coalballs of the Lower Coal-measures, and the preservation is often remarkably perfect. There is every reason to believe that it belongs to a true Fern, though it would be futile to seek for any near affinities with recent families.

Postponing any further discussion of the extent and character of the Palaeozoic Fern-flora to the end of the following chapter, we will now pass on to consider some cases in which the anatomical structure is preserved, and affords evidence of Filiciaean affinities. We will first discuss an important group of stems in which the structure appears to be of a Marattiaceous type.

3. Anatomy - Psaronius. - Among the Fern-like remains from the Permo-carboniferous strata, and especially from their upper beds, specimens resembling Tree-ferns, in habit not altogether unlike those of the present day, are conspicuous. Some of these plants 
were of great size, with a stem reaching, it is said, as much as 60 feet in height.

The arrangement of the leaves on these trunks showed more variety than exists among living Treeferns. Thus, in the genus Megaphytum of Artis, the tall, somewhat slender stem bore the fronds in two vertical series, as shown by the distichously arranged leaf-scars, which were of large size, having a transverse diameter of 8 or IO, and a height of 5 or $6 \mathrm{~cm}$. There was thus a certain superficial and deceptive resemblance to large specimens of Ulodendron, with which the older authors sometimes confused these stems. This phyllotaxis is apparently unknown among arborescent or erect Fern-stems of the present age, though frequent in the case of prostrate rhizomes. In other Palæozoic Treeferns the leaves were ranged in four vertical rows, while in others, again, and these the most numerous, a spiral polystichous disposition prevailed, as in the arborescent Ferns of the present day. To guard against misconception, it may be well to say at once that the Palzozoic Tree-ferns only resembled those of the present day in general habit; their affinities doubtless lay in a direction quite remote from that of the Cyatheaceae.

The polystichous stems, in which the external surface, bearing the foliar scars, is shown, are known by the name of Caulopteris, while a separate generic name, Ptychopteris, is applied to stems in another state of preservation, in which the cortex has been stripped off and the vascular system exposed. Lastly, yet another genus had been founded for those stems of Tree-ferns which are preserved in a petrified condition, so as to retain their internal structure; the latter, whatever the 
disposition of their leaves may have been, are embraced under the common name Psaronius. We have thus a curious example of palæontological nomenclature, for one and the same stem, according to its mode of preservation, may be placed in any one of the three "genera," Caulopteris (or Megaphytum, as the case may be), Ptychopteris, or Psaronius. If the foliage and fructification were taken into account, still other generic designations would come into requisition. Yet these anomalies are unavoidable, for it is rarely possible to identify the same species through its different states of fossilisation.

For our present purpose, the name Psaronius is the most suitable, as it is with the anatomical structure of the stem that we are specially concerned.

The specimens of Psaronius, which are characteristic fossils in the Permian beds of Saxony and Central France, werc perhaps the earliest known of any fossil vegetable remains with structure preserved. They were quite familiar objects, even to the general public, in the eighteenth century, for, owing to the beauty of their surface when cut and polished, they became, for a time, favourite articles of ornament, under the name of "Staarsteine." 1 The markings, to which they owed their popularity, depend on their anatomical structure.

The genus contains a great number of described species, and though some may have merely a palæontological value, many no doubt represent real distinctions among the plants when living. The species from the Upper Coal-measures and Permian agree in having a

1 "Starling-stones," from the speckled surface. The technical name Psaronizs has the same origin. 
highly complex polystelic organisation, comparable to that of the most highly differentiated Fern-stems of our own day. The structure of the Psaronii has been worked out in a most elaborate manner by Corda, Göppert, and Stenzel in Germany, and by Zeiller and Renault in France. A very full description, covering many species and forming a model of fossil anatomical investigation, is that given by M. Zeiller in the first volume of the magnificent work, so often referred to, on the fossil flora of Autun and Epinac. ${ }^{1}$ M. Zeiller, discarding the somewhat complex methods of arrangement of earlier authors, classifies the members of the genus according to their phyllotaxis, ranging them in three groups-the Polystichi, with numerous vertical series of leaves; the Tetrastichi, with four such series; and the Distichi, with only two. The illustration in Fig. I I 3 is taken from one of the Tetrastichous division; this group is the least important of the three in number of species, but the form selected, Psaronius brasiliensis, Brongn., shows the anatomical structure with remarkable clearness. This fossil, as its name shows, came from Brazil, and, though its source is still uncertain, is probably of Permian age, like the majority of the European species.

The stem, as in all the Psaroniz, is made up of two well-defined regions-a central portion, including the whole of the vascular system proper to the stem,

1 Corda, Beiträge zur Flora der l'orwelt, Prague, 1845; Göppert, "Die fossile Flora der Permischen Formation," Palaeontographica, vol. xii. 1864; Stenzel, "Ueber die Staarsteine," Nova Acta, vol. xxiv. I854; Zeiller, Bassin houiller et permien d"Aulun et d'Epinac, vol. i. 1890; Rudolf, "Psaronien und Marattiaceen," K. K. Akad. d. Wiss. Vienna, 1905 ; Stenzel, "Die Psaronien," Beitr. z. Paláont. u. Geol. OestemeichUngarns, Igo6. 
and a broad peripheral zone of cortex, traversed throughout by innumerable adventitious roots, seen in approximately transverse section in our figure. In this case the limit between the two regions is sharply defined, by an almost continuous band of sclerenchyma. The immense development of the peripheral zone of roots is a most characteristic feature of the genus Psaronius. Most authors have regarded the zone in which the roots are embedded as forming part of the cortex of the stem, as in the Marattiaceae, in which the adventitious roots arise near the apex of the stem, and grow down through the cortical tissues for a long distance before they become free. ${ }^{1}$ There are two difficulties in applying this interpretation to Psaronius. The connection between the roots and the surrounding tissue is much more intimate here even than in Marattiaceae, and the root-zone is never traversed by the leaf-traces, as it should be if it belonged to the primary cortex. It has therefore been suggested that the embedding tissue in Psaronius may be formed by the compacted hairs of the roots themselves; in many cases the filamentous character of the tissue lends support to this explanation. On the other hand, the evident continuity between the tissue in question and the true cortex appears decisive in favour of the older view. Stenzel's explanation that the embedding tissue is a secondary zone, developed pari passu with the growth of the roots after the leaves had fallen, appears the most probable, the radial arrangement of the elements, often observable, agreeing well with a secondary

1 See the well-known longitudinal section of the stem of Angiopteris evecta in Sachs's Text-book and other manuals. 
development. The question, however, deserves further investigation.

In the central region of the stem we see at once that the vascular system is remarkably complex, consisting of a great number of regularly disposed steles,

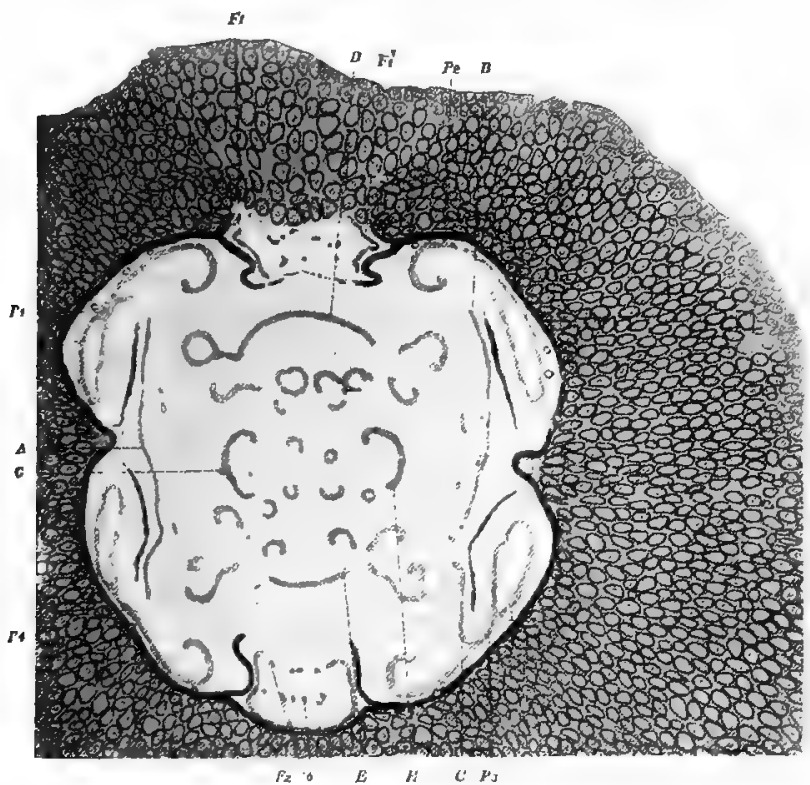

Fig. II3.-Psaronius brasiliensis. Transverse section of stem. The whole of the central portion, containing the vascular bundles, is shown, together with a great part of the cortex, traversed by innumerable adventitious roots. Fr, F2, leaf-gaps. For detailed description, see text. The round objects at $o$ are accidental perforations, Reduced. After Zeiller.

usually much elongated in transverse section, but varying greatly in size and form. At two opposite points (Fig. I I 3, F I and F2) outgoing leaf-traces are shown. The leaves appear to have been decussately arranged, but those of the same pair were not precisely at the same level. At $\mathrm{F}_{2}$ the open curve of the out- 
going stele is very evident; at $F_{1}$, which is cut nearer its exit, the trace is apparently divided into two, and the sclerenchymatous zone has almost closed in behind it. Stenzel found, however, that the two arms of the leaf-trace always form part of a single horse-shoe or elliptical bundle.

$A$ and $B$, at the sides of the figure, are the steles from which the leaf-traces of the next pair of leaves will be supplied, while $\mathrm{D}$ and $\mathrm{E}$ will give off, at a still higher level, the traces for the pair lying above $F_{I}$ and F2. These four bands, corresponding in position to the four orthostichies of leaves, may be called the reparatory steles. At the four diagonal corners, we see four very long and curved steles ( $\left.\mathrm{PI}_{\mathrm{I}}-\mathrm{P}_{4}\right)$, the "peripheral steles" of Zeiller, which have an important part to play. For one thing, it is from them that the adventitious roots take their rise; such roots are shown at several places between the peripheral steles and the sclerenchyma, or just passing through the latter. The peripheral steles are further concerned in the emission of the leaf-traces, for they anastomose with the reparatory steles immediately below the point where the leaf-trace passes out from the latter. Thus at $\mathrm{C}$ a branch is seen springing from the peripheral stele $\mathrm{P}_{3}$ to join the reparatory stele $B$.

The numerous internal steles- $\mathrm{G}, \mathrm{H}$, etc- - form a cauline system, the members of which, however, anastomose both among themselves and with the more external steles.

The whole subject of the vascular system of the Psaronii has been worked out by Zeiller, Stenzel, and Rudolf with a degree of completeness which could 
hardly have been exceeded if they had been dealing with recent instead of with fossil plants. We have here only given the main results for this particular species, which, however, may serve very well as a type of the rest.

The more minute histology has also been worked" out with a fair amount of detail. The steles have the typical concentric structure, cach consisting of a band of wood surrounded by phloëm. The xylem is composed of scalariform tracheides with or without xylemparenchyma, according to the species.

The ground-tissue is mostly parenchymatous, but internal sclerotic bands occur below the leaf-gaps (see Fig. I I 3 , on the right and left).

The outer, radiciferous cortex consists of parenchyma, but each of the roots by which it is permeated is surrounded by a dense sclerenchymatous envelope, probably to be regarded as belonging to the root itself. In Psaronius generally, the structure of the roots is polyarch; in the particular species, $P$. brasiliensis, the number of xylem-angles is usually five or six. Phloëm and cortex are sometimes very fairly preserved, and in the latter, secretory sacs or canals are conspicuous. The roots strongly recall those of Marattiaceous Ferns now living.

A species, $P$. Renaulti, occurring in the roof-nodules of the Lower Coal-measures of Lancashire, is interesting from its exceptional antiquity and from the simplicity of its structure. The stem in this species contains a single annular stele, enclosing a large pith, and interrupted only at the exit of the leaf-traces, the sole instance, at present known, of a solenostele in a Palæo- 
zoic stem. The phloëm, with its large sieve-tubes, is well shown in good specimens on both sides of the wood, and the protoxylem can be recognised, forming a number of small groups on the inner edge of the xylem, which is thus endarch (Fig. I I 4). Its position in the

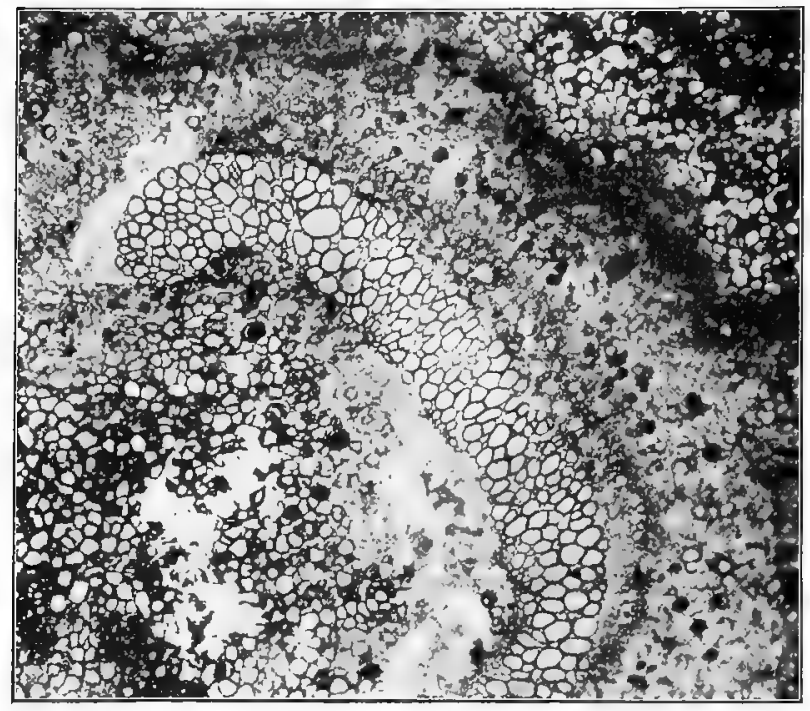

FIG. Ir4,-Psaronius Renanlti. Part of transverse section of stem, showing a portion of the solenostele. On the left is the edge of a leaf-gap. In the stele, note the protoxylem-groups on the inner edge of the wood. The phloëm, with large sievetubes, is well preserved on the outer side. The dark elements in the pericycle are secretory sacs. $X$ r3, S. Coll. 2I74. From a photograph by Mr. Tams.

numerous steles of the more complex species may be similar, but requires further investigation.

$P$. Renaulti may provisionally be regarded as the most primitive member of the genus. In a specimen probably referable to this species $\mathrm{Mr}$. Butterworth made the interesting discovery that some of the roots show a 
well-marked formation of secondary wood. A similar peculiarity has since been observed in a specimen of one of the Permian species. These are the only instances in which any trace of secondary tissues has been observed in the Psaroniz, apart from the quite peculiar case of the radiciferous cortex.

The petioles of these Ferns have occasionally been found apart from the stems, and bear the generic name of Stipitopteris. They are identified by the comparison between their transverse section and the marks on the leaf-scars of the Psaronii in the Caulopteris condition. It appears that the petiole usually received a single large bundle with a horse-shoe section, the opening being on the upper side, with the free ends either strongly incurved, or replaced by a distinct strand, lying within the curve of the main bundle.

M. Grand'Eury, in his researches on the Coal-flora of the Loire, ${ }^{1}$ found the stems of Psaronius, in situ, standing erect and rooted as they had grown. From the evidence of constant association, he has no doubt that their fronds were of the Pecopteris type, and identical with those on which fructifications such as Asterotheca and Scolecopteris were borne. This conclusion, which is confirmed by M. Renault's studies on the anatomy of certain Pecopteris leaves, would tend to show that the Psaronii were the stems of arborescent Marattiaceae, and there is little doubt that this was their true nature. There are, of course, various differences in detail, as, for example, in the great development of the sclerenchymatous tissues and in the single leaf-trace, points in which Psaronius diverges from the recent family.

1 Flore carbonifere du Departement de la Loire, 1878, pp. 78-98. 
The recent work of Rudolf on the anatomical relations between Psaronius and the Marattiaceae has on the whole confirmed the long-established view of their affinity; the common characters are to be found chiefly in the course of the vascular strands and in the structure of the roots, to which, as it now appears, the endarchy of the steles in the stem may be added. The evidence afforded by the Psaronius stems, taken in conjunction with that derived from the synangic fructifications, seems to leave little room for doubt that true Ferns with Marattiaceous affinities formed an important constituent of the Permo-carboniferous Flora, especially towards the close of that period. Where anatomical evidence is not available, it is, however, extremely difficult to distinguish between true Ferns of this group and plants more probably belonging to the Pteridospermeae. 


\section{CHAPTER IX}

THE FERNS-continued

\section{The Botryopterideae-Summary on the Ferns}

\section{Botryopterideae}

AMONG fossil plants generally, and in particular among those which may still be regarded as Ferns, it is only in rare cases that we are able to describe a plant as a whole, giving a connected account of all its organs. Where the evidence is such as to allow of even an approach to this desirable end, the fossil-botanist must regard himself as peculiarly fortunate.

For this reason the family of the Botryopterideae has long claimed a special interest among Palæozoic Filicales, for in two genera of this family the structure of all the important organs is fairly well known, and we have good evidence for connecting them together. Within the last few years the interest in this group has been greatly enhanced owing to the importance which now attaches to authentic. Palæozoic representatives of the class of Ferns, and especially to such representatives as appear to have a primitive character. 
The group, as we shall see presently, was in all probability an extensive one in Palæozoic times, but we will give our chief attention to those genera in which there is evidence as to the reproductive as well as the vegetative organs.

\section{A. Zygopteris Group}

I. Zygopteris. - We will first take the genus Zygopteris, founded by Corda in $\mathrm{I} 845$, on a species described by Sprengel and Cotta a good many years earlier. A number of species have now been recorded, but in many of them the structure of the petiole only is known; our knowledge of the stem extends to four species: Z. Brongniarti, Ren., ${ }^{1}$ from the Permian of Autun, in France; $Z$. scandens, Stenz., ${ }^{2}$ from a similar horizon in Bohemia and Saxony; $Z$. Grayi (Will.), ${ }^{3}$ and $Z$. corrugata (Will.), ${ }^{4}$ from the Lower Coal-measures of England. $Z$. scandens and $Z$. Grayi were regarded by Williamson, in spite of the difference in geological age, as identical. The anatomical description will be based chiefly on $Z$. Grayi, which may best serve as the type of the genus. We shall find that, throughout this family, our knowledge is for the most part based on petrified specimens, so that while the anatomical data are full and fairly satisfactory,

1 Renault, Cours de botanique fossile, vol. iii. chap. viii. I883; for his original memoirs see Ann. des sci, nat. (Bot.), ser. vi. vols, i, and iii. I875-76.

\footnotetext{
${ }^{2}$ Stenzel, "Die Gattung Tubicaulis," Cotta; Bibliotheca Botanica, Cassel, I889.

3 Williamson, "Organisation of Fossil Plants of Coal-measures," Part xv. Phil. Trans. I889, B.

+ Williamson, op. cit. Part viii. Phil. Trans. vol. 167, 1877.
} 
the evidence as to external habit is comparatively scanty.

The stem of Zygopteris Grayi was from io to I $5 \mathrm{~mm}$. in diameter, and no doubt attained a considerable length. In fact, Stenzel regarded his closely similar form as a climbing plant, and hence named it $Z$. scandens, for he always found the stems and petioles of his specimens intermixed with the crowded roots of a Psaronius, among which he. believes it to have scrambled, much in the same way as a Tmesipteris lives among the aërial roots of the New Zealand Tree-ferns at the present day. From the stem large petioles (little inferior to the stem in diameter) were given off, at considerable intervals; the phyllotaxis was a spiral one, and in certain cases, at any rate, the arrangement was clearly on the $\frac{2}{5}$ system (see Figs. I 5 and I I6).

In all the known Botryopterideae the stem was traversed by a single vascular cylinder; this monostelic structure, exceptional among recent Ferns, appears to have been more widely prevalent among those of Palæozoic age.

In our Zygopteris the stele has a very characteristic structure; its general form follows that of the wood, which in section has the outline of an irregular five-rayed star (see Figs. I I 5 and I I6). These rays are of very unequal length; the comparison of successive transverse sections shows that the shortest are those which have just given off a leaf-trace (Fig. I 16, I), while the longest are those which are just about to do so (Fig. Ir6, 5). From the position of the leaf-traces and their relation to the prominent corners of the 
wood, as shown in successive transverse sections, it follows that the angle of divergence between two successive leaves was in this case $\frac{2}{5}$ (Fig. I I 6, I -5 ). A short xylem-arm from which the leaf-trace has just separated appears merely as a slight bulge (Fig. I I 6, I);

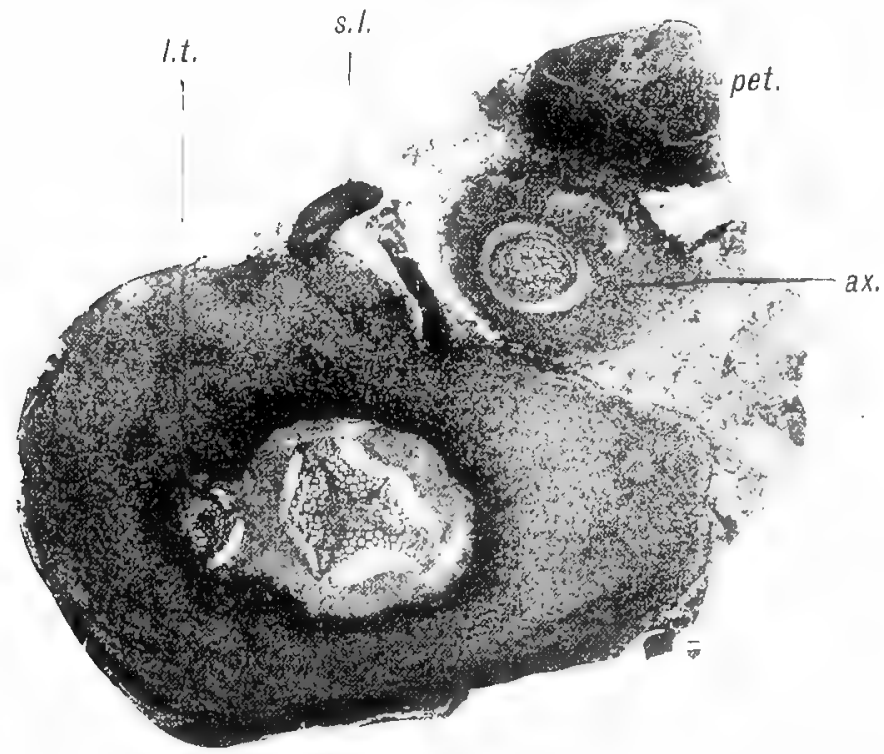

Ficro II5-Zygoptcris Grayi. Transverse section of stem, with axillary shoot and part uf petiole. In the middle of the stem the five-angled stele is seen (cf. Fig. I16). l.t., leaf-trace, about to give off the axillary strand; s.t., "scale-leaf" ; $a . x$, axillary shoot of next node below ; pet., part of petiole of the subtending leaf. The small strand in the cortex to the right belongs to a scale-leaf, $\times$ about 4 . From a photograph by Mr. L. A. Boodle. Will. Coll. Igig A.

those of successively greater length assume a truncated form at the end (Fig. I I6, 2, 3, and 4); while the longest arms of all spread out laterally, so as to be broadest at their termination, acquiring a bicornute outline (Fig. I I 6, 5). It is the enlarged end of the arm which, at a somewhat higher level, becomes detached, to 
form the xylem of a foliar bundle (Fig. I 15, l.t.). In the wood of the stele, a central and a peripheral region may be distinguished. The peripheral tissue consists principally of large scalariform tracheides. Towards the ends of the more projecting arms, and especially at

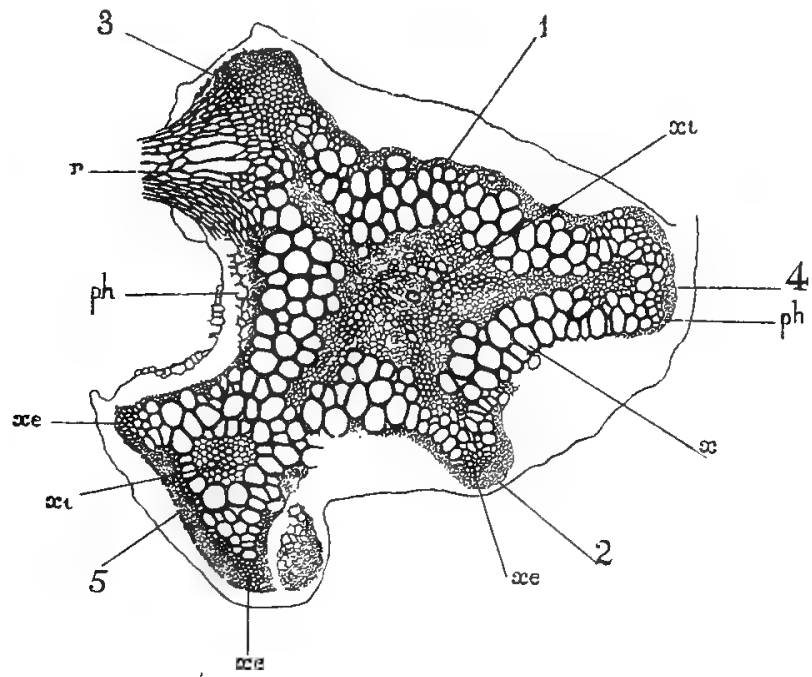

FIG. 116.-Zygopteris Grayi. Transverse section of stele, showing wood and remains of phloëm. I-5, the five angles of the wood, from which leaf-traces are given off, in order of the phyllotaxis, No. 5 belonging to the lowest leaf of the series ; $x$ principal ring of xylem; $x i$, small tracheides of internal xylem; $x e$, small tracheides at periphery; $\not h$, phloëm; $r$, base of adventitious root. $\times$ I4. Will. Coll. 1919 B. (G. T. G.)

the angles of the most prominent of them, much smaller elements occur (Fig. I I 6, xe). The central tissue, like the wood as a whole, has a stellate form; the main mass, which occupies the middle of the stele, sends out prolongations into each of the arms. The central tissue used at one time to be described as a pith, but that is not its true nature, for in addition to the delicate 
parenchyma, it contains a system of small tracheides, quite distinct from those of the external xylem (Fig. I I6, xi). This internal tracheal system forms a group or irregular ring about the centre of the stele, and from this central group radial bands of small tracheae extend outwards, up the middle of each arm (Fig. I I6). The groups of small external tracheides ( $x$ in Fig. I I 6) were no doubt continuous with the protoxylem of the foliar bundle, but they were also continuous, in the downward direction, with the smallest internal tracheides of the xylem-arms (see Fig. I I6, at 2, which, however, is not cut quite at the right level to show continuity). Hence the transverse section shows both internal and external protoxylem.

Some remains of the phloëm which surrounded the wood of the stele are preserved; it includes a single or double series of large elements, which probably represent the sieve-tubes (Fig. I I $6, p h$ ). The phloëm evidently followed the contour of the wood. The whole is surrounded by a zone of delicate tissue (which may best be regarded as an inner cortex), filling the spaces between the arms of the stele, and cylindrical in form (Fig. I I6). Beyond this is the wide outer cortex, the internal layers of which are thick-walled, forming a kind of sheath to the inner cortical zone. The epidermis was provider with multicellular hairs.

The course of the leaf-trace bundles can be very clearly followed; a single large bundle entered each petiole. To form the trace the whole distal part of one of the prominent arms (cf. Fig. I I6, 5) became detached, forming an approximately triangular concentric bundle, with the base directed outwards. In 
this region the central tissue of the trace contains small tracheides, continuous with the internal tracheal group of the stele. At the two external angles are the groups of small elements which no doubt constitute the protoxylem of the foliar bundle.

As we follow the leaf-trace outwards through the cortex, we find that it divides into two strands, of very different form, both lying on the same radius (see Fig. I I 5 , l.t., where this division is just beginning). The outer of the two strands is the foliar bundle, which is continuous with the external side of the original triangular strand, while the inner strand is destined for the axillary shoot. We will first follow the course of the foliar bundle, which, as it separates from the inner strand and passes out into the petiole, gradually assumes a somewhat complex form. At first the bundle consists simply of a tangential, somewhat bent, plate of wood, surrounded by phloëm, and spreading out a little at either extremity, but in its outward progress these lateral expansions increase in importance, so that the ultimate form, in transverse section, is that of the letter " $\mathrm{H}$," the cross-stroke of the $\mathrm{H}$ being placed tangentially with reference to the parent stem (cf. Fig. I I 8 , from another species). The largest tracheides are in this middle band; the smallest, constituting the spiral protoxylem, are at the outer edge of the side-pieces. The phloëm surrounds the xylem and follows its contour. This $\mathrm{H}$-shaped petiolar bundle is common, with slight modifications, to all species of Zygopteris, and, in fact, constitutes the character on which the genus was founded.

The other bundle, which is given off on the inner 
side of the leaf-trace, between the latter and the stele of the stem, is of special interest. It is continuous with the adaxial part of the original leaf-trace, and as it separates, assumes an elliptical form in transverse section (see Fig. I I $5, a x$ ), with the long axis placed tangentially. It consists of a ring of xylem, with large tracheides, surrounded by a zone of phloëm, and at the centre is a group of small tracheides accompanied by parenchyma. In fact, the structure of this bundle is that of the stele of the main stem, in an extremely simplified form. The axillary strand, as it is best termed, passed out into a cylindrical appendage, placed exactly in the axil between stem and leaf, and hence appropriately named by Stenzel the axillary shoot (Fig. I I $5, a x)$. This curious organ occurs in three out of the four forms of Zygopteris in which the stem is known, ${ }^{1}$ but has not, so far as I am aware, been found in any other genus of fossil Ferns. There is, however, the closest possible analogy with the axillary branches of the recent Hymenophyllaceae, a family with which, in various other respects also, the Botryopterideae have much in common. Stenzel, the discoverer of the axillary shoots of Zygopteris, at first suggested another possible view of their nature, namely, that they might represent the fertile ventral lobe of the leaf, as in the Ophioglosseae. This was, at the time, a sufficiently probable interpretation, but was subsequently withdrawn by the author, on the ground that transitional forms occur, which are intermediate in structure between the

1 The bundle marked $r$ in IRenault's figure (Flore fossile a Autzın et d'Epinac, Part ii. Plate xxxi. Fig. 2) of Z. Brongniarti, from its form and position, manifestly belongs, as Stenzel detected, to the axillary shoot, though interpreted by the author as an adventitious root. 
axillary shoot and the normal stem of Zygopteris; this fact, which is also shown in the English specimens, seems quite conclusive in favour of the cauline nature of the axillary organ.

Besides the foliage-leaves, Zygopteris possessed rudimentary leaf-like organs, of small size, termed

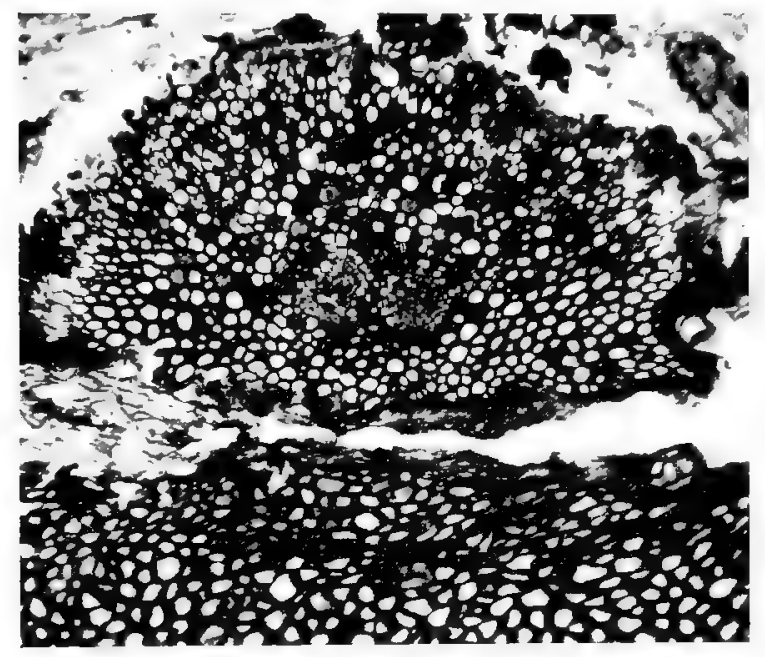

Fig. r17.-Zygopieris corrugata.- Tranverse section of an "Aphlelia" with part of the outer cortex of the leaf-base to which it belongs. The appendage contains two vascular bundles. From a photograph by Mr. L. A. Boodle. $x_{36}$. Will. Coll. 264.

scale-leaves by Renault and Stenzel, who discovered them in $Z$. Brongniarti and $Z$. scandens respectively. I have recently observed them in the British species, $Z$. Grayi (Fig. I I 5) and $Z$. corrugata (Fig. I I 7), and am thus able to confirm the statements of the authors cited, as to which I previously felt some doubt. 4 curious feature of these appendages, which have a simple, scalelike form, is that they occur on the petiole-bases as 
well as on the stem. A single bundle enters each appendage, and then divides into two, three, or four strands. An example from $Z$. corrugata is shown, in transverse section, in Fig. II 7 ; it has just detached itself from the base of a petiole, and contains two bundles. The morphology of these curious organs, which in some respects recall the Aphlebiae of other Palæozoic Ferns and Pteridosperms, requires further elucidation.

The stem also bore adventitious roots; the vascular strands supplying them can be distinguished from those of the scales by their more horizontal course.

Such evidence as we possess from other species as to the form of the foliage-leaf will best be considered at a later stage, after the fructifications have been dealt with. The petiolar structure is better shown in some other forms of Zygopteris, the stems of which are not in all cases known. Thus in a petiole named $Z$. Lacattii by M. Renault, which is frequent in the English Coal-measures, as well as in those of France, all the tissues are sometimes well preserved. In this case the tracheides are generally pitted rather than scalariform, a character which was clearly very variable in this group, though of considerable constancy in other families. The subject of the so-called tracheides of Palæozoic Ferns and allied groups requires further investigation in the light of Mr. Gwynne-Vaughan's remarkable discovery that the scalariform elements of Ferns are not tracheides, but a peculiar form of vessel, in which not only the closing membranes of the pits, but the middle lamellae of the cell-walls are absorbed, leaving only the bars of thickening, connected by the 
solid vertical angles of the vessels. This unexpected result, which was first suggested by observations on fossil Osmundaceae, goes to show that the true scalariform duct, far from being primitive, is a highly modified form of tracheal organ.

The protoxylem in $Z$. Lacattii occurs, as already mentioned, on the outside of the two lateral bands of wood, forming two groups on each side. The phloëm surrounds the wood completely, and contains large elements, presumably the sieve-tubes; the whole bundle is enveloped by a dense sheath. The inner parenchymatous zone of the cortex is traversed by numerous sacs, supposed to have been of a secretory nature. The outer layers of the cortex form a continuous zone of thick-walled mechanical tissue.

The leaf was obviously a compound one, for lateral bundles are given off from the side-pieces of the main strand, starting from the points where the spiral elements are placed. There were thus four rows of appendicular bundles in all, two on each side of the petiole. The significance of this peculiar arrangement, which was widely distributed in this family, is not yet understood. In some cases there is evidence that the smaller lateral strands supplied the "Aphlebiae," but in other cases they certainly passed into branches of the rachis. Mr. Tansley, ${ }^{1}$ on theoretical grounds, suggests that "this tendency to radial organisation of the frond may perhaps be regarded as a relic of the time when the structure of the fronds of Ferns was but little differentiated from that of the stem." ${ }^{1}$ It must be

1 "I. Lectures on the Evolution of the Filicinean Vascular System. II. The Botryopterideae," New Phytologist, vol. vi. I907, p. 65. 
remembered, however, that in these Botryopterideae we are often dealing with specialised fertile fronds.

Our illustration (Fig. I I 8 ) is taken from the petiole of another species, $Z$. bibractensis, Ren., in which the structure is rather more complex. The bundle has esscntially the usual $\mathrm{H}$-like sectional form, but

$$
\text { hy i.c. } \quad x \quad x^{\prime} \quad x^{\prime \prime}
$$

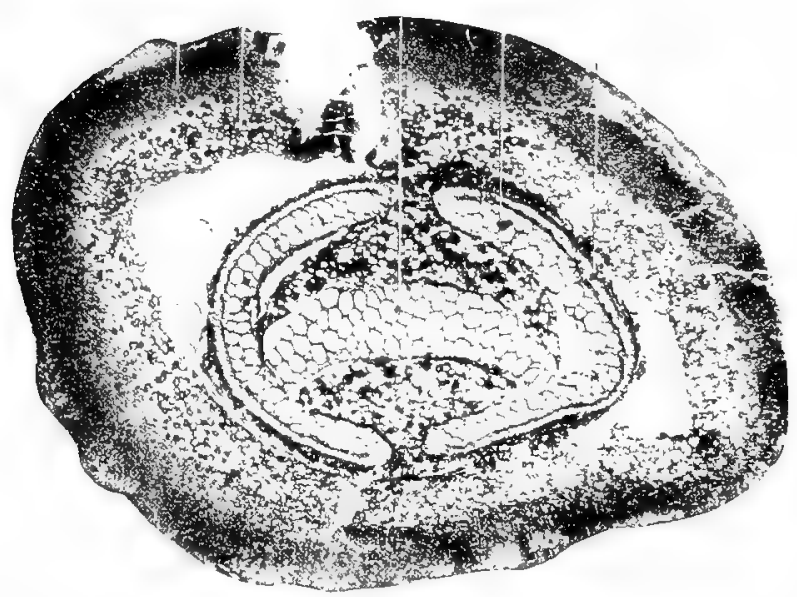

Fici. I18.-Zyopteris bibractensis. Transwerse section of a petiole, show ing the doubleanchor form of stele. $x$, middle band of xylem ; $x^{\prime}$, the main lateral bands; $x^{\prime \prime}$, the small-celled external arcs of xylem; the protoxylem lies between $x^{\prime}$ and $x^{\prime \prime}$; i.c., inner cortex; hy, sclerenchymatous hypoderma. $\times 7$. From a photograph by MI. L. A. Boodle. S. Coll, gr4.

the lateral pieces are considerably incurved, giving to the whole the shape of a double anchor. The peculiar feature of this species consists in the presence of an additional external band of xylem $\left(x^{\prime \prime}\right)$ on the outer side of each of the lateral plates $\left(x^{\prime}\right)$, separated by parenchyma from the main lateral plate, but united with it at its two ends (Fig. I I S). The cxternal bands 
consist of smaller elements than the rest of the wood; the spiral tracheides are placed on the inner edge of the external bands. It was from the latter that the strands were given off, which passed out into the leaflets. In this species we find once more that the scalariform type of tracheides prevailed. The petiole bears characteristic spines, formed of sclerotic tissue. ${ }^{1}$

In connection with the petiole just described, a few words may be said about $Z$. corrugata (Will.), ${ }^{2}$ a species in which all the vegetative organs are known. The petiole (once called Rachiopteris insignis, but already identified by Williamson) has the complex "Bibractensis" type of structure. The stele of the stem has an almost cylindrical form, except where it is affected by the emission of a leaf-trace, which is preceded by the formation of a double lobe, quite comparable to a bicornute arm of the stele in $Z$, Grayi. The system of internal tracheides is the same as in that plant, but in $Z$. corrugata there is no external protoxylem; its absence is correlated with the fact that the protoxylemgroups of the leaf-trace are immersed, as continues to be the case when the petiolar strand assumes its ultimate structure (cf. Z. bibractensis). The leaf-trace,

1 It must be remembered that, in the case of these isolated petioles, the affinity with the more complete specimens of Zygopteris is not strictly proved, for we have only the anatomical characters of the petiole to judge by. These characters, however, are so peculiar that we run no risk of serious error in taking them as a provisional guide to affinity. In any case the question is not a very grave one, for we know enough of the petioles actually connected with the stem in other species, to be certain as to the main points in their structure.

2 The Rachiopteris corrurata of Williamson, "Organisation of Fossil Plants of Coal-measures," Part viii. Phil. Trans. Roy. Soc. vol. I67, 1876, p. 213, Figs. 1-24. The plant has proved to be quite distinct from Tubicaulis, with which I was once inclined to connect it. 
on first leaving the stele, has a curved transverse section, concave outwards, as in Tubicaulis, and the $\mathrm{H}$-like form is only very gradually assumed. The "Aphlebiae," which in this species are found chiefly in the petiole, have already been noticed (Fig. I I 7). The young leaves bear, in addition, a copious growth of ramenta.

The great peculiarity of $Z$. corrugata, as compared with the other three species in which the stem is known, consists in its mode of branching, which is not axillary, but rather of the nature of a dichotomy, the stem forking into two nearly equal branches without obvious relation to the leaf-insertion. This fact raises the question whether, as has been suggested, the apparent axillary branching of other species and of recent Hymenophyllaceae may not be a modified dichotomy, in which case the "undivided leaf-trace" would really be the stele of the smaller branch, and the "subtending" leaf would belong to this branch and not to the main axis. The data are insufficient to settle the question, and for the present it seems better to keep up the distinction between the two kinds of branching.

The adventitious roots of $Z$. corrugata are often well preserved; they are of relatively large size, usually with a diarch stele and a lacunar cortex.

The elements of the large-celled, peripheral wood in the stem of $Z$. corrugata occasionally show some tendency to a radial arrangement. In a fossil, provisionally placed in a new genus, Botrychioxylon, which in the structure of the internal xylem, the leaf-traces, and the mode of branching shows clear affinity with a Zygopteris of the corrugata type, the peripheral wood 
is ranged in regular radiating series, and has all the appearance of a secondary tissue, precisely as in a recent Botrychium. The stele, in fact, is related to that of a Zygopteris, as the stele of Botrychium is related to that of Ophioglossum. Botrychioxylon, which may eventually have to be included under Zygopteris, at present affords the only instance of secondary growth of the wood among the Botryopterideae.

We now come to the interesting subject of the fructification of Zygopteris, our knowledge of which is almost entirely due to the researches of M. Renault.

The evidence of identification, if not absolutely conclusive, is at least sufficient to leave no reasonable doubt. The sporangia (see Fig. I I9) occur in groups, often of considerable extent. They are elongated, slightly curved sacs, thickest towards the distal end, and of relatively large size, reaching a length of 2.5 $\mathrm{mm}$. and a diameter of $1.3 \mathrm{~mm}$. Each sporangium is attached by its thin end to a short pedicel; the pedicels are united in little tufts, three to eight in each tuft, on a common peduncle (Fig. I I9, I and 2). The whole mass is traversed by fragments of a branched rachis, on which the peduncles were no doubt borne. In some sections of the rachis the characteristic H-like form of the Zygopteris bundle is clearly shown; "it is, then," to quote the words of M. Renault, "very probable, if not certain, that these masses of sporangia constitute the fructifications" of Zygopteris. ${ }^{\text {? }}$

The wall of the ripe sporangium consisted of at

1 Flore fossile d'Autun et d'Epinac, Part ii. p. 43. The original discovery was made by M. Renault as early as 1876 . "Veg. silicifiés d'Autun,"- Ann. des sci. nat. (Bot.), ser. vi. vol. iii. 
least two layers of cells, of which the inner, more delicate layer has usually perished. The outer wall
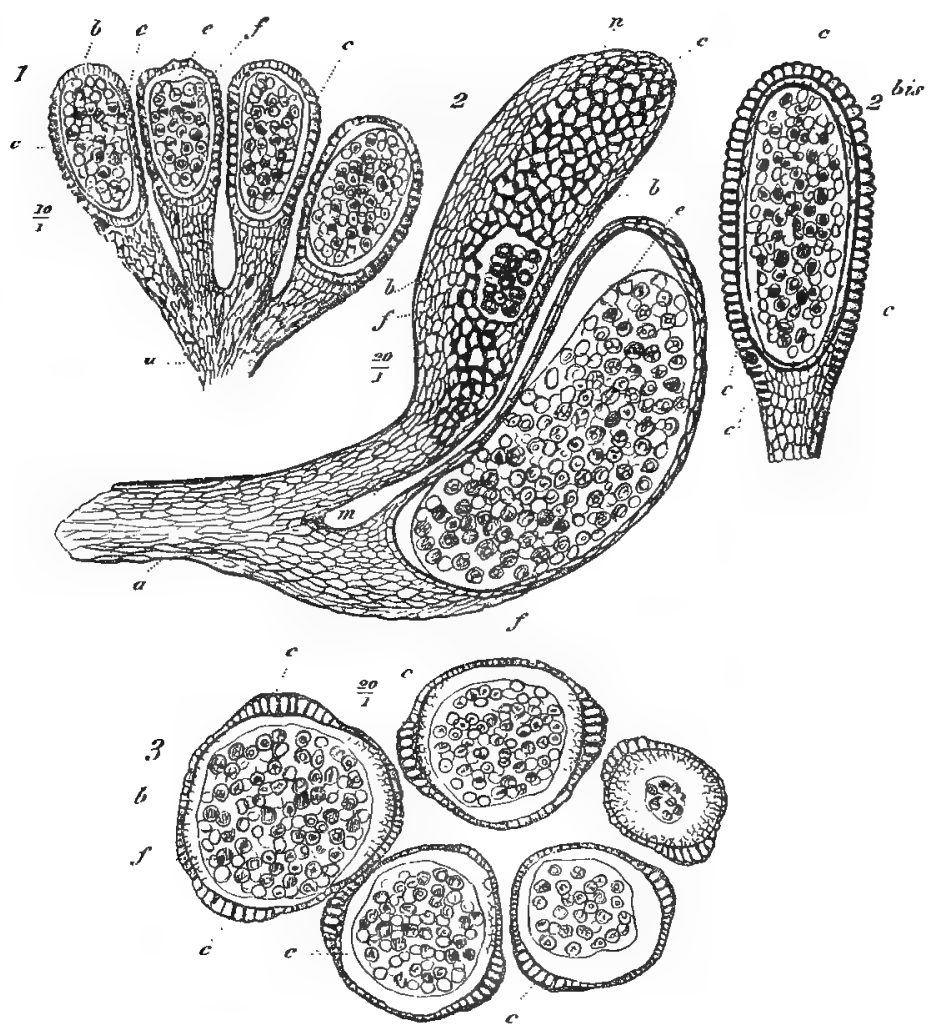

FIG. IIg.-Zygopteris, sp. - I. Group of four sporangia, on a common pedicel $(\alpha) \quad \times$ ro. 4. Two sporangia on pedicel. The upper shows the annulus (c) in surface-view, with spores exposed at $f$; the lower is in section. $\times 20.2$ bis. Sporangium, cut in plane passing through annulus. 3. Group of sporangia in transverse section. $\times$ 2o. Lettering common to the figures: $a$, common peduncle; $b$, sporangial wall ; $c$; annulus; $e$, tapetum (?) ; $f$, spores; $n$, pedicel of indiviclual sporangium; $n$, probable place of dehiscence. All after Renault.

shows a marked differentiation; on two opposite sides it consists of small elongated cells, becoming fibrous 
towards the base of the sporangium. But on the other two sides (alternating with the former) the cells are larger, with thicker walls, and with their maximum dimension vertical to the surface of the capsule (sec Fig. I 19). These larger cells thus form a vertical annulus, but one of a very peculiar kind, for it consists not of a single row of cells, but of a broad band, many cells in width (see Fig. I I 9, 2 and 3 ). At the summit of the sporangium the cells of the annulus thin out somewhat, so that we may regard it, if we like, as double, consisting of two distinct bands, one on each side. The pedicel is traversed, up to the base of the capsule, by a concentric vascular bundle, a condition very rare among recent Ferns, though approached in Helminthostachys and Botrychium. The pedicel, however, is best regarded as a branch of the rachis rather than as a sporangium-stalk.

Numerous spores are contained in the sporangia; they measure $.08 \mathrm{~mm}$. in diameter, which would be an ordinary size for the spores of recent Ferns. They are of the tetrahedral type, as is shown by the presence of the three radiating ridges, which are often visible on the exospore. M. Renault found other spores, of similar dimensions, in the same sporangia, which do not show the triradiate marking, but present a reticulate appearance, suggesting the presence of a group of polygonal cells within their cavity. This appearance has proved to be illusory, and the difference in the spores no doubt depends simply on their condition at the time of preservation, and is no indication of heterospory. The type of fructification is rather that of a homosporous member of the Filicineae. The leaves, or divisions of the 
leaf, must have been dimorphic, for the branched rachis associated with the sporangia shows no signs of a lamina. We know, from numerous specimens preserved as impressions, that dimorphism was an exceedingly common phenomenon among the Ferns and Fern-like plants of the Carboniferous period. As to the form of the leaf, either sterile or fertile, beyond the fact that it was a compound one, we have no direct evidence from the silicified specimens.

Pear-shaped sporangia, with a very broad and extensive annulus, are commonly found associated with $Z$. bibractensis and $Z$. corrugata in the petrifactions of the English Lower Coal-measures, and in all probability represent the fructifications of those species.

M. Grand'Eury described, under the name of Schizopteris, specimens from the Coal-measures of the Loire, which are related to the structural specimens we have been considering. One of the forms described by Grand'Eury, Schizopteris pinnata, is a large bipinnate frond, with an apparently fleshy rachis, bearing small flabelliform and laciniate leaflets on its ultimate subdivisions. The author also described a fertile frond (Schizostachys frondosus) very similar to the former, but bearing tufts of elongated sporangia in the place of the laciniate leaflets of the sterile Schizopteris. ${ }^{1}$ The arrangement, form, and size of these sporangia agree very closely with the characters of those described by Renault in his $Z_{\text {ygopteris. }}$ The structure of the Schizostachys sporangia is to some extent preserved, and the spores are visible in their cavities. The agreement

1 Grand'Eury, Flore carbonifère du Departement de la Loire, I877, pp. 198-203, Plate xvii. 
in all points with the petrified specimens of Zygopteris is so exact as to make it certain that, as M. Renault first suggested, they belonged to some allied species of that genus. As it is also beyond doubt that Schizopteris and Schizostachys belonged together, we are enabled to form a fair idea of the external form of both the sterile and fertile leaves of Zygopteris. These fronds are included by Zeiller ${ }^{1}$ in the latter genus, under the name of Zygopteris pinnata. Having inspected the fine specimens from Commentry in the collection of the École des Mines, I have no doubt that the attribution to Zygopteris is correct.

2. Other Genera.-The genus Corynepteris of Baily appears, according to Zeiller's investigations, to have been closely allied to Zygopteris. Several species have been described, and in some the form of the frond is well known. In certain of the species it is of the Sphenopteris type, resembling the frond of Zygopteris pinnata, but Pecopteroid fronds have also been found with a similar fructification. The sori are borne on pinnules, either like those of the sterile frond or comparatively little modified. The sporangia, so far as the annulus is concerned, are much like those of $Z$ ygopteris, but in most cases they are grouped in a ring round a centre, so as to resemble the synangium of an Asterotheca. Corynepteris thus, to a certain extent, combines the characters of Marattiaceae with those of Botryopterideae. ${ }^{2}$

1 Zeiller and Renault, Flore fossile de Commentry, p. 76, Plate xxxii. Figs. 5-7, St. Étienne, I 888.

${ }_{2}$ For an account of the genus Corynepteris, see W. H. Baily, Journal Geol. Soc. Dublin, vol, viii. I860; Zeiller, Flore fossile du Bassin houiller de Valenciennes, r888, pp. $4 \mathrm{I}$ and II7. 
Corynepteris is at present only known from impressions; we may compare with it a genus, Diplolabis, Renault, ${ }^{1}$ which has been studied entirely in petrified material. The stem is unknown, but the structure of the petiole indicates affinity with Zygopteris. In both the species described, $D$. forensis, from the Upper Coalmeasures, and D. esnostensis, of Lower Carboniferous age, the fructifications are described as synangia, with

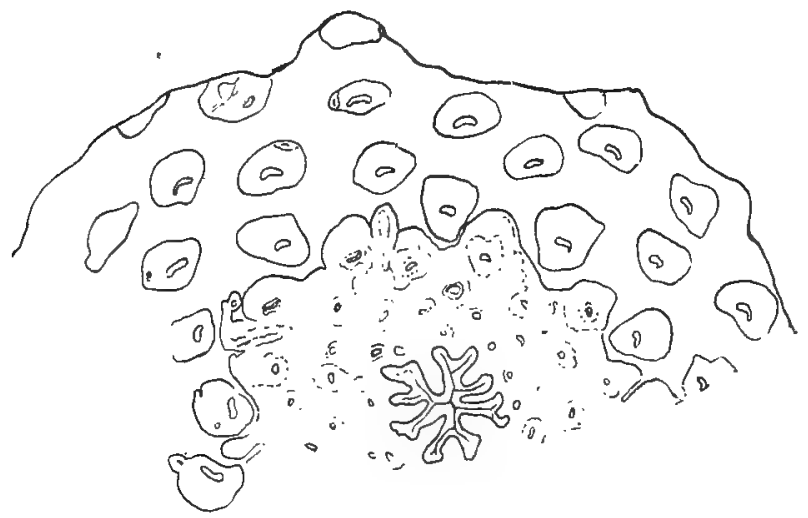

FIG. Izo.-Asterochlaena laxa . Part of transverse section of stem with surrounding petioles. The deeply lobed stele is shown, also the leaf-traces and the curved bundles in the petioles. Nat. size. After Stenzel. From Tansley. Nezu phytologist.

from three to six sporangia attached to a common central receptacle. The sporangia differ from those of Corynepteris in having no differentiated annulus. It is also probable that the synangia were borne on a naked rachis, and not on an expanded lamina, as in the former genus.

Two genera, of which only the vegetative anatomy is known, may be shortly mentioned. Anachoropteris,

1 Flore fossile d'Autun et d"Epinat, t. ii. p. 1 I. 
from the Carboniferous and Permian, has a stemstructure (in $A$. Decaisnei, Ren.) almost identical with that of Zygopteris Grayi, but the petiolar bundle has quite a different shape, forming a strongly incurved arc, concave towards the parent stem. Asterochlaena, ranging from the Upper Devonian to the Permian, has a very deeply lobed stele, with the forked arms much more prominent than in Zygopteris (see Fig. I 20). The protoxylem, in a section shown me by Mr. Kidston, appeared to be sunk below the projecting corners of the wood. The petiolar bundles are lunulate, with the concavity directed outwards or inwards, according to the species. Their relation to the stele has not yet been fully cleared up, and the interesting genus much needs reinvestigation.

\section{B. Botryopteris Group}

3. Botryopteris.-We will next consider Botryopteris, the type-genus of the family, and very distinct from the Zygopteris group. Our knowledge of this genus was, in the first instance, based on M. Renault's species, $B$. forensis, which that author described very thoroughly, though he had only a single specimen of the stem to

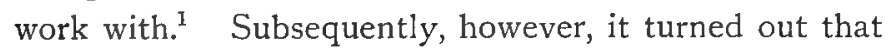
certain English Coal-measure fossils, which fortunately occur in considerable abundance, must be placed in the same genus. Hence we are able to supplement the descriptions of the original discoverer by observations on our own, specifically distinct, examples. Anatomically, Botryopteris shows a decidedly simpler structure

1 Cours de bot. foss. vol. iii. chap. viii.; Ann. des sci. nat. (Bot.), ser. vi. vol. i. I875; Flore fossile d"Autun el d'Epinat, Part ii. p. 33. 
than the former group. Here, as in the family generally, the stem is monostelic; the stele, however, is of a rather rudimentary type, consisting of a more or less cylindrical strand of solid wood, surrounded by phloëm, in which, in the English species ( $B$. ramosa and $B$. hirsuta $\left.{ }^{1}\right)$, the large sieve-tubes are sometimes preserved. These two forms are very similar, and not always easy to distinguish, though it is possible that more than two species are concerned. $B$. hirsuta (Will.) had a small stem, about $2-3 \mathrm{~mm}$. in diameter, and bore spirally arranged, somewhat crowded leaves, the petioles of which were at least equal to the stem in diameter. In B. ramosa, where the petioles, as a rule, are relatively smaller, the stem is usually larger than in $B$. hirsuta, sometimes reaching a diameter of 5-6 mm., while in the French species, $B$. forensis, it attains a diameter of $7.5 \mathrm{~mm}$., in M. Renault's specimen. In all the species, the surface of the stem, and of the leaves also to some extent, was clothed by filamentous multicellular hairs, which, in the case of the French species, had a very peculiar structure, for each cell bore a ring of teeth at its distal end, giving the hair the appearance of a miniature Equisetum. This peculiarity proved of some importance in identifying the various organs of the plant.

The wood of the stem consists entirely of tracheides, mostly pitted, with a transition to scalariform structure, especially in the smaller elements. The proportion of the two kinds of tracheides is very variable in different specimens, and may prove to afford specific distinctions. The protoxylem is not always well

I Rachiopteris ramosa and hirsuta of Williamson. 
marked; its position in the stem will be considered in connection with that in the petiole.

In the British species a $\frac{2}{5}$ phyllotaxis appears to have prevailed. The petiolar bundle is often actually larger than the stele of the stem, and contains larger

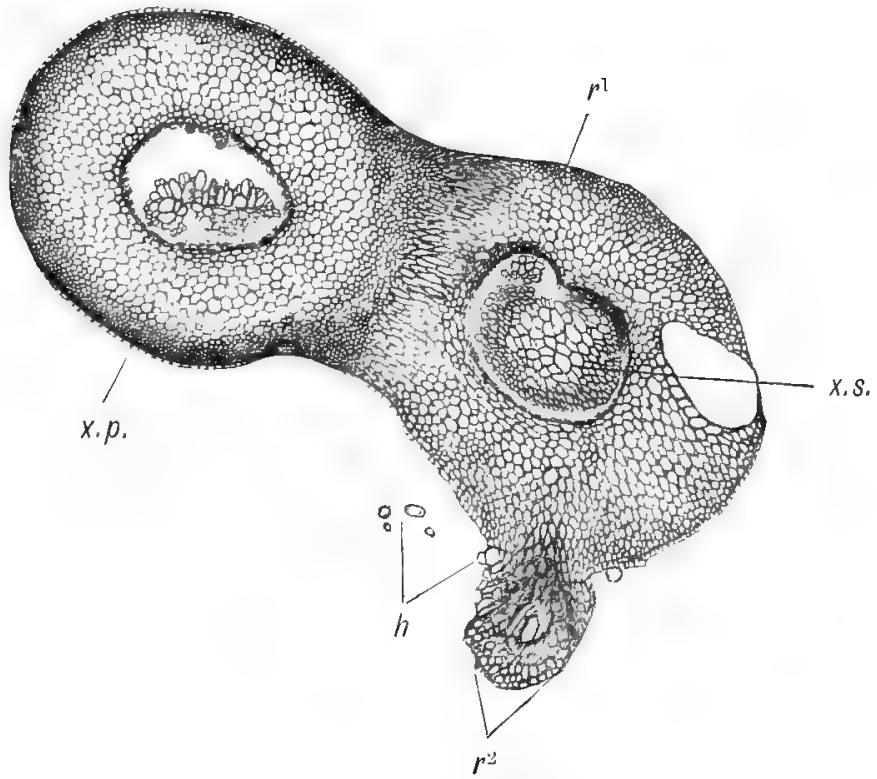

FIG. I2I. - Botryopteris hirsuta (Will.). Transverse section of stem at its junction with the petiole; $x_{. s}$, xylem of stem; $x . \not$. xylem of petiole; $r^{-1}, r^{2}$, diarch roots, springing from the stem; $h$, hairs. $x$ about $x 5$. (G. T. G.) S. Coll. 569.

tracheides (see Fig. I 2 I). Its form, as seen in transverse section, is very characteristic. The elliptical band of xylem has three prominent points, all projecting on the same side, and directed towards the upper and inner face of the petiole. Hence the specific name tridentata, given to this petiole by Felix, before its 
connection with $B$. hirsuta was known. 'The three prominent points (occasionally reduced to two) mark the position of the spiral protoxylem-elements. In some specimens the phloëm encircling the wood is exquisitely preserved.

Where the leaf-trace joins on to the vascular cylinder of the stem, its spiral tracheae are directed inwards. As, however, the bundle left the stele, it swung round, as it were (as often happens in recent Ferns also), taking up the position shown in Fig. I2I. In M. Renault's type the form of the petiolar bundle is essentially the same as in the English species, but the structure is less simple and the three xylem-points are much longer, so that he compares the sectional form of the wood with that of the Greek omega $(\omega)$.

The structure of the cortex of the stem shows no striking differentation; in the petiole the outer cortical layers constitute a continuous sclerotic zone (Fig. I 2 I).

The stem, in all the species, gave rise to very numerous diarch adventitious roots (Fig. I $2 \mathrm{I}, r^{1}, r^{2}$ ), resembling those of many living Ferns.

In the petiolar bundle the position of the protoxylem is shown, not only by the presence of spiral tracheides at the prominent points, but also by direct developmental evidence, such as is rarely to be found in a fossil plant. In several cases a petiole or rachis has fortunately been preserved when still young, with its xylem only partially lignified, so that the small, thick-walled elements of the protoxylem, already differentiated, contrast sharply with the rest of the wood, in which the walls are still unthickened (see Fig. I 22).

As the leaf-trace approached the stele its three 
adaxial protoxylem-groups commonly united into one, and as fusion with the stele took place, this group necessarily took up an internal position in the stelar wood; every stage of the fusion is shown in serial sections of $B$. hirsuta or ramosa. Thus the xylem of the stele was endarch; spiral elements are not often to be found in the stem, which was a comparatively

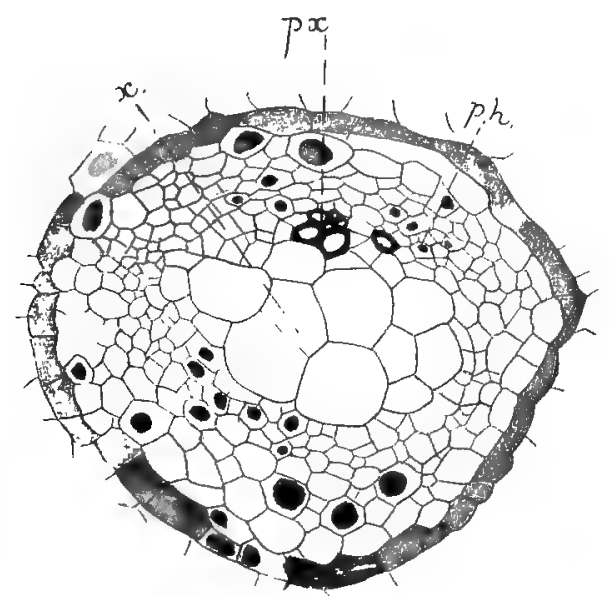

FIG. 122.-Botryopteris hirsuta. Iransverse section of vascular bundle of young petiole, showing the xylem in course of differentiation, $\not x x$, lignified protoxylem; $x$, thin-walled xylem not $y$ et lignified; $p h$, phloëm-zone. The dark external layer may be the endodermis. $x_{5}$ I5. S. Coll. 564 . R. S.

short and presumably rather slow-growing rhizome. The small tracheides sometimes found at the periphery of the wood were probably in connection with the adventitious roots.

The rachis of the English species often shows branching, its branches being given off singly, and not in pairs as in Zygopteris, but such knowledge as we have of the form and structure of the lamina is entirely 
derived from M. Renault's observations on the French specimens. The fine branches of the rachis had a simpler anatomical structure than the main petiole; they bore broad, lobed pinnules, with prominent veins, which branched repeatedly by dichotomy. The tissue of the lamina appears to have been fleshy; on the one

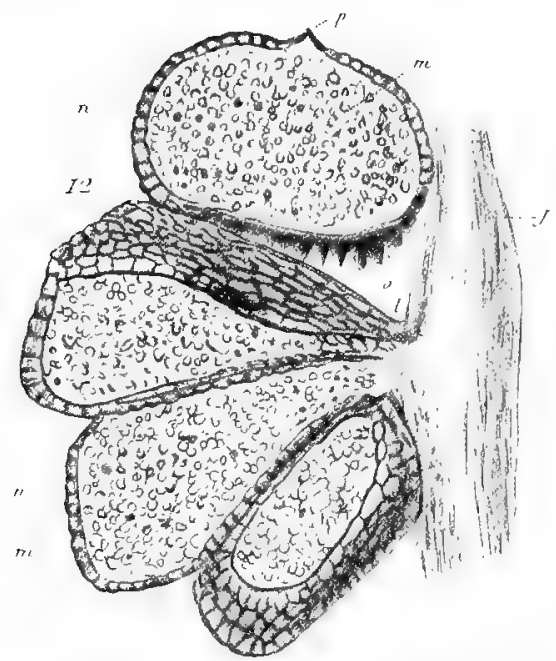

FtG. 123.-Botryopteris forensis. Group of sporangia, $m, n$, incerted on rachis, $j$; 2, pedicel of sporangium; $n$, wall of sporangia; 0 , multiseriate annulus. The uppermost sporangium is in nearly transverse section; $\not$, , stomium, or place of dehiscence. $\times 35$. From Renault.

surface numerous stomata were present, while the other bore the characteristic equisetiform hairs; it is on the latter feature that the identification of the leaf is based. M. Renault regards the stomatiferous surface of the leaf as the upper one, and supposes that the leaves of Botryopteris floated on the surface of the water, while other aërial leaves were borne by the same plant. These conclusions must be considered as highly hypothetical. 
In one case M. Renault described a young frond in beautiful preservation, which was still circinately coiled, and bore numerous equisetiform hairs on its outer surface.

The fructifications of Botryopteris forensis bear a general resemblance to those of Zygopteris, but differ

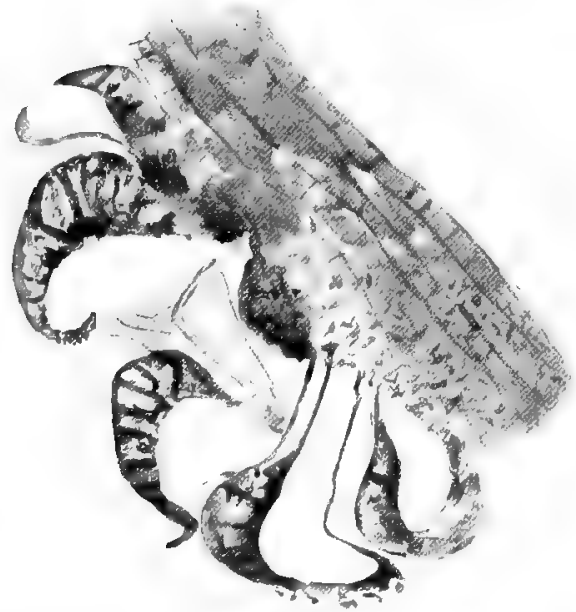

FIG. 124, -Botryopteris. Group of sporangia attached laterally to an axis, probably part of rachis. The sporangia show the multiseriate annulus; they have already dehisced. Associated with B. ramosa. Cf. Fig. I23. $\times 66$. S. Coll. 776. R. S.

in detail. The sporangia occur associated in large masses, and crowded together, representing, no doubt, the collective output of a compound fertile frond. The pyriform sporangia are shortly stalked and grouped in tufts, on the branches of the fertile rachis (see Fig. I23). The latter shows in section the characteristic $\omega$-shaped vascular bundle of the specics, thus placing the identification beyond doubt. 
The size of the individual sporangia is somewhat smaller than in Renault's $Z$ yoopteris, their length ranging from $\mathrm{r} .5$ to $2 \mathrm{~mm}$., and their maximum diameter from .7 to I $\mathrm{mm}$. The essential difference, however, from the sporangia of Zygopteris is in the annulus, which in Botryopteris was limited to one side of the capsule, where it formed a broad, oblique band of thick-walled cells (Fig. 123). The spores, except for their somewhat smaller size, agree exactly with those of $Z$ yopteris, and, curiously enough, the same two states of the spore, already discussed in the case of that genus, recur here.

In one case a group of sporangia was found to be associated with a very curious envelope or indusium, of complicated structure, which $\mathrm{M}$. Renault regarded as derived from a zone of sterile and highly modified sporangia.

It may be mentioned that the English specimens of $B$. hirsuta and ramosa are found associated with numerous sporangia, which appear to have essentially the same structure as those of the French species, but are of much smaller size. It is extremely probable that they represent the fructification of the English representatives of the genus. The association is close and practically constant, and as these species are among the commoner coal-ball fossils, this fact is of great weight. In one case the sporangia, which appear to have already dehisced, are found grouped on a rachis, as in Renault's specimens (see Fig. I 24). They are, in the common form, of roundish shape, $350-400 \mu$ in diameter, with a broad band of enlarged cells on one side, comparable to the false annulus of Osmundaceae (see Fig. I 25). The somewhat triangular spores are characteristic. 
4. Other Genera.-With Botryopteris we may compare another plant often found in the petrifactions of the English Lower Coal-measures, the Rachiopteris cylindrica of Williamson. ${ }^{1}$ This has a slender stem, frequently branching by dichotomy, and occasionally bearing the bases of leaves. The preservation is often perfect; the stele resembles that of a small Botryopteris, but has a very well-marked central protoxylem-group. The leaftrace bundles also bear some resemblance to those of Botryopteris, and the associated petioles are of a very similar type, i.e. the nearly straight bundle has the protoxylem-points all on the same side. The habit of the plant, with its long slender stem and, as it appears, very scattered leaves, must have been widely different from that of other Botryopterideae, and, though it has been proposed to include the species under Botry-

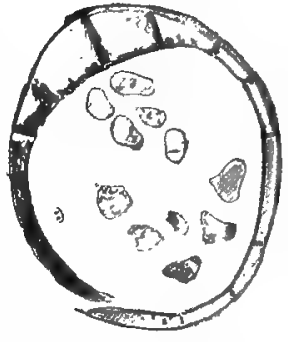

FIG. I25.-Botryopteris. Sporangium in transverse section, showing the multiseriate annulus, and containing some spores. Associated with $B$. ramosa. $x$ about too. $S$. Coll. 933. R, S. opteris, it may be preferable to found a new genus for it.

Another genus closely allied to Botryopteris, and perhaps forming the simplest type of the family, is Renault's Grammatopteris, founded on a species, $G$. Rigolloti, ${ }^{2}$ from the Permo-Carboniferous of Autun. The habit represents the opposite extreme to that of 1 "Organisation of Fossil Plants of Coal-measures," Part ix. Phil. Trans. Koy. Soc. Part ii. I878, p. 350, Figs. 80-87. Figs. 80, 86, and 87 are of the stem; the smaller sections appear to be of roots. For a more modern account see T. Hick, "On Rachiopteris cylindrica," Mem. and Proc. Manchester Lit. and Phil. Soc, vol. xli. I896.

2 Flore fossile d'Autun et d' Epinac, p. 45, Plate xxx. Figs. 9-I I, Plate xxxi. Fig. I. 
the plant last described, for the crowded petioles here form a dense envelope round the stem. The stele has a solid cylinder of xylem, as in Botryopteris; the spiral elements are stated to be at the periphery, but this requires further investigation. The leaf-traces and petiolar bundles have the form of a straight tangential band, described as having the spiral elements at the two ends. The genus is imperfectly known. Small sporangia of the Zygopteris type were found by Renault in association with the plant, but there is no proof of connection.

The genus Tubicaulis, as now limited, has a remarkable history. Only two specimens referable to it have ever been discovered; one was found in the Permian of Saxony in I8I5, and described by Cotta in $1832 ;^{1}$ the other was found by Mr. Lomax a couple of years ago in a roof-nodule in the Lower Coal-measures of Shore, Lancashire, and described by Miss Stopes in I906. ${ }^{2}$ The two specimens are, of course, specifically distinct. The Permian species is T. Solenites, Cotta; that from the Coal-measures is named $T$. Sutcliffi, Stopes. Both were large plants; the specimen of $T$. Solenites was, when found, a yard long, and from 5 to 8 inches in diameter, most of this thickness being made up of the crowded leaf-bases and petioles, while the fragment representing $\dot{T}$. Sutcliffi had a diameter of $2 \times 4 \frac{1}{2}$ inches. The structure of the stem is excessively simple, the stele having a solid cylindrical strand of xylem, which Miss Stopes believes

1 Die Dendrolithen in Beziehung auf ihren inneren Bau, p. 2I, Taf. il.

2 "A New Fern from the Coal-measures: Tubicaulis Sutcliffi, spec. nov.," Mem. and Proc. Manchester Lit. and Phit. Soc. vol. ]. 
to have been wholly or chiefly centripetal in development. The petioles, which increased rapidly in diameter after leaving the stem, contain a horse-shoe bundle, with the concavity outwards; the protoxylem groups clearly lie on the convex, adaxial side. The numerous adventitious roots are diarch. Small sporangia, much like those attributed to the British species of Botryopteris (Fig. I 25) are associated with the specimen, and as no other plant is present in the nodule, this association has some significance.

The three forms last described, Rachiopteris cylindrica, Grammatopteris, and Tubicaulis, are evidently closely allied to Botryopteris, and, together with that genus, constitute a sub-family, with which the Zygopteris group, including Anachoropteris and Asterochlaena, may be contrasted. The great distinction lies in the stele, a simple cylindrical column with solid xylem in the Botryoptereae, while in the Zygoptereae it has usually a more complex form, and appears always to have a double xylem, with the small internal tracheae accompanied by parenchyma. There is no constant distinction in the petiolar bundle, though here also the Zygoptereae tend to complexity, but the double series of rachisbranches appear to be characteristic of the Zygopteris group. There can be no doubt that the latter are the more highly organised, and the Botryoptereae presumably, although not certainly, the more primitive. It must be remembered that Asterochlaena, which clearly falls into the Zygopteris division, is, on present evidence, the most ancient of the whole family. The two groups have so much in common (especially in the 
fructification, where known) that their association in a single family is fully justified.

We have still to consider a genus which at present stands a little apart from the rest of the family.

5. Stauropteris. - The best-known species, $S$. oldhamia, Binney, is one of the commonest fossils of the Coal-measure nodules; a very similar species, of Lower Carboniferous age, has recently been named $S$. burntislandica by $\mathrm{M}$. Paul Bertrand. We will confine our attention to the former.

The stem is unknown; the specimens consist of fragments of the petiole and rachis of a highly compound frond, without any recognisable lamina, but bearing sporangia on its ultimate branches. In the large petioles the xylem has a characteristic cruciform section, while the whole stele is approximately square, the phloëm filling up the bays between the xylem-arms, and sometimes extending to the centre, so as to interrupt the continuity of the wood (Fig. I 26). The example figured is tetrarch; often, however, there is more than one protoxylem-group at each angle, though this condition may be correlated with the branching. As M. P. Bertrand has observed, the protoxylem is sunk a little below the surface of the wood, which is therefore not strictly exarch. The phloëm contains large sieve-tubes, and the sieve-plates on their lateral walls are sometimes clearly shown. A lax, palisadelike tissue occurs below the epidermis, and probably had the function of assimilation. The branches were given off in pairs, successive pairs springing from opposite sides of the rachis, a mode of branching 
recalling that of the $Z$ ygopteris petioles. The branches are of many orders; those of intermediate dimensions have a three-armed xylem, while the excessively fine terminal ramifications are traversed by a bundle of correspondingly simple structure. Certain slender strands which are given off concurrently with the

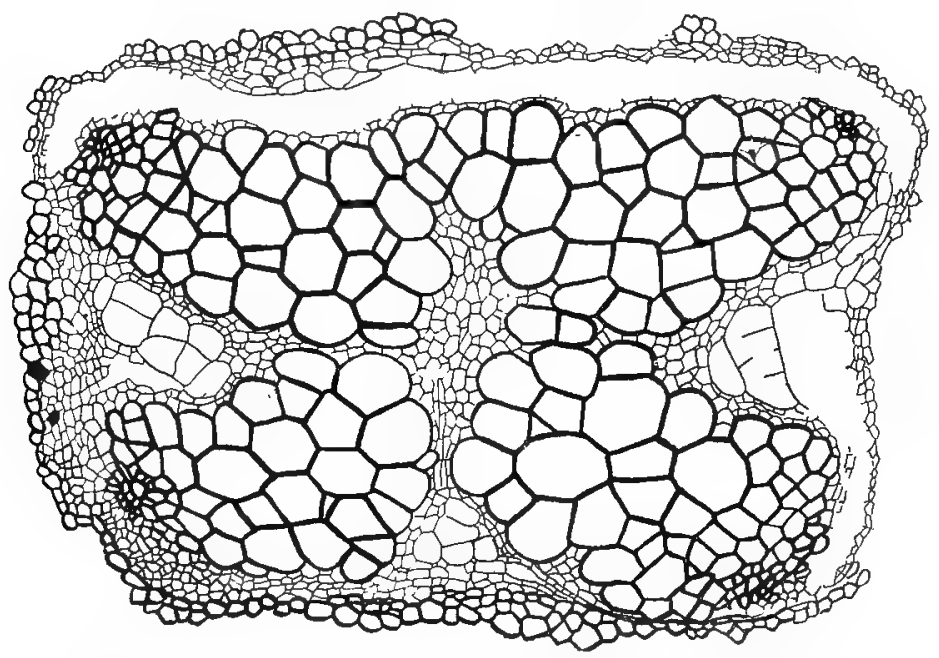

Fig. 126.-Stauropteris oldlamia. Transverse section of vascular bundle of main rachis, showing the cruciform xylem with protoxylem near the foitr angles. Groups of large sieve-tubes are seen in the bays of the wood, and small-celled phloëm between wood and cortex. $\times 60$. S. Coll. 2202. From Tansley, Neru Pliytologist.

main branches are described by M. P. Bertrand as supplying aphlebiae-another point of analogy with Zygopteris.

It was on the delicate ultimate branches of the rachis that the terminal sporangia were borne (Fig. I27). The fronds at present known appear to be all fertile; whether other vegetative leaves also occurred, or the foliage was of an extreme xerophytic type, with the 
laminae wholly suppressed, cannot yet be determined. The analogy of Zygopteris and Botryopteris, however, speaks strongly for the former hypothesis.

The sporangia are nearly spherical sacs, about $.7 \mathrm{~mm}$. in diameter, with a wall several cells thick and the outermost layer strongly differentiated. There is no annulus, but a well-marked stomium at the end

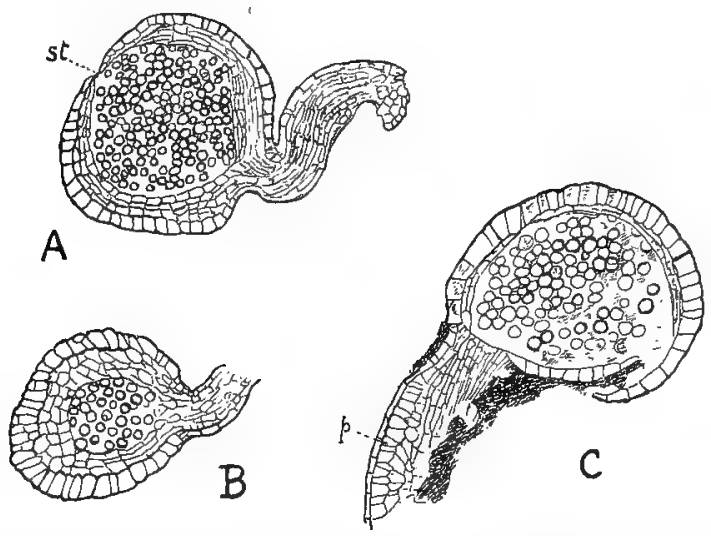

FIG. 127,-Stanuropteris oldhamia. Three sporangia inserted terminally on ultimate branches of the rachis. In A the stomium, st, is shown. B is cut tangentially. In $\mathrm{C}, \not$ is the palisade-tissue of the rachi. The relatively large spores in $\mathrm{C}$ are probably beginning to germinate. Cf. Fig. I28. $\times$ about 35. S. Coll. ; A, 2213; B, 2207; C, 2219. R, S.

opposite the stalk (Fig. I 27, A) served for dehiscence. Numerous spores of the tetrahedral type fill the cavity.

At the time when these sporangia were first discovered, the question was left open whether the plant was a Fern or a Pteridosperm, for there was nothing to show for certain whether the fructification represented

1 Scott, "The Sporangia of Stauropteris oldhamia," Nerw Phytologist, vol, iv. 1905. 
homosporous sporangia or microsporangia. A year previously a case had been observed in which spores were found germinating inside an isolated sporangium, the stages agreeing with those found in recent Ferns. ${ }^{1}$ Subsequently, similar stages of germination were detected in typical sporangia of Stauropteris oldhamia, establishing a strong presumption that this plant also was a true homosporous Fern. ${ }^{2}$ Some of the germinat-

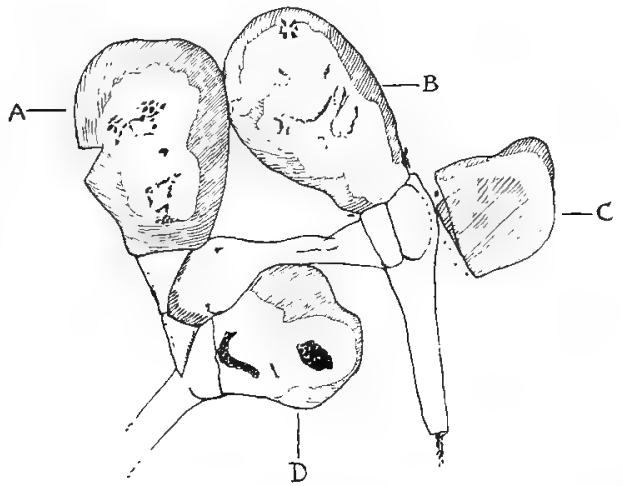

Fig. 128.-Stauropteris oldhania. Four germinating spores from the interior of a sporangium. All four are putting out rhizoids. In C (lying horizontally) an additional cell has been cut off between rhizoid and spore. $\times$ 335. S. Coll. 2215. Drawn by Mr. L. A. Boodle.

ing spores are shown in Fig. I 28. All four have sent out rhizoids, cut off by a wall from the body of the spore, and in $\mathrm{C}$ another cell has been cut off above the rhizoid. In the light of these observations there is no longer any reason to doubt that Stauropteris was

1 Scott, "Germinating Spores in a Fossil Fern-Sporangium," New Phytologist, vol. iii. I904.

2 Scott, "The Occurrence of Germinating Spores in Stauropteris oldhamia," Newe Phytologist, vol. v. I906. I an indebted to my wife, Mrs. D. H. Scott, F.L.S., for much help in these observations. 
really a Fern, while the analogies with $Z$ yoopteris and other Botryopterideae are sufficiently close to justify us in classing the whole family with the Ferns. I am inclined to agree with the Messieurs Bertrand that the affinity between Stauropteris and $Z$ ygopteris is a fairly near one. At the same time, the absence of an annulus from the sporangia of the former marks a real distinction, though it will be remembered that Diplolabis, a genus also betraying some affinity with Zygopteris, has the same peculiarity.

6. Affinities of the Family. - The habit, anatomy, and sporangial characters all point to the Botryopterideae having been true Ferns. The germinating spores of Stauropteris, agreeing so closely with the corresponding stages in recent homosporous Ferns, raise this presumption almost to a certainty, and there is at present no countervailing evidence to be weighed.

We have now to consider, very briefly, the question of the probable affinities of the group with other Filicales.

The fructification, on which one would naturally lay the chief stress, appears to remove the family from any of the more typical groups of Leptosporangiate Ferns. The size and form of the sporangia are too variable to be characters of any importance, but the annulus, when present, has definite peculiarities. In the genera Zygopteris and Botryopteris it forms a welldefined longitudinal or oblique multiseriate band of cells, occurring on both sides of the sporangium in Zygopteris, on one side only in Botryopteris. The nearest analogy among recent Ferns is perhaps to be 
found in Osmundaceae, where the annulus is represented by a unilateral group of thickened cells, the areola, resembling the Botryopteris arrangement in a reduced form.

On the other hand no annulus is differentiated in Diplolabis or Stauropteris, genera which were certainly allied to the Botryopterideae, though this character would exclude them from the farnily as defined by Renault. ${ }^{1}$ The annulus evidently afforded less constant characters among Palæozoic Ferns than is now the case.

The position of the sporangia in Zygopteris, Botryopteris, and Stauropteris, where they are terminal on ultimate branches of the rachis, is not very closely paralleled among recent Ferns, but finds its nearest analogy in Helminthostachys and Botrychium among the Ophioglossaceae, ${ }^{2}$ the comparison being closest with the case of Botryopteris (Fig. I 23).

The dimorphism of the fronds, though so striking a character, is not of the first importance, for we know that it recurs in almost every group of living Ferns, and that within the same genus some species may be dimorphic, while in others there is no differentiation between the sporophylls and the ordinary foliage. ${ }^{3}$

At the same time the great modification of the fertile frond in Zygopteris, Botryopteris, Stauropteris,

1 Flore fossile d"Autun et d" Epinac, t. ii. p. 33, 1896.

a See Bower, "Spore-producing Members. II. Ophioglossaceae," Plate v. Fig. $8 \mathrm{I}$.

3 The word dimorphism is used to include both the differentiation of sterile and fertile leaves, and that of sterile and fertile parts of the same leaf. In the case of fossil Ferns it is usually impossible to say which was the case, and among recent Ferns the distinction is not always constant, even in the same species. 
and probably Diplolabis, is of importance as evidence against any direct connection between these genera and the Ferns of later periods. Among the latter dimorphism has appeared in most of the families, but, except in the Ophioglossaceae, it is never a family character. There is a strong presumption that in Hymenophyllaceae, Schizaeaceae, Osmundaceae, Cyatheaceae, and Polypodiaceae uniformity of foliage is a more primitive condition than specialisation of sporophylls, and that each of these families, as well as the Gleicheniaceae and Marattiaceae, started with sporangia borne on the ordinary frond. If this be so, it implies that the typical Botryopterideae cannot have been on the direct line of descent of the Leptosporangiate Ferns.

Vegetative, and especially anatomical characters, must also carry considerable weight. The monostelic structure, and the single petiolar bundle, suggest a comparison with one of the four families, Osmundaceae, Schizaeaceae, Gleicheniaceae, and Hymenophyllaceae. The axillary shoots of $Z$ ygopteris indicate the last-named group as that with which the analogy is most evident, and other anatomical features confirm this indication. The resemblance between the anatomy of one of the larger species of Trichomanes and that of Zygopteris is in fact very striking. ${ }^{1}$ The stele of Trichomanes reniforme, for example, has a simpler form than that of the main stem in $\mathcal{Z}$. Grayi, but the arrangement of its elements is much like that in the fossil plant,

1 See L. A. Boodle, "Comparative Anatomy of the Hymenophyllaceae, Schizaeaceae, and Gleicheniaceae, I. Hymenophyllaceae," Ann. of Bot. vol. xiv. I900. 
and if we consider the axillary shoot of the latter, where the stele has a simple bilateral structure, the agreement is almost exact. The protoxylem of $T$. reniforme is placed internally, forming two groups, accompanied by parenchyma, while, small elements also occur at the periphery of the wood, where they are connected with the insertion of adventitious roots. 'In other species, however, the protoxylem may be wholly peripheral (e.g. T. scandens) or scattered (e.g. T. spicatum). The leaf-trace gives off the stele of the axillary branch precisely in the same manner as in Zygopteris, the resemblance extending even to details. It would be rash to push the comparison too far, but, from an anatomical point of view, there is no doubt that the Hymenophyllaceae show the closest analogies with the genus Zygopteris, and especially with those species which have axillary branching. With Botryopteris there is also a general agreement, though a much less close one. As Mr. Boodle says (loc. cit. p. 489), "The solid stele of Botryopteris, as the wood consists of tracheides only, resembles the stele found in the lower part of the seedling-stem of Trichomanes rather than the solid stele of $T$. spicatum, etc." The general analogy between Botryopterideae and Hymenophyllaceae was early recognised by Renault. It is, however, improbable that anything more than a remote affinity is indicated by the analogies referred to.

As already pointed out, there is a fairly sharp distinction between the anatomy of the Botryopteris type and that represented by Zygopteris. The former, so far as the stem is concerned, is perhaps the simplest in any known vascular plant, though many 
circumstances forbid us to assume that this simplicity is primitive. The Zygopteris type of stele is far more complex, and an interesting point is that its structure lent itself to secondary growth, so that in Botrychioxylon we find the primary wood replaced by secondary, just as is the case in Botrychium as compared with Ophioglossum. Of course nothing more than an analogy is suggested here, for the internal xylem of the $Z$ ygopteris group is unrepresented in the recent family. Still it is quite possible that some real affinity may exist.

The Botryopterideae may fairly be called a synthetic group, in so far as they show analogies with a number of families of later origin. Attention has already been called to points of resemblance between them and the Hymenophyllaceae, Osmundaceae, and Ophioglossaceae. They have also been compared with Schizaeaceae on account of the biseriate annulus sometimes observed in that family, though differing in position from that in our fossils; anatomically a basis of comparison may be found in the internal tracheides occurring in the stele of Schizaea malaccana and other species. ${ }^{1}$ If Corynepteris is rightly associated with Botryopterideae, the synangia suggest a relation to Marattiaceae; the fructification of Diplolabis points in the same direction, and Sturiella (Fig. I09, D) may also be regarded as combining Marattiaceous with Botryopteridean characters.

In the first edition of this book I expressed the opinion that the Botryopterideae not improbably

1 Tansley and Chick, "Structure of Schizaea malaccana," Ann. of Bot. vol. xvii. I903; Boodle, "Comp. Anat. of Hymenophyllaceae, Schizatacene, and Gleicheniaceae. IV. Further Obs. on Schizaea," ibid. 
represented the stock from which some at least of the existing families of Ferns were subsequently derived. Mr. Kidston has recently made a similar suggèstion, regarding the descent of Leptosporangiate Ferns from the Botryopterideae as much more probable than from any other Palæozoic group so far as known to us at present. ${ }^{1}$ Mr. Arber, ${ }^{2}$ taking a somewhat broader view, derives the Leptosporangiatae from an ancient Palæozoic race, which he names the Primofilices, of which the Botryopterideae were but one important family. $\mathrm{He}$ further suggests (loc. cit. p. 227) that possibly the origin of the Eusporangiatae is also to be sought for in the group termed the Primofilices. I regard Mr. Arber's views as an advance on those previously held. The Botryopterideae, or at least their better-known members, appear too specialised to have themselves been the ancestors of the modern Ferns, but the analogies which they present with so many families of the latter indicate that they are probably an offshoot from the same main line of descent. Kidston and Gwynne-Vaughan, in discussing the comparative anatomy of Osmundaceae and Botryopterideae, state that they "regard the Osmundaceae as directly descended from an ancestral stock from which at least two other types of structure arose-that of Botryopteris and that of Zygopteris," ${ }^{3}$ a conclusion entirely in harmony with the general view indicated above.

1 "On the Microsporangia of the Pteridospermeae," Phil. Trans. Roy. Soc. B, vol. cxcviii. I906, p. 442.

2 "On the Past History of the Ferns", Ann. of Bot. vol. xx. 1906, p. 22 r.

3 R. Kidston and D. T. Gwynne-Vaughan, "On the Fossil Osmundaceae," Part i. Trans. Roy. Soc. Edinburgh, vol. xlv. Part iii. Igo7. 
The possible affinities of Botryopterideae in other directions than that of the Ferns will be considered later on.

\section{Summary}

The general conclusion to which we are led by a consideration of the evidence bearing on the existence of Ferns in the Palæozoic period is that this class was then fairly well represented, though by no means holding the dominant position formerly assigned to it. On the one hand we have, as a characteristic group, the remarkable family of the Botryopterideae, very different from any of the more modern families of Ferns, though presenting analogies with them in various directions. On the other hand, we have the Marattiaceous type, much more complex in anatomical structure, and with clear affinities to the recent Ferns of that group. The doubts that have lately been cast on the authenticity of Palæozoic Marattiaceae have been suggested by the similarity between supposed Marattiaceous fructifications and the pollen-bearing organs of certain Pteridosperms and Cycadophyta. In the absence of anatomical evidence we are doubtless often left in uncertainty whether a given fructification is to be referred to the one category or the other. The structure of the Psaronius stems, however, appears conclusive as to the existence of a considerable group of true Palæozoic Marattiaceae, to which, no doubt, many of the fronds bearing synangia belonged.

Mr. Arber's proposed group, the Primofilices, embracing all the more primitive Palæozoic Ferns, with the 
Botryopterideae as at present the best-known family, has already been referred to, and the idea is likely to be a fertile one. We are not, as yet, in a position to fill in the features of this ancient race, for outside the Botryopterideae themselves, or their immediate allies, our knowledge of such Ferns is scanty. But, as Mr. Arber points out, many of the Fern sporangia of the petrifactions will doubtless find their place here, and so, perhaps, will some of the fructifications, such as Oligocarpia or Senftenbergia, which have been provisionally referred to definite recent families. Pteridotheca Williamsonii (Fig. I I 2, p. 293) is a good example of a Palæozoic Fern with annulate sporangia borne on leaflets of an ordinary vegetative type, and there are several similar cases. Various families of Ferns are known to have been well developed in the Mesozoic Period, and their ancestors must have been present in Palæozoic times. For reasons already given, I can no longer regard the Botryopterideae as lying on the direct line, but some of the forms of "Primofilices" with non-specialised sporophylls may well have been nearer the progenitors of Ferns as we know them.

The genus Corynepteris suggests a possible connection between the Primofilices and the Marattiaceae, an hypothesis which, indeed, is almost inevitable on general grounds. The Ferns grouped under Primofilices, as this name is intended to imply, are of great antiquity, occurring commonly in the Lower Carboniferous (various Botryopterideae) and extending back to the Devonian (Asterochlaena), while the Marattiaceae are not known to be older than the Upper Carboniferous (Lower Coal-measures). 
It is doubtful if the distinction between Eusporangiate and Leptosporangiate Ferns existed in Palæozoic times-in other, words, whether the development of the sporangium from a single cell had yet been arrived at. In the Botryopterideae, at any rate, it is improbable that this was the case, the mode of insertion of the sporangia, and their large size in many cases, pointing to a multicellular origin.

The conclusions of Professors Campbell and Bower, as to the relative antiquity of the Eusporangiate type, are thus amply justified by palæontological evidence. On the other hand, it may be doubted whether this evidence justifies the view that the confluent synangium was a primitive form of Fern-fructification. Many Palæozoic Marattiaceae, it is true, possessed synangia, but, on the whole, the sporangia of which they were composed were less completely united than in most of the recent members of the family. While in Ptychocarpus the cohesion was complete, in Scolecopteris, Asterotheca, Sturiella, and the Grand'Eurya of Stur the individual sporangia enjoyed a considerable measure of independence. Neither were the Marattiaceae by any means the most ancient Ferns. The Botryopterideae were older, and had, in most cases, free sporangia. Among the fairly numerous Fern-sporangia preserved in the petrified material of the British Lower Coalmeasures and Lower Carboniferous rocks, it is rare to find any signs of cohesion. The fossil evidence, on the whole, supports the view that free sporangia represent the original form of Filicinean fructification, and that their cohesion to form synangia was 
a secondary modification, though one which, in certain groups, took place at a very early period. ${ }^{1}$

From an anatomical point of view, two main types of stem are sharply distinguished among the Palæozoic Ferns. On the one hand, we have the large, highly complex, polystelic stems represented by Psaronius, and belonging, no doubt, to the Marattiaceous Treeferns. On the other, we have the herbaceous monostelic forms, such as the Botryopterideae.

The monostelic group is generally further characterised by having only a single vascular bundle in the petiole, and it is remarkable that this peculiarity also extended to many of the polystelic forms (species of Psaronius), which, in the simplicity of their petiolar structure, differed widely from Marattiaceae, while agreeing with them in the anatomy of the stem. On the evidence now available, it appears that monostelic structure of the stem was more common among Palæozoic than among recent Ferns, while monodesmic structure of the petiole was the rule, ${ }^{2}$ though not, of course, without exceptions. Summing up the results, we may say that the Palæozoic, or at least the Carboniferous Ferns, group themselves anatomically into two main cycles-the Palro-Marattiaceae on the one hand, and on the other that great synthetic group of Ferns (Primofilices) with a simple anatomical

1 Stur came to a similar conclusion, "Culm- und Carbonfarne," p. I6I. See, however, F. O. Bower, "Studies in the Morphology of Spore-producing Members," iii. Marattiaceae, Phil. Trans. Roy. Soc. I897, B, p. 35, for an able statement of the opposite view; also his Origin of a Land-Flora, p. 523, 1908 .

2 See L. A. Boodle, "On the Comp. Anatomy of Hymenophyllaceae, Schizaeaceae, and Gleicheniaceae," Ann. of Bot. vol. xiv. I900, vol. xv. I90I, vol. xvii. I903. 
structure, of which we may take the Botryopterideae as the best-known examples.

Space forbids us to extend our studies to the Ferns of later epochs. It may be interesting, however, to point out that during the Mesozoic period nearly all the different groups of recent Ferns made their appearance.

Among the Marattiaceae, the Palrozoic genus Asterotheca has been found to persist in the Triassic and even Rhaetic beds. On the other hand, specimens from the Rhaetic and the Lias have been referred to the recent genera Marattia and Danaea.

Gleicheniaceae have been identified as far back as the Lias, and perhaps the Trias.

One of the most curious features of the Fernvegetation throughout the Secondary period is the prominence of the family Matonineae, now represented by a single genus, with two species, Matonia pectinata and $M$. sarmentosa, plants of limited distribution in the Malayan region. This group, which combines the characters of Cyatheaceac and Gleicheniaceae, can be traced back, on evidence derived from the fructifications as well as from foliar characters, at least as far as the Rhaetic beds. ${ }^{1}$

Cyatheaceae can be identified as far back as the Lias, and Schizaeaceae are found in the Jurassic.

Osmundaceae have been recognised by their fructifications in the Rhaetic and Trias, and fossils from these rocks have even been referred to the recent genera Osmunda and Todea.

1 See Seward, "On the Structure and Affinities of Matonia pectinata, with Notes on the Geological History of the Matonineare," Phil. Trans. Roy. Soc. vol. I9I, B, I899. 
The fossil history of the Osmundaceae from an anatomical point of view is now being investigated by Kidston and Gwynne-Vaughan. Among the forms already dealt with, the Osmundites skidegatensis of Penhallow, from the Lower Cretaceous of Queen Charlotte Islands, British Columbia, may be mentioned. The preservation is astonishingly perfect and the stem is remarkable for possessing a well-developed internal phloëm. This feature, however, was found to be absent from the still older members of this family.

There appears to be little satisfactory evidence as yet as to Mesozoic Hymenophyllaceae.

The family Dipteridineae, formerly included under Polypodiaceae, appear to have a long geological record, Ferns referred to this group having been found in the Lias, Rhaetic, and Trias. ${ }^{1}$

True Polypodiaceae have not been traced further back at present than to Jurassic rocks. ${ }^{2}$

The palæontological data just cited may be compared with the arrangement of the families of Ferns, proposed by Professor F. O. Bower, ${ }^{3}$ on the basis of an exhaustive investigation of the development of the sorus, and the output of spores. The main lines of his classification are exhibited in the following table :-

1 Seward and Dale, "On the Structure and Affinities of Dipteris, with Remarks on the Geological History of the Dipteridinene," Phil. Trans. Royal Soc. B, vol. 194, I9or.

2 For a fuller summary see Zeiller, "Les Progrès de la Paléobotanique de l'Ere des Gymnospermes," Progressus Rei Botanicae, vol. ii. 1907.

3 " Studies in the Morphology of Spore-producing Members," iv. The Leptosporangiate Ferns, Phil. Trans. vol. 192, B, 1899. For a more recent statement, see his Origin of a Land-Flora, I9o8, especially the scheme on p. 653 . 


\section{FILICES-Isosporeae}

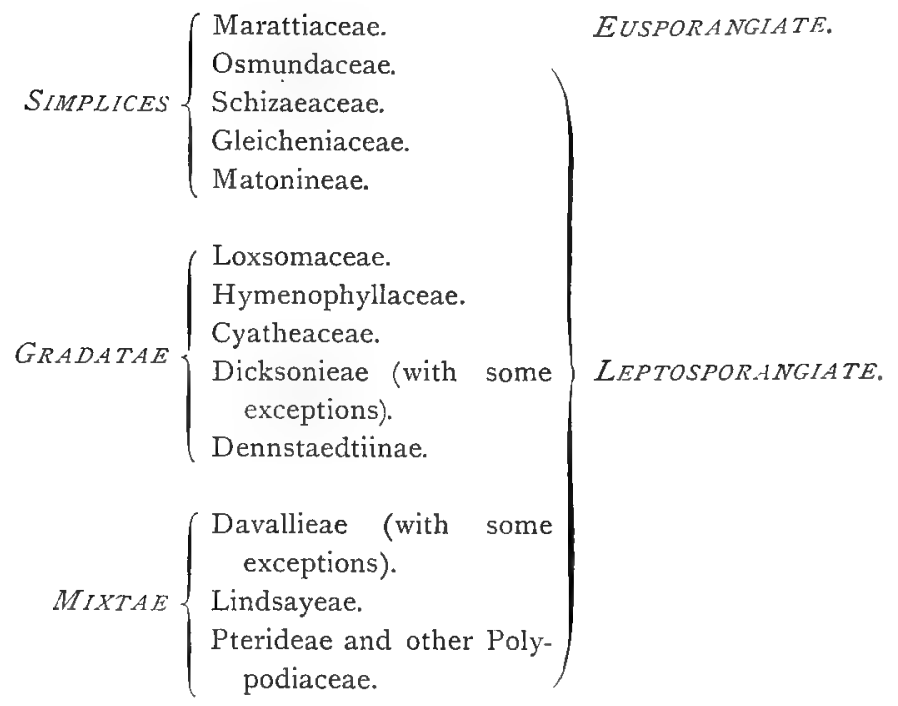

The Simplices are those Ferns in which all the sporangia of a sorus are produced simultaneously, the Gradatae those in which there is a definite succession in time and space, the Mixtae those in which there is a succession in time, but no regular succession in space.

Other characters of importance coincide more or less with the above; for example, the sporangia tend to become smaller, with fewer spores in each, as we advance from the Simplices to the Mixtae.

It will be seen that the geological evidence, so far as it goes, harmonises well, on the whole, with the main divisions in Professor Bower's system. The old distinction between Eusporangiatae and Lepto- 
sporangiatae takes a secondary place, and to this the palæobotanist can make no objection, for on existing evidence it is doubtful whether the distinction existed among Palæozoic Ferns.

A remarkable lacuna in our knowledge of the older fossil Filicales is the entire absence, so far as is yet ascertained, of any satisfactory evidence for the existence of heterosporous forms. Fossil Rhizocarps have often been described, but, so far as the earlier strata are concerned, on the most questionable evidence.

There are strong reasons for supposing that heterospory must have appeared among Ferns in Palæozoic times, but this question will be considered in the last chapter of the book. 



\title{
CHAPTER X
}

\author{
PTERIDOSPERMEAE
}

\section{Lyginodendreae}

WE now leave the Ferns, and pass on to the Pteridospermeae, a series of forms which are among the most interesting made known to us by fossil botany, for they unite in their organisation the characters of two of the main divisions of the Vegetable Kingdomthe Seed-plants and the Ferns.

It has long been recognised that many of the fronds from the Carboniferous strata, commonly described as those of Ferns, are subject to grave suspicion of not having really belonged to the class Filicineae. Such suspicions attach not only to the so-called genera Alethopteris and Neuropteris, and to a large part of Sphenopteris, but to an actual majority of the Fern-like fronds. The plants in question have never been found with recognisable fructifications of a Fern-type, whereas in the accepted fossil Ferns, specimens with sori occur in a fairly large proportion of cases. It was 
on such negative evidence as this (which is not without its value, if drawn from sufficiently numerous instances) that Stur in I 883 based his exclusion of certain of these genera from Ferns and their reference to Cycads. Subsequently, a large body of well-ascertained positive data accumulated, derived mainly from anatomical investigation, on which, indeed, we then had to depend, for in none of the plants concerned were the organs of reproduction known with certainty up to the year I 903. The anatomical characters observed indicated a position intermediate, at least in certain respects, between Ferns and Gymnosperms, the particular class of Gymnosperms approached being that of the Cycadophyta. Hence the convenient name Cycadofilices was applied by Professor Potonie to the group, and generally adopted.

The remarkable progress made in the last four or five years leaves no doubt that most, if not all, the members of this intermediate group, which embraces the majority of the Fern-like plants of the Palæozoic, bore seeds. They have thus proved to be much nearer Gymnosperms than appeared before, but on account of vegetative and other characters they retain an intermediate position, and are now associated under the name Pteridospermeae. This class may be provisionally defined as :

Plants resembling Ferns in habit and in many of their anatomical characters, bearing seeds of a Cycadean type; seeds and microsporangia borne on fronds only slightly modified as compared with the vegetative leaves.

The Pteridosperms were thus, as Van Tieghem has said, "Phanerogams without flowers." 
We will begin our account of the Pteridosperms with the family Lyginodendreae and the genus Lyginodendron, the type species of which now has the distinction of being the most completely known of all fossil plants (see Fig. I, Frontispiece).

\section{LYGINODENDRON}

The species, or rather, perhaps, group of species, with which we are concerned at present is that named by Williamson Lyginodendron oldhamium. ${ }^{1}$ Although the plant was first described by Binney, in 1866 , it is mainly to Williamson's work that our present, very thorough knowledge of its vegetative structure is for the most part due. Fortunately, specimens of Lyginodendron oldhamium are among the very commonest remains contained in the calcareous nodules of the English Coal-measures; their preservation is often wonderfully perfect, so the material for investigation is altogether favourable.

The vegetative anatomy will be first considered, thus following the historical order in the progress of our knowledge, and subsequently the recently discovered seeds and male organs will be dealt with.

Both foliage and roots are now well known, and we are able to form a fairly accurate idea of the habit of the plant (see Fig. I, Frontispiece). We will begin our description with the stem, the part to which the name Lyginodendron oldhamium was first applied,

1 For nomenclature see Williamson, "Organisation of the Fossil Plants of the Coal-measures," Part iv., Phil. Trans. 1873, p. 377; also Williamson and Scott, "Further Observations, etc.," Part iii., Phil. Trans. 1895, B, p. 705. Potonié has re-named the genus Lyginopteris. See his Lehrbuch der Pfanzen-palcontologie, Leipzig, I898, p. I60. 
before its connection with the other organs was established.

I. The Stem.-The stems vary in diameter from about $3 \mathrm{~mm}$. up to about $4 \mathrm{~cm}$. The description will be based on the larger specimens, from $\mathrm{I}$ cm. in diameter upwards, as the smaller stems are in some ways exceptional, and will be best dealt with later.

The stem is, in all cases, of monostelic structure; the middle of the stele is occupied by a large pith, chiefly parenchymatous, but containing irregular groups of dark sclerotic tissue (see Figs. I 29 and I 30).

Around the pith are disposed several distinct strands of wood, varying in number from five to about eight or nine, and constituting the primary xylem of so many collateral vascular bundles (Fig. I 29, $x$ ) Immediately outside the ring of primary xylem-strands, we find, in all except the youngest stems, a broad zone of secondary wood, consisting of radial series of pitted tracheides, with parenchymatous medullary rays, both principal and secondary, between them (Figs. I 29 and I 30 ). This zone was manifestly the product of a cambium, and, in fact, the cambial cells themselves are, in some of the specimens, quite evidently preserved at the exterior of the secondary wood (see Fig. I 34, cb). Beyond the cambium is a well-marked zone of phloëm, also divided up by the rays, and for the most part of secondary origin. Opposite each of the primary xylem-strands, however, a group of primary phloëm can be recognised in well-preserved specimens (see Figs. I 29 and $\mathrm{r} 34, p h$ ). We see, then, that the vascular structure, in its broad features, is that typical of the stems of normal Gymno- 
sperms or Dicotyledons-a ring of collateral bundles, forming secondary wood and bast by means of a cambium.

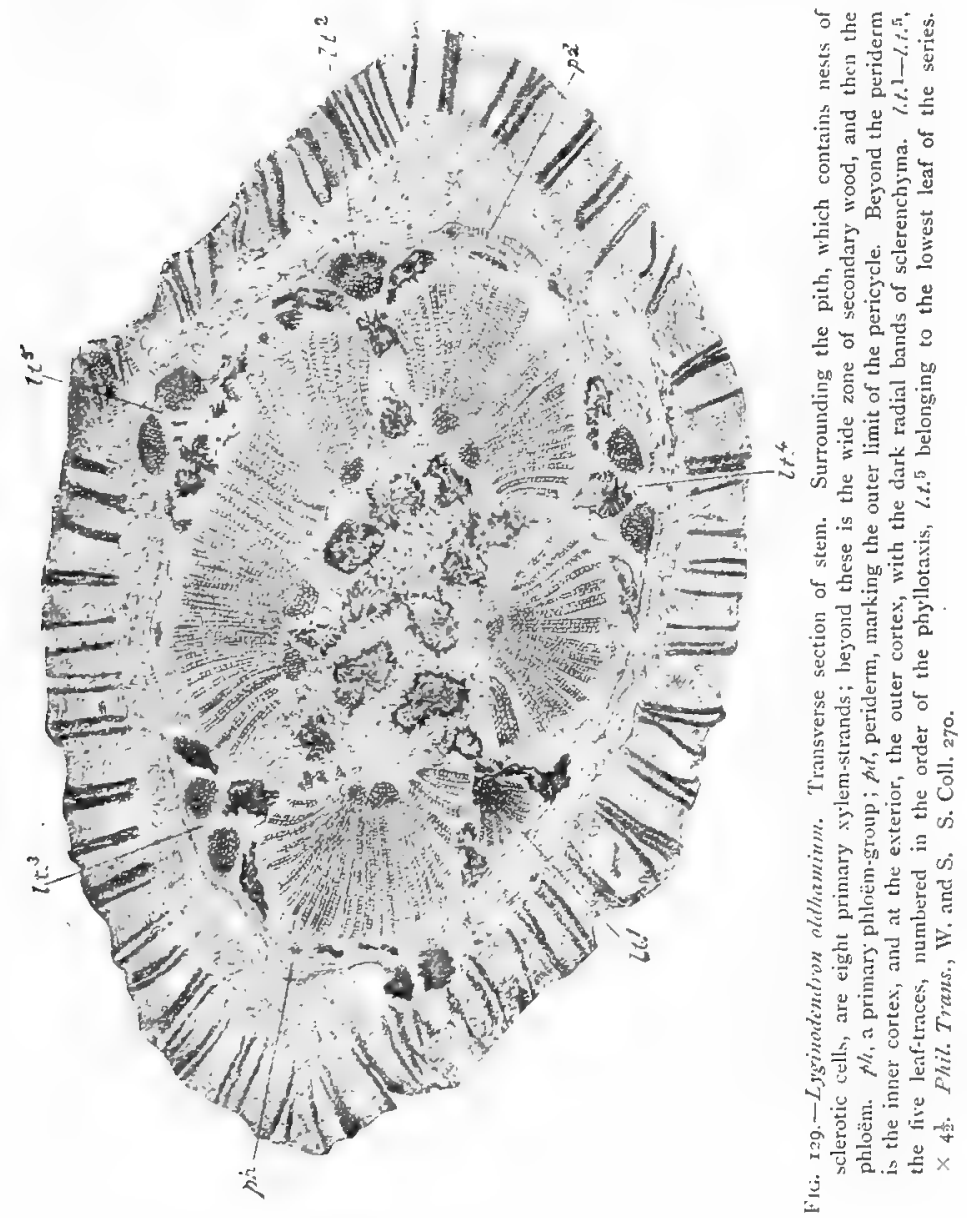

Beyond the phloëm-zone is a pericycle, containing groups of thick-walled elements, like those which occur in the pith. Embedded in the pericycle we find the 
outgoing leaf-trace bundles, which are collateral in structure (Figs. I 29 and I 32). They keep a nearly vertical course for some distance, and do not leave the pericyclic zone until they bend out sharply through the cortex, to enter the bases of the leaves.

The outer cells of the pericycle have generally

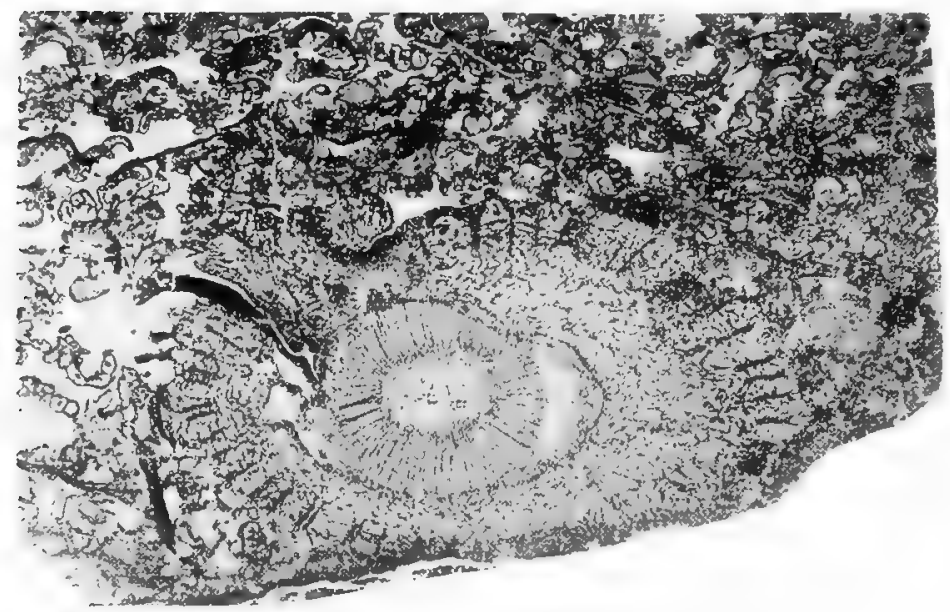

IIG. 130.-Lyginodendron oldhaminm. Transverse section of stem (ntructure as in Fig. 129), surrounded by a mass of foliage, showing rachis and leaflets cut in various directions. On the left, the stem is giving off als adventitious root. $\times 4$. From a photograph by Mr. L. A. Boodle. S. Coll. 636 .

given rise to a few layers of periderm (Figs. I 29, I 32 , I $34, p d)$, which, however, does not reach any great development in Lj'ginodendron. Beyond the periderm we come to the thin-walled inner cortex, usually ill preserved, and then to the very characteristic outer cortex, consisting of interlacing strands of fibrous sclerenchyma, forming a network, with the meshes occupied by cellular tissue. In transverse section the 
sclerenchyma appears in the form of dark radial bands (see Figs. I 29 and I 30). A few parenchymatous layers terminate the cortex towards the exterior.

The course of the vascular bundles through the stem is an important feature. The xylem-strands surrounding the pith constitute the downward continuation of the same leaf-trace bundles, which we find passing gradually outwards through the pericycle. That this is so is proved by our frequently meeting with the bundles in an intermediate position, on their way through the zone of secondary wood, which intervenes between pith and pericycle (Fig. I 29, l.t. ${ }^{1}$ ). When the leaf-trace is once clear of the secondary wood, it rises very steeply through the pericycle, following, as already mentioned, a nearly vertical course, but still passing slowly outwards, so that the pericycle is eventually bulged out to make room for it (see Fig. I 29, l.t..$^{5}$ ). The trace, which on starting is a single bundle, divides into two, during its passage through the pericycle. The twin-bundles thus formed are very characteristic of the plant (see Figs. I 29, l.t. ${ }^{3}-$ l.t. $^{5}$, and I 32). The double trace finally bends out sharply through the cortex, and enters the base of a leaf-stalk (see Fig. I 36$)$.

It is a very constant rule that, in any transverse section of the stem, five leaf-traces are present outside the wood. They are not all equally far out, and in good sections it is easy to tell which of them is nearest its exit into a petiole, and which is only just leaving the wood, and, in fact, to determine the exact order of all five (see Fig. 129). If we begin with the trace farthest inwards (l.t. ${ }^{1}$ in Fig. I 29), we find that the 
next outer one $\left(l_{. t} .^{2}\right)$ is separated from the former by $\frac{2}{5}$ of the circumference, the next outer one again $\left(l . t^{3}\right)$ by another $\frac{2}{5}$, and so on through the whole circuit. This arrangement of the leaf-traces points clearly to a $\frac{2}{5}$ arrangement of the leaves themselves, which is confirmed by direct evidence, when we have pieces of the stem long enough to show the bases of two or more leaves. The phyllotaxis, then, was a spiral one, with a divergence of ${ }_{5}^{2}$, at least in the larger stems. Of course phyllotaxis is a variable character; in the very small stems of Lyginodendron there appears to have been a $\frac{1}{3}$ arrangement, and other divergences may very probably be met with.

As the leaf-traces of five successive leaves appear in the same transverse section, it follows that each leaftrace must have extended through a length equal to five internodes, between leaving the wood and entering the petiole. As the internodes were often about an inch long, it is evident that the outward passage of the bundles was a very gradual one. The strands of wood around the pith are, as we have seen, continuous with the leaf-traces, and, in fact, form the lower part of the same system. Their number is less constant than that of the more external leaf-traces; sometimes it is five, sometimes more. Where there are five xylem-strands only around the pith, they are alternate with the five leaf-traces in the pericycle. Where there are more than five, the excess is due to the fact that some of them are double; their alternation with the outer traces is still maintained (Fig. 129). Each of the bundles surrounding the pith is, in fact, a sympodium, composed of the united lower ends of successive adjacent leaf- 
traces. Where one of the circum-medullary xylemstrands is double (Fig. I 29), one half is about to pass out to constitute a leaf-trace, while the other will continue the sympodium in a vertical direction.

We thus see that the entire vascular system of the Lyginodendron stem is built up of leaf-traces, in a manner comparable to that of the Gymnosperms or Dicotyledons, and in some degree to that of Osmunda among the Ferns.

The more detailed structure of the vascular tissues must now be considered. The primary xylem of the leaf-trace, whether examined at the margin of the pith, or at some point on its outward course, shows a constant arrangement of its elements. The small spiral tracheae (protoxylem) are invariably placed in the interior of the xylem-strand, but nearer its outer than its inner edge (see Figs. I 3 I, I 32, $p x$ ). Thus the greater part of the primary wood in each bundle was developed centripetally, on the inner side of the protoxylem, while a smaller portion was formed centrifugally, on its outer side. The tracheides adjacent to the spiral primitive elements are scalariform, but the bulk of the primary wood, especially its centripetal portion, is formed of tracheides with bordered pits (cf. Fig. I 57, p. 406, from Heterangium). A few parenchymatous cells adjoin the protoxylem (see Figs. I 3 I and I 32), usually on the inner side. The bundles, as we have already seen, are collateral; this fact is most clearly seen in the outgoing leaf-traces (see Fig. I 32), for in the bundles of the circum-medullary ring, xylem and phloëm are usually widely separated by the intercalated zone of secondary wood. Vascular bundles with the primitive elements 
in the interior of the primary wood are conveniently termed mesarch; those in the stem of Lyginodendron may thus be described as mesarch collateral bundles. This is a rare structure in recent plants, and, in fact, is almost limited to the leaves and petioles of Cycadaceae. The agreement between these foliar bundles and those in the stem of Lyginodendron is wonderfully close, as is

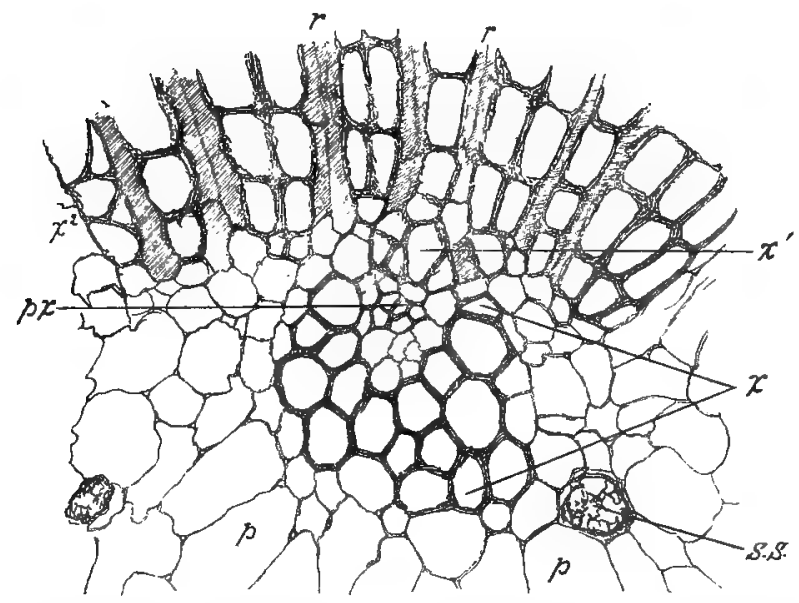

Fic. 13r.-Lyginodendron oldhamium. Part of transverse section of stem, showing a primary xylem-strand, and adjacent tissues. $p_{x} x^{2}$, protoxylem; $x$, centripetal primary wood; $x^{1}$, centrifugal primary wood; $x^{2}$, secondary wood; $r$, medullary rays; $p$, pith; s.s., secretory sac. $\times$ ıco. Phil. Trans., W. and S. Will. Coll. 1884.

shown, for example, by the comparison of Fig. I 32 , representing a leaf-trace of Lyginodendron, with Fig. I 33, drawn from a petiole of the recent Stangeria. In the stem of recent Cycads, however, the bundles are normal (endarch), with the spiral elements on the inner side of the wood. The occurrence of mesarch bundles in the stem of Lyginodendron and some other fossil plants, suggested a search for possible traces of the 


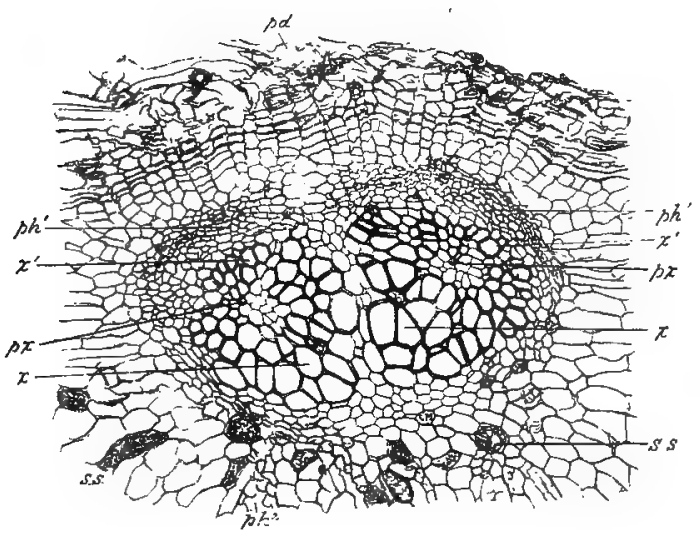

FIG. 132.-Lyginodendron oldhamitum. Part of transverse section of stem, showing a double leaf-trace, and adjacent tissues. $p x$, protoxylem of bundles; $x$, centripetal, $x^{1}$, centrifugal, part of xylem ; $p h^{1}$, phloëm of leaf-trace ; $p h^{2}$, phloëm of stele; s.s., secretory sacs; $p d$, periderm, $x$ about 4 o. Phil. Trans., W. and"S. Will. Coll. I884.

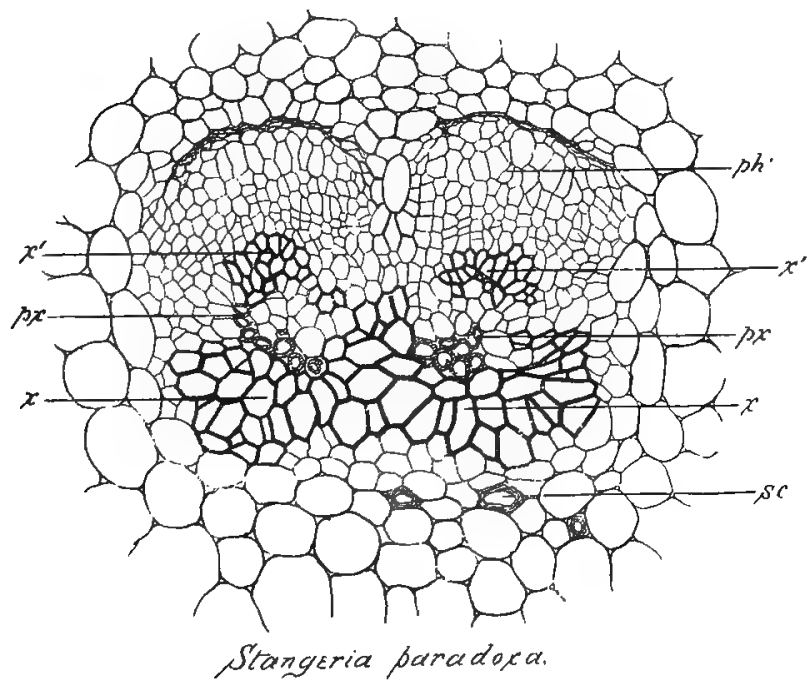

FIG. 133. -Stangeria paradoxa. Part of transverse section of petiole, showing a double bundle, to compare with Fig. I3z. sc, stone-cell. Other lettering as in Fig. I32. $\times 95$. From a drawing by Mr. G. I3rebner. 
same structure in the stems of recent Cycads, and the search was successful, for though no mesarch bundles have as yet been found in the vegetative stems, yet they occur distinctly in the peduncles of the cones in several Cycads, of the genera Stangeria, Bowenia, Zamia, Ceratozamia, and Dioon. In Stangeria and Dioon especially, the centripetal part of the xylem in these organs is still well developed, though in the others it is more reduced. ${ }^{1} \quad$ In these cases, then, the floral axis appears to have retained primitive characters, as is also shown in the simple course of its vascular bundles.

The secondary wood of Lyginodendron oldhamium forms a continuous ring, except where it is interrupted by the outward passage of a leaf-trace (Fig. I 29). The fascicular and interfascicular cambium must have sprung into activity almost simultaneously (Fig. I 35 ). The medullary rays vary much, both in height and width; they are sufficiently developed to have given the wood a somewhat soft parenchymatous character, approaching that of recent Cycadaceous woods. The tracheides are pitted on their radial walls only; the pits are multiseriate and bordered (cf. Fig. I 57, p. 406, from Heterangium). Beyond the cambium (Fig. I 34, cb), we come to the secondary phloëm $\left(p h^{2}\right)$. Here the medullary rays become more or less dilated, breaking up the phloëm proper into narrow strands, each of which is made up of alternate tangential bands of large and small elements; the former were probably the sieve-tubes (Fig. I 34). Where a leaf-trace bundle

I Scott, "The Anatomical Characters presented by the Peduncle of Cycadaceae," Annals of Botany, vol. xi. 1897, p. 399. F. W. South and R. H. Compton, "The Anatomy of Dioon edule," New Phytologist, vol. vii. 1908, p. 222. 
passes out, a gap, filled by parenchyma, is left in the wood, which only closes up behind the bundle at a higher level (Fig. I 29). When the leaf-trace leaves the wood of the stele, it is at first accompanied by its own secondary tissues, which, as seen in transverse section, form a fan-shaped mass on the outer side of the primary wood (see Fig. I 29, l.t. ${ }^{1}$ ). As the strand

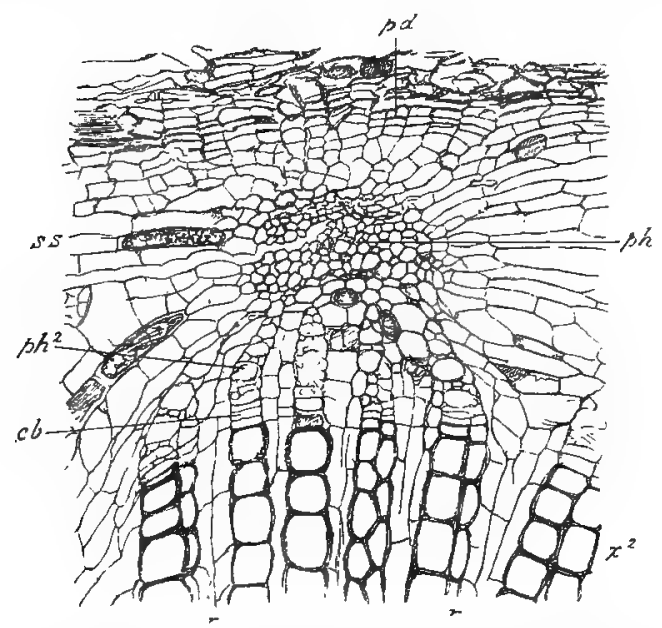

FIG. 134.-Lyginodendron oldhamium. Part of transverse section, from outer part of stele. $x^{2}$, secondary wood; $r$, medullary rays; $c b$, cambium; $\not h^{2}$, secondary, $p h$, primary, phloëm; s.s., secretory sac; pd, periderm. $\times 52$. Phil. Trans., W. and S. Will. Coll. 1640.

passes up through the pericycle, this secondary portion is gradually lost, and has usually disappeared at the level where the bundle divides into two (see Figs. 129 and I 32). The collateral structure, however, is still maintained. It is only where the leaf-trace finally bends out, to enter the petiole, that this structure changes. Here the phloëm begins to encroach on the inner side of the xylem, until, in the leaf-stalk itself, the 
arrangement becomes completely concentric (cf. Fig. I 38). Thus Lyginodendron, like Osmunda among recent Ferns, had collateral bundles in the stem, which became concentric in the leaf.

As regards the other tissues of the stem, little more need be said. Nests of thick-walled cells are abundant in the pith and pericycle, and extend out through the cortex into the petiole (Fig. I37). Sacs with dark contents, probably representing some kind of secretory organs, are frequent in all the soft tissues of the plant (Figs. I 3 I, I 32, I 34). When considerable secondary growth had taken place, the cells, of the more external tissues have often become much dilated tangentially, and this dilatation is naturally most conspicuous in the outermost tissues, namely in the parenchyma between the fibrous strands of the external cortex (Figs. I 29 and I 30 ).

Very curious, flask-shaped, multicellular outgrowths (Fig. I 37, c) arre often found on the surface of the stem, each consisting of an outer sheath of thick-walled cells, surrounding a parenchymatous core; the two tissues are continuous with the sclerenchyma and parenchyma respectively of the outer cortex. Very similar blunt spines occur on the petioles of some recent Tree-ferns, such as species of Alsophila. These emergences have been of great service in the investigation of Lyginodendron, for, as they occur on the leaves (Fig. I 39,e) as well as on the stem, they rendered it possible to identify these organs as belonging to the same plant, before they had been found in actual continuity.

Very young twigs, still in the bud condition, which are sometimes met with, either detached or in connection with mature stems, are densely covered with the 
spinous outgrowths, just as the young parts of recent Ferns are covered with the ramenta.

In addition to the spines, glandular outgrowths, apparently homologous with them, also occur, and in some forms of the plant are extremely abundant on stem, rachis, and leaflets. These organs, as we shall

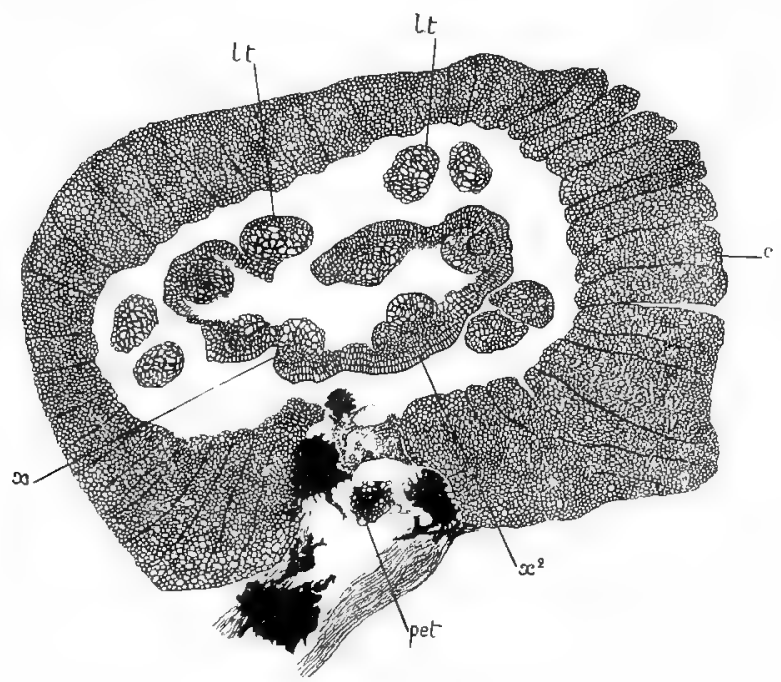

FIG. 135.-Lyginodendron olthaminm. Transverse section of a very young stem, at the commencement of secondary growth, $x$, one of the six primary xylem-strands surrounding the pith, which is not preserved; $x^{2}$, narrow zone of secondary wool; l.t., leaf-trace bundles; $c$, outer cortex; pet, base of petiole. $\times$ II. Will. Coll.

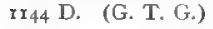

see, have played an even more important part than the spines in the advancement of our knowledge of the plant, for it was by means of the glands that the seeds of Lyginodendron were first identified (sce p. 388). The glands are sometimes sessile, but more usually rested on a stout multicellular stalk, the actual gland consisting of a more or less spherical head, which is 
filled by a small-celled secretory tissue (Fig. I 36). In certain conditions the glandular tissue has broken down and the head is left empty (Fig. I46).

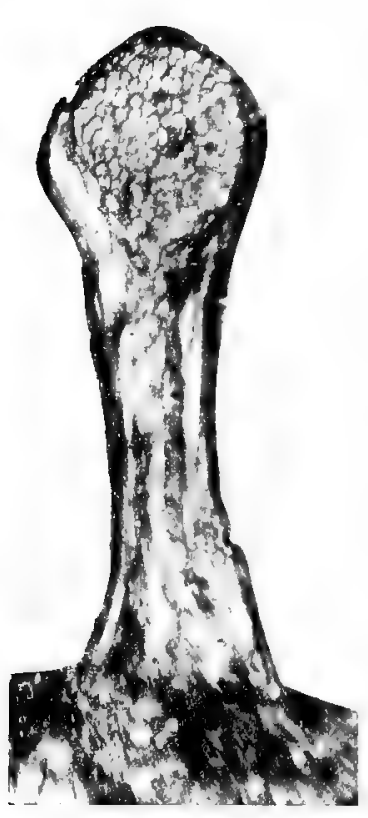

Fir. ${ }_{3} 6$. Lyginatend'on olthamium. Vegetative gland, showing well-prestrved secretory tissue filling the head. 'The depression on the right of the stalk is a itona. $x$ atrout 60, S. Coll. 447. From a photograph lyy Mr. L. A. lsoodle, F.L.S. (Plit. Trans. Oliver and Scott.)

We have so far described the ordinary structure of the Lyginodendron stem, such as is common to the great majority of the specimens. Sometimes quite young stems are met with, with little or no secondary growth; one of these is represented, in transverse section, in Fig. I 35, at a stage when the secondary wood $\left(x^{3}\right)$ was still quite thin. Such specimens show very clearly the identity of the leaf-traces (l.t.) with the strands (x) surrounding the pith. At this stage, the outer cortex contains only narrow bands of parenchyma; evidently this tissue increased by dilatation as the stem enlarged in girth.

In some cases small stems are found which are not merely young, but really have a different structure from the usual kind. Some of these little stems have a very small pith, surrounded by a more or less continuous ring of primary xylem, instead of by separate bundles. These specimens may very likely be the stems of 
seedlings or very young plants, which had not yet attained their normal structure. We know that the embryonic stem of an Osmunda has a continuous ring

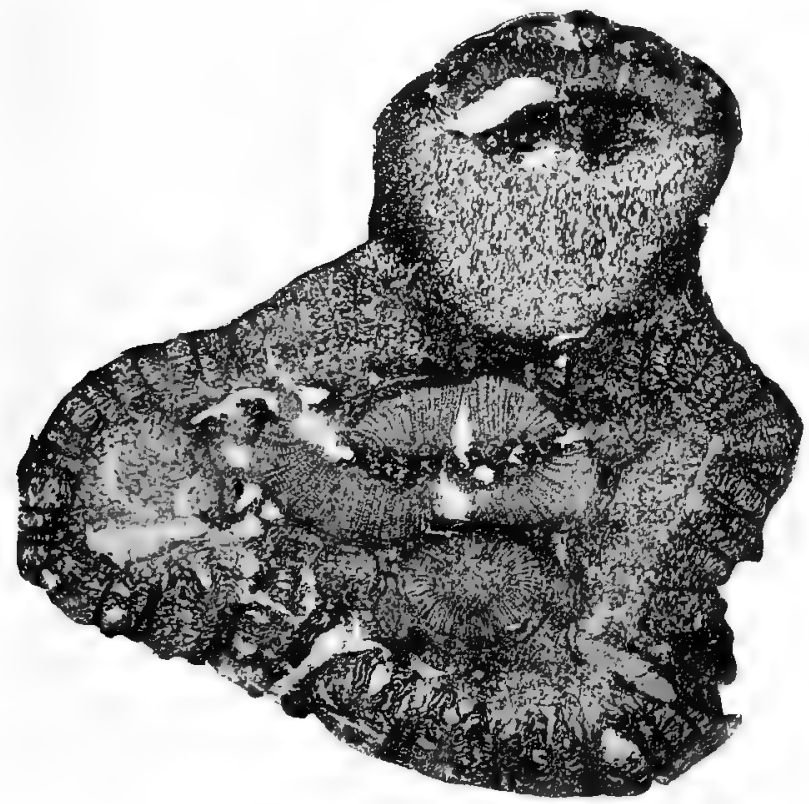

FiG. 137.-Lyginodendron oldhamium. Transverse section of branching stem. At the top of the figure is the base of a petiole containing two bundles . The stele of the branch lies below that of the main stem. $x$ about 4. S. Coll. 2077. From a photograph by Mr. Tams.

of xylem, while, in the later-formed parts of the axis, this is gradually replaced by a ring of distinct bundles.

For many years after the discovery of Lyginodendron only unbranched stems came under observation, and it was not till I 902 that the first cases of branching were discovered by Mr. James Lomax. Fig. 137 shows, in 
a transverse section belonging to a series cut from one of the original specimens, a stem about to give off a branch, which is still in connection with the main axis. A peculiar feature of the branching is that two of the leaf-traces in the pericycle of the main stem pass out into the branch, one on each side, and supply its first two leaves; the third leaf of the branch receives a trace from its own stele, passing out between the two former.

In some specimens branching of the stem has been found to be often repeated at short intervals, and in these cases it is always axillary, though it is not certain that this condition was constant. It is quite possible that the occurrence and mode of branching may prove to characterise distinct species still included under the collective name $L$. oldhamium. ${ }^{1}$

Various individual anomalies, in the anatomical structure have been observed; the most frequent and interesting consists in the formation of secondary wood and bast, with inverted orientation, in the pith, immediately within the normal ring of bundles. The anomaly, in fact, is the same as that occurring in certain species of Tecoma and Iodes among recent Dicotyledons. It is evident that the anomalous cambium, giving rise to these medullary formations, was sometimes, if not always, continuous, through the trace-gaps, with the normal cambial zone. Thus it occasionally happened that each segment of the wood became completely surrounded by a zone of cambium, and grew in thickness on its own account, so that such a stem

1 The branching of Lyginodendron has recently been fully investigated by Miss Brenchley, whose results are not yet published. 
assumed a pseudo-polystelic structure. These anomalies, though only found in some specimens of Lyginodendron oldhamium, are interesting, not merely as an example of the plasticity of structure which the formation of cambium gives to a plant, but because they reappear, apparently as constant features, in some allied fossil stems.

2. The Leaves.-We have now to consider the evidence as to the nature of the leaves of Lyginodendron oldhamium. Almost every specimen of the stem of that plant is surrounded by a mass of finely divided foliage, the stalks and leaflets of which are cut in every direction by the plane of section. A good example is shown in Fig. I 30, from a photograph. The main petioles of the leaves associated with the Lyginodendron stems are of large size, reaching a centimetre in diameter; they are often found branching, and the successive branches diminish in size, the ultimate ramifications being quite slender. The smallest of these are sometimes found in connection with the leaflets, which are deeply lobed, with veins diverging from one another at an acute angle. The material with structure preserved can only be studied in sections, and is more or less fragmentary, so that it is impossible to reconstruct, from it alone, a complete picture of the form of the highly compound leaf. Enough, however, is shown to enable us to identify these petrified specimens with certain fronds preserved as impressions, in which the whole configuration is manifest, and there is now no doubt that the foliage in question is identical with that of Sphenopteris Höninghausi, a form described 
by Brongniart as long ago as $1829^{1}$ (see restoration, in Frontispiece).

It was suspected by Williamson, from the time of

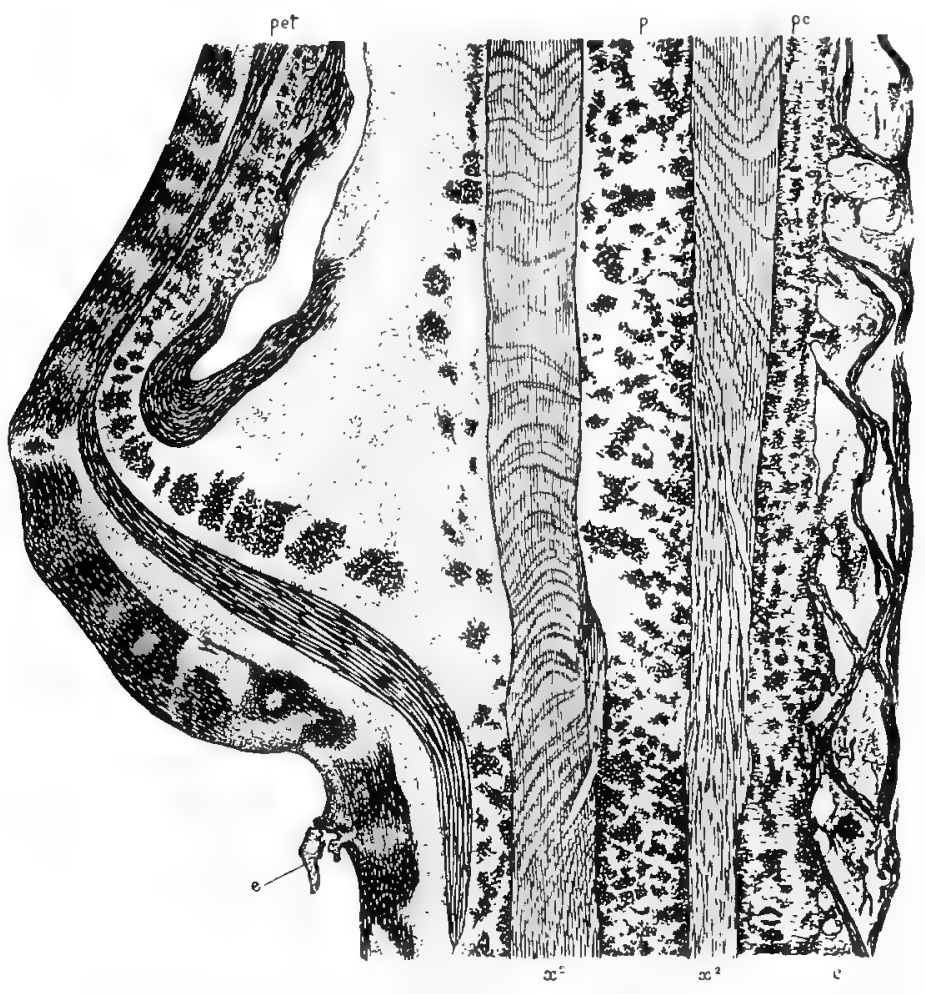

FIG. r38.-Lyginodindron dahamizm. Radial section of stem, passing through the base of a periole. $\tau^{2}$, wood of utem, enclosing pith; pc, pericycle; $c$, outer cortex ; pet, petiole; the vascular bundle cxtends from the petiole down into the pericycle of the stem; $t$, cortical spines. $\times 3 . j$. Will. Coll, I982. (G. T. (i.)

his first observations on the petioles of these leaves,

1 The identity of the Lysinodendron folinge with this species of Sphentopteris has recently been demonstrated in detail by Mr. Kidston in his paper on the microsporangia of Pteridosperneae, cited below. 
that they might belong to Lyginodendron oldhamium, an opinion which has since been raised to a certainty, by the discovery, in many instances, of the stem and petiole in actual connection (see Fig. I 38, which shows the stem and petiole in radial section through the node). Before this discovery, the petioles were named

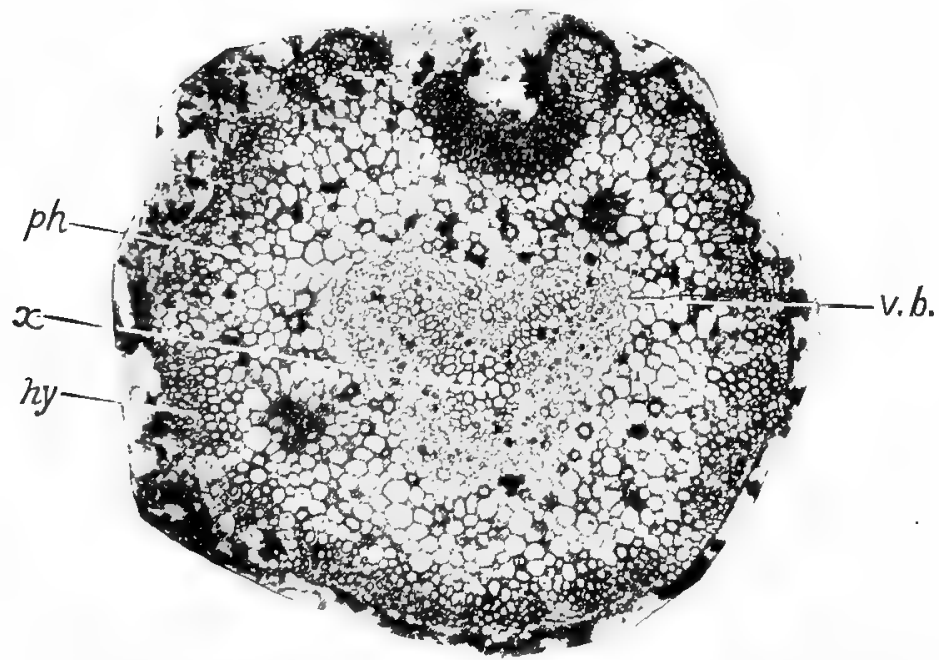

FIG. 139.-Lyginodendron oldhamium. Transverse section of rachis. $x, \mathrm{~V}$-shaped xylem; ph, phloëm, completely surrounding xylem, forming the concentric bundle i.b.; hy, hypoderma. $\times$ about 35 . From a photograph. Phil. Trans., W. and S. Will. Coll. 145 .

Rachiopteris aspera. The petiole, which forked at some distance from the stem, to form two equal main branches of the rachis, contains either two distinct vascular bundles, or a single fused bundle, having the form in transverse section of $\mathrm{a} \mathrm{V}$ or a $\mathrm{W}$. In the finer branches of the rachis, the single $\mathrm{V}$-shaped bundle is constant (see Fig. I 39). The structure is in all cases concentric, the phloèm completely surrounding the 
xylem. In the specimen figured the preservation is surprisingly perfect, every cell of the phloëm being present. The convex side of the bundle is directed towards the lower surface of the petiole. The structure of the wood is like that of the primary bundles in the stem; the spiral elements occur in several groups in each bundle, and are placed in the interior of the xylem, towards its lower surface. In the specimen shown in Fig. I 39 there are probably three protoxylem-groups, one near the bend of the $\mathrm{V}$, and one towards the end of each arm.

The inner cortex contains bands of sclerotic tissue, like those in the stem, but more distinctly transverse, and the outer cortex is here also a network of fibrous strands, enclosing parenchyma in their meshes. The curious blunt spines, described above as occurring on the stem, are just as abundant on the leaf, where they are present on all parts of the petiole and rachis, and even extend onto the leaflets (see Fig. I 40).

In some cases the minute structure of the leaflet is wonderfully well preserved (see Fig. I40); below the epidermis of the upper surface we can distinguish a hypodermal layer, beneath which again is well-characterised palisade-parenchyma. Towards the lower surface the mesophyll has a laxer structure, constituting the spongy parenchyma ; occasionally, traces of stomata have been detected in the lower epidermis. The fine vascular bundles traversing the lamina are enclosed in distinct sheaths, and appear to have been collateral in structure, as is so often the case in the ultimate ramifications of the bundles in the leaves of recent Ferns. The whole structure is altogether comparable to that of a 
fairly coriaceous Fern-leaflet at the present day, and indicates that the conditions to which the structure was adapted could not have been fundamentally different from those which prevail in our own epoch.

A xerophytic structure is clearly exhibited in the presence of a hypoderma, the considerable thickness of the leaflets, and their conchoid, incurved form. Such indications of xerophytic adaptation are exceedingly

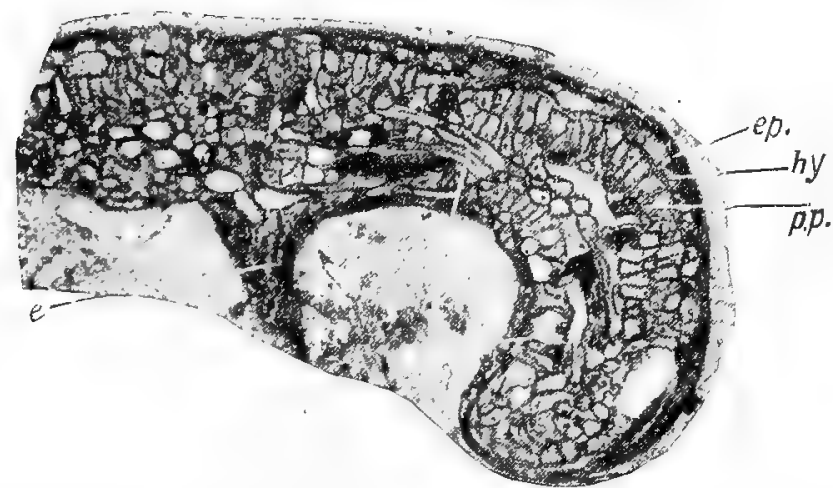

FiG. I40.-Lyginodendron oldhamizun. Vertical section of a leaflet. $c p$, upper epidermis; $h y$, hypoderma ; $p . p$., palisade-parenchyma ; $s p$., spongy parenchyma ; $v . b$. , vascular bundle; $e$, spine. $\times$ about 7 o. From a photograph. Phil. Trans., W. and S. Will. Coll. rig6.

common among the plants of the Coal-measures, as already noticed in the case of Sigillaria (p. 225, vol. i.). The ends of the vascular bundles of the leaflets in Lyginodendron are commonly dilated as regards the xylem, a character which has also been observed in the xerophytic leaves of the Mangrove plants of tropical sea-shores.

The proof that the Sphenopteris form of foliage just described, which in structure, as well as in form and venation, is essentially Fern-foliage, really belonged to 
Lyginodendron oldhamium, is clearly a point of great importance, for from the characters of the stem alone the affinity with Ferns is much less evident. This proof has been afforded, first, by finding the petioles in continuity, through their finer ramifications, with the Sphenopteris leaflets, and next, by finding the petioles themselves in continuity with the stem. The petiole is connected with the stem by a broad but not sheathing base (see Fig. I 38). The twin leaf-trace bundles bend out sharply into the leaf-base, sometimes becoming fused as they enter it, sometimes remaining distinct. The sclerotic nests, already referred to, are very abundant in the cortex of the axillary region. The petioles found in connection with the stem can often be traced for some distance after they become free, and their branching can be followed; sometimes a fortunate section passes through the point of bifurcation of the main rachis. There is thus no doubt that the leaves of Lyginodendron oldhamium were of a forked and highly compound form. In all their characters, so far as the vegetative condition is concerned, they suggest the foliage of a Fern (see below, p. 384).

3. The Roots.-The adventitious roots of Lyginodendron oldhamium were known for many years as separate objects, before their relation to Lyginodendron was discovered. Like so many other detached organs. of fossil plants, they received a distinct name, and were long known as Kaloxylon Hookeri. They have since been so constantly found in connection with the stem, that their true nature is fully established.

The roots are often most perfectly preserved, and 
are beautiful objects, showing the characteristic points of root-structure with diagrammatic clearness. Some of the specimens are still in their primary condition, while others show the secondary tissues at all stages of their development. Some of the smallest rootlets are

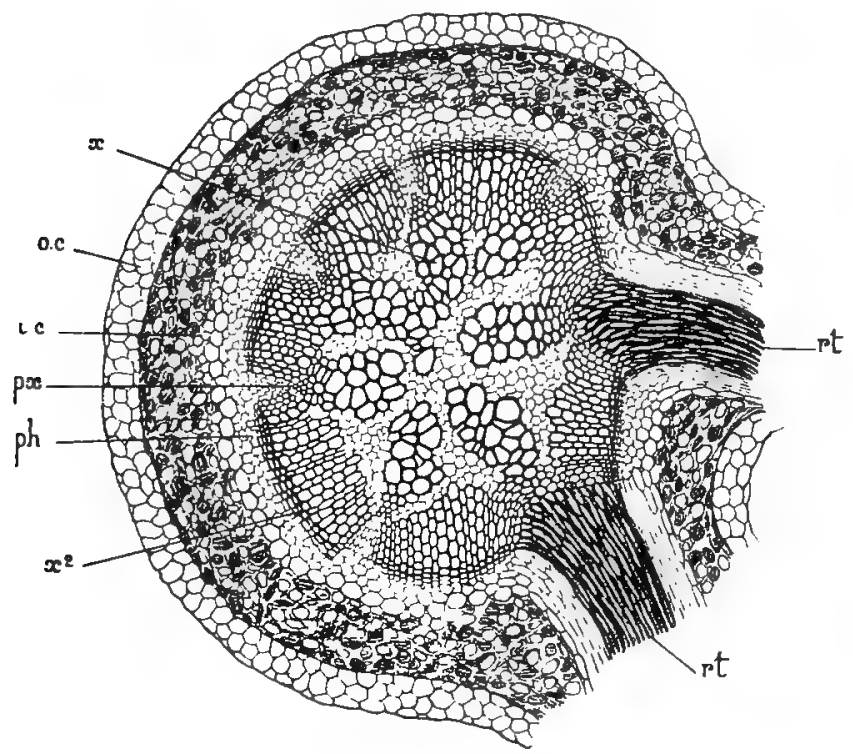

FIG. 141.-Lyginodendron oldhamitum. Transverse section of root, somewhat diagram matic. $p x$, one of the protoxylem-groups; $x$, the heptarch primary wood; $x^{2}$ secondary wood; $p h$, phloëm; i.c, inner cortex; o.c, outer cortex; $r t$, rootlets, opposite two protoxylem-groups. $\times 24$. Founded on S. Coll. 448 . (G. T. G.)

triarch, or even perhaps diarch, but the larger and more characteristic specimens have from four to eight initial groups of xylem, alternating with as many strands of phloëm. The root shown in Fig. I 4 I was a heptarch one. The primary wood has a well-marked stellate form, as seen in transverse section (see Fig. I 4 I). The smallest tracheides, which are shown by longitudinal 
sections to be spirally thickened, are at the prominent angles $(p x)$, constituting a peripheral protoxylem, such as is characteristic of roots. Towards the interior the tracheides become rapidly wider, and assume pitted structure. They are intermixed with conjunctive parenchyma, which, however, never forms a definite pith. In good preparations the primary groups of phloëm, lying in the furrows of the wood, between the protoxylem-angles, can be clearly recognised, separated from the neighbouring wood by one or more layers of conjunctive parenchyma. The delicate, elongated elements of the phloëm are quite distinct, as -seen in longitudinal section, from the adjoining parenchymatous cells. We thus see that there was a perfectly regular alternation of the xylem and phloëm-strands, just as in recent roots. A pericycle, one or more layers thick, surrounds the vascular tissue; the endodermis beyond this is often well defined, and in specially favourable cases its radial cell-walls stand out more sharply than the others. The broad inner cortex of the root consists of a lax parenchyma (Fig. I $4 \mathrm{I}$, i.c), in which numerous elongated elements with dense carbonaceous contents, probably secretory sacs, are scattered. The outer border of the root is formed by a very well-defined double layer of large cells (o.c), generally well preserved, and constrasting sharply with the more perishable internal cortex. This double peripheral layer (exodermis) is one of the most useful characters in recognising the roots of Lyginodendron, though it was, perhaps, common to those of some closely allied genera. The roots, before secondary thickening set in, had a maximum diameter of about $5 \mathrm{~mm}$; they vary from this size 
down to perhaps one-tenth of the diameter in the case of minute rootlets.

The roots branched freely; their lateral appendages are always rootlets, i.e. the branches are decidedly smaller than the parent organ; their branching was thus monopodial, as in Ferns or Cycads, not dichotomous, as in Lycopods. The rootlets were of endogenous origin, and their xylem is always in connection with one of the protoxylem-angles of the main root (see Fig. I $4 \mathrm{I}, r t$ ). In these points, as in all others, the morphological character of these organs, as typical roots, is manifest.

Cases have recently been observed, by Professor F. E. Weiss and others, in which the structure of the rootapex is perfectly preserved. Details have not yet been published, but it appears that the growing point, unlike that of most Fern-roots, had no definite apical cell.

All the larger roots show, if old enough, well-marked secondary growth. Every stage of the process has been observed, showing that it took place exactly in the manner characteristic of the roots of Gymnosperms and Dicotyledons at the present day. The cambium first arose by the division of conjunctive cells, lying immediately within the phloëm-groups. The isolated cambial arcs thus formed were next united into a continuous zone, by the division of pericyclic cells lying outside the protoxylem-angles. Opposite each of these angles a principal ray was formed, and thus the secondary vascular tissue was at first broken up into distinct bundles, corresponding in number and position to the primary groups of phloëm (see Fig. I 4I, which shows the secondary tissues at a rather early stage of development). Subsequently, the principal rays became 
partly filled up by the intercalation of intermediate strands of secondary wood and bast. The activity of the cambium was, in fact, in all respects normal; the secondary wood and bast agree in structure with the corresponding tissues in the stem. No distinct formation of periderm has been observed in these roots.

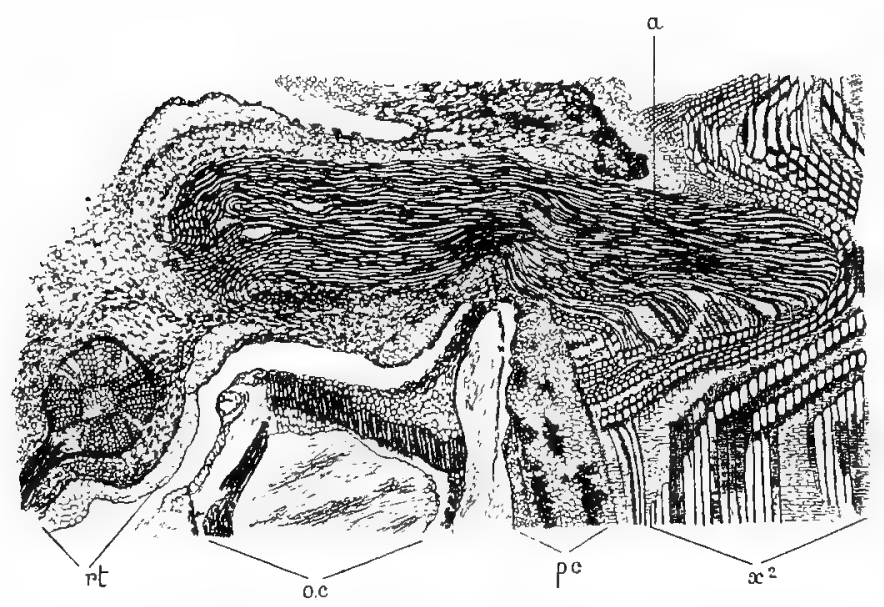

FIG. I42.-Lyginodendron oldhamium. Part of radial section of stem, showing an adventitious root, which is so curved as to be seen partly in longitudinal, partly in transverse section. $x^{2}$, secondary wood of stem; $p c$, pericycle; $0 . c$, outer cortex; $a$, connection between root and wood of stem; rt, root, in transverse section, showing tetrarch structure, and giving off a rootlet. $\times 9$. S. Coll. $466 . \quad$ (G. T. G.)

It is certainly a fact of great interest that the roots of our fossil, which, in their primary condition, much resemble those of recent Marattiaceous Ferns, or of Helminthostachys among the Ophioglossaceae, should exhibit a mode of secondary tissue-formation absolutely indistinguishable from that of typical Dicotyledons or Gymnosperms.

Naturally, all the roots of Lyginodendron with which 
we are acquainted were adventitious. They are very commonly found in connection with the stem (see Fig. I 42), where they are inserted indiscriminately on nodes or internodes, and on all sides alike. They are not, however, found on all portions of the stem, and were probably limited to its lower region (see restoration, in Frontispiece). By tracing characteristic specimens, with the structure of "Kaloxylon Hookeri", to their junction with the stem, proof was afforded that this fossil was simply the root of Lyginodendron oldhamium. The mode of connection between the adventitious roots and the stem affords proof that the former were endogenous organs, for the cortical tissues proper to the root can be traced throughout the whole thickness of the cortex of the parent stem. Fig. I 42, from a radial section of the stem, shows clearly the connection of its tissues with those of the root. The latter happened to be bent, so as to show its transverse section, which is that of a tetrarch root with the structure of "Kaloxylon."

4. Habit.-We have already described the principal features in the structure of all the vegetative organs of Lyginodendron oldhamium. We may now attempt a reconstruction of the plant, so as to gain some idea of its habit, before going on to consider the subject of the organs of reproduction.

The stem must have been a comparatively slender one, of great length compared with its diameter. This appears to be proved by the length of the internodes (about an inch or so), and by the fact that every piece of stem shows, on the average, the traces of ten successive leaves (five traces outside the vascular ring, 
and five or more around the pith). As the great majority of the specimens show no signs of any approach to the apex or base, it seems clear that they represent fragments of very long stems, bearing a large number of leaves. Although the stem was well constructed mechanically, thanks principally to the sclerenchymatous network of the outer cortex, it may be doubted whether an axis of such length and such slender proportions, bearing numerous leaves of large size, could have supported itself unaided in the vertical position. Yet the plant shows complete radial symmetry, and could not well have been of prostrate habit. It is not unlikely that Lyginodendron oldhamium was a climbing plant of the "scrambler" type, a suggestion which is confirmed by the presence of spines on the stem, and on all parts of the compound leaves. These spines may well have been organs of attachment, enabling the plant to cling to the trees or shrubs which supported it, just as we see in the recent Fern Davallia aculeata, where, however, it is only the frond, and not the stem that climbs. On the other hand, a comparison has been suggested with the tall, erect species of Todea, such as $T$. australis.

The evidence for the identification of the foliage of our fossil with Sphenopteris Höninghausi is now conclusive. The agreement is exact in the venation, form and size of the leaflets, and in their conchoid curvature, in the mode of branching of the rachis, the presence of spines on all the parts, and the reticulated cortex of the petiole. Further, casts have been figured by M. Zeiller, which agree closely with the stem of Lyginodendron, and which at the same time bear the 
foliage of Sphenopteris Honinghausi. ${ }^{1} \quad$ The leaves of this species, which are very perfectly preserved as impressions, from the same horizon to which the specimens of Lyginodendron oldhamium belong, were of large size, and highly compound-tripinnate or more. There are various other species of Carboniferous Fern-fronds of very similar habit, and it is quite possible, as M. Zeiller ${ }^{2}$ has suggested, that all may have belonged to stems of the Lyginodendron type.

The arrangement of the Sphenopteris leaves on the Lyginodendron stem, in $\frac{2}{5}$ phyllotaxis, has already been mentioned, and appears to agree with that of the specimens described by M. Zeiller. In the „drawing ${ }^{3}$ reproduced in the Frontispiece, an attempt has been made to give a restoration of the plant, as it would have appeared in nature. The slender stem (of which only the lower part could be included in the figure) is shown somewhat inclined, to indicate that it was probably supported by other plants. Its surface bears the characteristic spines, and shows traces of a reticulated cortical structure. The arrangement and form of the large, highly compound leaves are known, from the evidence given above, to be essentially true to nature, the lamina of the leaf having been copied from that of Sphenopteris Höninghausi. The forking of the main rachis, however, does not come out in the figure. The position of the branching adventitious roots on the

${ }^{1}$ Zeiller, Bassin howiller de Valenciennes, p. 84, Plate vi. Fig. 1, I886. See also Kidston, "Microsporangia of Pteridospermeae," Phil. Trans. R.S. $\mathrm{B}$, vol. 198 , 1906 .

2 Zeiller, "Obs. sur quelques fougères des depôts houillers d'Asie Mineure," Bull. Soc. Bot. de France, vol. xiv. p. 195, I897.

" Prepared, according to my instructions, by Mr. J. Allen, a skilful botanical artist. 
stem is correct; some of them were borne on aërial parts of the stem, as shown in the figure, while others were, no doubt, entirely buried in the soil. The drawing was made before the discovery of the branching of the stem, which we now know to have occurred freely in many specimens (p. $37 \mathrm{I}$ ).

The pendulous, tufted bodies shown, in Fig. I (Frontispiece), on parts of the foliage, are intended to represent the lobed cupules, discovered by Stur in another species, and now known to have enclosed the seeds.

5. The Seed.-Up to the year I go3 our knowledge of Lyginodendron was practically limited to the vegetative organs. Any previous observations bearing on the mode of reproduction were then of uncertain significance; some of them will be referred to below. The first definite evidence was obtained by Professor F. W. Oliver, F.R.S., when he identified the seed of Lyginodendron by means of the glands on its enveloping husk. ${ }^{I}$ The seed in question was named by Williamson (in MS.) Lagenostoma Lomaxi; the genus was founded by him, but he left this species undescribed.

The seed is barrel-shaped, and of rather small size compared with many other Palæozoic seeds, the extreme dimensions reaching $5.5 \mathrm{~mm}$. in length by $4.25 \mathrm{~mm}$. in maximum diameter. It is enclosed in an outer husk or cupule, which completely enveloped the seed when young (Fig. I 43), though it was no doubt open at maturity (see Fig. I 44, from a model). In one or two fortunate

1 Oliver and Scott, "On Lagenostoma Lomaxi, the Seed of Ljginodendron," Proc. Roy. Soc, vol. lxxi. 1903; "On the Structure of the Palæozoic Seed Lagenostoma Lomaxi," Phil. T'rans. Roy. Soc. (B), vol. 197, 1904. 


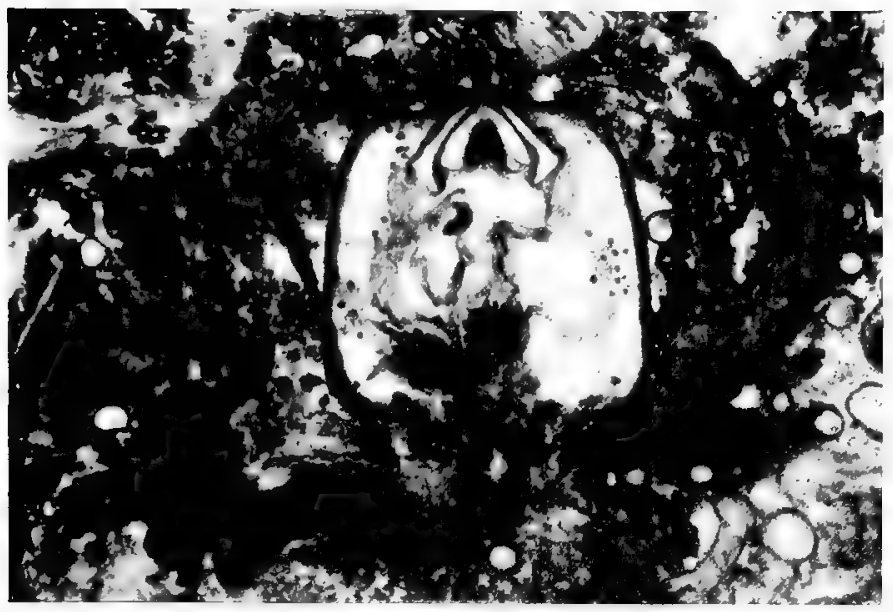

FIct. I43.-Lagenostona Lomaxi. Longitudinal section of a small seed, invested by the lobed cupule, which bears numerous glands. Micropyle and pollen-chamber well shown; chalazal tissue displaced. From a photograph by Mr. Boodle, Oliver and Scott. Phil. Trans. $\times$ about I5. Will. Coll. I931, A.

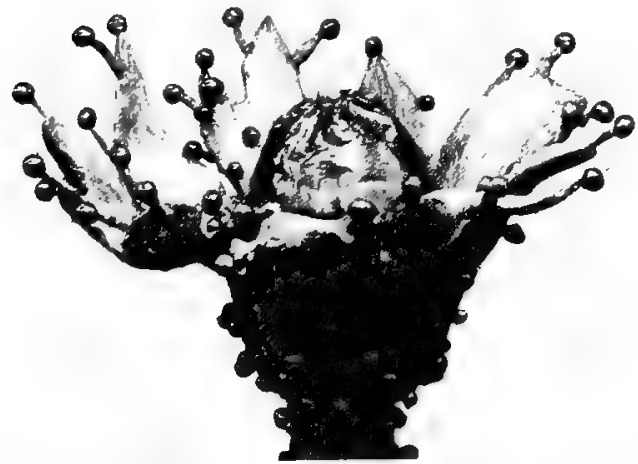

FIG. 144,-Restoration of the seed of Lyginodendron (Lagenostona Lomaxz), from a model by Mr. H. E. Smedley. The seed is shown surrounded by the open glandular cupule. 
cases the seed is found still attached to its pedicel; both pedicel and cupule are studded with capitate glands (Figs. I 43, I 44), usually borne on a stout, multicellular stalk. The cavity of the head is empty, and the whole structure is identical with that of the glands on the leaf

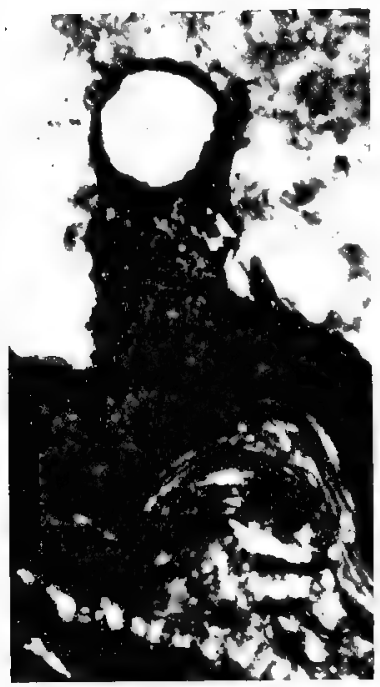

FI $C_{x}$, T $_{45}$ - Capitate glandlon theicupule of Lagenostoma Loma_zi. $\times 70.1$ Oliver and Scott, Phil. Trans. S. Coll. 558.

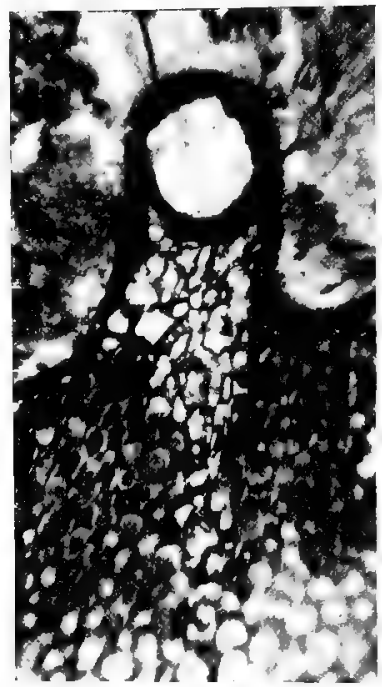

FiG, 145.-Capitate gland on the periole of Lyginodendron oldhamizm. $\times 70$. Oliver and Scott, Phil. Trans. Univ. College Coll. $M$ I I. $c$.

Figs. I45 and I 6 from photographs by Mr. Hoodle.

and stem of Lyginodendron, at a stage when the secretory tissue has perished (compare Fig. I 45, from the cupule of Lagenostoma Lomaxi, with Fig. 146, from a petiole of Lyginodendron). No other fossil plant is known with glands of this kind, and, considering the close and constant association of the seed with the vegetative organs of Lyginodendron, there can be no doubt as to 
the correctness of the attribution. Further structural evidence is not wanting, as we shall see below.

The cupule, which in general form has been compared to the husk of a hazel nut, was ribbed in its lower part and divided into lobes above (see Figs. I 44 and I 49); it sprang from the pedicel immediately below the base of the seed, around which it formed a

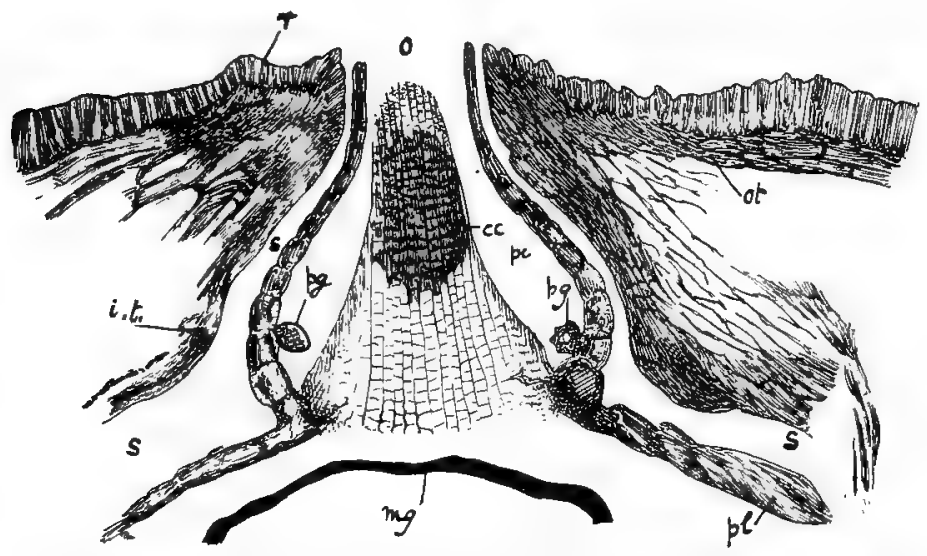

Fig. 147.-Lagenostona Lomaxi. Apex of seed in median longitudinal section through micropyle. $r$, palisade-layer; ot, outer; $i . t$. , inner wall of canopy (integument); $s$, space between canopy and nucellus; $p c$, cavity of pollen-chamber; $o$, its orifice; $c c$, central column of pollen-chamber; $p g$, pollen-grains ; $p l$, part of nucellus supporting pollen-chamber; wg, membrane of megaspore. $x$ about 50. After Oliver. Univ. College Coll. $\mathrm{R}$.

perfectly free envelope (see diagram, Fig. I48). The pedicel was traversed by a single concentric and mesarch vascular strand, which, before entering the chalaza of the seed, gave off a number of bundles (probably nine or ten) into the cupule; the cupular bundles were branched, and appear to have been collateral and mesarch in structure. There is a detailed agreement between the strands of the pedicel and cupule and those of the 
rachis and leaflet, respectively, in the vegetative foliage of Lyginodendron. Thus all the evidence goes to show that the pedicel and cupule were of a foliar nature.

The seed itself is orthotropous, and, broadly speaking, of a Cycadean type; it shows perfect radial symmetry

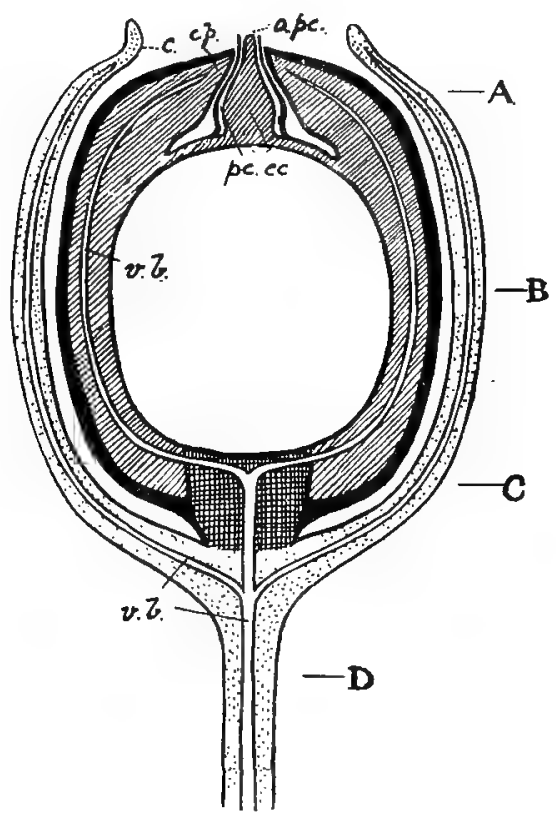

FiG. 148. - Lagenostoma Lomaxi. Diagram of seed in median longitudinal section. $c$, cupule; v.b., vascular bundles of pedicel, cupule, and integument; $c \not p$, canopy of integument; $p c$, cavity of pollen-chamber; $c c$, central column; $a p c$, orifice. A, $\mathrm{B}, \mathrm{C}, \mathrm{D}$, planes of the transverse sections in Fig. I 49 . After Oliver.

(Fig. I 49); the integument, which has a somewhat complex structure, is single, and completely adherent to the nucellus, except in the apical region (Fig. I 48).

The central strand of the pedicel, after giving off the cupular bundles, passes straight up, and becomes the chalazal strand of the seed; it is here surrounded by a 
mass of thick-walled strengthening tissue. The chalazal bundle then breaks up into the peripheral strands (usually nine in number) which traverse the whole length of the integument (Figs. I 48 and I 49). The
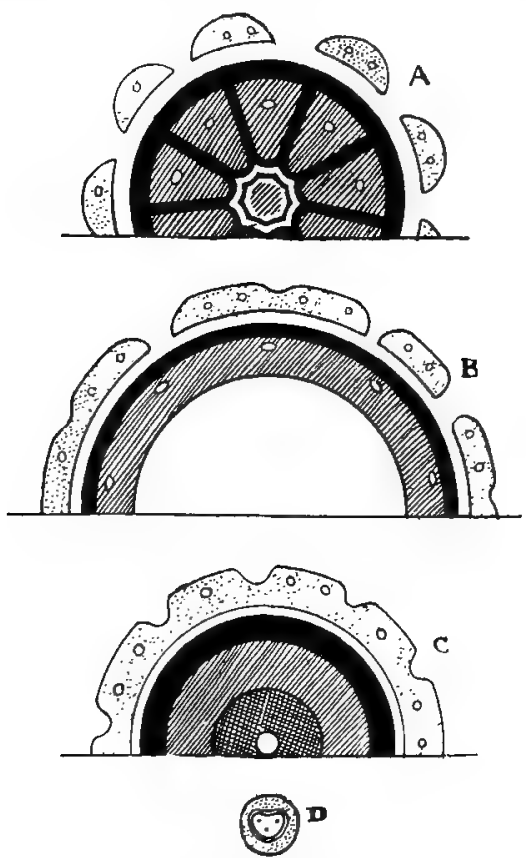

FIG. I49,-Lagenostona Lontaxi. Diagrammatic transverse sections in the planes $A, B, C$, and D of Fig. 148 . A (through micropyle) shows pollen-chamber canopy of integument and free lobes of cupule; $B$ (tbrough body of seed) shows fused nucellus and integument, with vascular bundles, and cupule partly divided into lobes; C (through chalaza) shows central bundle, chalazal tissue, hase of integument, and continuous, furrowed cupule; $D$, section of the rachis-like pedicel. After Oliver.

latter expands in its free part, towards the micropyle, into the chambered "canopy," a ring of nine loculi, separated from each other by thick partitions, but filled by a delicate tissue which has commonly perished. Into each of these loculi, one of the nine vascular bundles 
entered, and there terminated (see Fig. I 49, A). The canopy may represent a provision for water-storage, serving, perhaps, as has been suggested, to supply the necessary liquid for pollination by means of a "dropmechanism." The outer layer of the integument has a columnar or palisade-like structure; there is some evidence that a secretion of mucilage took place from this layer, as in the testa of so many recent seeds.

As in the recent Cycads and in Ginkgo, the free apex of the nucellus forms the pollen-chamber, a cavity for the reception of the pollen-grains, ${ }^{1}$ which in the case of Lagenostoma has a peculiar and characteristic form, for a solid column of tissue rises up in the middle of the chamber, leaving only a narrow annular space, in which the pollen-grains are found (Figs. I 43, I 47, 148, 1 49, A). The outer wall of the flask-shaped pollen-chamber projects a little through the micropyle, as an open tube, and no doubt received the pollen-grains directly, without their having first to traverse a micropylar passage (Figs. 147 and 148). The pollen-grains occurring in the chamber appear to have been multicellular, but this point is better shown in other cases (see Figs. 173 and $174, \mathrm{pp} .458$ and 459 ).

The interior of the seed has not been found in a good state of preservation. The outlines of the megaspore or embryo-sac can usually be traced, but its membrane cannot always be distinguished from the disorganised tapetal layer of the nucellus.

The discovery of the seed of Lyginodendron afforded, for the first time, the proof that a member of the Cycadofilices was a seed-bearing plant, and led, as

1 For the pollen-chambers see Chap. XII. p. 542. 
further evidence came in, to the establishment of the new class Pteridospermeae.

The seed is, as we have seen, a complex one, and already far removed from the Cryptogamic megasporangium ; there is indeed little trace of anything primitive in Lagenostoma beyond the fact that the reception of the pollen was still left to the nucellus-the sporangial part of the seed-and not yet assumed by the integument. The absence of any trace of an embryo is a negative character common to all known Palæozoic seeds, though there are many instances of the preservation of archegonia (see, for example, Fig. 198, p. 549). Yet the seeds, as a rule, are evidently mature and not mere ovules. Neither, considering the frequent presence of pollen-grains in the pollen-chamber, can we assume that all the seeds found happened to be barren. It is possible that, though pollinated, they were not yet fertilised, the latter process taking place an appreciable time after the seed was shed; or again, it may be that a resting stage followed immediately on fertilisation before any marked development of the embryo had taken place. In any case it appears that in these ancient seeds the period of rest came much earlier with, reference to the growth of the embryo than in most of our recent seeds. ${ }^{1}$ We find a relic of the old conditions in living Cycads, in which the embryo is often scarcely to be recognised when the seed is ripe and ready for sowing.

Returning to the seed of Lyginodendron, we have seen that the structure of the pedicel shows that the

1 It is interesting to see that the Mesozoic Bennettites was completely modern in this respect, for there the embryo was far advanced, and filled the whole embryo-sac before the seed was shed (see Fig. 205, p. 574). 
seed-bearing organ formed part of a leaf. Evidence from closely allied species leaves no doubt that the seeds were borne on compound fronds or pinnae, only differing from the sterile foliage in the suppression of the laminae of the leaflets, or rather, perhaps, their modification to form the cupules.

Calymmatotheca Stangeri, a fructification of Lower Carboniferous age, discovered by Stur in $1877,{ }^{1}$ consists of stellate, usually six-rayed bodies, borne on a naked branched rachis. A reinvestigation of the specimens has confirmed Stur's attribution of the fructification to a Sphenopteris closely similar to S. Höninghausi (the foliage of Lyginodendron oldhamium), and also his interpretation of the stellate bodies as foliaceous indusia, and not groups of sporangia. There is little doubt that these organs ${ }^{2}$ are of the same nature as the cupules of our Lyginodendron, but in Stur's, specimens the seeds

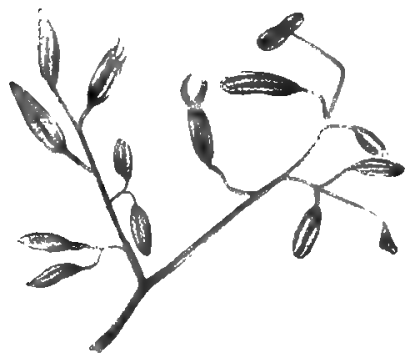

FIG. I 50.-Lagenostoma Sinclairi. Portion of branched rachis, bearing cupulate seeds. Nat, size. After Arber. had been shed, perhaps prematurely.

Mr. Arber has described aseed, Lagenostoma Sinclairi, Kidston, of Lower Coalmeasure age, which agrees closely in external characters with L. Lomaxi, and, like the latter, is invested in a lobed cupule (Figs. I 50 and I 5 I). The cupulate seeds were borne on the terminations of the finer branches of a highly compound frond, with reduced lamina, in all I Stur, "Die Culmflora der Ostrauer u. Waldenburger Schichten," Abhandl. d. k. k. geol. Reichsanstalt one Wien, vol. viii. Part ii.

${ }^{2}$ Indicated in the restoration of Lyginodendron in Fig. I, Frontispiece. 
probability of the Sphenopteris type. ${ }^{1}$ The character of the seed itself suggests the presence of a "canopy."

In Sphenopteris Dubuissonis, a Lower Coal-measure species from Brittany allied to S. Höninghausi, M. Grand'Eury has observed six-lobed cupules, in some cases still containing the seeds, situated at the extremity of long, slender pedicels, identical with the ultimate ramifications of the rachis. ${ }^{2}$

The specimens described by Stur, Arber, and Grand'Eury are all FIG. 151.-Lagenostona Sinclair: Two seeds, preserved in the form of impressions; they

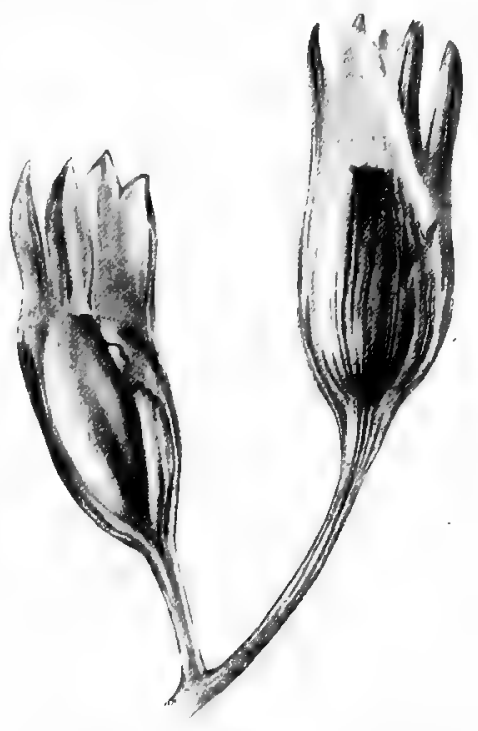
ally on branches of the rachis. $\times 5$. After Arber.

supplement, in a most satisfactory manner, the evidence of the structural specimens, and leave no doubt that the seeds of the Lyginodendron group were borne on the rachis of the frond. The analogy of the pollenbearing organs, next to be described, establishes a presumption that the fertile rachis formed part of the same frond which elsewhere bore vegetative leaflets.

The well-known seed Lagenostoma ovoides, of which

I Arber, "Some New Species of Iagenostoma, a Type of Pteridospermous Seed," proc. Roy. Soc. (B) vol. Ixxvi. 1905.

2 Grand'Eury, "Sur les Graines de Sphenopieris," etc., Comptes Rendus t. 14I, p. 8I2, I905. 
the structure was described by Williamson, agrees so closely with $L$. Lomaxi that it must clearly have belonged to some plant of the Lyginodendron type. Physostoma elegans ${ }^{1}$ (= Lagenostoma physoides), another of Williamson's discoveries, is more remarkable, and perhaps more primitive, for here the micropylar tube is replaced by a ring of about ten free tentacles, surrounding the apex of the nucellus, and apparently corresponding to the loculi of the canopy in Lagenostoma. In neither of the seeds last mentioned has a cupule as yet been discovered.

6. The Microsporangia. - Nothing certain was known of the male fructification of Lyginodendron, or indeed of that of any Pteridosperm, until Mr. Kidston, in I 905, discovered a species of Crossotheca (C.Höninghausi, Kidston) in organic connection with the foliage of Lyginodendron. ${ }^{2}$ The genus Crossotheca was founded by Zeiller in I $883{ }^{3}$ on a fructification found by him in connection with a Sphenopteris (see Fig. I 09, F, Vol. I. p. 280); the genus was characterised by the arrangement of the sporangia, hanging from the lower surface of the oval or spathulate fertile segments, the whole resembling an epaulet with its fringe. On account of the absence of an annulus and the appearance of a slight fusion between the sporangia, Zeiller referred Crossotheca to

1 A full investigation of this seed by Professor $\mathrm{F}$. W. Oliver has appeared in the Annals of Botany for January I909.

2 Kidston, "On the Occurrence of Microsporangia in Organic Connection with the Foliage of Lyginodendron," Proc. Roy. Soc. (B) vol. lxxvi. p. 358, I905; "On the Microsporangia of the Pteridospermeae," Phil. Trans. Roy. Soc. B, vol. I98, I906.

3 "Fructifications de Fougères du Terrain Houiller," 1nn. sci. nat. Bot. sér. vi. t. xvi. 
the Marattiaceae, a view which was generally adopted

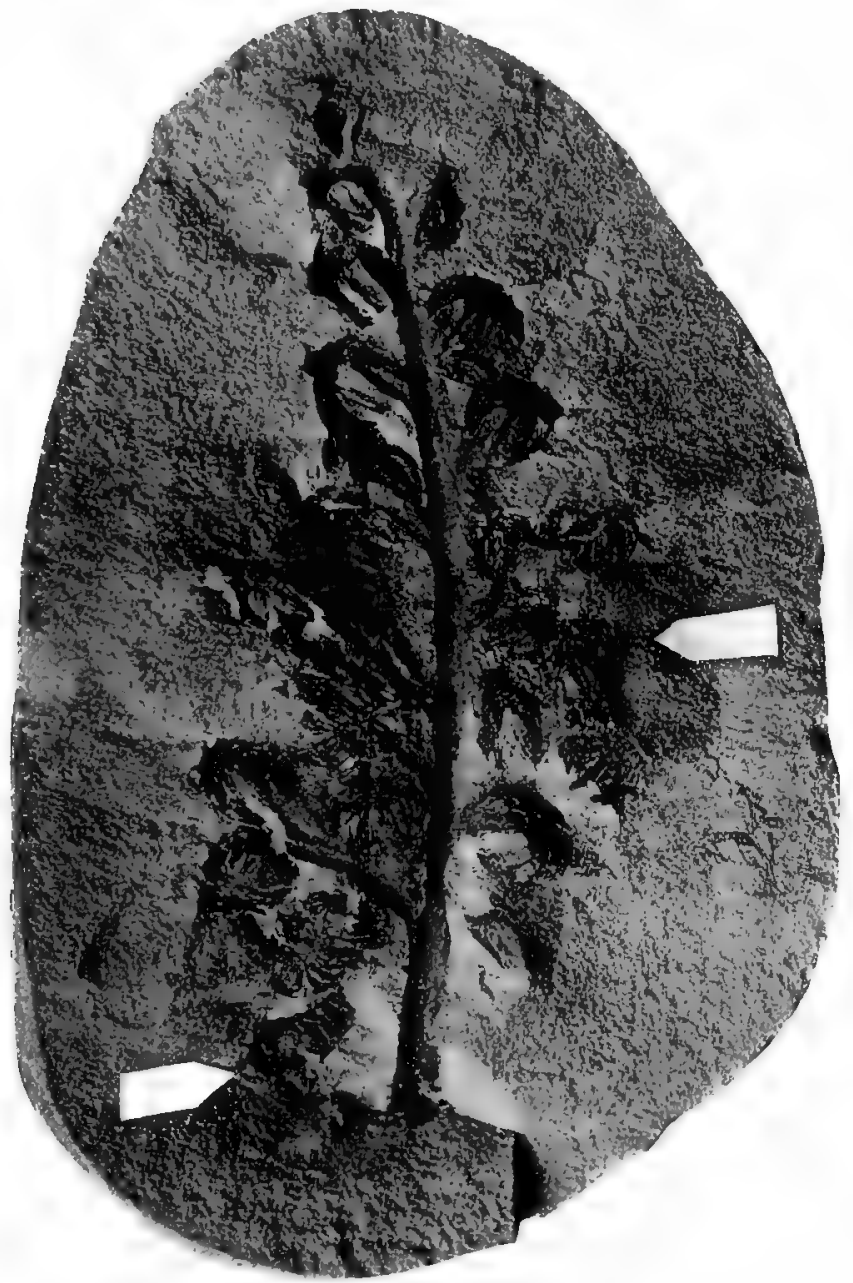

FIG. I52,-Crossotheca Honinghausi (the microsporangiate fructification of Lyginodcndron oldhamiun). Fertile pinna, contained in an ironstone nodule. On the ultimate branches of the rachis are borne the somewhat peltate fertile pinnules, from the under surface of which the long microsporangia hang down. $\times 3$. Enlarged from a photograph lent by Mr. R. Kidston, F.R.S. 
up to the date of Mr. Kidston's discovery. In the meantime a number of other species had been described, some with the Sphenopterid and others with the Pecopterid type of foliage.

Mr. Kidston's specimens were found in ironstone nodules from the Dudley Coal-field (Westphalian series) (Fig. I 52). The specimens are preserved in the form

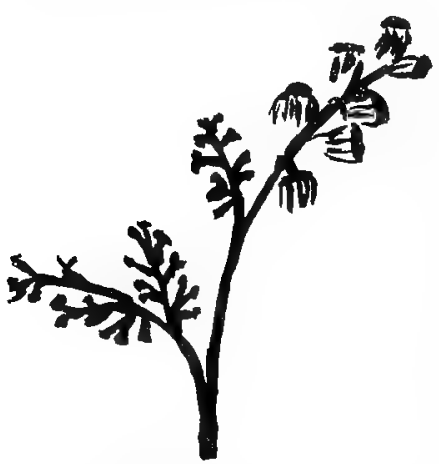

FIG. I53-Crossotheca Höninghausi. Fertile pinna in connection with sterile pinnae of Sphenopteris Höninghausi (leaf of $L y$. ginodendron). $\times 2$. R. S. From a sketch after a photograph lent by Mr. Kidston. of casts, but the cavities in some cases are infiltrated with carbonate of lime, and so retain their natural form, with some degree of structural preservation. Though most of the fertile specimens bear no sterile pinnules, in some cases the two forms occur in organic connection (see Fig. I 53), proving that the Crossotheca was borne on foliage identical with that of Lyginodendron. Fig. I 52, from a photograph, shows clearly the general structure and arrangement of the fertile pinnules, which are oval in form, about $2-2.5 \mathrm{~mm}$. in length, and borne on stout pedicels, the mode of insertion rendering them somewhat peltate. The pinnule is of some thickness, and appears to be traversed by a branched vein. "Each fertile pinnule usually bore six, rarely seven, bilocular microsporangia. They are fusiform and end in a sharp point." 1 The sporangia are described as convergent

1 Kidston, Microsporangia of Pteridosperneac, p. $42 \mathrm{I}$. 
when young, but opening out later, and then assuming the fringe-like arrangement. They are about $3 \mathrm{~mm}$. long and $1.5 \mathrm{~mm}$. in maximum width, while each loculus has a diameter of about $.5 \mathrm{~mm}$.

No evidence of cohesion among the sporangia was observed, but each "bilocular sporangium" may be interpreted as a synangium, though this does not appear to be Mr. Kidston's view. The nature of the preservation is such as to leave the detailed morphology somewhat uncertain. The microspores were still contained in the cavities of the sporangia, and could be studied in some detail. Each spore has a distinct triradiate ridge, indicating tetrahedral development, and the surface of the outer wall is rough with minute points. The diameter of the spore varies from .05 to $.07 \mathrm{~mm}$.

Mr. Kidston finds that "the cleft by which dehiscence took place passed longitudinally down the centre of the inner face of the microsporangium, and thus the microspores of both loculi would be liberated simultaneously."

Mr. Kidston observed in the Dudley nodules, another species of Crossotheca, C. Hughesiana, which has cordate fertile pinnules, but is otherwise closely similar to $C$. Höninghausi.

Shortly before Mr. Kidston's discovery of the connection between Crossotheca and Lyginodendron, Miss M. Benson, D.Sc., described a fructification (Telangium Scotti) with structure preserved, from the Coal-measure nodules, and was inclined to attribute it to Lyginodendron. ${ }^{1}$

1 Benson, "Telangium Scotti," Ann. of Bot. vol. xviii. 1904. A preliminary note was published two years earlier. 
The sporangia are long and pointed, resembling those of Mr. Kidston's Crossotheca in shape and size, but are united in their lower part to form large synangia often with as many as eight members.

Miss Benson described the synangia as borne terminally on the ultimate ramifications of a rachis, but I have since satisfied myself that they were in reality seated on a flat disc or lamina, quite comparable to a fertile pinnule of Crossotheca. Thus the most important of the distinctions enumerated by Mr. Kidston (l.c. p. 424) between Crossotheca. and Telangium Scotti is removed, and I have little doubt that Miss Benson's fossil will find a place in the genus Crossotheca. The possible relation of Telangium Scotti 'to Lyginodendron requires further investigation, but it is not unlikely that it may prove to belong to one or other of the forms at present grouped under the name Lyginodendron oldhamium. ${ }^{1}$

It may be mentioned that in the same petrifactions in which Telangium Scotti occurs, bisporangiate synangia have lately been observed, but with the additional complication that each sporangium is subdivided into two loculi. It is possible that these specimens may have belonged to one of Mr. Kidston's species of Crossotheca. ${ }^{2}$

Though many interesting questions as to the male fructification of Lyginodendron still await solution, the main point is made clear by Mr. Kidston's discovery that Crossotheca, hitherto assumed to be the fertile frond

1 An interesting point emphasised by Miss Benson is the resemblance of the spores of Telangizm to the pollen-grains found in the pollen-chamber of Lagenostoma ovoides.

2 I am indebted to my friend Professor F. W. Oliver, F.R.S., for my knowledge of these preparations. 
of a Fern, constitutes the pollen-bearing organs of this genus of Pteridosperms, a fact that must affect our judgment on many other Palæozoic fructifications. In bearing its microsporangia on a pinna of the same frond which in other parts has purely vegetative characters, Lyginodendron shows a lower degree of differentiation than any Seed-plant previously known. The reproductive organs of this genus present the same combination of characters which we found in the vegetative structure. While the highly organised seed indicates a clear affinity with Cycadophyta, the microsporangiate organs are of a more Fern-like nature.

Lyginodendron oldhamium has been described at considerable length because, from our exceptionally complete knowledge of the plant in all its parts, it may best serve as the type of the Pteridospermeae. We now pass on to review, more briefly, other representatives of the class.

\section{Heterangium}

Several species of this genus have been described, some from our own country, others from the Carboniferous strata of France and Germany. The geological range of these plants is considerable, for some species have been found in the Calciferous Sandstone rocks of Scotland, at the very base of the Carboniferous formation, while others appear in the Coal-measures, and others again in the Permian beds of Autun, in France. Our description will be based, in the first instance, on the Heterangium Grievii of Williamson, the oldest of the species at present described, and the one which 
happens also to have been most completely investigated. The specimens, with structure preserved, were first discovered in $187 \mathrm{I}$, among the calcified remains brought to light in that year by Mr. G. Grieve, at Pettycur, near Burntisland, in Scotland; the horizon of this bed, which has often been referred to above, is that of the Calciferous Sandstones. The plant was described by Williamson, who at first named it Dictyoxylon Grieviz, but shortly afterwards (I 872) placed it in Corda's genus Heterangium, which up to that time had only been known from a single fragment.

In the case of Heterangium we have as yet no certain knowledge of the reproductive organs, and the reference of the genus to Lyginodendreae is therefore based entirely on vegetative characters.

The specimens of Heterangium Grievii are numerous in the Burntisland deposit, and the structure is often very well preserved, as in the specimen represented, in transverse section, in Fig. I 55. To quote Williamson's words, it "always appears in the form of straight, slender, unbranched stems." Branching, however, may have occurred occasionally, for we have found one instance in a closely allied species ( $H$. Lomaxii), but in any case it must have been rare. The restoration of a portion of stem, shown partly in section and partly in surface-view, reproduced in Fig. I 54, from Williamson's original memoir, ${ }^{1}$ gives an accurate idea of the general structure. In external form the stems, which have not been found to exceed about $1.5 \mathrm{~cm}$. in diameter, are angular; the projecting ribs are

1 "Organisation of Fossil Plants of Coal-measures," Part iv., Phil. Trans. 1873 . 
formed by the decurrent bases of the spirally arranged leaf-stalks (Fig. I54). The general character of the foliage is known; the leaves, like those of Lyginodendron oldhamium, were highly compound, and are referable to the Sphenopteris type (cf. Fig. I60). There is, in fact, good evidence for the identification of Heter-

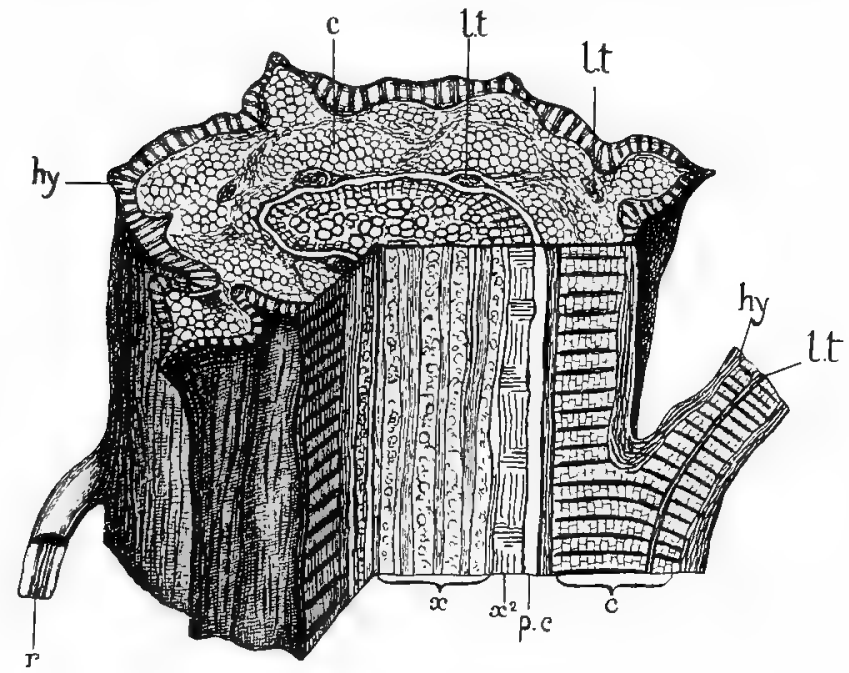

FIG. 154:-Heterangium Grievii. Restoration of a portion of the stem, showing transverse and longitudinal section, and part of the external surface. $x$, primary wood of stele; $x^{2}$, secondary wood; $p c$, phloëm and pericycle (left blank); $c$, cortex, with horizontal sclerotic bands; $h y$, hypoderma of stem and petiole; l.t, leaf-traces, one of which is entering the petiole; $r$, adventitious root. The bases of several petioles are shown. Enlarged. After Williamson, Phil. Trans.

angium Grievii with a definite species of Sphenopteris, but before entering into this question it will be necessary to describe the organisation of the specimens with structure preserved.

I. The Stem (H. Grieviz).-The stem of Heterangium, like that of Lyginodendron, had a single vascular 
cylinder, from which the leaf-traces were given off. The stele differs, however, from that of the other genus in one striking point; in Heterangium the whole interior of the stele is occupied by the primary wood

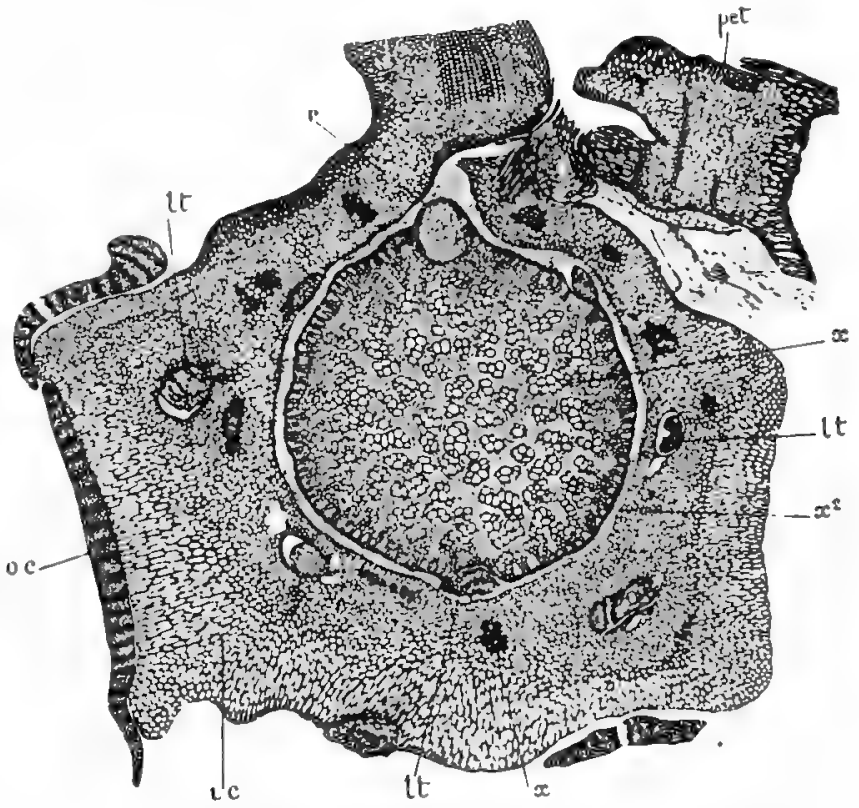

Fig. 155-Heterangium Grievii. Transverse section of stem. $x$, central mass of primary wood, consisting of tracheides and parenchyma; $x^{2}$, secondary wood, beginning to form; next come phloëm and pericycle; i.c, inner cortex ( $x$ in this zone is a sclerotic group); l.t, leaf-traces; $r$, base of an adventitious root; o.c, outer cortex or hypoderma (only present in places); pet, base of petiole, partly detached. $\times$ about 5. S. Coll. 396 . (G. T. G.)

(see Figs. I 54 and I 55), which extends to the centre, leaving no pith whatever, while in Lyginodendron, as we have seen, the large pith is a constant feature. The difference is so striking that it might seem, at first sight, to preclude the idea of any close relationship between the two genera; yet, as Williamson at once 
recognised, and as all subsequent research has confirmed, the evidence of consanguinity is clear and convincing.

The primary wood in Heterangium is composed throughout of irregular anastomosing groups of tracheae, interspersed with strands of conjunctive parenchyma

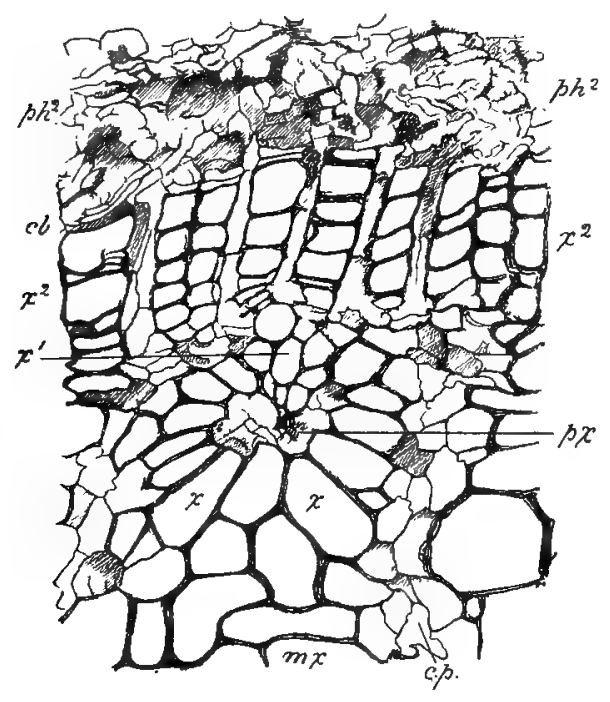

Fig. 156.-Heterangium Grievii. Part of transverse section, from outer part of stele, showing a primary xylem-strand and adjacent tissues. $p x$, protoxylem of strand; $i$, centripetal, $x^{1}$, centrifugal, primary wood ; $m x$, metaxylem, $c . p$, conjunctive parenchyma; $x^{2}$, secondary wood; $c b$, cambium; $p k^{2}$, phloëm. $\times 135$. Phil. Trans., W. and S. Will. Coll. Iz93.

(Figs. I 54 and $155, x$ ). As a rule, the tracheae are more abundant than the parenchyma, and even where the reverse is the case, there is never any aggregation of the cellular tissue to form a pith. The structure of the primary wood is not, however, uniform in all its parts. Around its periphery, definite clusters of tracheides can be distinguished, each of which agrees 
exactly in structure with one of the primary strands of xylem in Lyginodendron (compare Fig. I 56 with Fig. I 3 I). The smallest elements of the cluster are internal, lying at a short distance from its outer limit (Fig. I 56, $p x)$; these smallest elements are shown by longitudinal

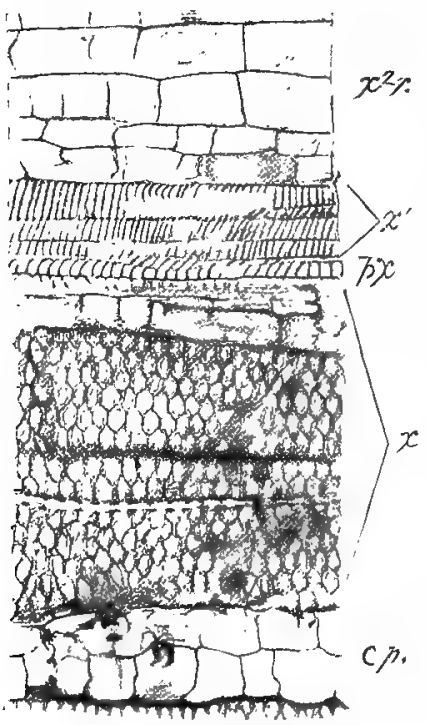

FIG. I57.-Corresponding Iongitudinal section, showing the structure of the tracheides. $x^{2} r$, parenchyma at the commencement of a medullary ray. Other lettering as in Fig. $156 . \times 135$. J'hil. Trans., W. and S. Will. Coll. I266. sections to be tracheides, with a lax spiral thickening; they thus constitute the protoxylem of the bundle (Fig. I 57,px). They are succeeded towards the exterior by more densely spiral or reticulate tracheides, of somewhat larger size (Figs. I 56 and I 57 , $x^{1}$ ). The protoxylem is accompanied by a little parenchyma, and the rest of the primary strand, including all its lateral and interior part, is formed of large tracheides, with multiseriate bordered pits, as in Lyginodendron (Figs. I 56 and I 57 , $x)$. Similar pitted elements extend throughout the whole interior of the stele, forming the mass of primary wood. The central wood, as distinguished from the peripheral xylem-strands, may be termed the metaxylem. From the nature of the case, the primary strands are not obviously distinct, as in the former genus, but they are characterised at once by their mesarch structure, and by the fact that they alone 
are continued outwards into the cortex, to form the xylem of the foliar bundles. The stele of Heterangium thus differs from that of Lyginodendron in the fact that in the former the xylem extends through the whole central region, forming a continuous mass of primary wood, traversed by irregular bands of conjunctive parenchyma, but without a pith.

In some stems this primary structure has remained unaltered; in such cases, the phloëm, which, no doubt, formed a zone round the wood, can only be recognised as a ring of imperfectly preserved tissue. Most specimens, however, had already produced secondary wood and phloëm, though not usually to so great an extent as in Lyginodendron. The secondary wood consists of rather small tracheides, arranged in regular radial series, with medullary rays between them (see Figs. I 54 , I 55 , and $156, x^{2}$ ). The secondary tracheides bear numerous bordered pits, which are usually limited to the radial walls. Beyond the wood the cambium and secondary phloëm are often fairly well preserved (see Fig. I 56, $\left.c b, p h^{2}\right)$. In all cases, whether secondary thickening had taken place or not, the stele is surrounded by a well-marked pericycle, consisting of several layers of thin-walled parenchyma.

The wide inner cortex has a very characteristic structure. Its ground-mass consists of short-celled parenchyma, but in this tissue numerous horizontal plates of thick-walled mechanical elements are embedded (see Fig. I 54, c). The sclerotic plates do not extend all round the stem, but are isolated and ranged in vertical series. Thus, a radial section of the stem may either show a whole row of them, one above the other, 
or, if it happen to pass between two series, may miss them altogether. The cells of which the sclerotic plates are composed are short, and similar in structure to the stone-cells of many recent plants. The transversely striated appearance, which these plates give to the cortex, often serves to identify Heterangium at once, even on a naked-eye inspection of rough specimens or carbonised impressions (cf. Figs. I 59 and 160).

The outer cortex, or hypoderma, is formed of alternating strands of fibres and parenchyma (Figs. I 54, hy, and I 5 5, o.c). The structure, as seen in transverse section, is much like that of the same region in Lyginodendron, except that the parenchymatous tracts are narrower; in tangential section a greater difference is shown, for in Heterangium the fibrous strands take a straight vertical course, and only anastomose with one another at long intervals.

We have now to consider the distribution and structure of the vascular bundles which supply the leaves. The main points in their longitudinal course were determined by Williamson in his first investigation of the plant in 1872 , when he examined a series of eight transverse sections from a piece of stem nearly two inches long. In this length the bases of two leaves were met with, into each of which a vascular bundle was traced. The arrangement of the leaf-traces in this specimen, as well as in others, shows that the phyllotaxis was $\frac{3}{8}$. This. was probably the usual arrangement in the larger stems of Heterangium Grievii; in the smaller specimens a $\frac{2}{5}$ divergence is found.

The leaf-trace bundles passed out very gradually, as 
in Lyginodendron, so that a considerable numberusually about eight-are met with in any transverse section of the stem (Figs. I 54 and I 55, l.t). They are of large size, and closely resemble the leaf-traces of Lyginodendron, except that they are usually without any secondary tissues. On leaving the stele the leaftraces are collateral, but become concentric before entering the base of the leaf itself. They soon pass out from the pericycle into the cortex, and are most frequently found in the latter tissue, whereas in Lyginodendron they follow the pericycle for a longer distance. The trace usually remains undivided throughout its course; this, however, is only a specific character, for other forms of Heterangium resemble Lyginodendron in having twin leaf-traces.

2. The Leaves.-The leaf-bases are constantly found in connection with the stem, to which they give an angular form, as they are decurrent, and the sharp projection which marks the position of each leaf in the stem extends a long way down-probably to the next leaf of the same vertical series. Hence, when the phyllotaxis is $\frac{3}{8}$, the stem has eight more or less prominent angles, corresponding to the orthostichies (Figs. 154 and 159 ).

The structure of the petioles is well shown in those which are still attached to the stem, and the knowledge thus gained enables us to identify the free specimens with certainty. The petiole is traversed by a single vascular bundle of concentric structure. The inner cortex contains conspicuous horizontal plates of sclerotic tissue, like those of the stem, while the hypoderma 
consists of the usual alternating longitudinal strands of sclerenchyma and cellular tissue. The whole structure is much like that of the petiole of Lyginodendron oldhamium, but the spinous emergences characteristic of the latter plant are absent.

The petiole branched freely, and the smaller ramifications of the rachis are only about one-tenth as thick as the main leaf-stalk. Thus the leaf, like that of Lyginodendron, was a highly compound one; remains of the leaflets are often found, but it has not as yet been possible to determine their minute structure. The evidence available, from the petrified specimens, leads to the conclusion that the foliage was of the same type, as regards both anatomy and general Sphenopterid form, as that of Lyginodendron oldhamium.

3. The Roots.-The bases of adventitious roots are often found in connection with the stem; in a specimen from the Coal-measures, belonging to $H$. Lomaxii, a species closely allied to $H$. Grievii, ${ }^{1}$ three such roots were found together, ranged in a vertical row on the stem. They were clearly of endogenous origin, and are placed opposite one of the primary bundles of the stem. The steles of stem and root are connected by a system of oblique vascular strands, apparently of secondary origin.

Miss M. Benson, F.L.S., has recently obtained evidence as to the structure of the roots of $H$. Grievii,

${ }^{1}$ In the memoir by Dr. Williamson and myself ("Further Observations," etc., Part iii. Lyginodendron and Heterangium) these two species are united. It is, however, better to separate them, as there are some slight distinctive characters, and their horizons are widely apart. The name $H$. Lomaxii was suggested by Williamson in MS. for the Coal-measure form, which Mr. Lomax first found at Dulesgate. 
previously unknown. She permits me to quote the following brief statement of her results : "Recently in a series of nineteen transverse sections through a single stem of $H$. Grievii, roots were found emerging from the stele and branching in the cortex, which was locally much thickened. In some sections these roots were cut transversely, and proved to be diarch or triarch. No exodermis could be distinguished from the rest of the cortex, as in Lyginodendron." In the case of the Coalmeasure species, H. Lomaxii, there is some evidence that the roots were tetrarch, but proof of continuity is not yet established.

4. Heterangium tiliaeoides. - The other forms which have been referred to the genus Heterangium agree in essentials with $H$. Grievii, but there is one which deserves special notice, on account of the astonishing perfection with which its tissues are preserved. This is the Heterangium tiliaeoides of Williamson, first described by that author in $1887,{ }^{1}$ from specimens found in the Lower Coal-measures of Halifax. The general structure is like that in the species already described, and here also the entire interior of the stele is occupied by groups of tracheides interspersed with conjunctive parenchyma. The primary, mesarch xylemstrands at the periphery of the central wood, are, however, much more distinct in the Halifax species, and at once strike the eye as definite bundles, separated from one another by bands of conjunctive tissue. The

1 "Organisation of Fossil Plants of the Coal-Measures," Part xiii., Phil. Trans. Roy. Soc. B, vol. I78, 1887. See also Williamson and Scott, "Further Observations," etc., Part iii., Phil. Trans. B, vol. I86, I895. 
secondary wood attained a considerable thickness, and is divided up into distinct groups, corresponding to the peripheral primary strands, and separated from one another by the principal medullary rays, while numerous secondary rays are also present. The bordered pits

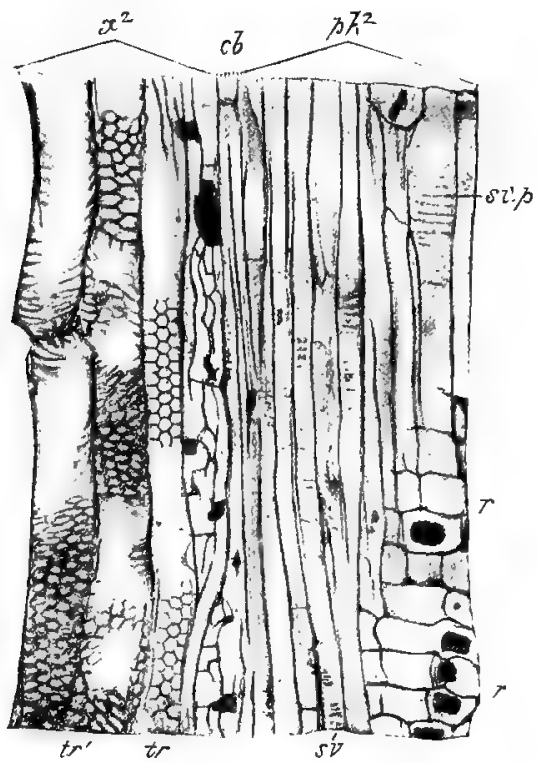

FiG. 158.-Hutcrangiun tiliacoides. Radial section through part of secondary wood and phloüm. $x^{2}$, secondary wood; $t^{2}$, fully developed pitted tracheides; $t r$, tracheides with pits beginning to form; $c b$, camlium; $p k^{2}$, secondary phloëm; sv, sieve-tubes ; st.p, sieve-plate; $r$, phloëm-ray, $x$ 112. Phil. Trans., W. and $S_{+}$Will. Coll. 1628.

on the tracheal walls are exquisitely preserved, and in favourable cases their development can even be traced, in the elements bordering on the cambium (Fig. I $58, t r$ ). The cambium itself is also perfectly preserved, but the special interest of the specimen centres in the phloëm, which is perhaps better shown 
in $H$. tiliaeoides than in any other fossil plant. On entering the phloëm-zone, the principal rays become widely dilated, broadening out into conspicuous wedges, and exactly resembling the phloëm-rays of the limetree, a fact to which the fossil owes its specific name.

The phloëm attained a great thickness, scarcely inferior to that of the secondary wood. To the outside of each group, the primary phloëm, corresponding to the primary xylem-strand within, can be distinctly recognised. The greater part of the phloëm is secondary, and has a definite radial seriation of its elements.

The phloëm proper, as distinguished from the secondary rays which pass through it, consists of alternating bands of long parenchymatous cells, and of sieve-tubes. The latter are so perfectly preserved as to show, in some cases, the compound sieve-plates on their radial walls, closely resembling similar structures in recent Cycads. Details of this kind are necessarily among the rarities of fossil preservation (see Fig. I 58 sv.p). ${ }^{1}$

Beyond the phloëm-zone is a very wide pericycle, the structure of which agrees closely with that in Lyginodendron, as it contains groups of stone-cells, elements which, in the case of Heterangium Grievii, are limited to the cortex. The pericycle in H. tiliaeoides also resembles Lyginodendron in showing the beginning of periderm-formation in its outer layers.

The cortex, which is less perfectly preserved than

1 For details of the sieve-tubes, see Williamson and Scott, "Further Observations," etc., Part iii., Plate xxix., Figs. 38 and $38 \mathrm{~A}$. 
the other tissues, agrees in structure with that of the former species.

The outgoing leaf-trace bundles are nearly always found in pairs, as in Lyginodendron. Judging from the one instance in which a petiole has been found, in this species, in connection with the stem, it appears that the two bundles united on entering the leaf-base.

In $H$. tiliaeoides, as in the other forms, adventitious roots were borne on the stem, but we are not as yet acquainted with their detailed structure.

Apart from the exceptionally perfect preservation of its tissues, Heterangium tiliaeoides is of special interest from the fact that in several details-as in the distinctness of the peripheral xylem-strands of the stele, the distribution of the sclerotic elements, and the paired leaf-traces-it approaches Lyginodendron oldhamium, while in its general structure it retains all the essential Heterangium characters. The affinity of this species with Lyginodendron is so evident as to prove beyond reasonable doubt that the proper place of Heterangium is in the Lyginodendreae, rather than in the Medulloseae (see next chapter). It is also interesting to see how closely the detailed structure of the secondary tissues, in this Fern-like plant, resembled that in the recent Cycads.

5. Habit.-As regards the external habit of the genus Heterangium, we have good evidence in the case of the species $H$. Grievii. From the study of the specimens with structure preserved, we know that the plant possessed long angular stems, about a centimetre or a centimetre and a half in diameter, bearing, at 
intervals of a couple of centimetres or more, large stalked leaves, with a repeatedly branched rachis, bearing numerous, finely segmented leaflets; the arrangement of the leaves on the stem was a spiral one, and the commonest divergence appears to have been $\frac{3}{8}$. Now there is $\mathrm{a}^{\circ}$ "Fern," of which the external characters are well known, which agrees in all the points mentioned with our fossil, and which is common in deposits of the same geological horizon, both in Scotland and on the Continent. This is the Sphenopteris elegans of Brongniart, which is represented in Figs. I 59 and I60, from Stur's figures. The stem, a portion of which, slightly reduced, is shown in Fig. I 59, bears the bases of several petioles, and Stur, who investigated specimens from the Culm of Bohemia, found that the phyllotaxis was $\frac{3}{8}$. The angles of the stem correspond to the orthostichies of leaves; the general aspect of the frond, which was large and of the Diplotmema form (i.e. with the primary pinnae forked), is indicated in Fig. 160.

But, besides the general resemblance in external habit, there is one character which appears decisive as to the identity of Heterangium Grievii with Sphenopteris elegans. It will be remembered that the inner cortex of $H$. Grievii, both in stem and petiole, contains numerous horizontal plates of stone-cells, giving a characteristic transverse striation to the specimens, wherever this part of the tissue is exposed to view. Now in Sphenopteris elegans, though only preserved in a carbonised condition, without any minute structure, precisely the same feature is shown; wherever the superficial layers had broken away from the stem or leafstalk, so as to expose the more internal cortical tissues, 
a transverse striping is exhibited, answering exactly to the sclerotic plates of the petrified specimens

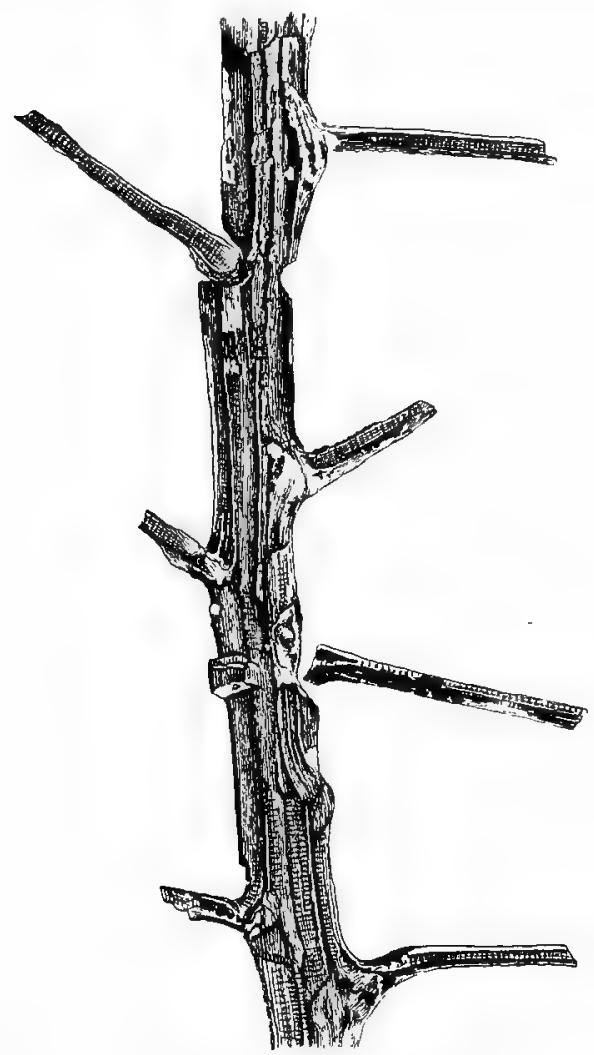

FiG. 159.-Sphenopteris elegans (probably = Ileteranginn Grienii). Ribbed stem, bearing several petioles. Note the transverse marks on the surface, where the inner cortex is exposed, corresponding to the sclerotic bands of $H$. Gricvit, as shown, for example, in Fig. 154. $\mathfrak{3}$ nat, size. After Stur.

(sec Figs. I 59 and I60, and compare with Fig. I 54). We may therefore, on the whole of the cvidence, take it as proved that the structural specimens 
known as Heterangium Grievii are identical with

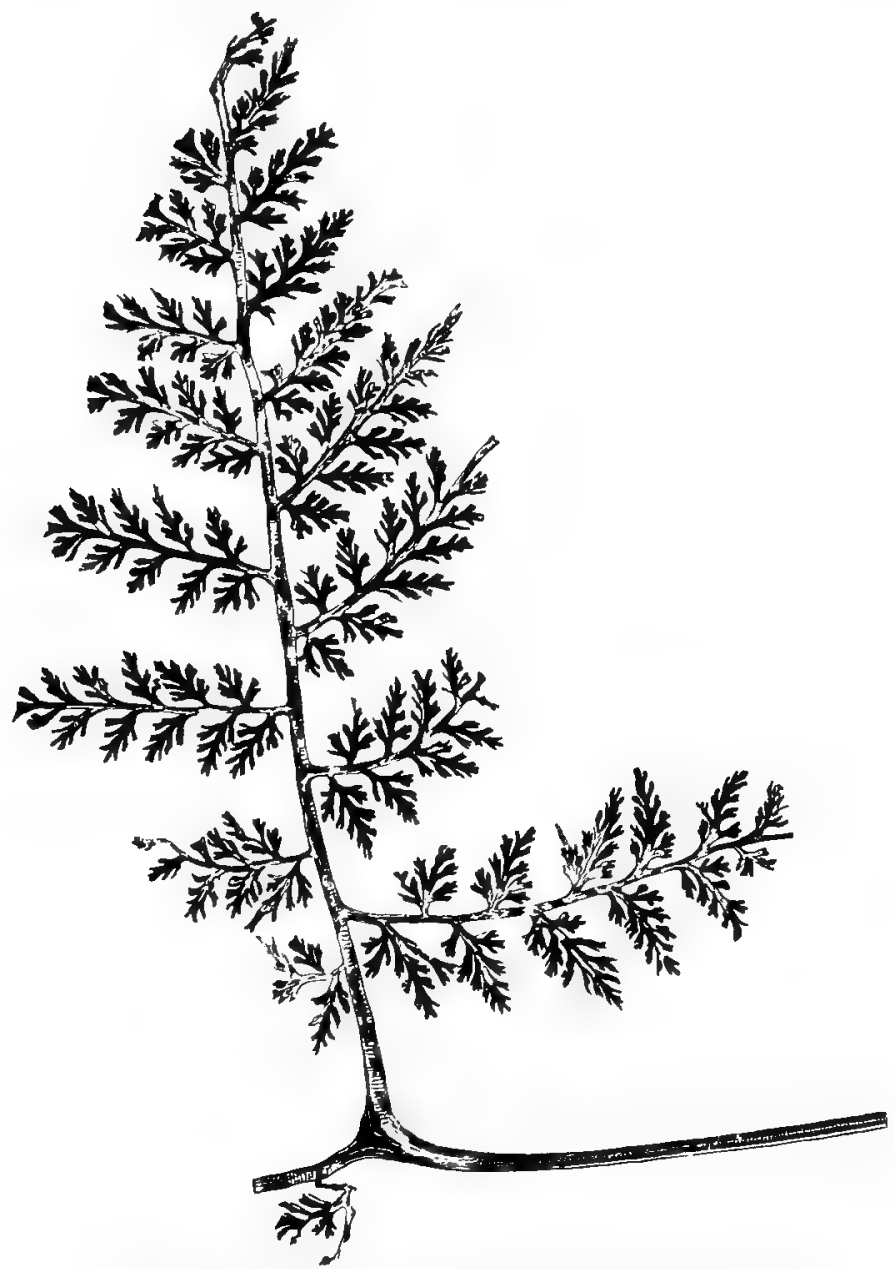

FIG. 160.-Sphenopteris elegans (probably foliage of Heteranginm Grievii). Part of frond. Note the transverse bands on the rachis, as in Fig. 159. 3 nat. size. After Stur.

Sphenopteris elegans, Brongn., or with some closely 
similar species of Sphenopteris. This identification was, in the first instance, due to the penetration of Mr. R. Kidston, ${ }^{1}$ who has further pointed out to me that at least two other Lower Carboniferous fronds, S. Linkii (Göpp.) and $S$. dissecta, Brongn., also show characters identifying them with Heterangium, of which there must clearly have been several species in this Flora.

We have therefore to picture Heterangium Grievii to ourselves as a Fern-like plant, with a long, upright, or perhaps trailing, ribbed stem, bearing large and graceful, finely divided fronds, much resembling those of some recent Asplenium. ${ }^{2}$

\section{AfFinities of LyGinodendreaE}

At present we have no certain knowledge of the fructification of Heterangium; the various species of Sphenopteris which no doubt represent the foliage of the genus have so far only,been found in the sterile condition. Associated with Heterangium Grievii in the Burntisland petrifactions are seeds (Conostoma ovale and $C$. intermedium), described by Williamson in $1876,{ }^{3}$ which are evidently very nearly allied to Lagenostoma, as shown by the structure of the testa and pollenchamber. It is very probable that they may have belonged to Heterangium, but there is as yet no direct evidence. As has been shown above, the agreement

1 Kidston, "Fructification and Internal Structure of Carboniferous Ferns," Trans. Geol. Soc. Glasgow, I889, p. 49.

"When first discovered, the present Sphenopteris elegans was identified with Fumaria officinalis, which is thus a synonym for Heterangium Grieriz, certainly a strange freak of nomenclature!

3 "Organisation of Fossil Plants of Coal-measures," Part viii., Phil. Trans. Roy. Soc. vol. 167, p. 243, Figs. 80-87. 


\section{AFFINITIES OF LYGINODENDREAE}

in the vegetative structure, including habit as well as anatomy, between Heterangium and Lyginodendron is sufficiently close to leave no doubt that they belonged to the same family, and presumably bore a similar type of fructification. Nevertheless the fact of the protostelic structure of the Heterangium stem, apparently so unlike anything known in other Spermophyta, will give a peculiar interest to the discovery of the reproductive organs of this genus (compare Sutcliffia, p. 447).

But while Heterangium was in all probability a Seed-plant like Lyginodendron, it is important to recall the points in which it shows affinity with the Ferns.

The external habit was altogether that of a Fern, so much so that no modern botanist would have hesitated" in placing it, so far as these characters are concerned, among the Filices. The internal organisation to a great extent confirms this conclusion. The concentric structure of the vascular bundle in the petiole is quite Fern-like, while an even more important character, the primary structure of the stem agrees wonderfully closely with that of some of the simpler Filices. We must, of course, go to a protostelic Fern for an analogy, and it is with the simpler species of Gleichenia that the correspondence is closest. In most Gleichenias the single stele consists of a central mass of xylem, surrounded by a zone of phloëm. The xylem is made up of intermixed tracheides and conjunctive parenchyma, just as in Heterangium, and the position of the protoxylem is the same in the recent as in the fossil genus, for in both, the spiral tracheides form a number of groups" a little within the periphery of the wood, of which the greater part is consequently centri- 
petal, while a small portion is developed centrifugally. The phloëm-zone is surrounded by a pericycle several cells thick.

The general structure of the stele is thus very closely similar to that in Heterangium. The leaftraces, one of which passes out to each leaf, are not alike in detail, and we must not push the analogy too far. The anatomical agreement between Gleichenia and Heterangium is, however, quite near enough to prove that the stem-structure of the latter genus is essentially that of a protostelic Fern, from which it differs in scarcely anything but the presence of secondary tissues, and the mode of pitting of the tracheides; the latter character, however, is common to many of the Botryopterideae.

If Heterangium, and especially H. Grievii, stood alone, we should have little reason for regarding it as anything more than a Fern, which had acquired the power of secondary growth, just as the fossil Lycopods acquired it without thereby becoming anything more than Lycopods. But even within the same genus, when we consider $H$. tiliaeoides, it is impossible not to be struck by the resemblance of the secondary tissues to those of Cycads, and by the distinctness of the peripheral strands of the wood, recalling the mesarch xylem of Cycadean foliar bundles.

When we come to Lyginodendron, which we know to have been a Seed-plant, the vegetative anatomy still shows many points of agreement with Ferns, though the Cycadean characters are more evident. The primary bundles are here isolated from one another, and disposed around a wide pith. The whole organi- 
sation of the vascular zone, both primary and secondary, is what that of a Cycad would be if the mesarch structure of the foliar bundles were continued down from the leaves into the stem. But we now know that this is precisely what occurs in certain Cycadean peduncles, which are themselves portions of the stem.

The stem-structure of Lyginodendron is, in fact, as a whole rather Cycadean than Filicinean, though in the young condition, before secondary growth had set in, there is a clear analogy with such a Fern as Osmunda. In the form and structure of the leaf Lyginodendron is as Fern-like as Heterangium. In both genera the abundant adventitious roots are suggestive of a Fern rather than a Cycadophyte; their anatomical structure, when young, is not unlike that of the roots of Marattiaceae, or some Ophioglossaceae, though the secondary changes soon give them a more Cycad-like character.

The discovery of the reproductive organs, while it has finally transferred the Lyginodendreae to the Spermophyta, has in one important respect emphasised their affinity with the Ferns. The male fructification Crossotheca and the probably allied Telangium described by Miss Benson bear an unmistakable resemblance to the synangia, such as those of Scolecopteris and Asterotheca, attributed to Marattiaceae, and also to those of recent Ferns of that order. Even if all the supposed Carboniferous Marattiaceae turned out to be Pteridosperms (a very improbable supposition, as shown in Chapter VIII.), the Fern-like character of the microsporangia in the latter class would only be the more significant. 
A more general discussion of the affinities of Pteridosperms will follow later; as regards the Lyginodendreae it is evident that their affinities, on the Cryptogamic side, are altogether with the Ferns, though doubtless they sprang from that stock long before any of the Fern families now familiar to us had come into being. On the other hand, the near relations between the Lyginodendreae and the Cycadophyta are manifest, as shown, above all, in the structure of the seed.

The Lyginodendreae have also been named the Sphenopterideae, and there can be little doubt that a large proportion of the Fern-fronds of the Sphenopteris type belonged to this Pteridospermous family. If, however, we may take the Crossotheca type of microsporangiate organ as characteristic, the family was not limited to Sphenopterid foliage, for various species of Crossotheca are known to have been borne on Pecopterid fronds. ${ }^{1}$ As regards seeds referable to Lyginodendreae, it appears certain that the various species of Lagenostoma and some of those in Williamson's genus Conostoma, so similar in all essentials to the seed of Lyginodendron oldhamium, must have belonged to the same group of plants. This probably also holds good for Physostoma, in spite of its unique peculiarities (see above, p. 396). ${ }^{2}$

A very remarkable fructification which may prove to have affinity with this family is that described by

1 Three such species are enumerated by Mr. Kidston, Microsporangia of Pteridospermeae, l.c. p. 432 , besides two other Pecopterids, regarded by M. Zeiller as probably belonging to Crossotheca. One of the latter, Pecopteris exigua, is especially interesting, as the structure is known, and bears considerable resemblance to that of Telangium Scotti. See Renault, Cours de bot. foss. t. iii. Plate xix. Figs. I3-I8.

2 See Prof. F. W. Oliver "On Physostoma elegans," Amn. of Bot. vol. xxiii. January ı gog. 
Renault under the name of Gnetopsis elliptica, ${ }^{1}$ from the Permo-Carboniferous of St. Étienne. In this case four seeds (of which two are often abortive) are enclosed within a common envelope or cupule, consisting of two partly fused bracts, each of which is divided into about five teeth above, and traversed by the same number of vascular bundles. The seeds or ovules are small (2.5 $\mathrm{mm}$. long) and have a remarkable structure. The integument, which is traversed by four vascular strands, expands around the micropyle into a chambered or lacunar region,comparable to the canopy of Lagenostoma, and bears two long feathery appendages. M. Renault ingeniously suggested that the seed was thus adapted to transport either by water or wind. The pollenchamber appears to have a central column as in Lagenostoma, while the neck of the chamber is divided into lobes. The endosperm and the two archegonia are preserved. In several points-the structure of the pollen-chamber and integument and the presence of a cupule-there are thus decided analogies with the seed of Lyginodendron, though the differences are no less marked. An affinity with the Lyginodendreae certainly seems more probable, in the present state of our knowledge, than that with the Gnetaceae, originally suggested by the discoverer.

Our knowledge of the Lyginodendreae is far too fragmentary at present for it to be possible to frame the essential character of the family. The following points may be mentioned as likely to occur in members of the group:

1 Cours de Bot. foss. t. iv. I885, p. I79; Plate xx., Plate xxi. Figs. I-6, Plate xxi. Figs. 2-4. 
Leaves filicoid (Sphenopterid or Pecopterid).

Stem monostelic; leaf-trace and main foliar bundle single or double, concentric in the petiole. Xylem mesarch.

Reproductive organs borne on somewhat modified pinnae of the frond.

Microsporangiate organs of the Crossotheca type.

Seeds with radial symmetry, of Cycadean type, with nucellus adherent to integument, and with a single vascular system. Seed or seeds often enclosed in a cupule.

The relations of the Lyginodendreae to other groups will be further discussed at a later stage. 


\section{CHAPTER XI}

\section{PTERIDOSPERMEAE-continued}

Medulloseae; Aneimiteae; Seed-bearing Pecopterideae; Other Cycadofilices

\section{MEDULLOSEAE}

$H_{A B I T}$. As long ago as 1883 the Austrian palæobotanist Stur, as already mentioned, proposed to exclude certain of the principal genera of fossil Fern-like fronds from the Ferns, on the ground that, in spite of all the research devoted to them, they had never been found to bear Filicinean fructifications. The genera which he specially cited were Neuropteris, Alethopteris, Odontopteris, and Dictyopteris; these genera, along with others, are now often grouped in the family Neuropterideae, based on external characters, corresponding in part, if not altogether, to the Medulloseae as defined by structure. Recent investigation has fully justified Stur's conclusion (though not accepted at the time), and, as we shall see, there is now every reason to believe that the Neuropterideae generally were seedbearing plants (Pteridosperms) and not Ferns. Among the genera in question Neuropteris and Alethopteris 
are the most extensive and, at present, the best investigated.

The leaves of Neuropteris are of a very large size, bipinnate, tripinnate, or even quadripinnate in composition, with ovate or oblong leaflets somewhat

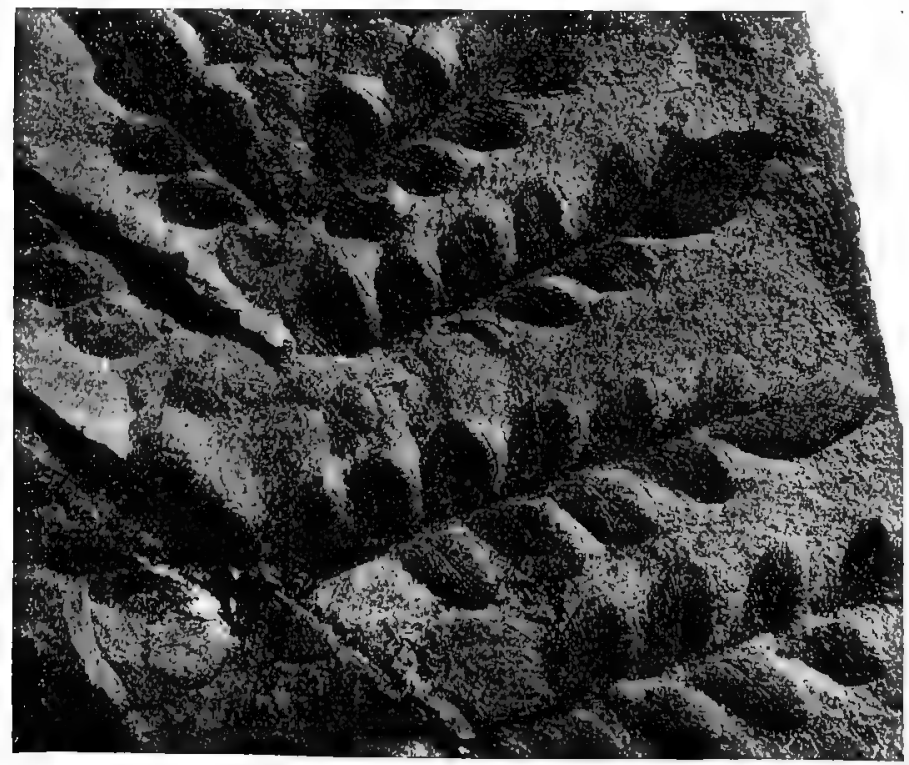

FIG. I6I.-Newroptcris heterophylla. Part of vegetative frond, slightly enlarged. From a photograph by Mr. R. Kidston, F.R.S.

cordate at the base, and usually attached to the rachis by a short stalk. The median nerve of the pinnule is distinct till near the end, where it breaks up into smaller dichotomous nervules; similar nervules are given off from the sides of the median nerve throughout its length; they leave the latter at an acute angle, and bend outwards to the margin (Fig. I6I). The fronds recall those of some recent Osmundas. 
In some cases, pinnae of a different form, without a median nerve, and described under the name of Cyclopteris, were attached directly to the rachis, and may have been of a stipellar nature. These organs are of the same kind as the "Aphlebiac," mentioned in Chapter VIII. as occurring on the fronds of Ferns.

In the genus Alethopteris the leaves are likewise large, and bito tripinnate, but here the thick, usually oblong pinnules are inserted on the rachis by a broad, decurrent base, and are in some cases confluent with one another. The edges of each leaflet are incurved on the lower side. The median nerve extends the whole length of the pinnule, and is prominent on its under surface; the secondary nerves leave the median

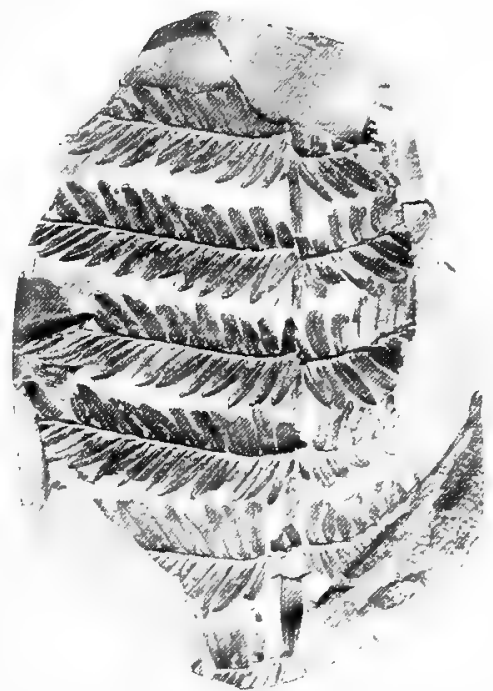

Fig. 162.-Aluthopteris lonchitica (folinge of a Medullosa). Part of frond. Reduced. From a photograph by Mr. W. Hemingway. one at a wide angle, and pass directly, with or without dichotomy, to the margin (see Fig. I62). The habit resembles that of the recent Marattiaceous Fern Angiopteris.

In the case of both these so-called genera, founded on the external characters of the leaf, there is now good evidence that they belonged to stems of the family Medulloseae, of which the structural characters 
are known. The nature of the proof will be given later, after describing the anatomy of the stem, but while considering this, it is necessary to bear in mind that we are dealing with plants which possessed a highly compound Fern-like foliage, and which, in some forms, at any rate, must have had a habit not unlike that of some of the existing Tree-ferns. We will first describe the anatomy of various representatives of the family, beginning with the type genus Medullosa, and will then go on to the evidence which we now possess as to the reproductive organs, especially the seeds.

ANATOMY-Medullosa.-The anatomical description will be based, in the first instance, on a British species, which is of greater geological antiquity than most other known members of the genus, and is likewise simpler in structure. As this form is now known with a considerable degree of completeness, it will best serve to give an idea of the essential anatomical characters of the group.

Medullosa anglica is derived from the Lower Coalmeasures of Lancashire, at the same horizon to which most of our British Coal-plants, with structure preserved, belong. The original specimens were found in nodules from the coal-seam at the Hough Hill Colliery, Stalybridge, at dates ranging from I 892 to 1898 , by the late Mr. G. Wild 'and Mr. Lomax. ${ }^{1}$ It is a curious fact that these specimens were the first stems of a Medullosa to be found in this country, though the petioles of plants belonging to this genus had long been familiar among

1 For a fuller description, see my paper, "Structure and Affinities of Fossil Plants from the Palrozoic Rocks, iii. Medullosa anglica, a New Representative of the Cycadofilices," Phil. Trans, vol. I9 I, B, I899. 
the common objects of the calcareous nodules. Specimens have since been found in other localities, and it is interesting that at Shore Littleburgh they occur in the roof-nodules, which usually show a distinct Flora from that of the nodules in the seam below. ${ }^{1}$

The stems are of rather large size, having a mean diameter of 7 or $8 \mathrm{~cm}$., in the specimens at present known. This dimension includes the leaf-bases, which were adherent to the stem for a long distance before becoming free; in fact, practically the whole external surface was formed by these leaf-bases, which were spirally arranged, the phyllotaxis, where it could be determined, having followed the $\frac{2}{5}$ arrangement. Fig. I63 will give an idea of the external appearance of the fossil stem; the surface of the large adherent leaf-bases is marked by a longitudinal striation, due to the hypodermal ribs of sclerenchyma, which stand out prominently in the fossil, though during life they must have been nearly or quite concealed from view by overlying tissue. The transverse section, represented somewhat diagrammatically in Fig. I64, shows the chief points in the organisation of the stem. This section was cut near the bottom of a piece of stem about a foot long. At this level, three large leaf-bases are shown; that marked $c$ in the figure is the nearest to its separation from the stem, and actually became free an inch or two higher up. The next leaf to become free is that marked $b$, while $a$ remains in connection with the stem for a vertical distance of 5 or 6 inches. At

$1 \mathrm{Mr}$. Arber described in 1903 a specimen in the Binney Collection at Cambridge. This must have been discovered many years before the typespecimens, but had apparently lain unnoticed. See Arber, "On the Roots of Medullosa anglica," Ann. of Bot. vol. xvii. 1903. 
higher levels, two new leaf-bases make their appearance, the first $(b c)$ between $b$ and $c$, and the next $(a b)$ between $a$ and $b$. Thus the order of insertion of the leaves from below upwards was $c, b, a, b c$, $a b$, an arrangement which implies a $\frac{2}{5}$ phyllotaxis. The habit of the stem,

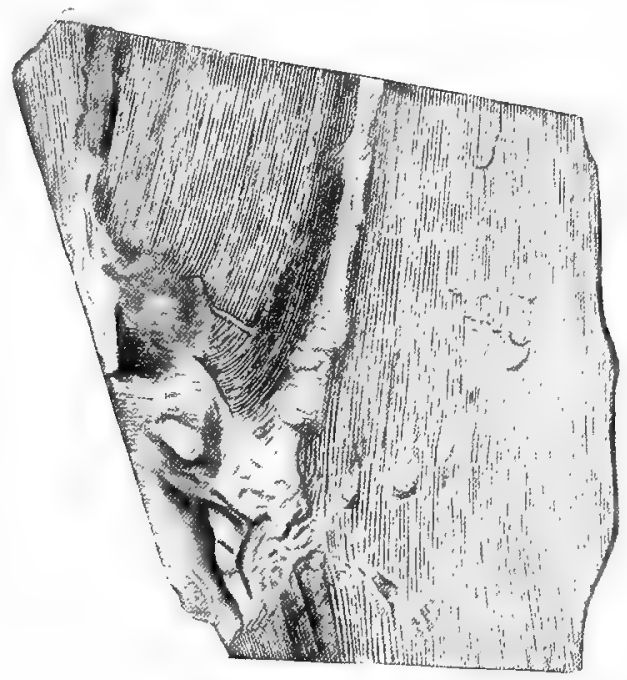

FIG. I63.-AIcdullosa anglica. External view of stem, showing two large leaf-bases, with a furrow between them. The surface is ribbed, owing to the presence of hypodernal strands of sclerenchyma. 产 nat. size. S. Coll. (G. T. G.)

clothed with its large adherent leaf-stalks, may well have resembled that of some of the Tree-ferns.

Coming now to the internal structure of the stem, we find that its organisation resembles that of the majority of the Ferns, in being of the so-called polystelic type. The number of the steles in $M$. anglica is

1 I have adhered to the now familiar terms "polystely" and "polystelic," but they are used in a purely descriptive sense without any implication that each of the several steles is to be regarded as homologous with the single stele of a typical monostelic stem. 
normally three (see Fig. I64, st); each has a somewhat elongated and irregular transverse section ; traced longitudinally, they divide and again fuse with one another at long intervals. The structure of the individual stele is almost identical with that of the single vascular cylinder of a Heterangium. The central part of each stele is completely occupied by the primary wood, consisting of groups of tracheides intermixed with

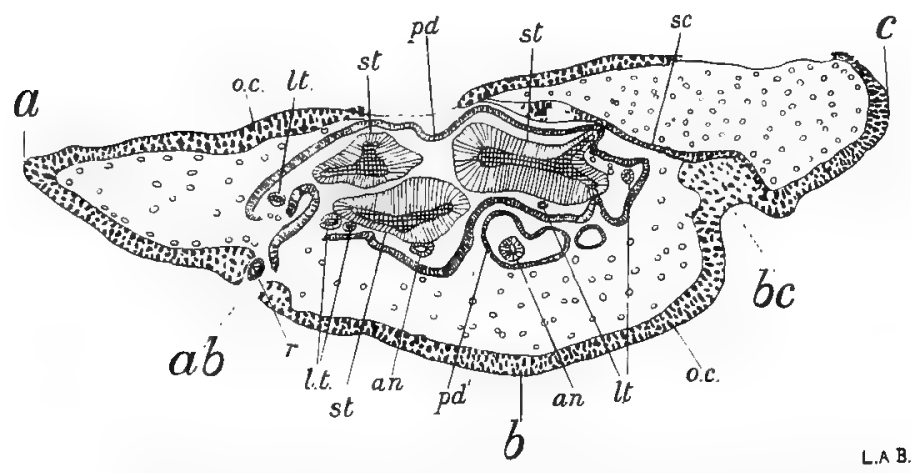

FIG. I64.-Medullosa anglica. Transverse section of stem, showing three large leafbases, $a, b$, and $c$. $a b, b c$, position of next leaf-bases above. st, the three steles; l.t, leaf-traces; an, accessory rings of wood and bast; $p d$, periderm, forming a ring round the group of steles, and also enclosing one of the accessory strands; $r$, adventitious root; $O_{0} c$, hypoderma; $s c$, sclerenchymatous band between leaf-base and stem. Slightly reduced. Pliz.. Trans., S. S. Coll. 737.

conjunctive parenchyma. The primary tracheides are for the most part pitted, just as in Heterangium; the spiral tracheides of the protoxylem, accompanied by a few scalariform or reticulated elements, occur in several groups near the outer margin of the primary wood (see Fig. 165, which includes parts of two steles).

Each stele is surrounded separately by its own zone of secondary wood and bast (Figs. I 64 and $165, x^{2}, p h$ ), so that we have in this family a combination of polystelic 
structure with normal secondary growth of the individual stele. This is the great anatomical character of the genus $M T_{c d u l l o s} \alpha$, with its immediate allies, and separates them at once from all plants now living, though there

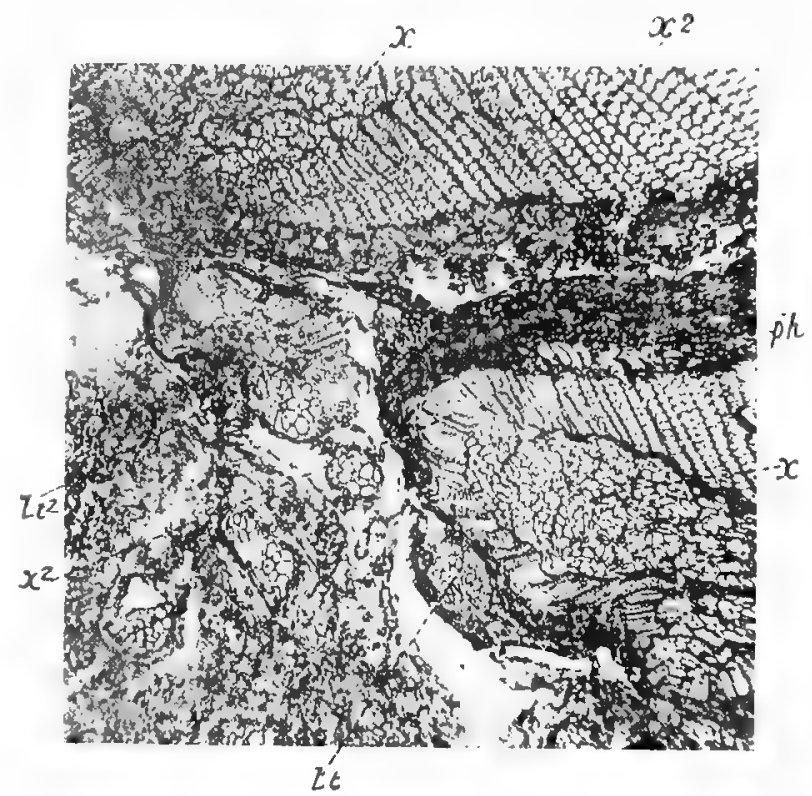

Fig. 165.-Medullosa anglica. Part of transverse section, showing portions of two steles, and leaf-traces going off from them. $x$, primary wood of steles; $x^{2}$, secondary wood; $p h$, phloëm ; $l . t$, leaf-trace, just detached from its stele; $l . t^{2}$, large leaf-trace, beginning to divide. Other smaller bundles are shown. $\times$ ro. Phil. Trans., S. From a photograph. S. Coll. 579 .

is one other fossil family (that of the Cladoxyleac) which shares the peculiarity (see p. 496.)

The secondary wood has the same structure as in Heterangium or Lyginodendron (see Fig. 165). The tracheides, which are in radial series, accompanied by muriform medullary rays, are, as a rule, pitted on their radial walls only The pits are multiseriate and 
bordered, just as in the genera last mentioned. Only slight remnants of the cambium are preserved, but sufficient to show that it was in the normal position, forming wood internally and phloëm externally, with reference to each stele. The phloëm itself is fairly preserved in places (Fig. I65, ph), and consisted of strands of long tapering elements, clearly the sievetubes, forming a network, the meshes of which were occupied by the rather wide phloëm-rays. In the Binney specimen, described by Mr. Arber, the sieve-tubes are perfectly preserved, and have conspicuous sieveplates on their lateral walls, just as in Heterangium tiliaeoides. ${ }^{1}$ There appears to have been a pericycle around each stele, but its structure is ill-preserved.

So far, the general organisation of Medullosa anglica may be roughly described as that of a polystelic Heterangium. In the points which remain to be described, the Heterangium type is departed from more widely; the differences are partly correlated with the polystely, and partly depend on the greater size and complexity of the plant as a whole.

The leaf-trace bundles were given off, for obvious reasons, only from the free, peripheral side of the steles. Where a leaf-trace first becomes free from the stele, it is a large bundle, to all appearance truly concentric in structure (see Fig. I65, l.t). It consists of a central mass of primary wood, with one or more protoxylemgroups near its external margin. This is surrounded by a zone of secondary wood and phloëm. The primary wood of the leaf-trace is continuous with the outer part of that of the stele from which it springs.

1 Arber, loc. cit. Plate xx. Fig. 4. 
As the leaf-trace passes upwards and outwards through the cortex, it loses its secondary tissues, and divides up repeatedly (Fig. I $65, l . t^{2}$ ) to form a number of smaller bundles, each of which eventually assumes a collateral structure. These ultimate leaf-trace bundles have their protoxylem directed outwards, adjoining the phloëm (see Fig. I66, in which two exceptionally well-preserved

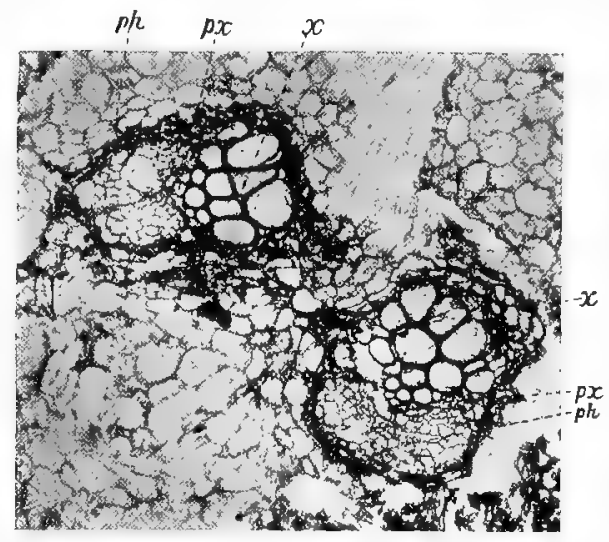

FIr. 166.-Medullosa anglica. Two lenf-trace bundles from the outer cortex of the stem, in transverse section, showing collateral exarch structure. $\not x x$, protoxylem: $x$, centripetal xylem; th, phloëm. $\times 35$. Phil. Trans. S. From!a photograph. S. Coll. 579 .

collateral bundles are shown); their xylem usually consists of spiral and finely scalariform elements only, the pitted tracheides, which are abundant in the undivided leaf-traces, disappearing as the ramification of the bundle goes on.

The cortical tissues of the stem require no detailed description; they consist of short-celled parenchyma, traversed by numerous secretory canals, much resembling the gum-canals of recent Cycads. 
A zone of internal periderm was formed around the central part of the stem, enclosing the group of steles, and separating them from the outer cortex and leafbases (Fig. I 64, $p d$ ). The periderm was probably for the most part of a suberous nature; it is extremely well preserved, and was evidently formed wholly or chiefly on the external side of the phellogen.

In one specimen, apparently forming part of an old stem, the whole of the outer cortex, together with the leaf-bases, had been exfoliated, leaving the periderm exposed. It may be doubted, however, whether this exfoliation was a normal process.

A point of some anatomical interest is the occasional presence, in the cortex, of accessory vascular strands, of concentric structure, and probably of wholly secondary origin (Fig. I64, an). These formations recall the similar cortical bundles occurring in the genus Cycas and some other members of the Cycadaceae at the present day.

The petioles of Medullosa anglica were of large size, having a diameter of $4 \mathrm{~cm}$. or more, at the point where they became free from the stem. Each leaf-stalk received a large number of vascular bundles, as many as seventy or eighty in all, derived from the repeated ramification of several of the principal leaf-traces. The supply of bundles did not all enter the leaf-base from the stem at the same level; they passed in successively, in groups corresponding to the various principal leaf-traces from which they were derived. Thus their number, in the leaf-base, increased from below upwards. At a certain height, however, the leaf-base was marked off from the interior of the stem by a band of internal sclerenchyma, 
and above this level no more bundles were received (see Fig. I 64, c). The petiole, where it first detaches itself
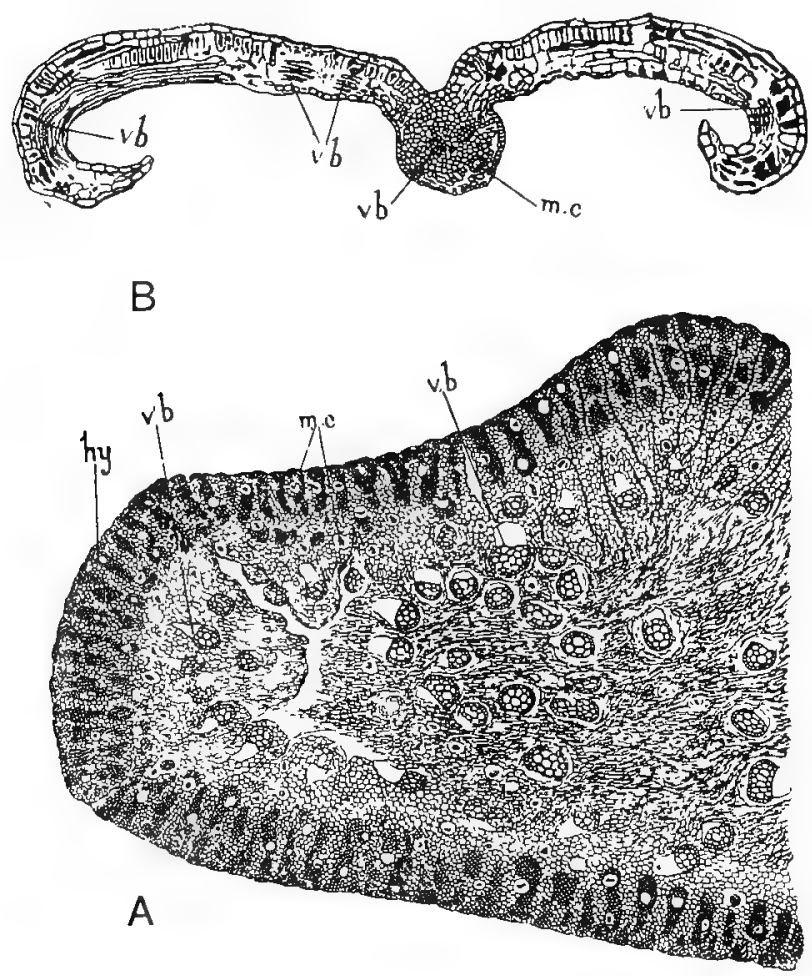

FIG. $167 .-$ Nedmllosa anglica. A. Transverse section of petiole, showing the numerous

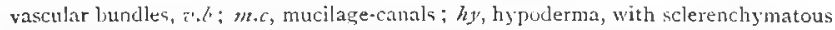
ribs. The whole bas the structure of " $M_{y}{ }^{\prime} l o x y$ ton Lamariotil." $x$ about $8 . \mathrm{S}$. Coll. 686. (G. T. G.) H. Vertical section of leaflet. 7'.', vascular luundles of midrib, and lamina; n.c., mucilage-canal. Palisade-tissue shown towards upper surface. ¿28. Phil. Tians. S. S. Coll. 691.

from the stem, has the following structure (Fig. 167, A) : On the cxtreme outside we may find a layer or two of palisade-like tissue (rarcly preserved), which probably served for assimilation. Within this is the broad hypo- 
dermal zone $(h y)$, consisting of numerous vertical strands of fibres, interspersed with parenchyma, and accompanied by secretory canals of the usual Cycadean type.

The whole interior of the leaf-stalk is occupied by a short-celled ground-tissue, containing secretory canals (m.c), and traversed by the numerous vascular bundles $(v \cdot b)$, ranged more or less regularly in concentric circles. The general structure was, in fact, much like that of the petiole of a recent Cycad. The individual bundles likewise resemble those of the recent family, differing only in the fact that their xylem was entirely centripetal, while in a modern Cycad a small amount of centrifugal wood is also present. This difference, however, does not seem to have been an absolutely constant one, for in some of the Medulloseae the foliar bundles are described as having precisely the Cycadean structure.

Petioles of the kind described have long been known under the generic name of Myeloxylon; the particular form belonging to our Medullosa resembles that named by M. Renault Myeloxylon Landriotii, distinguished chiefly by the multiseriate arrangement and elliptical transverse section of the fibrous hypodermal strands. The same petiolar structure, however, was no doubt common to certain other species of Medullosa. The fact that the fossils named Myeloxylon are nothing but the petioles of Medullosa had previously been proved, by Weber and others, for one of the Continental species. ${ }^{1}$ In the case of $M$. anglica the conclusion is perfectly obvious,

1 See Weber and Sterzel, Beiträge z. Kenntniss der Medulloseae, Chemnitz, I896. The original discovery was made by Weber, about the year 1880 . 
for the leaf-bases, still attached to the stem, show in all respects the typical Myeloxylon structure. The genus Myeloxylon is therefore one of those which can now be dispensed with, or at most be retained, as a matter of convenience, for those petioles which have not yet been referred to their particular species of Medullosa.

The petioles of Medullosa anglica were of great length, and branched repeatedly, the successive branches diminishing in size, and undergoing some simplification in structure. The whole evidently constituted the rachis of a highly compound, probably bi- or tripinnate leaf. The final ramifications, which are no more than a millimetre in diameter, contain only a very few vascular bundles, but these still retain the same collateral, exarch structure as those of the main petiole. Gum-canals occur throughout the rachis; the hypodermal structure becomes simplified in the finer branches, consisting of an almost continuous zone of peripheral sclerenchyma.

Associated with the branched rachis, leaflets of characteristic structure are found. As shown by transverse sections, these leaflets are constantly revolute at their margins (see Fig. I 67, B); the parenchyma towards the upper surface is of palisade-like structure, while the lower portion of the mesophyll is more lacunar. The lateral bundles, which traverse the lamina in an oblique direction, are accompanied by fibrous elements. The midrib is very prominent on the lower surface, and shows the same structure as a small branch of the rachis. From constant association and agreement in structural details, there is no doubt that these pinnules formed part of the Medullosa leaves. This conclusion is of great interest, because the pinnules in question 
agree closely with certain leaflets described by M. Renault in I 883 , which, as shown by their external characters, belonged to an Alethopteris. ${ }^{1}$ The rachis and petiole of M. Renault's Alethopteris showed the anatomical structure of "Myeloxylon Landriotii." Thus the French author's observations, taken in conjunction with Weber's discovery that "Myeloxylon Landriotii". was the leaf-stalk of a Medullosa, proved that the wellknown Alethopteris fronds were borne as foliage on certain of the Medullosa stems.

From the organisation of the petioles and leaves in Medullosa anglica, there can be little doubt that the English species also bore foliage of the Alethopteris type, an example of which is illustrated in Fig. I62 from $A$. lonchitica, very probably the actual species concerned.

The roots of $M$. anglica have frequently been found in connection with the stem, on which they were borne in vertical series, between the leaf-bases. They have a normal triarch structure, and; with increasing age, formed a large amount of secondary wood and bast, interrupted opposite the protoxylem-angles by large medullary rays, just as in recent roots with secondary growth. The detailed structure of the xylem agrees with that of the corresponding tissue in the stem. $\mathrm{Mr}$. Arber finds that the phloëm much resembles that in the stem of Heterangium tiliaeoides. The groups of sievetubes are accompanied by phloëm-parenchyma, and separated by dilated parenchymatous rays. The sievetubes show the lateral sieve-plates particularly well $;^{2}$

1 Renault, Cours de Botanique fossile, vol. iii. p. I 59, Plate xxvii.

2 Arber, loc. cit. Plate xx. Fig. 5. 
this appears to be the only case in which this structure has been recognised in the root of a fossil plant. A very characteristic feature of these roots, with the exception of the youngest specimens, is the presence of a wide zone of large-celled periderm, forming the external covering of the organ. Developmental stages have been observed, proving that the periderm was an internal one in origin, arising by division of the pericyclic cells, and thus causing the exfoliation of the whole cortex. A small amount of phelloderm was formed on the inner side of the cork-cambium. ${ }^{\text {I }}$ In all respects the roots of Medullosa anglica agree with those of recent Gymnosperms.

The larger roots reached a diameter of about half an inch. They branched pretty freely, giving off rootlets of various orders. The xylem of the rootlet was always inserted on an angle of the primary wood of the main root, in the way normal for these organs.

If we now sum up our knowledge of the vegetative organs of Medullosa anglica, we find that it had a polystelic stem, each of the steles, usually three in number, resembling, as regards both the primary and secondary tissues, the single central cylinder of a Heterangium.

Externally, the stem was clothed by the bases of the large, spirally disposed leaves, which were repeatedly compound, and no doubt presented the external characters of an Alethopteris, with which they agree in anatomical structure.

Each leaf received from the stem a large number of vascular bundles, derived from the repeated subdivision 
of a number of the principal leaf-traces springing from the steles. The principal leaf-traces were concentric in structure, and surrounded by secondary wood and bast, but, as the bundle underwent subdivision, its branches gradually lost their secondary tissues, and, at the same time, assumed a collateral, exarch structure. The petiole and rachis had in all respects the structure of "Myeloxylon Landriotii." The stem bore triarch, adventitious roots, forming secondary wood and bast, and coated by a periderm of pericyclic origin.

The form of Medullosa just described, which happens to be the one most completely known up to the present time, represents the genus, as it were, in its simplest expression. ${ }^{1}$ Several Continental species had previously been investigated, all of which are of later geological age than $M$. anglica, belonging chiefly to the Permian beds. They all have a more complex vascular system than the English species; the steles are usually more numerous, and in all cases show a differentiation among themselves. The larger steles are associated to form a single or double peripheral ring, while others, of much smaller size, are grouped in the central region of the stem. In most of the specimens, as, for example, in those of the form known as Medullosa stellata, the peripheral steles are few in number, and much elongated in the tangential direction, so that they collectively

1 A very small Medzellosa (named provisionally $M$. pusilla), the stem with the leaf-bases not exceeding $2 \mathrm{~cm}$. in diameter, has since been found by Mr. P. Whalley of Colne, Lancs. The stem has three steles and agrees very closely with.$T$. anglica except in size. In the Renault collection at Paris there are sections, under the name Heterangizun geriense, of the stem of a Medullosa, apparently of the same type as MT anglica, from the Upper Coal-measures of the Ride de Gier, near St. Etienne. This species may bear the name Medullosa geriensis. 
form an almost continuous ring, with few interruptions. In some cases the peripheral ring appears to have been completely unbroken, forming a solenostele, such as we find in various recent Ferns and Fern-allies, as, for example, in Loxsoma, Dicksonia, and Marsilia. In all cases, however, so far as satisfactory investigations have been made, the structure of the individual stele is essentially like that in Medullosa anglica. The interior is occupied by primary wood, sometimes containing a rather large amount of parenchyma, and this is surrounded on all sides by secondary wood and phloëm. The small central steles usually have an approximately circular transverse section; they anastomose both among themselves and with the peripheral steles, which they resemble in structure. We see, then, that in all these forms of Medullosa, the structure of the stem was polystelic, as in the simpler species, $M$. anglica, with which we started. The differentiation of the steles into a central and peripheral system marks, however, a distinct advance on the part of the later representatives of the genus. The outer, more or less continuous, stelar zone allowed of indefinite growth in thickness, on its free external side. It is the rule, in the older stems of the type of Medullosa stellata, to find that the great bulk of secondary wood and bast was developed on the outer side of the peripheral steles; on the inner side of 'the same zone, and around the small central steles, the growth was of necessity limited by want of space. Consequently, an old stem of Medullosa stellata may assume a very different appearance, as seen in transverse section, from that typical of the genus, the external wood and bast predominating so largely over all the 
other tissues, that the original polystelic organisation sinks, as it were, into the background.

In some exceptional instances, additional complications made their appearance. This was the case, for example, in a huge specimen of Medullosa stellata (var. gigantea), the largest as yet discovered, the stem of which, though decorticated, was over a foot and a half thick. The central ground-tissue, 5 or 6 inches in diameter, was traversed by forty-three central steles, some of which were an inch in diameter. The peripheral zone of steles was enormously thickened on its outer surface, but, in addition to this, there were three concentric extrafascicular layers of wood and bast, which had been formed successively around the whole of the normal vascular system. Thus, in this specimen, the anomaly characteristic of the recent Cycadean genera, Cycas, Macrozamia, and Encephalartos, co-existed with the polystelic structure of a Medullosa. ${ }^{1}$

It is evident that some of the Permian Medulloseae reached the dimensions of fair-sized trees; others appear to have had long and comparatively slender stems; it has been conjectured that some of the latter may have been climbers, like the lianes of tropical forests, but for this supposition there is no real evidence. The resemblance of the anatomical structure of the Medulloseae to that of the stems of certain climbing Sapindaceae, pointed out in I 88 I by Göppert and Stenzel, ${ }^{2}$ is more apparent than real. Some of the Sapindaceous lianes have a number of vascular cylinders in the mature stem, but this is merely an anomaly of

1 See Weber and Sterzel, l.c.

2 "Die Medulloseae, eine neue Gruppe der fossilen Cycadeen," Palceontographica, I88I. 
secondary growth, depending on the peculiar distribution of the cambium $;^{1}$ the whole structure is no doubt an adaptation to a climbing habit. In Medullosa the primary organisation was evidently polystelic (dialystelic), as in most recent Ferns, and there is no reason to assume that it had any relation to scandent growth.'

It may be pointed out here that the polystely of Medullosa differs from that of the typical polystelic or dictyostelic Ferns in having, so far as appears, no relation to the presence of "leaf-gaps." In the species at present investigated the leaf-traces of Medullosa are given off from the outer faces of the steles, and leave no gaps; the breaking up of the original stele depended on some other cause. Further investigation is necessary to show whether this distinction is absolute.

In one or two of the Continental Medulloseae, something has been ascertained as to the course of the leaf-traces ; thus, in $M$. stellata, the leaf-traces are given off from the peripheral steles, and each is at first surrounded by its own zone of secondary wood. They then divide up, lose their secondary tissues, and become collateral, just as in $M$. anglica. They have not, however, been traced into the leaves, which are as yet unknown in $M$. stellata.

In another Continental species, $M$. Leuckarti, ${ }^{2}$ the leaf-traces behave in the same way, though their connection with the steles appears not to have been seen at present. In $M$. Leuckarti the structure of the leaf-bases is known, and, as in the English species, is of the type of "Myeloxylon Landriotiz."

${ }^{1}$ Cr. De Bary, Comparative Anatomy of Phanerogams and Ferns, English edition, I884, p. 58I.

"Solms-Laubach, "Ueber Medullosa Lenckarti," Bot. Zeitung, I897. 
In both the species of Medullosa just mentioned, the leaf-traces are given off from the outermost steles. In $M$. Solmsii, however, where there is a double zone of peripheral steles, it appears that the bundles arise from the inner ring. In no case were the more central cylindrical steles directly connected with the leaf-traces, though there was indirect communication, by means of fusions with the peripheral system.

Our knowledge of the foliage of the Continental Medullosae is a matter of inference. MI. Leuckarti, as already mentioned, bore leaf-stalks with the structure of "Myeloxylon Landriotii," and we know, from M. Renault's 'researches, that petioles with that structure belonged to Alethopteris. There is therefore a strong presumption that the foliage of Medullosa Leuckarti, like that of $M$. anglica, was of the Alethopteris type. $M$. Leuckarti seems to have had a short stem, and may have been of almost herbaceous habit. From the structure of the leaf-traces in $M$. stellata, which includes the largest specimens of the genus, there is little doubt that its petioles were also of the "Myeloxylon" kind, but we have no more direct evidence as to the nature of the leaf.

"Myeloxylon" petioles, of the type named by $M$. Renault $M$. radiatum, characterised by the radially elongated hypodermal bands of sclerenchyma, were shown by him to belong to the genus Neuropteris. There is therefore strong evidence that the latter genus, as well as Alethopteris, consisted, wholly or in part, of the foliage of species of Medullosa. Fern-like leaves of certain other genera, such as Odontopteris, Callipteris, 
and Taeniopteris, have been found in association with stems of the same type.

A curious fossil stem, from the Permian of Autun, in France, named by Brongniart Colpoxylon aeduense, and subsequently more fully described by M. Renault, ${ }^{1}$ agrees in many respects with the simpler forms of Medullosa, but is peculiar in having, for a part of its length, a single vascular cylinder only. The stele has a very irregular outline, and is surrounded by secondary wood and bast of the structure usual in Medulloseae. In the interior there are scattered groups of tracheae, embedded in parenchymatous tissue.

Towards one end of the specimen, the stele divides, first into two, and then into six or seven parts, so that the stem of Colpoxylon was monostelic in one part, and polystelic in another. The leaf-trace bundles are preserved, and appear to agree essentially with those of Medullosa. Their ultimate branches are collateral, and of the "Myeloxylon" type; in. some of them, centrifugal as well as centripetal wood has been found. The external surface of the stem bears a general resemblance to that of Medullosa anglica; the leaves are unknown. There can be no doubt that Colpoxylon belonged to the family Medulloseae; very possibly it may ultimately prove to have been simply an aberrant representative of the genus Medullosa itself. The local reduction of the vascular system of the stem to a single stele is the point of chief interest. There is some evidence that Colpoxylon was the stem of an Alethopteris. ${ }^{2}$

1 Flore fossile a'Autzn et d'Epinac, Part ii.

2 Grand'Eury, "Sur les organes et le mode de végétation des Neuroptéridées et autres Ptéridospermes," Comptes Rendus, t. cxlvi. p. 1243, 1908. 
Sutcliffia.-Professor Seward described, under the name of Rachiopteris Williamsoni, ${ }^{1}$ a petiole which bears a great general resemblance to "Myeloxylon," but differs from it (among other minor points) in the vascular bundles having concentric, instead of collateral structure. Considering that in Medullosa the leaf-traces were, to all appearance, concentric on first leaving the steles, it was not surprising that in some forms they should have retained this structure after entering the petiole, and it thus appeared from the first highly probable that Rachiopteris Williamsoni represented the leaf-stalk of some unknown member of the Medulloseae.

This conclusion has now been confirmed by the discovery of a new Medullosean stem (Sutcliffia insignis, Scott), found by Mr. J. Lomax in material from $\mathrm{Mr}$. Sutcliffe's colliery at Shore, Lancashire. ${ }^{2} \quad$ Sutcliffia, like Professor Seward's fossil, is derived from the roofnodules, where it is associated with Goniatite shells (Fig. I68). The roof-nodule specimens no doubt represent the drifted fragments of a distinct Flora, flourishing at some little distance from the coal-forming forests; to the latter the ordinary seam-nodules owed their origin.

The stem is a large one, measuring I $2 \times 6.5 \mathrm{~cm}$. in diameter in its present somewhat distorted condition. In a length of 9 inches not more than one petiole leaves the stem, so the plant was presumably of a tall stature. The stem is clothed by large, spirallyarranged leaf-bases, but detached petioles have been found greatly exceeding in size those borne by the

1 Annals of Botany, vol. viii. I894, P. 287.

2 Scott, "On Sutcliffia insignis, a New Type of Medulloseae from the Lower Coal-measures," Trans. Limn. Soc. London, and ser. Bot. vol. vii. Part iv, Igo6. 


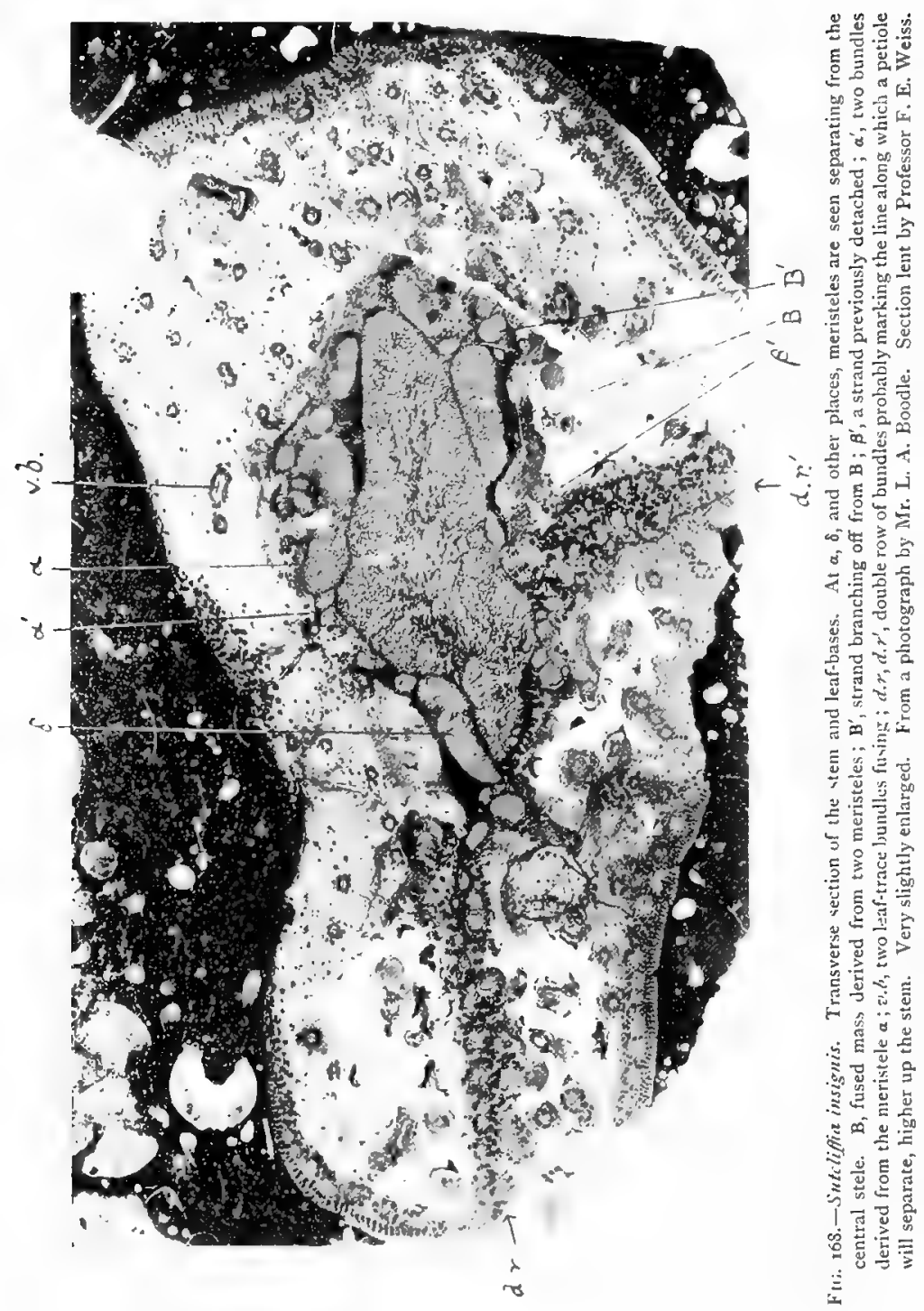


stem, which must have been a small specimen-probably from a young plant.

The main feature of the anatomy, in which Sutcliffia differs from any Medullosean stem previously known, is the presence of a single central stele, of large size (measuring $4.7 \times 1.8 \mathrm{~cm}$. in the section figured, Fig. I68). There is no pith, and the wood has the same structure as in a stele of Medullosa anglica, except that in Sutcliffia the protoxylem-groups are peripheral, the xylem thus being exarch. A zone of phloëm, in which strands of sieve-tubes can be recognised, surrounds the wood. In the stem investigated (the only specimen as yet discovered) secondary growth was just beginning.

From the main stele, large, irregular strands, the meristeles or subsidiary steles, were detached at intervals, giving a remarkable and unique appearance to the transverse sections (see Fig. I68, $a, \mathrm{~B}$, and $\delta$ ). The meristeles break up into smaller strands, but the main branches of adjacent meristeles often fuse with one another. "Thus the large mass B, in Fig. 168 , is the product of such a fusion, as shown by the comparison of serial sections. The strands derived from the further subdivision of the meristeles or their fused branches (Fig. I68, $\boldsymbol{a}^{\prime}, \beta^{\prime}, \mathrm{B}^{\prime}$ ) ultimately constitute the numerous bundles of the leaf-trace (Fig. I 68, d.r., v.b.). The vascular strands in the leaf-bases and petioles always, however, retain a concentric structure, and their xylem contains parenchyma, so that they preserve a more stele-like character than the corresponding bundles in a Medullosa. The structure of the petiole agrees in all essentials, though not in every detail, with that of 
Seward's Rachiopteris Williamsoni, which appears to be the petiole of some other species of Sutcliffia.

The vascular system of Sutcliffia has no parallel among any plants at present known, though a remote analogy may be traced with the anomalous structure of certain lianes belonging to the Sapindaceae. The genus is referred to the Medulloseae on account of the general organisation of the leaf-base and petiole, the numerous leaf-trace bundles, the tendency to dialystely shown in the formation of the subsidiary steles, and the histology of the vascular and cortical tissues.

The stem, however, has not deviated far from the monostelic condition, for the single central cylinder forms the dominant feature of the vascular system, while the meristeles serve to effect the transition to the leaf-traces. The plant is of considerable interest, as indicating the probable derivation of the Medullosean stem from a simple protostelic type, such as exists in Heterangium among the Lyginodendreae.

FRUCTIFICATION OF MEDULLOSEAE.-There is one case in which we have clear and direct proof that a member of the Medulloseae, or, as we should rather say, of the Neuropterideae, was a seed-bearing plant. In the same year in which the seepd of Lyginodendron was first identified, Mr. Kidston was able to demonstrate the presence of seeds in a species of Neuropteris, one of the genera which Stur, twenty years before, had proposed to exclude from the Ferns.

In the well-known species $N$. heterophylla, the frond of which is illustrated in Fig. I6 I (p. 426), bodies of about the size of a hazel-nut, but relatively longer, were 
discovered by $\mathrm{Mr}$. Kidston, in nodules from the Middle Coal-measures of Dudley, attached to a rachis bearing the characteristic pinnules of Neuropteris heterophylla ${ }^{1}$ (Fig. I69). The specimens are casts, not petrifactions, so no detailed study of structure has been possible, but the external characters leave no doubt that the organs in question are seeds. They are of the radially symmetrical type, and the testa has a fibrous structure. Chiefly on account of the latter character Mr. Kidston refers the seeds to the genus Rhabdocarpus of Göppert and Berger. ${ }^{2}$ The seeds appear to be borne terminally on the fertile branches of the rachis; it is a striking fact that the seed-bearing frond or pinna should be so

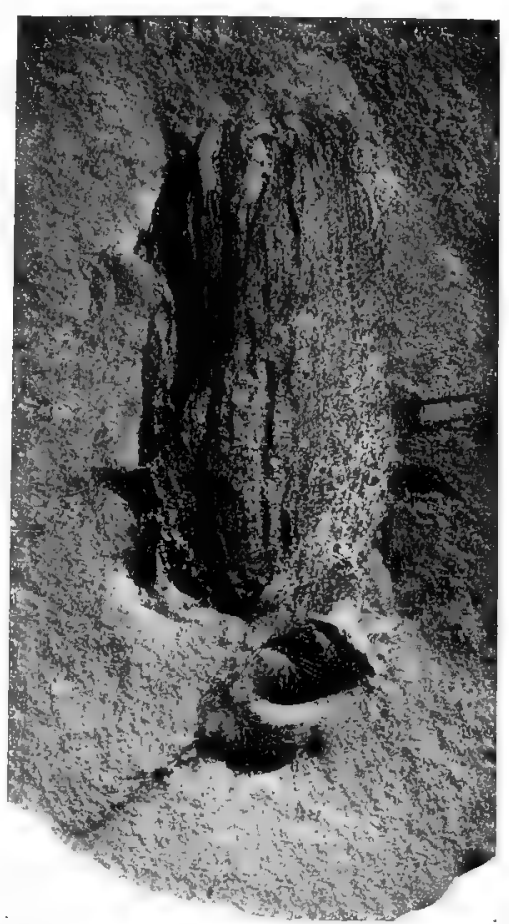

FIG. I6g.-Neuropteris heterophylla. Seed, at. tached to a branch of the rachis bearing two characteristic pinnules. $\times 2$, After Kidston.

little modified as to show the same form of pinnule as the vegetative foliage; the differentiation of the

1 R. Kidston, "The Fructification of Neuropteris heterophylla," Phil. Trans, Royal Soc, B, vol. cxcvii. I904.

2 Brongniart, however, limited the genus Rhabdacarpus to seeds with bilateral symmetry (Platyspermeae of Oliver), see Fig. 185, p. 5 I3. 
sporophyll had scarcely even begun in a case like this.

Mr. Kidston was thus the first to observe direct continuity between the seed and the frond in a Fernlike Palæozoic plant, and it was his discovery, in conjunction with the equally strong though less direct evidence in the case of Lyginodendron, which first suggested the institution of the class Pteridospermeae.

There is at present no instance of a petrified seed, showing structure, which can be referred to the Medulloseae or Neuropterideae with the same certainty as Mr. Kidston's casts. One of the best-known Palæozoic seeds, however, Trigonocarpus Parkinsoni, Brongn., may be attributed with great probability, as we shall see, to Alethopteris; we will therefore shortly describe its structure.

Trigonocarpus Parkinsoni is found in three distinct states of preservation in the English Coal-measures: (I) in the common condition of nut-like, somewhat triangular casts, which, as shown by Hooker and Binney and by Williamson, are really internal casts of the seed cavity; (2) as external casts, showing the testa and the true form of the seed ; (3) as petrifactions, in which the structure is more or less perfectly preserved. From these various data a fairly complete knowledge of the organisation of the seed has been gained; its more important features are shown in the diagrammatic figures I $7 \mathrm{O}-\mathrm{I} 72$.

The seed is a very large one, the length reaching $5 \mathrm{~cm}$., of which quite half is accounted for by the enormously long micropyle; the body of the seed has a maximum diameter of over $2 \mathrm{~cm}$. (Fig. I 70). The testa 
consists of two clearly distinct layers-the outer layer or sarcotesta, composed of delicate, partly lacunar tissue, bounded externally by a sharply differentiated hypoderma and epidermis, and the inner ribbed sclerotesta, constructed, like the stone of a peach, of dense, thickwalled tissue. The ribs show a very definite arrangement. There are three principal ridges, corresponding to sutures, in the sclerotesta, and usually three secondary ridges in each space between the former, making twelve ribs in all (Fig. I 7 I); within the sclerotesta there are some traces of an inner soft layer. The nucellus has a definite epidermis, and appears to have been free from the integument, from the chalaza upwards; it terminates at the apex in a dome-shaped pollen-chamber, provided with a long, narrow beak (Fig. I 7O, p.c, p.c.b), as in the seeds of the Cordaiteae, described in Chap. XII. The membrane of the megaspore or embryo-sac is evident, but the prothallus has not yet been found preserved.

The vascular system of the seed is double. At the base six bundles branch off from the common supplystrand and pass upwards through the sarcotesta (Fig. I 70), taking a definite position opposite certain of the secondary ridges (Fig. I 7 I). These bundles appear to have been collateral, with external phloëm, and there is evidence that the xylem was mesarch. The inner vascular zone formed a complex tracheal network in the nucellus; near the chalaza the sheath of nucellar tracheides is continuous; farther up they range themselves in longitudinal strands connected by abundant transverse anastomoses. The most remarkable feature of the seed is the long micropylar tube, formed by an extension of the ribbed sclerotesta, and enclosed in a 


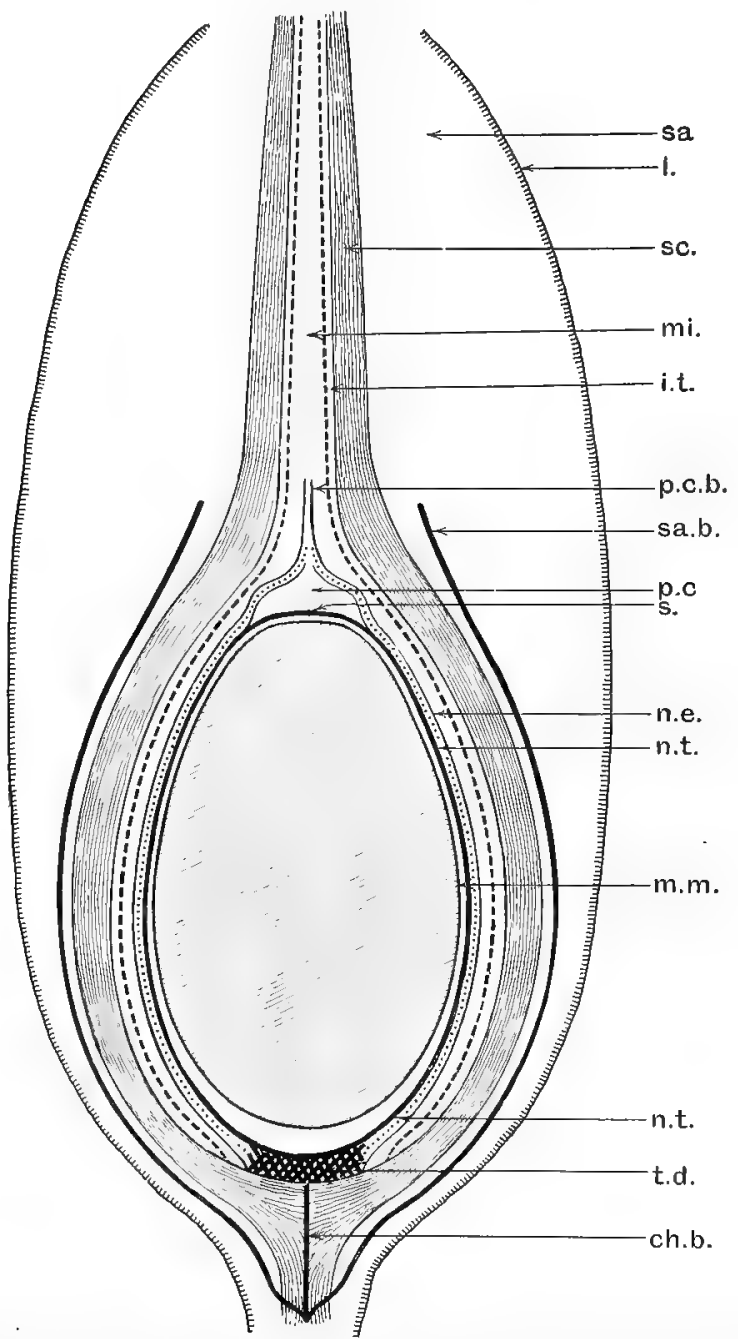

FIG. I70.-Trigonocarpus F'arkinsoni. Diagrammatic median section in the plane of the "wing" (Fig. 172). sa, sariotesta; $l$, its limiting layers; sc, sclerotesta; mi, micropyle; i.t, remains of "inner flesh"; $s a . b$, surcotestal bundles; $p . c$, pollenchamber; p.c.b, its beak; s, septum at bottom of pollen-chamber; u.e, nucellar epidermis; $n . t$, nucellar tracheal system; $n . m$, membrane of megaspore; $t . d$, tracheal dise at chalaza; ch, b, chalazal bundle, $x$ about 3 . From a drawing by Mir. A. J. Maslen, F.L.S. 
broad, wing-like prolongation of the sarcotesta (Figs.

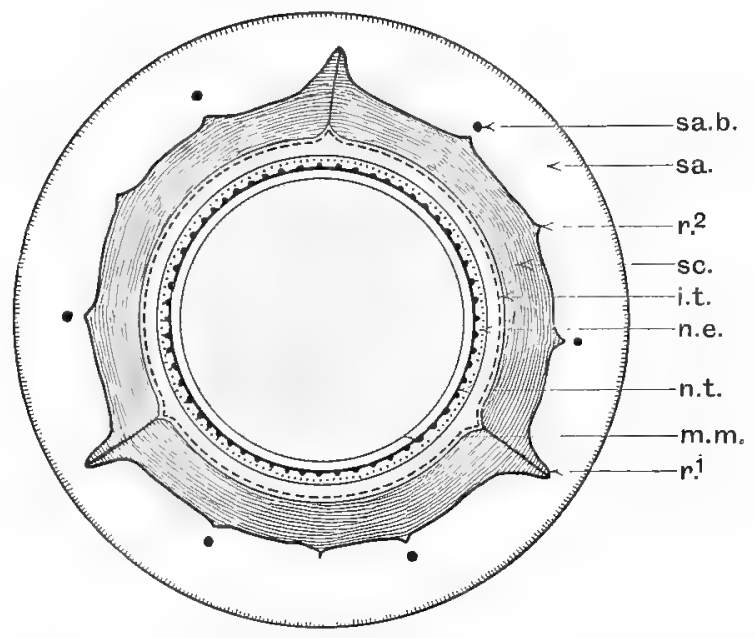

F1G. 171.-Diagrammatic transverse section through the body of the seed, at about the level of the line $m . m$. in Fig. $170 ; r^{2}$, principal ridges; $r^{2}$, secondary ridges. Other lettering as in Fig. x $70 . \times$ about 3 . From a drawing by Mr. A. J. Maslen.

I 70, I 72). It is not quite certain, however, to what

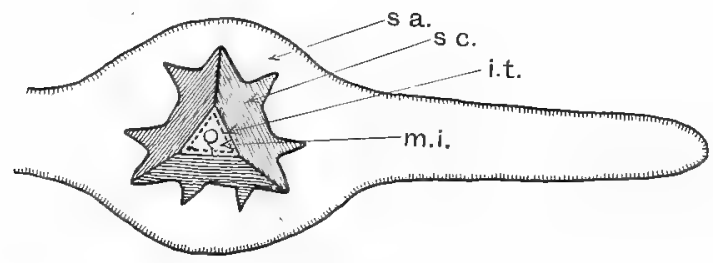

p.c.b.

FIG. 172.-Dingrammatic transverse section through the micropyle, at about the level of the line p.c.b. in Fig. 17o, showing the wing on one sicle. Lettering as in Fig. 170. From a drawing by Mr. A. J. Maslen.

extent the flattened form of this part of the seed is natural. 
The seed, with its fleshy and stony coats, double vascular system, and pollen-chamber, is evidently very nearly akin to the seed of a recent Cycad, the chief difference consisting in the free nucellus, whereas in the modern family it is adherent to the integument.

The petrified specimens of Trigonocarpus Parkinsoni are, almost without exception, associated with the leaflets, petioles, and other organs of Medullosa anglica, while the casts very generally occur together with the Alethopteris foliage, which no doubt belonged to that plant and allied species of Medullosa. Histologically there is a striking agreement in the tracheides, a peculiar, finely scalariform type being characteristic both of the Medullosa and the Trigonocarpus. There is also a certain similarity between the limiting, layers of the sarcotesta and those of the petiole. The evidence is of course far from amounting to proof, but the presumption is entirely in favour of this seed being the fructification of the Alethopteris (probably A. lonchitica), which formed the foliage of Medullosa anglica. ${ }^{1}$

No pollen-grains have yet been observed in the pollen-chamber of Trigonocarpus, but in another genus of the same group, Stephanospermum, Brongn., recently reinvestigated by Professor F. W. Oliver, they have been found in perfect preservation. The species to which Figs. I73 and I74 refer, Stephanospermum akenioides, Brongn., is one of the numerous seeds,

1 On Trisonocarpus see Hooker and Binney, "On the Structure of certain Limestone Nodules enclosed in seams of bituminous Coal, with a description of some Trigonocarpons contained in them," Phil. Trans. Royal Sor. vol. cxlv. I855. Williamson, "On the Organisation of the Fossil Plants of the Coal-measures," Part viii. itzid. vol. clxvii. I877. Scott and Maslen, "The Structure of Trigonocarpus," Ann. of Bot. vol. xxi. 1907 . 
originally described by Brongniart, from the Black Pebbles of St. Croix, near St. Etienne, of Upper Coalmeasure age. It is a comparatively small seed (measuring about Io $\times 4.5 \mathrm{~mm}$.), and, though the sarcotesta is not preserved, is evidently of the same general type as Trigonocarpus, with which it agrees in the radial symmetry, the prolonged micropyle, the beaked pollenchamber, and the apparently free nucellus, of which the characteristic tracheal investment forms part.

The most striking peculiarities of the seed consist in the presence of a prominent ring or collar of the sclerotesta around the micropylar region, and in the nature of the nucellar tracheal system, which forms a continuous mantle of spiral or scalariform tracheides, extending as far as the pollen-chamber and spreading over its floor.

In this seed the prothallus is sometimes well preserved; the archegonia appear to have been only two in number; in the egg-cell the nucleus has been recognised.

The apex of the pollen-chamber was prolonged into a long beak or tube, engaging with the micropyle (cf. Fig. I70, Trigonocarpus). ${ }^{1}$ Through this beak the pollen-grains entered the pollen-chamber, in which they are found in almost every seed. They also occur loose in the matrix, where they are of small size, averaging only about $60 \mu$ in length, while the average dimensions of those in the pollen-chamber are I60 $\times$ I OO $\mu$ (2 I0 $\mu$ being the extreme length observed), so that, as Renault first showed, the pollen-grains developed actively after

I In Fig. I73 the conical mass at the top of the figure represents the funnel-shaped base of the tube, but the tube itself is missed. 
entering the seed. The multicellular structure of the pollen-grains, in this and other cases, was first demonstrated by Renault, and fully confirmed by the more recent observations of Oliver, who finds that there are about twenty cells in each grain, so arranged that five radial septa are seen when the grain is cut transversely

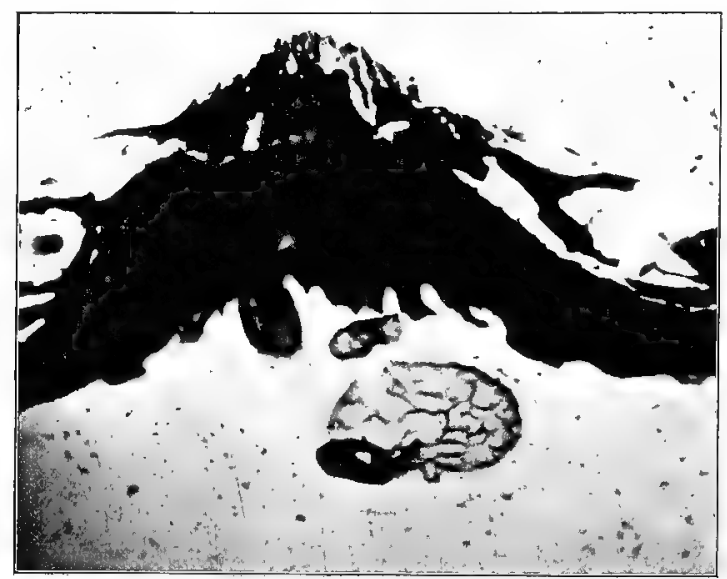

FIG. I73.-Stephanospermum akenioides. Upper part of pollen-chamber, showing part of its wall, with the base of the beak. In the chamber a large multicellular pollengrain is shown, also three small foreign pollen-grains, one of which partly overlies the large grain. $\times$ go. Will. Coll. r486a. From a photograph lent by Prof. F. W. Oliver, F.R.S.

(Fig. I 74). Ultimately the internal cells appear to have become retracted towards the periphery, leaving behind them in the middle of the grain a framework of cellwall — the "replum" (see Fig. I 74).

In the light of our present knowledge of the reproduction of Ginkgo and the Cycads it is an obvious suggestion that the internal cells of the pollengrain were antheridial cells, producing spermatozoids. 
Renault, however, actually anticipated the discovery of Ikeno and Hirase. In an allied seed, Aetheotesta, as well as in Stephanospermum itself, the cell-walls of the pollen-grains which they contain are perforated, and Renault suggested, in 1887 , "that the perforations served for the passage of mobile bodies analogous to antherozoids." $\mathrm{He}$ adds : "We do not regard as

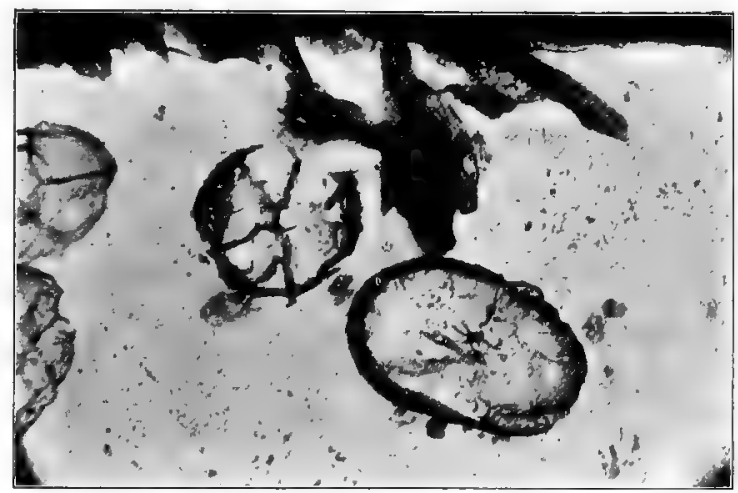

FIG. I74.-Stephanospermum akenioides. Multicellular pollen-grains in pollen-chamber; some shreds of the wall extend into the cavity. The middle pollen-grain is in transverse section, and shows the radiating septa dividing up the grain. The grain to the right is in longitudinal section, and shows the peripheral cells and the "replum" in the middle (see text). X 137 . Univ. College Coll. S 7A. From a photograph lent by Prof. Oliver.

impossible the existence in the past of pollen-grains, which, instead of effecting fertilisation by means of a tube, discharged into the pollen-chamber of the appropriate seeds antherozoids capable of performing this function." 1

1 Renault, "Note sur le Genre Aetheotesta," MTem. de Soc. d" Hist. Nat. de Saône-et-Loire, pp. 156, I58, I887. For Stephanospermum see Brongniart, Graines Fossiles Silicifieses, I881 ; Renault, Cours de bot. fossile, t. iv. p. 184, Plates xxi. and xxii. $1885 ; \mathrm{F}$. W. Oliver, "Structure and Affinities of Stephanospermam," Trans. Linn. Soc. London, 2nd-ser. Bot. vol. vi. Part viii. 1904 . 
Renault's prescience has been fully justified by subsequent discoveries; possibly even the direct proof of the existence of spermatozoids in fossil Seed-plants may yet be obtained. ${ }^{1}$

The presence of a pollen-tube in the case of Stcphanospermum and other Palæozoic Spermophytes is very doubtful. Small papillae are occasionally observed (as in the large pollen-grain shown in Fig. I 73), but their significance is still uncertain. Some further reference to the question will be made in discussing the fertilisation of the Cordaiteae (Chap. XII. p. 543).

It is only in the case of Neuropteris heterophylla that we have, as yet, the direct proof that Neuropterideae bore seeds; as we have seen there is strong, though less conclusive, evidence that the seed Trigonocarpus Parkinsoni belonged to Medullosa anglica, which, according to its foliage, was certainly an Alethopteris.

A considerable mass of evidence, mainly from association, has further been accumulated through the extensive investigations of M. Grand'Eury both in the Upper Coal-measures of Central France and in the more ancient deposits of Belgium, Northern France, and the Saar Valley. This observer, whose experience in such researches is unrivalled, finds that the vegetative organs of Neuropterideae, wherever there is evidence that they grew in situ, are constantly associated with seeds of the radially symmetrical type, such as rarely occur in company with plants of any other group; he further finds special types of seed in close association with

1 Evidence on this subject is adduced in Prof. F. W. Oliver's memoir "On Physostona elegans," Ann. of Bot., January 1909. 
definite genera and species of frond. Considering the wide field covered by M. Grand'Eury's observations, and the fact, which he established, of the social growth of plants of the same group, there can be no doubt of the value of the conclusions arrived at. M. Grand'Eury is led to refer some fifteen genera or sub-genera of seeds to the Neuropterideae, the general characters of the seeds being that they are of radial symmetry, and striated, polygonal, or winged, the number of the angles or wings being some multiple of three.

Among Grand'Eury's special results we may mention that he refers the huge seed Pachytesta gigantea (sometimes 4 inches long) to a species of Alethopteris ( $A$. Grandini) and smaller seeds of the same type to other species of the genus. In the Northern Coal-fields, however, he finds Trigonocarpus seeds associated with certain Alethopterids (in agreement with our conclusion as to $T$. Parkinsoni), and points out the affinity between Pachytesta and Trigonocarpus.

A considerable variety of seeds is referred to Neuropteris; the seed attributed to $N$. flexuosa appears to be of the same type as that of $N$. heterophylla, discovered by Kidston.

Various seeds are also referred (not to mention other cases) to the genera Odontopteris and Linopteris (= Dictyopteris), which are some of those which Stur had already removed from the Ferns in 1883 .

M. Grand'Eury has in several cases detected the "inflorescence" or fertile rachis on which the seeds were borne, but details have not yet been published. $\mathrm{He}$ is of the opinion that, as a rule, the organs of reproduction of Neuropterideae and other Pteridosperms 
were borne "on special organs, separate from the leaves, i.e. on independent inflorescences." In Neuropteris heterophylla, however, and in other cases, to be subsequently mentioned, the seeds were borne on a frond but slightly modified, so there can be little doubt that the organ supporting them, even when more specialised, was still foliar in nature. ${ }^{1}$

We have as yet very little knowledge as to the nature of the male organs in the Neuropterideae. In I $887 \mathrm{Mr}$. Kidston described a form of fructification in Neuropteris heterophylla, the species in which he subsequently discovered the seed. The specimen ${ }^{2}$ consists of a forked rachis, bearing the normal vegetative pinnules below, while the branches terminate in fourlobed bodies, which may be interpreted either as groups of sporangia or as cupules. As there is no evidence for the presence of cupules of this kind in Neuropterideae, the former interpretation is somewhat the more probable, in which case the specimen would no doubt represent the microsporangiate fructification. M. Grand'Eury has also observed a rachis bearing sporangium-like bodies in Neuropteris, and "floral discs," which he regards as male, in Linopteris, but our information is still too imperfect to allow of the subject being pursued further at present.

M. Grand'Eury has recently found evidence that

1 C. Grand'Eury, "Sur les Graines des Neuroptéridées," Comptes Rendus, t. I 39, pp. 23 and 782, I904; "Sur les Inflorescences des Fougères à Graines du Culm et du Terrain Houiller," Comptes Rendzes, t. I43, p. $76 \mathrm{r}, 1906$.

2 The figure and description are reproduced in Mr. Kidston's paper on "The Fructification of Neuropteris heterophylla," above cited. 
various Neuropterideae possessed stolons and other means of vegetative propagation. ${ }^{1}$

\section{Affinities of Medulloseae}

We may provisionally treat the family names Medulloseae and Neuropterideae as synonymous, for though there can as yet be no strict proof that the groups indicated were coextensive, yet there is evidence that the Medullosean type of structure existed in several of the genera with Neuropteridean characters in the frond.

In the Medulloseae, as in the Lyginodendreae, we are able to point to definite structural characters, quite apart from the habit, which indicate affinity with the Ferns. So far as Medullosa itself is concerned, the most Fern-like feature is the vascular system of the stem, which in its primary "polystelic" arrangement appears essentially Filicinean, and was compared by Weber and Sterzel in 1896 with that of Psaronius. The fact that this original ground-plan becomes more or less obscured as secondary growth goes on does not affect the significance of the primary structure, but a more serious difference from the Ferns consists in the absence of leaf-gaps in Medullosa (see above, p. 444). The discovery of the Sutcliffia type of vascular system, which may be described as a modified protostele, renders it probable that polystely arose within the family Medulloseae, and if so we must regard this character rather as a parallel development to the polystely of the Ferns than as a direct inheritance from them. In

1 C. Grand'Eury, "Sur les organes et le mode de végétation des Neuroptéridées, et autres Ptéridospermes," Comptes Rendus, t. I46, p. I24I, I908. 
Sutcliffia, however, the anatomy of the stem, peculiar as it is, can only be compared with that of a protostelic Fern, while the concentric foliar bundles accentuate the relationship. There is nothing as yet to indicate from what group of primitive Ferns the Medulloseae may have sprung, and indeed the great complexity of the seed shows clearly enough how remote the Fernconnection must have been. On anatomical grounds it seems not unlikely that this family may have had a common origin with the Lyginodendreae from some unknown protostelic type.

On the whole, the Medulloseae or Neuropterideae strike one as a more advanced group than the Lyginodendreae. Their seeds, if we may take Trigonocarpus as a type, perhaps approach nearer than any other Palæozoic seeds to those of recent Cycadaceae, as shown by the differentiation of the integument into a sarcotesta and a sclerotesta, the double vascular system and the form of the pollen-chamber; the chief difference lies in the apparently free nucellus of the fossil seeds, a feature with which other distinctions may be correlated. As regards anatomical characters, the petiole and rachis of Medullosa very closely resemble those of a Cycad in structure; the same may be sid of the root. The stemstructure, however, throughout the Medulloseae is essentially different, for neither in the almost protostelic Sutcliffia, nor in the more complex polystelic stems of Medullosa, do we find, as it seems to me, any fundamental agreement with the stem either of recent Cycadaceac or of Mesozoic Bennettiteae, though certain analogies can be traced. On the whole of the evidence an affinity between the Medulloseae and the Cycado- 
phyta of later periods appears well established, but we cannot for a moment suppose that the former were the direct ancestors of the latter. The question will receive some further consideration in the final chapter.

\section{Anermiteae}

The genus Aneimites, ${ }^{1}$ Dawson, may be mentioned in connection with the Neuropterideae, to which it has sometimes been referred on foliar characters, though, as we shall see, the fructification shows that there can have been no near affinity. The habit of the fronds is like that of a Maiden-hair Fern (Adiantum), as the original generic name Adiantites implied; the genus extends from the Devonian to the Middle Coal-measures, and is characteristic of the Lower Carboniferous. In a species (Aneimites ${ }^{2}$ fertilis) from the Pottsville beds of West Virginia, of an age corresponding to that of our Millstone Grit, Dr. David White has demonstrated the presence of seeds on the fronds. They are borne on the apices of branched, terminal extensions of the peripheral pinnae; the pinnules on the adjacent sterile portions of the frond, though considerably reduced, retain the characteristic cuneiform shape. The small seeds (averaging $4.5 \mathrm{~mm}$. in length) are rhomboidal in form, lenticular in cross-section, and winged; it thus appears that they were of the platyspermic (bilaterally symmetrical) type, which was once supposed to characterise the Cordaiteae. As the specimens are only

1 David White, "The Seeds of Aneinıites," Smithsonian Miscellaneores Collection, vol. xxvii. p. 322, 1904.

2 It is to be regretted that the older and more familiar name, Adiantites, Göppert, has had to be abandoned, on grounds which will only appeal to the specialist in nomenclature. 
known in a carbonised condition, nothing certain can be said as to the structure, though the discoverer believed that he detected indications of the micropyle and pollen-chamber. The isolated seeds were named Wardia fertilis before their connection with the frond was observed. Dr. White has discovered different forms of the Wardia seeds in the most intimate association with four other species of the genus; in one of these, A. tenuifolius, Göppert, they again occur in actual connection with the frond. The author points out that the proof of the Pteridospermous nature of Aneimites throws suspicion on various similar frond-genera, in one of which, Eremopteris, there appears to be strong cvidence from other sources for the occurrence of seeds of a platyspermic type. The seeds of Aneimites resemble some of those grouped under the name Cardiocarpon, and it may be hoped that this clue may eventually lead to the recognition of their structure.

\section{SeEd-Bearing Pecopterideae}

Up to the year I 905 the form-genus Pecopteris was regarded as the stronghold of the true Ferns, no suspicion of other alliances attaching to any of its members. In that year, however, M. Grand'Eury made the striking discovery that the species Pecopteris Pluckeneti, from the Upper Coal-measures of St. Étienne, was a seed-bearing plant. ${ }^{1}$ In twenty specimens he found the seeds attached by hundreds to the fronds. Sometimes they occur on pinnae of the usual vegetative form, but where they are numerous the lamina is somewhat reduced. The seeds

\footnotetext{
1 "Sur les Graines trouvées attachées au Pecopteris Pluckeneti, Schlot.," Comptes Rerdus, t. cxl. p. 920, 1905.
} 
are attached at the ends of the stout lateral veins of the pinnules (see Fig. I75). They are described as forming a wide angle, when in the natural condition, with the plane of the lamina, so that they no doubt hung down freely from the under side of the fertile frond. The seeds, like those of Aneimites, are winged (Fig. I75), and resemble Samaropsis, the seed of the Gymnosperm Dorycordaites (see p. 520) so closely, that the two may easily be confused when found isolated.

The species P. Pluckeneti belongs to a section of the genus characterised, according to Professor Zeiller, by the large, lobed pinnules, and the dichotomously branched frond, with a bud, capable of further growth, in the axil of

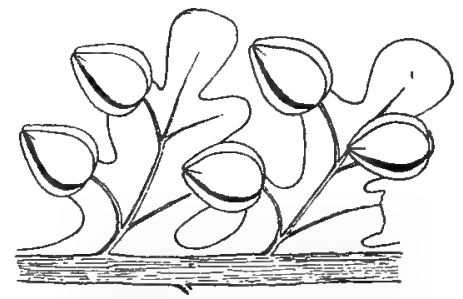

Fig. 175.-Pecopteris Pluckeneti, Fragment of a fertile pinna with seeds attached near the ends of the lobes. $\times_{3}$. From Zeiller, after one of Grand'Eury's specimens.

each bifurcation. ${ }^{1}$ Though usually included in Pecopteris, some authors have placed the species in other genera, and notably Sterzel, in 1883, founded a new genus, Dicksoniztes, for its reception, because he observed, in some specimens, round discs at the margins of the pinnules, which he compared to the sori of .Dicksonia. ${ }^{2}$ The nature of these bodies appears to have been elucidated by a recent observation of $M$. Grand'Eury's. He states that he found "stellate groups of anthers in the place of the receptacles," and that they were borne on different specimens from those

1 Zeiller, Éléments de Paléobotanique, p. 89, 1900.

2 " Über Dicksoniites Pluckeneti," Bot. Centralblatt. Bd. xiii. 1883. 
showing seeds. We may hope for more detailed information on this interesting point. ${ }^{I}$

There is another species of Pecopteris, P. Sterzeli, Zeiller, which so closely resembles $P$. Pluckeneti, in the form and mode of branching of the frond, that Professor Zeiller has no doubt that this too was a Pteridosperm, though the seeds have not yet been observed. There is evidence of considerable weight that the fronds of P.Sterzeli were borne on a Caulopteris stem-Caulopteris, as already stated, representing the casts of "Tree-fern" stems, the structure which, when known, is that of Psaronius (Vol. I. p. 295). Although Professor Zeiller no longer regards the connection between Pecopteris Sterzeli and the Caulopteris as proved, it seems desirable to call attention to the question, for there appears to be little reason for doubting the evidence, beyond the $a$ priori improbability of a seed-bearing plant having had the stem of a supposed Marattiaceous Tree-fern. ${ }^{2}$ If Professor Zeiller's original opinion should be confirmed by future investigation, the relation of the Marattiaceous to the Pteridospermous Pecopterids will need serious reconsideration.

It has already been mentioned (Vol. I. p. 289) that additional evidence for the Pteridospermous nature of certain Pecopterids is afforded by the fact that they bore fructifications of the Crossotheca type. $\mathrm{Mr}$. Kidston ${ }^{3}$ enumerates three species of Crossotheca in which the foliage is known to have been that of a

1 See Grand'Eury, "Sur les Inflorescences des Fougères a Graines," etc., Comptes Rendus, t. cxliii. p. 764, 1906.

2 For the history of this question see Zeiller, Flore Fossile de Commentry', Pt. i. t. I888, p. 184, Plate viii. ; Bassin Honiller et Permien de Blanzy, Flore Fossile, I906, p. 62.

3 Microsporangia of the Ptcridospermeae, p. 432. 
Pecopteris, and there are two other species in which this was probably the case. As Mr. Kidston sáys: "Having shown that the supposed sporangia of one species of the genus [Crossotheca] are in reality the microsporangia of one of the Pteridosperms, I think we are justified in provisionally concluding that all the remaining species also belong to the Pteridospermeae, even though we do not possess a complete knowledge of the structure of their microsporangia." There is thus a presumption that a considerable fraction of the old genus Pecopteris is made up of seed-bearing plants.

One of the probable Pecopteroid Crossothecas, Pecopteris exigua, Ren., ${ }^{1}$ from the Permo-Carboniferous of Autun, occurs in the silicified condition, with structure preserved, but only fertile portions of the frond appear to be known. The little fertile pinnules, elliptical in form and about $1 \mathrm{~mm}$. long, are inserted on the rachis like the leaflets of a Pecopteris. Each pinnule bears, on its lower surface, two rows of ovoid, pointed sporangia, three or four in each row; they appear to be free from each other, and do not show the bilocular structure described by $\mathrm{Mr}$. Kidston in the Crossotheca of Lyginodendron. There is, of course, no proof that they were microsporangia, but the general resemblance to a Crossotheca tells in favour of this supposition.

In Callipteris, a characteristic Permian genus of comparatively small bipinnate fronds, placed by M. Zeiller in Pecopterideae, M. Grand'Eury has found evidence that seeds were present in at least two species. The seeds, which appear to have been borne on a slender,

1 Renault, Cours de Bot. Fossile, année 3, p. I15, Plate xix. Figs. I3-I8, I883. 
branched rachis, are of an elliptical or roundish shape, and from 5 to $10 \mathrm{~mm}$. in length, and are described as resembling berries, and as the simplest in form of any Pteridospermous seeds. Bodies resembling an enormous Crossotheca, 2 to $3 \mathrm{~cm}$. in length, and bearing marginal sporangia, are regarded as possibly constituting the male organs of the plant. M. Grand'Eury points out that Callipteris differs widely from the Neuropterideae in its organs of reproduction as well as in foliar characters. ${ }^{1}$

The common Coal-measure "Fern," Mariopteris muricata, with forked primary pinnae and a Lygodiumlike habit, has quite recently been found by $M$. Grand'Eury in close association, if not in connection, with small seeds, ${ }^{2}$ so it is probable that this Pecopteroid form, in which no Fern-like fructification has ever been observed, will likewise prove to belong to the Pteridosperms.

We see then that on present evidence therc is every reason to believe that a large proportion of the Fernlike Palæozoic plants with Pecopteroid foliage will find their place, like Pecopteris Pluckeneti, among seed-bearing plants. As we have already seen (Chap. VIII. Vol. I.) there are still good grounds for the opinion that some other Pecopterids were true Ferns; much further investigation will be necessary before we are able to discriminate with certainty between the two classes of plants represented among fossils of this habit.

1 Grand'Eury, "Sur les Graines et Inflorescences des Callipteris," Comptes R'endus, t. cxliii. p. 664, 1906.

2 Grand'Eury, "Sur les organes et le mode de végétation des Neuroptéridées et autres Ptéridospermes," Comptes Rendus, t. cxlvi. p. 1243, 1908. 


\section{Summary on the Pteridosperms}

We have now completed our sketch of those Fernlike Palæozoic plants in which there is reason to believe that seeds were produced. Direct and conclusive evidence is still limited to a few instances, but these few are widely distributed. The fully established cases of Lyginodendron oldhamium, Neuropteris heterophylla, Aneimites fertilis, and Pecopteris Pluckeneti represent four distinct families, ${ }^{1}$ in each of which there is further a considerable body of collateral evidence, varying in its degree of cogency, but all pointing the same way, so as to leave no doubt that the seed-bearing habit was very widely spread. Fragmentary as our knowledge at present is, it is sufficient to establish a strong probability that a large majority of the Fern-like plants of Palæozoic age were Spermophytes.

It is obvious that it would be altogether premature, in the present rudimentary state of our knowledge, to attempt to define the limits of the Pteridospermeae or to assign them precise characters. As regards the extent of the Class, it no doubt embraced most of the Neuropterideae and Sphenopterideae, a considerable part of the Pecopterideae, and various outlying genera, such as Aneimites and Eremopteris. It is impossible to tell how much further the limits of the group may be extended by further research. Equal caution is necessary in attempting to draw up the characters of the Pteridospermeae, for it is only in comparatively

1 Aneimites (Adiantites) was placed by Professor Zeiller, on account of its frond-characters, in the Neuropterideae ; the form of the seeds, however, indicates that the affinities of the genus lie in a different direction. 
few cases that we have any knowledge of structure. Provisionally, the following diagnosis, agreeing with that already given in Chapter $X$. (p. 356), may serve the purpose of distinguishing the group from the other Palæozoic seed-plants.

Male and female sporophylls little differentiated from the vegetative foliage; no cones formed. Anatomy of either stem or leaf or both, of a Filicinean type, as was also the habit.

The first part of this diagnosis requires a word of explanation, as it appears inconsistent with M. Grand'Eury's opinion that the reproductive organs were usually borne on special inflorescences. The part of the sporophyll immediately bearing the seeds or microsporangia may be modified by suppression or alteration of the lamina, but in many cases (Neuropteris, Aneimites, Pecopteris Pluckeneti, Crossotheca) the fertile rachis forms part of an otherwise normal foliage-leaf, and this may have been so generally. Even where no pinnules have been found in connection with the fertile rachis, the latter resembles that of the vegetative leaf in its branching. We may safely take it as a character of the Pteridosperms that their sporophylls were more like the foliageleaves than in any other group of Spermophyta; in some cases they are even less modified than in many Ferns.

No diagnostic character can at present be based on the seed itself; the radially symmetrical seeds of Lagenostoma and Trigonocarpus are no doubt characteristic of certain families of Pteridosperms, but nothing is known of the structure of the platyspermic type of seed found in Aneimites and Pecopteris Pluckeneti; 
these seeds cannot, therefore, be distinguished from those of the Cordaiteae, to be considered in the next chapter. The presence of a pollen-chamber and of a well-developed vascular system are characters which the seeds of the Pteridosperms share with those of the Cordaiteae, Cycadaceae, and Ginkgoaceae.

As regards the male organs our information is too limited to allow of any generalisation; so far as appears at present the microsporangia of the. Pteridosperms did not differ essentially from the isosporangia of Marattiaceous Ferns.

The anatomical characters have already been discussed at some length, and further reference will be made to them in the concluding chapter. There is probably no constant distinctive character in the structure of either stem or leaf; but taking the sum of the anatomical characters the Pteridosperms, so far as we know, appear to have retained much more of a Fern-like organisation than any of the true Gymnosperms. As we have already seen, it is probable that both Medulloseae and Lyginodendreae were derived from some simple protostelic Fern-type, Sutcliffia on the one hand and Heterangium on the other showing a convergence in that direction.

\section{OTHER CyCAdofilices}

There are a certain number of fossil plants which cannot yet be classed as Pteridosperms because we have no evidence as to their fructification, but which, from their vegetative characters, appear to belong to the same great class of plants. For such fossils, Potonié's 
name Cycadofilices may be provisionally retained. Some of these very varied forms will now be shortly described.

\section{Megaloxyleae}

Professor Seward some years ago described the structure of an interesting stem from the Lower Coalmeasures of Lancashire, which he made the type of a new genus of Cycadofilices, under the name of $\mathrm{Mega}$ loxylon Scotti. ${ }^{I}$ The specimen, which consists of the wood only, is between 4 and $5 \mathrm{~cm}$. in diameter, the central primary wood having a maximum diameter of nearly $2 \mathrm{~cm}$., while the rest is made up of the secondary xylem-zone. The structure bears a general resemblance to that of Heterangium, but differs from the latter genus in several important points. The stem has no pith; the whole central region of the stele is occupied by the primary wood, which has a very remarkable structure. The greater part, which may be termed the metaxylem, consists of large, usually very short tracheides, often broader than long, interspersed with tracts of thinwalled parenchyma. This tissue is interrupted by large horizontal gaps, probably due to shrinkage, and recalling the appearance of the discoid pith of Cordaites. ${ }^{2}$

Five large leaf-trace strands are ranged round the periphery of the primary wood. Their arrangement points to a $\frac{2}{5}$ phyllotaxis. Each trace is made up of elongated pitted tracheides, separated by vertical rows of short parenchymatous cells. At the extreme out-

1 A. C. Seward, "Notes on the Binney Collection of Coal-measure Plants," Part ii. Megaloxylon, Proc. Cambridge Phil. Soc. vol. x. I899, p. I 58 .

2 Similar gaps occur in the pith of Pitys antiqua. See below, p. 5 I5. 
side of the trace, adjacent to the secondary wood, are several groups of spiral elements (protoxylem), showing that the xylem of the bundles of Megaloxylon was centripetally developed, or exarch, as distinguished from the mesarch strands of Heterangium or Lyginodendron.

As the leaf-trace is followed downwards into the stele, it is found to spread out laterally, in a fan-like form, its tracheides becoming shorter and more irregular, until they gradually become merged in the metaxylem. The leaf-trace passes through about four internodes, at the periphery of the primary wood, before losing its individuality.

The secondary wood requires little description. It is of the Lyginodendron type, and is characterised by the author as practically identical with that of Cycadoxylon robustum, described below (cf. Fig. I 78, p. 483).

The large leaf-traces can be followed, as they pass obliquely outwards through the secondary wood, enclosed by a secondary zone of their own, continuous on the exterior with that of the stem itself. Professor Seward infers that the trace was probably concentric in structure.

The most essential points of difference from Heterangium, which are sufficient to place Megaloxylon provisionally in a distinct family, are, first, the exarch structure of the primary wood, and secondly, the peculiar form of the short tracheides of the metaxylem, which may probably have served for the storage rather than for the conduction of water.

The former character is shared by Sutcliffia among the Medulloseae, with which there is otherwise nothing to connect Megaloxylon. The short tracheides of the central 
wood reappear in Zalesskya diploxylon, a Permian plant recently described by Kidston and Gwynne-Vaughan, ${ }^{1}$ and shown by them to be a primitive member of the Osmundaceae. In the Zalesskya, however, there is no xylem-parenchyma, and many other differences forbid the suggestion of affinity. The conversion of the central wood into a water-reservoir, as it became superfluous for conducting purposes, may well have happened in more than one line of descent (cf. Lepidodendron selaginoides).

The position of the genus is best defined in the words of its discoverer :-

"Megaloxylon adds another connecting link between the Palæozoic Cycadofilices and recent Ferns; in anatomical characters the two genera Lyginodendron and Heterangium approach most nearly to the Osmundaceae and Gleicheniaceae respectively; in Megaloxylon, on the other hand, the structure of the primary xylem affords evidence that the Lygodium type of stem was also represented in the Cycad-Fern alliance which played so prominent a part in Palæozoic vegetation." 2

A more complete knowledge of the plant will be necessary before its affinities can be determined.

\section{Calamopityeae}

Calamopitys. - While Megaloxylon recalls in a general way the structure of Heterangium, the plants next to be considered show a type of anatomy comparable to that of Lyginodendron, though here also the differences

1 "On the Fossil Osmundaceae," Part ii. Trans. Royal. Soc. Edinburgh, vol. xivi. Part ii. p. 226, I908.

2 Seward, l.c. p. I7I. 
appear to justify a separate family-name. ${ }^{1}$ Several species, of Lower Carboniferous and Devonian age, are known, all of which are at present referred to the genus Calamopitys of Unger. The generic name is unfortunate, as it suggests an affinity with Calamites, with which, as all recent investigations have shown, the genus has nothing whatever to do, while the relationship to Lyginodendron is clear.

The species of which we have the most complete knowledge is Calamopitys Saturni, Unger, from Saalfeld in Central Germany; Count Solms-Laubach, to whom we owe a full account of its anatomy, ${ }^{2}$ now regards the horizon as Devonian, ${ }^{3}$ and not, as was previously believed, Lower Carboniferous.

Only three or four fragmentary specimens are known, the largest of which is about $1.5 \mathrm{~cm}$. in diameter (see Fig. I 76 ).

The stem has a small pith ( $\mathrm{I}$ to $2 \mathrm{~mm}$. in diameter) surrounded by the primary wood, which consists of about half a dozen bundles, apparently somewhat confluent with each other laterally. ${ }^{4}$ In the middle of each xylem-strand is a group of small elements, no doubt constituting the protoxylem. The primary strands of xylem abut more or less immediately on the surrounding zone of secondary wood, the elements of

${ }^{1}$ In this I now follow Count Solms-Laubach. In the previous edition Calamopitys was included under Lyginodendrea.e.

2 "Pflanzenreste des Unterculm von Saalfeld." Abhandl. der k. preuss. geol. Landesanstalt, neue Folge, Heft 23, p. 63, 1896. A true Calamite, now known as Arthrodendron, was described by Williamson under the same name, Calamopitys; see Chapter II. p. 34.

3 "Die Bedeutung der Paläophytologie für die systematische Botanik," Mitt. der philomath. Gesellsch. in Elsass-Lothringen, Bd. iii. 1906.

4 A doubtfully distinct species, C. annularis, differs in the larger pith $(7 \mathrm{~mm}$.$) and the more confluent xylem-strands.$ 
which are radially arranged; the wedge-shaped groups of secondary tracheides are separated from one another by medullary rays, usually more than one cell in thickness. The sculpturing of the tracheides consists of several rows of crowded circular pits, limited to the

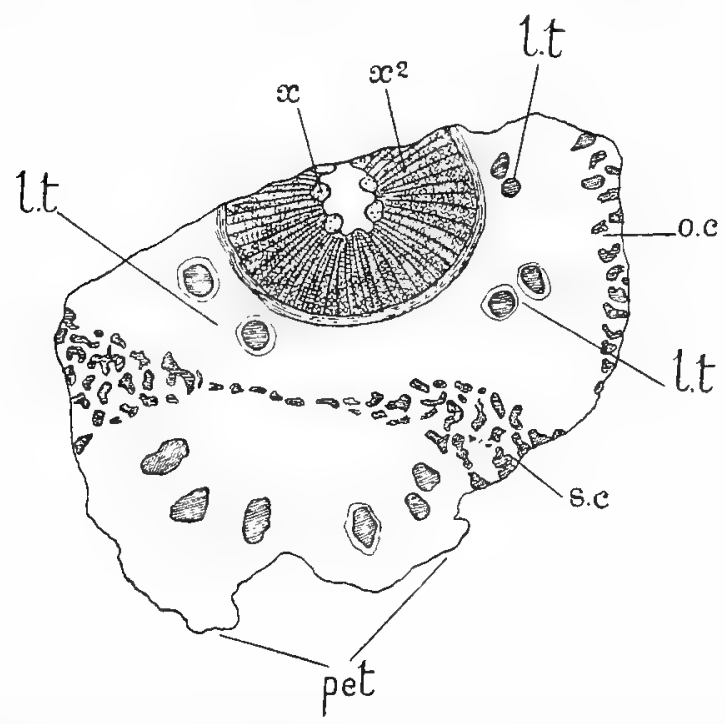

FIG. x76.-Calamopitys Saturui, Unger. Transverse section of stem. $x$, primary xylemstrands; $x^{2}$, secondary wood ; o.c, outer cortex, with fibrous strands; l.t, doubleleaf-traces; pct, petiole-base, containing six bundles; s.c, sclerenchyma at junction of petiole with stem. $x$ about 4. After Solms-Liubach.

radial walls in the case of the secondary elements, but occurring on all sides of those tracheides which belong to the primary wood.

The phloëm is preserved in one fragment, and contains bast-fibres, in addition to the elements of the soft bast. The wide inner cortex is parenchymatous, while its outer zone is strengthened by strands of hypo- 
dermal fibres, as in Heterangium and other genera (Fig. I $76,0 . c)$.

The cortex is traversed by the large leaf-trace bundles (l.t). The trace, when it first leaves the wood, is a single bundle, but immediately divides into two, precisely as in Lyginodendron. The leaves were spirally arranged, and the phyllotaxis appears to have followed the $\frac{2}{5}$ arrangement. Each transverse section constantly includes the trace-bundles of five successive leaves, which appear to have been more crowded than in Lyginodendron, for the same transverse section may show two leaf-bases in connection with the stem. The petioles were of large size, even exceeding the stem itself in diameter.

The characters shortly described, according to the investigations of Count Solms, to whom our whole knowledge of the anatomy of this species is due, agree so closely with those of Lyginodendron, that even a generic separation would scarcely seem justified, if it were not for two points which are still to be mentioned. One of these is the fact that the leaf-trace bundles appear to have assumed concentric structure immediately on entering the cortex of the stem; the other and more important point is that, on entering the leaf-base, the two bundles underwent further divisions, so that the petiole contained half a dozen bundles or more, instead of two at most, as in Lyginodendron. The leaf-stalks, characterised by the ring of large vascular bundles and the hypodermal strands of sclerenchyma, would fall into the old genus Kalymma, one of the numerous fossil genera founded on isolated organs of plants, which subsequent research is gradually enabling us to identify. 
The free Kalymma petioles contain many bundles and are known to have branched; there is little doubt that they represent the stalks of compound Fern-like leaves.

Their structure is so different from that of the petiole in Lyginodendreae that it is best to keep the families distinct, especially as we know nothing of the reproduction of Calamopityeae. I have recently identified specimens of Calamopitys in material from the Upper Devonian of Kentucky, sent me by Professor E. C. Jeffrey, and Kalymma has long been known from similar horizons. The great antiquity of the genus is thus well established.

Two other species may be shortly described. In C. fascicularis, from the Lower Carboniferous of Dumbartonshire and the North of England, only the pith and wood are known, but their structure is well shown (see Fig. I 77). The small pith ( 2 to $3 \mathrm{~mm}$. in diameter) is surrounded by a circle of distinct primary xylemstrands, eight or nine in number. These strands are very unequal in size, attaining their maximum diameter where they leave the pith to pass outwards through the secondary wood (Fig. I77, B and A). Traced downwards from this point they diminish rapidly in size, and each strand unites with a small " reparatory" strand on the side corresponding to the downward (kathodic) direction of the leaf-spiral (see Fig. I77 and the description). The comparison of successive sections shows that the phyllotaxis was $\frac{2}{5}$ and that the course of the xylem-strands was essentially the same as in Lyginodendron. The strands can be followed out

${ }^{1}$ D. H. Scott, "On the Primary Structure of certain Palæozoic Stems with the Dadoxylon Type of Wood," Trans. Roy. Soc. Edinburgh, vol, xl. Part ii. 1902. 
through the secondary wood, and evidently belonged to the leaf-trace bundles. Their structure is typically mesarch; in the large strands, approaching their exit,

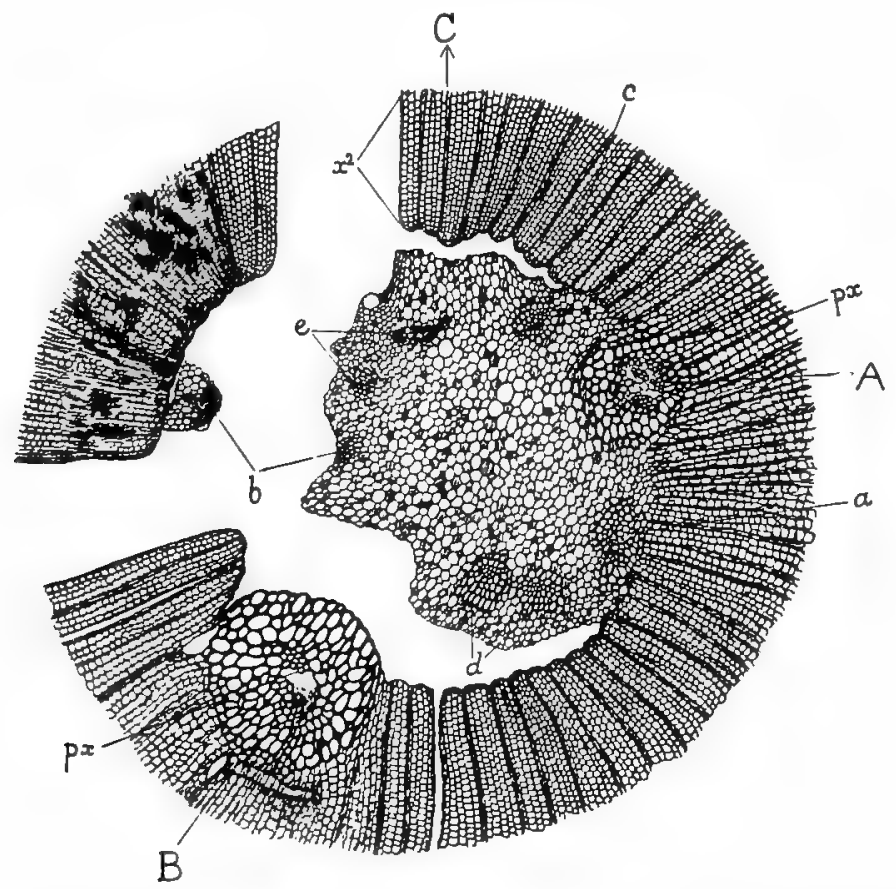

FIC. 577.-Calamopitys fascicularis. Transverse section of central part of stem, showing the pith (rather contracted), the primary xylem-strands, and part of the secondary .wood. A, large xylem-strand, about to pass out to a leaf; B, still larger strand, already on the way out; $\not p x$, protoxylem-groups; C (arrow), direction of another outgoing strand; $a, b, c$, reparatory strands of the bundles A, B, C. $d, e$, main and reparatory strands of two other leaf-traces, lower down in their course. $\times z$. Kidston Coll. 540A. (G. T. G.)

the protoxylem is central; lower down, as the strand diminishes in diameter, the centripetal wood becomes relatively reduced in amount. In the lower part of their course the xylem-strands become embedded in 
the pith (Fig. I 7 7, $d$ and $e$ ). The secondary wood has a dense structure, with narrow medullary rays, one or at most two cells thick, and resembles that of the Cordaiteae (see Chapter XII.). The tracheides bear multiseriate bordered pits. An interesting peculiarity is the presence of wide and short tracheides in the inner layers of the secondary wood; presumably they served, like the similar primary tracheides of Megaloxylon and Zalesskya, for water-storage, but here they form part of the secondary tissue-system.

Another species, Calamopitys Beinertiana, ${ }^{1}$ occurring in the Calciferous Sandstones of the Tweed, and at Falkenberg, in Silesia (Lower Carboniferous or possibly Devonian) is remarkable for the large pith, containing " sclerotic nests" like those of Lyginodendron. The numerous primary xylem-strands resemble those of the last species, except in the interesting fact that in the lower part of their course they become endarch, losing their centripetal wood altogether-a first approach towards the structure of the typical Gymnosperms. In this species a scale-bark was formed on the older stems.

The Calamopityeae show clear affinity with Lyginodendron in the structure and arrangement of the primary strands of wood; in the secondary wood they approach nearer to the Cordaitean type; the structure of the petioles (not yet investigated in sufficient detail) is peculiar, and rather recalls Medulloseae than Lyginodendreae. The family evidently formed one branch of

1 The Araucarites Beinertianus of Göppert. See Scott, l.c. p. 34 I. 
the great plexus of Palæozoic forms lying on the confines of Ferns and Gymnosperms.

\section{Cycadoxyleae}

We have now to consider a series of fossil forms of which our knowledge is still imperfect, but which are of great interest, as they appear to connect the Lyginodendreae with a more distinctly Cycadean type of structure.

A portion of a large stem, Cycadoxylon robustum, regarded by Williamson as belonging to Lyginodendron, and subsequently named $L$. robustum by Professor Seward, was discovered by Nield more than thirty years ago, in the Lower Coal-measures of the Oldham district. Although the specimens are fragmentary, they show some points of considerable interest. No cortical tissues are preserved, and even the wood is probably incomplete, but the remaining, central part of the stem has a diameter of about $14 \mathrm{~cm}$., so, in the natural condition, the plant must have reached the dimensions of a small tree. The secondary wood, which, in its present state, has a thickness of nearly $6 \mathrm{~cm}$., resembles that of Lyginodendron oldhamium (Fig. $178, x^{2}$ ). The medullary rays are broad, and of great height, so that the whole character of the wood was very parenchymatous, like that of the recent Cycads. The tracheides, which have a somewhat sinuous course, bear. multiseriate bordered pits on their radial walls.

The pith, which is almost $3 \mathrm{~cm}$. in diameter, is imperfectly preserved, but there are distinct remains of 
scattered, dark groups of sclerotic tissue, such as we find in the pith of $L$. oldhamium.

The most characteristic feature of Lyginodendron, however, namely the strands of primary wood on the

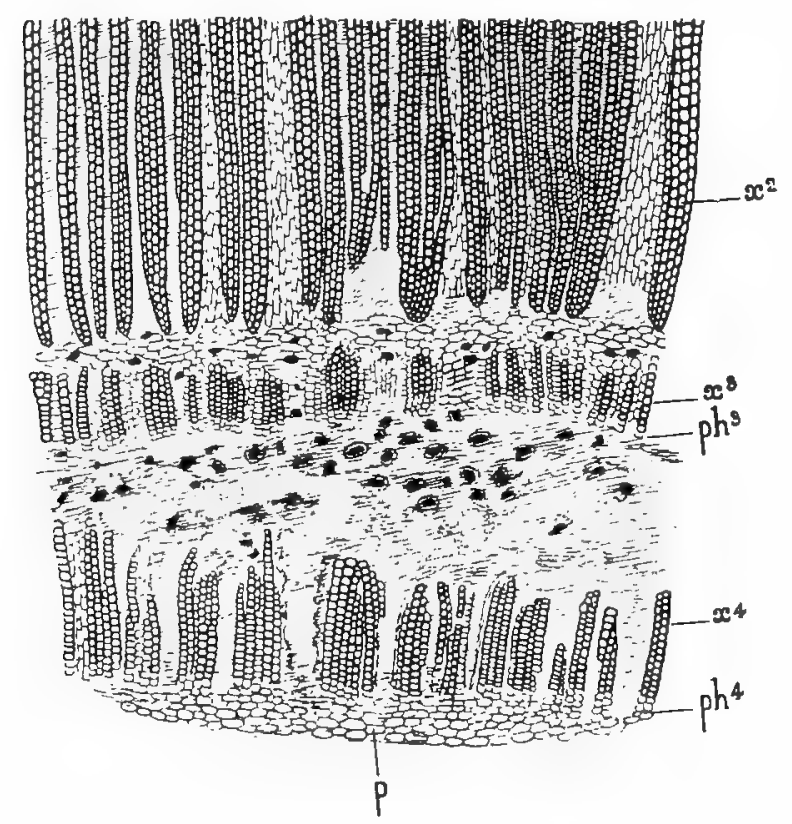

FIG. ${ }_{7} 8 .-C y$ cadoxylon robustum. Part of transverse section, showing inner portion of normal wood, with two anomalous zones of wood and bast. $x^{2}$, normal secondary wood; $x^{3}, p h^{3}$, first inverted band of medullary xylem and phloëm; $x^{4}, p l^{4}$, second band of the same; $p$, pith. $x$ r2. S. Coll. 457 - (G. T. G.)

border of the pith, cannot be recognised with certainty in Nield's specimen, and if present, must, it would seem, have been much reduced. The remains of leaftraces, passing out through the secondary wood, are seen at several places, but even here the primary xylem of the outgoing bundle has not been detected. It must 
therefore remain an open question whether the primary structure of the xylem was of the Lyginodendron type, or whether the whole wood developed centrifugally, as in the stem of recent Cycads or Conifers. On the other hand, the large stem presents a peculiarity of structure which occurs in some specimens of Lyginodendron oldhamium. It was mentioned above (p. 372) that, in that plant, anomalous vascular tissues are sometimes developed' in the outer part of the pith, immediately within the normal ring of bundles. These tissues, when present, have inverted orientation, the xylem facing outwards, towards the normal wood, and the phloëm inwards, towards the centre of the pith. Precisely the same anomaly reappears, in a more striking form, in Cycadoxylon robustum. There is a distinct zone of secondary wood at the margin of the pith, reaching in places a thickness of about sixteen tracheides in a radial row, and on the inner side of the anomalous zone, a corresponding band of phloëm can be recognised (Fig. I 78, $x^{3}, p h^{3}$ ). Thus, the medullary vascular tissues had the same reversed orientation as in the corresponding anomalous formations sometimes found in Lyginodendron oldhamium. In Cycadoxylon robustum the anomalous vascular zone is at some places double, the second band of medullary wood and bast having the same orientation as the first (see Fig. I 78 , $\left.x^{4}, p h^{4}\right)$.

The structure as a whole leaves little doubt that the fossil Cycadoxylon robustum really possessed some affinity with Lyginodendron, but, as there is no proof that the primary structure of the two was similar, we no longer place them in the same family, but have trans- 
ferred the species discovered by Nield to the type-genus of the Cycadoxyleae, to which, as we shall now see, it naturally belongs. ${ }^{1}$

The interest of the fossil depends on two points. The first is the thoroughly Cycadean character of the secondary wood, a character shown much more evidently in this large stem, which in its dimensions is comparable to that of a recent Cycad, than in the smaller stems of the Lyginodendreae. The second point is the marked development of the anomalous medullary vascular tissues, which we have already found, as an individual peculiarity, in Lyginodendron oldhamium.

A small stem, from the Lower Permian of Autun, described by M. Renault, and named Cycadoxylon Fremyi, shows still more perfectly the type of structure just described. The stem is from 20 to $25 \mathrm{~mm}$. in diameter; the cortex, which is fairly preserved, contains gum-canals, and large pitted elements, probably with a mechanical function. Within the cortex is a ring of normal wood and bast, both well preserved, and exactly resembling the vascular tissue of a modern Cycad. The medullary rays are extremely wide, exceeding in extent the tracheal bands between them. The tracheides are for the most part pitted; the bordered pits are ranged in numerous series on the radial walls. Towards the interior of the normal zone of wood, scalariform

1 On Cycadoxylon robustum, see Williamson, "Organisation of the Fossil Plants of the Coal-measures," Part iv., Phil. Trans. 1873, p. 386 ; Williamson and Scott, "Further Observations," etc., Part iii., Phil. Trans. vol. I86, B, 1895, p. 742 ; Seward, "A Contribution to our Knowledge of Lyginodendron," Annals of Botany, vol. ix. I897, p. 65 .

As Professor Seward points out, the specimen described by M. Renault in the Flore fossile d'Autum et d'Epinac, Part ii., under the name of Medullosa gigas, appears to be almost identical with Nield's plant. 
tracheides occur, and at its inner limit are the spiral elements of the protoxylem. It would thus appear that the whole normal wood was centrifugally developed, as is usual in recent Cycads. Professor Seward, however, states that at one place he detected a distinct strand of primary xylem; this may indicate that some trace of the mesarch structure of the Lyginodendreae still persisted in Cycadoxylon, though much reduced. The wide phloëm-zone consists of alternating concentric bands of parenchyma and sieve-tubes.

Within the normal vascular ring, are two or more interrupted zones of anomalous wood and bast, with inverted orientation, the phloëm facing inwards. These medullary vascular arcs are separated by parenchyma from the normal centrifugal wood. The whole structure is thus comparable to that of Cycadoxylon robustum, except that the normal zone is much less developed, which may simply be a matter of age.

Curiously enough, no leaf-trace bundles have so far been found in Cycadoxylon Fremyi. The characters, as at present known to us, strongly suggest Cycadean affinities, though the characteristic anomaly of Cycadoxylon, the formation of inverted zones of secondary wood and bast in the pith, is not known in the same form among recent Cycads. On the other hand, it is identical with the most frequent anatomical variation occurring in stems of Lyginodendron oldhamium.

Another silicified stem from the Permian of Autun, the Ptychoxylon Levyi of M. Renault, presents a somewhat similar combination of characters. In this fossil the dimensions are greater than in Cycadoxylon Fremyi, the stem of Ptychoxylon attaining a diameter of 5 or 6 
$\mathrm{cm}$. The external surface bears the marks of spirally disposed appendages. The character of the genus depends on the arrangement of the vascular tissues.

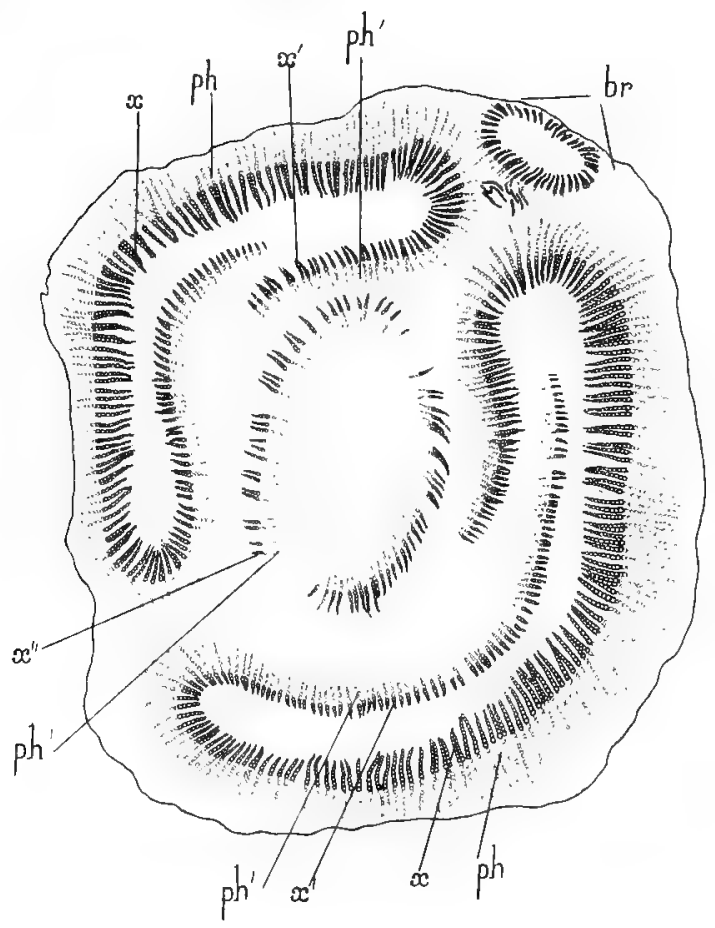

FIG. I79.-Ptychoxylon Leryi.-'Transverse section of a decorticated stem. $x$, ph, normal xylem and phloëm; $x^{\prime}, p h^{\prime}$, first inverted medullary bands of xylem and phloèm, continuous at the leaf-gaps with the normal zone ; $x^{\prime \prime}, p / h^{\prime \prime}$, second inverted zone; br, stele of a branch. Slightly magnified. After Renault.

There is an outer, more or less continuous cylinder of wood and bast, surrounding a very large pith, within which are several secondary vascular bands, with their wood developed centripetally, while that of the normal outer ring is centrifugal (Fig. I 79). The traces of both 
leaves and branches are present, and, as the two organs appear to correspond in position, it is not improbable that the latter were axillary. It seems that the phyllotaxis was $\frac{3}{8}$.

Where the bundles of a leaf or branch pass out, the external vascular cylinder is interrupted, and its edges are incurved, to unite with two of the internal vascular bands (see Fig. I 79, $x^{\prime}, p h^{\prime}$ ). The latter are thus always continuous, at some point of their longitudinal course, with the normal vascular ring. This, it will be remembered, is precisely what happens in some specimens of Lyginodendron oldhamium, where the anomalous medullary wood and bast are likewise connected, at the leaf-trace gaps, with the normal vascular tissues (see p. 372). In Ptychoxylon, however, the conditions are more complicated, for there are often two or three concentric systems of internal vascular arcs, joining on at different levels, to the external ring (see Fig. I 79, $\left.x^{\prime \prime}, p h^{\prime \prime}\right) .^{1} \quad$ The character of the wood and bast of each ring is very parenchymatous, like that of Cycadoxylon, or of a recent Cycad. The phloëm, which is external in the case of the normal zone, but internal in each of the anomalous bands, is beautifully preserved, and even the details of the sieve-tubes have been made out. There appears to be no indication in this genus of any primary centripetal wood in the stem.

The leaf-traces, however, appear, from M. Renault's description and figures, to have essentially the same structure as in Lyginodendron; the trace consists of two bundles, side by side; in each bundle there is a large

1 Compare the double anomalous zone in Cycadoxylon robustum, Fig. 178. 
arc of secondary wood on the outer side of the primary strand; the spiral elements lie near the limit of primary and secondary wood, so it appears that the former was wholly or mainly centripetal in its development.

The parenchymatous cortex, which contains secretory sacs, or canals, is coated externally by periderm; this may account for the absence of any hypodermal fibres, which had very probably been lost by exfoliation.

The branches, at their base, had a normal vascular ring, but as they became free, gradually assumed the complex structure of the main stem. ${ }^{1}$

The stems just described, Cycadoxylon robustum, C. Fremyi, and Ptychoxylon Levyi, may be grouped under the family-name of Cycadoxyleae, a designation already used by $M$. Renault, but in a somewhat more extended sense. ${ }^{2} \quad$ The interpretation of their structure, which, in agreement with the views of Professor Seward, ${ }^{3}$ I desire to suggest, is that they may have been derived from some form resembling Lyginodendron oldhamium, from which they have deviated in two principal respects. On the one hand, they have gradually lost the primary centripetal wood of the vascular bundles in the stem. In Cycadoxylon robustum, this tissue has not been recognised with certainty, and must at most have been relatively unimportant; in $C$. Fremyi it was certainly on the verge of extinction; in Ptychoxylon it had

I For a full description of Cycadoxylon and Ptychoxylon, see Renault, Bassin Howiller et Permien d"Autun et a'Epinac, Flore fossile, Part ii. pp. 307-2 I, 1896.

$2 \mathrm{M}$. Renault includes Medullosa and Colpoxylon in the Cycadoxyleae. On the view here taken, these two genera belong to a different, though related, line of descent, as has already been shown.

3 "Contribution to our Knowledge of Lyginodendron," Annals of Botany, vol. xi. 1897 . 
probably disappeared altogether. This change is in a Cycadean direction, for the recent Cycads (as well as the Mesozoic Bennettiteae) have wholly lost the centripetal primary wood of their vegetative stems, while retaining it in their leaves, and occasionally in the peduncles of their cones. It is very interesting to find that the leaf-trace bundles in the cortex of Ptychoxylon retain the Lyginodendron structure: in a typical Cycad they would not possess centripetal wood in this part of their course.

The extinction of the centripetal xylem was, no doubt, correlated with the advance of secondary growth. As the centrifugal wood became more and more predominant, with the increasing activity of the cambium, the small centripetal portion (the "Cryptogamic" wood of the French authors) became insignificant in comparison, and could be dispensed with, so far as the stem is concerned. In the roots there was a special physiological reason, connected with the absorptive function, for its retention, ${ }^{1}$ and here it has held its own all through; in the leaves, where secondary tissueformation is less marked, it persisted in many cases, as in Cycads, Cordaiteae, and perhaps Coniferae, but in the highly modified sporophylls, even of Cycads, it tends to disappear. ${ }^{2}$

On the other hand, the Cycadoxyleae became modified in another direction, and one peculiar to themselves among the allied groups. The anomalous formation of inverted medullary wood and bast, which in Lyginodendron only appears as an individual and

${ }^{1}$ See Strasburger, Histologische Beiträge, iii. p. 140.

2 See Worsdell, "Vascular Structure of the Sporophylls of the Cycadaceae," Annals of Botany, vol, xii. 1898. 
comparatively unimportant peculiarity, had in the Cycadoxyleae grown to be a constant and marked character. We regard this structure as a new formation, due to the spreading inwards of cambial divisions through the leaftrace gaps, as is clearly shown in Lyginodendron itself, and in Ptychoxylon. There is no reason to suppose that the anomalous centripetal wood thus formed had anything to do with the primary and normal centripetal wood of the more primitive forms: the example of Lyginodendron oldhamium shows that the two structures were quite independent. Neither does it seem practicable to derive the structure of Cycadoxyleae from a system of Medullosean steles. Scattered medullary bundles are a characteristic anatomical feature in the recent genera Encephalartos and Macrozamia, ${ }^{1}$ but continuous zones or extensive arcs of inverted wood and bast do not appear to be known in the pith of undoubted Cycads. Such anomalies, however, as shown by similar cases in many recent Dicotyledons, are extremely variable, and the peculiarity in question cannot hinder us from recognising the essentially Cycadean character of the stems of Cycadoxyleae.

It must always be remembered that the Cycadophyta were once an extensive and dominant class of plants, and that the few, which have survived to our own time, only give us a very imperfect and partial idea of the range of organisation which the group once exhibited (see Chap. XIII.).

It is interesting to find that the same Permian beds of Autun, which have yielded the stems of Cycadoxyleae,

"See Worsdell, "Anatomy of the stem of Macrozamia," etc., Annals of Botany, vol. x. 1896. "The Structure and Origin of the Cycadaceae," ibid. vol. xx. Igo6. 
also contain both leaves and fructifications which may be of a Cycadean character. The leaves are referred to the genera Pterophyllum and Sphenozamites, the former recalling the foliage of the recent Dioon, and the latter that of some species of Zamia. The agreement, in form and venation, with typical Cycadean leaves, is sufficiently close to render it probable that the affinities of these fossils were with the Cycadophyta.

The fructification referred to-Cycadospadix milleryensis, Ren. ${ }^{2}$ - is a very remarkable one, represented in Fig. I 80. The axis bears numerous fimbriated sporophylls $(l)$, concave on their lower surface, and on the under side of each sporophyll two seeds (s) were borne. M. Renault, the discoverer, states that the sporophylls are spirally arranged, and regards the whole structure as constituting a lax cone. Some of the specimens are inserted,

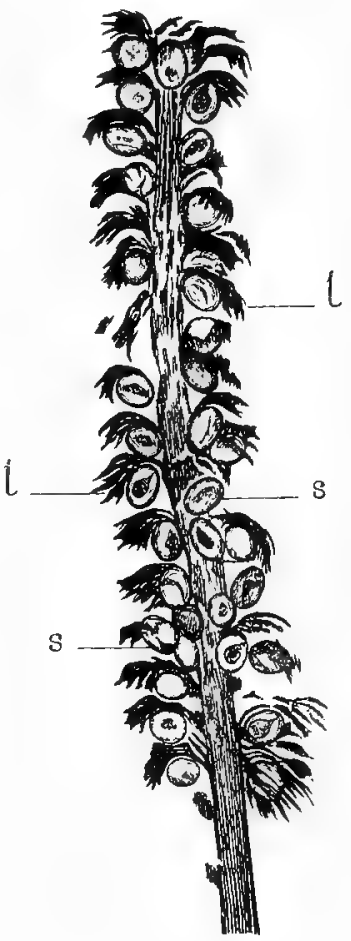

Fra. 180.-Cycadospadix millerycnsis. Fructification, consisting of an axis, bearing numerous laciniate sporophylls $(D)$, each of which bears seeds $(s)$ (probably two to each spirophyll) on its lower surface. Slightly reduced. After Renault. almost at right angles, on a branch little thicker than the axis of the cone itself. Such an arrangement is not found among true Cycads, but the com-
${ }^{1}$ See Renault, Flore fossile a Autzun et a" Epinac, Part ii.
2 Loc. cit. 
paratively slender, branched stem of the Rhaetic Anomosamites (see Chap. XIII.) offers an analogy, and as Ptychoxylon, at any rate, is known to have branched pretty freely, it is quite possible that $\mathbf{M}$. Renault's interpretation is the right one. It seems not impossible, however, that the whole structure may represent a single compound leaf or sporophyll, or even a single fertile pinna, the bodies immediately bearing the seeds being of the nature of leaflets. In the latter case, we should have a sporophyll more complex than that of any recent Cycad, and its affinities would probably be with the Pteridosperms; on M. Renault's interpretation, the fructification would represent a nearer approach to the cones of the Zamieae. In any case the fossil is of the greatest interest, and it is much to be hoped that specimens with structure preserved may yet be discovered.

Whether these leaves and fructifications belonged to Cycadoxyleae or not, it is probable that the stems in question (or some of them) were those of plants which had already passed the boundary (at most a very indefinite one) between Pteridosperms and Gymnosperms.

\section{ProtopityeaE}

The Lyginodendreae, Calamopityeae, and Cycadoxyleae appear to form one group, though by no means a linear series. The next type of Cycadofilices to be considered is represented by a remarkable and isolated form, our present knowledge of which is due to the investigations of Count Solms-Laubach. This is the Protopitys Buchiana of Göppert, a very ancient fossil, 
derived from a Lower Carboniferous or possibly Devonian horizon at Falkenberg, in Silesia. ${ }^{1}$

The stem attained a great thickness; one of the specimens was almost a foot and a half in diameter. The greater part of this thickness is made up of the secondary wood, which has the general structure of Cordaitean or Coniferous wood, consisting of tracheides and small medullary rays, the latter usually one or two cells in thickness, and from one to eight or ten cells in height. The bordered pits, however, which are limited to the radial walls of the tracheides, are transversely elongated, and are thus intermediate between the scalariform type and the usual Pteridospermous or Gymnospermous form of pit. 'The secondary bast is preserved in some cases, and proves to have consisted of alternating zones of sieve-tubes and stone-cells. The primary part of the structure is in striking contrast with that of the secondary region. The middle of the stem is occupied by a large elliptical pith, surrounded by a zone of primary wood, of very unequal thickness, but continuous, and not broken up into distinct bundles. On the sides of the ellipse, the primary xylem thins out to a width of from one to three elements only, but at the ends it is greatly thickened, and, in this part, xylemparenchyma is intermixed with the scalariform primary tracheides. It was from the ends of the elliptical stele, that the bundles passed out to the distichously arranged leaves. The leaf-traces were of large size, and forked immediately on becoming free from the xylem-ring. The gap, left in the latter by the departure of the leaftrace, was gradually filled by the enlargement and

1 Solms-Laubach, Botanische Zeitung, I893, p. 197. 
coalescence of the adjacent edges of the interrupted zone of primary wood. It is only in this region, that any indication of protoxylem-elements has been detected.

The stem gave off branches, of much smaller size than the main axis. The whole structure is quite peculiar : the arrangement of the primary tissues points clearly to Filicinean affinities, while the secondary tissues have a Gymnospermous, though by no means a specially Cycadean, character. The organisation departs widely from that of the Lyginodendreae, notably in the distichous arrangement of the leaves. We can only agree with Count Solms, in regarding this plant as the representative of a distinct family, forming one more of those Palaozoic types which combine the characters of Filicineae and Gymnosperms. Protopitys is thus an isolated genus, the relation of which to the other groups described in this chapter is doubtful, though its provisional place is clearly among the Cycadofilices.

Another species has since been discovered by $\mathrm{Mr}^{\text {r }}$. Kidston in the Yoredale Rocks of Yorkshire, but has not yet been described.

\section{Cladoxyleae}

Before-leaving the Cycadofilices, it will be well to refer shortly to an interesting group of early Palæozoic plants, which have long been known, but the true structure of which was only cleared up in I 897 , by the investigations of Count Solms-Laubach. ${ }^{1}$

The fossils in question, belonging to the genus Cladoxylon of Unger, were found in Thuringia, at the

1 "Pflanzenreste des Unterculm von Saalfeld," above cited. 
same horizon and locality which yielded the specimens of Calamopitys Saturni, described above. Their age is now considered to be Devonian. They are fragments of stems, referred to several so-called species, but agreeing in the fact that they have a complex, polystelic structure. In Cladoxylon mirabile the steles are much elongated, as seen in transverse section, often curved and sometimes fusing with one another, their long axis usually lying in the radial direction. In C. dubium they are shorter and simpler in form. The point of interest is that in most of the specimens each stele has its own zone of secondary wood, while in other cases the primary structure has remained unaltered, thus presenting altogether the appearance of a polystelic Fern-stem. Both primary and secondary wood are made up of scalariform tracheides; the secondary zone is traversed by numerous medullary rays. In the primary wood, one or more groups of spiral elements have been recognised, usually situated (according to the species) at one or both ends of the stele. In one case, an appendage, containing a single concentric bundle, was found in connection with the stem, and was no doubt of the nature of a petiole. The general organisation is clearly comparable to that of a Medullosa, though there are many differences in detail. It is certainly interesting to find, that this remarkable combination of polystelic organisation with secondary growth had already appeared at so ancient a period as that of the Devonian.

It is not probable that the relation between the Cladoxyleae and the Medulloseae was at all a close one, for the differences in the minute structure of the wood, 
and in the organisation of the petiole, as well as in the arrangement of the steles, appear to be of considerable weight. The two families probably represent parallel lines of development.

A comparison has been suggested between the complex system of steles in Cladoxylon and the deeply lobed and forked stele of Asterochlaena (see Vol. I. p. 324), and it is possible that there may be a real affinity between the two groups.

There are other types of Cycadofilices still undescribed; one of these may be shortly referred to, though its affinities cannot yet be determined. This stem comes from the Lower Carboniferous of the Tweed; the first specimen was discovered by Mr. Mathieson in r $87 \mathrm{I}$; within the last few years additional material has been collected by Mr. Kidston, who has the fossil under investigation; it has been named Stenomyelon tweedianum, Kidston in MS. The primary wood consists of a mass of tracheides, continuous except where it is traversed by bands of parenchyma, which may be regarded as forming a narrow and irregular pith. The position of the protoxylem appears to have been external. The secondary wood is of considerable thickness, and has a rather dense structure, with narrow medullary rays. The tracheides are mostly of the usuai multiseriate-pitted type, though transitional scalariform elements occur near the protoxylem. The outer cortex has the common strengthening-bands of sclerenchyma; numerous leaf-trace bundles lie between wood and cortex, and there is some evidence that they arose by the subdivision of a smaller number of main strands. 
A distant resemblance to the structure of Sutcliffia may be traced, but we must await the results of further investigation before forming any opinion as to the true relationships of the fossil.

The question of the relation of the families still provisionally grouped under Cycadofilices to the Seedplants on the one hand and to the Ferns on the other, must necessarily remain an open one so long as any satisfactory evidence as to the fructification is absent. In the case of the Calamopityeae and Cycadoxyleae the high anatomical organisation affords a presumption that we here have to do with Pteridospermeae, even if not with more advanced Spermophyta; the analogy between the structure of Megaloxylon and that of Heterangium among the Lyginodendreae points, though much less decidedly, in the same direction. The Protopityeae and Cladoxyleae, however, appear too isolated, at present, for us even to venture on any conjecture as to their affinities, beyond what is implied in classing them as "Cycadofilices." 


\section{CHAPTER XII}

THE CORDAITALES

\section{Poroxyleae; Pityeae; Cordaiteae}

\section{Poroxyleae}

WE now pass on to a group of fossil plants, which occupies a somewhat different position from those which we have just described. The latter were found, on the whole, to combine the characters of the Ferns with those of the great Cycadophytic stock, and might thus be regarded as indicating the probable derivation of the latter from the former. The group next to be considered, that of the Poroxyleae, while having much in common with certain of the Pteridosperms and Cycadofilices, especially with the Lyginodendreae and Calamopityeae, show affinities not so much with the Cycadophyta as with a wholly extinct order of Gymnosperms, the important Palæozoic family Cordaiteae. The three families, Poroxyleae, Pityeae, and Cordaiteae, are, in fact, so interrelated that they may best be united under the common class-name Cordaitales.

The Poroxyleae are represented at present by the one genus Poroxylon (of which two or three species are 
known). Poroxylon is a genus in which the available data chiefly relate to the vegetative structure; such evidence as we possess concerning its organs of reproduction will be considered later on. Our present, very complete knowledge of the anatomical structure, which is preserved in astonishing perfection, was due in the first instance to the investigations of the two French palæobotanists, MM. Renault and Bertrand. ${ }^{1}$

The genus was originally discovered in the PermoCarboniferous deposits of Grand Croix and Autun, in France; an allied species has recently been recorded from the Lower Coal-measures of Lancashire.

The two best-known French forms, Poroxylon Boyssetii (which includes the specimens first discovered, and described by M. Renault in I 879) and $P$. Edwardsii, only differ from each other in unimportant characters, which may or may not be of specific value.

The stems of these plants were comparatively slender, the specimens described not much exceeding half an inch in diameter; they bore spirally arranged leaves, separated from each other, for the most part, by rather long internodes; the French authors have worked out the phyllotaxis, from the course of the leaf-trace bundles, and found the divergence between two successive leaves to be $\frac{5}{13}$. The leaves themselves were very different in character from those of any of the Pteridosperms, as at present known. They were broad, thick, simple leaves, inserted on the stem by a definite petiole, and tapering towards the opposite extremity. The lamina

1 Renault, Tiges de la flore carbonifere, 1879; Bertrand et Renault, "Les Poroxylons," in Archives bot. du Nord de la France, 1886. 
was traversed by numerous parallel veins. ${ }^{1}$ This is quite a different type of leaf from anything we have met with among the groups already considered.

The structure of the stem, however, is of a type already familiar to us. The transverse section of a young stem is represented in Fig. I $8 \mathrm{I}, \mathrm{B}$. We see at once that there is a well-marked pith, surrounded by a ring of collateral vascular bundles. The primary xylem-strands of these bundles, which border immediately on the pith, are clearly marked off from the surrounding zone of radially arranged secondary wood, which is succeeded externally by the well-preserved cambium and phloëm. The stem thus had secondary growth in thickness, of a normal character. The pericycle, immediately surrounding the phloëm, and the inner primary cortex, contain structures interpreted as gum-canals, and similar organs are also present in the pith. The outer cortex was strengthened by a system of hypodermal strands of sclerenchyma, such as we have so often met with in the stems of Palæozoic plants. The general anatomy of the stem is thus strikingly similar to that of a Lyginodendron, and a more detailed examination shows that the resemblance is a real one. A general agreement with Calamopitys is also evident.

The bundles surrounding the pith are rather more numerous than in Lyginodendron, a fact which is correlated with the more complex phyllotaxis of

1 The leaves, or at least their laminae, do not appear to have been found in connection with the stem, in these species, but as MM. Bertrand and Renault pointed out, the close anatomical agreement between stem and leaf established a strong presumption that the two organs belonged to identical or closely related species. In the British species, $P$. Sutcliffi, the connection between the stem and leaf-bases is clear. 

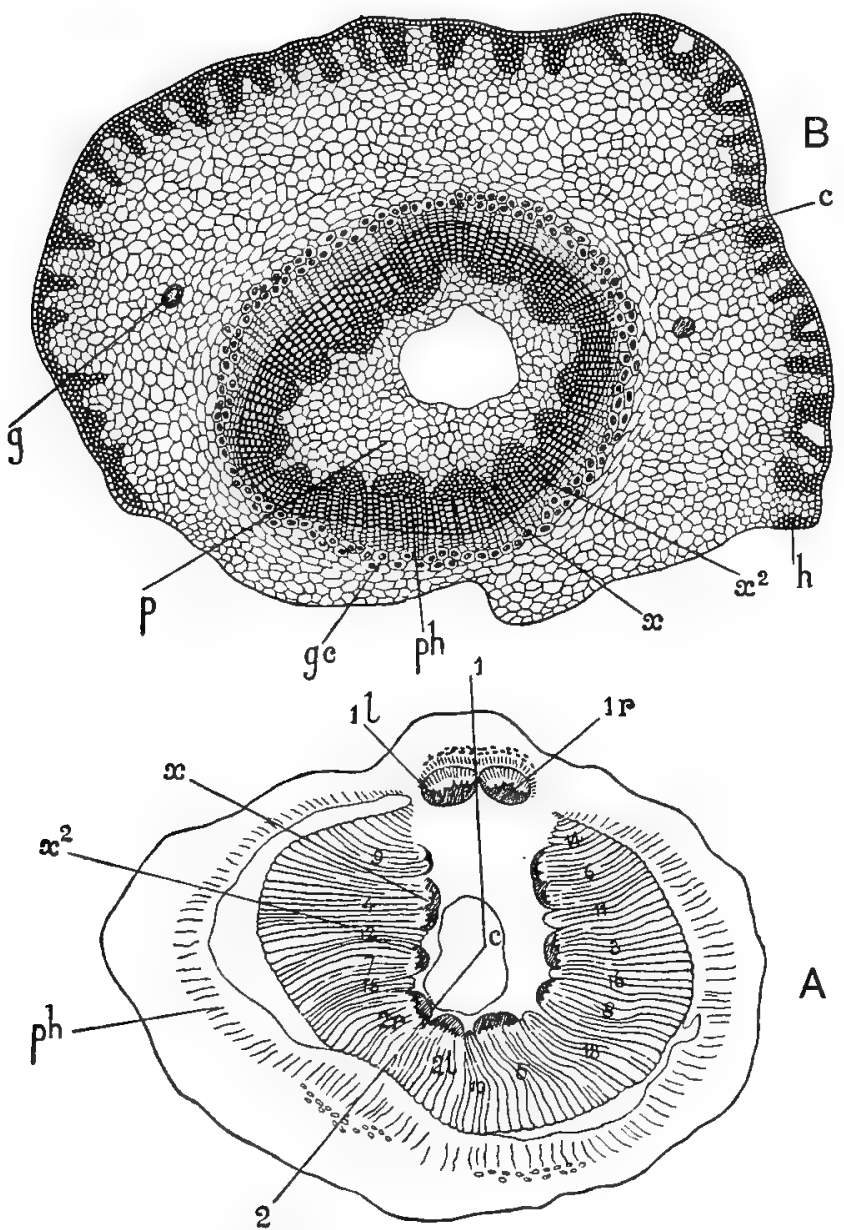

FIG. 18t.-A, Povoxylon Edwardsii. Transwerse section of stem. c, cavity in pith; $x$, primary wood of bundles, which are numbered in the order of the $\frac{5}{13}$ phyllotaxis, No. I belonging to the lowest leaf of the series; the angle $I, c, 2$, is that of the divergence between two successive leaves; I $c$ and $I \gamma_{2}$ the two bundles constituting the outgoing leaf-trace; $x^{2}$, secondary wood; $\not h$, phloëm. $\times$ about 5 . After Bertrand and Renault. B, $P$. Boyssetii. Transverse section of young stem. $p$, pith; $x$, primary wood of bundles; $x^{2}$, secondary wood ; $p h$, phloëm; $g c$, secretory (?) sacs or canals; $g$, mucilage-canal; $c$, cortex; $h$, hypoderma. $\times 7$. After Renault. 
Poroxylon. Each leaf-trace, on entering the stem from a leaf, runs down through thirteen internodes, before joining the trace of a leaf vertically below. Hence, in any transverse section of the stem, the traces of thirteen successive leaves are met with (see A, Fig. I 8 I).

The internodes are long, and as the leaf-trace traverses the cortex in about half the length of an internode, it follows that in any transverse section of the stem not more than one outgoing trace (if any) is shown (see Fig. I $8 \mathrm{I}, \mathrm{A}$ and B). Each leaf-trace, in the upper part of its course, consists of a double bundle. It will be remembered that in Lyginodendron also the leaf-trace is a double one. In that genus, however, the two strands of the trace unite, as we follow them inwards through the pericycle (see Fig. I 29, p. 359); in Calamopitys they unite in the same region (Fig. I76), whereas in Poroxylon they remain distinct for some distance below their entry into the interior of the stele. Thus, the two strands of primary wood shown in Fig. I 82 both belong to the same leaftrace, which (proceeding from the second leaf above) has already taken up its position at the margin of the pith.

This figure also serves to illustrate the important point that the development of the primary xylem of the bundles was centripetal. At the level of the section each of the twin-bundles has two protoxylem-groups $(p x)$, separated by parenchyma from the secondary wood on their exterior side. The centripetal xylem of each strand forms an arc, abutting, at its ends, on the secondary wood. The whole structure is strikingly like that in Lyginodendron (cf. Fig. I 3 I, p. 364), except 
that, according to the observations of MM. Bertrand and Renault, there is no centrifugal primary xylem in the case of Poroxylon. This is a point which might repay further investigation.

The elements adjoining the spiral protoxylem are scalariform, while the more internal part of the centri-

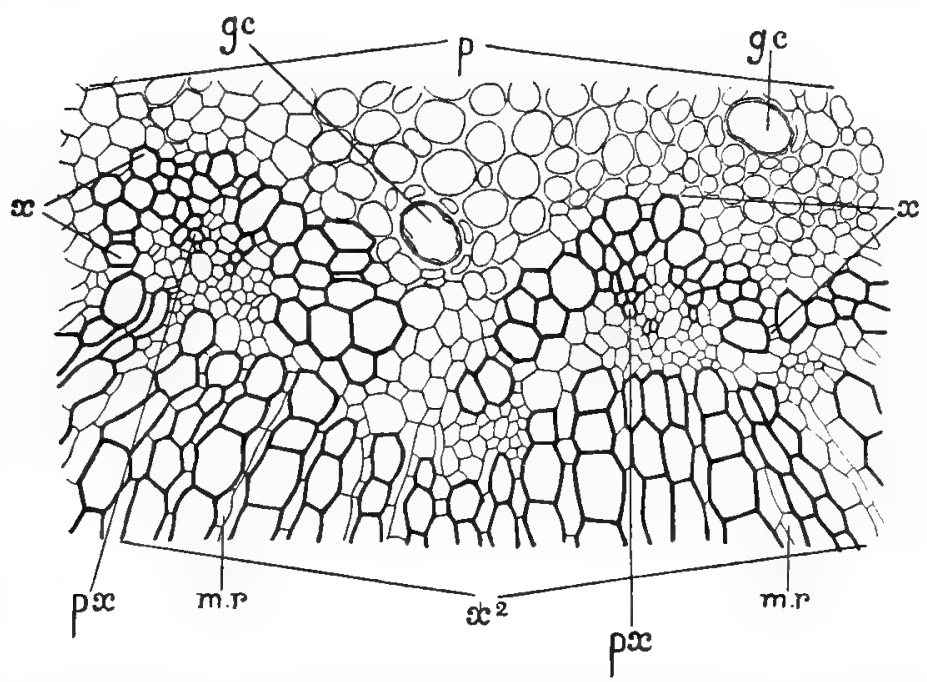

FIG. 182.-Poroxylon Edwardsii. Transverse section of the stem, showing two primary xylem-strands, with adjacent tissues. $p$, pith; $g c$, mucilage-canals; $p x$, protoxylen ; $x$, primary centripetal xylem; $x^{2}$, secondary xylem; m.r, medullary rays, $\times 66$. After Bertrand and Renault.

petal wood consists of pitted elements, exactly as in Lyginodendron or Heterangium. Traced further downwards in the stem, the structure of the primary wood becomes simplified; the protoxylem-groups fuse with each other, and ultimately die out. It is a fact well known to anatomists that the spiral elements often disappear in the lower part of the course of a bundle, as is very clearly seen in the Fern Osmunda, the 
structure of which is in many respects comparable to that of the plants under consideration. Eight internodes below the node the centripetal xylem also disappears, leaving only the wedge of secondary wood to mark the position of the trace (see Fig. I 8 I, A, bundles IO-I 4 ; cf. Calamopitys Beinertiana, p. 482). The communication between the different leaf-traces was kept up by lateral fusions, during their passage down the stem.

The secondary wood presents no peculiarities; it consists of regular, radial series of tracheides, with medullary rays between them. The rays are of considerable height, and two or three cells in thickness; the tracheides have several rows of round or hexagonal bordered pits on their radial walls. The structure, in fact, is identical with that of the wood in Lyginodendron, so that the two could scarcely be distinguished.

The secondary phloëm, which is extraordinarily well preserved, is traversed by the medullary rays, and made up of alternate tangential bands of sieve-tubes and parenchyma. Poroxylon is one of the few fossil plants in which the structure of the sieve-tubes can be made out. A radial section of $P$. Edwardsii is figured by MM. Bertrand and Renault, in which the numerous compound sieve-plates on the radial walls are perfectly plain, just as in some recent Cycads. Heterangium tiliaeoides, Medullosa anglica, and Stauropteris oldhamia, among British fossil plants, sometimes rival Poroxylon in the perfection with which the phloëm is preserved.

The French authors state that there is no pericycle, distinct from the primary phloëm. That is a matter of interpretation, but it is an interesting point that the 
formation of periderm took place on the inner border of the cortex, and immediately outside the "primary phloëm"-in fact, in just the same position which it occupied in Lyginodendron. In the older stems, the whole of the cortex was thrown off as bark, a stage which has not been observed in the latter genus, though Calamopitys may offer analogies.

The double leaf-trace, as it passes out through the cortex, preserves its collateral structure, and is accom-

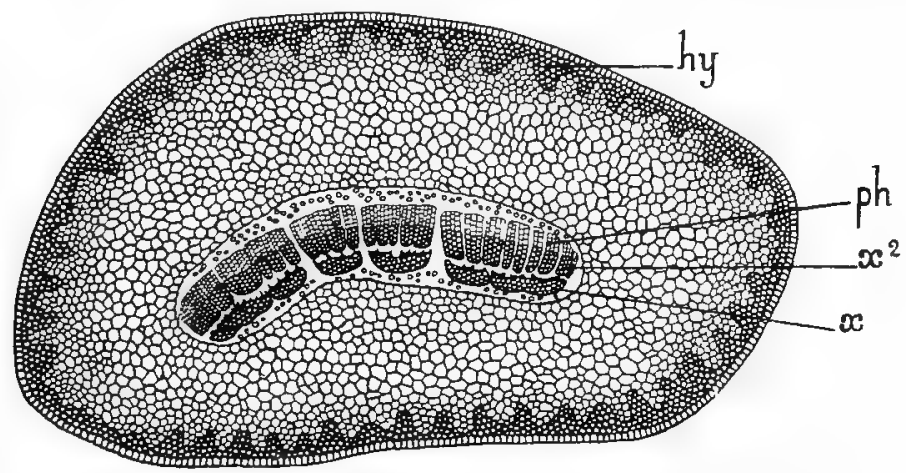

FIC. 183.-Poroxylon Boyssctii. Transverse section of petiole. $x$, primary xylem; $x^{2}$, secondary xylem; ph, phloëm; $h y$, hypoderma. $x$ about ıo. After Renault.

panied by secondary wood and bast on its outer side. The same structure is maintained in the leaf itself. Fig. I 83 represents a transverse section of the petiole of $P$. Boyssetii. The vascular bundles, which have begun to subdivide, are arranged in a transverse series, the phloem facing downwards and the xylem upwards, as is usual in leaves; they present essentially the mesarch structures of the bundles of Cycadean leaves (cf. Fig. I 33, p. 365). The petiole, like the stem, had a strong mechanical construction, owing to 
the presence of hypodermal ribs of sclerenchyma (Fig. I $83, h y$ ).

The petiole widened out gradually into the broad simple lamina, which was traversed by numerous parallel bundles, derived from the subdivision of those of the petiole, and branching dichotomously. The larger bundles, which are crowded together in the median region of the lamina, have the same structure as those in the petiole; the finer strands, toward the edges of the leaf, are simplified, and no longer show any centrifugal wood. Just the same simplification of structure occurs in the smaller bundles of the leaf, in recent Cycads. The lamina was of considerable thickness, and was stiffened by the usual hypodermal fibrous strands on both surfaces. The dense mesophyll is said to show some traces of palisade-like arrangement. The larger bundles of the lamina were connected by transverse bridges of thick-walled elements.

M. Grand'Eury ${ }^{1}$ has recently identified the leaves of Poroxylon in the form of carbonaceous impressions. He finds that they are of great size, reaching a length of a metre, with a breadth of 15 to 20 metre. They are narrowed at the base, passing insensibly into the petiole.

In these leaves we have a highly remarkable organisation, totally different from anything met with, either in the Ferns themselves, or among the genera associated under the Pteridospermeae and Cycadofilices. The detailed structure is, in fact, that of a Cycad, but the leaf of Poroxylon was a simple, not a compound

1 "Sur les Rhabdocarpus, les graines et l'évolution des Cordaitées," Comptes Rendzes, t. cxl. p. 995, 1905. 
one, so that the whole leaf has been compared to a single leaflet of a Cycad such as Bowenia.

In the fact that the vascular bundles retain collateral structure throughout the leaf, Poroxylon agrees with Medullosa but differs strikingly from Lyginodendron, in which, as described above (pp. 367 and 375), the structure becomes concentric as the petiole is entered. We shall see presently that the leaves of Poroxylon present the closest analogies with those of the Cordaiteae.

An interesting point in the morphology of the genus Poroxylon is the fact that the stem bore axillary branches, thus presenting a further analogy with some forms of Lyginodendron. The vascular system of the branch was inserted on the two bundles of the main axis, between which the trace of the subtending leaf passed out. Thus, in the section shown in Fig. I $8 \mathrm{I}, \mathrm{A}$, the branch, if present, would have been in vascular connection with the bundles marked 6 and 9 . The first few internodes of the branch were short, and the first leaves probably rudimentary, judging from the small development of the leaf-traces supplying them. In its upper part, the branch assumed the same structure as the main stem.

Poroxylon appears to have possessed a complex branch-system, for shoots are found of very different calibre, independently of differences due to age.

Roots and rootlets, which have been found in association with Poroxylon Boyssetii and Edwardsii, agree so exactly, in the structure of their histological elements, with the stems of those plants, as to leave no reasonable doubt that MM. Bertrand and Renault 
were justified in referring them to the genus Poroxylon. The rootlets, in particular, are perfectly preserved, and their anatomy has been fully investigated. The structure is, as a rule, diarch; in a few cases a tetrarch cylinder has been observed. The anatomy of the roots and rootlets is, in all respects, such as characterises Gymnospermous roots at the present day. In the usual case of diarch organisation, the secondary wood and bast form two large masses, one on either side of the primary xylem-plate, while a broad ray corresponds to each of the two protoxylemgroups at the ends of the plate. In the details of wood and phloëm the roots agree precisely with the stem. The whole cortex was thrown off at an early stage by the formation of pericyclic periderm. Thus the outer surface of the root was formed by a layer of cork, just as in the roots of Medullosa anglica, described in the last chapter, or in those of recent Gymnosperms.

MM. Bertrand and Renault were able to observe the mode of insertion of the rootlets on the main root, and to determine that the plane of the diarch xylemplate coincided in the two organs. This is a point of interest, for, as is well known from the researches of Professor van Tieghem and others, this arrangement is characteristic of the roots of Gymnosperms and Phanerogams generally, while, in the case of the diarch roots of Vascular Cryptogams, the plane of the xylem-plate of the rootlet lies at right angles to that of the parent root.

Our summary has so far been based on the species discovered by Bertrand and Renault; the anatomy 
was worked out in the most elaborate detail by the French investigators, owing to whose labours this genus became one of the most completely known, so far as the vegetative organs are concerned, among fossil plants.

An English species, of older date than the French

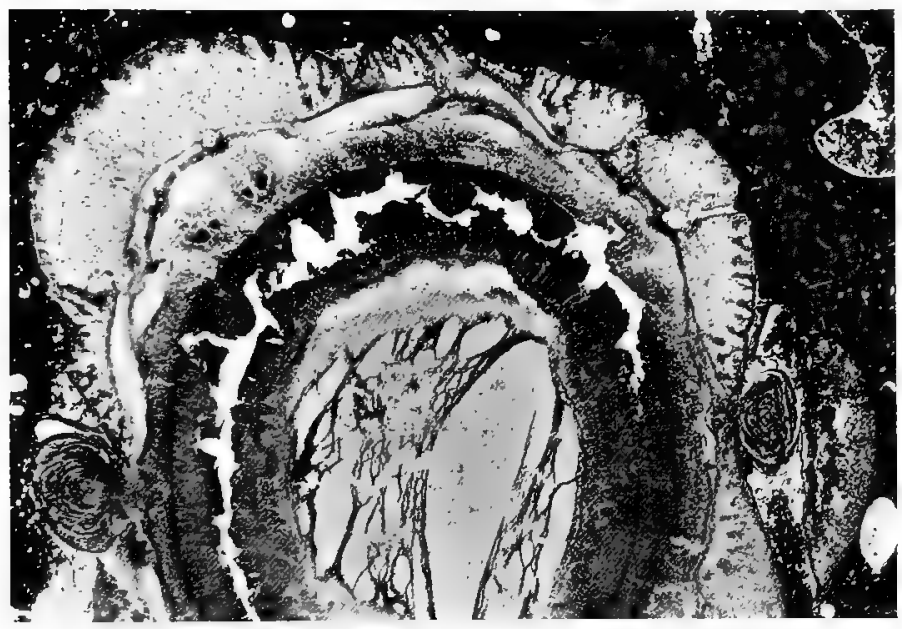

Fig. 184.-Poroxylan Sutcliffi. Transverse section of stem, showing the large pith, the ring of wood and phloem, and the cortex, with leaf-bases attached, into which the leaf-traces are entering. Two axillary buds are shown; the one to the right is accompanied by the subtending leaf-base. $\times$ nearly 4 . From a photograph by Mr. L. A. Boodle. Scott Collection.

forms, was found a few years back by Mr. Lomax, in a roof-nodule from the Lower Coal-measures of ShoreLittleborough, Lancashire; the species has been named Poroxylon Sutcliffic (Fig. I 84), after the owner of the mine, to whose co-operation palæobotanists owe so much; though the plant is certainly related to the French Poroxylons, its place in the same genus must 
be regarded as provisional, until the investigations now in progress are completed. The main features of the structure are the same as in the species already described; the primary strands of centripetal wood, the double bundles passing out from the pith, the cortical structure and the axillary branching are obvious points of similarity. The subdivision of the leaf-trace pairs, first into four and then into six strands, as they pass through the cortex, is particularly well shown, as are also the small axillary buds (Fig. 184). The leaves were evidently much more crowded on the stem than in the French type; the secondary wood is denser, with smaller tracheides and narrower rays; the pith is discoid, like that of Cordaites; the phloëm also has some peculiarities; it is thus probable that the distinctions existing may prove to be of generic value. In any case, the discovery of the Poroxylon type of stem at an horizon considerably lower than that of the species originally described, is one of much interest.

Until recently we were quite in the dark as to the fructification of Poroxylon. On grounds of association, however, M. Grand'Eury ${ }^{1}$ now attributes the seeds known as Rhabdocarpus, Brongniart, to these plants, with which he also finds "floral axes, bearing large and long male and female buds, without bracts." Rhabdocarpus, as limited by Brongniart, is a genus of seeds with bilateral symmetry, characterised by the presence of numerous fibrous strands in the sarcotesta. The seeds are of the same general type as those of the Cordaiteae, described below (see p. 546). Fig. I 85 shows a seed of this genus in transverse section, 'See his paper above cited, "Sur les Rhabdocarpus," etc. 
displaying the characters of the platyspermic type. The discovery, if confirmed, will considerably strengthen the affinity otherwise indicated bctween the Poroxyleae and Cordaiteae.

MM. Bertrand and Renault regarded the genus as related, on the one hand, to Sigillaria, and, on the other, to Cordaiteae. The affinity with the Cordaiteae seems indisputable, as will appear when we come to describe that family; the relation to Sigillaria, however,

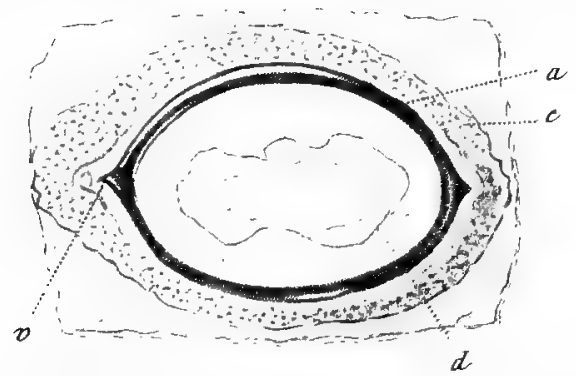

FIG. 185.-Rhabdocarpus swlinnicatus Grand'Eury. Transverse section of seed, to show the platyspermic type of structure. $a$, sclerotesta; opposite the ridge (v) at each side is a vascular bundle; $c$, sarcotesta, with numerous fibrous strands; $d$, contracted nucellus, within which is the embryo-sac. $x$ about 3. After Brongniart.

though it appeared tenable at the time it was suggested, and was supported by the case of Sigillariopsis, with its double foliar bundle and occasionally pitted tracheides (see Vol. I. p. 230 ), now seems to be excluded by the manifest affinity between Poroxylon and the Pteridosperms of the Lyginodendron group. As has already been pointed out, and as the French observers recognised, the agreement in structure between Poroxylon and Lyginodendron is in many respects a close one, so much so that there can scarcely be a doubt that the two genera are allied. The same remark applies, to 
a great extent, to the Calamopityeae also. These. Pteridosperms, however, as is now abundantly proved, had their nearest relationships with the Ferns, and the inference appears justified that Poroxylon also, though more modified, was derived from a Filicinean, rather than a Lycopodinean stock. The importance of this conclusion will become evident when the Cordaiteae have been considered.

\section{The Pityeae}

Before going on to the Cordaiteae we will shortly consider a group of fossil plants which, so far as our limited knowledge shows, appear to lead up to that family, and to form part of the wider group which we call Cordaitales.

Most of the stems in question fall under the genus Pitys of Witham, as emended by Göppert. ${ }^{2}$ There are three species, all from the Lower Carboniferous of Southern Scotland, and all described by Witham in his famous pioneer work of 1833 . The species are chiefly distinguished by the width of the medullary rays, the principal rays being as much as seven cells wide in $P$. primaeva, five or six cells in $P$. antiqua, and four cells in P. Withamii. Pitys Withamii is the well-known Craigleith tree, of which a trunk is set up in the grounds of the Natural History Department of the British Museum. A stem of this species found at Craigleith, near Edinburgh, in 1830, was 47 feet in

1 The Internal Struature of Fossil Vegetables found in the Carboniferous and Oolitic Deposits of Great Britain, described and illustrated, Edinburgh, 1833, p. 71 .

2 "Revision meiner Arbeiten iiber die Stämme der fossilen Coniferen," Botan. Centralblatt. Band v. and vi. I88I. 
length; at the top, the wood still had a diameter of I $\frac{1}{2}$ feet.

The pith and wood are the only parts preserved in any of the species, as at present known. The wood, except for the greater width of the principal medullary rays, is of the Araucarian type, and thus, as we shall see, agrees with that of the Cordaiteae (cf. Fig. I go, p. 528); the secondary tracheides have multiseriate bordered pits, confined for the most part, to their radial walls.

The point of chief interest is the presence, in all three species, of a number of small strands of primary wood, disposed around the pith. ${ }^{1}$ This structure is best shown in Pitys antiqua, the Lennel Braes tree, from which the illustration in Fig. I 86 is taken. The imperfectly discoid pith is large, sometimes as much as 2 inches across; in a specimen where the pith measured only $22 \mathrm{~mm}$. in diameter, the number of xylem-strands round the pith was between forty and fifty. The diameter of each xylem-strand is small, averaging about $25 \mathrm{~mm}$.; most of the strands are embedded in the pith at some little distance from the inner edge of the woody zone (Fig. I 86), with which they only come into contact when about to make their exit as leaftraces. Where a xylem-strand passes out into the zone of secondary wood, its place is taken by a reparatory strand lying behind it, deep in the pith. The outgoing strand shows some sign of division into two, but the two halves appear to reunite further out in its course.

1 Scott, "Primary Structure of certain Palæozoic Stems," etc., Trans. Roy. Soc. Edinburgh, vol. xl. Part ii. Igo2. 
Branching and anastomosis of the strands are found at many places.

In the great majority of the xylem-strands the structure is definitely mesarch, the spiral protoxylemelements lying in the interior (Fig. I $86, p x$ ). The

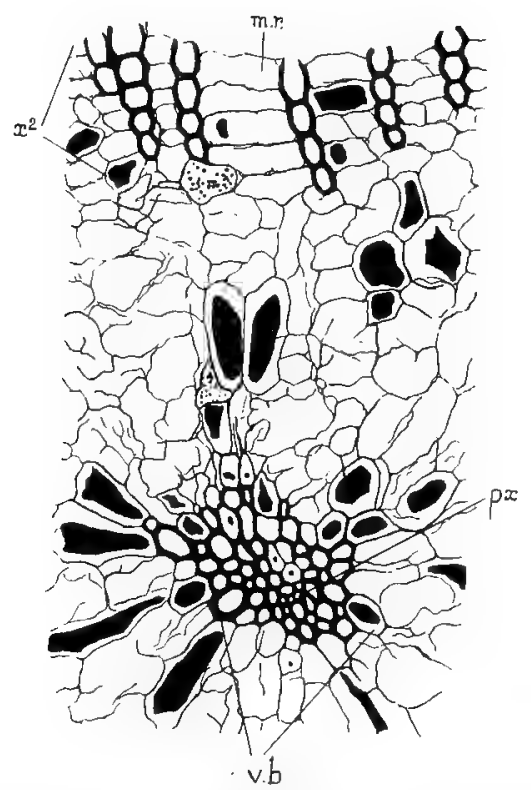

FIG. 186.-Pitys antigua. From a transverse section of the stem. z'b, primary xylem. strand embedded in the pith; $x x$, protoxylem; $x^{2}$, inner part of secondary wood; m.r, medullary rays. The cells with black contents may be secretory sacs. $\times 73$. Kidston Coll. 598A, (G. T. G.)

primary tracheides are accompanied by a little xylemparenchyma.

No spiral elements could be detected at the inner edge of the woody zone, so it would appcar that the primary wood is represented only by the medullary strands. The considerable separation between the latter 
and the main zone of wood is difficult to account for, and suggests some specialisation of function, as, for example, that the primary strands might have become superfluous for the main work of water-conduction and have served to supply the bulky parenchymatous pith.

The mesarch xylem-strands, in spite of their reduced size and the peculiarities of their arrangement, are evidently comparable to those of the Lyginodendreae and Calamopityeae. On the other hand, the arboreal habit suggests affinity with the Cordaiteae; leaves and seeds attributed to this family have been found in beds of the same age. Thus it is probable that the Pitys trees may form a link between the Pteridospermeae and the true Cordaiteae, though their position cannot be finally determined until we have a more complete knowledge of their structure.

In connection with Pitys another stem may be mentioned, which is of some interest from the same point of view. This is Dadoxylon Spenceri, a fossil from near Halifax; there has been some doubt as to the horizon, which is probably low down in the Upper Carboniferous. The stem has a rather small, obtusely pentagonal pith, and a very dense secondary wood, with the tracheides narrow, and the medullary rays almost always uniseriate. The leaf-traces are given off in pairs, just as in Ginkgo; at the angles of the pith and in contact with the woody zone there are pairs of small primary xylem-strands, corresponding to the leaf-traces. Traced downwards, the strands of each pair fuse; they are mesarch in the upper part of their course, but at a

1 Scott, l.c. p. 357. Dadoxylon is an old name for fossil stems with wood of the Araucarian type, especially those of Palæozoic age. 
lower level the centripetal wood appears to die out, as in Poroxylon or Calamopitys Beinertiana.

The interest of Dadoxylon Spenceri lies in its combining the wood-structure of a typical Cordaites with the primary xylem-strands of Lyginodendron or Calamopitys in a reduced form.

The exact relations of Pitys and Dadoxylon Spenceri cannot be determined until we know more of their structure. The characters already investigated indicate that these plants, like the Poroxyleae, belong to a plexus of forms connecting the Pteridosperms and Cycadofilices with the typically Gymnospermous family of the Cordaiteae, but standing nearer to the latter.

\section{The CoRdaiteaE}

The forms hitherto considered in this chapter appear in some respects intermediate between the Pteridosperms and the true Gymnosperms; we now pass on to a family which belongs beyond question to the latter class. The Poroxyleae and Pityeae are at present chiefly or solely known to us by their vegetative characters; we have now to deal with a group in which our evidence is drawn from all the organs of the plant-reproductive as well as vegetative. Though even here our knowledge is but limited and urgently needs to be extended, the fact remains that the family in question - that of the Cordaiteae-is one of the best known, as it is also among the most remarkable, of those which fossil botany has revealed to us.

Among the vegetable remains from the Carboniferous and Devonian strata, specimens have long been 
known, such, for example, as fragments of petrified wood, which present Coniferous characters, while others, such as the impressions of large parallel-veined leaves, suggest at first sight Monocotyledons of the Yucca type. Associated with these remains, fossil catkin-like inflorescences (Antholithus) have sometimes been found, as well as a considerable variety of seeds, of the bilateral type. The piecing together, on sure evidence, of these remains, apparently so diverse, and the revelation of their structure, was essentially the work of the two French investigators, Grand'Eury and Renault, ${ }^{,}$though valuable contributions from other hands have not been wanting.

I. External Characters.-We may begin by stating the general results of the reconstruction which has been arrived at, and then go on to describe the organisation of the various organs more in detail. The Cordaiteae were tall, somewhat slender trees, with trunks rising to a great height before branching, and bearing at the top a dense crown, composed of branches of various orders, on which simple leaves of large size were produced in great abundance (Fig. I 87). The stumps of the trees, with the roots attached, have often been found; the root system is said to have been rather feebly developed. The stems, in their present state, attain a diameter of a couple of feet or more, which is small in comparison with the height of the trees, for Grand'Eury finds that in various specimens the shaft alone (below the crown) reached a height of 10,20 ,

1 See especially Grand'Eury, Flore carbonifere du Departement de la Loire, 1877 , and Renault, Structure comparée de quelques tiges de la flore carbonifere, 1879 . 
or even 30 metres. It must be remembered, however,

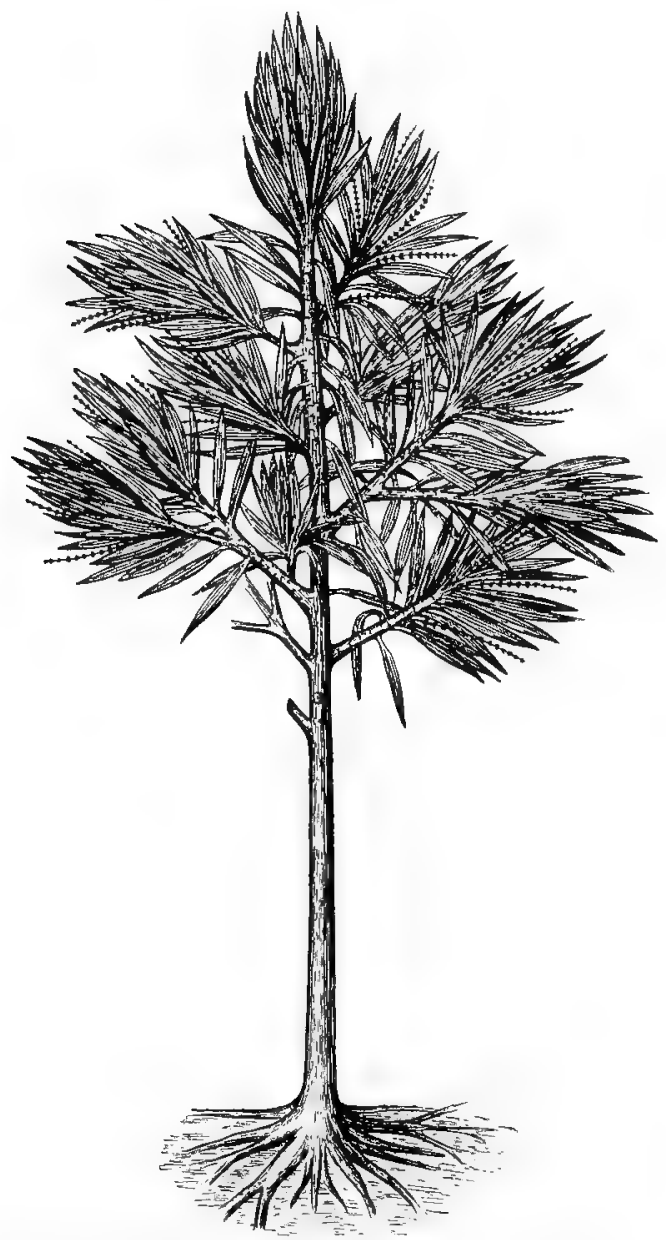

Ino. I87.-Dorycorlates, sp. Restoration, showing roots, trunk, and crown, the latter composed of branches bearing large lanceolate leaves and inflorescences. The trunk is shown too short. After Grand'Eury. Modified.

that the large specimens have their wood reduced to 
coal, so that the total diameter was no doubt considerably greater in the natural state, than appears from the fossil remains.

The leaves were borne in a spiral sequence, on the ultimate branches; they were simple elongated leaves, varying considerably in form in different members of the group; on these differences genera or subgenera have been founded. Thus, in the typical Cordaites (Eu-Cordaites) the leaves are spathulate, with blunt ends; they reached in some cases a length of a metre, and a width of $15 \mathrm{~cm}$. To this group the forms most fully investigated belong (see Fig. I 88). Then we have Dorycordaites, with leaves little inferior in length to those of the last group, but lanceolate and sharply pointed. Our Fig. I 87 represents a restoration of a tree belonging to this subgenus. Finally there is Poacordaites, with grass-like leaves, reaching half a metre in length, by only a centimetre or so in breadth. The leaves of Cordaiteae, whatever their form may have been, are all characterised by parallel venation, giving them much the appearance of Monocotyledonous leaves, such as those of a Yucca or Dracaena; consequently, the earlier writers on fossil botany always placed these fossils in the class Monocotyledons. The veins are repeatedly forked, except in the narrow leaves referred to Poacordaites. In many instances branches bave been found, bearing the leaves (cf. Fig. I 88), or marked by the scars due to their fall. The scars are usually transversely elongated, and sometimes bear the prints of the vascular bundles which entered the leaf. The leaves were crowded in some forms, more remote in others, but there was always a free internodal surface 
between their insertions. In some cases a lateral twig

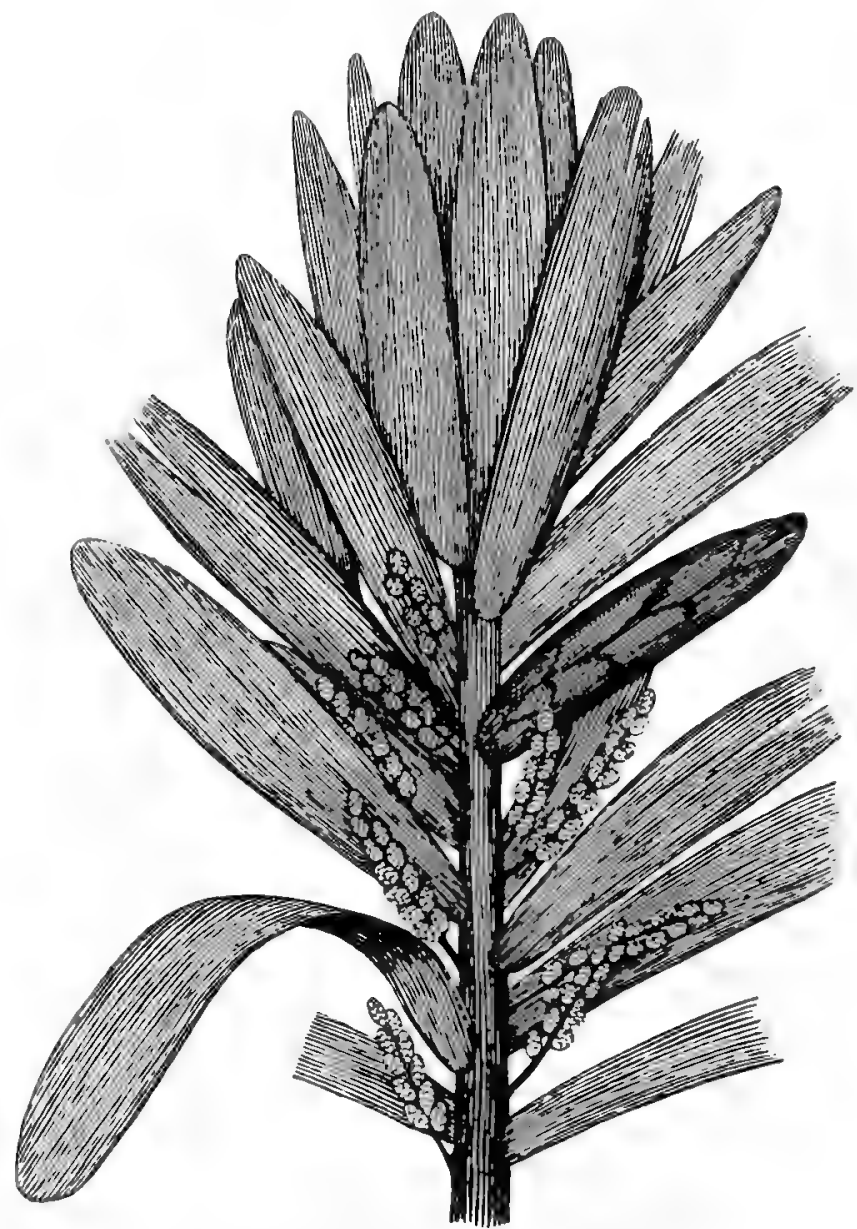

FIG. I88.-Cordaitcs latis. Branch (restored) bearing the large spathulate leaves, with parallel venation, and the inflorescences, each with numerous catkins. A large bud is also shown. Reduced. After Grand'Eury*

is found to be terminated by a large leaf-bud, as shown in Fig. 188. 
The habit of the Cordaiteae must have been different from that of any trees with which we are now familiar. The species with comparatively short leaves may be compared with such Coniferae as Agathis (e.g. the Kauri Pine of New Zealand), or with certain forms of Podocarpus, and these trees may best serve to give us some idea of the appearance of the extinct family. But the longer-leaved species must have had a habit very different from anything which we are accustomed to associate with Gymnosperms at the present day.

Branches, showing the characteristic marks of Cordaites, have been found by Grand'Eury with structure preserved, and this important discovery enabled palæobotanists to identify a large proportion of the apparently Coniferous woods of the Palæozoic strata, named Araucarioxylon or Dadoxylon, as belonging to the Cordaiteae. The anatomical structure will be described below ; here it is only necessary to say that the large size of the pith, sometimes attaining a diameter of nearly 4 inches, is characteristic of these plants, and at once distinguishes their stems from those of the Coniferae.

Casts of the pith-cavity of Cordaites are well-known and characteristic fossils, which used to be called Artisia or Sternbergia. They are cylindrical, or somewhat ribbed casts, sometimes very slender, but usually an inch or more, and sometimes approaching 4 inches, in diameter, and marked by numerous transverse constrictions at very short intervals, so that the whole resembles a pile of coins. Williamson, in $185 \mathrm{I}, 1$ found a cast of 1 "On the Structure and Affinities of the Plants hitherto known as Sternbergiae," Mem. Manchester Lit. and Phil. Soc, ser. ii. vol. ix. I85I. 
this kind still enclosed in wood, which proved on investigation to have the structure of Araucarioxylon. This was one of the first steps made towards the reconstruction of these fossils, for we now know that the wood in question, resembling that of the recent Araucarias, belonged to certain members of the Cordaiteae. The peculiar appearance of the casts, as Williamson explained, is due to the discoid structure of the pith, such as is found, not only in the Walnut, and in some Jasmineae and Euphorbiaceae, but also in certain species of Pinus, at the present day. The pith undergoes transverse rupture in many places, so as to leave numerous diaphragms, separated by empty spaces. The constrictions on the cast in the fossil specimens, mark the position of the diaphragms (cf. Fig. I 90, A).

The recognition of the true nature of Sternbergia has proved important, for by this means the large, rooted stumps, found in the Coal-measures of the Loire, containing Sternbergia casts, have been identified as belonging to Cordaiteae.

The floral organs of the Cordaiteae were known, so far as their external characters are concerned, long before their nature was recognised. These fossils, which were at first placed in the provisional genus Antholithus, consist of a simple or branched stalk, bearing laterally little catkin-like bodies, not-often exceeding a centimetre or so in length. The male and female catkins cannot always be distinguished externally; in some forms, however, the axis of the female inflorescence appears to have borne solitary ovules, accompanied only by a few bracts. 
Grand'Eury was so fortunate as to find inflorescences such as these in connection with the leafbearing shoots of Cordaites. An example (more or less restored) is shown in Fig. I 88, where we see a leafy branch, bearing several fertile peduncles, each of which in its turn bears a number of catkins, probably female. The inflorescences appear to have been inserted a little above the subtending leaves, and not immediately in their axils.

We see, then, that the connection of all the organs -stems, roots, leaves, and flowers-has now been established, at least for some species of the genus Cordaites. The other genera or subgenera are at present less completely known. We will now go on to consider the internal organisation of the various parts, beginning with that of the stem.

2. The Stem.-The general type of structure of the stem of Cordaites was that of a Conifer, but the pith, as we have seen, was far larger than we ever find it in the Coniferae, and in its dimensions rather resembled that of a Cycad. It has already been mentioned that, in many cases (though probably not in all), the pith was discoid, as shown in Fig. I90, A. This structure was no doubt due to the fact that the more central part of the pith was not able to follow the growth of the stem in length, and consequently split across at short intervals, leaving gaps between the persistent diaphragms. At the outer edge, next the wood, the medullary tissue remained continuous.

In those specimens which were originally referred to Cordaiteae, the wood, unlike that of the Poroxyleae 
and Pityeae, was wholly centrifugal in its development, the first-formed spiral elements lying on the interior margin, next the pith (Fig. I90, B, $p x$ ); they are localised in groups, often projecting somewhat into the pith, and marking the position of the primary bundles. In stems from Shore, however, which I have recently examined, showing the discoid pith and other characters indistinguishable from those of a typical Cordaites, arcs of centripetal xylem are present at definite points, no doubt corresponding to the position of the leaf-traces. The structure appears to be essentially the same as in Poroxylon, though the number of elements in the centripetal part of the xylem-strands may be smaller. In the Cordaiteae the old "Cryptogamic" or centripetal wood appears to have been on the verge of extinction, and its presence or absence may here be of little taxonomic significance.

In Cordaiteae of the type described by Renault, the elements of the wood are radially arranged throughout, so that in transverse sections there is no distinction between primary and secondary xylem (see Fig. I 89, $x$ ). In radial sections, however, such as that from which Fig. I go, B, was drawn, we find a marked change, from the pith outwards, in the structure of the walls of the tracheides. The narrow spiral elements of the protoxylem are succeeded by wider spiral tracheides, and these again by scalariform elements. It is not until many rows have been passed, that we come to the pitted tracheides $(b t)$ which form the bulk of the wood. The transitional region between primary and secondary xylem was thus more extensive in these plants than in most of the recent Conifers. 
The secondary wood has essentially the structure of that of Araucaria, and was hence named Araucarioxylon by Kraus, ${ }^{1}$ a name which is now superfluous in cases where the connection with Cordaites has been established. The bordered pits, which are limited to the radial walls, are usually in two or more rows, and are

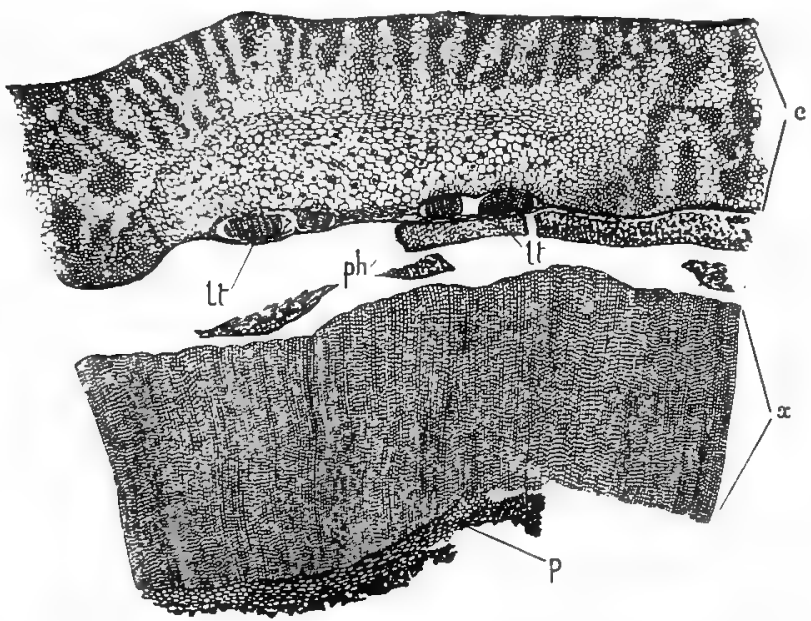

FIG. I89. - Cordnites, sp. Part of transverse section of a stem, from the English Coal. measures. $p$, pith ; $x$, zone of wood ; ph, phloëm; $l t$, double leaf-trace, each bundle subdividing ; $c$, cortex, containing sclerenchymatous strands. $x$ about 6. S. Coll. 306. (G. T. (G.)

densely crowded in alternating series, the borders thus having a hexagonal outline (Fig. I $90, \mathrm{~B}, b t$ ). In good material, the pore of the pit can be recognised clearly, and has the form of an inclined elliptical slit. Certain variations in the diameter of the tracheides of successive zones were regarded by Renault as indicating periods

I The names Dadoxylon, of Fndlicher, and Araucarites, of Göppert, are often used in the same sense as Arazcarioxylon. Dadoxylon is preferable in so far as it does not suggest any affinity with the Araucarieae. 
of growth, but, generally speaking, annual rings cannot be distinguished.

The medullary rays are narrow; the principal rays,

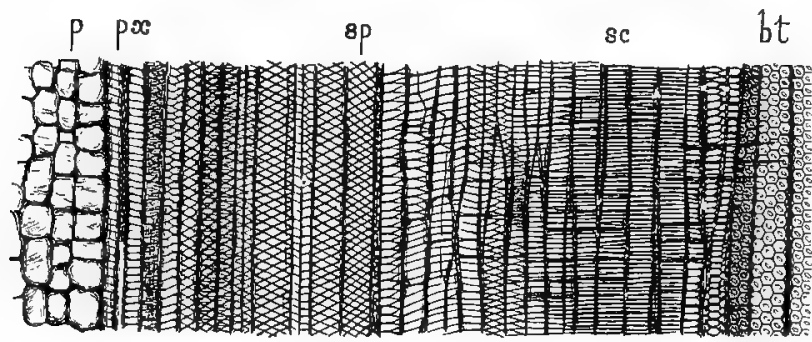

B

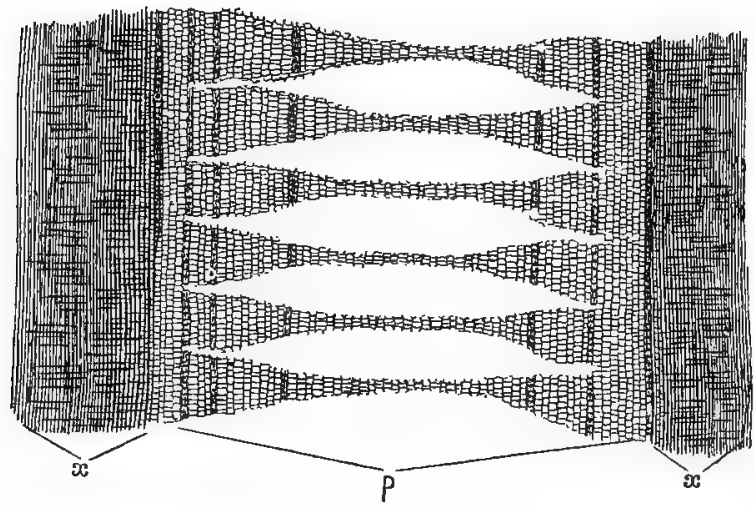

\section{A}

Fic. Igo,-Cordaites (Araucariaxylon) Brandlingiz. A, Radial section (somewhat restored) of middle part of stem, showing discoid pith $(p)$ and wood $(x) . \quad \times$ about 7 . $\mathrm{B}$, Inner part of wood, with adjacent cells of pith, in radial section, $p$, pith-cells ; $p x$, narrow spiral tracheides of protoxylem; $s p$, wider spiral tracheides; $s c$, scalariform tracheicles; $b t$, tracheides with bordered pits. $\times 95$. Kidston Coll. 185 (Coalmeasures of Dudley). (G. T. G.)

between the original bundles, may be as much as three cells in thickness, but the secondary rays are usually one, or at most two cells thick. The narrow rays have 
been used to distinguish the wood of Cordaites from that of other families, such as Poroxyleae and Calamopityeae, but the distinction does not always hold good.

We see, then, that, so far as the secondary wood is concerned, the structure of Cordaites is indistinguishable from that of a Conifer, of the family Araucarieae.

The phloëm, when preserved, shows a radial arrangement of its elements, corresponding to that in the wood (see Fig. I $89, p h$ ). Sieve-tubes and phloëm-parenchyma have been distinguished, and in some forms bast-fibres are also present.

The parenchyma of the primary cortex was traversed by secretory sacs, and strengthened by many radial bands of fibres, which formed a hypodermal system, and also extended deeply into the inner cortical tissues (Fig. I 89, c). These fibrous strands have a vertical course, and are rarely found to anastomose.

The bundles passing through the cortex on their way to the leaves are often met with in transverse sections of the stem (Fig. I 89, l.t). In the neighbourhood of the out-going leaf-trace, in the species figured, the cortex is parenchymatous, the fibrous strands being absent (see Fig. I 89). The leaf-trace was very often a double one, a point to which Williamson called attention long ago, as offering a close analogy with Ginkgo among recent Gymnosperms. ${ }^{1}$ It will be remembered that we have found a double leaf-trace in Lyginodendron, Ptychoxylon, Poroxylon, and other cases.

I Williamson, "Organisation of Fossil Plants of Coal-measures," Part xii. p. 470, Phil. Trans. I883, Part ii. In the section here figured (Fig. I89) each bundle of the double trace is subdivided. This represents a natural fission; in some forms of Cordaites it has been observed that a number of bundles entered the base of the leaf. 
The character, from its frequency in Cycadofilices and the early Gymnosperms, appears to have considerable taxonomic significance-a suggestion borne out by recent work on the occurrence of the double leaf-trace in recent Gymnosperms, and in Angiospermous seedlings. ${ }^{1}$

The large stems of Cordaiteae are known to have formed a thick and complicated bark, but its development has not yet been satisfactorily worked out.

3. The Root.-Mixed with the remains of leaves and branches of Cordaites, silicified specimens of roots have also been found; they agree so well in histological structure with the stem, that there is no reason to doubt the correctness of M. Renault's conclusion, that they belonged to the same plants, though I am not aware that roots showing structure have yet been found in actual connection with the stem. In the French specimens the roots are diarch, with a broad zone of secondary wood. The elements of the protoxylem are spiral, the rest of the primary tracheides scalariform, while the surrounding secondary zone is made up of pitted tracheides and medullary rays, and agrees in all essential respects with the wood of the stem. The root is limited on the outside by a broad zone of periderm, which, from M. Renault's description, would appear to have been derived from the external cortex. This is unusual in Gymnospermous roots, and the point seems to deserve further investigation.

Our Fig. I $\mathrm{I}$ is taken from a root known as Amyelon

1 Miss E. N. Thomas, "A Theory of the Double Leaf-trace, founded on Seedling-Structure," New Phytologist, vol. vi. 1907, p. 77. 
radicans, frequent in the Lower Coal-measures of England, which in all probability belonged to some member of the Cordaiteae. All the tissues, both primary and secondary, are well preserved. In this case the roots are usually triarch—sometimes tetrarch;

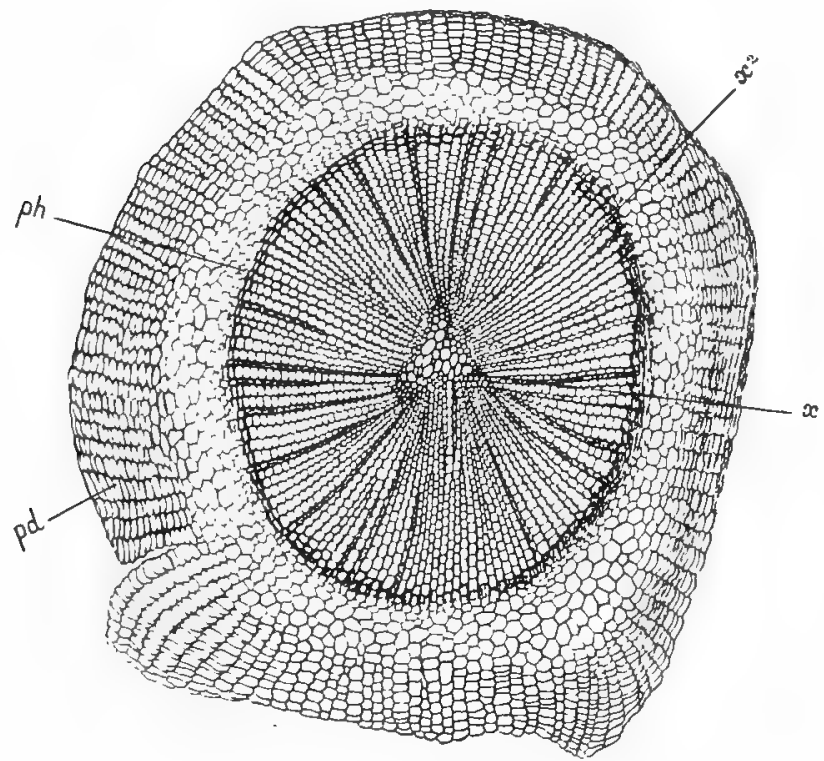

FIG. rgr.-Amyelon radicans (probably a root of one of the Cordaiteae). $x$, triarch primary xylem; $x^{2}$, secondary xylem; $p h$, phloëm; $p d$, periderm. $\times 23 . \mathrm{S}$. Coll. 450. (G. T. G.)

in other respects there is sufficient agreement with the French specimens, to have little doubt as to the affinities of our fossil. In Amyelon, at any rate, the origin of the periderm was, no doubt, deep-seated, the cortex being exfoliated. The same was the case in a diarch root associated with a Cordaites from Shore. 
4. The Leaves.- The leaves of Cordaites are fossils of frequent occurrence, especially in the Upper Coalmeasures, as, for example, at Radstock in Somersetshire, and in the coal-fields of Central France, where they appear to have played an important part in the formation of coal. At St. Etienne, certain beds of coal are said to consist exclusively of dense masses of the carbonised leaves of Cordaiteae. But in addition to the carbonised remains and impressions, which are ill adapted for the investigation of structure, petrified specimens also occur. Thus, in the "black flints" of Grand Croix. silicified remains of Cordaitean leaves are packed together in layers, "like damp Beech-leaves on the ground in our forests." 1 These silicified specimens are often in a state of exquisite preservation, and rendered it possible for the French palæontologists, notably M. Renault, to work out the structure in great detail. The anatomical specimens hitherto recorded are all referable to the genus Cordaites, though there is often some doubt as to the particular species (as determined from impressions) to which they belonged.

Broadly speaking, the structure of the leaf of Cordaites resembles that of a single pinna of the leaf of a Cycad, such as Zamia, while there is a more general resemblance to the leaf of Agathis, or one of the larger-leaved Araucarias. There are, as might be expected, appreciable specific differences among the various Cordaitean leaves examined. For example, in the leaf shown in transverse section in Fig. I92, A, referred provisionally to $C$. angulosostriatus, each of the numerous parallel vascular bundles is enclosed in

\footnotetext{
1 Solms-Laubach, Fossil Botany, English edition, p. I05.
} 
a strong sheath, which abuts, above and below, on a hypodermal strand of fibres. Smaller hypodermal ribs

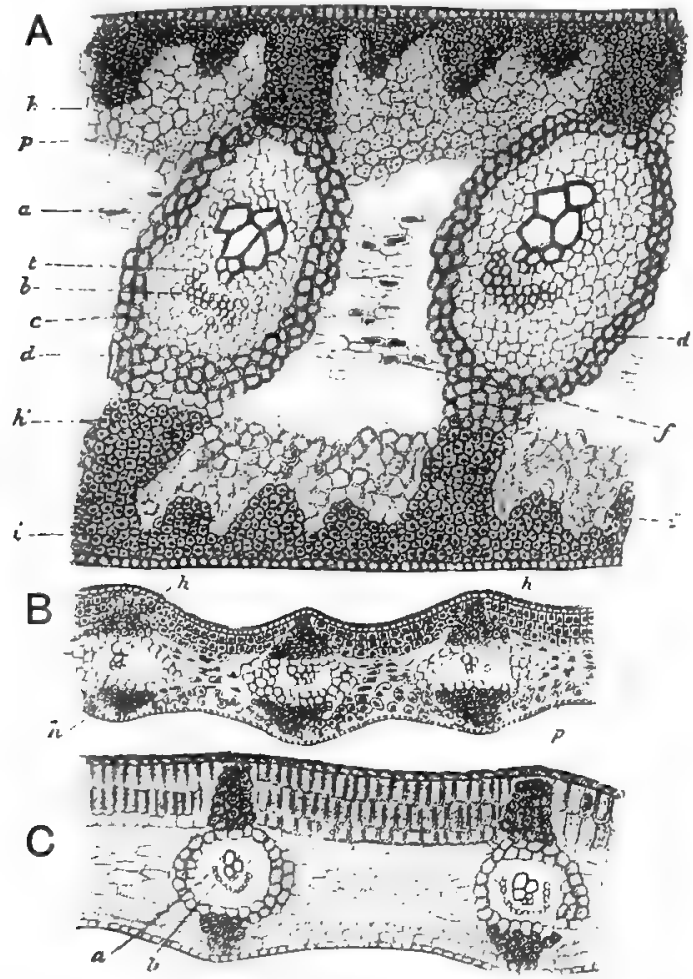

FI(, I92.-Cordaites. J.eaves in transverse section. A. C. angufosostriatus (1). $h, i$, hypodermal ribs of sclerenchyma; $p$, mesophyll; $d$, bundle-sheath ; $a$, centripetal xylem; $t$, protoxylem; $b$, centrifugal xylem; $c$, phloèm; $f$, tissue connecting the bundles. $\times 60$. B. C. Hombinowis. Here the rilss of sclerenchyma only occur in connection with the bundles; palisade-tissut and spongy parenchyma are differentiated. $\times$ 50. C. C. lingulatus. Ribs as in B; palisade-tissue well marked. $<$ 5o. All after Renault.

are interposed between the vascular bundles. The bundle-sheaths are connected together latcrally by transverse bridles of thickened cclls, which may perhaps 
be compared to the accessory transfusion-tissue which occurs in the genus Cycas. ${ }^{1}$ In this species of Cordaites, the mesophyll shows little differentiation. The most interesting point is the structure of the bundles themselves, which agree exactly with those in the leaves of recent Cycads. The xylem is in two parts, with the spiral elements $(t)$ between them. The larger portion is towards the upper surface (centripetal, $a$ ), and the smaller towards the lower surface (centrifugal, $b$ ). Below this again is the phloëm, usually ill preserved. In a word, we have in these cases (Fig. I 92, A and C) the collateral, mesarch structure, characteristic of the bundles of Cycadean leaves, and already familiar to us in other fossil plants. Some other species show the same structure of the bundles, but in several the centrifugal part of the xylem is absent, as in the petioles of Medullosa, whereas it only dies out in the finer bundles in the case of recent Cycadean leaves. ${ }^{2}$

In other anatomical points there is considerable diversity of detail. The mesophyll is in some forms clearly differentiated into an upper palisade layer, and a lower lacunar portion (see Fig. I 92, B and C). This is beautifully shown in a species investigated by Miss Stopes, and identified as C. principalis. In the same species Miss Stopes observed the very interesting fact that both the inner and outer sheaths surrounding each bundle consist of elements with bordered pits, and may

1 A reticulate system of thick-walled tracheides, which extends from the midrib to the margin of the leaflet in this genus. See Worsdell, "On Transfusion-Tissue," Trans. Lizn. Soc. 2nd ser. (Bot.), vol. v. 1897, p. 308.

2 See Miss M. C. Stopes, "On the Leaf-Structure of Cordaites," New Phytologist, vol. ii. r9o3, p. 9 I. 
thus be regarded as forms of transfusion-tissue. In certain cases the hypodermal ribs are limited to the upper and lower surfaces of the bundles, not occurring between them. In one form ( $C$. crassus) the leaf had a distinctly fleshy character, as if adapted to xerophytic life. Numerous stomata, of normal structure, occur in these leaves, on the epidermis of the lower surface, to which they seem to be limited. The general conclusion to which we are led is that, while the leaf, in its simple form and general structure, approaches most nearly to that of such Conifers as Agathis, in the details of internal organisation it agrees more closely with a single leaflet of a Cycad, thus showing a striking combination of characters, such as we have already met with in the leaf of Poroxylon.

5. The Flowers.-We now come to the most interesting point in our present subject-the floral morpho$\log y$ of the Cordaiteae. The general arrangement and external appearance of the inflorescences have already been described. Our knowledge of these organs has been built up by the labours of successive observers, notably Carruthers, Grand'Eury, and Renault. It is to the last-named author that our acquaintance with the intimate structure of the flowers is chiefly due, for M. Renault was so fortunate as to find silicified specimens, allowing of minute structural investigation, which were clearly of the same nature as the catkins found on the branches of the Cordaiteae. As, however, the petrified flowers could not be referred with certainty to the particular members of the family to which they belonged, the generic name Cordaianthus 
was applied to them, and is still used, as a matter of convenience.

\section{A. The Male Flower}

The specimen shown in longitudinal section in Fig. 193, and known as Cordaianthus Penjoni, Renault, is a single male catkin, ${ }^{1}$ corresponding to one of those which are represented in their external aspect in Fig. 188, borne laterally on the peduncles. The catkin (about a centimetre in length) consists of a rather thick axis, bearing spirally arranged bracts, between which the stamens (using the word provisionally) are inserted (Fig. I93, A). The stamens are either isolated, each in the axil of a bract, or are grouped, two or three together, around the apex of the catkin. Each stamen consists of a filament, surmounted by three, four, or more ${ }^{2}$ long, vertical pollen-sacs. The filament is traversed by a vascular bundle, which sends a branch to the base of each pollen-sac (Fig. I 93, B, g). Some of the sacs in M. Renault's specimens had already undergone dehiscence, by a longitudinal opening (Fig. I93, B,e); others are preserved intact, and are still filled with the pollen-grains $\left(e^{\prime}\right)$. The wall of each pollen-sac consists of a single layer of cells (Fig. I 93, B). In other species (e.g. C. Saportanus) the stamens are limited to the apical region of the catkin, and are fewer in number, with shorter filaments.

The morphology of these male catkins of Cordaites

1 The word catkin is used, rather than cone, to avoid any assumption of homology with the male cone of the Coniferae.

2 M. Renault gives the number as three or four, but, as pointed out by Count Solms-Laubach, the transverse section shows five or six sacs to each stamen. 
is open to various interpretations. M. Renault regards the male "flower" as consisting of a group of two or three stamens at the apex of the catkin, but as reduced to a single stamen, where the position is axillary. Count Solms-Laubach prefers to regard each
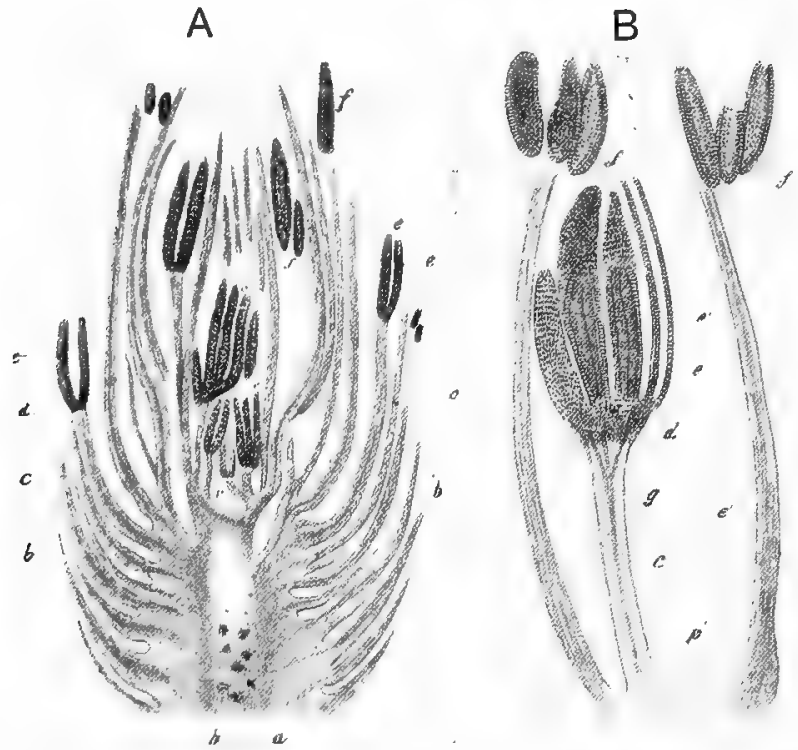

FIG. 193-Cordaianthus Pinjoni. A. Longitudinal section of male catkin. $a$, axis; $b$, sterile bracts; $c$, filament, bearing the pollen-sacs $(e)$ at the top ; $d$, junction of filament with pollen-sacs; $f$, detached pollen-sac; $\theta$, apex of axis, with stamens around it. $\times 6 \frac{1}{2}$, B. Stamens, more highly magnified. $g$, vascular bundle of filament, sending branches to the pollen-sacs; $c$, pollen-sac after dehiscence; $e^{\prime}$, sac still full of pollen; $\not$, apex of axis. Other letters as in $\mathrm{A} . \times 2_{3}$. Both after Renault.

of Renault's "stamens" as itself constituting a male "flower," the stalk on which the pollen-sacs are borne thus representing a pedicel, and not a filament, while the pollen-sacs are themselves the stamens. On this view there would be a certain resemblance to the male flowers of Gnetaceae. In Gnetum, for example, 
the male flower consists of a stalk bearing two pollensacs, each of which is considered to represent a sessile stamen. In Ephedra the arrangement is similar, but the sessile stamens vary in number, according to the species, from two to eight, and each consists of two pollen-sacs. The Gnetaceae, however, are a highly modified group, as to the geological history of which we have no certain information. We must be cautious in using their morphology (which in itself is none too clear) to explain that of an ancient family like the Cordaiteae, which is known to have existed as far back as the Devonian period. If, as has recently been suggested, the flowers of the Gnetaceae are reductions from a much more complex type like that of the Bennettiteae (see Chap. XIII.) it is clear that the family can have only the most remote affinity with the Cordaiteae. ${ }^{1}$

M. Renault's summary of the morphological conditions in the male Cordaianthus certainly has the merit of simplicity. He says:- "In the midst of sterile bracts arose one or more fertile bracts, the filament of which, scarcely modified, bore at its summit three or four sacs containing the pollen." 2 On this view, the stamens would in no case be axillary structures, but would represent so many sporophylls, interspersed among sterile bracts. We might compare each stamen to that of Ginkgo; in the latter the pollen-sacs are usually only two in number, though stamens with three or four sacs sometimes occur, and are pendulous instead

${ }^{1}$ See Arber and Parkin, "Studies on the Evolution of the Angiosperms : the Relationship of the Angiosperms to the Gnetales," Ann. of Bot, vol. xxii. July 1908, and the papers there cited.

2 Renault, Tiges de la flore carbonifère, p. 308. 
of erect; these differences, however, are of trifling importance. The male catkin of Cordaianthus would thus chiefly differ from that of Ginkgo, in the presence of sterile bracts among the sporophylls, a difference comparable to the relation which we find, in a remote family, between the strobilus of a Calamostachys and that of a recent Equisetum. The data, however, are insufficient to justify any definite conclusion as to the exact morphology of the male Cordaianthus. It is quite clear, at any rate, that its structure is totally distinct from that of the male cone of a Cycad, and very different from that of a Conifer, or from the male inflorescence of Gnetaceae. On the whole, Ginkgo affords perhaps the best parallel.

The pollen-grains of Cordaianthus were rather large, measuring, in some examples studied by M. Renault, $.09 \times .05 \mathrm{~mm}$, their form thus being ellipsoidal. The outer membrane had a rather rough surface; in the interior of the pollen-grain, a small group of cells (prothallus or antheridium) can often be detected (Fig. I 95, C), an important observation, to which we shall return, when speaking of the phenomena of pollination.

\section{B. The Female Flower}

M. Renault found that the young female catkins of Cordaites were scarcely to be distinguished from the male by external characters, though somewhat more globular in form. In the early stages, the ovules were completely hidden by the overlapping bracts. Here also, sections of the silicified specimens have revealed the internal organisation. In a fructification, to which 
the discoverer gave the name of Cordaianthus William-

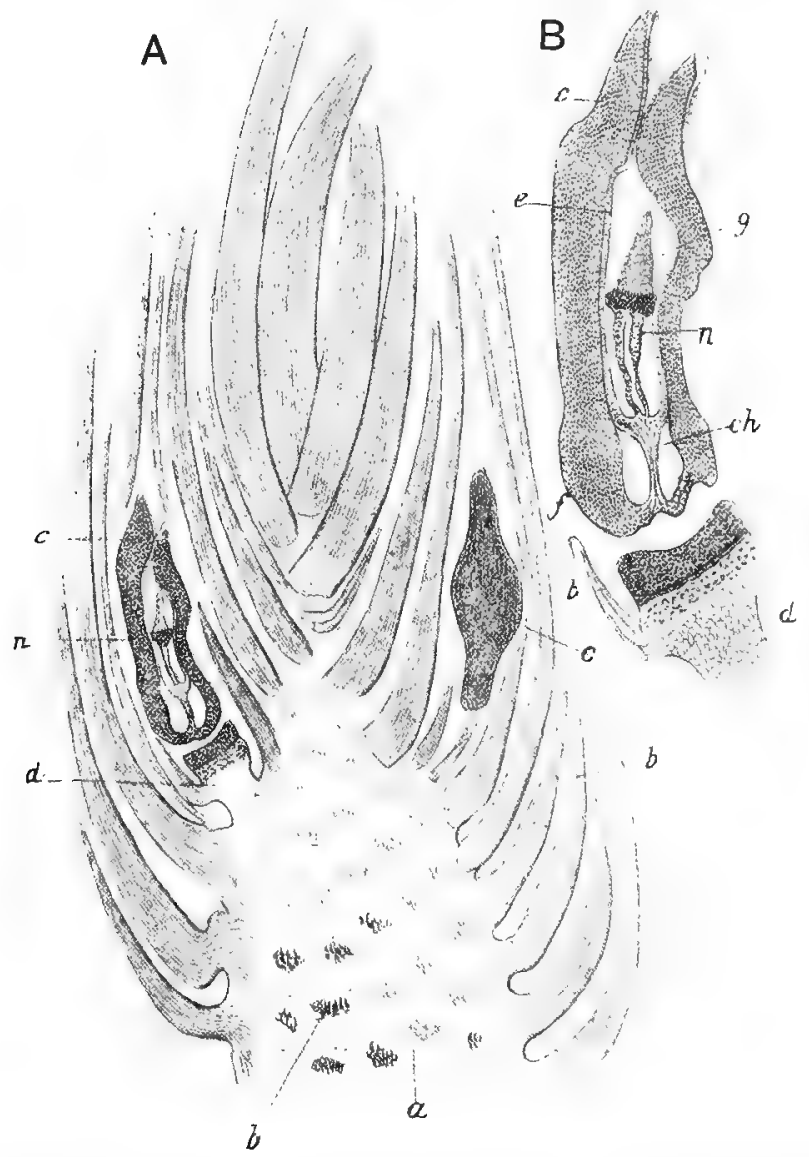

Fig. I94.-Cordaianthus Williamsoni. A. Somewhat tangential section of a female catkin, showing two ovules. $a$, axis; $b$, sterile bracts, and hudles running to them; $c$, ovules; $d$, axillary shoot, bearing an ovule; $t$, nucellus. $x$ about to. B. Ovule, more highly magnified. $d$, short axillary shoot, terminated by the ovule; $b$, bracteole; $c-f$, outer, $c$, inner integument; $c / t$, chalaza; $u$, shrivelled nucellus; $g$, apex of nucellus. $x$ about 35. After Renault.

soni (Fig. I94, A), the axis bore numerous, spirally 
disposed bracts, most of which were sterile, while in the axils of some of them the ovules $(c)$ were borne. Each ovule was situated at the end of a very short lateral axis (d), which itself bore some bracteoles; a transverse section of a similar fructification showed four ovules.

The ovule, according to M. Renault, had two integuments; the outer of the two was thick and fleshy (Fig. I94, B, c), while the inner (e) formed a delicate lining to the outer, from which it was perhaps not really distinct. At a later stage the inner layer or integument became hard and resistant, the outer remaining fleshy. In the middle was the nucellus $(g, n)$ (somewhat shrivelled in the specimen figured), the upper part of which contained the pollen-chamber. A vascular bundle entered the chalaza, and sent out branches both into the integument and the nucellus.

Further details have been worked out in a fructification, specifically distinct, named Cordaianthus Grand'Euryi by M. Renault. Here the short lateral axis, terminated by the ovule (shown detached in Fig. I95, A), bore several bracts. The outer integument is broken, and the inner has almost disappeared, leaving the nucellus nearly isolated in the middle of the ovule. In the upper part of the nucellus, we see the pollenchamber $(c . p)$, surmounted by a very curious neck, shown, on a large scale, in Fig. 195, B. Both in the pollen-chamber itself and in the canal leading to it, pollen-grains $(p)$ are contained, so that this ovule, as $M$. Renault said, was "surprised at the very moment of pollination." The wall of the canal has a characteristic structure, for the cells in its lower part are 
transversely elongated, so as to partially close the passage (Fig. I 95, B, g). Possibly this may have been an arrangement for shutting the entrance to the pollen-chamber after pollination had been effected.

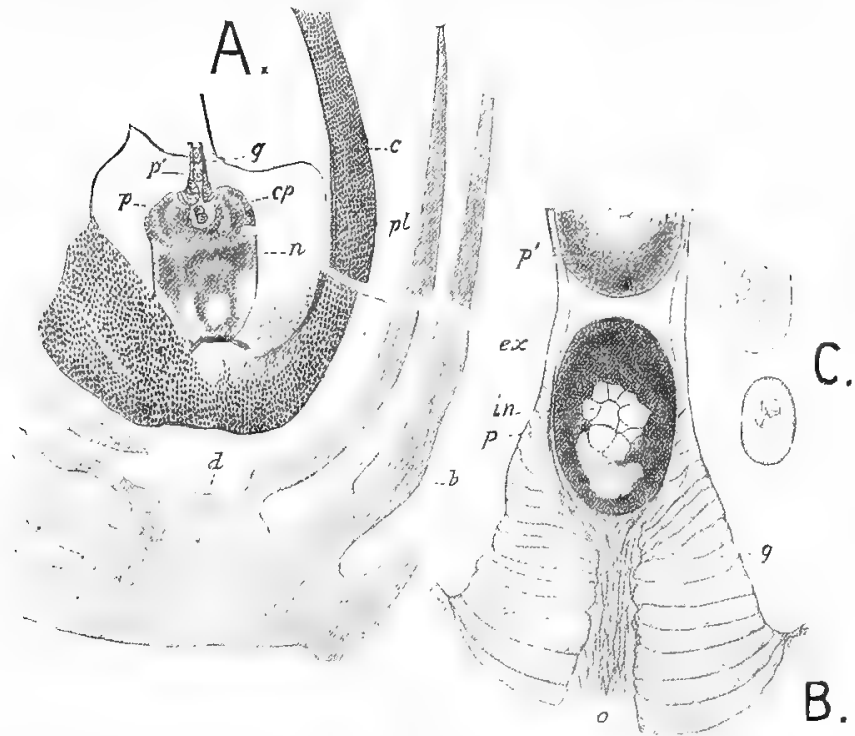

FIG. 195.-Cordaianthus Grand' Euryi. A. Longitudinal section of female flower, showing one ovule, just pollinated. $d$, axis; $b$, bracts; $c$, integument; $n$, nucellus ; $c . p$, pollen-chamber; $g$, canal of pollen-chamber; $\not p$, pollen-grains in chamber, and $p^{\prime}$, in canal. $\times 24$. B. Canal of pollen-chamber enlarged. $g$, dilated cells, enclosing the canal, $o ; \not p, \not p$, two pollen-grains in the canal; $c x$, outer membrane of pollen-grain; in, group of prothallial or antheridial cells within the grain. $\times$ I5O $_{5}$ C. Grains of pollen, showing internal cells; the smaller grain from an anther, the larger from the canal of an ovule. $\times$ about roo. All after Renault.

The pollen-chamber is, as we have already seen (Chap. X. p. 392, and Chap. XI. p.453), a general feature in Palaeozoic seeds. The pollen-chamber of Trigonocarpus, for example, among the Pteridosperms bears a rather close resemblance to that of a Cordaitean seed (see Fig. I 7o, p. 454). The Cycadaceae and Ginkgo 
are the only recent plants in which this organ is known; the pollen-chamber of Cycas was originally discovered more than sixty years ago by our countryman Griffith, who gave excellent figures of it, which are here reproduced ${ }^{\mathrm{I}}$ (Figs. I96, I97). Many years later it was rediscovered independently by De Bary

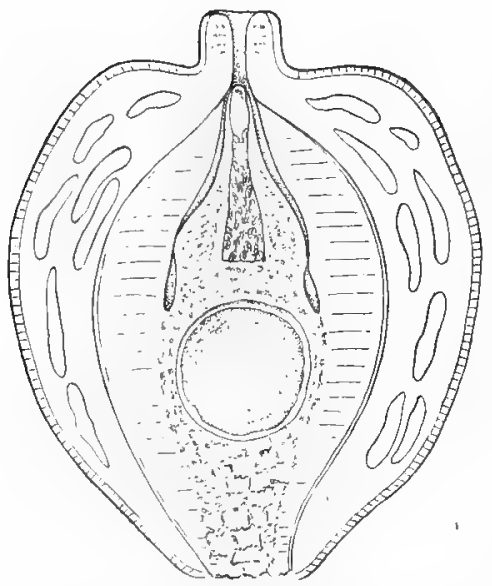

Fı. 196.-Cyeas, sp. Longitudinal section of ovule, showing the thick double-layered integument enclosing the nucellus. The round body in the lower half of the nucellus is the embryo-sac; the flask-shaped cavity in the upper part is the pollen-chamber containing pollen-grains. From Griffith, 1852.

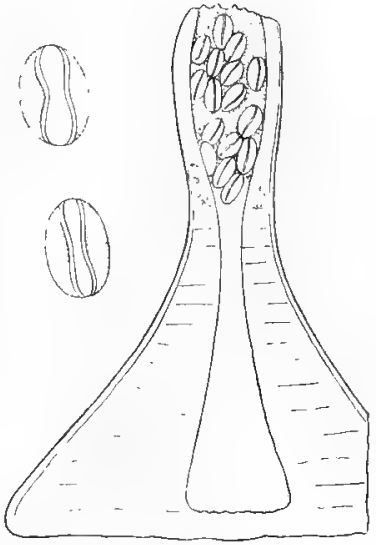

Fir. 197--Pollen-chamber enlarged, showing pollen-grains in the canal. Two pollen-grains, further enlarged, on the left. From Grifith, $185 \%$.

and Brongniart, both of whom were unaware of Griffith's observations.

The pollen-grains in the canal and pollen-chamber of the ovule of Cordaites are larger than those still contained in the anther, and their internal group of cells

1 Griffith, Icones Plant. Asiat. Part iv, Pl. 377 and 378, 1852. Notulae ad Plant. Asiat. pp. 6-8, 1854. Both these works were posthumous; Griffith died in 1846 . 
is more developed (Fig. I95, C) ; grains, which were found lying free in the matrix, were in an intermediate condition; M. Renault drew the conclusion, that the pollen-grains continued to grow after their discharge from the anther, and more especially after their entrance into the pollen-chamber.

The cells within the pollen-grain of Cordaites are more numerous than in most recent Gymnosperms ; in the pollen-tube of Microcycas, however, described by Caldwell, sixteen spermatozoids are produced, while in that of Araucaria the number of nuclei present ranges from about twenty to forty-four. ${ }^{2}$ In the pollen-grains of Cordaites, as M. Renault pointed out, the cells appear to have been all of one kind. That this structure, whether it be regarded as a prothallus or as an antheridium, should have been more developed in primæval seed-plants than is usual in those of our day, is quite what we should expect, from our knowledge of the conditions in the heterosporous Cryptogams. ${ }^{3}$

Pollen-grains have now been observed, in a number of instances, within the pollen-chambers of Pteridospermous and Gymnospermous seeds of the Carboniferous period. There appears to be little or no evidence at present for the formation of pollen-tubes, though the preservation is sometimes good enough for even so delicate a structure to have been detected. It is probable that such pollen-grains as those of Cordaites or Stephanospermum may have been a stage nearer the Cryptogamic microspore than those of Cycas or Ginkgo,

1 "Microcyias calocoma," Bot. Gazette, vol. xliv. 1907, p. I18.

2 Lopriore, "Über die Vielkernigkeit der Pollenkörner von Araucaria Bidwillit," Ber. d. Deutsch. Bot. Gesellschaft. vol. xxiii. 1905, p. 335.

${ }^{3}$ See the account of Stephanospermum above, p. 456 . 
that no pollen-tube was developed, but that the relatively large antheridium at once produced a number of spermatozoids, for we are probably justified in regarding the cellular body within the pollen-grain of Cordaites as an antheridium, rather than as a vegetative prothallus. In the absence of a pollen-tube, the spermatozoids would have needed to be more numerous, for, having a longer distance to cover by their own movements, they would presumably have reached their goal with less certainty. The pollen-tube may probably be regarded as a later adaptation, which served the purpose of economising spermatozoids, and ultimately rendered their motility unnecessary. Even in the Cycads and Ginkgo, where the pollen-tube serves mainly as an anchoring and food-absorbing organ, its growth ultimately brings the spcrmatozoids with much precision to their goal-the necks of the archegonia. ${ }^{1}$

As regards the morphology of the female Cordaianthus, there seems no reason to doubt M. Renault's view, that the ovules were borne singly, on the apex of short axillary shoots, as in Taxus. If we compared the female catkin with a cone, such as that of the Abietineae or Taxodieae among recent Conifers, we should be led to adopt one of the theories which interpret the seminiferous scale in those families as representing a reduced axillary shoot. Other authors have preferred the comparison with Gnetaceae, and especially with Ephedra, chiefly on the ground of the double integument or envelope of the ovule. It does not seem to be perfectly certain, however, that this structure in Cordaites was

1 See, for example, Webber, Spermatogenesis and Fenundation of Zania, U.S. Dept. of Agriculture, I 90 I, p. 63. 
really double at its origin, and the analogy with Gnetaceae appears to be of little value. A comparison with the female fructification of Ginkgo has been suggested, and on general grounds would seem justified, but the homologies of the parts have not been clearly determined. However this may be, it appears evident that, in the case of the female flower, the indications of affinity point towards Coniferae or Ginkgoaceae, rather than towards Cycadaceae, to which, so far as the floral morphology is concerned, the Cordaiteae seem to bear little resemblance. We must, however, remember that our living Cycads only represent one or two special surviving groups of a Class once infinitely more extensive and varied. The possibility of a comparison between the floral structure of the Cordaiteae and that of certain Mesozoic Cycadophyta (the Bennettiteae) has been maintained by some botanists, but no longer appears tenable (see Chap. XIII.).

6. The Seeds.-In some cases seeds, in a more or less ripe state, have been found attached to the inflorescence, and in connection with the leafy twigs of Cordaiteae. These seeds sometimes appear to have been solitary, a single seed representing the female catkin as found in the younger specimens of such fructifications as Cordaianthus Williamsoni. This may indicate a real morphological difference, like that between Taxus or even Ginkgoaceae and the Coniferae with true cones, but it may be equally well explained if we suppose that only one ovule in each catkin developed into a ripe seed. In some specimens, as in Cordaianthus anomalus, Carruthers, each seed 
was seated on a long slender stalk or peduncle; ${ }^{1}$ this may have been developed during the ripening of the seed. Our knowledge of the comparative morphology of the Cordaiteae has unfortunately made little progress in recent years, owing to the want of adequate material.

In certain cases, characteristic heart-shaped seeds have been found in connection with the inflorescences of Cordaites. This has rendered it possible to identify, with great probability, a certain number of the isolated seeds, as belonging to this family. Such direct evidence is very necessary, for, as we have already seen (Chaps. X. and XI.), a large number of the Palæozoic seeds belonged to Pteridospermeae, and, where they were of the platyspermic type, may be extremely difficult to distinguish from those of Cordaiteae. It is also probable that the seeds of primitive Coniferae and Cycadophyta (both of which groups already existed, at least in the later Palæozoic times) may be represented among the detached seeds. We will first describe that type of seed which is known, from the evidence of attached specimens, to have been produced by the Cordaiteae, and was therefore named Cordaicarpus by M. Renault. ${ }^{2}$

These seeds are heart-shaped at the base, and somewhat flattened, being of the platyspermic type. The testa is double, the outer envelope, or sarcotesta, having been soft and fleshy during life, while the inner layer,

1 Carruthers, "Notes on some Fossil Plants," Geol. Mag. vol. ix. I872.

2 These seeds were originally named Cardiocarpus by Brongniart, a name used by Carruthers and Williamson in the form Cardiocarpon. As pointed out in Vol. I. Chapter VI. (p. I94), certain "seeds" referred by Williamson to Cardiocarpon really belonged to Lycopods and are now named Lepidocarpon. 
or sclerotesta, was hard and lignified. M. Renault regarded the two layers of the testa as having been derived from two integuments, a view which he believed to be supported by the structure of the ovule, as above described. There is, in fact, the same doubt here as in the case of recent Cycadaceous seeds, in which some botanists regard the double testa as representing two integuments, while others consider that a single integument has undergone differentiation into distinct layers.

The vascular bundle which enters the chalaza gives off branches, both into the testa and into the nucellus; the former traverse the inner part of the sarcotesta, a single or double bundle running up on each side of the seed, just outside the lateral edges of the sclerotesta (cf. Rhabdocarpus, Fig. I 85), while the latter enter the nucellus and apply themselves to the membrane of the embryo-sac. At its micropylar end, the nucellus, which was probably free from the integument, contains a pollen-chamber, provided with a neck, which projects into the micropyle. Apart from its bilateral symmetry, the seed agrees very nearly in structure with the Trigonocarpus type, described on p. 452. In certain species of Cordaicarpus the archegonia have been found. They occur in the usual position, at the upper end of the endosperm, and two of them are shown in a longitudinal section of the seed.

Our illustration, Fig. I98, is from a seed which M. Renault separated generically from Cordaicarpus, on account of the distribution of the vascular bundles. In Cycadinocarpus, as the new genus is named, the inner vascular system follows the endotesta, and does 
not enter the nucellus, a course which resembles that in the seeds of recent Cycads, as interpreted by many observers. In other respects the seed agrees with Cordaicarpus. Two archegonia (or), spherical in form, are clearly shown; between them, the endosperm has an upward prolongation, which is interesting, as it exactly corresponds to the structure found in Ginkgo at the present day, and compared by Hirase to a

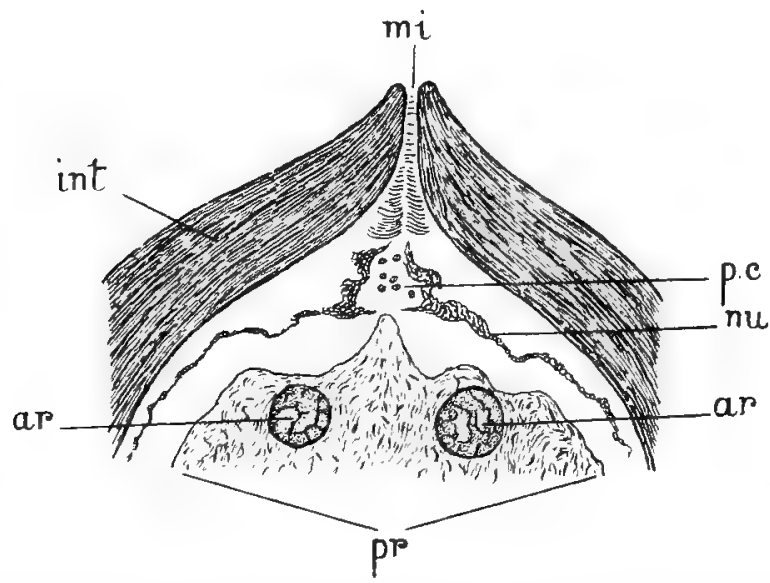

FIG. 198.-Cycadinocarpus augustolunensis. Upper part of seed, in longitudinal section,

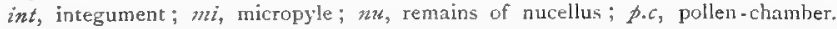
containing pollen-grains; the chamber has a long neck or canal, extending up into the micropyle; pr, endosperm; ar, archegonia. Magnified. After Renault.

tent-pole, supporting the nucellar membrane, which represents the tent. The pollen-chamber (pc.), with its long neck rising up into the micropyle ( $m i$; cf. Figs. I 96 and 197), contains pollen-grains. Only the sclerotesta (int) of the seed is shown in the figure.

Although so many Pteridospermous and Gymnospermous sceds have been discovered in the Carboniferous formation, and often in a wonderful state of 
preservation, no embryo has, as yet, been found in any of them. The possible explanation of this fact has been discussed in connection with the seed of Lyginodendron (see Chap. X. p. 393).

The investigation of the Palæozoic seeds, which was allowed to rest for some time after the classical researches of Brongniart, Renault, and Williamson, is now again being actively pursued, having been greatly stimulated by the discovery of the seeds of the Pteridosperms.

7. Affinities. - We have now completed our sketch of the principal characters of the Cordaiteaè, and may briefly sum up the conclusions to which we are led.

In their vegetative characters, the Cordaiteae hold the balance very evenly between Cycads and Conifers, while at the same time showing much that is peculiar to themselves. The structure of stem and root is, on the whole, very near that of the Coniferae; the secondary wood especially would by itself rouse no suspicions that we had anything but an Araucarian Conifer before us. The large size of the pith in the stem, however, is unlike anything known in Coniferae, and rather suggestive of a Cycad, though in its peculiar discoid structure the pith of some Cordaiteae is quite different from that of Cycads.

The double leaf-trace is a striking point of agreement with Ginkgo on the one hand, and with certain of the Pteridosperms on the other; Poroxyleae form a connecting link with the latter in this respect.

The wood of the stem was wholly centrifugal in development, in many of the specimens investigated 
belonging to undoubted Cordaiteae; but this distinction is no longer absolute, for, as we have seen, there are stems, apparently of true Cordaiteae, in which some centripetal wood is present, as it is in the Poroxyleae and Pityeae. In fact, on our present knowledge it is impossible to draw any sharp distinction between these three families, and we have therefore grouped them under the common name Cordaitales. If the seeds of Poroxylon are represented, as M. Grand'Eury believes, by Rhabdocarpus, the very close affinity of this family to true Cordaiteae is further confirmed.

The leaves, in their general form and venation, recall those of such Coniferae as Agathis, though often greatly exceeding those of any known Conifer in size. ${ }^{1}$ In internal structure the leaves agree almost exactly with the single pinnae of the leaf in Cycads.

In general habit, the lofty stem, with well-marked internodes, departs altogether from the ordinary Cycadean type, and much more resembles that of a Conifer, but, in many species, at any rate, the crown, with its abundance of huge simple leaves, must have presented an appearance totally unlike anything in either of the recent families.

It is to the reproductive organs-the male and female fructifications and the seeds-that we naturally attach the chief importance in considering the affinities of the Order. It is just in these organs, however, that we find the most remarkable combination of characters, both such as are common to various other families and such as are altogether peculiar to the

1 In Agathis macrophylla, from the Queen Charlotte Islands, the leaves attain a length of $17 \mathrm{~cm}$., and a breadth of $5 \mathrm{~cm}$. Seward and Ford, "The Araucarieae," Phil. Trans. Royal Soc. B3, vol. 198, 1906, p. 315 . 
fossil group. The staminiferous flowers (however we may interpret them) are very different from anything known to us, either in the Cycadaceae or the true Coniferae. A comparison, though in either case a remote one, is possible with the Gnetaceae (Gnetum or Ephedra), on the one hand, or with Ginkgo, on the other. On the former alternative, we should have to regard the stalked tuft of pollen-sacs as representing an axis, bearing sessile anthers; on the latter, we should interpret it as a single sporophyll, with terminal microsporangia. The latter view is the simpler, and the analogy with Ginkgo, in many respects a primitive type, is more valuable than that with the highly specialised Gnetaceae. On any view, however, the organisation of the male flower of Cordaiteae is quite peculiar, and unlike that in other Gymnosperms, and even if it stood alone, would serve to mark them as a distinct Order.

The female strobilus, like the male, is as remote as possible from that of the Cycads, but agrees well enough with the cone of the Coniferae, if we adopt the view that in the latter the ovule is borne on an axillary shoot, more or less modified. This, in fact, seems, provisionally, quitc a tenable view, for on this supposition we should have the ancient Cordaiteae showing, in its simplest form, an arrangement which became much modified and disguised in the more recent Order, Coniferae. ${ }^{1}$ At the same time it must be admitted that the true relation of the Cordaiteae to the Coniferae is still an open question (Chap. XIV.). The

1 For a summary of the various views as to the morphology of the female cone in Coniferae, see Worsclell, Annals of Botany, March 1900. 
affinity with Ginkgoaceae, which in many respects also hold an intermediate position between Cycadophyta and Coniferae, appears the strongest from every point of view.

The comparison of the female inflorescence with that of the Gnetaceae seems to rest on a very weak basis. It is not proved beyond doubt that the ovule of Cordaiteae had two integuments, still less is there any indication that the two w'ere of a different morphological nature, as appears to be the case in Gnetaceae. It is probable that the affinities of the Gnetaceae may lie in quite a different direction, namely, in that of the Mesozoic Bennettiteae (see Chap. XIII.).

The structure of the seeds which are known to have belonged to Cordaiteae, is altogether Cycadean, and, as we have seen, even minute details, such as the form of the pollen-chamber, can be exactly paralleled among recent Cycads. These facts, together with the foliar structure, appear to prove conclusively a real affinity between the two families, though in other respects they diverged widely from one another. But just in the points where there is a strong agreement with Cycadaceae (with Bennettiteac the relation, as regards the seed-structure, is much less close) the Pteridosperms are likewise approached. The anatomical characters, together with the seed-characters and those of the multicellular pollen-grain, show such manifest correspondence that there can scarcely be a doubt that Cordaiteae sprang from the same stock with Pteridosperms, though at a very remote period. The characters which they share with the Cycadophyta 
may be due to their common origin rather than to a direct connection in later periods.

Returning for a moment to the anatomical characters, it may be pointed out that the general structure of the leaf in Cordaiteae agrees so closely in essential points with that of Poroxylon, that we can scarcely doubt that the two groups were nearly allied. Poroxylon retained centripetal wood in the stem, a primitive character which some of the Cordaiteae had lost. The Poroxyleae appear thus to combine the characters of Lyginodendreae or Calamopityeae with those of Cordaiteae, though their horizon is too late for us to regard this family as an actual link with the Pteridosperms. The Pityeac belong to the earliest Carboniferous times, but, to judge from the few characters available for investigation, were already far advanced on the Cordaitean line of descent.

The affinities of the Cordaiteae and of the Cordaitales generally are, as we have seen, extraordinarily complex, and cannot be cleared up until our data are much more extensive than at present. The great step which has been made in the last few years is the full confirmation of the affinity between Cordaitales and the Pteridosperms, which the discovery of the seeds of the latter class has afforded. The relations to Cycadophyta, Ginkgoaceae, and Coniferae have long been recognised, and thus a strong presumption is established that the whole of the Gymnosperms sprang originally from the same ancient stock of Fern-like plants (see Chap. XIV.). 


\section{CHAPTER XIII}

THE MESOZOIC GYMNOSPERMS

\section{Cycadophyta}

OUR studies have so far been almost entirely limited to plants of Palæozoic age; in order to carry out our plan of directing attention to discoveries of fundamental botanical importance, we have now to give an acçount of the Mesozoic Cycadophyta, a group among which some of the greatest triumphs of Palæobotany have been won.

From the Trias onwards to the Lower Cretaceous, the Mesozoic vegetation maintained, on the whole, a very uniform character, widely different from that of the preceding Palæozoic period. Throughout the earlier Mesozoic ages true Ferns were abundant, more so, no doubt, than in the preceding period; Conifers, often much resembling recent types, had become a dominant group, and the family now represented solely by the Maidenhair tree (Ginkgo) was of considerable importance. The most striking feature of the vegetation, however, in all parts of the world, was the abundance of plants belonging to the same great class with the recent Cycadaceae, now so 
limited a group. The Cycadophyta, in fact, were as characteristic of Mesozoic vegetation as are the Dicotyledons of our present Flora. Among the commonest remains are leaves, which in many cases closely simulate those of existing Cycadaceous genera, and have hence received the names Zamites, Dioonites, and Cycadites. These generic resemblances, however, are usually deceptive; the Zamites and Dioonites leaves are now known to have belonged to plants which had only a somewhat distant affinity with the Order Cycadaceae, while in certain leaves once referred to Cycadites, or even to Cycas itself, the similarity to those of the recent genus has proved to be illusory (see below, p. 595). In other leaf-genera, again, such as Otozamites and Anomozamites, the foliage, while of a Cycadean type, differs evidently from that of any of the existing genera. ${ }^{1}$

In addition to the leaves, fossil trunks, which present the external characters of Cycadean stems, are of common occurrence in the older Secondary rocks, as, for instance, in the Wealden of Sussex and in the well-known "dirt-bed" of the Lower Purbeck strata in the Isle of Portland, and at other places along the Dorsetshire coast. The stems are usually short, though they may appear shorter than they actually were, owing to pressure of the superincumbent strata. The surface is usually covered by the closelyset bases of the leaves; the upper end of the stem is commonly hollowed out, owing to the decay of the growing apex. "Fossil crows' nests" is the name by

1 Numerous figures of the leaves of Mesozoic Cycadophyta will be found in Seward's Catalogue of the Mesozoic Plants in the Department of Geology, British Museum, Parts ii.-iv. 1895-1904. 
which such specimens are known to the Portland quarrymen. In certain trunks from the Sussex Wealden, named Bucklandia by Mr. Carruthers, an alternation of the scars of foliage and scale leaves has been traced, such as is found in Cycas at the present day. In some cases the stems attained a more considerable height, as in the Cycadeoidea gigantea of Seward, a fine specimen of which, almost 4 feet high, with a girth of $3 \frac{1}{2}$ feet, was found some years ago in the Isle of Portland, and is now set up in the Geological Department of the British Museum. ${ }^{1}$ In favourable cases the Cycad-like stems are completely silicified, and their structure preserved with wonderful perfection. A number of important specimens of this nature, referred to many species, have been found in our own country, France, Italy, and other parts of Europe, but the United States of America are far richer than any other country in such material. No less than sixty species of silicified trunks of Cycadophyta have already been described from the Mesozoic of North America, ranging in age from the Upper Triassic to the Lower Cretaceous. In the Eastern States the Potomac beds of Maryland (approximately of Wealden age) have yielded seven species, but the richest localities are in the West, on the Rim of the Black Hills of Dakota and the Freezeout Hills of Wyoming; from the Upper Jurassic and Lower Cretaceous beds of these districts forty-nine species have been obtained. The specimens are very numerous; thus the twenty-nine species from the Black Hills of

1 Seward, "On Cyiadeoidea gigantea, a New Cycarlean Stem from the Purbeck Beds of Portland," Quarterly Journal of the Geol. Soc. vol. liii. 1897 . 
South Dakota are represented by nearly Iooo, more or less complete trunks. ${ }^{1}$ The Cycadophyta of the American Mesozoic rival in palæontological value the

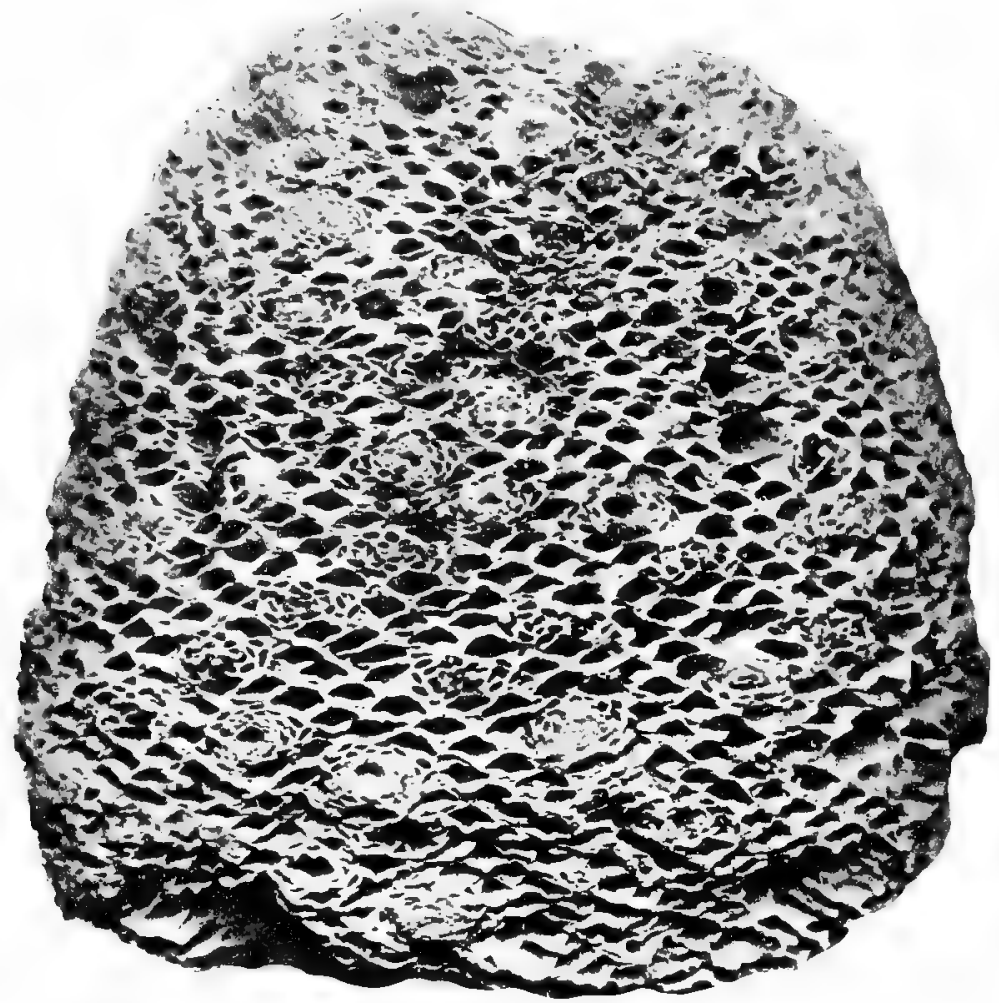

FIG. I99--Cycatioidea marylandica.-The earliest described American fossil Cycad. From an original daguerrotype. Nearly thirty young fruits are marked in the present view by the groups of bract-scars interpolated between the old leaf-bases. About natural size, From Wieland.

gigantic Saurian animals, with the remains of which they are often associated. Fig. I 99 represents the 1 See Wicland, American Fossil Cycads, Carnegie Institution, Washington, I906, and the systematic works by Lester Ward, there cited. 
trunk of Cycadeoidea marylandica, the first American Cycad to be discovered; it was found about the year I 860, between Baltimore and Washington, by the geologist Philip Tyson. Many years elapsed before any further discoveries were made; it was not till I 893 that additional specimens came to light in Maryland and that the rich deposits of the Black Hills of Dakota began to be explored.

The vast majority of the Mesozoic Cycadophyta at present investigated differ essentially from the existing Order Cycadaceae, and have been grouped under the family name Bennettiteae or Cycadeoideae.

I. BENNETTITEAE.-In a great number of cases, fructifications have been found in association, or, more often, in actual connection, with the stems of Cycadophyta, and it is only in the rarest instances that these fructifications have proved to be of the Cycadean type, as known to us from its recent representatives. In an overwhelming majority of the fructifications belonging to the Mesozoic Cycadophyta (using that form of name, as suggested by Professor Nathorst, to indicate a group enormously wider than our recent Cycadaceae), the structure of the organs of reproduction is found to have been totally different from anything known in the recent Order, and of a far more highly differentiated type. The main purpose of the present chapter is to give some account of these plants, which formed the dominant group of Cycadophyta in the Mesozoic period.

The family in question is that of the Bennettiteae, so named from the type-genus Bennettites, founded by $\mathrm{Mr}$. 
Carruthers in 1868 , for several species, ranging from the Middle Oolite to the Lower Greensand. The characters of the genus were thus given by the author in his classic memoir:- "Trunk ovoid, in transverse section elliptical, covered with the somewhat long permanent bases of the petioles. Medulla entirely cellular, with numerous gum-canals. Wood consisting of a thin interrupted cylinder of striated tissue, everywhere penetrated by medullary rays. Fruits borne on secondary axes, not protruding beyond the bases of the petioles." 1

The elliptical transverse section of the stem has not proved to be valid as a generic or even a specific character, but on the whole the short description just quoted still holds good. The American palæobotanists use Buckland's generic name Cycadeoidea in preference to Bennettites.

The following account is based in the first instance on the observations of Carruthers (who laid the foundation of our knowledge of the group), SolmsLaubach, Lignier, and others, confirmed, as regards the fructification of Bennettites Gibsonianus, by a study of the original preparations. The still more important results obtained from the investigation of the American material by Dr. Wieland have in some respects profoundly modified our conception of the group, and will be considered in due course.

In external aspect, the stems of the Bennettiteae presented the same general appearance as those of the recent Cycads in which the stem remains clothed in an

1 Carruthers, "On Fossil Cycadean Stems from the Secondary Rocks of Britain," Trans. Linnean Soc. vol, xxvi. I87o. 
armour of persistent leaf-bases (sec Fig. 200, B). The dimensions were also of the same order. The stem of

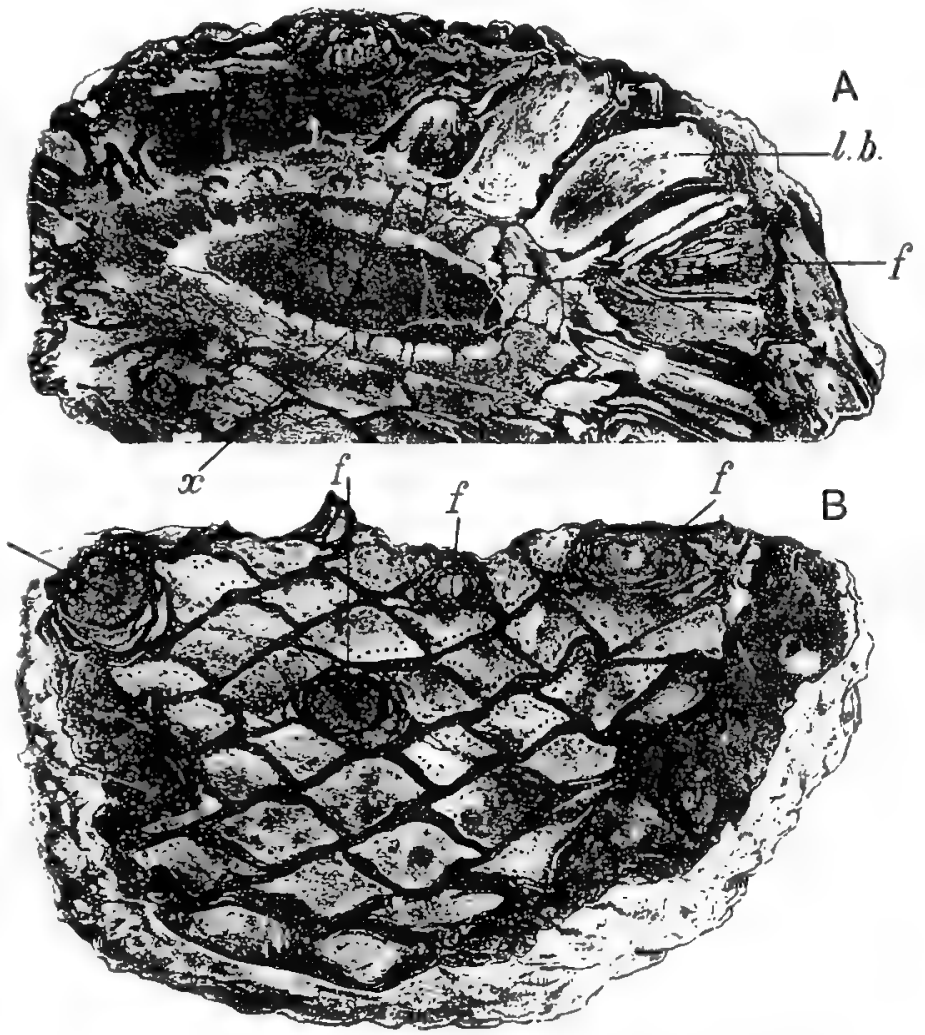

FIG. 200.-Bennetite's Gibsonianus. A. Stem in tranverse section, showing the ring of wood, $x$, surrounding the large pith, the leaf.bases, 1.6. , completely covering the surface, and a fructification, $f$, seen in longitudinal section, hetween the leaf-bases. B. Stem in tangential section, through the armour of leaf-hases, the vascular bundles in which are shown. Several fructifications, $f$, are seen, in transverse section. Both reduced. From the Linnean Soc. Trans. After Carruthers

B. Gibsoniumus, shown in Fig. 200, from Mr. Carruthers' paper, attained a maximum diameter of 1 I inches; a 
considerable part of this diameter was made up of the persistent leaf-bases, as shown in the figure. The American species Cycadeoidea marylandica, represented in Fig. I 99, was of larger dimensions, and may serve as a typical example of the external characters of the family. The great feature in which these stems differ, even in outward aspect, from those of any recent Cycads, is the presence of numerous short lateral oranches, resembling large buds, which are wedged in here and there between the bases of the leaves (Figs. I 99, 200, $f$ ). These lateral appendages are the fructifications, one of which is shown in Fig. 200, A, in longitudinal section, inserted by a short stalk on the stem, and lying horizontally between the bases of the leaves. It is probable that the position of the fructifications was axillary; in any case they were lateral branches, and cannot have been terminal on the main axis, thus differing in position from the cones of living Cycads. Hence, the fertile stem of Bennettites appears' to have had a monopodial, and not, as in the recent Order, a sympodial construction.

The main features in the anatomy of the stem were worked out by Carruthers, whose conclusions have been confirmed by the work of later investigators. The structure is shown with special clearness in Bennettites Saxbyanus, a species from the Wealden beds of Brook Point, in the Isle of Wight (see Fig. 2OI). The large pith is surrounded by a ring of wood and bast, of no great thickness, built up as in normal Gymnospermous stems, of anastomosing vascular bundles with collateral structure. The histological details of both wood and bast (which have more recently been minutely studied 
by Count Solms-Laubach in an Italian species, and by Dr. Wieland in the American material) agree precisely with the corresponding structures in a recent Cycad. .

It is only when we come to the course of the bundles passing out to the leaves, that important differences

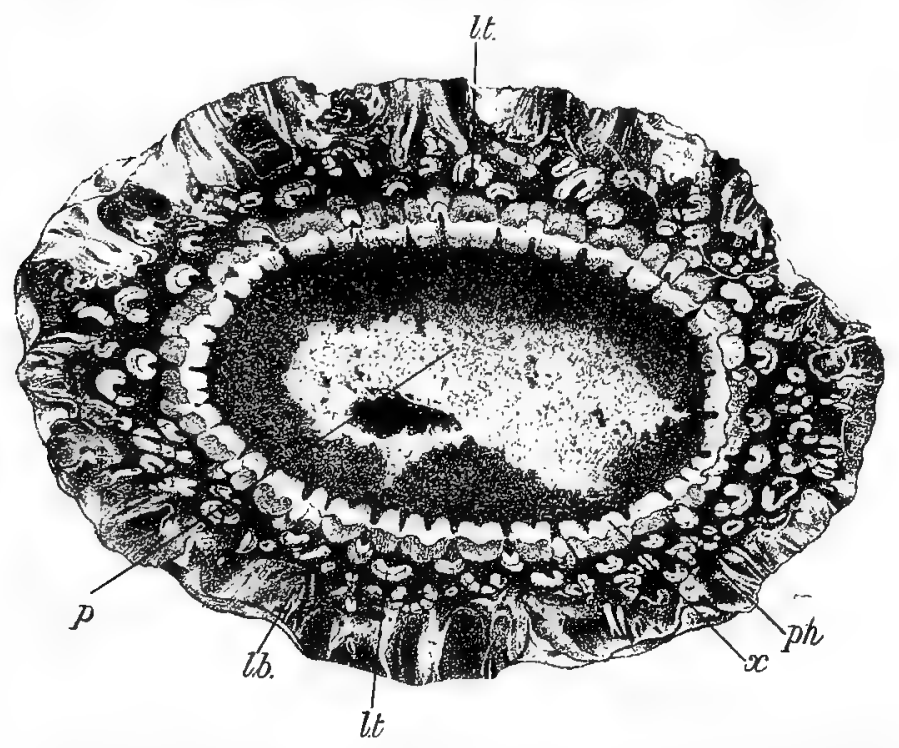

FiG. 2or.-Bemnettites Sirxbyanus. - Transverse section of stem. $p$, pith; $x$, wood, $p 7 l$, phloëm, together constituting a ring of collateral bundles; $\ell . t$., leaf-trace bundles, passing out through the cortex, and subdividing repeatedly; l.b., bases of leaves, which clothe the stem. Reduced. From the Linnean Soc. Trans. After Carruthers.

show themselves. In recent Cycads, as is well known to the botanical student, the course of the leaf-traces is peculiar and characteristic. To supply each leaf, two bundles leave the stele; they start near together, and, curving in opposite directions, pass nearly half way round the stem, thus entering the leaf-base on the opposite side from their starting-points. They then 
subdivide, to form the numerous bundles of the petiole. In their course through the cortex, the outgoing bundles are connected by cross-branches with one another, as well as with other leaf-traces, and with the bundles of the primary ring. ${ }^{1}$

In Bennettites the arrangement is a far simpler one. A single bundle leaves the ring, starting from the lower angle of one of the meshes, which (as shown in tangential section) are occupied by the primary medullary rays. As the leaf-trace passes out through the cortex, it assumes a horse-shoe form, with the concave side inwards. It then brealis up by successive subdivisions into a number of smaller bundles, which cnter the base of the leaf (see Fig. $20 \mathrm{I}$, l.t.).

In the petiole, the vascular bundles arrange themselves in an almost closed curve, slightly open and involuted towards the upper surface, as is well shown in tangential sections passing through the armour of leaf-bases see (Fig. 200, B).

In some Bennettiteae, as, for example, in the species B. Peachianus, from the Middle Oolite of Sutherland, the pith contains several isolated rings of differentiated tissue, which at first sight suggest medullary vascular strands, and were at one time erroneously compared with the central steles or "star-rings" of the Permian Medulloseae. $^{2} \quad$ More recent observations leave no doubt that the medullary rings occurring in Bennettites

I See De Bary, Comparative Anatomy of Phanerogams and Ferns, English edition, 1. 608 .

2 See above, Chapter XI. p. 44I. The statement, to this effect, in Solms-Laubach's Fossil Balany, p. 98, was corrected by him in his joint work with Capellini, on the trunks of Italian Rennettitere, Mem. $\mathbb{R}$. Accad. Sci. Bologna, vol. ii. Isgr. 
have nothing to do with the vascular system, and consist merely of bands of internal periderm, an abnormal condition which is often met with in the stems of recent Cycads.

We see, then, that the structure of the Bennettiteae, so far as it is at present known, was a simple monostelic one, resembling in its main features that of the less complex Cycads now living, but differing from any existing Cycads in the simpler course of the bundles supplying the leaves. In this latter point, the Bennettitean stem has been compared by Solms-Laubach with the peduncle of recent Cycads, an organ which in other points also appears to show a more primitive anatomy than that of the vegetative stem. ${ }^{1}$

In Cycadeoidea Jenneyana, one of the Dakota trunks, there is some evidence for the presence of numerous successive zones of wood and bast, as in the recent Cycas and Macrozamia, but the point is not yet settled."

In $B$. Gibsonianus, the vascular bundles of the leafbases are beautifully preserved, and show essentially the same structure as the foliar bundles of the recent Cycadaceae. They are of the collateral mesarch type, whereas those of the stem are endarch; the centripetal wood forms a mass of large elements, with a band of the radially arranged tracheae of the centrifugal wood on the outside. The same structure is found in various Ámerican species, but in Cycadeoidea micromyela, a French species probably of Liassic age, centripetal wood appears to be entircly absent. ${ }^{3}$ The detailed

1 See Chapter X. p. 366.

2 Wieland, American Fossil Cycads, p. 79.

3 Lignier, "Tégétaux foss. de Normandie, III. Cycadeoidea micromyela," Alem. Soc. Linn. de Nornandie, t. xx. Igor. 
structure of the xylem in the bundles of Bennettiteae still needs further investigation. Beyond the wood is the phloëm, often fairly preserved, and the outer edge of the bundle is occupied by a group of bastfibres.

The parenchymatous tissue, both of the stem and leaf-bases, abounds in large gum-canals, the contents of which have often become fossilised. These organs closely resemble the similar secretory passages in recent Cycads.

Between the leaf-bases, and around the fructifications and their bracts, the spaces are densely packed with multicellular hairs, very different from anything known in Cycadaceae, but closely resembling the ramenta of Ferns. The hairs are scale-like structures, one cell thick near the margin, but reaching a thickness of from two to five cells in their middle part (see Fig. 203, B). The cells of which they are composed attain a great length in the longitudinal direction of the ramentum. The ramenta are borne both on the leaf-bases and on the bracts, which, as we shall see, envelop the fructification. The Fern-like character presented by the ramenta is a surprising feature in a genus so far advanced in Phanerogamic organisation as Bennettites.

We now come to the consideration of the fructifications themselves, and in approaching this subject we must divest our minds of all preconceptions drawn from a knowledge of existing Cycadean cones. The reproductive organs of the Bennettiteae are wholly different in organisation, both from the cones which characterise the majority of recent Cycadaceae, and from the rosette 
of leaf-like carpels which forms the female flower in the genus Cycas.

The following description of the fructification is based, in the first instance, on the species Bennettites Gibsonianus ${ }^{1}$ of Carruthers. In this species only the female organs are known, but, as we shall see later, the investigation of the American material has proved that in most cases, and possibly in all, the fructification was hermaphrodite. We have already learnt that each fructification is a lateral appendage, seated by a short stalk on the main stem. The whole fruit is somewhat pear-shaped, and about 5 centim. in extreme length. Although fully ripe in the specimens investigated, as shown by the condition of the seeds, the fruit is completely enclosed in imbricated bracts, which spring from the stalk, and close in over the apex (see diagram, Fig. 203, A, and Fig. 202).

The stalk is expanded into a hemispherical receptacle, on which all the organs of the fruit are inserted. From the convex surface of the receptacle spring a great number of slender pedicels, which pass vertically upwards, or diverge slightly towards the curved surface of the fruit. Each of these pedicels bears at its end a single erect seed, with the micropyle directed outwards (see Fig. 202, and diagram, Fig. 203, A). The seeds are so placed that their micropyles meet the surface of the fruit approximately at a right angle.

The spaces between the pedicels are packed with

1 The original specimen of this magnificent fossil was found by Mr. T. F. Gibson in 1856 or 1857 in the Lower Greensand at Luccomb Chine, in the Isle of Wight. I'art of the specimen is now at Kew, and part at the British Museum (Natural Iistory Department). A second specimen was afterwards discovered by Dr. Leeson, of Bonchurch, Isle of Wight. 
sterile appendages, which may be called the interseminal scales. Towards the periphery of the fruit, in its lower portion, the sterile organs are more numerous

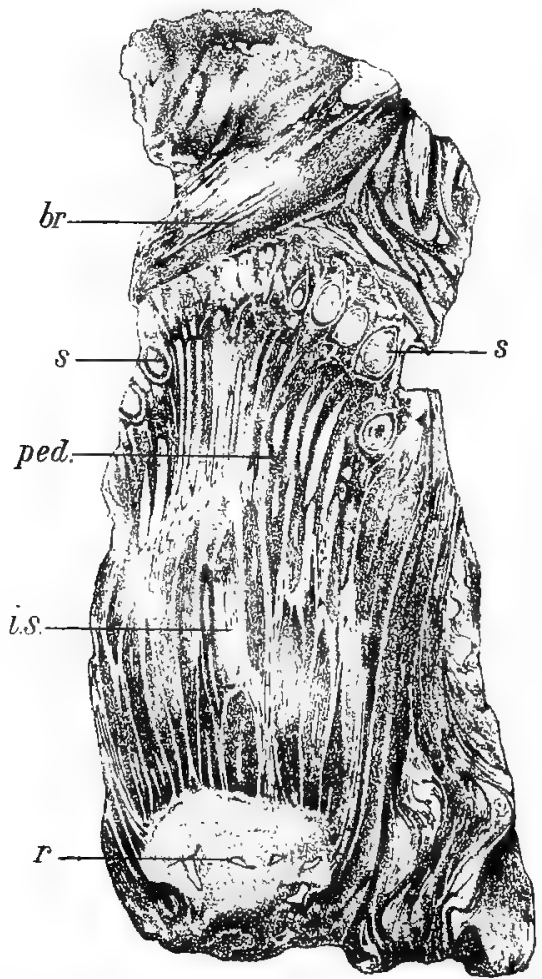

Fin. ro2.-Benntitits Cilsonianus, Longitudinal section of a fructification. r, receptacle; lir, bracts, encloning the fruit; $s$, seeds, each borne at the summit of a long pedicel, ped.; i.s., interseminal scales. $x$ alsout 2. From Linnean Soc. Trasts. After Carruthers.

than the pedicels, and around the base of the receptacle the former are prescnt alone (Fig. 203, A).

All the organs of the fruit are closcly packed together, and at its periphory (i.c. immediately within 

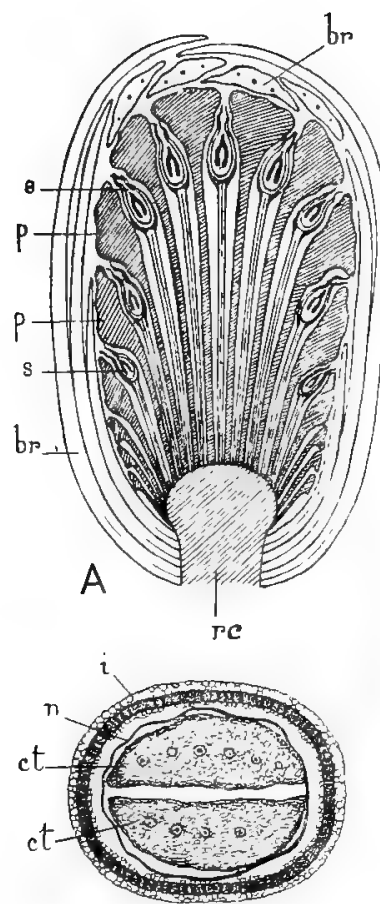

C

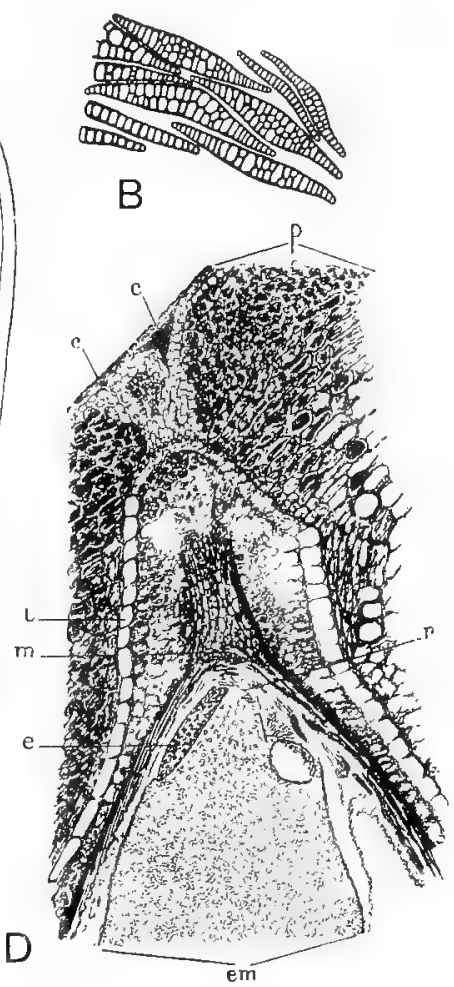

Fic. 203.-Binnettit's Gibsonianus. A. Diagram of the fruit, in radial section. re, receptacle; br, bractu, which overlap at the top of the fruit; $s$, seeds, each lome on a long pedicel, springing from the receptacle; in each seed the dicotyledonous embryo is indicated; $\phi$, dilated ends of the interseminal scales, which, in nature, arc more numerous and hecome conlluent, forming the pericarp. Modified, after SolmmLaubach and Potonie. B. Ramenta, in transverse section. $x$ about I5. C. Trans. verse section of a seed, $i$, the double-layered testa; $n$, membane representing the nucellus; $c t$, the two cotyledons of the embryo; in each cotyledon the procambial vascular bundles are visible. $x$ about 12. S. Coll. 350. D. Somewhat oblique longitudinal section through the micropyle of a seed. cm, radicular end of embryo; $"$, apex of radicle; $c$, remains of endosperm (\%): $n$, micropyle, oblicuely cut by the plane of section; $i$, outer layer of testa; $p$, part of pericarp; $c, c$, crevices in pericarp, corresponding to the limits of it constituent interseminal scales. $\times 20$. S. Coll. 357. The original figures $\mathrm{B}, \mathrm{C}$, and D, as well as Figs. 204 and 205, are from sections cut for Count Solms from the type-specimen, and now in my collection. (G, T. G.) 
the enveloping bracts) the tissue appears to be actually continuous, forming, as it were, a closed pericarp, perforated only by the micropyles of the seeds (see Fig. 203, A and D, p). The pericarp is formed by the cohesion of the interseminal scales. These organs are dilated at their distal ends, between the seeds, so as to form a continuous envelope, only interrupted by narrow pits, into which the seeds exactly fit (see Figs. 202 and 203, A). In the lower part of the fruit, below the region of the seeds, the pericarp is formed by the union of the outer and shorter scales. In order to make the somewhat complicated arrangement more intelligible, we may further quote Count Solms-Laubach's summary:- "We have in the fructification (spadix) two kinds of organs of different character and closely crowded together: the seedstalks (cords) [our pedicels] diverging above, clusterwise, and each terminating in a seed; and the interstitial organs [our interseminal scales], increasing constantly in length from the periphery of the cluster towards the inside, appearing by themselves in the periphery, but mixed with the seed-stalks further in, overtopping the seeds with their apices, and forming by the union of their apices the homogeneous tissuelayer of the surface of the fructification. In consequence of this arrangement, every seed is sunk in a pit, the orifice of which then narrows over the seed, owing to the lateral outgrowth of its walls." 1

This description should be compared with the diagram, Fig. 203, A, and with the more detailed Figs. 202, 203, D, and 204. We will now take the 
various constituent organs of the fruit, and consider their structure a little more in detail.

The receptacle forms, as we have seen, the enlarged termination of the axis of the fruit. The peduncle has a structure like that of the stem, on a small scale, and the bundles given off to the bracts divide up like those of the vegetative leaves, though only to a small extent. A remarkable feature in the anatomy of the peduncle is the great development of the phloëm, which much exceeds the wood in thickness. This peculiarity, which recurs in some of the American species, may be explained by the great demands on the organic food-supply made by the crowded reproductive organs, and especially by the seeds: The receptacle itself is poorly preserved, but shows here and there sections of collateral vascular bundles, on their way out to the appendages.

The bracts have, on the whole, the structure of reduced foliage-leaves. Their outer surface is clothed by ramenta, and stomata have been detected in their epidermis. ${ }^{1}$ Towards the inner surface of the bract, the mesophyll has a fibrous structure, but the bulk of the parenchyma is formed of short cells with a curious scalariform thickening on their walls. Several large gum-canals traverse the bract, which in this species usually contains three vascular bundles. These bundles are reduced in structure, but near the base, where they are best developed, they seem to be of the mesarch type usual in the foliar bundles of Cycads.

The seed-pedicels, which are seen in great numbers in the transverse section of the fruit (see Fig. 204),

${ }^{1}$ C. A. Barber, in MS. 
have an approximately cylindrical form, with their sides somewhat flattened by pressure. Through the middle of each pedicel runs a vascular bundle, which, so far as the preservation allows of an opinion, appears to have had a concentric structure. Outside the vascular strand is a well-marked bundle-sheath, suc-

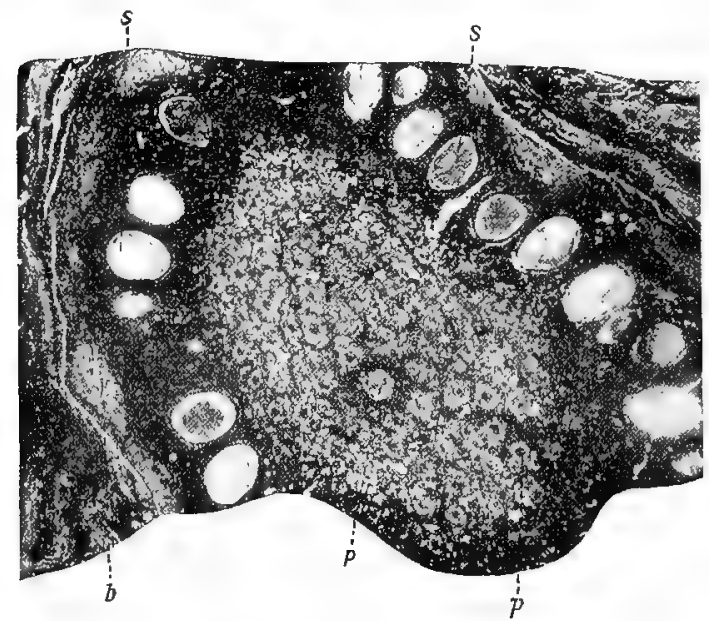

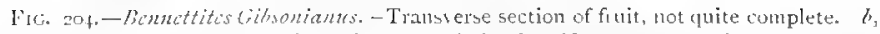
bracts; $s$, seed, ranged in a ring around the fructificaton; $\not p$, pedicels, lielonging to other seeds, borme at a higher lesel; between the peclicels the interseninal scales can be recognisecl. The pericarp is the dark zone in which the seeds are embedede $x$ about 3. From a photogrtaph hy Dr. Ioustield. S. Coll. 350.

ceeded by a wide cortex.' The surrounding epidermis belongs in reality, as Dr. Wieland has shown, to the adjacent interseminal scales.

Each pedicel terminates directly in an orthotropous seed. The xylem of the bundle ends at the chalaza

1 It is pussible, however, that the "bunclle-sheath" is really the epidermis, and that the so-called "cortex" is built up of epidemal appendages. 
in a small disc, while the adjacent tissues of the pedicel pass over into the testa. The seeds have a length of over $3 \mathrm{~mm}$, not counting the micropylar tube, and a diameter of nearly $2 \mathrm{~mm}$. The seeds which have been investigated were fully ripe, for each, when well preserved, contains a large embryo, nearly filling the cavity (see Figs. 204, $s, 203, \mathrm{C}$, and 205). The testa is made up of three layers, an inner and outer layer of small comparatively thin-walled cells, and a middle layer of large square or palisade-like cells, which appear almost solid, an appearance which may be due to extreme thickening of their cell-walls (Fig. 203, C and $\mathrm{D}$ ).

Towards the micropyle, the middle layer of the testa is greatly dilated, and is here several cells in thickness; it is surrounded by the external zone, which in this part is very distinct (Fig. 203, D). The inner layer of the testa forms the internal tube of the actual micropyle, which, however, in these ripe sceds is closed, as is usually the case (see Fig. 203, D, which represents a somewhat oblique longitudinal section through the micropylar end of a seed). The distal end of the micropyle (not shown in our figure) narrows out considerably, owing to reduction of the middle layer of cells, but appears to be somewhat dilated again at the extremity. The testa is everywhere closely adherent to the surrounding tissue of the pericarp. In the body of the seed, the nucellus is only to be traced as a structureless membrane (see Fig. 203, C, n), but it is better preserved at the apex (Fig. 203, D, m).

The embryo so nearly fills the cavity of the seed that the latter may be spoken of as exalbuminous, 
though it is quite possible that here, as in most socalled exalbuminous seeds, some slight remains of the endosperm persisted. The small mass of tissue marked $e$ in Fig. 203, D, in which the nuclei appear to be preserved, may probably be a portion of the remaining endosperm, though it might also be interpreted as belonging to the root-cap of the embryonic radicle.

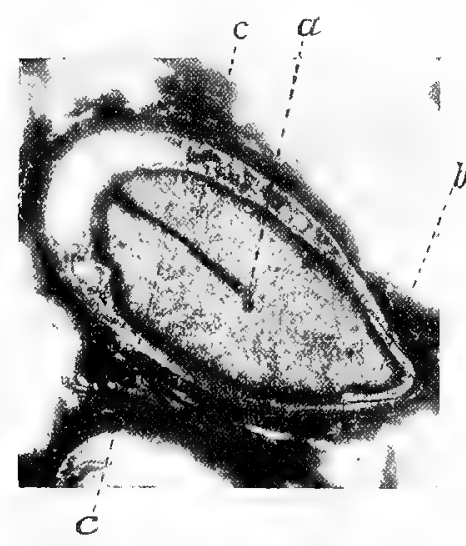

FiG. 205.-Bennitites Gilsonicuns. Longitudinal section of seed, showing dicotyledonous embryo. $c, c$, the two cotyledons; $a$, apex of plumule; $b$, raclicle. $\times 12$. From a phntograph by Dr. llousfield. S. Coll. 35I.

The cmbryo is very well preserved, indeed the Bennettitcae afford the only cases in which it has becn possible to study the embryos of fossil plants in detail. The embryo is a typical dicotyledonous onc, with the pointed radicle directed towards the micropyle. The hypocotyl is short; more than half the whole length of the embryo is occupied by the two thick cotyledons, the surfaces of which are in contact (see Figs. 203, C, 205). Between them, the growing point of the plumule has been recognised in favourable preparations (Fig. 205, a). The tissue of the embryo is to some extent preserved, and the position of the young vascular bundles in the cotyledons can be determined (sce Fig. 203, C, which represents a seed in transverse section, passing through the two cotyledons, $c t$ ). The vascular cylinder of the hypocotyl has also been 
recognised, and its connection with the cotyledonary bundles traced. ${ }^{1}$ The number of seeds in which the embryo is well preserved is so considerable as to leave no doubt regarding the correct interpretation of the main facts. The general structure of the dicotyledonous embryo is in no way surprising in a plant of Cycadean affinities, but the practically exalbuminous character of the seed is without example among recent Gymnosperms. Of course, in speaking of Bennettiteae as Gymnosperms, we are referring rather to their presumed affinities than to the actual structure of the fruit, which comes very near to being angiospermous.

The interseminal scales, which combine to form the pericarp, have proved difficult to investigate, owing to their state of preservation. In their lower part, where they pass between the pedicels of the seeds, they are crushed out of shape, and much disorganised, so as to be reduced in many cases to a vascular bundle with an irregular epidermis loosely surrounding it, the intermediate tissue having disappeared. The interseminal scales are somewhat similar in structure to the pedicels of the seeds, but the homologies of their respective, tissues are not yet clearly understood.

The expanded outer ends of the interseminal scales unite to form the "pericarp," a dense, apparently continuous zone, starting at the base of the fruit, from the sides of the receptacle, and extending, with increased thickness, over the top. In its upper portion, as already explained, it encloses the seeds, and is perforated by their micropyles. Its external surface is furrowed, the furrows forming a network.

1 Solms-Laubach, l.c. p. 440. 
The pericarp, from its dense structure, has at first sight the appearance of a distinct organ of the fruit, but, as above stated, there is no doubt that it is in reality built up of the distal parts of the interseminal scales (Fig. 203, A). The furrows thus correspond to the lines of junction of the constituent scales. The outer surface is coated by a distinct epidermis, which extends into, and lines the furrows (see Fig. 203, D, c). The inner tissue of the pericarp-zone $(p)$ is formed of parenchymatous cells, with moderately thick walls, and abundant dark contents, perhaps indicating the presence of some reserve food-substance during life. Tangential sections of the upper part of the fruit show the micropyles of the seeds, lying at the angles where the limits of the constituent interseminal organs meet. In Fig. 203, D (from a radial section), two of the furrows marking these limits (c) are shown close together, having been cut at a short distance from the micropyle towards which they converged. Vascular bundles run out into the pericarp between the seeds, and are the continuation of those seen in the lower portion of the interseminal scales.

So far as the bracts and gynæcium are concerned, the classic Bennettites Gibsonianus may still serve as a type of the complex Bennettitean fructification. Other similar European examples have been described, among which one from the Oxford Oolite of Normandy, called Bennettites Morierei, was fully investigated by Professor Lignier of Caen. ${ }^{1}$ The specimen is a detached fruit, not known in connection with the stem

1 O. Lignier, L'sostaux fossiles de Normandie, "Structure et affinités du Bennettites Aorierei," Caen, 1894 . 
on which it grew. It has hence been supposed that it may have had a longer stalk than that of B. Gibsonianus, and so may have been more easily detached. A Cycadean stem (Fittonic Brongniartii of Saporta), to which it may possibly have belonged, was found in the same locality. The fruit is somewhat larger than in our English species, with which, however, it agrees in all essential points of structure. The exceptionally beautiful preservation enabled Professor Lignier to work out the details of structure with remarkable precision.

It is, however, to the investigation of the magnificent American material that the recent remarkable progress in our knowledge of Mesozoic Cycadophyta is principally due, and some account of the chief results attained must now be attempted.

As regards habit, the American, like the contemporary European Cycadophyta, seem to have been plants of no great stature; there is no evidence at present for trunks of a height of more than 10 or 12 feet, while the great majority of the stems were quite short, like that shown in Fig. I 99. In some cases the stems were nearly spherical ; often several are connected together as branches of the same stock. In seeking analogies among recent Cycads we must therefore go to the shorter-stemmed genera, such as Bowenia or Stangeria, or perhaps Macrozamia, rather than to tall plants like Microcycas and various species of Cycas.

So far as the foliage and the external features of the trunk are concerned, the remarks made at the beginning of the chapter apply to the American as well as to the European forms. The majority of the latter 
are included by their investigators in Buckland's genus Cycadeoidea (synonymous with Bennettites of Carruthers ${ }^{1}$ ), but a new genus, Cycadella, has been founded by Lester Ward for a number of dwarf stems, distinguished by their abundant ramental covering, which often envelopes the trunk; twenty species have been referred to this genus, which is characteristic of somewhat older beds than those in which Cycadeoidea is prevalent.

Anatomically, the American stems so far investigated agree wonderfully closely, often down to the most minute detail, with the European species of Bennettites. It is, however, quite probable that when the investigation of the vast material has proceeded further, more variety may be found. As regards the form and structure of the leaves of the Bennettiteae, practically all our information comes from Dr. Wieland, who in various specimens has succeeded in finding the young leaves still folded in the bud and preserved in great perfection. His observations were chiefly made on Cycadeoidea ingens, a species in which he estimates the length of the mature leaf at about ro feet, and on Cycadella ramentosa, a much smaller plant, so that both the later and the earlier types are represented. It is sufficient, without going into details, to say that Dr. Wieland's investigations show that in form, prefoliation, venation, and anatomical structure these leaves show a

I The name Cycadeoidea is employed by some European writers for trunks of the Bennettitean type without fructifications, as in the case of Professor Seward's Cycadeoidea ingens. In discussing the American species, I follow the usage of the palreobotanists of that continent, employing the names Cycateozdea and Cycadella throughout. It is desirable, however, that an agreement as to the nomenclature should be arrived at. 
close agreement with those of recent Cycads of the suborder Zamieae; the vascular bundles were collateral and mesarch, without radial arrangement of the centrifugal wood or phloëm. Speaking especially of Cycadeoidea ingens, Dr. Wieland says, "Were one to adjudge the taxonomic position of the fossil species on the basis of its foliage only, one might, bearing in mind the general absence of scale-leaves, place it near Hacrozamia or Encephalartos." " The leaves of Cycadella only differ in details; the structure of the pinnules is found to be almost identical with that in the recent Bowenia. ${ }^{2}$ This close correspondence in foliar characters with the recent Cycadaceae is the more remarkable when we consider how totally the two groups differed in their reproductive organs, the organisation of which has only been fully revealed by Dr. Wieland's researches.

The European specimens had yielded scarcely any information as to the nature of the microsporangiate organs of the Bennettiteae. In an Italian species, Cycadeoidea etrusca, ${ }^{3}$ bodies interpreted as pollen-grains were discovered by Count Solms-Laubach in the interior of a fructification, lying in the space between the apex of the ovuliferous receptacle and the surrounding bracts. Though, owing to bad preservation, the stamens were not detected, the inference was drawn that they

1 American Fossil Cycads, p. 94.

2 L.c. p. IоI.

3 The specimen was found on an Etruscan tomb at Marzabotto near Bologna ; Capellini and Solms-Laubach, "I tronchi di Bennettitee dei Musei Italiani," Mem. d. R. Accad. delle Sc. dell' Ist. di Bologna, series v. vol. ii. 1892. Dr. Wieland, who has since reinvestigated the fructifications and found some further remains of structure, compares them with those of Cycadella. See his "Historic Fossil Cycads," Amer. Joumal of Science, vol. xxv. February 1908, p. 93. 
were probably borne in the same fructification with the ovules. This suggestion has been completely confirmed by the investigation of the perfectly preserved specimens which have since come to light in America.

The male sporophylls of the Bennettiteae were first discovered in I 899, in the Dakota species Cycrdeoidea ingens, already referred to ${ }^{1}$ their relation to the gynacium was established two years later, in the same species, when the organisation of the hermaphrodite or bisexual flower was described for the first time. ${ }^{2}$ Twentyfive trunks with bisexual fructifications, belonging to seven American species, have now been investigated. The fructifications were borne laterally on the stem, precisely in the same way as those of Bennettites Gibsonianus and other European forms, which were probably also bisexual (see p. 588). The plant bore a considerable number of fructifications at the same time (see Fig. I 99); on a single specimen of Cycadeoidea dacotensis sixty-one fruits, all more or less at the same stage of development, were counted, and Dr. Wieland is inclined to think that the plants were "monocarpic," fruiting once for all and then perishing, as is the case with many Palms and Bamboos at the present day.

The structure of the bisexual fructification or "flower," as it may be appropriately called, will first be described in the case of Cycadeoidea dacotensis, one of the species most fully investigated. It may, however, be said at once that no important differences in

1 Wieland, "A Study of some American Fossil Cycads, Part i. The Male Flower of Cycadeoidea," Amer. Joum. Science, vii. I899.

"L.c. Part iv. "On the Microsporangiate Fructification of Cjucadeoidea," Amer. Joum. Science, xi. rgor. 
the floral morphology of the different species have been detected.

The whole fructification has a length of about

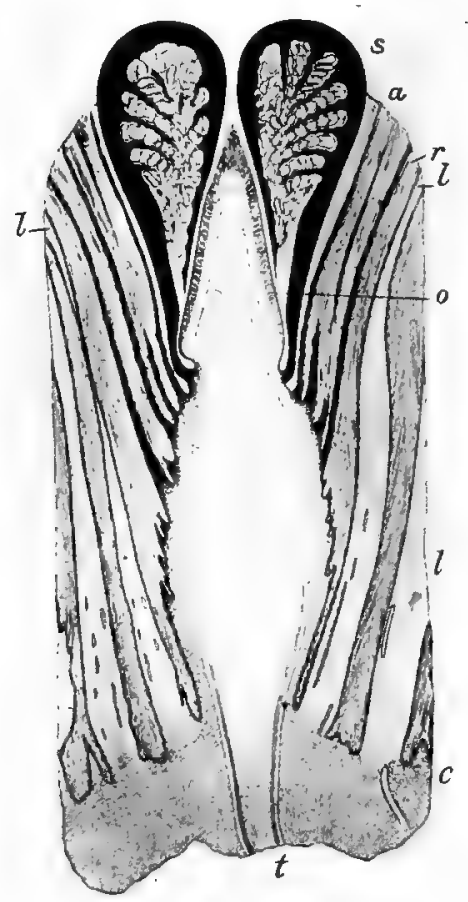

Fro. 206.-Cycadeoilea dacotensis. - Median longitudinal section of a bisexual flower. The peduncle, with the surrounding leaf-bases and bracts, is drawn from one section; the ovulate cone and microsporophylls are drawn from several other sections of similar strobili. $s$, the incurved microsporophylls; 0 , the ovuliferous cone; $a$, eroded outer border of the armour and bracts, forming the trunk-surface; $r$, ramentum between outermost bracts and adjacent leaf-base; $l$, leaf-base ; $c$, cortex of trunk; $t$, bundles supplying peduncle. About $\frac{2}{3}$ natural size. From Wieland.

I $2 \mathrm{~cm}$., protruding somewhat beyond the leaf-bases of the trunk. (See the restored section shown in Fig. 206.) About half this length consists of the stout peduncle, which bears ioo or more spirally arranged 
bracts on its upper part. The centre of the flower is occupied by the ovuliferous receptacle, about $4 \mathrm{~cm}$. in height, terminating the peduncle, as in Bennettites Gibsonianus (cf. Fig. 203, A). In C. dacotensis, however, the form of the receptacle is much more acutely conical, and the stage of development, in the present case, is a far earlier one, minute immature ovules taking the place of the ripe seeds of the specimens previously described.

The stalked ovules and interseminal scales here form a layer only $1.5 \mathrm{~mm}$. in height (see Fig. 207, where this zone is better shown), whereas in the mature seed-bearing condition these organs have grown to at least ten times the length. We have, in fact, at the stage now under consideration, to do with a flower, while the fructification of Bennettites Gibsonianus, described above, was already a fruit. The receptacle bears ovules in its middle region; the base and apex are sterile, and clothed only with the barren interseminal scales, which at the apex are prolonged into a tuft (Fig. 207). The details of structure of the ovules at this stage have not yet been published.

Surrounding the ovuliferous cone, and enclosed by the bracts, is the whorl of compound microsporophylls which forms the most striking feature of the flower. The microsporophylls, or stamens, are numerous, numbering from eighteen to twenty in $C$. dacotensis, and are ranged in a single verticil; they are inserted hypogynously, below the base of the gynæcium (see Fig. 206), and their stalks are united to form a continuous sheath (the "disc" of Wieland), like the monadelphous stamens of a Mallow (see diagrams, 
Figs. 208 and 209). The connate sheath extends up to about the height of the top of the gynacium; at this level the stamens become free from each other; they are large and complex structures about Io $\mathrm{cm}$. in length, if straightened out; they are always found,

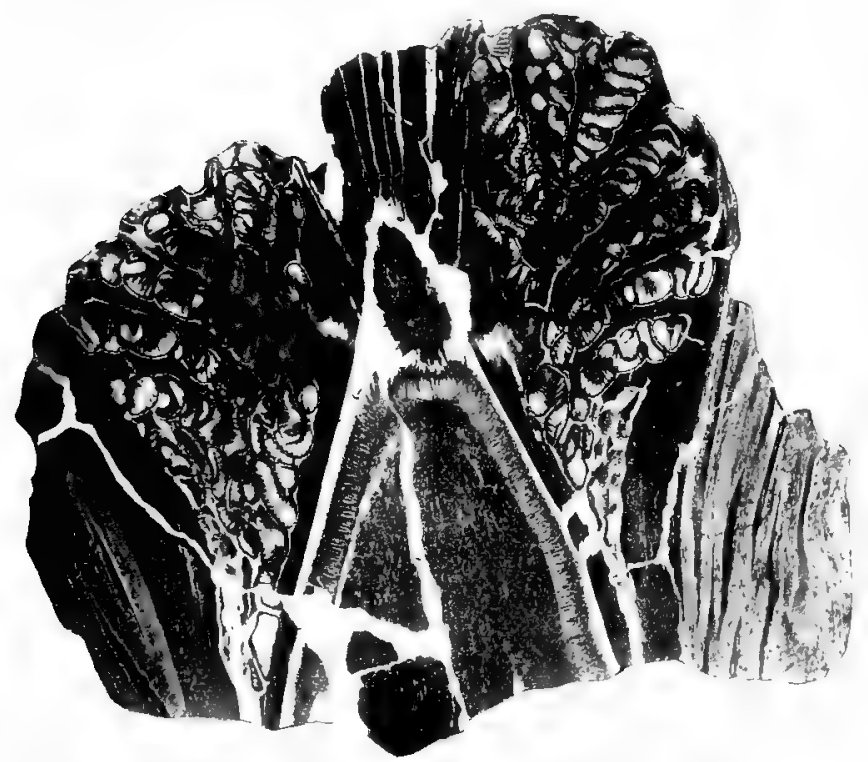

FIc. 207.-Cycadtoitta dacotonsis.- Longitudinal section through the summit of an unexpanded bisexual flower. In the middle is the upper part of the oruliferous cone, showing the zone of oviles and interseminal scales and the terminal tuft. To the right and left the compound stamens are seen, with their tips infulded parallel to the sides of the central cone. The upper curved portion of each stamen is missing (cf. Fig. zo6, s). The pinnæ, each bearing a series of synangia, are cut longitudinally. On the outside of all are the bracts. $\times 2$. From a photograph. After Wicland.

however, to be infolded in a circinate manner, the sporophylls curving over towards the gynacium, so that their deflexed tips reach down almost to its base (see Figs, 206 and 207). Each stamen is a pinnately compound leaf with about twenty pairs of alternate 
pinnæ, directed inwards from the concave side of the whole organ (Figs. 206 and 207 ; cf. the diagrams, Figs. 208 and 209). The apical and basal pinne are sterile; all the rest bear synangia, arranged in two rows, the synangia numbering about ten in each row

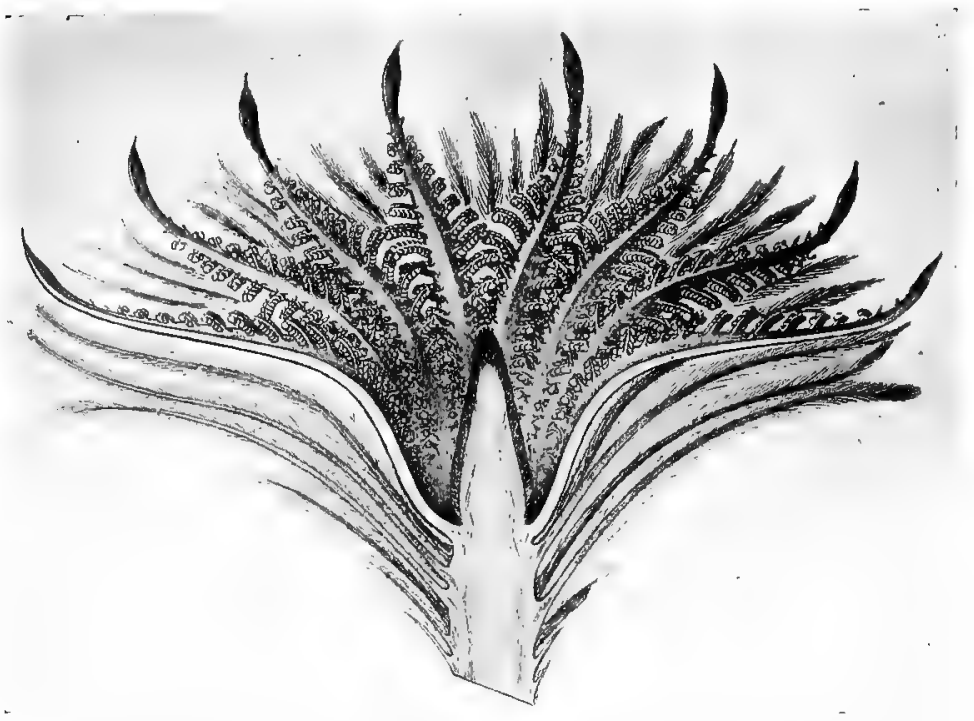

FIG. 208.- Cycatcoided ins'ns.-Renturation of an expanded bisexual flower in longi. tudinal section, whowing the central ovuliferouscone, the hy posy noun whorl of pinnately compound stamens, loearing numerous synangia, and the surrumding bracts, hairy with ramenta. About half natural size. From Wiclank.

in the case of the longest pinnat. If, with Dr. Wicland, we regard each synangium as representing a reduced pinnule, the whole sporophyll must be called bipinnate. The stamen was thus a highly complex organ, recalling the fertile frond of a Fern rather than the comparatively simple type of microsporophyll which we meet with in the stamens of the higher plants. The elaborate 
organisation of the whole flower is well shown in the diagrammatic figures 208 and 209, drawn by Dr. Wieland to represent the flower in an expanded condition.

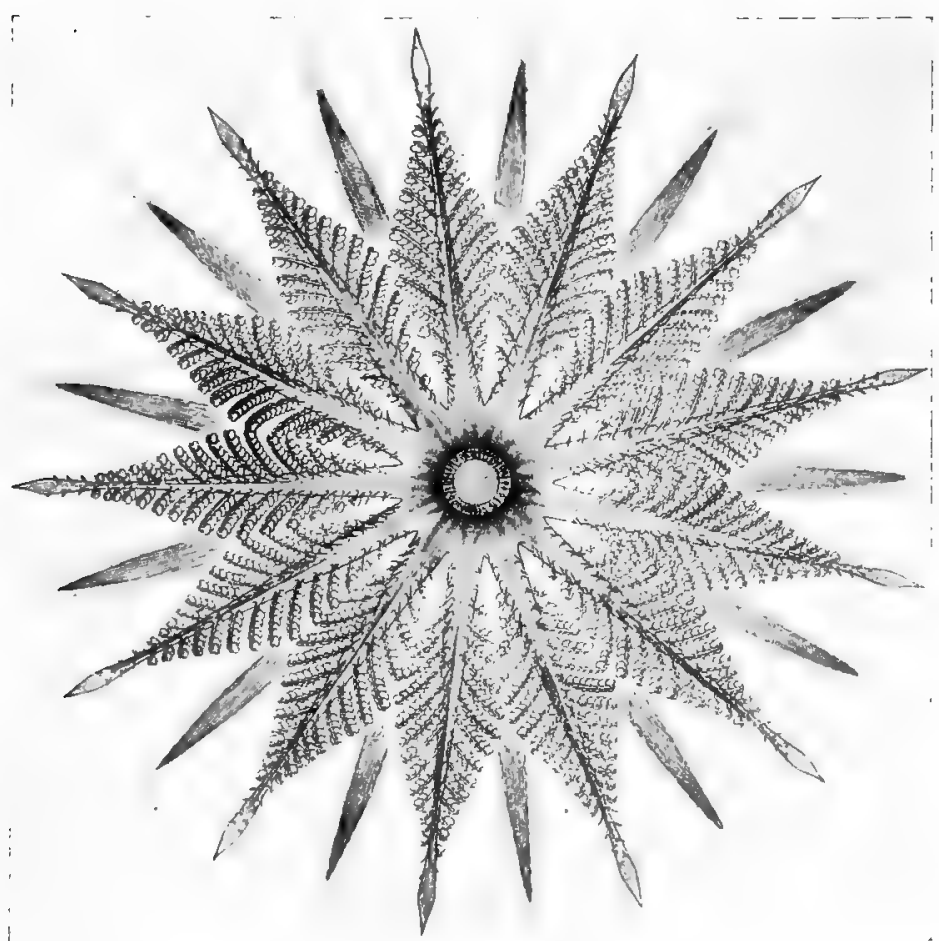

FiG. 209. - Cycadvoidea ingens. - Plan of the bisexual flower, showing the central ovuliferous cone, the whorl of thirteen conpound stamens, united at the base, and bearing synangia on their pinne, and a series of the hairy bracts. The diagram is about on the same scale as Fig. zo8, and shows the flower as it would aprear, seen from above, if all its parts were fully expanded. Frent Wieland.

These diagrams are based on the specics Cycadeoider ingens, in which the number of stamens is less than in C. dacotensis. It will be noticed that the arrangement of the parts is just the same as in a typical Angiospermous 
flower, with a centrai superior gynæcium, a whorl of hypogynous stamens, and an enveloping perianth.

The anatomical structure of the microsporophylls has not yet been fully investigated, but it is known that two ranks of vascular bundles are present in the connate disc, and that a considerable number

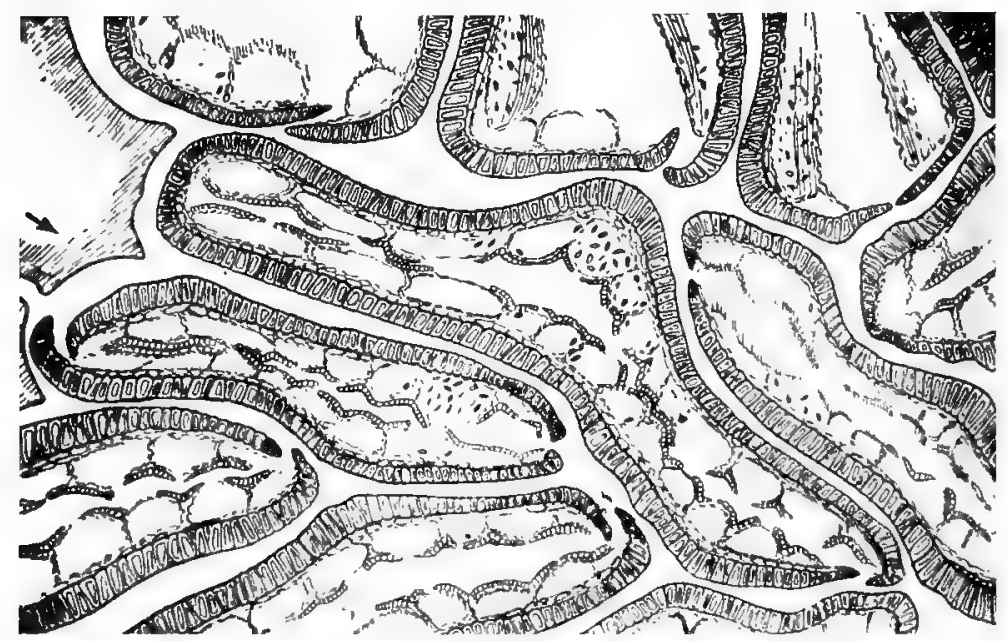

Fig. 2ro.-Cycaleoidia dacotensis. - Transverse section through rachis of a sporo. phyll and adjacent synangia. The middle and lower synangia are cut transversely, the upjer very obliquely. The palisade-layer, walls of the loculi, and spores are all shown. $\times$ alpout 25. From Wieland.

enter each rachis as it becomes free. The general arrangement of the bundles is compared with that in the rachis of a Cycad leaf.

The synangia, as alrcady mentioned, are inserted in two rows on each pinna; their insertion is described by Dr. Wieland as "sub-lateral." Such a position is common on the modified fertile fronds of Ferns, where the insertion of the sporangia on the lower surface, usual 
in the case of unreduced sporophylls, is often departed from. The shortly-stalked synangia are much broader than long, contain two rows of loculi (Figs. 2 Io and 2 I I), and closely resemble those of certain Marattiaccae, simulating in a remarkable degree the stalked synangia of Marattia Kaulfussiz. ${ }^{1}$ The analogy of this species, though not of any special taxonomic significance, shows that there is no absolute necessity to regard the pedicellate synangia of the Bennettitcae as representing distinct leaflets.

The form of the synangia in Cycadeoidea is somewhat affected by their crowded arrangement in the limited space afforded by the infolded sporophyll (Fig. 210 ).

The synangia shown in Fig. 2 Io are for the most part cut transversely, showing the full number (20-30) of the loculi, while Fig. 2 I I represents a single synangium cut longitudinally through the

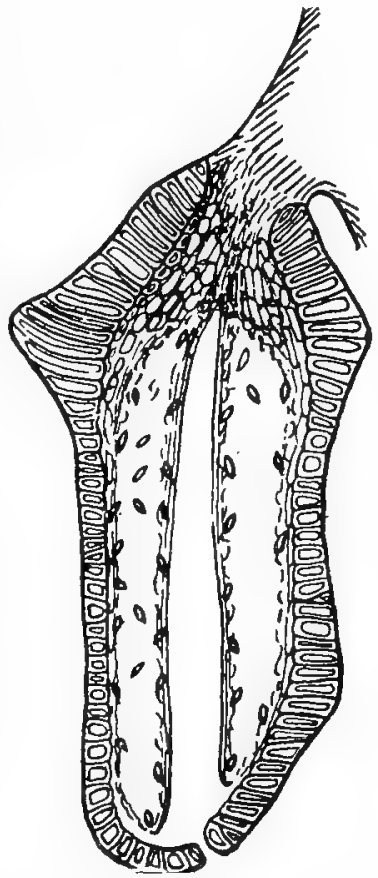

1Fics. 2IJ, - Longitudinal section of at nyongium, showing short stalk attachiug it to rachis. The "buteressing "of the basal part of the wall is shonn; also two luculi, in lungitudinal section, contrining sume pollen-grains. Dehiscence appears to have begun. $\times 40$. From Witland.

short stalk, in a plane at right angles to the rows of loculi, so that two loculi only are shown. The extcrior of the synangium is formed by a well-developed

I See Christ, Farnkmuler der Erile, 1'. 359, l'ig. I 129 , I 897. 
palisade-layer, thickened near the base (Fig. 2II); this is lined by a layer of small, thin-walled cells, which also form the inner walls of the loculi (Fig. 2 I 0 ). In dehiscence the two rows of loculi appear to have split apart, the synangium thus opening by two valves, while the individual loculi dehisced by longitudinal slits (Figs. $2 \mathrm{IO}$ and $2 \mathrm{II}$ ). If this was the case, the resemblance to Marattia extended to the mode of dehiscence.

The microspores or pollen-grains have been carefully examined by Dr. Wieland, but without finding any decisive proof of the presence of antheridial cells. In size the microspores are intermediate between those of Cordaiteae and recent Cycads.

As already mentioned, the variation in structure among the flowers of the American Bennettiteae, so far investigated, is unimportant; neither do their flowers differ essentially, as it appears, from those of such European species as Bennettites Gibsonianus and $B$. Morierei. The group, in fact, was morphologically a narrow one, however rich in specific forms. The smallest number of stamens observed was ten, in Cycadeoidea Jenneyana. The discovery of the bisexual flower of Cycadeiodea Paynei is of interest, because in the form of the receptacle and other characters this species agrees so closely with Bennettites Gibsonianus as to leave no reasonable doubt that the flowers of the British species were likewise bisexual, the absence of stamens in the specimens observed being simply due. to the maturity of the fruit at the time of fossilisation. The same applies to Bennettites MIorierei, and indecd it is quite probable, though not yet demonstrated, that all Bennettiteae had bisexual flowers. In many 
strobili, both young and old, where the stamens were not preserved, Dr. Wieland was able to detect the remains of the staminate disc, seated on the rim of the receptacle. The genus Cycadella appears to have had precisely the same floral structure as Cycadeoidea. In a very small fructification of Cycadella zeyomingensis, only $7 \mathrm{~mm}$. in diameter, a whorl of thirteen stamens, surrounding the central receptacle, was found, just as in Cycadeoidea ingens.

From the comparison of the younger and older stages (as, for example, in $C$. dacotensis), it appears that as the fruit matured the expanding gynæcium encroached on and ultimately filled the space originally occupied by the whorl of stamens. Dr. Wieland inclines to the view that the flowers were protandrous, the pollen being ripe before the ovules were ready for fertilisation; a detailed knowledge of the condition of the ovules in flowers of different ages will be necessary before this point can be decided. In a magnificent fossil Cycad, Cycadeoidea Reichenbachiana, found about the year $I 753$ near Cracow in Poland, and probably of Lower Cretaceous age, Dr. Wieland has recently demonstrated the bisexual structure of the flowers, which appear to agree in all essential points with those of $C$. dacotensis ; the number of stamens in a whorl is sixteen in $C$. Reichenbachiana. This is the first time that the presence of bisexual flowers, like those of the American Cycadophytes, has been clearly observed in a European species, though, as we have seen, the indirect evidence left little doubt as to the facts. ${ }^{1}$

1 IVielant, Historic Fossil Cycads, abuve cited. Sce also F. Lester Ward, "A Famous Fossil Cycad," Amer. Journ. of Scicnie, vol, xviii. I904. 
Many years before the existence of such a family as that of the Bennettiteae was even suspected, certain remarkable fossils were described from the Lower Oolite of the Yorkshire coast, under the name of Zamia gigas. ${ }^{1}$ The fullest account of these fossils is that presented by Williamson to the Linnean Society in I 868. Our Fig. 2 I 2 (from Williamson's memoir) represents the plant in a restoration which has been proved by more recent investigations to be essentially correct. Mr. Carruthers, in his paper on Cycadean stems above referred to, established the new genus Williansonia for the reception of Zamia gigas and allied forms, and this name is the one now used. ${ }^{2}$

The various organs of the plant are, as usual among fossils, almost always found separately. They consist of the large Zamia-like leaves (from which the old generic name was taken), portions of the stem, covered with the rhomboidal leaf-scars, and lastly the fructifications, with the long scaly stalks on which they were borne. Williamson pieced these various parts together, as shown in his restoration, and Brongniart confirmed his conclusions, but other authorities entirely rejected them, regarding the fructifications as those of Monocotyledons, and as having nothing to do with the Cycadean foliage or stem. Williamson's view has proved to be the correct one.

The fructification of Williamsonia is in size and appearance something like a common artichoke, and

1 Lindley and Hutton, Fossil Flora of Great Britain, 1830 . Originally figured by Young and Bird, Geological Ster'ty of the Yorkshive Coast, I822.

2 Williamson, "Contributions towards the History of Zamia gigas," Linnean Society's Transactions, vol. xxvi. (published 1870); Carruthers, l.c., in same volume. 
was borne at the end of a long stalk, 20 or $30 \mathrm{~cm}$. in length, covered with spirally arranged scale-leaves.

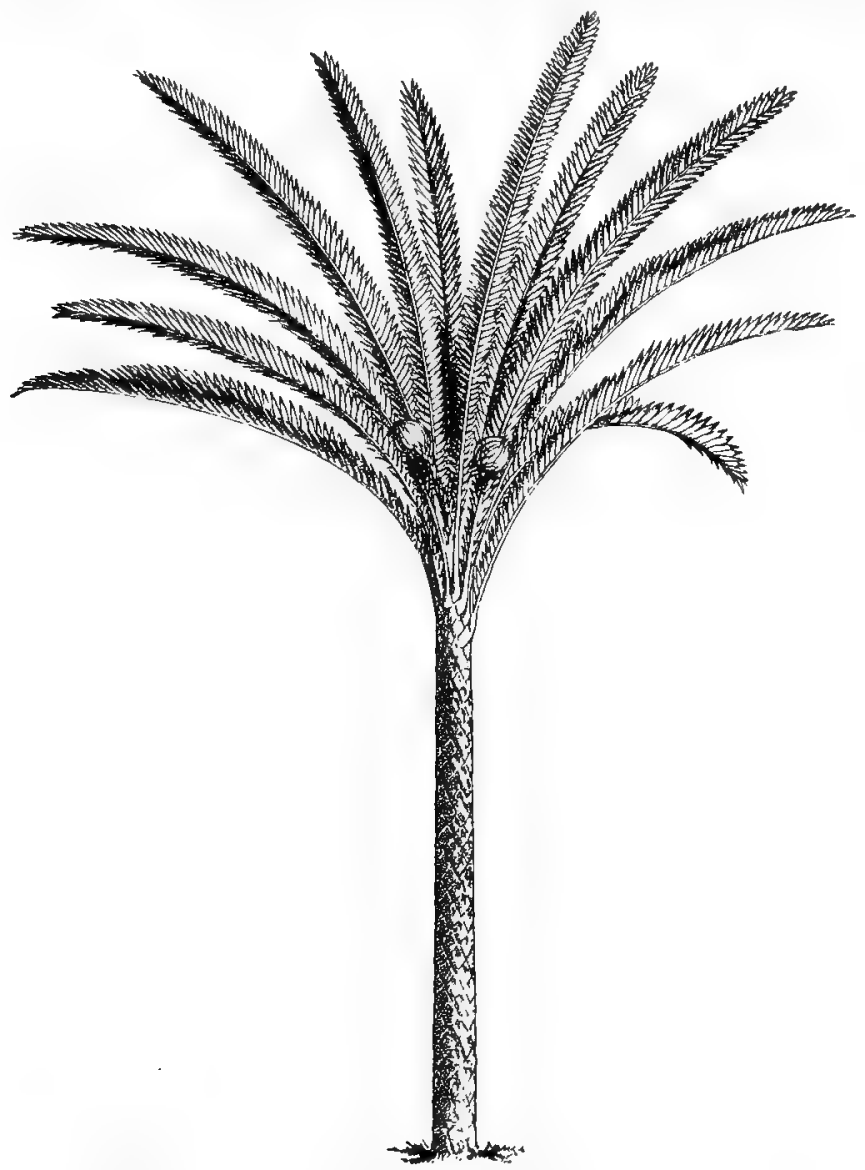

Fic. 2r2.-I'illiantonia gigas. -Williamson's original restoration of the plant, showing the upright stem, with rhomboidal leaf-scars, the crown of $\%$ amia-like leaves, and the scaly, spherical fructifications. From the Linnean Suc. Trans.

The exterior of the globular fructification was formed by the overlapping, involucral bracts. No petrified 
specimens appear to be known, but the structure has now been interpreted with considerable probability, in the light of that of the hermaphrodite flowers of Cycadeoidea. The middle of the fruit is occupied by a stout pyriform axis, which no doubt represents the central ovuliferous receptacle, while traces of the surrounding stamens have also been detected. Williamson described some forms of fructification as male and others as female, but they, in all probability, represent merely different states of preservation of the same bisexual flowers. Details will be found in Wieland's American Fossil Cycads. ${ }^{1}$

Professor Seward, from the study of an English specimen now at Paris, as well as from other evidence, proved conclusively that the Williansonia fructifications and the $Z$ amia-like leaves were borne on the same stem.? He regarded the plant as closely allied to Bennettites, ${ }^{3}$ and this view has proved to be fully justified, though the degree of relationship can only be determined when specimens of Williamsonia are discovered with microscopic structure preserved. On present evidence, it appears most probable that Williamsonia (of which several species, from various parts of the world, extending to North America and India, are known) belonged to the Bennettitales, differing from Bennettites chiefly in the long peduncles on which the fructifications were borne, and in the taller and more slender stem.

1 See especially his Plate xIvi. with the description of figures.

2 Seward, "On the Leaves of Bennettites," Proc. Cambridge Phil. Soc. vol. ix. p. 273, 1897. The critical specimen, showing both lenves and foral peduncles in connection with the stem, has been refigured by Wieland in his paper on Hisloric Fossil Cycads, above cited.

3 See his Catalogue of Mesoroic Plants: Fossil Mlants of the Wealden, Parl ii. I895, and Jurassic Flora, Part i. I900. 
A very interesting Cycadophyte, from the Rhætic of Southern Sweden, has been described by Professor Nathorst, under the name Williamsonia angustifolia. ${ }^{1}$ The stems are long and slender and repeatedly forked by "false dichotomy," a flower usually terminating the axis between the two branches. The floral structure, so far as the material allows of its investigation, appears to be that of a Williansonia, though the flowers are on a small scale compared with those of $W$. gigas. The flowers were described by the discoverer as male and female, but now that the bisexual flowers of Bennettiteae are known, it appears most probable that in this species also they were all of one kind, the differences observed being due merely to the stage of development and state of preservation. This is rendered the more likely by the fact that the flowers originally described as male, in some cases distinctly show the central (presumably ovuliferous) receptacle. The leaves, which occurred chiefly in rosettes at the points of branching of the stem, werc narrow and pinnate, of the form known as Anomosamites, ${ }^{2}$ and were of small size, about 7 or $S \mathrm{~cm}$. in length. The habit of the plant is totally unlike that of Cycadaceae or of the typical Bennettiteae, and has suggested the possibility of a nearer approach to the Angiosperms than is shown by other Mesozoic Cycadophyta.

1 A. G. Nathorst, "Beiträge z. Kenntnis einiger mesozoischen Cycadophyten," Kongl. Suenska Letenskaps Akad. Handl. vol. xxxvi. No. 4, 1902, and the earlier papers there citerl.

" The plant is referred to Anomozamiles minor (Brongn.), the name used by Dr. Wieland. 
2. CYCADACEAE.-Side by side with the Bennettiteae, true Cycadaceae, or closely allied plants, probably existed in Mesozoic times, but the evidence for their presence is scanty in the extreme.

Male cones, of a Cycadean type, have been recorded under the name of Androstrobus, as, for example, A. Nathorsti, a species from the Wealden of Sussex, described by Professor Seward. ${ }^{1}$ The thick axis of this cone bears spirally arranged, more or less triangular scales or sporophylls, 1 to $1.5 \mathrm{~cm}$. in length. "Towards one end of the specimen the basal part of a scale is seen in surface view, and on it are clearly preserved what are taken to be the outlines of pollen-sacs. . . . The striking regularity with which these impressions are arranged is much more marked than in the pollen-sacs of recent Cycads. On the lower surface of a staminal leaf of Dioon or Encephalartos, we find, on the removal of the pollen-sacs, a fairly distinct reticulate marking, but of much less regularity than in the fossil." 2 From the evidence of this specimen and one or two similar fossils, it has been inferred that male cones, not essentially different from those of living Cycads, occurred in Mesozoic floras. The evidence, however, is not wholly convincing, and has been considerably shaken by Professor Nathorst's discovery that a cone originally described by him as Androstrobus Scotti, and referred to Cycadaceae, was in reality a Lycopodineous fructification with megaspores, for which he has now created the new genus Lycostrobus. ${ }^{3}$

1 Fossil Plants of the Wealden, Part ii. p. IIo.

"Seward, l.c. p. III.

3 A. G. Nathorst, "Paläobotanische Mitteilungen, 3. Lycostrobus Siotii," Kongl. Svenska Vetenskaps Akad. Handl. vol. xliii. No. 3, igo8. 
As regards female cones of the Cycadaceae, such as are characteristic of the recent suborder Zamieae, the fossil evidence is unsatisfactory. It is quite probable that cones of this kind may occur in various Mesozoic deposits, but, generally speaking, the state of preservation of such specimens is so poor that it is impossible to distinguish them with any certainty from Coniferous strobili of similar habit. ${ }^{1}$

We have already seen (Chapter XI. p. 493) that fructifications, possibly referable to Cycadophyta, occur even in the Permian beds, though their true affinity is an open question.

The recent genus Cycas differs entirely from other members of the Order in the structure of the female fructification. The carpels are among the most characteristic of vegetable organs, and fossils resembling them have been recorded from various Mesozoic strata. In at least one case (Cycadospadix Hennoquei, Saporta, from the Lower Lias) the carpel, fimbriated like that of Cycas revoluta, has a seed still attached. ${ }^{2}$ The evidence for the existence of near allies of Cycas in Mesozoic times so far seems strong, but, on the other hand, much doubt has recently been cast on the

${ }^{1}$ Cf. Seward, Fossil Plants of Wealden, Part ii. p. II3. One of the most perfect specimens attributed to the Zamieae is the Beania gracilis of Carruthers ("On Beania, a New Genus of Cycadean Fruits from the Yorkshire Oolites," Geol. Mag. vol. vi. 1869), which consists of an elongated axis, bearing a number of peltate sporophylls, on each of which two seeds are inserted. The sporophylls themselves agree closely with those of a recent Zamia, but they are much more remote from each other than in that genus. Professor Seward is inclined to regard Beania as more probably belonging to Ginkgoaceae than to the Cycads. See Seward and Gowan, "The Maidenhair Tree," Annals of Botany, vol. xiv. I90o. Also Sewarcl, Jurassic Flora, Part i. 1900, p. 272.

2 See Saporta et Marion, L'évolution du rigne vegetal, Les Phanéroganles, t. i. p. II r, Fig. 59, A, I 885. 
nature of the leaves referred to Cycas or Cycadites, with which the carpels are sometimes associated. Professor Nathorst ${ }^{1}$ has shown that in several species from the Cretaceous of Greenland, formerly placed in the genus Cycas, the vascular bundle of the pinna was not single, as in the recent genus, but double, and that the distribution of the stomata was also quite unlike that in Cycas. He has therefore placed these forms in a new genus, Pseudocycas, and no longer regards them as belonging to the same suborder as Cycas. It is probable that the species now placed in Cycadites may prove to have similar peculiarities.

Thus the whole question of the existence of Mesozoic Cycadaceae, whether of the suborder Zamieae or Cycadeae, is in an unsatisfactory position and the positive evidence singularly meagre. There are a great number of Cycad-like fossil remains, known only as impressions and casts, the true nature of which must remain doubtful until specimens showing structure come to light. At present such specimens, of Mesozoic age, are almost wholly limited to the Bennettiteae.

3. Affinities of MEsozolC CycADOphyta.-The Cycadophyta of Nathorst form a main subdivision of the Gymnosperms, including the Cycadales, the Bennettitales, and no doubt other groups, which we are not yet in a position to characterise. " The Cycadales correspond simply to the Order Cycadaceae, with the two well-known suborders Cycadeae and Zamicae;

1 A. G. Nathorst, "Paläobotanische Mitteilungen, I. Psendocycas," Kongl. Suenska Vetenskaps Akad. Handl. vol. xlii. No. 5, 1907. The cuticle of carbonised specimens was examined microscopically.

3 Nathorst, " Beitr. «. Kenntnis kl. mesozoischen Cycadophyten," P. 3. 
in like manner the limits of the Bennettitales are at present identical with those of the Bennettiteae, if we include the Williamsonieae, which should perhaps count as a distinct Order or Sub-order.

Throughout our description of the Bennettiteae we have assumed that these plants really had affinity with Cycads. The sum of their vegetative characters can leave no doubt that this supposition is justified, but it is a striking fact that in their reproductive organs, that is to say, in the very characters on which systematists are accustomed to rely, the Bennettiteac differ toto coelo from the Cycadaceae. The organisation of the flower is so different from that of the cones of any recent Cycad that it is difficult to determine with any certainty the homologies of the parts in the two groups. It is, of course, possible that future palæontological discoveries may reveal the existence of types of fructification intermediate between those of Cycadales and Bennettitales; at present, however, it seems as if their development had followed different lines from a very early stage.

The points in which Bennettitales agree with Cycadales are, the form and general structure of the stem, the histological details of its tissues, the arrangement of the leaves, their form and minute structure; in all these respects the agreement is exact, so far as the existing investigations on American and European species enable us to judge. The only differences worth mentioning, in the vegetative organs, are the simpler course of the leaf-trace bundles in Bennettitales, and the presence of ramenta like those of Ferns, instead of the woolly hairs of Cycads. In these two 
respects the Bennettitales appear to be more primitive than the sister class. It has been suggested by Dr. Wieland that in Triassic times there may not yet have been any definite border-line between the two classes, so far as vegetative features are concerned. ${ }^{1}$ In Anomozamites minor (Williamsonia angustifolia of Nathorst), the oldest known member of the Bennettitales, the habit was cqually unlike that of typical Cycadaceae and of typical Bennettiteae. It has recently been suggested that an abortive bud occurring beneath the peduncle of the cone in the recent Cycad Dioon is the second lateral branch of the primitive dichasium, an interpretation which would tend to bring the Cycadaceous morphology a step nearer to the type of Anomosamites. ${ }^{2}$

On the other hand, the fructifications are on a far higher level of complexity in the Bennettitales. The lateral, probably axillary position of the fertile shoots (flowers) is the first difference to be noted. As Dr. Wieland puts it (p. 229), the Bennettitales have seized on the lateral bud as a means of fructification, thus ensuring the production of more numerous strobili. That the axis of the inflorescence is a modified branch of the stem is clear ; the enveloping bracts are, no doubt, modified leaves or possibly leaf-bases, and likewise present no difficulty. We might well compare them to the scale-leaves, in which the young cone of an ordinary Cycad is enwrapped. It is when we come

1 Anerican Fossil Cycads, p. 228, The anthor gives a very full comparison between the two groups, as regards both vegetative and reproductive characters, in his Chapter IX.

2 F. W. South and R. H. Compton, "Anatomy of Dioon edule," Nere Phytologist, vol. vii. Dec. I908, P. 225. 
to the internal organs of the fructification - the stamens, the seed-pedicels, and the interseminal scales-that difficulties begin.

There appears to be no doubt as to the morphological nature of the stamens, which are clearly sporophylls of a highly complex and leaf-like character, borne directly on the axis of the fructification. So far, then, as the andrœcium is concerned, the Bennettitean strobilus is admittedly a flower. The organs of the gynæcium, however, have received various interpretations, which may be grouped under two heads. Either all the organs (seed-pedicels and interseminal scales), are of a foliar nature, in which case the fructification throughout is comparable to a flower, or the seedpedicels are axial structures, ${ }^{1}$ and this part of the fructification is an "inflorescence." The question is important on account of the comparison with the Angiosperms, on which much stress has been laid by recent writers. We will first consider the second view, of which Professor Lignier is the chief advocate. On his interpretation the interseminal scales are modificd leaves, homologous with the bracts, and ultimately with the foliage leaves, while each seed-pedicel is a sporophyll borne on a unifoliar bud, which is probably axillary to an interseminal scale. Professor Lignier points out the analogy which, on his view, exists between the strobilus (or rather the female part of it) and the vegetative stem, in which also only a minority of the leaves have buds (usually fructifications) in their axis. The unifoliar bud, which would thus represent a female flower,

1 The third view mentioned as possible by Count Solms-Laubach, that the interseminal scales are also axial, does not seem to be upheld. 
is, of course, extremely reduced. ${ }^{1}$ The analogy with the main stem is the strongest point in this interpretation, but it appears to be open to three serious objections: (I) there is no structural evidence that the seed-pedicel is a bud, or an axial structure of any kind $;^{2}$ (2) neither is there any evidence that the pedicels are axillary to certain of the interseminal scales; (3) there is no known structure among the Cycadophyta or Pteridospermeae from which such an organ as the supposed unifoliar female flower could have been derived by reduction. In an earlier work ${ }^{3}$ Professor Lignier supported his interpretation by a comparison with certain fructifications of Cordaiteae, in some of which, as already mentioned, the seeds were borne at the ends of long peduncles. The analogy, however, is of little value, for the two familics are so far apart that their common origin was probably too remote to have led to any community of floral characters. On the whole, the axial theory of the seed-pedicels, though supported with much ingenuity, appears, so far as our present knowledge shows, to lack an adequate structural or comparative basis.

On the alternative hypothesis, ali the organs constituting the gynæcium are of the nature of leaves, and borne, in accordance with the observed facts, directly on the axis. Dr. Wieland regards as most tenable "the theory that the seed-pedicel and the

1 O. Lignier, "Le fruit des Bennettitées et l'ascendance des Angiospermes," Bull. Soc. Bot. de Francë, ser. iv. L. viii. 1908.

"Unless it be found in the somewhat deeper insertion of the interseminal scales, as compared with the pedicels-a very dubious indication. See Wicland, l.c. p. 1 I 8 .

3 Structure et affuite's du Bennettites Morierei, 1894, pp. 68 and 72. 
interseminal scale are greatly reduced sporophylls analogous to and derived from sporophylls like those of the existing Cycads." 1 Arber and Parkin, who likewise regard the whole fructification as a flower, or "anthostrobilus," to use their own term, ${ }^{2}$ consider that the interseminal scales are "homologous with the carpels of the Angiosperms, despite the fact that they subtend and do not bear the seed-pedicels." ${ }^{3}$ They point out "a possibility that the seed-pedicels may, in part, represent a lobe of the carpellary leaf," ${ }^{4}$ and that they may or may not be homologous with the funicle of Angiospermous seeds." ${ }^{5}$ Professor Lignier argues with considerable force against the suggestion that seed-pedicels and interseminal scales represent lobes of the carpellary leaves, pointing out the complete independence of the bundles supplying the two organs, the absence of any definite relation in their arrangement, the differences in their structure, and especially the fact that in Bennettites Morierei the outer interseminal scales have several vascular bundles and are flattened like the bracts. ${ }^{\circ}$ It seems better to take the view that the interseminal scales are, like the bracts, modified leaves, though much more reduced, while we regard the seed-pedicels as the reduced megasporophylls or carpels. The interseminal scales may be sterile

1 I.c. p. $23 \mathrm{I}$.

2 They apply the term "pro-anthostrobilus," to the Bennettitean flower, to indicate its primitive features.

3 Origin of Angiospermls, p. 59.

4 L.C. p. 66.

5 I... P. 65 .

6 O. Lignier, Le fruit des bennettilies, 1908, p. 7 ; "Notes complémentaires sur la structure du Bennetlites Norierei," Bull. de la Soc. Linn. de Normandic, sér. v. vol. xiii. 1904. I have occasionally observed inter. seminal scales with two bundles in Bennettites Gibsonianus. 
carpels, but there seems to be no reason for assuming this, and the transitional forms between scales and bracts are against it. On the view here provisionally adopted, the whole lateral axis constituting the flower may be compared to the main axis of a Cycas, or rather to that of a hypothetical Cycadophyte or Pteridosperm bearing both male and female sporophylls, the leaves adjacent to the sporophylls being reduced, as are the scale-leaves of Cycas. The bracts are but little modified, while the stamens fully retain their foliar characters, and have been well compared by Wieland to the megasporophylls of Cycas. The interseminal scales and the monospermic carpels have undergone a somewhat extreme reduction, and their arrangement appears very different from that of the whorled stamens, though a verticillate order may possibly yet be traced in the organs of the gynæcium. The reduction demanded by the carpellary theory is, of course, far less than that which the axial theory of the pedicel requires; on the latter view each monospermic pedicel would be the homologue, not merely of a carpel, but of an entire strobilus.

As compared with the seed of a Pteridosperm or Cycad, that of the Bennettiteae is considerably simplified, especially in its vascular system, which appears to be almost limited to the chalazal disc or socket. This reduction is no doubt correlated with the enclosure of the seeds in a fruit.

Our knowledge of the earlier Cycadophyta is at present quite insufficient to enable us to form any conception of the course of evolution of the Bennettitean flower. The discovery of Triassic Cycadophytes 
with structure preserved would be likely to throw some light on the question. Unfortunately our accurate knowledge of the structure of these plants in Mesozoic times, though of extraordinary interest and value, is still limited to a comparatively narrow group-a special family which had attained a leading position in those days, somewhat as the Compositae have in the recent Flora. The Williamsonias diverge widely, in habit, from the usual Bennettitean type, but in their case we have as yet no knowledge of the internal structure.

The discovery of the bisexual nature of the flower and the arrangement of its parts has so greatly strengthened the Angiospermous analogies of the Bennettiteae, that an actual, though not a direct relationship, now appears probable. This important subject, however, will be left for discussion in the concluding chapter.

As regards affinities in other directions, the relation to the Cycadaceae is universally recognised, and has been sufficiently dwelt on above. Further research will be necessary before we can hope to determine the common ancestry of the two lines, with which other Cycadophytic phyla, as yet unknown, may have converged.

Advanced as the Bennettiteae were in their floral organisation, there can be no doubt that they were still Gymnosperms as regards their mode of fertilisation, as shown by the fact that the micropyles were exposed, protruding through the openings left between the coherent scales of the pericarp.

The stamens, while in their arrangement and monadelphous fusion they suggest the androecium of 
a fairly advanced Angiosperm, in structure and form correspond to the sporophylls of a Fern, their compound pollen-sacs, or synangia, exactly recalling those of some recent Marattiaceae. It is, however, improbable that these Fern-like characters (among which the ramenta must also be reckoned) came to the Bennettiteae directly from any group of true Ferns. There can be little doubt that the Bennettiteae and the Cycadophyta generally trace their descent through the Pteridosperms, and that it is by their means that the Filicinean features, so conspicuous in the microsporophylls, have been handed on to the later group; the presence of synangia, in particular, can thus be explained. It is certainly a striking fact that this family, so highly advanced in general floral structure and in the characters of the gynæcium, should have retained, with so little modification, a form of microsporophyll which is essentially that of a Fern.

The Bennettiteac thus present an extraordinary combination of characters, Filicinean, Gymnospermous, and Angiospermous. Their investigation, as we shall see in the next chapter, has for the first time thrown light on the great and obscure problem of the descent of the higher Flowering Plants.

\section{CONIFERAE}

The question of the origin and early history of the Coniferae, now the predominant Order of Gymnosperms, is clearly one of the most important on which fossil botany may be expected to throw light. At present, however, the cvidence on these points is 
imperfect, so that Coniferous remains, though abundant enough, have been spoken of as among the most unsatisfactory objects with which the palæobotanist has to deal. Of late years some real advance has been made, but the Coniferae are still, in the present state of our knowledge, unsuited for full treatment in the present course, the object of which is to bring forward only the best-ascertained results in our subject. One or two points, however, may be briefly referred to.

The Coniferae are evidently of great antiquity, for remains which can only be referred to this Order have been found with certainty in the Permian and possibly in earlier Palæozoic strata. An interesting Permian genus, unfortunately still imperfectly known, is Walchia, leafy twigs of which are common fossils, while some specimens have been found in fruit. The habit of these branches, of which several species have been described, is quite like that of some of the recent Araucarias, such as the Norfolk Island Pine, $A$. excelsa. Certain curious fossils, long described as a distinct genus, under the name of Tylodendron or Schizodendron, have turned out to be casts of the medullary cavity of stems, probably identical with those of Walchia, to which they would thus stand in precisely the same relation as that of the Sternbergia casts to the stem of Cordaites. The casts are marked with a characteristic areolation, corresponding to the course of the primary vascular bundles, and agree wonderfully closely with the configuration of the pith in the recent genus Araucaria. The structure of the wood, surrounding the pith of Tylodendron, is sometimes preserved, and is found to be of an Araucarioxylon type, known as 
A. Rhodeanum, differing from the Cordaitean wood in the arrangement of the pits and some other trivial characters.

Unfortunately, our knowledge of the Walchia fructifications does not go much beyond their external features. On certain specimens, small scaly cones are borne, some of which were probably male, while others are known to have been female; in Walchia filiciformis, Zeiller ${ }^{1}$ showed that each scale of the female cone bore a single seed, an important Araucarian character. In a specimen described by Renault, on the other hand, the lateral twigs each terminate in a bud-like body apparently containing a solitary seed ${ }^{2}$ (Walchia frondosa, Ren.). On the evidence available there appears to be some ground for referring such a species as $W$. filiciformis to the Araucarieae, the essential character of which lies in their fructification, and especially in the carpellary scales, each of which in the recent members of the family bears one ovule directly, without the intervention of a seminiferous scale. In vegetative characters there is also considerable agrcement, but it appears most probable that under the name Walchia very distinct types have been confounded. It has been maintained that Araucarieae are the oldest tribe of Coniferae; this statement, in the first instance, no doubt depended largely on confusion between Cordaiteae and Araucarieae; the former group is now excluded from the question, but there is some evidence, as we have seen,

1 Bassin houller et permien de brise flore fossile, 1892, 1. 99, Plate xv.

" Renault, Flore fossile d'Antum et d'Epinac, I'art ii. p. 357, I'late lxxviit. See also Potonié, Lehrbuch der Iflansenpalciontolonie, I899, p. 292, for a general account of Walchia. 
that, in the Permian period, Conifers resembling Araucarieae both in vegetative and reproductive characters already existed.

The evidence for the antiquity of the Araucarieae has recently been summed up by Professor Seward. ${ }^{1}$ In Triassic, Rhætic, and Liassic beds there are a number of specimens of twigs, wood, and cones which may probably be Araucarian, but none appear to be absolutely decisive. From the Jurassic onwards the evidence, from well-preserved cones and other remains, is ample and convincing. It is interesting to find that examples of probable Araucarieae with more than one seed on the carpellary scale have recently been described from Cretaceous horizons. In the genus Protodammara, of Hollick and Jeffrey, from the State of New York, there are three seeds on each scale, while the anatomical structure indicates a relation to the recent genus Agathis. ${ }^{2}$ In the Pseudoaraucaria of Fliche, from the Albian of the Argonne, each scale bears two seeds, and the structure suggests a possible link between the Araucarieae and Abietineae.

The Taxodieae, the tribe to which the famous "Big Trees" of California (Sequoia gigantea) belong, may claim a high antiquity, if the genus Voltzia, from the Upper Permian and Triassic, is rightly referred to this group. The evidence in this case does not depend merely on vegetative characters, but is strengthened by the morphology of the cone, the

1 Seward and Ford, "The Araucarieae, Recent and Extinct," Phil. Trans. Royal Soc. B, vol. I98, I906, p. 370.

2 A. Hollick and E. C. Jeffrey, "Affinities of Cretaceous Plant Remains commonly referred to Dammara and Brachyphyllum," American Natualist, vol. xl. 1906. 
seminiferous scales of which are lobed, as in the recent genus Cryptomeria. Voltzia, however, has also been regarded as an Araucarian. A number of other fossil remains have been referred to the Taxodieae, but they are for the most part of Tertiary or Cretaceous age. Cones closely resembling those of Sequoia, attached to leafy branches of the type known as Brachyphyllum, have, however, been found by Professor Zeiller in the Lias of Madagascar.

As regards remains of the Abietineae, the fossil cones are seldom well enough preserved to show the seeds in relation to the seminiferous scale, the character on which the identification of the tribe depends; in the case of such a genus as Pinus, however, the grouping of the needles on short twigs is so characteristic as to leave little doubt of the affinity, when this feature is associated with a resemblance in the habit of the cones. It has been known for some time that Abietineae, allied to Pinus, occurred in the Wealden formation; the evidence is strengthened by the occurrence of Abietineous wood at the same horizon. ${ }^{1}$ Recently the genus Pinus has been recognised, on the evidence of characteristic cones, in the Portlandian (Upper Oolite), while Abietinean wood has also been found in deposits of Jurassic age. Professor Jeffrey has lately described, under the name of Prepinus, leaves of a Cretaceous Conifer, preserved as lignite, which, while showing clear indications of affinity with Pinus, possess centripetal xylem in the bundle, and other primitive characters, even recalling the structure of

1 Seward, "Plants of the Wealden," Part ii. p. 193; "On a New Species of Conifer, Pinites R'uffordi," Joumal of the Linnem Society, vol. xxxii. p. $417,1896$. 
Cordaitean leaves to some points. $\mathrm{He}$ regards Prepinus as a probable ancestor of the true Pines. ${ }^{1}$

- Fossils from beds of much greater age-the Rhætic, for example (Schizolepis)-have been referred to Abietineae, but the evidence does not seem to be decisive.

Cupressineae have not been traced with certainty very far back, though twigs and cones of Cupressineous habit occur in the Jurassic. A fossil species of the recent genus Callitris (Widdringtonia) has been described from the Upper Cretaceous of Moravia, and seems to be an extraordinarily clear specimen, with characteristic cones of both sexes well preserved. ${ }^{2}$ If a recent genus already existed, in a characteristic form, in Cretaceous times, it is certain that the group to which it belongs must have been of very considerable antiquity, but we can only look to future discoveries for further light on its history.

The Taxaceae, as now limited (exclusive of Ginkgo), have not been traced back with certainty to a lower horizon than the Cretaceous, though branches with leaves like those of the genera Cephalotaxus and Podocarpus have been described from the Potomac formation, probably of about Wealden age. Professor Nathorst ${ }^{3}$ has quite recently shown that his genus

I E. C. Jeffrey, "On the Structure of the Leaf in Cretaceous Pines;" Ann. of Bot. vol. xxii. I908.

2 Potonié, l.c. p. 317, Fig. 322. The student will find an excellent summary of the geological history of the Coniferae in Professor Potonié's text-book. For the more recent work on the subject see Zeiller, "Les Progrès de la paléobotanique de l'ere des gymnospermes," P'rogressus Rci Botanicae, Bd. ii.·1907.

3 " Paläobotanische Mitteilungen. 7. Ueber Palissya, Stacliyotaxzs, und Palaeotaxus," Aongl. Svenska Vetenskap. Hiad. Handl. Band xliii. No. 8, Dec. 1908. 
Stachyotaxus, of Rhætic age, has much in common with Dacrydium, though in the fossil there are two seeds to each carpellary scale, instead of one. He further suggests the possibility that the contemporary Palissya, with five or six pairs of seeds on each carpel, may be related, though he points out as an alternative view that these genera may belong to an extinct race of Gymnosperms, intermediate between Coniferae and Cycadophyta.

Coniferous wood, in a petrified, and especially in a silicified condition, is among the commonest fossils of the Mesozoic strata. Such specimens, for example, are most abundant in the Lower Greensand and Wealden of the Isle of Wight, and in the Purbeck beds of Eastern Dorsetshire. Often, the preservation is absolutely perfect, so that the finest details of histological structure can be studied. ${ }^{1}$ Yet the results of such investigations have so fàr been on the whole unsatisfactory, and, however elaborately carried out, have rarely, as yet, enabled us to determine with any certainty the particular family to which a given Coniferous specimen belonged. The recent investigations of Dr. Gothan, ${ }^{2}$ however, in which additional characters, and especially the details of structure of the medullary rays, are taken into account, give promise of more definite results.

The study of the fossil Coniferae is not yet sufficiently far advanced for us to decide which of their

1 See Barber, "Cupressinoxylon zectense," for an especially careful and detailed examination of a Mesozoic Coniferous wood, Annals of Botany', vol. xii. 1898 .

2 See W. Gothan, "Zur Anatomie lebender und fossiler Gymnospermen Hölzer," Abhandl. der k. Preuss. Geol. Landesanstalt, Heft 44, 1905. 
families is the most ancient, or to form any clear conception of the course of their evolution. The direct palæontological evidence, however, apart from theoretical considerations, is favourable to the opinion that the Araucarieae have the longest fossil history, probably overlapping that of the typically Palæozoic Order Cordaiteae.

The discovery of fresh sources of evidence from remains with structure preserved, as in the case of the Cretaceous lignites of the eastern United States, now under investigation by Professor Jeffrey and his colleagues, is likely to throw much new light on the geological record of the Coniferae.

\section{GinkgoaceAe}

That isolated type, the genus Ginkgo, now regarded as constituting an Order, or even Class, by itself, has proved to be of great antiquity. Here we have to do with a well-characterised, easily recognised group, and the palæontological evidence is consequently of great significance.

The habit of the leaves of Ginkgo is so characteristic, that the evidence from fossil leaves, agreeing in form and venation with those of the recent genus, is in itself of some value. Such leaves have been recorded in abundance, from the Coal-measures onwards, and though many are doubtful, and may probably have belonged to Ferns, resembling in their foliage Actinopteris, or certain species of Schizaea, others are in all probability rightly attributed to the Ginkgoaceae. The genus Whittleseya, from the Lower Carboniferous, with 
leaves differing from those of Ginkgo in their short petioles and other characters, appears to be connected with the typical form by the new genus Ginkgodium. from the Lower Oolite of Japan. The genus Baiera of Braun is the most important group, and is distinguished from the recent Ginkgo by possessing a lamina with more numerous and narrower segments. This distinction, however, has no constant value, as some forms of leaf, even in the recent species, are much more deeply dissected than others. "The genus," says Mr. Seward, "was probably most widely spread during the Jurassic period, but there is fairly strong evidence in favour of extending its range to the Palæozoic epoch." I Many of the Triassic and Jurassic leaves are referred to the genus Ginkgo itself, and some are even indistinguishable from those of the recent Maidenhair tree, or can only be distinguished by the microscopic characters of the epidermis and stomata, points which have now been investigated with much success in carbonised specimens.

The evidence from the leaves is supported by the discovery of specimens of flowers and seeds, which appear to be conclusive as to the existence of the Ginkgoaceae, at least in Mesozoic times. As regards the Palæozoic evidence, Mr. Seward is of the opinion that "the plants which possessed characters nearest akin to those of Ginkgo were probably members of the Cordaitales, an extinct stock with which the Ginkgoaceae are closely connected" (l.c. p. 142).

In the Jurassic beds of Siberia, male flowers, agree-

1 Seward and Gowan, "The Maidenhair Tree (Ginkgo biloba, L.)," Annals of Botany, vol. xiv. March 1900. See also A. Sprecher, Le Ginkgo biloba, Geneva, 1907 . 
ing closely with those of the recent species, have been found, associated with the Ginkgo leaves, and similar specimens have been described from the Inferior Oolite of Yorkshire. ${ }^{1}$ Male flowers, found in Germany at a lower horizon, on the boundary of the Trias and Lias, were associated with Baiera leaves, and differed from the flowers of Ginkgo in the greater number of pollensacs borne on each stamen. This point is of interest, in view of the comparison with the male flower of Cordaiteae suggested above (Chapter XII. p. 538). Female flowers and seeds have also been discovered, but as the seeds are usually detached, the evidence is not quite so satisfactory on this side. Prof. Seward's views as to the Ginkgoaceous affinities of Beania have already been mentioned (p. 595). In this case, however, the reasons for connecting the flower with Cycadaceae seem about equally strong.

On the whole, the sum of the fossil evidence is of sufficient weight to prove the great antiquity of the Gymnospermous family now represented by the Maidenhair tree, which appears to be best regarded as the one surviving member of an ancient stock, derived from the same cycle of affinity as the Palæozoic Cordaiteae, once the dominant type of Gymnosperms.

1 A. C. Seward, Jurassic Flora, Part i., Ig00, p. 260. 


\title{
CHAPTER XIV
}

\author{
GENERAL RESULTS
}

THE first broad conclusion arrived at from the study of fossil botany - the great relative antiquity of the Vascular Cryptogams and Gymnosperms, as compared with the Angiospermous Flowering Plants-still holds good, though we should now state this fundamental generalisation in rather different terms from those used by its original author, the great Brongniart. ${ }^{1}$ The lower Seed-plants were more prominent in Palæozoic times than Brongniart was aware, and differently constituted, for while his Asterophylliteae and Sigillarieae ${ }^{2}$ have proved to be Cryptogamic families, the ranks of the Spermophyta have received a more than equivalent accession in the Pteridosperms, now transferred to them from the Ferns. Brongniart's conclusion was far from being an obvious one at the time, for he and his contemporaries still included the Gymnosperms under Dicotyledons, so that in recognising the much higher antiquity of the former the palæontologist anticipated the results of the comparative morphologist.

1 See his "Tableau des genres de végétaux fossiles," p. 93, Dictionnaire universel d'histoire naturelle, 1849.

2 L.C. p. 97. 
The question of the classification of the groups of plants with which we have been concerned may be considered here, before going on to the results under each group. To a considerable extent the question turns on the position of the Sphenophyllales; we have recognised that they form a synthetic group, and have dwelt especially on their apparent relations to the Equisetales and the Lycopods, suggesting the common origin of these phyla. As regards the relation between the Sphenophyllales and the Equisetales there is little room for doubt, as will be shown below (p. 619); this may be expressed by grouping together the two classes under the name Articulatae, in accordance with a suggestion of Professor Lignier's, and adding the new group Pseudoborniales. The same author regards both Sphenophyllales and Equisetales as derived from primitive Ferns, ${ }^{1}$ and although I am not able to follow all his arguments in detail, I think there is some evidence of affinity in this direction. The Sphenophylls resemble certain Ferns in the venation and frequent dichotomous division of their leaves; they are not really microphyllous like the Lycopods. The oldest Equisetales likewise had forked leaves, while in the Devonian Pseudoborniales, which clearly belonged to the Articulatae, the leaves were highly compound. So far as the leaf-characters are concerned, the Lycopods appear to stand alone as the one truly microphyllous phylum. On the other hand, the Sphenophylls certainly approach the Lycopods in their anatomy, though the taxonomic

1 O. Lignier, "Equisétales et Sphénophyllales, leur origine filici-

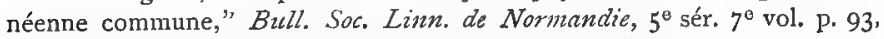
Caen, 1903; "Sur l'origine des Sphénophyllées," Bull. Soc. Bot. de France, sér. 4, tome viii. p. 278, 1908. 
value of the characters which they have in common is difficult to estimate. In some respects the Psilotaceae seem to connect the Sphenophylls with the Lycopods, but it is not wise to rely much on evidence from a recent family in questions of remote ancestry. Although various attempts have been made to group all the classes of vascular plants under two main heads, it seems that in the present state of our knowledge a threefold division is still to be preferred, so as to avoid prejudicing questions which are still open.

The affinities of the Equisetales, Pseudoborniales, and Sphenophyllales are generally admitted; to them we may append the Psilotales, for reasons which will be subsequently explained (p. 626). The Lycopodiales are at present best left by themselves, for the fossil members show little or no approximation to any other phylum.

The Ferns likewise appear to have followed their own course of development from the earliest times to which our records extend; they show, however, evident affinities with the great bulk, at any rate, of the Seedplants. Our provisional arrangement may, therefore, take the following form :-

SPHENOPSID.A $\left\{\begin{array}{l}\text { Equisetales } \\ \text { Pseudoborniales } \\ \text { Sphenophyllales } \\ \text { Psilotales }\end{array}\right\}$ Articulatae.

LYCOPSIDA . Lycopodiales

PTEROPSIDA $\left\{\begin{array}{l}\text { Filicales } \\ \text { Pteridospermeae } \\ \text { Gymnospermeae } \\ \text { Angiospermeae }\end{array}\right\}$ Spermophyta. 
It will be noticed that this grouping crosses the customary division of Vasculares into Pteridophyta and Spermophyta. Though the traditional classification will, no doubt, continue to be used on grounds of convenience, it no longer, in the light of the palæobotanical evidence, expresses a natural arrangement, for the affinities between Pteridosperms and Ferns appear to be far closer than those between Ferns and any other Pteridophytic phylum.

The divisional name Pteropsida is taken from Professor Jeffrey, and used in the same sense as by him. His Lycopsida, however, are here limited to the Lycopodiales, the typically microphyllous phylum, while he included our Sphenopsida in the same division. This is not the place for a detailed discussion, but I am no longer of opinion that the affinity between Lycopods and the sporangiophoric Pteridophytes (Professor Bower's name for our Sphenopsida ${ }^{2}$ ) is sufficiently established to render their inclusion under a common name expedient. The name Sphenopsida has been selected because of the synthetic character of the class Sphenophyllales, rendering them the best type of the division.

A certain degree of convergence between the main divisions of Vascular Plants may be traced as we follow their history back to its earliest records. Some of the oldest Sphenopsida show an approach in leaf-characters to the megaphyllous Fern-phylum, while anatomically they tend rather towards the

1 As in the subtitles given to the two volumes of the present book.

${ }^{2}$ F. O. Bower, Origin of a Land Flora, I908, Chapters xxvii.-xxix. The author's association of the classes with specialised sporangiophores appears eminently natural and suggested the arrangement here adopted. 
Lycopods. The record does not go far enough back to show whether this convergence really indicates a common origin for all Pteridophyta from a single stock, though such an hypothesis is quite tenable.

The question of the ancestry of the Vasculares or of the origin of their characteristic alternation of generations is not as yet directly touched by the palæontological evidence. The general character of the earliest known land-floras, however, and especially the prevalence of megaphyllous types, lends no support to the idea that the spore-bearing plant of the Pteridophytes was ever derived from a sporogonium, whether Bryophytic or otherwise. On the other hand, the evidence, so far as it goes, is perfectly consistent with the hypothesis of the origin of the sporophyte from a brauched thallus, a view which has gained ground of late years. ${ }^{1}$

As regards the difficult question of the relation of the Pteridophyta to the Bryophyta, we have no positive evidence from fossil botany, for scarcely anything is known of the history of Bryophytes. One or two supposed Liverworts and Mosses have been recorded from Palæozoic rocks, but in the absence of any knowledge of their structure or reproduction the nature of the specimens must remain doubtful. It is remarkable that no remains of Bryophyta have been detected in the petrified material, in which the most

1 See A. G. Tansley, "Evolution of the Filicinean Vascular System," New Phytologist Reprint, Igo8, Lecture I.; W. H. Lang, "A Theory of Alternation of Generations, based upon Ontogeny," Nez Phytologist, January igog. The antithetic view, on the other hand, forms the basis of Professor F. O. Bower's work, The Origin of a Land Flora, 1908. The present position of the question is illustrated by a discussion at the Linnean Society, reported in the Nerw Phytologist for 1909. 
delicate tissues are preserved and a great variety of organisms represented. The question of the existence of Palæozoic Bryophyta must still be regarded as an open one. The hypothesis that the Pteridophyta arose from a Bryophytic ancestry has thus received no support from the palæontological record.

We will now go on to consider, somewhat more fully, the affinities of the various groups of Vascular Plants dealt with, beginning with the articulated Sphenopsida.

\section{SPHENOPSIDA}

The general morphological agreement between the two classes Sphenophyllales and Equisetales is manifest, and extends to Nathorst's new class Pseudoborniales. The articulated stem, and the constant verticillate arrangement of the appendages, are characters obviously common to the whole series. Archaeocalamites, the oldest of the known Equisetales, distinctly approaches the Sphenophyllales in the superposition of the verticils and in the dichotomously divided leaves, while in many Calamariaceae the individual leaves resemble the leaves or leaf-segments of the plurifoliate Sphenophyllums so closely as to be almost indistinguishable. Professor Lignier has endeavoured to carry the comparison further and to place it on an anatomical basis. In the typical species of Sphenophyllum there are six leaves in a whorl, but the vascular strands supplying each two leaves start from the same angle of the triarch stele, suggesting that three was the original number of leaves in a verticil. In some 
species (e.g. Sphenophyllum Dazesoni, p. IOI) the increased number of leaves has affected the stele itself, each of its angles being double. When the leaves are further segmented, a further forking of the bundles takes place within the cortex, and it appears indisputable that the numerous leaves of such a species as $S$. myriophyllum represent the segments of a few deeply divided original appendages. In the Calamariaceae, on Lignier's view, the same process has gone further, the increased dimensions of the stem involving a corresponding multiplication of the leaves and of the bundles in the stem. In cases like the axis of Calamostachys, we have a clear analogy with Sphenophyllum in the fact that each two bracts receive their vascular supply from the same axial bundle, while in Palaeostachya vera the axial bundles are themselves duplicated, forming evident pairs (p. 65). It certainly appears highly probable that the small and numerous whorled leaves of the Calamariaceae may have arisen, as in the Sphenophyllales, by the subdivision of a smaller number, with corresponding anatomical changes. That the leaves were originally compound or much cut is rendered probable by the presence of such divided leaves in the early fossils Archaeocalamites, and more especially Pseudobornia, the leaves of which, when found isolated, were actually taken for the fronds of a Fern.

In anatomy, the Sphenophyllales, with their solid protostele, appear to be clearly more primitive than the Equisetales, which in all cases have a pith and distinct vascular bundles. The anatomical gap between the two classes appeared a very wide one, until it was partly bridged by the discovery of centripetal wood in 
the stem of the Lower Carboniferous Protocalamites (p. 37). ${ }^{1}$

The evidence from the fructifications strongly supports the affinity between Sphenophyllales and Equisetales, though the detailed comparison presents some difficulties. The minute structure of the sporangia is strikingly similar in the two classes, and the resemblance extends to the sporangiophores. Those of Cheirostrobus in particular, which have four sporangia, are almost identical with those of Calamostachys (pp. 54 and II6). Where the number of sporangia is smaller the resemblance to the Equisetal type becomes less evident.

Throughout the Sphenophyllales the sporangiophores occupy the position of ventral lobes of the sporophyll ; in one species, S. fertile (p. I I I), the dorsal lobes are also enlisted for the same service. This latter case is of special interest, because the dorsal and ventral lobes are on an equal footing, both being organised in the same way; the segments of each lobe constitute typical bisporangiate sporangiophores. I incline to regard this form as a secondary modification rather than a primitive type, partly because the case is at present altogether exceptional and of no special antiquity, and partly because the dorsiventral arrangement seems best explained on the supposition that the dorsal lobes were originally sterile and protective

1 Mr. Gwynne-Vaughan has suggested that the lateral xylem-strands in the recent Equisetzm may represent the centripetal wood. Their position, however, is very different from that of the centripetal wood in Protocalamites, and the matter requires further investigation. See D. T. Gwynne-Vaughan, "Remarks upon the Nature of the Stele of Equisetum," Ann. of Bot. vol. xv. 1901, p. 774 . 
in function. It may be added that the very leaf-like character of the bracts in most Sphenophylls, and especially in Sph. majus (p. I I 3), makes it difficult to interpret them as sterilised sporangiophores. But whether we regard $S$. fertile as a modified or a primitive form, ${ }^{1}$ it shows clearly that the sporangiophores and bracts have equal claims to be regarded as lobes of the sporophyll. This conclusion applies also to Cheirostrobus; it is only in Sphenophyllum emarginatum that the sporangiophores and bracts appear to have been independent, as they have left separate scars on the axis of the cone. ${ }^{2}$

In Calamostachys, among the Equisetales, the two organs are externally quite separate, but the course of the bundles supplying the sporangiophores suggests that the latter may represent displaced ventral appendages of the bracts (p. 6o). Palaeostachya, from the position of the sporangiophores immediately above the bracts (p. 66), seemed at first to form a link with the Sphenophyllales, but Mr. Hickling's observations on the vascular supply rather suggest a modification of the Calamostachys arrangement. The Equisetum type of strobilus appears to have been already represented in Palæozoic times, and in Archaeocalcmites the bractwhorls were, at most, few and scattered. It has been proposed to derive the bractless arrangement from that found in Sphenophyllum fertile, the assumption being that the lobes of a wholly fertile sporophyll underwent a displacement like that which appears to

1 The latter view is maintained by Lady Isabel Browne in her interesting résumé of the "Phylogeny and Inter-relationships of the Pteridophyta," New Phytologist, vol. vii. I908, p. 94.

2 As shown by an unpublished observation of Mr. W. Ilemingway's. 
have taken place between the sterile and fertile lobes in Calamostachys. ${ }^{1}$ The evidence, however, is as yet insufficient to establish any such interpretation, and it may well be that the Sphenophyllum analogy has been pushed too far. There is no need to reduce every sporangiophore to a leaf-lobe, for it is not at all unlikely that in the Sphenopsida, as in the Pteropsida, the spore-bearing organ may be sometimes a lobe of a leaf, sometimes an entire leaf, especially as it is often so difficult to distinguish between leaf-segments and leaves in the vegetative region.

Professor Bower regards the sporangiophore as "a part sui generis as much as the sporangium is, and not the result of modification of any other part." 2 Miss Benson, from a different point of view, has been led to a similar conclusion." There is much to be said for this interpretation, which I provisionally adopted in the First Edition of these "Studies" (p. 498). On the actual evidence, however, there is nothing to prevent our regarding the sporangiophore as always of a foliar nature, and it appears unadvisable to multiply categories of organs without necessity. The sporangium and the sporangiophore are not really on the same footing, for there must always have been distinct organs of reproduction, whereas in innumerable cases the organ which bears them is simply a leaf, or part of a leaf. At the same time it is probable that the differentiation of the sporangiophore took place very early,

1 Scott, "Present Position of Palæozoic Botany," Progressus Rei Botanicae, Bd. i. p. 162, 1906.

${ }^{2}$ Origin of a Land Flora, p. 426.

3 "The Sporangiophore-a Unit of Structure in the Pteridophyta," New Phytologist, vol. vii. I908, p. 143. 
in certain lines of descent, and that the organ is thus of considerable morphological importance.

On the whole of the evidence there can be no doubt that a real affinity exists between the Sphenophyllales and the Equisetales, the former being clearly the more primitive class of the two, or rather the representatives of a more primitive stock, for the known Sphenophylls are evidently specialised in various directions. The arguments for the aquatic habit of Sphenophyllum do not hold good, as already pointed out (p. 88); the great development of the wood relatively to the size of the stem is the reverse of what one would expect in a water-plant ; on the other hand Professor Seward's suggestion that Sphenophyllum may have been "a slender plant which flung itself on the branches and stems of stronger forest trees for support," ${ }^{1}$ agrees well with the habit and structure. The occurrence of extensive secondary growth in this genus is interesting, as showing that this character was not necessarily correlated, even in Palæozoic times, with an arborescent habit.

The enormous development of the Equisetales in early geological periods, compared with their reduced condition at the present day, is a striking fact. It is of interest to consider in what respect the gigantic Palæozoic Horsetails differed from their humbler successors.

One great and obvious difference was the formation of secondary wood and bast and of periderm. Starting with a structure in stem and root essentially like that of a recent Equisetum, the Calamariaceae, by the activity of a normal cambium, produced new wood and phloëm,

1 Fossil Plants, vol. i. 1898, p. 392. 
to an indefinite extent, precisely as in a Gymnospermous tree, and replaced their primary cortex by a broad zone of secondary periderm. It was one of Williamson's greatest services to science that he always, in the face of much opposition, insisted on the true "exogenous growth " of the Calamites, while maintaining with equal decision their Cryptogamic nature. He thus established one of the most striking instances of homoplastic modification, for the close agreement in these anatomical characters between certain Cryptogams and Phanerogams is not, in itself, any proof of affinity.

As has already been pointed out, it is probable that the microphyllous character is not a primitive one in Equisetales, and that the leaves are reduced from a larger and more complex type, as seen in Archaeocalamites and Pseudobornia.

The old opinion of the French school that some Calamariaceae were seed-bearing plants has not been substantiated by later work. Heterospory, however, appears in a perfectly well-marked form in some of the fructifications, though the differentiation of the two kinds of spore was not so extreme as in heterosporous Lycopods or the recent Water-ferns. In other Calamarian strobili the evidence is all in favour of homospory; the abortion of certain spores in sporangia of this type may have prepared the way for the heterospory of the more advanced members of the group (p. 57). In this, respect the Equisetales seem to have reached a higher level than the Sphenophyllales, among which only doubtful indications of incipient heterospory have so far been detected.

Considering the high development of the Palæozoic 
Equisetales, it is an interesting question whether our living Equiseta are their degenerate descendants, or the offspring of a simpler stock which may have co-existed with the arborescent forms in ancient times. The earlier Mesozoic Equisetales appear to have been intermediate in certain respects between the Calamariaceae and the recent genus, as shown especially by Mr. Halle's results (p. 83). By Wealden times, forms almost identical with modern Horsetails had appeared. These facts favour the hypothesis of reduction, which may also be supported by the observation (if rightly interpreted) of secondary growth, at the nodes of some living Equiseta. ${ }^{I}$ The Equisetales, as a class, have conspicuously failed to hold their own in the secular struggle for existence, though the survivors are extraordinarily well adapted to particular conditions, and maintain their ground, when once established, with singular obstinacy.

The possibility of a relation between the Sphenopsida and the Lycopsida will be discussed under the latter head, but we have now to consider the reasons for including the recent group Psilotaceae in the same division with the Articulatae. The question concerns us here because it turns entirely on the relations between the recent family and the Palæozoic class Sphenophyllales. The points of comparison of chief importance are the anatomy of the stem and the morphology of the sporophyll. As regards the former, Psilotum presents a nearer analogy with Sphenophyllum than any other living plant; the resemblance becomes very marked in those branches

${ }^{1}$ Cormack, Annals of Botany, vol. vii. I893, p. 63. 
which have a triarch stele with the wood reaching the centre; in other parts of the Psilotum stem a resemblance to the stele of Cheirostrobus has been traced. Mr. Boodle's discovery that, at the base of the aërial stem and in adjoining parts of the rhizome, a distinct formation of secondary wood takes place in old plants ${ }^{1}$ materially strengthens the anatomical analogy. The mesarch structure of Tmesipteris finds some slight analogy in that of Cheirostrobus (p. I I g). Evidence from the anatomy is, however, insufficient by itself, for on anatomical grounds a comparison of the Psilotaceae with recent and fossil Lycopods is also admissible. The morphology of the sporangial apparatus is more significant, and must now be considered.

The nature of the synangium of the Psilotaceae has long been in dispute. In modern times there have been two principal views: (I) that the synangium is borne directly on the subtending leaf, a forked bract, which is thus regarded as a true sporophyll; and (2) that the synangium represents a fertile branch, the first two leaves of which are fused to form the forked bract. On the second view the sporophylls are assumed to be entirely suppressed. Celakovsky, who upheld the first of these opinions, interpreted the synangium as a fertile, ventral lobe of the sporophyll, comparable to the spike of Ophioglossum, and this comparison was adopted by Bower, who regarded the synangium or fertile spike in both cases as ultimately derived from a sporangium which had become septate. ${ }^{2}$

1 L. A. Boodle, "On the Occurrence of Secondary Xylem in Psilotum," Ann. of Bot. vol. xviii. 1904, p. 505.

${ }^{2}$ For the most recent statement of Professor Bower's views, see his Origin of a Land Flora, 1908, Chapters xxviii. and xxxi. 
The comparison with Ophioglossum was also emphasized by Mettenius and Solms-Laubach, and from a purely morphological point of view appears to be well justified. The groups Psilotaceae and Ophioglossaceae are, however, so widely divergent in their other characters, that any affinity between them must be remote in the extreme. In the Sphenophyllales, on the other hand, we have a group, with which, as we have seen, the Psilotaceae have other characters in common. In the Sphenophylls the sporangia are borne on a ventral outgrowth of the bract or sporophyll, each fertile outgrowth having its own vascular supply, arising as a branch-strand from the bundle of the dorsal bract. In Tmesipteris (the less reduced of the two genera of Psilotaceae) the agreement with Sphenophyllum is clear. A leaf-trace passes out from the stele and enters the base of the sporophyll, where it divides into three (Fig. 2I3, B). Two of the branchstrands enter the two forks of the sporophyll, while the third turns upwards, passes through the pedicel of the synangium, and extends into the septum between its two constituent sporangia ${ }^{1}$ (Fig. 2 I 3, A). Thus the position of the pedicellate synangium and its anatomical relation to the subtending sporophyll correspond exactly to the conditions in the Sphenophyllales. The comparison, originally pointed out in my paper on Cheirostrobus in 1897 , and further emphasised in the first edition of these "Studies" (p. 499), has received valuable support from the observations of Professor Thomas, ${ }^{2}$ of Auckland, New Zealand, who has

1 For some more detailed observations see below, p. $63 \mathrm{r}$.

3 A. P. W. Thomas, "The Affinity of Tmesipteris with the Sphenophyllales," Proc. Royal Society, vol. lxix. I902, p. 343. 
had specially favourable opportunities for the investigation of Tmesipteris under natural conditions. He has
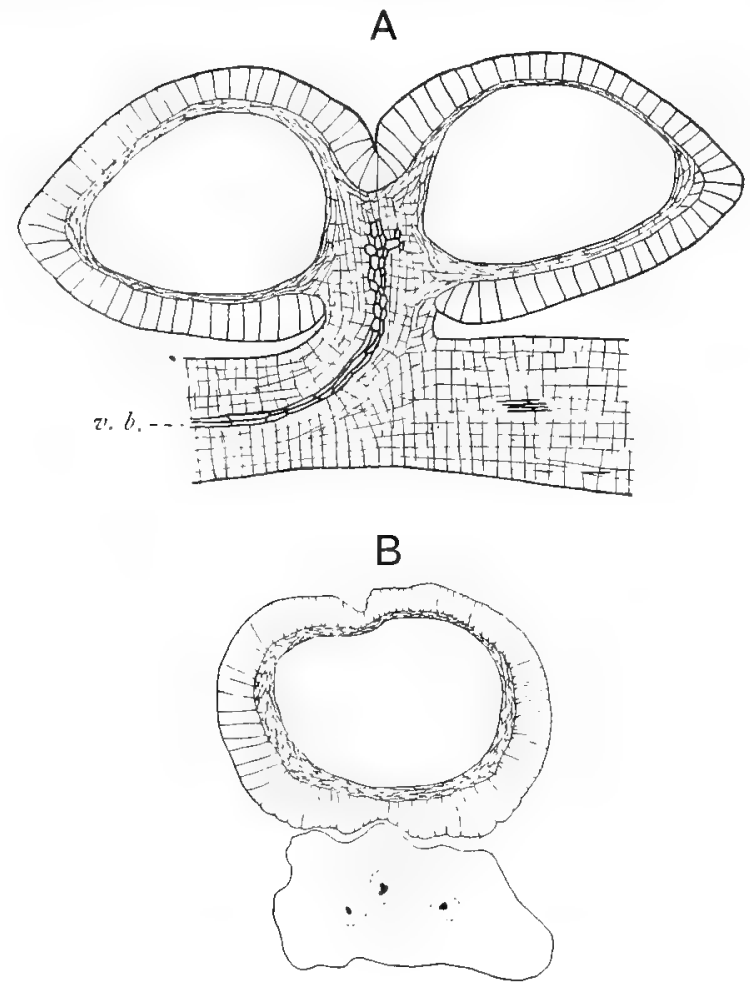

FiG, 2I3.-Tmesipteris. A. Somewhat diagrammatic radial section of synangium and part of sporophyll, showing vascular bundle, $7, b .$, passing into sporangiophore from sporophyll; on the right a fragment of one of the bundles of the forked sporophyll is shown.

B. Transverse section of synangium and sporophyll in a plane lying between the sporangiophore and the stem. In the sporophyll three bundles are chown, the middle strand belonging to the sporangiophore and the two laterals to the forked sporophyll.

found that certain interesting variations normally occur in the species. The most important variation consists in the repeated bifurcation of the sporophyll, a synangium 
being present at each bifurcation. This variation occurs, in varying degrees, in the middle of the reproductive region of the most vigorous plants, and is extraordinarily frequent, sometimes extending to a majority of the sporophylls on the shoot. Professor Thomas compares the arrangement in these compound sporophylls with that in Cheirostrobus (p. I I 6); a closer parallel may be found in the repeatedly forked sporophylls of Sphenophyllum majus (p. I I 3), with which the agreement appears to be almost exact, except for an unimportant difference as regards the number of sporangia in each group. In other instances observed by Thomas the synangium acquires an elongated stalk, with somewhat pendulous sporangia, as in Bormanites Römeri. Some similar variations were also observed in Psilotum. The repeatedly forked form of sporophyll, which appears to be so common as to fall under the head of normal variations, is unfavourable to the idea of any near affinity between Psilotaceae and the Lycopods, while it affords strong evidence for a relationship to the Sphenophyllales. Such a relationship also explains the forked form of the normal sporophyll characteristic of the family. Taking the anatomical characters also into account, there is thus a strong case for an affinity between the Palæozoic Sphenophyllales and the recent family. I do not, however, go so far as Professor Thomas and Professor Bower, who include the Psilotaceae in the class Sphenophyllales. The differences are, in my opinion, too great to allow of so close a union. The most obvious distinction is in the phyllotaxis, which is spiral, or at least alternate, in the Psilotaceae, while it is always verticillate in the Palæozoic Sphenophyllales. 
From the great constancy of this character throughout the Articulatae I am inclined to attach considerable importance to it in this case, though in other groups it may be variable. The mode of branching is also very different, dichotomy occurring in the Psilotaceae, while monopodial branching prevails in the Sphenophyllales. For these reasons, among others, it seems best to regard the Psilotaceae as forming a class of their own, the Psilotales, while including them under the main division Sphenopsida.

Miss Sykes, in an interesting memoir on the anatomy and morphology of Tmesipteris, ${ }^{1}$ adopts the axial theory of the fructification of Psilotales, and extends it to the Sphenophyllales and the Equisetales, regarding the sporangiophore as representing a branch throughout all these groups. She thus accepts the general view of the relationships maintained by Thomas, Bower, and myself, and endeavours to reconcile it with the axial theory of Bertrand, Goebel, and others. In the special case of Tmesipteris, the latter theory is supported, among other arguments, by the observation that the vascular strand entering the synangium-pedicel branches into three, the central strand soon terminating, while the two lateral branches run round the periphery of the septum. The axial interpretation might be a tenable one if the Psilotales stood alone, but throughout the Articulatae there appears to be no satisfactory evidence that the sporangiophore is a branch, while there is much in favour of its foliar nature, as has been shown above. The axial theory seems, on present evidence, to rest on too slender a basis.

1 Annals of Botany, vol. xxii. 1908, p. 63. 
Professor Lignier, ${ }^{1}$ on the other hand, while regarding the synangium as a terminal spikelet, takes the view that the Psilotales are excessively primitive, being the nearest living representatives of his hypothetical proLycopod type, which he supposes to have formed the starting-point of the Vascular Plants. I cannot accept the epiphytic group Psilotales as really primitive, for one of the two genera bears obvious marks of reduction in relation to habitat, while the other shows signs of modification in the same direction, though in a lesser degree. Neither is there any satisfactory geological evidence for the antiquity of the family in its present form.

\section{LYCOPSIDA}

On the whole the fossil record as yet throws singularly little light on the origin and affinities of the Lycopodiales. In the first edition of these "Studies" I laid stress on the relation of this class to the Sphenophyllales, and, through them, to the Equisetales. Professor Jeffrey, on independent grounds, united all these classes in his Lycopsida, ${ }^{2}$ as a main division of Vascular Plants, while his Pteropsida included all the remaining groups. It now appears probable that the Articulatae were derived from megaphyllous plants, whereas we have at present no evidence that the Lycopods were ever anything but microphyllous, though the possibility of a reduction from large-leaved forms remains open. Further, the Articulatae and Psilotales are "sporangio-

1 See his two papers cited above, p. 615.

2 E. C. Jeffrey, "Structure and Development of the Stem in the Pteridophyta and Gymnosperms," Phil. Trans. Royal Soc. B, vol. 195, 1902, p. I44; also his earlier papers there cited. 
phoric," bearing their sporangia on specialised appendages, whereas throughout the Lycopods we find a single sporangium seated directly on the sporophyll, or in its axil. This simple arrangement may also be due to reduction; the ventral outgrowth of the sporophyll which bears the sporangium in Spencerites has been compared to the sporangiophore of Sphenophyllales, and Miss Benson has recently interpreted the sterile tissue of the sporangium in Mazocarpon and an allied fructification as representing a sporangiophore. These suggestions are very interesting, but at present too hypothetical for any conclusion as to affinity to be based on them. ${ }^{1}$

In the anatomy there is no doubt a considerable analogy between the Lycopods, especially the Palæozoic types, and the Sphenophyllales. The stelar structure of Cheirostrobus, for example, is much like that of a Lepidodendron such as $L$. selaginoides, allowing for the fact that the leaf-arrangement is verticillate in the one and spiral in the other. This type of stele, ${ }^{2}$ however, may also occur in Ferns (though not characteristic of that class); its wide distribution is one of the facts in favour of an ultimate common origin for all the vascular phyla. On the whole it appears probable that some remote affinity really exists between the Lycopods and the Sphenopsida, but probably no closer than that between the Sphenopsida and the Ferns.

The Lycopods manifestly attained their highest development in Palæozoic times, as regards abundance,

1 See also Miss M. G. Sykes, "Notes on the Morphology of the Sporangium-bearing Organs of the Lycopodiaceae," Nerw Phytologist, vol. vii. 1908 , p. 41 .

i.e. an exarch protostele. 
stature, and organisation, both vegetative and reproductive. In spite of their immense development at that time compared with their very subordinate position at the present day, the Lycopods, as a whole, constitute a very homogeneous class of plants, characterised throughout by a microphyllous habit, an anatomy based on an exarch type of protostele, and a simple relation between sporangium and sporophyll. There is no departure from the first-named character; for though the leaves were often long, they were never large in proportion to the plant, and were always of the simplest form. The double bundle of Sigillariopsis, a form of leaf belonging to certain species of the somewhat advanced genus Sigillaria, is the only departure from the prevailing simple type of foliar structure (p. 230).

Attention has already (p. I 26) been called to the simplicity of the primary anatomical structure of the stem in Palæozoic Lycopods, the one character in which these plants have proved to be more "primitive" than most of their recent allies. A gradual transition may be traced from the protostelic type, through the medullated forms of Lepidodendron and the ribbed Sigillarias, to the smooth-barked Sigillarias, in which the ring of wood separates, more or less completely, into distinct bundles (p. 220). It is these last forms which depart most widely from the common Lycopod type, but the change is not a great one, and does not appear to indicate a transition to any form of Gymnospermous stem.

As regards the secondary growth, characteristic of the arborescent Lepidodendreae, there are some peculiarities; the agreement with the normal secondary 
thickening of Gymnosperms and Dicotyledons is somewhat less exact in this class than in the Sphenopsida or the Pteridosperms. In some forms (Lepidophloios fuliginosus, for example,-p. I 54) the zone of thickening is extremely irregular, and although in other Lepidodendreae it approaches the normal type more nearly, it is doubtful whether in any case the same cambium remained continuouslyactive throughout. The secondary growth of Isoëtes presents some interesting analogies with that of the Lepidodendreae.

The enormous development of the secondary cortical tissue, chiefly phelloderm, is a striking feature of the tree Lycopods, and with this again the growth of the cortex in Isoëtes alone presents any analogy, though, at best, only a remote one.

The difficult question of the morphology of Stigmaria, the subterranean part of the Lepidodendroid plant, already discussed (p. 259), suggests that the differentiation between "root and shoot" may have been less sharp in this group than in other Vasculares. Similar indications are to be found in the rhizophores of Selaginella and the stem-like roots of some Lycopodiums at the present day. A suggestion has recently been made by Professor F. E. Weiss that an analogy for the Stigmarian axes may be found in the protocorm, the rudimentary, somewhat thalloid, stem which is the first product of germination in some species of $L y c o-$ podium, and appears to be persistent in the tuber of Phylloglossum.

It is a curious fact that among the very numerous fructifications that have been investigated, no certain 
instance of a homosporous Palæozoic Lycopod has yet been discovered. Wherever the material has allowed of a definite conclusion, two forms of spore, as sharply differentiated as in any recent members of the class, have been found. Spencerites is sometimes cited as an exception, but the evidence is inconclusive, and the spores are singularly unlike those of any known homosporous Lycopod I (p. 189). The oldest known genus of Lycopods, Bothrodendron, was markedly heterosporous, if we may judge from the Coal-measure species. Among the herbaceous as well as the arborescent Lycopods, only heterosporous forms have so far been detected; in some of the former (Selaginellites primaevus) there is an exact agreement with the recent Selaginella (p. 264).

It is impossible to doubt that homosporous Lycopods existed in Palæozoic times, but the prevalence of higher methods of reproduction shows how far the class had already advanced at the period when our fossil record begins.

Certain Lycopods, as we have seen (p. I 93), went beyond mere heterospory, and developed organs closely analogous to true seeds. Of the two genera in which seed-like organs are known, the one, Lepidocarpon, clearly belonged to the Lepidodendreae, while the other, Miadesmia, appears to have been a small herbaceous plant, perhaps, as Miss Benson has suggested,

${ }^{1}$ Professor W. H. Lang has recently traced some analogies between the structure of the cone of Spencerites and that of Lycopodizim cermum. These resemblances, even if fully confirmed, cannot, however, be accepted as indicating affinity until the comparison rests on a much broader basis. See Lang, "Preliminary Statement on the Morphology of the Cone of Lycopodium cernum and its Bearing on the Affinities of Spencerites," Proc. Royal Soc. of Edinburgh, vol. xxviii. Part v. I908. 
epiphytic on the larger Lycopods with which it is associated. The affinities of Miadesmia, which in some respects resembles a Selaginella, are not yet determined, but in any case it seems clear that this genus acquired the seed habit on its own lines, and independently of Lepidocarpon.

The seed-like organs of these Lycopods, though they may probably have been functionally seeds in the same sense as those of the Pteridosperms, are greatly inferior to the latter in morphological differentiation, and stand much nearer the Cryptogamic type of megasporangium. They are, in fact, the only really "primitive" seeds known to us, and as such are of special interest, though they probably only represent a side-line of evolution.

As regards the relation of the "Palæozoic to the recent Lycopods, only the heterosporous forms of the latter come under consideration, for as yet we know nothing certain of the history of the homosporous Lycopodiaceae. It now seems clear that the genus Selaginella, or types scarcely distinguishable from it, already existed in the Palæozoic Flora, and that it had no near relation to the arborescent Lepidodendreae. On the other hand, there may well be some connection between the Lepidodendreae and the greatly reduced heterosporous genus Isoëtes, which, in the structure and insertion of its sporangia, as well as in anatomical characters, has much in common with the Palæozoic tree Lycopods. In the occurrence of sterile trabecula in the sporangia of some Lepidostrobi, Professor Bower has recognised an interesting point of agreement with Isoëtes. ${ }^{1}$

1 The curious Triassic genus Pleuromeia has been regarded as is link between the two groups, but if, as is stated, the sporangia of Pleuromeia 
The question of a possible relationship between the Palæozoic Lycopods and certain Seed-plants will be discussed when we come to the Gymnosperms.

\section{PTEROPSIDA}

The result of the palæobotanical research of the last twenty years has been to exalt the importance of the Fern phylum, which now appears to have been the source from which the great majority, if not the whole, of the Seed-plants were derived. At the same time the recent discoveries have greatly reduced our estimate of the actual number of the true Ferns in Palæozoic times (most of them having already become Seed-plants at that period), and difficulties have arisen in discriminating between the Ferns proper and their more advanced allies the Pteridosperms. Any certain knowledge of Palæozoic Filices is, for the moment, practically limited to the family Botryopterideae and a few other forms probably allied to them. We may follow Mr. Arber ${ }^{1}$ in using the name Primofilices for the whole group. As regards the Marattiaceae, long considered as the dominant Ferns of the Carboniferous period, the question is much more difficult, as has been shown in Chapter VIII.

There is no reasonable doubt that the Botryopterideae were true Ferns; all their characters, both were borne on the under side of the sporophyll, there is great difficulty in accepting this view. On Pleuromeia see Solms-Laubach, "Ueber das Genus Pleuroneia," Bot. Zeitung, Bd. 1vii. I899, p. 227; H. Fitting, "Sporen im Buntsandstein-die Makrosporen von Pleuromeia?" Ber. d. Deutschen Bot. Gesellschaft, Bd. xxv. I907, p. 434.

1 E. A. N. Arber, "On the Past History of the Ferns," Ann. of Bot. vol. xx. 1906, p. 221. 
vegetative and reproductive, point in this direction, and the evidence has been materially strengthened by the observation of 'spores in process of germination, agreeing closely with corresponding early stages in the development of recent Fern prothalli (p. 339).

Anatomically, the Botryopterideae show two types of structure, the one (Botryopteris and its allies, p. 325 ) exceedingly simple as regards the stem-structure, while the other ( $Z$ ygopteris and its allies, p. 306) shows a considerable degree of differentiation. The solid strand of tracheides, surrounded by phloëm, which constitutes the central cylinder in the Botryopteris group, is perhaps the simplest form of stele known in any Fern, but it would be rash to infer from this fact that these plants were necessarily of a specially primitive nature. Their roots are diarch, like those of most recent Ferns, their petioles attain some degree of complexity in vascular structure, while the differentiation of special fertile fronds indicates a rather high grade of organisation.

The affinities of the Botryopterideae with other Ferns have been fully discussed in Chapter IX., and the conclusion arrived at, that while they show some affinity with various Filicinean families of later origin, they cannot be considered as on the direct line of their descent. This line will have to be sought among other Primofilices, of which, as yet, we have only a scanty knowledge, though the occurrence of annulate sporangia on ordinary Fern pinnules, as in Pteridotheca Williamsonii, is a promising indication (p. 293).

Some relation between the Botryopterideae and the Ophioglossaceae was recognised by Renault when he first discovered the fossil family, the resemblances he 
detected lying in the fructification and in the occurrence of reticulated tracheides. He regarded the Botryopterideae as intermediate in stem and fructification between the Hymenophyllaceae, representing the Ferns properly so-called, and the distinct group Ophioglossaceae ${ }^{1}$ - a view for which there is still much to be said. The sporangia of Stauropteris (a genus not known to Renault) present an almost exact agreement with those of Botrychium, as regards their structure and the mode of attachment by vascular pedicels. ${ }^{2}$ The resemblance in the structure of the tracheides has proved to be even more striking than Renault was aware, for true pitted tracheides of a "Gymnospermous" type occur in both groups. It may be added that the structure of the stem in the new Botryopteridean genus Botrychioxylon (p. 3 I 8) if it lost the internal wood (a change likely to occur, from the analogy of parallel cases elsewhere ${ }^{3}$ ) would be almost exactly that of a Botrychium. The fact that the frond (at least the fertile frond) of certain Botryopterids branched in more than one plane has been compared with the dorsiventral branching of the frond characteristic of Ophioglossaceae. ${ }^{4}$

On the whole, a real affinity between the fossil and the recent family seems probable-in fact, of known plants, it is the Botryopterideae which appear to have most in common with the Ophioglossaceae.

Professor Bower thinks it "probable that the

1 B. Renault, Végétaux silicifiés d'Autun, etc., Autun, 1878, p. I I4.

"In Botrychimm they are short, in this respect resembling those of Botryopteris.

8 See below, p. 651 .

" Lady Isabel Browne, "Phylogeny and Inter-relationships of Pteridophyta, vi. Filicales," New Phytologist, vol. vii. I909, p. 27. 
Ophioglossaceae sprang from some offshoot of the sporangiophoric Pteridophytes, allied in some degree to the Sphenophyllales," I while he recognises an analogy with the Filicales. My own feeling is that the converse way of putting the relations is to be preferred. It appears probable that the Ophioglossaceae were derived from primitive Ferns, allied to the Botryopterideae, while they show analogies, in the way their sporangia are borne, with the sporangiophoric Pteridophytes, such as Sphenophyllales and Psilotales. On the view here adopted we should naturally regard the Ophioglossaceae with well-developed Fern-like leaves as, on the whole, the more primitive members of the family. ${ }^{2}$

All the evidence we possess as to the Ferns of early periods shows that they were already megaphyllous forms, comparable in habit to their later successors, and affords no ground for the supposition that they were derived from a microphyllous ancestry. It must, however, be admitted that our palæontological record for the Ferns (as for other Pteridophytic groups) is too short to settle questions of origin.

The majority of the Lower Carboniferous and Devonian Fern-like plants were probably Pteridosperms. It is as yet impossible to distinguish by the habit between these plants and the Ferns, and indeed the best proof we now have of the presence of true Ferns in Devonian rocks is the occurrence of petrified stems of Asterochlaena (p. 324).

1 Origin of a Land Flora, p. 492.

2 The evidence for saproplyytic reduction within the family seems to be materially strengthened by the case of extreme reduction which has been found in Ophioglossum simplex. See, however, the views of Bower, Origin of a Land Flora, p. 477. 
Though the Botryopterideae formed the basis of the group Primofilices, as proposed by Mr. Arber, some doubt has since been expressed whether this family really belonged to the Primofilices in the true sense of the

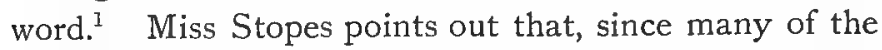
Botryopterideae have tracheae with multiseriate bordered pits, like those of Gymnosperms, they are in this respect not absolutely true Ferns, but have taken one step towards Gymnosperm anatomy; the group therefore appears to contain members which are "Pro-Pteridosperms" rather than Primofilices pure and simple. The view has been taken here (p. 345) that the Botryopterideae are probably an offshoot from the same line of descent with the later Ferns, rather than their direct ancestors. They seem, however, to have been sufficiently near the original stock ${ }^{2}$ to deserve in an eminent degree the name Primofilices, which does not necessarily imply direct ancestry. As regards the pitted tracheae, it appears probable that this form of water-conducting element was once common to the Fern phylum generally, but that the true Ferns have since for the most part lost it, adopting the very specialised scalariform type of vessel which is now characteristic of them (p. 3 I 4).

The question of the affinity of the Botryopterideae to the Pteridosperms is of great interest. The Pterido-

1 M. C. Stopes, "A New Fern from the Coal-Measures, Tubicaulis Sutcliffi," Mem. and Proc. Manchester Lit. and Phil. Soc. vol. 1. No. 10, I 906, p. 23.

2 See especially the fine series of memoirs by Kidston and GwyuneVaughan on the fossil Osmundaceae, in which the close relations of this family with the Botryopterideae are demonstrated, Trans. Royal Soc. Edinburgh, vol, xiv. Part iii. p. 759, I907; vol, xlvi. Part ii. p. 213, 1908; Part iii. p. 65, Igog. 
sperms are so ancient that we can have no direct knowledge of their ancestry, but one naturally looks to the oldest known types of Ferns for indications of what it may have been.

It has been suggested that the more complex Botryopterideae, such as Asterochlaena, may have been related to polystelic types of Pteridosperms, such as Medullosa. A breaking up of the deeply lobed stele into separate meristeles is quite conceivable, and may well have led on to the structure of Cladoxyleae, in which the numerous steles tend to a radial arrangement (p. 497). ${ }^{1}$ No light, however, is thus thrown on the history of the Medulloseae themselves, for, since the discovery of Sutcliffia, it seems clear that polystely arose within this Pteridospermous family, and was not derived as such from any ancestral stock.

It has already been pointed out that the Pteridosperms may probably have arisen from some early Fern-like type with a protostelic stem (pp. 464 and 473). In this respect, and in the structure of the tracheae, the simpler Botryopterideae may resemble the hypothetical ancestors of the Seed-plants, but there are not sufficient grounds for assuming any near relationship.

Professor F. W. Oliver's interesting discovery of a sporangium (Tracheotheca), similar to that of certain Botryopterideae, containing tracheides in the inner layers of its wall, ${ }^{2}$ suggests an early approach to

${ }^{1}$ M. Paul Bertrand has quite recently come to the conclusion that Clepsydropsis, a Zygopteridean petiole, was borne on the stem of a Cladoxylon, "Sur les Stipes de Clepsydropsis," Comptes Rendzes, Nov. I6, I 908.

${ }^{2}$ F. W. Oliver, "On a Vascular Sporangium from the Stephanian of Grand Croix," Neze Phytologist, vol. i. 1902, p. 60. 
seed-structure, and may prove to be a valuable indication. At present, however, the case is too isolated for any phylogenetic conclusions to be drawn.

There can be little doubt that the Pteridosperms have.some affinity with the Marattiaceae in the widest sense, though the connection between them may be indirect and impossible to trace accurately in the present state of our knowledge. We have already considered in some detail the evidence for the presence of Marattiaceae in the Carboniferous Flora (Chapter VIII.). The probability is decidedly in favour of their existence as a group of some importance at that time, though the question is by no means without difficulty (see p. 468). In any case the structure of the Pteridospermous male fructification Crossotheca (p. 396), and still more that of the stamens in the Mesozoic Bennettiteae (p. 586), indicates affinity between the older Seed-plants and Ferns of the Marattiaceous type, and heightens the probability that the latter are an ancient race. There are thus good grounds for the view expressed by $\mathrm{Mr}$. Kidston that the Pteridosperms and Marattiaceae had a common origin. This hypothesis is not inconsistent with the idea of a relation between the Pteridosperms and the Botryopterideae, for, as we have seen, possible links between the latter family and Marattiaceae are to be found in Corynepteris and other genera (p. 344).

In the absence of any evidence of heterospory among Palæozoic Ferns, it appears that the gap between any known group of Ferns and the related Seed-plants must be a wide one. The general conclusion, however, that the Pteridosperms belonged to the 
same phylum with the Ferns appears indisputable and needs no detailed proof. In all characters in which these early Seed-plants approach the Cryptogams, whether in habit, anatomical structure, the morphology of the sporophyll, or the nature of the microsporangiate fructification, it is with the Ferns alone that affinity is shown. The stock from which they were derived is still unknown, and may well have differed widely from any group of Ferns with which we are familiar, but there is no longer any room for doubt that it had far more in common with the Ferns than with any other race of Pteridophytes.

We have to conceive of the Pteridosperms as a vast plexus of varied forms, of which the few types as yet adequately known can give but a very imperfect idea. For example, we know nothing as yet of the structure of those Pteridosperms which, like Aneimites or Pecopteris Pluckeneti (pp. 465, 466), bore seeds of the bilateral type, resembling those of Cordaiteae. Our detailed knowledge is limited at present to the two series, Lyginodendreae (Chap. X.) and Neuropterideae (Chap. XI.), and even within these limits is very imperfect. The two families appear fairly distinct, as shown both by the vegetative and anatomical characters and by those of the seeds. Anatomically, the trend of evolution in the Lyginodendreae has been towards the elaboration of the single stele, in the Medulloseae (on the whole larger plants) towards the breaking up of the stele. The latter was an unprofitable course, ill adapted to the conditions of secondary growth, and it is probable that the polystelic line, after attaining an extreme elaboration, 
became extinct about the close of the Palæozoic period.

In the series of the Lyginodendreae it appears evident that Heterangium represents, from an anatomical point of view, the most primitive stage known (p. 40r). Lyginodendron itself is anatomically a Heterangium which has acquired a pith and isolated its leaf-traces. ${ }^{1}$ It thus lies on the direct way to the stem-structure of the higher plants.

The view that the medullate stele of Lyginodendron was derived, by suppression of the central xylem, from the protostele of the Heterangium type is materially confirmed by the observations of Kidston and GwynneVaughan on the fossil history of the Osmundaceae. In this analogous series they are led, by the investigation of various Permian Osmundaceae with tracheal tissue occupying the centre of the stele, to the conclusion that the pith of this family has been derived directly from an originally solid xylem mass. ${ }^{2}$

The Calamopityeae (p. 476) evidently form a parallel series to the Lyginodendreae ; they are, perhaps, of even greater antiquity, and we have no light, as yet, on their derivation.

In later Palæozoic times we find, in the Cycadoxyleae (p. 483), plants which appear to have affinity with the Lyginodendreae, and may even have sprung from them.

1 On the question of the anatomical evolution, my article on "The Old Wood and the New," Nere Phytologist, vol. i. I902, p. 25, may be referred to.

2 "On the Fossil Osmundaceae," Part iii. Trans. Royal Soc. Edinburgh, vol. xlvi. Part iii. I909, p. 663. More direct evidence appears to be afforded by certain newly discovered stems of Lyginodendreae from the Moravian coal-balls (see below, p. 663) which further connect the structure of Lyginodendron with that of Heterangium. 
These stems have taken an aberrant line of development, through the elaboration of anomalous secondary growth, and thus present some analogies with the more modified of the recent Cycadaceous stems. They may well have been Cycadophyta, though probably not closely allied to the known Mesozoic or recent types.

The relation of the Pteridosperms to the Cycadophyta is as clear as that to the Ferns, and indeed, as we have seen, it is often difficult to draw the line between the two first-named classes. For the present, it is convenient to keep the Pteridosperms distinct, on account of their relatively primitive character, but there is every reason to hope that further discoveries will effectually link them on to the typically Gymnospermous Cycadophyta. The anatomical resemblances, which led to the recognition of the Cycadofilices as a transitional group, have been immensely strengthened by the discovery of the seeds, which are sufficient in themselves to demonstrate a near affinity between the Pteridosperms and the Cycads. Curiously enough, the relation is closest with the seeds of the recent Cycadaceae, a group of which the geological history is still obscure. Those of the Mesozoic Bennettiteae are not so readily comparable, and evidently represent a more advanced stage of evolution, their seeds having been modified and in some respects simplified in correlation with the development of the complex fruit.

As regards the microsporangiate organs of the Pteridosperms, our present somewhat scanty information indicates that they were of the nature of synangia (p. 399); they thus find a remarkable analogy in the compound pollen-sacs of the Mesozoic Bennettiteae 
(p. 586). The sporophylls, so little differentiated from the vegetative foliage, may best be compared with the stamens of Bennettiteae on the one hand, or with the foliaceous carpels of Cycas on the other.

The question whether the Lyginodendreae or the Medulloseae were the nearer to the main line of Cycadean evolution may be a sterile one, for there were doubtless many other races of Pteridosperms, among which the true ancestry may lie concealed. A few points of comparison may, however, be noted. So far as the anatomy of the stem is concerned, Lyginodendron appears to come near the Cycads, for the general organisation is of a similar character, and the mesarch structure of the bundles is still retained in the peduncles of the cones of some recent Cycads as well as in the leaves (p. 364). The habit and anatomy of the Lyginodendron foliage is, however, unlike anything known either in Mesozoic or recent Cycadophyta. ${ }^{1}$ It has been suggested that Lagenostoma, the seed of Lyginodendron, may have given rise to the seed of Cycadaceae by the cupule becoming adherent to the integument, and thus constituting the supposed outer integument of the Cycadean ovule. ${ }^{2}$ This view, however, assumes that the integument of the seed in recent Cycads is double, an interpretation which is still open to much doubt.

1 It is conceivable that a reduction of a leaf of the Sphenopteris type might lead to a structure not unlike that of the leaf in the genus Cycas, with uninervate pinnæ. The very curious Annam species, C. Micholitzii, Dyer, with quadrifid pinnæe, is of interest from this point of view. See Gardener's Chronicle, August 19, I905.

2 Miss M. C. Stopes, "Beiträge z. Kenntnis der Fortpflanzungsorgane der Cycadeen," Flora, Bd. xciii. I904; "On the Double Nature of the Cycadean Integument," Ann. of Bot. vol. xix. Ig05. 
Seeds of the Trigonocarpus type (p. 452), referable to Medulloseae, appear to have much in common with those of the Cycadaceae, as shown by the drupelike differentiation of the testa, the double vascular system, and the form of the pollen-chamber. The chief difference lies in the free nucellus of the Trigonocarpeae, which contains the inner vascular system, whereas in the Cycadaceae the nucellus is adherent to the integurnent, and the inner vascular system is said to belong to the latter-a point exceedingly difficult to determine. In 'spite of these differences, I am inclined to regard the Trigonocarpus type as the nearest approach among Pteridosperms, so far as we know at present, to the seed of the Cycadaceae.

Anatomically, the Medullosean stem differs from that of recent or Mesozoic Cycadophyta in being polystelic (except in the protostelic Sutcliffia, which does not affect the question). Certain local peculiarities in the vascular system of various Cycads, due to anomalous distribution of the cambium, have recently been interpreted as relics of a polystelic structure, but these exceptional irregularities do not appear to bear more than a superficial resemblance to the primary polystely of the Medulloseae. ${ }^{1}$

On the other hand, the structure of the petiole and the organisation of the leaves generally are very similar in Medulloseae and Cycadaceae, and the resemblance

1 Some of the most striking cases of so-called "polystely" among recent Cycads occur in the root, an organ which in the Medulloseae was monostelic. For the polystelic interpretation of Cycadean structure see Worsdell, "Structure and Origin of the Cycadaceae," Ann. of Bot. vol. xx. I906, p. 129; Matte, Récherches sur l'appareil libero-lignezex des Cycadaces, 1903 . 
extends to the Bennettiteae of the Mesozoic. On the whole of the evidence available it appears likely that some at least of the Cycadophyta may have been derived from plants resembling the Medulloseae (Neuropterideae) in certain characters, though probably with monostelic rather than polystelic structure of the stem.

Leaving the Cycadophyta for the moment, we have now to consider the relation of the Pteridosperms to the Cordaitales, the characteristic Gymnosperms of the Palæozoic. In some respects two groups of plants could scarcely appear more different than the Fern-like Spermophyta and the typical Cordaiteae. In habit there is no resemblance, the Cordaitean trees having externally much more in common with Araucarian Conifers than with any of the known Pteridosperms (pp. 520, 522). The specialised cones or catkins of the Cordaiteae, grouped in inflorescences, are wholly remote from the compound, scarcely differentiated sporophylls, springing from the main stem, which bore the seeds and pollensacs in the Pteridosperms. The Cordaiteae are altogether on a far higher level of organisation, and deserve the place among true Gymnosperms which has always been assigned to them. But, though so advanced in structure, the family appears to be as ancient as any land-plants with which we are acquainted-a striking proof of the immense extent of evolution which had run its course before our palaontological record begins.

There are, however, clear proofs of affinity between Pteridosperms and Cordaitales, great as the differences between them appear. The strongest mark of affinity 
is in the seeds, which are essentially of the same type in the two groups-in fact, it is impossible at present to point to any constant distinction between them. Of seeds already known in detail, the closest agreement is between the Trigonocarpus group and the Cordaiteae (Pp. 452 and 546); they have in common the double vascular system, the drupe-like testa, the form of the pollen-chamber, and probably the free nucellus. On the other hand, they differ in the fact that the Trigonocarpeae are radiospermic, the Cordaiteae platyspermic, but this distinction has no general validity, for we have good evidence that bilateral as well as radial seeds occurred among the Pteridosperms (pp. 465 and 467$)$.

Rhabdocarpus, attributed to Poroxylon by Grand'Eury, only differs in small details from the seeds of Cordaiteae in the narrower sense (p. 5 I 2). We know nothing as yet of the seeds of the Pityeae, the third family making up our class Cordaitales.

As regards the anatomy, there is a very complete series leading from the stem of the Lyginodendreae to that of the typical Cordaiteae, as described by Renault. In Calamopitys we find the first signs of the dying out of the centripetal wood in the lower part of the leaftrace bundle (p. 482). In Poroxylon the same condition recurs, with a general structure much like that of Cordaites itself ( $p .506$ ). In the Lower Coal-measures of England, stems otherwise indistinguishable from those of Cordaites have distinct remains of centripetal wood in the stem (p. 526). The Pityeae have likewise reduced and modified their primary xylem, perhaps in relation to a change of function (p. 5 I 5). The series 
is not, of course, a chronological one, but it serves to link the stem of Pteridosperms of the Lyginodendreae type with that of true Cordaiteae ; it is at least an interesting point that the older Cordaitean stems generally show some trace of the centripetal wood, while it seems to have disappeared in the late Carboniferous or Permian species which Renault investigated. Concurrently with the gradual extinction of the old Cryptogamic wood, we find on the whole a tendency to greater density of the secondary wood, with a diminution in the width of the medullary rays. The double leaf-trace is a common, if not a constant, character at all stages, the division of the trace extending, on the whole, lower down into the stem in the later forms. Other details, such as the structure of the outer cortex, are also common to many members of the series, from the Devonian Calamopityeae to the Permian Cordaiteae. Without for a moment supposing that we have here the actual course of evolution before us, the series seems to afford as strong a proof as anatomical evidence is capable of affording that the Cordaiteae sprang from a Pteridospermous stock, while the leaf-structure supports this conclusion, the mesarch or exarch foliar bundles of Poroxyleae and Cordaiteae being a distinctly Pteridospermous character. On the evidence of the seed-structure and the anatomy together, the affinity of the Cordaitales with the Pteridosperms seems to be firmly established, though in point of time the connection must lie very far back.

The various Cycad-like characters which have long been remarked in both vegetative and reproductive organs of the Cordaiteae are doubtless to be explained, not 
by any direct relation to the Cycads, but by common descent from an early Pteridospermous stock.

The Pteridospermous affinities of the Cordaiteae have an important bearing on - the question of the systematic position of the Coniferae. It has generally been recognised that the Cordaiteae are related to the Coniferae, and if this be so, it follows that the latter are also ultimately of Pteridospermous descent, and thus belong to the great phylum of the Pteropsida.

Some authors, however, have endeavoured to derive the Conifers from the Lycopodiales, ${ }^{1}$ while others have limited this theory to a portion only of the Coniferae, ${ }^{2}$ implying that the order is an artificial assemblage, made up of at least two unrelated groups.

Of late the question has turned especially on the position of the Araucarieae, which Professor Seward has regarded as probably of Lycopodineous origin, while he leaves the question open for the rest of the Coniferae. ${ }^{3}$ Some brief discussion of the question seems necessary here, as the issue involved is that of the single or multiple origin of the existing Spermophyta. The position of the Araucarieae will be primarily considered, since it is this group especially which is now in dispute.

1 E.g. D. H. Campbell, Lectures on the Evolution of Plants, New York, I899, pp. I66-167.

¿E.g. H. Potonié, Lehrbuch der Pfanzenpaläontologie, Berlin, 1899, p. 320 .

3 A. C. Seward and S. O. Ford, "The Araucarieae, Recent and Extinct," Phil. Trans, Royal Soc. B, vol. I98, 1906, pp. 305-41I. See also the "Report of a Discussion on the Origin of Gymnosperms at the Linnean Society," New Phytologist, vol. v. I906, pp. 68 and I4I, where the views of various botanists are briefly given. 
The Araucarieae present a close agreement with the Cordaiteae in the structure of the stem, and especially in that of the wood, which, as universally admitted, is often indistinguishable in the two families. The essential feature is that the mass of the wood, apart from the medullary rays, is composed of tracheides with multiseriate bordered pits on their radial walls. This is the characteristic type of wood throughout the Cordaitales and Pteridosperms, extending also (in the form of primary xylem) to many of the older Ferns, while it is practically unknown among Lycopods, ${ }^{1}$ in which the tracheides are very constantly scalariform. The absence of centripetal wood in the Araucarian stem presents no difficulty on the hypothesis of Cordaitean affinity, for its gradual disappearance in certain Pteridosperms and in the older Cordaitales can be traced, until it is lost in the stems of the typical Cordaiteae. No such links with the stemstructure of Lycopods are known.

The roots in Araucarieae (and Conifers generally) are essentially of the same type as in Cordaitales, and show none of the peculiarities of Lycopod roots.

The leaves of Araucarieae, with their numerous parallel bundles, agree generally, though not in detail, with those of Cordaiteae. That the multinervate character is primitive is indicated by the fact that the cotyledons likewise contain several bundles. Lycopods as a rule have only one foliar bundle, which, in the case of Sigillariopsis, divides into two. If the Araucarieae

1 The only case I know of is in Renault's Sigillariopsis Decaisnei, where some of the tracheides are pitted, though they do not appear to agree at all closely with those of the Araucarieae. 
are relatively primitive Conifers, a point on which I am disposed to agree with Professor Seward, it appears that the more complex type of leaf-structure is the original one for the Order. While the general anatomy of the leaf is thus entirely favourable to Cordaitean affinities, the histology lends no decided support to either view of the affinities. The vascular bundles have no typical centripetal wood, but are accompanied by transfusion-tissue, which we may either regard, with $\mathrm{Mr}$. Worsdell and M. Bernard, as representing the centripetal xylem of Cordaiteae, ${ }^{I}$ or may compare with the welldeveloped transfusion-tissue occurring in fossil Lycopods. On any view, the centripetal part of the xylem is a tissue which becomes modified or lost in the higher plants.?

Passing on to the organs of reproduction, the male cones of Araucarieae show some points in common with those of Cordaiteae. As we have seen, the stamens of the latter group have been well compared with those of Ginkgo. The stamens of Araucarieae, with their distally attached pollen-sacs, are of the same type as in Ginkgo, but the large number of the sacs brings them nearer to the Cordaitean stamen; on the other hand they differ absolutely from the sporophylls of the Lycopods, in which the constant relation of one sporangium to one sporophyll is a

I It will be remembered that, according to Miss Stopes's observations, transfusion-tissue, as well as centripetal xylem, occurs in the Cordaitean leaf ( $\mathrm{p} .534)$.

2 The structure of Araucarian seedlings obviously caunot be used in the comparison with a fossil group. Recent work, however, shows that the anatomy of the seedling in Araucarieae conforms to the sane type as that of the Cycadaceae and Ginkgo, while other Coniferae show a modification of the type in the direction of reduction. 
character diagnostic of the class. ${ }^{1} \quad$ The numerous nuclei in the pollen-tube of the Araucarieae present a manifest analogy, as Professor Seward recognises, with the multicellular antheridia of Cordaiteae and Pteridosperms. At present we know nothing of the fertilisation of the "seed-bearing" Lycopods, so on this side the material for an equally close comparison is wanting.

The female cones of the Araucarieae alone appear to afford any real support to the Lycopod theory. The single ovule on the upper surface of the cone-scale offers an evident analogy with the sporangium and sporophyll of a Lycopod, though, if the Cretaceous Protodammara, with three ovules on each scale, is rightly referred to Araucarieae (p.607), the value of the analogy becomes very doubtful. In any case the vascular system of the Araucarian cone-scale is totally different from anything in the sporophylls of Lycopods. The comparison between Araucaria, in particular, and Lepidocarpon, on which Professor Seward lays stress, appears to amount to no more than a distant analogy, for the part which envelopes the ovule in Araucaria is not, as in Lepidocarpon, the integument itself, but an extra covering enclosing an already integumented megasporangium. ${ }^{2}$

Until the nature of the so-called ligule, and, generally, the rclation of the female cones of Araucarieae to those

L The comparison of the Araucarian stamen with the sporangiophore of Cheirostrobus, suggested by Professor Seward, is interesting, but by no means supports a relation to the Lycopods, with which Cheirostrobus can only have a remote affinity. The point is dealt with in the discussion on the "Origin of Gymnosperms" above referred to, pp. I43 and 147.

2 See Figs. 25 and 26, p. 362 of Seward and Ford's Araucarieae. 
of other Coniferae, are cleared up (which is far from being the case at present), it is useless to compare these strobili with fossil fructifications. It appears probable, however, that the comparison of the cone-scales with Lycopod sporophylls, though seductive, may be fallacious, the great complexity of the Araucarian conescale suggesting that the resemblance is limited to external characters.

The absence of a pollen-chamber in the Coniferous ovule is no doubt correlated with the abandonment of fertilisation by spermatozoids.

Without extending the discussion further, it may, I think, be concluded that the Araucarieae have many points in common with the Cordaitales, of sufficient weight to establish a real affinity, while the resemblances to the Lycopodineae are of a more doubtful and superficial nature, and appear to be completely outweighed by the great differences which separate these two groups.

Since the Araucarieae haye been chosen as the family most favourable to the Lycopod theory of Coniferous descent, it does not seem necessary to discuss the question for the other families. The idea that the Coniferae include two wholly diverse groups, belonging to distinct phyla, appears to me quite untenable-either all are Lycopsida or all Pteropsida. The separatist view has arisen from paying attention too exclusively to particular organs rather than to the whole sum of characters. If any group could be regarded as distinct in origin from the rest it is the Taxaceae; even here it is only the morphology of the female fructification that presents any serious difficulties, and in this very point a 
relation between the Podocarpeae (Taxaceae) and the Araucarieae has been traced, while the position of Cephalotaxus has oscillated between the Taxaceae and the Taxodieae, the latter being typical Pinoid Conifers.

Taking all the characters into account, there thus appears to be a decisive balance of evidence in favour of deriving the whole of the Coniferae from the Cordaitales, while not necessarily tracing them through the particular family Cordaiteae (of which, after all, our knowledge is still very narrow). The Conifers. thus fall within the great division Pteropsida, though their connection with Ferns is obviously remote, - a vast series of more or less primitive Spermophyta lying between. This view involves the conclusion that the microphyllous habit, which characterises so many of the Coniferae, is the result of reduction in the leaf, correlated with the increasing ramification of the stem, and also expressing a more perfect adaptation to the conditions of life on dry land.

The relations of the Ginkgoaceae to the Cycads and Cordaiteae are universally admitted, and need not be further discussed here (Pp. 552, 6 I 2).

The characteristic Mesozoic Cycadophyta, the Bennettitales, were fully considered in the last chapter. Although the fossil Angiosperms do not fall within the scope of these "Studies," a few words may be added on the relation of the great modern sub-kingdom to the scarcely less dominant Cycadophyta of the Secondary Period.

The general arrangement of the organs in the Bennettitean fructification, as shown by Dr. Wieland's 
classical investigations, is essentially the same as in a typical Angiospermous flower, with a central pistil, a surrounding whorl of stamens, and an enveloping perianth (see pp. 584, 585). The whole organisation, as Dr. Wieland at once recognised, is best compared with that of the flower in Magnoliaceae, such as the Tuliptree (Liriodendron), while the resemblance extends to other orders of polypetalous Dicotyledons, e.g. Ranunculaceae and Nymphaeaceae. These groups, especially the Magnoliaceae, have been widely accepted as relatively primitive, and there is evidence for their occurrence in Cretaceous rocks.

As we have seen, the gynæcium of Bennettiteae shows some approach to the structure of a closed Angiospermous ovary, while the seed was practically exalbuminous, the large Dicotyledonous embryo filling the embryo-sac-a condition otherwise met with only among the Angiosperms.

Taking the whole of the characters into consideration, the evidence of affinity between the Mesozoic Cycadophyta and the Angiosperms appears very strong. It cannot, of course, be supposed that the Bennettiteae were on the direct line of Angiospermous descent, for there are manifest points of difference, notably in the great complexity of the stamens and in the organisation of the ovary-wall or pericarp, which was not formed by the carpels themselves, but by the associated sterile scales. There may be a difference of opinion as to the nearness of the relation between Bennettiteae and the higher Flowering Plants, but the points of agreement are so striking that we can hardly fail to recognise that a real relation exists, and that the ancestry of the 
Angiosperms, hitherto the most obscure subject in the phylogeny of plants, is to be sought among the great plexus of Cycadophytes, which overspread the world during the Mesozoic Period. ${ }^{1}$

This conclusion opens up the question of the relation of Monocotyledons to Dicotyledons. If the Angiosperms were derived from Cycadophyta, it would appear to follow that the Dicotyledons were first evolved, for their structure has clearly much more in common with the Cycad type than that of the Monocotyledons. The latter would thus be regarded as a branch line of descent, diverging, no doubt at a very early stage, from the main Dicotyledonous stock. This view has been maintained, on other grounds, by various modern botanists. So far, however, as the palæontological record shows, the two classes are of almost equal antiquity, both appearing for the first time in Lower Cretaceous rocks. By the Upper Cretaceous age the Angiosperms had already seized the dominant position which they now hold; the Monocotyledons were always subordinate in numbers to the other class, but the occurrence of typical Palm-wood in Cretaceous rocks is a striking proof of the early evolution of one of the most characteristic Monocotyledonous families.

The relation of the Bennettiteae to the Pteridosperms, and through them to some early race of Ferns, has been sufficiently emphasised in preceding pages. We are thus led to the conclusion that the whole of the dominant sub-kingdom of Flowering Plants, if akin,

\footnotetext{
2 See Arber and Parkin, "The Origin of Angiosperms," Journal Linn. Soc. (Bot.), vol, xxxviii. 1907 .
} 
as we believe, to the Cycadophyta, belongs ultimately to the phylum which takes its name from the Ferns. We may add that the Gymnosperms, as a whole, may be referred to the same stock, for evidence has recently been adduced that the small group of the Gnetales (the only outstanding Gymnospermous family) may have been derived, by reduction of the floral organs, from forms allied to the Bennettitales. ${ }^{1}$

It thus appears, if the views here taken are justified, that the whole of the Spermophyta, whether Angiospermous or Gymnospermous, were ultimately derived, through primitive Seed-plants of the nature of Pteridorsperms, from the same stock with the Ferns. With this far-reaching conclusion we may conclude our consideration of the phylogenetic results of our studies.

In bringing these "Studies" to a close, it is well to "recall the necessary limitations of all attempts to unravel the past history of organisms. Our ideas of the course of descent must of necessity be diagrammatic ; the process, as it actually went on, during ages of inconceivable duration, was doubtless infinitely too complex for the mind to grasp, even were the whole evidence lying open before us. We see an illustration, on a small scale, of the complexity of the problem, in the case of domesticated forms, evolved under the influence of man. Though we know that our cultivated plants, for instance, have been developed from wild species within the human period, and often within quite recent years,

1 Arber and Parkin, "Relationship of the Angiosperms to the Gnetales," Annals of Botany, vol. xxii. I908. 
yet nothing is more difficult than to trace, in any given instance, the true history of a field-crop or a garden plant, or even, in many cases, to fix its origin with certainty. In the history of natural groups, where the geological record takes the place of the cultivator's notes, the problem increases so immeasurably in difficulty, that a full solution becomes impossible.

But although, in endeavouring to form an idea of the course of evolution of any part of the Vegetable Kingdom, we can only hope, at the best, to construct a scheme, representing in a much simplified form the real succession of events, we must take care not to be misled by our own constructions. We must remember that, at all periods, competition among living things was as keen as now, and that in every age all the available places must soon have been filled. Hence, even in the earliest times of which the palæontologist take cognisance, there must always have been specialised forms, and even what we call "synthetic" types were themselves specialised to suit some particular set of conditions. Thus, at every step in the investigation of the fossil evidence, the same caution in distinguishing between the newer and the older characters is demanded, as when we are dealing with recent organisms.

Yet, in spite of these difficulties, and others, more obvious, which will at once occur to the mind, there can be no question that the study of the actual records of the past is of inestimable value in attacking a problem which is in its essence an historical one.

In these"Studies" the fossil record has been considered almost wholly from a morphological and evolutionary 
point of view. There is room, even with the material already available, ${ }^{1}$ for important work on other lines. The subject of the biology and ecology of fossil plants, as illustrated especially by their physiological anatomy when suitably preserved, offers a wide and promising field of research. Such biological studies will be of the greatest intrinsic interest, and will also throw a new and welcome light on the problems of Evolution.

1 New sources of material, especially of petrified specimens showing structure, are urgently to be desired. As this book goes to press, I have received from $\mathrm{D}_{1}$. Kubart of Graz sections from the magnificently preserved nodules of the Moravian Coal-measures, a field hitherto unworked from a structural point of view. 



\section{INDEX}

An asterisk indicates that there is a figure on the page referred to.

Abietineae, 82, 244, 607, 608, 609 Actinopteris, 6II

Adiantites, 465. See Aneimites

Adiantum, 465

Aetheotesta, 459

Agathis, 523, 532, 535. 55I, 607 macrophylla, $55 \mathrm{I}$

Albian, 607

Alethopteris, 272, 355, 425, 439, 445, $446,45^{2}, 456,460$

Grandini, $46 \mathrm{I}$

lonchitica, ${ }^{427}, 439,456$

Algae, 6, 274

Allen, J., 385

Alsophila, 368

Alternation of generations, 6I 8

Amber, I2

Amyelon, $53^{\circ}$

radicans, $530,53 \mathrm{I}$

Anachoropteris, 324, 325, 335

Decaisnei, 325

Analysis of petrifactions, II

Androstrobus, male cones, 594

Nathorsit, 594

Scottii, 594. See Lycostrobus

Aneimiteae, $465-466$

Aneimites, $465,471,472,645$

fertilis, $465,47 \mathbf{I}$

tenuifolius, 466

Angiopteris, 28I, 284, 287, 288, 292, 427

Angiosperms, $4,530,593,599,60 \mathbf{r}_{1}$ 604

affinities, $658-66 \mathrm{I}$

Annularia, 75

fructifications of (see Bruckmannia), 75

brevifolia, " 75

stellata, 75

Annulus, 106, 276, 282, 291
Annulus of Botryopterideae, 340, 344

Botryopteris, ${ }^{*} 33$ I, 332, * 333

Corynepteris, $3^{2} 3$

Hymenophyllites, 290

Lygodium, 288

Oligocarpia, 290

Osmundaceae, $29 \mathrm{I}$

Pteridotheca, ${ }^{*} 292,{ }^{*} 293,294$, 347

Rencultia, ${ }^{2} 280,284$

Senftenbergia, *280, 287

Sturiella, ${ }^{*} 280,286$

Zygopteris, * $320,321,322$

Anomozamites, 494, 556, 593

minor, 593, 598

Antheridial cells, $45^{8}$

Antheridium, 545

Antherozoids, 459

Antholithus, 519, 524

Anthostrobilus, 60I

Aphlebiae, 273, 274, ${ }^{*} \mathrm{r}_{3}, 3 \mathrm{I}_{4}, 3 \mathrm{I}_{5}$, $318,337,427$

Araucaria, 523, 527, 532, 544, 550, 605,656

excelsa, 605

Araucarieae, 527, 606, 607, 6II, 650, $65^{8}$

affinities, $653-657$

cones, 656

stamens, 655

Araucarioxylon, 523, 524, 527, 605

Brandlingiz, ${ }^{*} 528$

Rhodeanum, 606

Araucarites, 527

Beinertianus, 48a. See Calamopitys Beinertiana

Arber, E. A. N., 230, 345, 346, 394, $395,429,433,53^{8}, 63^{8}, 642$

Arber, E. A. N., and Parkin, 601, 660,661 
Arber, E. A. N., and Thomas, H. H., 228,229

Archaeocalamites, $26,37,49,5 \mathrm{I}$, $70-72,79,619,620,622$, 625

fructifications, ${ }^{*} 6 r, 70,71,72$

leaves, $38, * 71,74$

roots, 45,72

sporangia, 70

stem, $7 \mathrm{I}$

radiatus, *61, *71

Archaeopteris, 290

hibernica, 290

Archegonium, 188, r95, r96, 425, $457,545,548,{ }^{*} 549$

Areola of Osmundaceae, $29 \mathrm{r}$

Argonne, 607

Arran, Isle of, I39, I40, I4I, I68

Arthrodendron, I5, 34, 74

Arthropityostachys Grand'Euryi, 59 Williamsonis, 8x

Arthropitys (see Calamites), I9, 33. $36,74,76,78,79$

bistriata, 29

Articulatae, 6I 5, 631, 632

Artis, F. T., 295

Artisia, 523, 527

Aspidiaria, I 33

Asplenium, 272, 4I8

Asterochlaena, $325,335,347,498$, $64 \mathrm{~T}, 643$

laxa, 324

Asterophylliteae, 6I 4

Asterophyllites, $36,62,76$, I 44 densifolius, * 77

Asterotheca, ${ }_{2} 80,28 I, 287,288$, $303,323,348,350,42 \mathrm{I}$

Astromyelon, 4I, 42, 44, 45, 72. See Calamites, roots

Autophyllites, 79

Autun, 290, 297, 306, 333, 446, 469, $486,487,492,493,5$ or

Axillary shoot, 312

Azolla, 187

Bacteria, Palæozoic, 202

Baiera, 6I 2

flowers, 6I 3

Bamboos, 580

Barber, C. A., 6ro

de Bary, A., 444, 543, 564

Beania gracilis, 595, 6I 3

Bennettitales, 596, 597, 598 affinities, $658-66 \mathbf{I}$

Bennettiteae, 289, 464, 49I, 546,
$553,559-593,597,598,603$,

$644,647,650$

Bennettiteae, embryo, 573-575

flowers, $579-589$

fructification, $566-569,579-5^{8} 9,593$

leaves, $565,566,57^{8}, 579$

ramenta, 566,567

seed, $567-575$

stem, 560-565, 578

Bennettites (see also Cycadeoidea), $559-578,592$

diagnosis, 560

embryo, 393

Gibsonianus, $560,{ }^{*} 56 \mathrm{I}$

bracts, 567,57 I

embryo, ${ }^{*} 569,572,573 .{ }^{*} 574$. 575

fructifications, ${ }^{*} 56 \mathrm{I}, 567-576$, ${ }^{*} 568,{ }^{*} 569,{ }^{*} 572,580,582$, 588,6 or

leaf-bases, 562,565

ramenta, 566, ${ }^{569,571,572}$

seed, $567-575,{ }^{*} 568$, ${ }^{*} 569$, * 572 , * 574

stem, $560-562,{ }^{*} 56 \mathrm{r}$

Morierei, 576, 588, 601

Peachianus, stem, 564

Saxbyanus, stem, 562, ${ }^{*} 53$

Benson, Miss M., 188, I97, 399, 400, $410,623,633,63^{6}$

Bergeria, I 32

Bernard, C., 655

Berridge, Miss, 189 , I90

Bertrand, C. E., $136,228,340,501$, $\cdot 502,505,506,509,510,513,631$ Paul, 336, 337, 340, 643

Binney, E. W., xo, 99, 239, 357, 429, $433,452,456,474$

Black flints, 532

Blanzy, 263

Boodle, L. A., 342, 343, 387, 5 I I, 627,628

Bornia. See Archaeocalamites

Bothrodendron, $167,192,199-203,636$ minutifolium, 200

mundum, I35, 20I, 259

cone of, $20 I$

stem of, 200

punctatum, 200, 202

cuticle of, 202

Botrychioxylon, 318, 319, 344, 640

Botrychium, 3I9, 32I, 34I, 344, 640

Botryopterideae, 268, 289, 291. 305346,420

affinities of, $340-346,63^{8-644}$ 
Botryopteris, 325, 334, 335, 639

fructifications, $330,{ }^{*} 330, * 33 \mathrm{r}$, * 333

leaves, * 329

stem, $326,{ }^{*} 327$

forensis, 325,326

fructifications, $330,{ }^{\pi} 33 \mathrm{I}$

Botryopteris group, $3^{2} 5-33^{6}$

hirsuta, $326,{ }^{*} 327,328,{ }^{*} 329,332$

ramosa, 326, 329, 332

Bowenia, 366, 508, 577

Bower, F. O., I78, I8I, 29I, 348, $35 \mathrm{I}, 6 \mathrm{r}_{7}, 6 \mathrm{r8}, 623,628,63 \mathrm{o}, 63 \mathrm{r}$, $637,640,641$

Bowmanites Darusoni. See Sphenophyllum Dazesoni

Römeri, I07-III, * Io9, "IIo, II3, 630

bracts, 108

sporangia, Io9

sporangiophores, 108

spores, IIo

Brachyphyllum, 608

Bracts, 567, 568, 569, 571, 572, 576

Brenchley, Miss W. E., 372

Brongniart, A., ro, 36, 80, I35, I 40 , $2 I I, 215,218,236,269,4 I_{5}$, $446,45 I, 456,459,5 x 2,543$, $547,55^{\circ}, 590,614$

Brook Point, 562

Brown, Richard, 239

Browne, Lady Isabel, 622, 640

Bruckmannia, 75

Grand'Euryi, 59

Bryophyta, 6I8, 6r9

Bucklandia, 557

Burntisland, II, 24, 94, 96, I I4, I43, I $82,197,336,402,418$

Butterworth, J., 302

Calamariaceae, $619,620,624$

Calamarieae, I5-82

affinities, 80

classification, $73-82$

fructification, 50-73, I00

leaves, $38-4 x, 60,68,71,75,76$, $77,7^{8}$

nomenclature, 36

roots, 4 I- 46

stem, $19-3^{8}$

Calamites, 5, 9, $15,{ }^{*}{ }_{17},{ }^{*} 18,19,20$, ${ }^{*} 21,{ }^{*} 22,{ }^{*} 23,24,{ }^{*} 25,26,{ }^{*} 27$,

${ }^{*} 32,{ }^{*} 38,{ }^{*} 39,{ }^{*} 40,{ }^{*} 43,{ }^{*} 45$,

$63,64,74,75,76,80,477$

branching, 3 I-33
Calamites, buds, 4I

infranodal canals, $47-48$

leaves, $3^{8-4} \mathrm{r}$

medullary casts, $16-19,33.46-48$, 73

roots, $4 \mathrm{I}-46$

stem, I9-33

cannaeformis, 76

communis, ${ }^{*} 27,29,{ }^{*} 3^{2}$

pedunculatus, 63

(Protocalamites) pettycurensis, 25 . 36, * 37

Suckowii, ${ }^{*}{ }_{7},{ }^{*} 18$

Calamitina, 73, 74, 77

"Calamitoid," 80

Calamocladus, 39,78

Calamodendreae, 80

Calamodendron, $15,34,35,36,42$, $45,74,75,78,79$

root, 45

stem, 34

intermedium, *35

Calamopityeae, $476-483,494,499$, $500,514,517,529,554,646$, 652

Calamopitys (Williamson) (see Arthrodendron $), 34,476,477,480,502$, $504,507,518,651$

annularis, 477

Beinertiana, 482, 506, 518

fascicularis, 480 , * $48 \mathrm{I}$

Saturni, 477, *478, 479, 497

Calamostachys, 49, 5I-60, 64, 67, 76, $77,78,106,539,620,621,622$, 623

axis, 5I

bracts, 53

sporangia, 54

sporangiophores, 53

spores, $55-5^{8}$

Binneyana, 50-55, * $50,{ }^{*} 51,{ }^{*} 52$, ${ }^{*} 54,{ }^{*} 55,{ }^{*} 56,57,60,65,69$, 84

Casheana, $55,{ }^{*} 57,5^{8}$

Grand'Euryi, 60

Ludwigi, 58

Calcareous nodules, I2, 357, 429

Calciferous Sandstone series, 94, 96,

II 4, I 43, I $82,40 I, 402,482$

Calcified specimens, xo

Calcium carbonate, Io

Caldwell, O. W., 544

Callipteris, 445

fructification, 469,470

Callitris, 609 
Caliztris, fructification, 609

Calymmatotheca, 286

Stangeri, 394

Campbell, D. H. , 348, 653

Canals, carinal, 22 infranodal, 47,48

Cancellatae. See Clathraria

Canopy, of seed, 390, 39I

Carboniferous, 5, 6

formation, 518

limestone, 202

Lower, 5, 394, 4x8, 465,477,480, $482,495,498,5 I 4,6 I I, 64 I$

Upper, 5, $5^{\mathrm{I}} 7$

Cardiocarpon, 547 anomalum, 196

Cardiocarpus, 547

Carruthers, W., 58, I 44, 535 557, $560,56 I, 563,567,568$

Cash, W., and Hick, T., 4I, 42

Casts, 7, 45I

medullary, 9, 16-19, 33, 46-48, 73, 257

Catkins, 522, 524, 525,536,537, 539, 545

Caulopteris, 295, 296, 303, 468

Celakovsky, L. J., 627

Cephalotaxus, 609, 658

Ceratozamia, 366

Chalaza of Bennettites, 572

Cordaiteae, 540, 54x, 548

Lagenostoma, $387,389,390,39$ I

Trigonocarpus, 453,454

Cheirostrobeae, I I 4-I 23

Cheirostrobus, 86, II4-I23, 62I, 622, $627,628,630,633,656$

affinities of, I2I

pettycurensis, * II6, " II7, * II9

axis, II $5, \operatorname{II} 8$

bracts, II 7

diagram, * I 6

peduncle, I2I

sporangia, II8, I 20

sporangiophores, I I 7, I 20

spores, I 2 I

sporophylls, II 5, Izo

Christ, H., $5^{8} 7$

Cingularia, $49,50,67-70$

bracts, 67

sporangia, 69

sporangiophores, 68

typica, *68, *69

Cladoxyleae, 496-499, 643

Cladoxylon, 496-498, 643

dubium, 497
Cladoxylon mirabile, 497

Classification, $\mathbf{I}_{3}$

Calamarieae, 73.82

Ferns, 351

of Vasculares, 6r5-6r9

scheme of, 616

Clathraria, 2II, 2I2, 214, 215, *216, 258

Clepsydropsis, 643

Club-mosses. See Lycopodiales

Coal, 9, I3

Coal-balls, Io-r 3

Moravian, 646, 663

Coal-flora, 6

Coal, Leaf, 202

Coal-measures, 5, 357, 6 I I

Lower, 4II, 428, 474, 483,-50I, 5 II, 53 I

Middle, 45I, 465

Upper, 44I, 457, 460, 466, $53^{2}$

Colpoxylon, 446, 490

aeduense, 446

Compositae, 603

Coniferae, 49I, 523, 546, 547, $55 \mathrm{I}$, $55^{2}, 553,554,604-6 \mathrm{II}$

affinities, $653^{-6} 5^{8}$

antiquity of, 605

Permian, 605, 607

Coniferous wood, 610

Conifers, 5, 82, 485, 525, 526, 529, $535,539,545,550,555$

Conostoma, 422

intermedium, 418

ovale, 4 r 8

Corda, A. J., 288, 297, 306, 402

Cordaianthus, 535

female, $539-546$

male, $536-539$

pollination, 54I

anomalus, 546

Grand' Euryi, 54I, " 542

Penjoni, 536, " 537

Saportanus, 536

Williamsoni, ${ }^{*} 540,546$

Cordaicarpus, $547,548,549$

Cordaitales, 500-554, 6 I 2 affinities, $650-657$

Cordaiteae, 453, 49I, 500, 509, 5I2, $5 x_{3}, 517,518-554,600,61_{3}, 650$, $65^{8}$

affinities, 550-554

external characters, 519-525

flowers, 524, 535-546

leaves, 532-535, 609

roots, $530,{ }^{*} 53 \mathrm{I}$ 
Cordaiteae, seeds, 546-550, 553 stem, 525-530

Cordaites, $465,473,474,482,518$, $605,606,6$ II, 65I

branches, 523

flowers, $535-536,544$

female, $521,{ }^{*} 540,{ }^{*} 542,539-546$ male, $536-539$, * 537

habit, 523

inflorescence, " 522,525

leaves, ${ }^{*} 522,529,532-535,{ }^{*} 533$

root, $530-53^{x}$

stem, $525,{ }^{*} 527$

stomata, 535

angulosostriatus, $532,{ }^{*} 533$

Brandlingii, " 528

crassus, 535

laevis, ${ }^{*}{ }^{22}$

lingulatus, ${ }^{*} 533$

principalis, 534

rhombinervis, ${ }^{*} 533$

Cormack, B., 626

Corynepteris, 273, 287, 323-324, 344, 347,644

Cotta, C. B., 306, 334

Cotyledons, ${ }^{*}{ }_{59},{ }^{*} 574,654$

Cracow, $5^{88}$

Craigieith, 5I 4

Cretaceous formation, 4, 35I, 596, $607,608,611,659,660$

Lower, 555, 557

- Upper, 609

Crossotheca, ${ }_{280} 286-289,421,422$, $468,469,470,472,644$

Höninghausi, 396, * $397,{ }^{*} 398,399$, 400

Hughesiana, 399

Crow's nest, fossil, $55^{6}$

Crowfoot, Water, 88

Cryptogamic wood, 491, 652

Cryptogams, Vascular, I4, I5 antiquity of, 6I 4

Cryptomeria, 608

Culm, 268, 4I 5

Cupressineae, 609

Cupressinoxylon vectense, 6 Io

Cupule of Gnetopsis elliptica, 423, 425 Lagenostoma Lomaxi, ${ }^{*} 3^{87},{ }^{*} 388$, *390, *39r, 648

Sinclairi, *394, *395

Neuropterideae, 462

Sphenopteris Dubuissonis, 395

Cuticle of Bothrodendron, 202

Cyatheaceae, 295, 342, 350

Cyathotrachus altus, 279
Cycadaceae, $366,435,464,473,491$, $542,552,553,555,556,559,579$, $594-596,597,6 r_{3}, 647,649,655$

Cycadales, 237, 596, 597

Cycadella, $578,579,588$

ramentosa, 578

wyomingensis, $5^{89}$

fructifications, 589

Cycadeoidea (see also Bennettites), 560

flower, $5^{80-589},{ }^{*} 5^{81},{ }^{*} 5^{8} 3,{ }^{*}{ }^{84}$, ${ }^{*} 5^{8} 5$

fruits, $5^{80}, 5^{89}$

gynæcium, $5^{82}, 5^{8} 3,5^{89}$

stamens, $579,5^{80-} 5^{8} 3,{ }^{*} 5^{81},{ }^{*} 5^{8} 3$, ${ }^{*}{ }_{5} 84,{ }^{*} 585,{ }^{*} 586,{ }^{*}{ }^{8} 87$

dacotersis, $5^{80},{ }^{*} 5^{81}, 5^{82},{ }^{*} 5^{8} 3$, ${ }^{*} 5^{86},{ }^{*} 5^{8} 7,589$

etrusca, 579

gigantea, 557

ingens, $578,579,580,{ }^{*} 5^{8} 4,{ }^{*} 5^{8} 5$

Jenneyana, $565,5^{88}$

marylandica, ${ }^{*} 55^{8}, 559$

micromyela, 565

Paynei, $5^{88}$

Reichenbachiana, $5^{89}$

Cycadeoideae (see Bennettiteae), 578

Cycadinocarpus, 548

augustodunensis, ${ }^{*} 549$

Cycadites, 556,596

leaves, 595

Cycadofilices, 268, 473-499, 500, 508, 530,647

Cycadophyta, 5, 346, 356, 40I, 422, $464,492,500,546,547,553,554$, $555-604$

affinities, 647-650, 658-66 I

affinities of Mesozoic, 596-604

results of American research, 577604

Cycadospadix Hennoquei, carpel, 595 milleryensis, * 493

Cycadoxyleae, $483-496,646$ affinities of, 490,499

Cycadoxylon, 487, 489

Fremyi, 487,490

robustum, $475,483,{ }^{*} 484,485$, $486,487,489,490$

Cycads, $5,356,364,366,392,420$, $421,434-436,443,458,483$, $485-487,489-494,506-509,532$, $534,535,539,545,546,550$, $551,55^{8}, 559,562,563,565$, $566,577,579,589,592,594$

Cycas, $534,544,556,567,577,595$, $596,602,648$ 
Cycas, ovule, *543 Micholitzii, 648 revoluta, 595

Cyclopteris, 427

\section{Dacrydium, 6xо}

Dactylotheca, *280, 284,285 dentrita, ${ }^{*} 27 \mathrm{I}$

Dadoxylon, 480, 517, 523, 527 Spenceri, 5I7, 518

Dakota, $557,55^{8}, 559,565,580$

Dalmeny, $\mathrm{r}_{42}$

Danaea, 28I, 285, $35^{\circ}$

Danaeites, 285,288

Davallia aculeata, $3^{84}$

Dawkins, W. Boyd, 226

Devonian formation, $5,6,268,465$, $477,482,495,497,518,6 I_{5}$, 641,652

Upper, 70,480

Dialystelic, 444

Dicksonia, 442, 467

Dicksoniztes, 467

Dicotyledons, 372, $3^{81}, 382,492$, $556,659,660$

Dictyopteris. See Linopteris, 425

Dictyostelic, 444

Dictyoxylon Grieviz, 402

Dioon, 366, 493, 594, 598

Dioonites, 556

Diplolabis, 324, 34I, 342, 344 esnostensis, 324

forensis, 324

Diplotmema, 272, 273, 4I5

Diploxylic, 217

Diploxylon, 226

Dipteridineae, $35 \mathrm{I}$

Discoid pith, 464, 524, 525

Distichi (see Psaronius), 297

Dixon Fold, 239

Dorycordaites, $467,{ }^{*} 520,52 \mathrm{I}$

Dracaena, 52 I

Dudley Coal-field, 398, 45 I

Dukinfield, 239

Dulesgate, 4IO

Elaters, 84

Embryo, absence in Palæozoic seeds, $393,55^{\circ}$

Bennettites, $393,{ }^{*} 569,572,573$, *574, 575

Cycads, 393

sac, 548. See Megaspore

Encephalartos, 443, 492, 579, 594

Endarch bundles, 148, 565
Endlicher, S. L., 527

Endodermis, 45

Endosperm, 425, 549, 569, 574

Endotesta, 548

Eocene, 4

Ephedra, 545, 552

Epinac, 297

Equisetales, $x_{5}-85,6 x_{5}, 616,63^{2}$ affinities, 6 I9-626

Mesozoic, $82-85,626$

Equisetites, 49

arenaceus, 83

Burchardti, 84

Equisetum, 5, 9, 15, 26, 45, 70, 72, $78,79,326,539,621,622$, 626

Hemingzeayi, 72

Eremopteris, 466, $47 \mathrm{I}$

St. Etienne, 44I, 457, 466, 532

Eu-Calamites, 74

Eu-Cordaites, 521

Fuphorbiaceae, 524

Eupodium (see Marattia), 284

Eu-Sigillariae, 2IO, 2II, 2I2, 213 , 225, 257

Eusporangiatae, 275, 276, 289, 345. 348

Exalbuminous seed, 573, 575

Exarch bundles, 148,475

Exodermis, 45, 46, $3^{80}$

Falkenberg, 495

Favularia, *207, 210, 2 II-212, 228

" Fern-fronds," 269

Ferns, 5, 15, 267-353, 355, 356, 376, $378,385,401,419,420,422$, $442,450,463,466,468,470$, $476,483,499,500,508,555$, $584,586,587,604,611,615$, $6 \pm 6,6 \times 7,633,660$

affinities, $638-645$

anatomy, 294-304, 306-3I9, 324$330,333-337$

classification, $35 \mathrm{I}-353$

fronds, $269-274$

fructifications, 274-294, *280

Mesozoic, 350.35I

summary, 346-353

Tree, 468

Filicales (see Ferns), 266

Fischer, Ed. , 68

Fitting, H., $63_{3} 8$

Fittonia Brongniartii, 577

Fliche, P., 607

Flowers, Angiospermous, 586, 659 
Flowers, bisexual, of Bennettiteae, $580-589,598-604,659$

of Cordaiteae, $535-546$

Fronds, dimorphic, 285

Fucoid algae, 274

Fumaria officinalis, 4 I 8

Galium, compared with Sphenophyllum, II 4

Germinating spores in Stauropteris, *339

Gibson, F., 567

Gibson, Harvey, 260

Ginkgo, 392, 458, 517, 529, 538, 539 . $542,544-546,549,55^{\circ}, 55^{2}$, $555,6 I_{1}, 6 I_{2}, 6 I_{3}, 655$

Ginkgoaceae, $473,546,55^{2-554,595}$, $6 I I-613,65^{8}$ affinities, 6I2-613

Ginkgodium, $6 \mathrm{I} 2$

Gleichenia, 274, 290, 419, 420

Gleicheniaceae, $280,290,342,350$, 476

Gnetaceae, 82, 423, $537-539,545$, 546,552

Gnetales, 66I

Gnetopsis, 81 elliptica, 422

Gnetum, 537, $55^{2}$

Goebel, K., $63^{I}$

Goldenberg, F., 2 I I

Goniatites, 447

Göppert, H. R., 36, 242, 297, 443, $451,482,494,514,527$

Gothan, W., 6I0

Gradatae, 352

Grammatopteris, 333

Rigolloti, 333, 335. 345

Grand Croix, 50I, 532

Grand'Eury, C., I6, 40, 72, 74, 76, $78,79,173,205,218,303,322$, $395,446,460-463,466-470,472$, $508,511,519,523,525,535,65 \mathrm{r}$

Grand' Eurya, 281, $34^{8}$

Greenland, 596

Greensand, Lower, 4, 560, 567, 6ro

Grieve, G., 402

Griffith, W., 543

Gum-canals in Bennettites, 566 Medullosa, $43^{8}$

Gwynne-Vaughan, D. T., 3I4, 35I, 621

Gymnosperms, $356,381,473,482$, $483,494,500,510,529,530$, 544
Gymnosperms, affinities, 66r

antiquity, $6 \mathrm{I}_{4}$

Mesozoic, 555-6r 3

origin, 653

Halifax, 4II

Halle, T. C., 83, 84, 264, 626

Halonia, I67-I73, * I69

Hapalopteris. See Renaultia

Hardinghen coal-field, 225

Havulea, *280, $28 \mathrm{I}$

Helminthostachys, 321, 341, $3^{82}$

Hemingway, W., 622

Hemitelia capensis, 274

Hesley Heath Colliery, I35

Heterangium, 40I-4I8, 43I, 450, $473-477,499,505,646$

affinities, 418.424

geriense (= Medullosa geriensis), $44 \mathrm{I}$

Grievii, 40I-4II, 4I8, 4I9

habit, 4I 4-4I 8

leaves, $409-410,{ }^{*} 4 \mathrm{I} 7$

roots, 4 IO- 4 II

stem, 403-409, " $403,{ }^{*} 404,{ }^{*} 405$, ${ }^{*} 406,{ }^{*} 416$

Lomaxii, 402, 4IO, 4II

tiliaeoides, 4I I-4 I8, *4I2, 439, 506

Heterosporous Calamariaceae, 625

Lycopods, 636,637

Heterospory in Calamostachys Casheana, 55

in Ferns, 353

Lepidostrobus, I76, 182-189, 193

Macrostachya, 73

Palaeostachya, 63

Sigillariostrobus, 233-235

Sphenophyllum, incipient, 107

Hick, T., 40, 4I, 256

Hickling, G., 64, 65, 67, 622

Hirase, S., 459, 549

Hollick, A., and Jeffrey, E. C., 607

Homosporous Lycopods, 636

Hooker, Sir Joseph D., 452, 456

Horsetails. See Equisetum

Hough Hill, 428

Hovelacque, M., I $50,15^{8}$

Hymenophyllaceae, 274, 290, 312, $342,343,344,35$ I, 640

Hymenophyllites quadridactylites, 290

Hypocotyl, 574

Ikeno, S., 459

Impressions, 7

Incrustation, 7 
Indusium, $33^{\text {I }}$

Infranodal canals of Calamites, 47,48

Integument, Bennettites, 572-573

Cordaiteae, 54I, 548, 549, $55^{I}$

Cycas, 543

Gnetopsis, 423

Lagenostoma, 389-392

in Lepidocarpon, I94, " $195,{ }^{*} \mathrm{I96}$

Miadesmia, * 198, * 199

Rhabdocarpus, 5I3

Stephanospermum, 357

Trigonocarpus, 453-456, 649, 65I

Iodes, 372

Isoëtes, I26, I53, I 57, I 59, I75, I 8 I, $184,235,259,266,635,637$

Isosporangia, 473

Isosporeae, $35^{2}$

Japan, 6 I2

Jasmineae, 524

Jeffrey, E. C., 480, 608, 6II, 6I7, $63^{2}$

Jurassic formation, $4,350,607,609$, $6 \times 2$

Lower, 84

Upper, 5, 557

Kaloxylon Hookeri (see Root of Lyginodendron), $378,3^{8} 3$

Kalymma, 479,480

Kathodic, 480

Kaulfussia, 277, 281, 284, 285

Kauri Pine, 523

Kidston, R. , 70, 72, II3,'I65, I72, I83, $200,228,232,233,234,235$, $236,286,29 \mathrm{r}, 344,345,35 \mathrm{r}$, $374,396-399,4 \times 8,422,450-45^{2}$, $469,496,498$

and Gwynne-Vaughan, D. T., 642, 646

Knorria, 133

Kraus, G., 527

Kubart, B., 663

Lagenostoma, $\quad 386-396, \quad 418,422$, 423,648

Lomaxi $=$ seed of Lyginodendron oldhamium, $386,{ }^{*} 3^{8} 7,{ }^{*} 388$, ${ }^{*} 389$, *390, "391, 392, 394, 396

ovoides, 396

physoides. See Physostoma elegans

Sinclairi, *394, *395

Laggan Bay, I 4 I

Lang, W. H., 618, 636
Leaf-scars, Bothrodendron, 199

Caulopteris, 295

Clathraria, 212, "216

Favularia, *207, 210

Leiodermaria, ${ }^{*} 209,212$

Lepidodendron, * $130,205,209$

Lepidophloios, I32, " 69

Megaphytum, 295

Rhytidolepis, *208, 210

Sigillaria, 206, *207, *208, *209, *216

Leaves of Abietineae, 608

Aneimites, 465

Archaeocalamites, $3^{8}, 7$ I, 74

Bennettiteae, 578

Botryopteris, 329

Calamarieae, $3^{8-4 I}, 60,68,71,75$, $76,77,78$

Calamopitys, 480

Cordaiteae, * $520,{ }^{*} 522,529,532-$ $535,{ }^{*} 533$

Corynepteris, 323

Cycadella, 579

Cycadeoidea, 578

Cycadites, 595

Ferns, 269-274

Ginkgoaceae, 6II, 6I2

Heterangium Grievii, 409-4IO, * 4 I 7

Lepidodendron, I 55-16I

Lepidophloios, 156, I 59

Lycopoditeae, 263,264

Lyginodendron oldhamium, ${ }^{*} 374$, ${ }^{*} 375,{ }^{*} 377$, frontispiece

Medullosa, 429, 430, ${ }^{4} 436,43^{8}$, 439

Pecopteris Pluckeneti, 467

Poroxylon, * $507-509$

Pseudobornia, I 23

Pseudocycas, 596

Sigillaria, 205, 222, 224, 225, 23 I

Sigillariopsis, $230-231$

Sphenophyllum, 87, 97, 98

Stauropteris, $336-33^{8}$

Sutcliffa insignis, 447, 449, 450

Williamsonia angustifolia, 590-593 gigas, *591

Zygopteris, 3I4-3I7, 322, 323

Leeson, Dr., 567

Leiodermaria, * 209,2 I I, 2I 2, 2 I8

Lepidocarpon, I94-I97, 547,636, 656

Lomaxi, I94-197, * I94, *I95. ${ }^{*}$ I 96,266

Wildianum, 197

Lepidodendreae, I25-197, 199-265, $634,636,637$ 
Lepidodendreae, fructifications, I73-| Lepidostrobus Veltheimianus, "I83,

I97, 20r, $23 \mathrm{r}-236$

spores, * $186,187,188$, ${ }^{*}$ 190

Lepidodendron, 8, 125, 130, 199, 208, $209,246,634$

branching, I6I-I 64

Britisb species showing structure, I35

habit, $126-133$

leaf-bases and leaf-scars, " I3०, 205 , 209

leaves, I 55-I6I

stem, I33-I55

aculeatum, $\mathrm{I} 35, \mathrm{x} 55$

brevifolium, I35, I43, "I $44, I_{54}$, I $57,164,218$

elegans, ${ }^{*} 127$

esnostense, 159,160

fuliginosum. See Lepidophloios fuliginosus

Harcourtii, I35, ${ }^{\text {I } 37, ~ I 38, ~ I 39, ~}$ I 40, I43, I48, I 54, I78

Hickii, 135, I38, I57, I59, ${ }^{\pi}$ I60, I6r, I70

intermedium, I35, I54

macrophyllum, I35

mundum.

See Bothrodendron mundum

obovatum, I35, I 54, I70

Ophiurus, * 129,173

parvulum, I 35

selaginoides, $135, I_{43},{ }^{*} \mathrm{I}_{45},{ }^{*} \times 46$, I49, I 50, " I5 I, I54, * I62, I63, 475,633

Veltheimianum, ${ }^{*}{ }^{1} 30,167$

Wiinschianum, I35, I39, I40,

* 142, I 43, I68, 169, 217,218

Lepidophloios, $\mathbf{r}_{32}, \mathbf{I}_{33}, \mathrm{I}_{54}, \mathbf{I} 55$, ${ }^{*}{ }_{156,}{ }^{2}{ }_{5} 5,211,217$

fuliginosus, I 35, 138, 1 39, I 54, 155 . I63, ${ }^{*}$ I $71, I 72,256,635$

laricinus, $\mathrm{x} 73$

scoticus, ${ }^{*}$ I69, I7o

Lepidostrobus, I74, I89, I92, I93. 194, 195, 200, 201, 637

axis, $176-178$

diagram, ${ }^{*} 7^{6}$

heterospory, I76, I82-189, I93

ligule, ${ }^{*} 176,180$

sporangia, $180,18 x, 183,184$

Brozonii, I75, I77

foliaceus, ${ }^{*} \mathrm{I} 87$

Hibbertianus, " I74

oldhanius, I76, I77, x79, I80, I $83, I 94$
${ }^{*} 184,{ }^{*} 185,{ }^{*} \mathrm{I} 86,187,{ }^{*} \mathrm{I} 88$

Leptosporangiatae, 275

Leptosporangiate, $342,345,348$

L'Escarpelle, 205

Lianes, $443,45^{\circ}$

Lias, $350,351,565,607,608,6 I_{3}$

Lower, 595

Liassic, 83

Lignier, O., 560, 565, 576, 577, 599 , $600,601,6$ I 5,6 I9, 620, 632

Lignite, $6 \mathrm{II}$

Ligule, Bothrodendron, 200, 201

Lepidocarpon, 195

Lepidodendron, ${ }^{*}{ }_{3}$, ${ }^{3} 3$ I, ${ }^{*} 45$, I 57-159

Lepidophloios, * ${ }_{5} 56,{ }^{*}{ }_{59}$

Lepidostrobus, ${ }^{\pi} \mathbf{1 7 6}, \mathbf{1 8 0}$

Miadesmia, * $198,{ }^{*}$ เ99

Sigillaria, * 209,229

Lindley and Hutton, 590

Linopteris =Dictyopteris, $46 \mathrm{I}, 462$

Liriodendron, 659

Lomaria, 273

Lomax, J., I72, 200, 334, 371, 447, 5 II

Lopriore, G., 544

Lotsy, J. P., 37

Loxsoma, 442

Luccomb Chine, 567

Lycopodiaceous seed-like fructifications, I93-I99

Lycopodiales, I 25-266, 6I6, 6 I7

affinities, $632-638,653-657$

heterosporous, 636,637

homosporous, 636,637

Lycopoditeae, 204, 26z-266

Lycopodium, I25, I28, 157, 200, 262, $263,266,635$

cernuum, 636

Lycopods, 5, I5, 253, 260, 262, 267, $547,615,616,618$

Palæozoic, I26, I94, I97, I99, 262266

Lycopsida, 6I6, 6I7, 626, 657

affinities, $632-63^{8}$

Lycostrobus Scotti, 594

Lyginodendreae, 280, 355-424, 432, $450,45 I, 463,464,473,477$, $480-483,486,494,499,500$, 5 I $7,554,645,646,651,652$

affinities, $418-424,645,646,648$ characters, 424

Lyginodendron, 286, 357-40I, 406-409, $4 I I, 4 I 3,4 I 9-42 I, 423,452$ 
$469,475,476,479,481,482,1$ Matonia pectinata, $35^{\circ}$

492, 502, 504-509, 513, 518, 529, $550,646,648$

Lyginodendron oldhamium (now includes Crossotheca Höninghausi, Kaloxylon Hookeri, Lagenostoma Lomaxi, Rachiopteris aspera, Sphenopteris Höninghausi), 357393, 396-399, 403, 410, 4I4, $422,47 \mathrm{I}, 483,486,487,489$, 490,492

anomalous stems, 372

branching, ${ }^{*} 37 x, 372$

gland, $369,{ }^{*} 370,{ }^{*} 388$

habit, $3^{8} 3-386$, * frontispiece

leaf-traces, $3^{60-36} 3,{ }^{*} 3^{6} 5,370$

leaves, $373-378,{ }^{*} 374,{ }^{*} 375,{ }^{*} 377$, *frontispiece

microsporangia and microspores, 396-40r, * $397, * 398$

periderm, * $359,360,{ }^{*} 365,{ }^{*} 367$, 382

phyllotaxis, $362,3^{8} 5$

root, $378-383,{ }^{*} 379,{ }^{*} 382$

seed, $386-396,{ }^{*} 3^{8} 7,{ }^{*}{ }^{8} 88,{ }^{*}{ }^{8} 89$, *390, *39 I

spines, 368,369

stem, 357-373, ${ }^{*} 357,{ }^{\pi} 358,{ }^{*} 359$, ${ }^{*} 360, * 364, * 365, * 367, * 369$, ${ }^{*} 37$ I, ${ }^{3} 374,{ }^{*}{ }_{3} 82$

robustum. See Cycadoxylon robustum

Lyginopteris (see Lyginodendron), 357

Lygodium, 288, 470, 476

Macrostachya, 49, 72-73, 78, 80 infundibuliformis, ${ }^{*} 73$

Macrosamia, 443, 492, 577, 579

Madagascar, 608

Magnoliaceae, 659

Maiden-hair tree. 'See Ginkgo

Mallow, $5^{82}$

Mangrove, 377

Maratia, 281, 283, 284, $35^{\circ}$ Kaulfussii, 587, $5^{88}$

Marattiaceae, 274, 276, 285, 290, 298, $303,347,348,349,350,382$, $397,421,468,473,587,604,63^{8}$ affinities, 644

Mariopteris, 470

muricata, $47^{\circ}$

Marsilia, 442

Maryland, 557, 559

Masien, A. J., 44, 454, 455

sarmentosa, $35^{\circ}$

Matonineae, $35^{\circ}$

Matte, H., 649

Mazocarpon, *188, 633

Medullary casts. See Casts, Medullary

Medullosa, 428-446, 447, 449, 456, $464,490,497,506,509,534$, 643

anglica, anatomy, 428-44I

gum-canals, $43^{8}$

leaves, $43^{8}, 439$

periderm, $435,440,44 \mathrm{r}, 510$

petiole, $435-439$, * 436

phyllotaxis, $43^{\circ}$

roots, $439-440,510$

stem, 429-435, ${ }^{*} 430,{ }^{*} 43 I_{1}{ }^{*} 43^{2}$,

* 434

summary, 440

Geriensis = Heterangium geriense, $44 \mathrm{I}$

Leuckarti, 444, 445

pusilla, 44I

Solmsii, 445

stellata, 44I-445

Medulloseae, 4I4, 425-465, 473, 482, $497,643,645,648,649,650$

affinities, $463-465,643,645,648$ $65^{\circ}$

anatomy, 428-450

fructifications, $450-463$

habit, 425-428

Megaloxyleae, $474-476$

affinities, 476,499 |

Megaloxylon, 475, 476, 482, 499

diagnosis, 476

Scottii, 474

Megaphyllous, 6r7, 632, 64I

Megaphytum, 295, 296

Megasporangia and megaspores-

Bothrodendron, $20 \mathrm{I}$

Calamostachys, 56, ${ }^{*} 57$

Lepidocarpon, * I94, *195, " I96

Lepidostrobus, ${ }^{*} 76,{ }^{*}{ }_{184},{ }^{*}{ }_{18}$, ${ }^{*} \mathrm{I} 86$

Macrostachya, 73

Mazocarpon, ${ }^{*} 88$

Pseudobornia, 124

Selaginellites, 263, 264

Sigillariostrobus, $233,{ }^{*} 234,235$

Megaspore or embryo-sac, ${ }^{*} 389,392$,

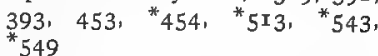

Meristele, $45^{\circ}$

Mesarch bundles, I48, 475, 565, 579 
Mesozoic period, 5, 265, 347, 491, 555-559

Equisetales, 82-84

Ferns, 350, 35I

Gymnosperms, 555-613

Lower, 6

Metaxylem, 405, 475

Mettenius, G. , 628

Miadesmia, 263, 265, 266, 636, 637 membranacea, ligule, r98-I99

seed-like organs, I97-I99, ${ }^{*}$ 198, ${ }^{*}$ I99

vegetative organs, 197

Microcycas, 544.577

Microphyllous, 615, 617, 632, 634, 641,658

Micropyle, Bennettites, 567,569, 570, $573,575,576$

Cordaiteae, 548, 549

Gnetopsis, 425

Lagenostoma, $3^{87}, 3^{89}, 390$, 39r, 392

Stephanospermum, 457

Trigonocarpus, 452, 453, 454, 455

Microsporangia and microspores, $35^{6}$, 469

Bothrodendron, $20 \mathrm{I}$

Calamostachys, ${ }^{*} 57$

Crossotheca, ${ }^{*} 397,{ }^{*} 398,399,422$, 469,544

Cycadeoidea, 579-588, ${ }^{*} 5^{81},{ }^{*}{ }^{8}{ }_{3}$, ${ }^{*} 584,{ }^{*} 585,{ }^{*} 586,{ }^{*}{ }^{8} 87$

Lepidocarpon, 196

Lepidostrobus, ${ }^{*} \mathrm{I} 76, \mathrm{I} 82,{ }^{*}{ }_{18}, \mathrm{I} 84$. ${ }^{*} \mathrm{I} 85$

Linopteris, 462

Lyginodendron oldhamium, 396-40I Macrostachya, 73

Neuropterideae, 462

Pecopteris, 469

Pseudobornia, 2or

Pteridospermeae, 421, 468, 472, 473

Selaginellites, 263, 264

Sigillariostrobus, 235

Millstone grit, 465

Miocene, 4

Mixtae, $35^{2}$

Mollusca, I2

Monocarpic, 580

Monocotyledons, 474, 519, 521, 590, 660

Moravia, 6o9, 646, 663

Mosses, 618

Myeloxylon = petiole of Medullosa, $437,43^{8}, 439,447$
Myeloxylon Landriotii, 437, 439, 441, 444

radiatum, 445

Myriophylloides, 42

Naiadita, 265

Nathorst, A. G., 84, 123, I24, 559, 592,609

Neocalamites, 83

Neuropterideae, 425, 47I, 645, 650

affinities, $463-465$

fructification, $45^{0}-46_{3}$

Neuropteris, 272, 274, 355, 425, 426, $445,450,46 \mathrm{I}, 47 \mathrm{I}, 472$ flexuosa, $46 \mathrm{I}$ heterophylla, *426, 450, *451, 460, $46 \mathrm{I}, 462,47 \mathrm{x}, 472$

seed, $45^{\circ},{ }^{*} 45 \mathrm{I}$

New York, 607

Nield, 483

Nodules, calcareous, 357,429 roof, I2, I3, 429, 447, 5II seam, 12, 447

Noeggerathia, 289

Nova Scotia, 239

Nucellus, Araucaria, 656

Bennettites, 572-573

Cordaiteae, 54I, 548, 549, 65 I

Cycas, 543

Gnetopsis, 423

Lagenostoma, 389-392, 648

Lepidocarpon, 656

Rhabdocarpus, $5^{1} 3$

Stephanospermum, 357

Trigonocarpus, $453-456,649,65$ I

Nymphaeaceae, 659

Odontopteris, $425,445,46 \mathrm{I}$

Oldham, 483

Oligocarpia, *280, 290, 347 robustior, 290

Oligocene, 4

Oliver, F. W., 386, 392, 396, 422, $45^{6}, 45^{8}, 459,460,643$

Oolite, 5

Lower, 590, 6I2, 6I3

Middle, 560,564

Oxford, 576

Upper, 608

Ophioglossaceae, $382,421,628$

affinities, 639-64I

Ophioglosseae, 276, 289, 3I2, 34I, 342,344

Ophioglossites, 289 
Ophioglossum, 289, 319, 344,627,628 simplex, 64I

Orthotropous, $39^{\circ}$

Osmunda, 350, 368, 37 I, 42I, 426, 505

Osmundaceae, 287, 29I, 292, 3I 5, $33^{2}, 342,344,345,350,476$, 642,646

Osmundites skidegatensis, 35 I

Otozamites, $55^{6}$

Ovule, ${ }^{*} 540,54 \mathrm{I},{ }^{*} 542,545,548$, $579-5^{8} 4,5^{89}$

\section{Pachytesta gigantea, $46 \mathrm{I}$}

Palaeopteris. See Archacopteris

Palaeostachya, 50, *61-67,77,82 bracts, 62,64

sporangia, 62,64

sporangiophores, $62,64-67$

spores, 64

gracilis, 62, 63, 76

pedunculata, ${ }^{*} 62$

vera, $64, * 65, * 66,620,622$

Palæozoic plants, 5

Palissya, fructification, 610

Palm, 580 wood, 660

Parichnos, * I $30, I_{3} I, I_{49}, I_{55},{ }^{*} I_{56}$, I 57, I79, *207, *209, 2 I 3,2 I 4 , $22 \mathrm{I},{ }^{*} 222,260,26 \mathrm{I}$

Parkin, J., $53^{8}$

Pecopterideae, affinities, 470 seed-bearing, 465, 466-470, 47I

Pecopteris, 272, 274, 277, 281, 282, $286,288,289,303,465,468$, 469,470

densifolia, $28 \mathrm{I}$

dentata, ${ }^{2} 2 \mathrm{r}$

exigzua, $287,289,422,469$

oreopteridia, $28 \mathrm{x}$

Pluckeneti, 288, 465,470, 47I$472,64.5$

Sterzeli, 468

Pedicel, 565, 570, 572, 573, 575

Peduncle, 57 I, 581, 582, 592

Penhallow, D. P., $35 \mathrm{I}$

Pericarp, 569, 570, 572, 573, 575, 576

Periderm in Amyelon, "53I

Bennettiteae, $5^{6} 5$

Bothrodendron, 201

Calamites, 30, 3I, 46

Cordaiteae, 530,53 I

Heterangium tiliaeoides, 4I3

Lepidodendron, I 34, т 39, "144, ${ }^{*}$ I 45.149 , I 50
Periderm in Lyginodendron, *359, $360,{ }^{*} 365,{ }^{*} 367,3^{82}$

Medullosa, *43I, 435, 440, 44I

Poroxylon, 507, 510

Sigillaria, ${ }^{*} 216,217,221,{ }^{*} 227$

Sphenophyllum, 94

Stigmaria, *243, 246, ${ }^{2} 247$

Permian formation, $5,19,35,83,87$, I28, 296, 306, 44I, 443, 446, $476,486,487,492,564,595$, $605,607,646,652$

Permo-Carboniferous formation, 423 , 469,5 OI

Petrifaction, 7, 9, II, I2, 45I, 663 analysis of, II

Pettycur, 402. See Burntisland

Phanerogams, 356,5 Io

Phelloderm, 440

Phylloglossum, 125, 193, 26I, 635

Phyllotaxis, Botryopteris, 327 Calamopitys, 479,480

Heterangium, 408

Lepidodendron, 128

I.yginodendron, $362,3^{8} 5$

Medullosa, 429, $43^{\circ}$

Megaloxylon, 474

Poroxylon, 501-504

Psaronius, 295

Ptychoxylon, 489

Zygopteris, 307

Phyllotheca deliquescens, 72

Physostomia, 422 elegans, 396,460

Pinus, 524, 608

Pits, bordered, significance, 642,654

Pityeae, 514-518, 525, 651 affinities, 5I8, 55I, 554

Pitys, 5I4-5I 7

habit, 5 I 4

stem, 5I4-5I7

antiqua, 474, 5I 4,5 I5, * 5 I6

primaeva, 5 I 4

Withami, 5I4

Platyspermic, $45 x, 465,466,472$, $5 \times 3,547,651$

Pleuromeia, 637

Plumule, 574

Poacordaites, 52 I leaves, $52 \mathrm{I}$

Podocarpeae, $65^{8}$

Podocarpus, 523, 609

Pollen-chamber, 464, 473

Aetheotesta, 459

Cordaianthus, $54^{\text {I-544, }}{ }^{*} 542,548$, 549 
Pollen-chamber, Cordaicarpus, $54^{8}$

Cordaiteae, 553

Cycadinocarpus, ${ }^{*} 549$

Cycas, "543

Gnetopsis, 423, 425

Lagenostoma, ${ }^{4} 3^{87}, \quad{ }^{*} 3^{89}, \quad{ }^{3} 390$, *39r, 392, 393, 400

Stephanospermum, $457,{ }^{*} 45^{8}$

Trigonocarpus, $453-456$, *454

Pollen-grains, 460

Cordaianthus, 538, 539, 54I-545, * 542

Cordaiteae, 553

Cycadeoidea dacotensis, 588 etrusca, 579

Cycadinocarpus, 549

Lyginodendron oldhamium, 392, 393, 400

Stephanospermum, 456-* $459,{ }^{*} 45^{8}$

Pollen-sacs, 655

in Cordaianthus, 536, ${ }^{\star} 537$

tube, 460,545 Araucaria, 544 Microcycas, 544

Polypodiaceae, 35I

Polypodiaceous, 294, 342

Polystely, $349,430,433,446,463$, $497,643,649$

Polystichi (see Psaronius), 297

Poroxyleae, 500-514, 518, 525, 529, $550,55 \mathrm{I}, 554,65^{2}$

affinities, $513-51_{4}, 65 \mathrm{I}$

Poroxylon, 500, 50I-514, 5I8, 526, $529,535,554,65 \mathrm{I}$

branches, 509

habit, 501

leaves, 507-509

phyllotaxis, 501,502

root, 509, 5 Io

seed, 5 I 2,513

stem, 501-507

Boyssetii, 501, "503, " 507

Edward'si, 501, "503, " 505,506 , 509

Sutcliffi, 502, 509, * 5 II

Portlandian or Upper Oolite, 608

Pothocites, 70-72

Potomac, 557, 609

Potonié, H., 356, 474, 606, 609, 653

Pottsville beds, 465

Prepinus, 608, 609

Preservation, modes of, 7

Primofilices, $345,346,347,638,639$, 642
Pro-anthostrobilus, 6oI

Propteridosperms, 642

Protandrous, $5^{89}$

Prothallus, Cycadinocarpus, ${ }^{*} 549$

Lepidocarpon, *I95, " 196

Lepidostrobus, 187, * 188

Mazocarpon, * 188

Miadesmia, 189

Stephanospermum, 457

Protocalamites, 37, 621

Protocorm, 635

Protodammara, 607 fructifications, 607,656

Protopityeae, 494-496, 499

Protopitys Buchiana, 494, 495, 496

Protostele, 4I9, 463, 473, 633, 643

Protoxylem, 23, 35, 37, 44, 52, 9o, 95. IOI, I 37, I 5I, 229, 248, 252, $254,302,310,315,328,329$, $336,406,433,434,449,475$, $481,487,496,498,505,530$

Psaronius, $288,307,346,349,463$ anatomy of, 294-304

brasiliensis, 297, *299, 301

Renaulti, 301, " 302

Pseudoaraucaria, fructification, 607

Pseudobornia, 620, 625 ursina, I23-I24

Pseudoborniales, 86, 123-I24, 6I5, $6 r 6$

Pseudocycas, 596

Psilotaceae, 616, 627

affinities, 6z6-632

Psilotales, 6I6, 63I, 632, 64I

Psiloteae, r26

Psilotum, 90, 262, 626, 627, 630

Pteridophyta, 69, 6I7, 618, 619 sporangiophoric, $6 \mathbf{I}_{7}$

Pteridospermeae, 355-473, 494, 499, $500,501,508,55^{1} 3,5^{1} 4,55^{18}$, $547,550,553,554,600,602$, $604,6 \mathrm{r}_{4}, 6 \mathrm{x}_{7}$

affinities, $642-653,654,656,660$

characters, $47 \mathrm{I}-473$

summary, $47 \mathrm{I}-473$

Pteridosperms, 268, 272, 346

fructifications, ${ }^{*} 280$

Pteridotheca, 29I

Butterworthii, *292

Williamsonii, ${ }^{*} 293,294,347,639$

Pterophyllum, 493

Pteropsida, 6I6, 6I7, 632

affinities, 638-66I

Ptychocarpus, $277,{ }^{*} 278,288,348$ 
Ptychocarpus unitus, 277

Ptychopteris, 295, 296

Ptychoxylon, 487, 489, 529

Levyi, 487, *488, 488-494

Purbeck beds, 610

Lower, 556, 557

strata, 5

Rachiopteris aspera, 375

corrugata. See Zygopteris commgata cylindrica, 333, 335

hirsuta. See Botryopteris hirsuta

insignis. See Zygopteris corrugata ramosa. See Botryopteris ramosa. Williamsoni, 447

Radicle, 574

Radiospermic, 65I

Radstock, 532

Ramenta, 3I8, 566, ${ }^{*}{ }^{6} 69,571,572$

Ranunculaceae, 659

Ranunculi, 88

Receptacle in Bennettiteae, 567, " 568 , ${ }^{*} 569,571,581,582,588,593$

Renault, B., IO, II, 42, 43, 59, 60, $62,63,70,71,72,80,81,82,89$, $90,97,98,188,202,216,218$, $221,223,224,230,257,282$, 286, 289, 297, 3I3, 3I9, 32I, $325,326,331,334,343,422$, $437,439,44 I, 446,457,458$, $459,460,469,486,487,490$, $493,494,501,502,505,506$, $509,510,513,519,526,527,530$, $536,537,538,539,541,542,544$, $545,548,549,550,606,639,640$, $651,652,654$

Renaultia, Stur (see Sturiella, Weiss), 286

Renaultia, Zeiller, ${ }^{*} 280,284,285$

Replum, $45^{8}$

Rhabdocarpus, 45I, 508, 5I2, 548, $55^{\mathrm{I}}, 65 \mathrm{I}$

subtunicatus, ${ }^{*}{ }_{5} \mathrm{I}_{3}$

Rhacopteris, 289

Rhaetic formation, $83,350,351,494$, $593,607,609,6 \pi 0$

Rhizocarps, 353

Rhizophore, 244, 262

Roof nodules, 12, 13

Root, 639,649

apex, 38I

Archaeocalamites, 45, 72

Botryopteris, 327, 328

Calamarieae, $4 \mathrm{I}-46$

Calamites, $41-46$
Root, Calamodendron, 45

Cordaiteae, $530,{ }^{*} 53 \mathrm{I}$

Heterangium, 4I0-4II

Lepidodendron. See Stigmaria

Lyginodendron, $378-3^{8} 3, \quad{ }^{*} 379$, ${ }^{*}{ }_{3} 82$

Medullosa, 439-440, 510

Poroxylon, 509, 5 IO

Psaronius, 298, 299, 301, 302

Sigillaria. See Stigmaria

Sphenophyllum, 98

Stigmaria, 205-206, 237-262

Tubicaulis, 335

Zygopteris, 314, 318

Rudolf, K., 304

Saarbrücken, 204

St. Helen's, 239

Salvinia, 26I

Samaropsis, 467

Sandstone, Calciferous, 94, 96

New Red, 5

Old Red, 290

Sapindaceae, 443, 548, 549

Saporta and Marion, 595

Sarcopteris Bertrandi, a9I

Sarcotesta, 456, 464, 512, 547

Scalariform vessels, 642

Scales, interseminal, 568, 569, 570, $572,575,576,5^{82}$

Schizaea, 6II

Schizaeaceae, $287,288,292,342,35^{\circ}$

Schizodendron $=$ Tylodendron, 605

Schizolepis, 609

Schizoneura, 83,84

Schizopteris pinnata, 322

Schizostachys frondosus, 322

Sclerotesta, 453, 457, 464, 513r 548

Scolecopteris, $\mathbf{2 8 \mathbf { 2 } ,} \mathbf{2 8 4}, \mathbf{2 8 7}, \mathbf{2 8 8}$, $289,3 \circ 3,348,421$

elegans, 282,283

polymorpha, 282, ${ }^{*} 283$

Seam nodules, 12

Secondary thickening in Arthrodendron, 34

in Calamarieae, 80

Calamites, 28,36

roots, 42

Calamodendron, 34

Cheirostrobus, I2I

Lepidodendron, I34, I40, I43, I 5 I, 154

Psaronizs roots, 303

Sigillaria, 216, 218, 219, 226 
Secondary thickening in Sphenophyllum, 9 I

roots, 98

Stigmaria, 244, $25^{8}$

rootlets, 255

Secretory organs in Calamites, 2I, 4I

in Cheirostrabus, II9

Lepidodendron Harcourtii, I39 Wunschianum, $\mathbf{3} 39$

Lepidophloios fuliginosus, 139

Psaronius Renaulti, 301,302

Sigillaria, $22 \mathrm{I}$

Seed, $35^{6}$

exalbuminous, 573, 575

Palæozoic, 452, 659

Aneimites fertilis, 465

tenuifolius, 466

Bennettites, $5^{67-575, ~}{ }^{5} 568,{ }^{*} 569$, * $572,{ }^{*} 574$

Cardiocarpon, 466

Conostoma, 422

intermedium, $4 \mathrm{I} 8$

ovale, $4 \mathrm{I} 8$

Cordaicarpus, 547

Cordaiteae, $473,546-550,553$

Cycadaceae, 456, 648, 649

Cycadospadix Hennoquei, 595 milleryensis, ${ }^{*} 493$

Dorycordaites, 467

Gnetopsis, 425

Lagenostoma Lomaxi, $3^{86-393}$, ${ }^{*} 387,{ }^{*} 388,{ }^{*} 389,{ }^{*} 390,{ }^{*} 391$ ovoides, 396

Sinclairi, *394, "395

Linopteris, 461

Lycopods, 636

Lyginodendron, $3^{86-396,648}$

Medulloseae, $45^{1-456}, 464$

Neuropteris flexuosa, $46 \mathrm{I}$ heterophylla, 450-452, " $45 \mathrm{I}, 46 \mathrm{I}$

Odontopteris, $46 \mathrm{I}$

Pachyiesta gigantea, 46I

Pecopteris Pluckeneti, $466,{ }^{*} 67$

Physostoma elegans, 396,460 , 472

Poroxylon, 5I2, 5 I3

Rhabdocarpus, 45I, 508, 5 I2 subtunicatus, ${ }^{*} 5^{\mathrm{I}} 3$

Samaropsis, 467

Sphenopteris, 395 Dubuissonis, 395

Stephanospermum, 456, 459 akenioides, $456,{ }^{*} 458,{ }^{*} 459$

Trigonocarpus, $452-456,472,649$, $65 \mathrm{I}$
Seed, Trigonocarpus Parkinsoni, 452$45^{6},{ }^{*} 454,{ }^{*} 455,460$

Wardia fertilis, 466

Seed-like fructifications of Lycopods, r93-I99

Seed-plants, 6

Seeds, 81, 268, 270, 288

Selaginella, I26, 159, I84, I93, I97, $259,260,262,263,264,635$, 636,637

oregana, 158

rupestris, 158

spinosa, 126, 244, 264

Selaginellites, 263,264

elongatus, 264, 265

primaevus, 264, 636

Suissei, 263, 264

Senftenbergia, ${ }^{2} 280,287,288,347$

Sequoia gigantea, 607, 608

Seward, A. C., 5, I08, I38, 447, 474, $483,486,487,556,557,592$,

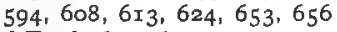

and Ford, 607, 653

and Gowan, 6r2

and Hill, A. W, 143,217

Shore, I3, III, 334, 429, 447, 5II, 526,531

Siberia, $6 \mathrm{I} 2$

Sigillaria, 5, I65, I67, 204-237, *227, 377, 513, 634

affinities of, 218,236

anatomical structure, 214-23I

fructifications, 23x-237

habit and external characters, 204214

roots of. See Stigmaria

Brardi, "209, 212, 214, 218, 224, 257

discophora, 236

elegans, 214, 228, 229, 235

elongata, 228

latifolia, ${ }^{*} 22$

lepidodendrifolia, 205

mamillaris, ${ }^{*} 208,229,235$

Menardi, 215, ${ }^{216}, 218,223$, 227,230

reniformis, 204, 226

scutellata, ${ }^{*} 229,230$

spinulosa, 212, 218, "220, $22 \mathrm{I}$,

${ }^{*} 222,223,224,227$

tesselata, ${ }^{*} 207$

Sigillarieae, 6I4

Sigillariopsis, $5^{\mathrm{I}} 3,6_{34}$

Decaisnei, 230, 654

sulcata, ${ }^{2} 230,23 \mathbf{I}$ 
Sigillariostrobus, 232-237

heterospory, 233-234

ciliatus, " 234

Crepini, 233, 235

nobilis, 232

rhombibracteatus, ${ }^{*} 234$

Tieghemi, 232

Silesia, 157

Silicic acid, 9

Silicified specimens, ro

Silurian formation, 6

Simplices, 352

Smedley, H. E., 387

Solenostele, 442

Solms-Laubach, Graf H. $2 u, 3$, Io, $59,71,72$, I08, II0, I 57, 444, $477,479,494,495,496,532$, $53^{6}, 560,563,564,565,579$, $599,628,638$

Sorus of Dicksonia, 467

South, F. W., and Compton, R. H., 366,598

Spencerites, 189-193, 201, 266, 633, 636

axis, IgI

sporangia, I90

spores, I9I, I92

sporophylls, I 89

insignis, r89, *I90, 233

spores, * 186

majusculus, 192

Spermatozoids, $45^{8}, 459,544,545$

Spermophyta, 47I, 6I 4, 6I7

affinities, $643-66 \mathrm{I}$

origin, 653

Sphenophyllales, $68,86, I_{23}, 6$ I $_{5}$, $616,617,628,632,641$

affinities, 6 I9- 626

Sphenophylleae, 86-I I 4

Sphenophyllostachys, 108

Sphenophyllum, 86-ז14, ${ }^{*} 87,619$, $623,626,628$

fructifications, 99-II3

habit, 86,624

leaves, $87,97,98$

roots, $9^{8}$

stem, 89-97

Cuneifolium, 88, 99, I04, 107

Dazusoni, 99, 100, *IOI, *IO2, I03, * I04, " I06, I07, I09, II3, I2I, 620

axis, I00, IO3

bracts, IOO, I0 5

sporangia, I0I, 106

sporangiophores, 102, 105
Sphenophyllum Dawsoni, spores, I06, 107

emarginatum, $6 z 2$

fertile, III-II2, *II2, I3I, 62I, 622

insigne, *95, 97, 98, $1 \leq 5$

majus, II2-II4, * II3, 622, 630

myriophyllum, 94, roo, 620

plurifoliatum, 89, "91, "92, "93,

$94,96,97,98,100$

quadrifidum, * 90

speciosum, 88

trichomatosum, II 3

Sphenopsida, 6I6, 6I7

affinities, $6 x_{9}-632,633$

Sphenopterideae, 422, 471, 472

Sphenopteris, 272, 273, 274, 284, 292, $355,377,378,403,422,648$

dissecta, $4 \mathrm{I} 8$

Dubuissonis, 395

elegans, 4I5, *4I6, *4I7, 4I8

Höninghausi, $373,3^{84}, 385,394$ r 395

Linkii, 418

Sphenozamites, 493

Spines of Lyginodendron, 368, 369, 377

Sporangia and spores of Archaeocalamites, 6I, 70

of Asterotheca, 279, ${ }^{*} 280$

Botryopteris, 330, *331, 332, ${ }^{*} 333$

Calamostachys, 53-57, ${ }^{*} 50,{ }^{*} 5$, ${ }^{*} 54,{ }^{*} 55,{ }^{*} 56$

Cheirostrobus, *II6, "II7, I20, I2I

Cingularia, *69

Corynepteris, 323

Cyathotrachus, 279

Dactylotheca, *280, 284

Diplolabis, 324

Ferns, 275-276, *280

Grand'Eurya, 28I

Hawlea, *280, $28 \mathrm{I}$

Hymenophyllites, 290

Oligocarpia, *280, 290

Palaeostachya, ${ }^{*} 61,62,64,{ }^{*} 65$, *66

Pteridotheca, "292, "293, 294

Ptychocarpus, 277, ${ }^{*} 278$

Renaultia, ${ }^{*} 280,284$

Scolecopteris, $282,{ }^{*} 283$

Senftenbergia, ${ }^{*} 280,287$

Spencerites, * 186, * I90, I9I, Ig2 
Sporangia and spores of Sphenophyllum, *IOI, "IO2, I03, *IO4, "I06, 107, 108, *109, *I10, III, *II 2 , "II 3

of Stauropteris, $337,{ }^{*} 338,{ }^{*} 339$

Sturiella, ${ }^{2} 80,286$

Zygopteris, 3I9, *320, 323

Sporangiophore, 49

in Archaeocalamites, 70

Bowmanites Römeri, ro9

Calamarieae, 49

Calamostachys, 53, 60

Cheirostrobus, II7, I20

Cingularia, 68

Palaeostachya, 62, 64, 66

Sphenophyllum, I02, IO5, III

morphology, 62I-624, 63I, 633

Sporangiophoric Pteridophyta, 64I

Sporangium, "bilocular," of Crossotheca, 399

Sprecher, A., 6 I $2_{2}$

Sprengel, K., 306

Staarsteine, 296

Stachyotaxze, fructification, 6ro

Stalybridge, 428

Stamens, Araucarieae, 655

Bennettiteae, 644, 648

Cycadella wyomingensis, 589

Cycadeoidea, 579-589 dacotensis, $580,{ }^{\circ} 58 \mathrm{I},{ }^{*} 583$, ${ }^{*} 586,{ }^{*} 587$

ingens, $580,{ }^{*} 5^{8} 4,{ }^{*} 5^{8} 5$

Reichenbachiana, 589

Staminate disc, 588

Stangeria, 273, 366, 577 paradoxa, * 365

Stauropteris, 336-340, 34I, 640

burntislandica, $33^{6}$

oldhamia, 336, *337, "338, "339, 506

anatomy, $33^{6}, 337$

sporangia, 337

spores, 339

Stem, Anachoropteris, 324

Archaeocalamites, 7 I

Arthrodendron, 34

Asterochlaena, 325

Bennettites, $560-566$

Bothrodendron, 200

Botrychioxylon, $3^{1} 8$

Botryopteris, 326, 327

Calamarieae, $19-38$

Calamites, 19-33

Calamodendron, 34
Stem, Calamopitys, $476-482$

Cladoxylon, 496-498

Colpoxylon, 446

Cordaites, $525-530$

Cycadoxylon, 483-487

Dadoxylon, $5 x 7$

Grammatopteris, 333

Heterangium, 403-409, 4II-4I4

Lepidodendron, I33-I35

Lepidophloios, I 54

Lyginodendron, 358-373

Medullosa, 429-446

Megaloxylon, 474-476

Pitys, 5I4-5I7

Poroxylon, 50I-507, 5II, 512

Protocalamites, 37

Protopitys, 494-496

Psaronius, 294-304

Pseudobornia, I23

Ptychoxylon, 487-49I

Rachiopteris cylindrica, 33

Sigillaria,

Sphenophyllum, 204-23I

Stenomyelon, 498

Sutcliffa, 447-450

Tubicaulis, 334

Walchia, 605

Zygopteris, 307-3I3, 3I7, 3I8

Stenomyelon treedian um, 498

Stenzel, K. G., 297, 298, 300, 306, $312,313,443,463,467$

Stephanian flora, 268

Stephanospermum, 81, 456, " 458 , * 459,544

akenioides, 456

Sternberg, C. von, 2 IO

Sternbergia, 523, 524, 605

Sterzel, J. 'T., 437, 443

Stigmaria, 14I, 201, 205, ${ }^{\pi} 258$

anatomy, 242-259

habit and external characters, $237^{*}$ 242

morphology, 259-262, 635

ficoides, ${ }^{*} 206, \quad{ }^{2} 238,240, \quad{ }^{*} 243$. $244,{ }^{*} 245,{ }^{2} 247,{ }^{250},{ }^{2} 252$, $253,{ }^{*} 254,{ }^{*} 255,{ }^{*} 256,259$

fexuosa, 257

clay, $24 \mathrm{I}$

Stigmariopsis, 257

Stipitopteris, 303

Stolon of Neuropterideae, 463

Stomata, 535

Lepidodendron esnostense, 160

L. Hickii, $\mathbf{1 6 0}$

Sphenophyllum, ro5 
Stopes, Miss M. C., Io, 45, 334, 534, $642,648,655$

Strasburger, E., 282, $49 \mathrm{I}$

Stur, D., 72, $157,348,35^{6}, 386,394$, $395,425,450,46 \mathrm{I}$

Sturiella, ${ }^{2} 280,286,344,348$

Stylocalamites, 74, 79

Sub-Sigillariae, 210, 21 I, 213, 228, 257

Sutcliffe, W., I3

Sutcliffia, $447-450,463,473,475,498$, 643,649

insignis, $447^{-} 45^{\circ}, * 44^{8}$

petiole, $447,449,45^{\circ}$

stem, 447, *448,449,450

vascular system, $45^{\circ}$

Swamp fiora, 7

Swamp, Great Dismal, 7

Sykes, Miss M. G., 631, 633

Synangia, $586,5^{8} 7,588,647$

bisporangiate, 400

morphology, 627

Synangium, ${ }^{*} 278,{ }_{2} 80,{ }_{2} 8_{3}, 285$, 289,324

Synthetic types, 662

Syringodendron, 213, 214, 221

\section{Taeniopteris, 446}

Tansley, A. G., 3I5, 6I8

Taxaceae, 609, 657

Taxodieae, $545,607,608,65^{8}$

Taxus, 545, 546

Tecoma, 372

Telangium Scotti, 289, 399, 400, 42I, 422

Tertiary, 608 plants, 4

Testa, 548, 573

Tetrastichi (see Psaronizus), 297

Thiselton-Dyer, Sir W. T., 648

Thomas, A. P. W., 628, 630, 63I

Thomas, Miss E. N., $53^{\circ}$

Tmesipteris, II3, 262, 306, 627, 628, ${ }^{*} 629,631$

Todea, $35^{\circ}$ australis, $3^{84}$

Toula, 202

Tovarkovo, 202

Tracheides, nature of scalariform, $3^{\mathbf{I}} 4$

Tracheotheca, 643

Transfusion-tissue, 534, 535, 655

Tree-ferns, 294-295, 368, 468

Trias, $83,87,350,35$ I

Triassic formation, $557,598,602,607$, $6 \mathbf{I 2}_{2}, 6 \mathbf{I}_{3}, 637$
Trichomanes, 342

reniforme, 342,343

scandens, 343

spicatum, 343

Trigonocarpeae, 649

Trigonocarpus, 46I, 649, 65I

Parkinsoni, 452, * $454,{ }^{*} 455,456$, $457,460,600$

Trizygia, 88

Tubicaulis, 317, 3I8, 334.336

Solenites, 334

Sutcliffi, 334

Tylodendron = Schizodendron, 605

Tyson, Philip, 559

Ulodendron, I65- ${ }^{*}$ 66, 200, 236, 295

Underclay, 205

Unger, $\mathrm{F}, 476$

Urnatopteris, *280, 286

Van Tieghem, P., 356, 5 ro

Vascular Cryptogams, 6

Vasculares, classification, 6I5-6I9

scheme, 6 I 6

Velum. See Integument

Volkmannia, 62

Dazusoni, 99. See Sphenophyllum Daresoni

Voltsia, fructifications, 607

Walchia, 605

fructifications, 606

filiciformis, 606

frondosa, 606

Walnut, $5^{23}$

Ward, Lester, 578

Wardia fertilis, $466^{\prime}$

Watson, D. M. S., Io, 135, I38, I67, 2OI

Wealden flora, $4,5,84$

formation, 556, 557, 562, 594, 608, $609,610,626$

Webber, H. I., 545

Weber, O., 437, 439, 443, 463

Weiss, C. E., 67, 73, 79, 201

Weiss, F. E., $58,156,172,253,256$, $257,3^{81}, 635$

Westphalian flora, 268

Whalley, P., 44I

White, David, 465, 466

Whittleseya, 6I I

Widdringtonia, 609

Wieland, G. R. , 5, 558, 563, 565, 572, $57^{8}-5^{89}, 592,593,598,600$, 602,658 , 
Wight, Isle of, 6ro

Wild, G., 9, I6

Williamson, W. C., 10, 19, 24, 30, $4 \mathrm{I}, 45,47,48,55,8 \mathrm{I}, 89,93$, $94,96,99$, гоo, гог, го $I 40, I 4 I, I 58, I 6 I, I 67, I 68$, I 96, 20I, 226, 238, 242, 245, $247,262,333,357,386,396$, $402,404,452,456,483,486$, $523,524,529,547,550,590$, 625

Williamsonia, 590

angustifolia, 593, 598

flower, 593

habit, 593

leaves, 593

stem, 593

gigas, fructification, 590, 591, 592, 593

habit, $590,{ }^{*} 591,592$

leaves, $590-59^{2}$

stem, 590, $59 \mathrm{I}$

Williamsonieae, 597,603

Witham of Lartington, 5 I4

Xanthorrhoea, 2 I4

Xenophyton radiculosum, 256, 260

Xerophytic, 225, 377

Yoredale rocks, 496
Yucca, 519, 52 r

Zalesskya, 476, 482 diploxylon, 476

Zamia, 366, 493, 532, 545 gigas. See Williamsonia gigas, 590

Zamieae, 494, 579, 595, 596

Zamites, $55^{6}$

Zeiller, R., I6, 99, I00, I08, I Iо, 165 , $200,204,231,232,263,268$, $272,290,297,300,384,385$, $396,422,467,468,471,608$, 609,616

Zygoptereae, 335

Zygopteris, 306-323, 329, 340, 639

aphlebiae, ${ }^{*} 3 \mathbf{I}_{3}$

fructifications, ${ }^{*} 320$

group, 306-325

petiole, 3II, 3I $4,{ }^{*} 3^{16}$

roots, 314,318

stem, 307-313, *308, "309, 317, 318

"zygopteris bibractensis, * $316,3^{1} 7,322$

Brongniarti, 306, 3 I 3

corrugata, ${ }^{*}$ 313, 314, 316, 317, 322

Grayi, 306, 307, ${ }^{*} 308,{ }^{*} 309-314$, 317,342

Lacattii, 3I $4,3^{I} 5$

pinnata, 323

scandens, $306,3^{07}, 3^{1} 3$

THE END

Printed by R. \& R. CLARK, LIMITED, Edinburgh. 



\section{AN $\cdot$ INTRODUCTION}

TO

\section{STRUCTURAL BOTANY}

By DUKINFIELD HENRY SCOTT, M.A., LL.D., PH.D., F.R.S.

\section{- Part I. FLOWERING PLANTS (Sixth Edition)}

Ilustrated with i 8 Figures

\section{Crown 8vo. Price 3s. 6d. Cloth. \\ SOME PRESS OPINIONS}

b " In noticing elementary books in these pages, we have lamented nothing more than the want of a book which should do for structural botany what Prof. Oliver's ' Lessons ' has long done for the study of the principal natural orders. It seems hard to realise that this grievance is no more, and that we possess such a book in our own language, and a book that no honest critic will fail to assess at a higher value than any known book in any language that has the same scope and aim. Nothing could well be more plain and simple, or more severely accurate or hetter judged from beginning to end." Joumal of Botany.

"As an introduction to botany, which is all that this work pretends to be, this is so excellent that we commend it most heartily to all who desire to be well grounded in the first principles of each department of botany, not of one only."-Gardener's Chronicle.

"An introduction to the study of structural botany has long been a desideratum in this country. . Dr. Scott's little book supplies this need in a most admirable manner, and he has thoroughly earned the gratitude both of teacher and student alike for the reshuess and clearness with which he has presented his subject." - Nature.

\section{PART II. FLOWERLESS PLANTS (Fifth Edition)}

Illustrated with I20 Figures

\section{Crown 8vo. Price 3s. 6d. Cloth.}

\section{SOME PRESS OPINIONS}

"The second part of Dr. Scott's admirable manual of Structural Botany is now before us. It consists of a most carefully worked out history of the structure of flowerless plants, which constitute more than half of the vegetable world. . Dr. Scott's position in the Royal Gardens at Kew will give a tone of authority for this book, which will carry considerable weight with its readers. It is one which cannot fail to hold its place among the most thoughtful of students of botany."-Science Gossip.

"We have nothing but praise for this neat little volume. With its companion (Part I. Flowering Plants) it forms as good an introduction as one can imagine, in our present knowledge, to the study of the plant-world of to-day. . We only fear lest, amid such a wealth of illustration, the student may deem an examination of the actual specimens to be unnecessary."-Guardian.

"Students of botany will welcome the second part of Dr. D. H. Scott's 'Introduction to Structural Botany' which has just appeared. . The language is clear and not unnecessarily technical, which is a great advantage to a beginner. We believe many. are deterred from the fascinating study of botany by the extremely numerous technical terms with which so many manuals abound. . . We do not remember reading a clểarer description of the growth of ferns than that in the chapter on vascular cryptogams."Westminster Reviere.

PUBLISHED BY A. \& C. BLACK, SOHO SQUARE, LONDON; W: 


\title{
A TREATISE ON ZOOLOGY
}

EDITE1) BY

\author{
E. RAY LANKESTER, M.A., LL.D., F.R.S.
}

HON. FELLOW OF EXETER COLLEGE, OXFORD; CORRESPONDENT OF THE INSTITUTE OF FRANCE; LATELY DIRECTOR OF THE NATURAL HISTORY DEPARTMENTS OF THE BRITISH MUSEUM.

In Demy 8vo. Illustrated. Bound in cloth, price 15s. each part net; on thin paper in paper covers, price 12s. 6d. each part net.

(Part IX. (First Fascicle), price zos. net and' I5s. net.)

Postage additional: cloth 6d., paper coirers $4 d$. per copy.

\section{VOLUMES READY}

PART I. (FIRST FASCiCle).

\section{INTRODUCTION AND PROTOZOA.}

By S. J. Hickson, M.A., F.R.S., F. W. Gamble, D.Sc., F.R.S., J. J. Lister, F.R.S., H. M. Woodcock, D.Sc., and the late Professor WeLdoN, F.R.S.

Par'T I. (Second Fascicle).

\section{INTRODUCTION AND PROTOZOA.}

By J. B. FArmer, D.Sc., F.R.S., J. J. Lister, M.A., F.R.S., E. A. Minchin, M.A., F.Z.S., S. J. Hicksox, F.R.S.

\section{PART II.}

\section{THE PORIFERA AND COELENTERA.}

By E. A. MinCHIN, M.A., F.Z.S., G. Herbert Fowler, B.A., Ph.D., and Gilbert C. Bourne, M.A.
PART III.

THE ECHINODERMA. By F. A.

BATHER, D.Sc., F.G.S., assisted by J. W. GREGORY, D.Sc., F.R.S., and E. S. GoODriCH, M.A., F.R.S.

$$
\text { PART IV. }
$$

THE PLATYHELMIA, MESOZOA, AND NEMERTINI. By W. B. BENHAM, D.Sc., M.A., F.R.S.

\section{PAR'T V.}

MOLLUSCA. By Paul Pelseneer, D.SC.

Part ViI. (Third Fascicle). APPENDICULATA (CRUSTACEA). By W, T. Calman, D.Sc.

PAR'C IX. (FIRST FASCICLE).

VERTEBRATA CRANIATA (Cyclo= stomes and Fishes). By E. S. GooDRICH, M.A., F.R.S. Cloth, price 20 . net. Paper, price $15 \mathrm{~s}$. net.

\section{SCOPE OF THE WORK.}

This comprehensive treatise on Zoology has been for some time in preparation under the editorship of Professor Lankester. Each of the larger groups of the Animal Kingdom is to be described by a separate author ; whilst, as far as possible, uniformity in method and scope of treatment are aimed at. The authors are, for the most part, graduates of the University of Oxford, though it may not be possible to maintain this limitation in future sections of the work.

The general aim of the treatise is to give a systematic exposition of the characters of the classes and orders of the Animal Kingdom, with a citation in due place of the families and chief genera included in the groups discussed. The work is addressed to the serious student of Zoology. To a large extent the illustrations are original. A main purpose of the Editor has been that the work shall be an independent and trustwortlay presentation, by means of the systematic survey or taxonomic method, of the main facts and conclisions of Zoology, or, to speak more precisely, of Animal Morphography.

The treatise will be completed in ten parts. It will at once be apparent that this limitation necessitates brevity in treatment which, however, will not, it is believed, be found inconsistent with the fulfilment of the scope proposed, or with the utility of the work to students.

PUBLISHED BY A. \& C. BLACK, SOHO SQUARE, LONDON, W. 



